






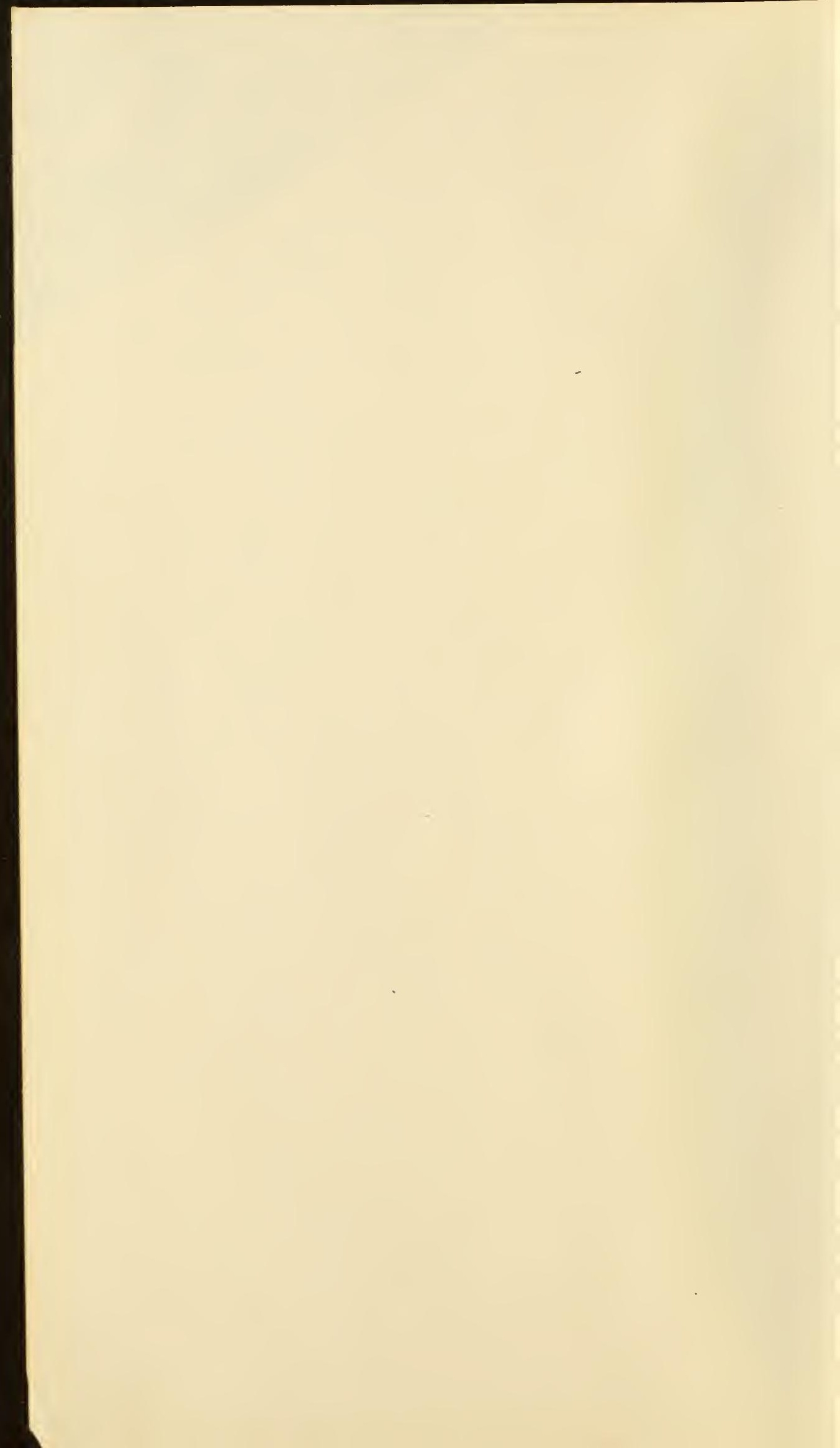


QL

568

V5\$2 25

ENT

SHITHSONIAN MISCELLANEOUS COLLECTIONS.

254

\section{S Y N O P S I S}

OF

\section{AMERICAN WASPS.}

BY

Dr. HENRI DE SAUSSURE, OF GENEVA, SWITZERLAND.

SOLITARY WASPS.

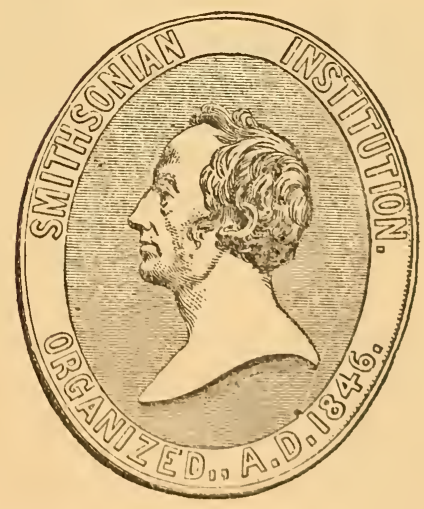

WAS H ING TON :

SMITHSONIAN INSTITU'TION. DECEMBER, 157.5. 


\section{A D T ERTISEMENT.}

THE present publication is the first part of a Synopsis of American Vespidae or Wasps, prepared by Dr. Henri De Saussure of Geneva, Switzerland, one of the highest living authorities on the subject.

This work relates to the "Solitary Wasps," and has been the result of many years of careful study and patient investigation. Unforeseen events have occurred to delay its publication, in addition to the loss of time occasioned by the necessity of transmitting the proofs and revises to the author in Europe.

In the introduction will be found suggestions by the distinguished author as to the philosophy of points of natural bistory, well worthy the attention of the general students of this branch of science, and the whole work will doubtless be considered a valuable addition to the sources of knowledge on entomology.

The Institution acknowledges the important aid rendered in the translation of the work into English, its careful preparation for the press and the revision of the proof-sheets, by Mr. Edward Norton of Farmington, Conn., whose services have also been acknowledged in the annexed dedication by the author.

\section{JOSEPH HENRY,} Secretary S. I.

Sirthsoniax Institetion,

Washington, December, 1875. 


\section{DEDICATION.}

\section{To Mr. Edward Norton.}

\section{Sir :-}

I am desirous of dedicating to you this first attempt to draw up a Hymenopterological Fauna of North America. The unflagging interest you have kindly taken in this work emboldens me to hope that you will accept my offering.

The readiness with which you placed at my service your collections, and the assistance of your valuable instructions, were already sufficient claims to my gratitude. Your kindness in taking upon yourself the task of translator makes me feel more strongly the extent of my obligations to you.

It is for me a subject of regret that my imperfect acquaintance with the English language has not permitted me to relieve you from the trouble of this work. Had I been capable of composing this book in the idiom in which it is to appear before the public, the many hours of enjoyment I have had in writing it would not be contrasted with the many tedious hours it is likely to occasion you.

Beside the peculiar charm which the study of nature erer possesses, the drawing up of this monograph has wafted me in thought to those regions of the New World which have, since I was a child, allured me with an irresistible spell. While comning over my insects, many a remembrance has loomed before my mind, and transported me to those thought-inspiring and soulstirring secnes of your magnificent country. As a swiss, I felt 
a secret pride in reflecting that its institutions are analogous to those of my own dear country, and that the grandeur of its physical scenery and the intellectual life which animates all classes of its people, have their counterpart in Helretia.

For me it is a source of satisfaction to be able to contribute, in my humble sphere, to the extension of the physical knowledge of that part of the American continent, whose natural riches we are daily more and more able to appreciate, thanks to the untiring zeal of its scientific men.

I trust, sir, you will deign to read these lines with an indulgence equal to the sincerity with which they are addressed to you, and that you will see in them a pledge of my gratitude and derotedness.

\section{HENRI DE SAUSSURE.}

Gexeta, Stitzerlayd, 1 May, 1863. 


\section{PREFACE.}

I PUBLISHed in 1852 my Monograph on the Solitary Wasps; which forms the first volume of my Studies on the Family of the Vespidæ. ${ }^{2}$ As soon as that work was printed, I perceived that it was very imperfect.

I was still a mere student when I composed the greater part of this book; it bears too evident marks of its premature publication. I consequently felt the necessity of correcting and completing it by means of a Supplement which occupies the greater part of the third volume of the Studies on the Family of the Vespidæ. This, however, was insufficient.

To the imperfections in the MS. of the work, attributable to my inexperience, were added those of the form. I had the misfortune to fall into the hands of a printer who not only delayed for year's the publication of the work, but who also executel it in a shameful manner, neglecting to make proof corrections, and printing the notes in the midst of the text.

Having lost all patience with the delay and errors of the work, I turned my back on the social wasps and started for America, leaving to the care of my excellent and worthy friend, Dr. Siebel, who had often aided me with his skill and advice, the task of superintending the impression. Two year's after, on my return to Europe, I found that only three or four sheets had been printed, and that the third volume was only on the eve of being finished, and it was not until 1857 and $185 \mathrm{~S}$ that the volume on the social wasps was completed, by the appearance of the general part, in which were developed the facts concerning the nidification of these insects, of which a summary alone had appeared in 1853 and 18.54. in the explanation of the plates, and in a special paper. IBuc

1 Monographie des fruipes Solitaires. Gendre, Paris.

2 Eturles sur la Famille des Vespides, 3 rols. and atlas. 
during the three years, while the manuscript had lingered in the hands of the printer, there had appeared a memoir, by Dr. Möbius, on Wasps' Nests, so that my work, at the time of its publication, was in arrear of science. ${ }^{1}$

To these contingencies I must add the death of the artist M. Taillant, ${ }^{2}$ of so interesting memory, during the publication of the first volume. The succeeding draughtsmen, by whom I replaced him, were far from equalling him, and have often produced inferior, sometimes eren bad drawings. ${ }^{3}$

It will be easily understood that all these vicissitudes have not a little contributed to render the work defective. From the very first, I have felt the necessity of recasting it. But as I could not undertake fresh journeys to visit the collections in distant centres, Paris, London, etc., I have adopted another method, which consists in correcting and completing my studies on the Family of the Vespidæ by means of successive memoirs, resulting from the study of collections, which are kindly communicated to me. ${ }^{4}$ All these works, together, will perhaps enable me one day to recompose a general work. An excellent oppor-

1 When, at length, the work was completed by the tardy appearance of the general part of the $2 d$ volume, Mr. Gerstacker spoke of this general part in his annual report on the progress of Entomology (Troschel's Archives), calling it, I know not for what reason, the commencement of a fourth volume. He reproached it disparagingly for not noticing recent works. True it is, he could not guess that it was an old laggard which had been some years in press.

$2 \mathrm{Mr}$. Vaillant was the artist attached to the scientific exploration of Algeria.

3 The drawings of the Pl. XVI, of Tome I, are in particular very bad.

4 I have thus composed the following memoirs, forming, as it were, a supplement to my Studies on the Vespidce:-

1. Description de quelques nouvelles Especès de Vespides du Musée de Londres. (Revue de Zoologie, VII, 1855.)

2. Nouveaux Vespides du Mexique et de l'Amerique septentrionale. (Rerue de Zonlogie, IX, 1857.)

3. Note sur la Famille des Vespides. (Ibid., X, 1858.)

4. Note sur les Polistes Americains. (Ann. Soc. Ent. de France, 1857.)

5. Description de quelques Vespides nouveaux. (Ibid., 1857.)

6. Bemerkungen über die gattnug Vespa. (Entonuoi. Zeitung von Stettin, 1857.)

7. Sur divers Vespides Asiatiques et Africains du Musée de Leyden. (Ibid., 1862.) 
tunity of extending my studies on the Wasps offered itself when the Smithsonian Institution was pleased to commission me to establish the fauna of the IIymenoptera of North $\Lambda$ merica. I was already in possession of numerous materials for the drawing up of such a work. I had brought from that continent considerable collections, the fruits of my explorations in West India, Mexico, and the United States. I had likewise acquired collections of Iymenoptera in my passage through this latter country, of $\mathrm{Mr}$. Rathvon (Lancaster, Pa.), Mr. Fuch (Tennessee), and others. Prof. Haldemann kindly made me a present of the remnants of his splendid collection, unfortunately almost destroyed. To these materials which I had got together as I went along, there came to be added later, the collections which the Smithsonian Institution forwarded me from different regions of the United States. But I owe a special mention to my friend Mr. Edw. Norton, of Farmington, Connecticut, an excellent entomologist, who afforded me the most valuable assistance for the work to which these lines serve as an introduction, and who with extreme kindness offered to undertake the translation of this volume himself. Finally, I have, moreover, received some parcels of insects direct from divers friends, especially from Tennessee, from Engineur de Freudenreich Falconnet, Engineer on the Nashville Railroad, and since then Major in the Confederate Army; from California, through Mr. Berton, Swiss trader at St. Francisco, and by Mr. Sutter.

Notwithstanding all these contributions, the collections which I inyself brought from America still form the staple of my materials; but these subsequent additions are very useful complements. I, therefore, avail myself of this opportunity to thank publicly

1 Hymenoptera from Rock Island, South Illinois, collected by Kennicott.

" " from Illinois, collected by Walsh.

" " from Lake Superior, collected by L. Agassiz.

" " from Williamstown, Massachusetts, collected by S. H. Scudder.

" " of the Cape St. Lucas, California, collected by Jolu Xantus.

" " $\quad$ from Rio Peros River, collected by Capt. Pope, U. S. A., and varions other Hymenoptera collected at Fort Tejon, California; English River, etc.

The first five collections had been formed by indiriduals in the interest of soience; the others by explorations carried on by order of gorerument. 
all the above-mentioned persons for the assistance which they have kindly afforded me. Among them I ought to name especially, Prof. Henry, as director of the Smithsonian Institution, and Prof. Baird, who have always shown me the greatest kindness.

I ought, however, to inform the reader that, notwithstanding so much help, the work does not contain all the species of America. I myself possess divers individuals, which, without offering characteristics distinct enough to be described from one individual, nevertheless betray the existence of species yet unknown. Moreover, the larger part of the smaller species seem till now to have baffled the researches of collectors. I do not hesitate to affirm, that, had I been able to collect undisturbedly in the United States, I should very likely have brought back from that country a number of small species as considerable as that which I have brought from Mexico.

But it is in the natural progress of science to adrance gradually towards completeness; and consequently, it is the lot of books of science to grow old and become obsolete; and thus, in their turn, to give way to more complete works. I do not, therefore, consider this monograph, incomplete as it may be, withont its use. I am not one of those who suppose it possible to exhaust a subject of investigation. On the contrary, I am of opinion that in entomology, as well as in the other branches of science, nothing perfect, nothing absolutely complete, can be accomplished, seeing that ererything in nature is undefined. The naturalists who think the contrary, and who are induced constantly to put off the publication of their labors from believing they shall wholly complete them, succeed but too often in losing the fruits of their studies; either because their writings grow oid while lying by, or because the authors are overtaken by death. The proper method in the study of nature is not that of perfection, but, on the contrary, that of approximation. Because from approximation to approximation, we are always getting nearer exactness and completeness, without ever attaining extreme perfection. In that precisely consists the progress of science, and that also it is which gives to its horizon the depth of infinitude. 
The foregoing was written some years ago. In 1865 the manuscript of the meinoir was sent to the Smithsonian Institution.

Its publication was at first delayed by the pressure of other matter, then by an unfortunate fire which cmbarrassed the finances of the Institution, and lastly the slow delays below mentioned.

'The book has been in the press several years, in consequence of the great loss of time caused by the transmission of the proofs from Europe to America, and vice versa.

In consequence of this long period of waiting, I have been obliged to make a review of the manuscript in reference to the writings of various entomologists, especially those of Mr. Cresson, which have been published from year to year, and have changed the names of the species which I had described and have adopted the names given by this author. I have not been able, however, to take account of the more recent writings of $\mathrm{Mr}$. Cresson, on the Hymenoptera of Texas, which only came to my knowledge when the printing of this book was almost finished.

The reader will excuse certain irregularities, consequent upon the difficulty of putting a work into perfect symmetry which was to be printed on the other side of the Atlantic. Hence the anthor has never had but a part of his work before his eyes at a time, during the long course of this publication. For example, it will be noticed in the synonymy that my work, "Etudes sur la Famille des Vespides" is sometimes cited "Et. Vesp.," sometimes only "Vespides." So with the "Revue et Magazine de Zoologie," it is sometimes cited "Rev. et Mag. de Zoolog.," and sometimes simply "Rev. de Zool."

The larger part of the book was written in French, and has been translated and corrected by Mr. Edward Norton. I owe to this naturalist also various communications and frequent sendings of insects, which have been of great use to me.

H. DE SAUSSURE. 



\section{INTRODUCTION.}

I PROPOSE in this volume, not to give a general history of the Wasps of America, but only to lay the foundations of the fauna of the Vespidæ of that continent, principally of North America. I leave aside whatever concerns the habits of these insects, on which we have but insufficient information, and I shall confine myself to speaking of them with respect to the genera or species which offer salient peculiarities.

This work is not to be taken for a mere catalogue of species, of no further use than to satisfy curiosity. I think that modern zoology ought to tend towards another aim. The existence of species, the composition of fauna, their relations with the parts of the globe which they populate, are not merely accidental facts. In my opinion, we must therein detect the last material and tangible manifestation of physiological forces, elucidating the study of which belongs to the domain of the highest natural philosophy. By him who adopts this view of the subject, a far-scarching study of species ought to be considered as one of the bases from which the search after the origin of species may start.

It would seem that in zoology we should take for a startingpoint the actually existing forms in which life manifests itself, and to ascend from them up to the primitive stack; just as in geology, we start from the actual existing structure of rocks and from the exterual configuration of the soil, to follow up the concatenation of the ancient events which have brought about as a last result the present state of the earth's crust.

The study of species ought especially to serre as a means of revealing to us their variations and the affinities between them. These affinities point to a common relationship, which is to be explained only by a direct affiliation of the types. The study of 
forms combined with that of their geographical distribution, comes afterwards to throw light on the cause of the filiation which the graduated resemblances of the species serve to reveal to us. It shows that this filiation obeys laws which have also their regularity, in so far as they are intimately connected with the physical laws which hold sway in every region of our globe.

Toward these grand philosophical queries, zoology ought in our time to tend, and species should be studied with a view to the solution of such questions. As in geology, the study of the actual existing state of the earth's crust, and the appreciation of the phenomena that there take place, of the intimate transformation of rocks, of the mechanical disturbance of the layers, of their reconstruction under new forms, allows us to draw an inference by analogy as to the more aucient transformations, and the agents which have produced them; so the study of species, and of their actual existing transformations seems likely to enable us to follow up the chain of these transformations to a point more or less close to their origin.

The definition of the first divergences observable in the permanent varieties which may be considered as nascent species, in order to ascend afterwards to the relationship of species separated by divergences more and more profound, such is, we deem, the point of view under which we should never neglect to study species.

Zoology, only when considered from this point of riew is philosophical. It has not its aim in itself; it serves only as a means to sift questions of a higher order. Now entomology is precisely the one of the branches of zoology, in which the study of the filiation of species may become the most fruitful in results, either on account of the multitude of ramifications of general types and of the multiplicity of forms under which each type appears, or on account of the smallness of the breaks which separate genera and species, or also on account of the immense variety of forms and of the facility with which species seem to become modified in proportion as they spread over the surface of the globe in diverging ways. Thanks to all these causes, it is not difficult to find examples of every kind of filiation, not difficult either to follow over latitudes certain still recent modifications which allow us to draw an inference by analogy as to other 
modifications more profound because they are more ancient, than as to others of a degree still more advanced. ${ }^{1}$

As may be anticipated from what precedes, my principal purpose in producing this work is to study the American fauna with a view to its origin. But this is a work of time which cannot be completed off-hand. The first thing to be done is to study the species carefully, to arrange them according to a good classification, and to describe their affinities. 'That is the fundamental preparatory labor. I do not pretend to overstep those limits in this monograph. The knowledge of the American fauna is not yet enough advanced to allow us to draw an inference with certainty as to the affinities of the species among themselves so as to prejudge their filiation. However, I hare made more than one remark on this topic, and I will hazard a few words on the matter when speaking of genera and species. But I reserve for another work the statement of comparisons which seem to me to cast some light on the dispersion of the Vespidre on the surface of the globe and on the modifications which hare been worked off under diverse latitudes; in other terms, on the origin of actual existing fauna.

The complex affinities of species, and still more the filiations which arise from these affinities, become obvious to the eye only when one has acquired a perfect knowledge of the species and genera of a fauna. To seize them in all their extent, it is necessary to know, as it were, all the species of the group by heart in order to be able to take it in at a glance, or to examine at pleasure each part in the picture that one has formed in one's memory. Only when one has attained this point in the study of a group, is it possible, from the inspection of a species, to feel its affinities; for they do not always appear in the more casily

1 Unfortunately, in our times the greater number of entomologists hare deviated too far from this philosophical path. They have turned entomology into a sort of amusement which has for object the discovery of new species; which loses itself in minntix, and at the bottom of which there exists no thought. Thanks to this tendency, eollecting has ceased to be the means, and has become the object. In becoming an amnsement entomology has gradually lost caste; it has fallen into the hands of dawdlers, and thus lost a part of its seinntific character. This transformation has led men, who aim at reaching an elevated rank in science, to be too much inclined to withdraw from the field of entomology. 
appreciable characteristics. They often discorer themselves in certain characteristics of appearance, which are at times of great importance, but which are not seized at a glance, or in certain relationships of form, which a long practice teaches oue to distinguish easily, though they can scarcely be defined.

The first basis of philosophical zoology is the profound knowledge of the detail of fauna. To give as complete an idea as possible of the fauna of the VESPID 2 of America is the purpose of this volume.

\section{PLAN OF THE WORK.}

The plan which I have decided on, in drawing up this work, is the following:-

I give, as much as possible, a complete description of the species which belong to the fauna of North America, considering as such all those which people the new continent to the north of the isthmus of Panama, including likewise the Antilles. This work is, therefore, more especially a molnograph of the Vespidæ of the United States, of Mexico, and of the Antilles. Besides, I have added, as a complement, a catalogue of all the species known till now in the rest of America, and have found it a great advantage in the classification, the method thus becoming more complete. Moreover, this plan allows me to enunciate views on the geography of insects, on the dispersion of the species, and on the modifications which take rise under the influence of diverse latitudes.

I have confined myself, among the species of South America, to cataloguing them, not having sufficient materials to make a monograph. However, for those of which I had the types beneath my eyes I have given Latin diagnoses, in order to describe them in a comparative manner with respect to the surrounding species, and, also, in order to complete my anterior studies on these insects, to review them and render the use more easy.

I think myself bound to add here, that, as to my method of description, I describe the species as far as possible in a relative manner. Descriptions made in an absolute sense have always appeared to me less useful, because they insist on many useless characteristics and often omit the most important. The reader 
will not be surprised, therefore, at my not repeating, with respect to genera, the characteristics peeuliar to every species or to the greatest number of them. In short, there are still other characteristics which I pass over, considering them rather useless either on account of their constancy (such as the presence of silky hairs on the tibiæ) or on account of their variableness, such as the color of the lower surface of the abdomen.

Descriptions are often made prolix by means of these superfluous indications, and thus the essential characteristics are drowned in useless developments. In this way, precision is diminished instead of being increased. Doubtless, here again nothing is absolute. Certain isolated species may be sufficiently characterized by some salient traits, while others surrounded by very elosely connected species, require minute descriptions. ${ }^{1}$ The first condition of guod comparative diagnoses resides in a wise coordination of the species which by way of exclusion may lead to choosing only between a small number of species. Though I do not like to find fault, I cannot, however, on this score, help complaining of the works in which the species, though described in all absolute manner (that is, by themselves and not comparatively with others) are jumbled up together without order, without division of genera, often in defiance of the most salient characteristics.

Such works, got up in a hurry, the plans of which are laid down with a view to the convenience of the author's and not for that of the readers, cause the latter to lose much valuable time with no great result. They do not come up to the precisiun now required by the progress of science, and they are therefore behind their time. The reader cannot occupy his mind with incomplete works, nor can he waste his time in striving to find out species which are not to be found out; for there is no doing impossibilities.

In most of my descriptions, I have been especially attentive to the forms and characteristies of the forms and carving, attributing

1 Absolute and very detailed descriptions onght, in my opinion, to be employed, when one describes species isolatedly, without kuowing thes most elosely conuected types (for instance, in the publication of geographical expeditions). It is the monographer's duty to eliminate, from these descriptions, both the commonplace and the useless. But in a monograph, the species are to be examined in a comparative manuer, and relatively to the adjacent types. 
to the color only a secondary importance, on account of its frequent variableness. However, there is nothing absolutely fixed in nature; the forms and the sculptrire likewise rary within certain liınits. Therefore the descriptions can be only arerages deduced from a certain number of individuals. The description should represent, as it were, the algebraical formula of the species, or its ideal type. It is not required that this should tally with the individual, but, on the contrary, that it should represent the average of the characteristics of the ensemble of individuals. But in practice, the description can never be so perfect, since it is drawn from a certain number of individnals and not from the ensemble of the individuals that represent the species. It is for the reader to know how to seize the connection that exists between the description and the heterogeneous individuals which he may have beneath his eyes. In a word, my method of description aims above all at generalizing, and requires that the reader should generalize likewise. It can hardly suit the amateur inclined to lose himself in a multiplicity of details, for whom the collection takes the place of nature, and for whom the determination of an individual is the final purpose of the study of a species.

From the principles just laid down, it follows that in the extreme subdivisions of genera, I have usually preferred the characteristics taken from the form to those taken from the color. Undoubtedly it is less convenient for the reader, for the natural method is always less easy to follow than the empirical systems; nerertheless, I think that it is preferable to proceed in that wise, for whatever may be done to seck the natural method, a large portion of empiricism is sure to remain, as I shall endeavor to show in the study concerning the filiation of the species. We cannot, therefore, abstain too carefully from classification of empirical elements. ${ }^{1}$

1 It is necessary to observe on this head that no absolute rule can be laid down as to the subordination of characteristics. To be sure, forms varying less than colors, they offer, in general, characteristics more important than the latter; but there is, however, now and then a case in which the colors are more fixed than certain forms, and assume a real importance-for instance, as being the stamp peculiar to a certain geographical zone. Thus, the division Fypodynerus (genus Odynerus), which depends greatly on the colors and facies, and which eomprises tlie most divergent forms. In this case, the livery becomes the stamp of a fauna, 


\title{
DIVERSE OBSERVATIONS
}

\author{
CONCERNING THE
}

\section{STUDY OF HYMENOPTERA IN GENERAL AND THAT OF TIIE VESPIDIE IN PARTICULAR.}

\section{Observations relalive to the Synonymy.}

1st. I make it a rule always to respect the most ancient name; however, if it is wrongly constructed and if it can be rectified without inconvenience, I do not scruple to correct it. 'Thus I spell Rhynchium instead of Rhygchium Latr.-Odynerus Bustellosi instead of $O$. Bustellos Sauss., etc.

$2 d$. When two different names have been affixed at the same date to the same species, I prefer that of the two which has been employed by the next subsequent author.

3d. I add the name of the author of a species only to its specific name. Consequently when the genus changes, I nevertheless maintain for the species the name of the author who first named it. Thus, I write: Odynerus 4-dens Lin., although Linnæus has described this species under the name Vespa 4-dens.

Montezumia Leprieurii Spin., although Spinola has described the species under the name of Odynerus Leprieurii.

Otherwise no author's, name would long keep its ground; besides those who act diferently do so in order to substitute their own names for that of the primitive describer. Such a proceeding cannot be too strongly censured.

Let it not be said that there are drawbacks to the advantages of that nomenclature, for if it be desirable to know the complete name as given by the first author, it will be found, such as it is, in the synonymy.

4th. I admit neither collection names, nor manuscript names, nor in letleris names. I admit for author's name only the name "Of him who has first described the species or genus.

Any other manner of acting becomes the source of profitless research and of waste of time. Whoever is anxious to athix his

and is very important. In the sncession of species it is generally observent that the colors vary much, even when the forms remain fixed (or viry less); but there are other cases in which it is color that remains stationary whilst the forms vary. 
name to a species that another has the task of describing, may for this purpose publish previously a short diaguosis under his name in any journal.

\section{Observation relative to the Types in Description.}

In insects in general, the female represents the type of the species. Though, in exceptional cases, the male may be the larger, the more beautiful, and at times with unusual appendages, he remains always more rariable than the female. Among the Hymenoptera, the males have hardly any other part to play than a passive one; the other sex it is, which alone develops that remarkable activity which manifests itself in the interesting habits of these insects. The females are larger and more stable in their forms and colors. The slightest examination renders it apparent that it is among the females the trpe of the species is to be sought for, and by no means among the males. In the Tespidæ, especially among the Solitary Wasps, the males are small and variable; at times, one would be inclined to consider them as abortions; they do not offer as good differential characteristics as the females, and they are to be determined only by the tentative method in referring them "de visu" to their respectire females.

There exists a number of species of which the males resemble each other so far as not to be distinguishable. This may be seen, for instance, among certain Odynerus, but it is especially among the Scolid that this phenomenon appears in all its intensity. There is a whole category of species in the genus Elis of which the females offer differences the most extreme, but of which the males are so confounded that they cannot be distinguished from each other. What is most remarkable on this score is, that these species are to be found spread orer every continent, and that each continent numbers several of them. Thus:-

America : Elis plumipes, limosa, trifasciata, dorsata, etc. Africa: Elis collaris, capensis, elegans, africana, fasciatella, etc.

Asia: Elis thoracica, annulata, marginella, limbata.

A ustralia: Elis radula, Z-cincta, etc.

Europe: Elis viliosa. 
Some of these species may doubtless be distinguished by their size ( $E$. villosa), or by the examination of their wings ( $E . Z$ cincta); but in most cases, if it is not known where they come from, there is no possibility of determining them, not even of referring by sight to their females.

The same fact may be noticed in a very developed state among other speeies of Elis which present another system of coloring: and which forms a part of the subgenus Trielis. Thus the

\section{Elis interrupta (Europe)-texensis (Texas)-Xantiana (Cali- fornia),}

though offering females very different from each other, coincide in the males.

I do not pretend to affirm, however, that all these males are perfectly identical. I only mean that they are so close neighbors that I have not succeeded in finding between them differential characteristics which appear to distinguish them.

The preceding will suffice to show that the femase ought, at all events, to be taken as type of the species.

\section{Preparation.}

In a great many collections, it is usual to spread the wings and legs of the hymenoptera. This is mere amateur's work, of no utility for study, sometimes even quite opposed to the purpose in view, by dissimulating the character of the insects instead of exposing it to view. This practice is to be regretted, moreover, by its increasing the value of the insects, on account of the time and expense wasted thereby, so that one is loath afterwards to place them in the softener when it becomes necessary to dissect the mouth.

It is usual with me to prepare each of my insects only when about to study them, because by so doing I can, after having softened them, give them whatever arrangement may be best calculated for bringing into relief such special characteristics as are particularly useful in the group to which it belongs. As the useful characteristics are not the same in each group, the preparation ought to vary according to the species. Of the Epripona 5 the mandibles are to be opened, the legs to be stretehed downwards, so that it may be possible to examine distinetly the haunches and thighs; of the Odynerus $\delta$, approximate to the group of $O$. 
nasidens, the antennæ are to be lengthened out, in order to judge of their terminations, etc.

For almost all the Solitary Wasps, but particularly for the Odynerus, it is essentially necessary to be able to distinguish clearly the characteristics of the metathorax. Now this cannot be effected otherwise than by separating the wings in a transrerse direction or rather downward, and by bending the abdomen downward as far as possible, the basis of which will, by this means, become at the same time easy to study. This posture is, cridently, very different from that given to the insects by spreading them out. I can affirm, that, whenever one has neglected to gire the insect this posture, the metathorax and the abdomen present themselves under the most delusive aspect, and may give rise to the most serious misconceptions. As to describing an Odynerus properly without having taken this precaution, it is an impossibility. One may, if need be, bend downwards the abdomen without softening the insect; but then, if the wings are directed backwards, eren obliquely, they are enough in the way to produce delusive appearances when the magnifying glass is nsed.

These observations, true especially for the Odynerus, apply likewise to all the sessile ventrated or semi-pedicellated Tespidæ.

\section{On the Determination of insects.}

There are two manners of proceeding, for the determination of insects. One is analytical, the other synthetical, the former employed by amateurs, the latter by naturalists. The first method consists, when having taken an individual insect, in turning over the leares of a book in search of the name of the species till one supposes to have hit on the description. This method seldom leads to certainty, often to error.

The second method requires a collection as numerous as possible in individuals. To procure it, the entomologist ought before all things to devote his efforts to a persevering and active chase after specimens. The greater the number of the representatives of each species, the mo:e certain the determination will become. In difficult performances, we must always begin with the more easy and proceed from the simple to the complex. We must, therefore, start by separating the most salient and most easy genera to 
study them first. Afterwards we must continue by way of elimination. As it is for the difficult genera, that it is especially inportant to adopt a good method, let us choose, for instance, the genus Odynerus and its approximates; it surely will answer oul purpose thoroughlily. Let us suppose that the peduneuliventrated genera have already been separated and that we have remaining unly the sessiliventrated, say the genera Alastor, Monobia, Plerochylus, Odynerus.

First we will exclude the Alastor, by the process of viewing of the wings. Scarcely any other will remain than the Odynerus and the Monobia; their species will at first appearance strike one as an inextricable jumble.

For the moment, we will not trouble ourselves about the Monobia, which are rare and southerly species. We will, therefore, begin by confining ourselves to setting aside the Ancistrocerus and the Symmorphus, characterized by the suture of the first abdominal segment, and we can then enter directly on the study of the species. But even here we will advance as far as possible without the assistance of books.

The next operation consists in sorting out the males and females in order to occupy ourselves exclusively with the latter. With a little practice this separation proceeds rapidly, since the males of the northern regions are distinguishable mostly by their entirely yellow clypeus. For whatever may concern the exceptions (either from the females offering the same character, or from the males not offering it) one has still as object of consultation, the form of the antenna, orgars which in most males are more generally terminated by a hook or a spiral. At last, as a final resource, and as an infallible means, we remove all doubts by counting the number of abdominal segments. The of have only 7 , the $q$ only 6 .

We will first occupy ourselves only witl the $f$ and will group the individuals by species on small boards. This is a work of time and patience. To succeed, we will make use of every appreciable characteristic, even of the most empirieal ones. In sorting out in this manner, the colors are always of the greatest assistance because they are obvious to the eye. One must, as much as possible, subordinate the importance of the spots to a graduated order, in beginning with the most fixed and character- 
istic, as for instance the spots on the scutellum and of the postscutellum. Thus:-

Range together all the species with post-scutellum alone yellow.

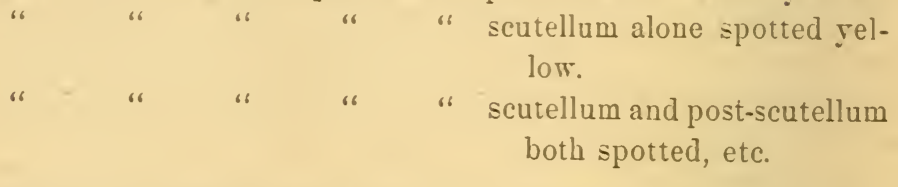

Then come the anterior and posterior borders of the prothorax; then the stripes of the abdomen, the spots of the metathorax, etc.

Thus you come to form more species than are really existing, erery rariety becoming a species; but, no matter, the work of reducing will at last arrire and will be easily carried through when species shall hare been studied and known, as it were, by heart.

Then we may look into books and tr? to determine each species while haring, beneath one $s$ eres, the ensemble of indiriduals.

Here we can get on only by groping about a long time in uncertainty. Often after comparing these similar indiriduals we shail detect tro species which at first had been confounded.

The determination can be carried on by two inverse proceedings. After haring sorted out apart by one's own obserrations the greater number of species, the entomologist often knows them already sufficiently to guess to what species such and such a description belongs. He can, therefore, either start from a species and seek the description which suits it, or start from a description, and in passing in reriew his series seek to what species this description is adapted. ${ }^{1}$ Moreorer, these two manners of proceeding rerge into each other repeatedls, when one bas beneath one's ejes, a large ensemble of rell-separated species. Indeed, when making use of the first proceeding, one often falls into the second, for one is often struck with the description of such and such a salient character which one recollects haring obserred in a species. Thus the search after one species leads to the determination of another. The work hastens along with accelerated motion and leads to results the more certain as each species is represented by a larger number of indiriduals comprising most of the possible

1 For this purpose short descriptions, i. e., diagnoses, which may at once be committed to mewors, are rery useful. 
varieties. In this entirely empirical labor, any process, even expedients are allowable.

Nevertheless, when one gets to the groups, in which the species lie elose together, one is often puzzled, and there remains no way of exclusion.

Once the females determined, proceed to an analogous sorting out and grouping of the males by species. Attribute to each female species its respective male, beginuing by the more easy and proceeding always by way of exclusion. This is a tentative work, in which one succeeds satisfactorily only when familiarized with a group which is being studied.

As to separating at the outset the Monobia from the Odynerus, the Symmorphus from the Ancistrocerus, the Odynerus from the Epipona, that cannot be done without being well acquainted with these groups so as to place therein at once the insects according to their facies. If one is not far enough advanced to do so, this separation will result quite naturally from the work of determiuation; nevertheless, to distinguish the Monobia, it will be necessary to dissect the mouth.

With that operation, we may finish, because we shall have no more to seek but among a small residue of species, whereas had we begun by establishing that distinetion, we should have been obliged to dissect the mouths of all the Odynerus which have been excluded from this operation by the mere fact of their determination. A work of determination made according to this manner of proceeding will afford synoptical views that alone will permit one to appreciate the true relations of species. Better than any other, it will prepare the entomologist to give comparative descriptions taken from a general point of view which will not lose itself in worthless details. 



\section{ANALYTICAL TABLE。}

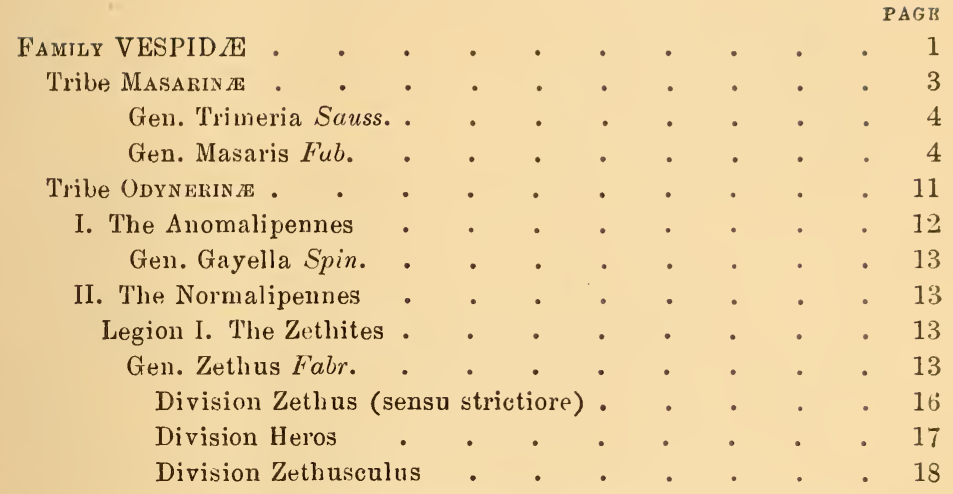

A. Antennæ of the males terminated by a rolling-up spiral . . • . • • . 19

a. Petiole presenting a nodulous or ovoid expansion 19

b. Swelling of the petiole cylindrical . . $\quad 23$

* Metathorax not excavated . . . . 23

* Metathorax excavated; the excavation margined with sharp carina . . . 25

† Thorax short, quadrate or rounded . . 2.j

if Thorax elongate, attenuated anteriorly, elliptical • • • • • • • 27

B. Antennæ of the males terminated by a hook . $\quad 29$

a. Species having the appearance of the true Zethus.

Head more wide than high; thorax short, not being one and a half times longer than wide: dilatation of the petiole elliptical or cylindrical, a little contracted behind; the second segment of the abdomen in form of a globular bell

B. Species which have more the appearance of $E$ menes or Discrilius. Head less inflated, less hollowed out at the occiput; thorax of moderato length; petiole more as in the Eumenes of Dirision 
$\boldsymbol{\gamma}$. Petiole quite linear, fliform, depressed, very much elongate, as in Eumenes of Division $\zeta$. Facies of a Culligaster.

C. Species which I do not know, and of which the antennæ $(\delta)$ have not been described . • 43

Division Didymogastra Perty • . . • 45

A. Antennæ of the males terminated by a rolled spiral 45

13. Antennæ of $\delta$ terminated by a look . . . 50

C. Species of which the section remains undetermined 51

Gen. Labus Sauss. • . . . . . . . 56

Gen. Discœlius Latr. . . . . . . . . 58

Legion II. The Odynerites • • • • • • 59

Gen. Eumenes Fabr. . . . . . . . . 59

Division Pachymenes . . . . . . . 60

1. Form rather lengthened; thorax longer than wide; abdomen haldly depressed, the $2 d$ segment not campanular . • • . . .

A. Petiole campanular, enlarged above beyond the middle, humped, the boss divided by a groove; its extremity bordered by a salient band . 61

a. Thorax rather compressed, lengthẻned . • 62

b. Thorax not compressed, moderately wide • 63

B. Petiole pyriform, depressed, less inflated abore, not divided by a groove . . . . . 66

Division Omicron . . . . . . • • 68

A. Thorax quite short, cubic-globular, larger than the pear of the abdomen; the $2 d$ segment of this wider than long (as in genus Tatua), wide-globular

B. Thorax a little more long than wide. The $2 d$ segment of abdomen sometimes rather elongate

C. Thorax not so wide; longer than broad; not larger, or even smaller than the pear of the abdomen. (Form very much as in Division Alpha.) . .

Division Beta. • . • • • • .

a. Mandibles short, pointed in the males; blunt, rounded at tip, with separated small teeth in the females . • . • • • • .

b. Mandibles more elongate, not truncate, rather hooked at tip, with strong teeth on the interior margin . 90

Division Alpha (Eumenes proprie dicti). • • • 92

A. Large species, with black wings. The pear of the abdomen rather depressed . • • . .

B. Smaller species, with the abdomen more globular or compressed. (Regular type of Dirision Alpha) 
a. Wings smoky, with violet iridescence . . 95

b. Wings transparent or yellowish . . . . 98

* Second abdominal segment witlout lateral yellow spots • • • . . . . 98

** Second abdominal segment with a yellow spot on each side (sometimes wanting in variety) 101

*** Second abdominal segment having on each side a yellow fascia, or a complete transverse yellow kand on its middle. • . . 102

c. Species of uncertain origin . . . . . 105

Division Zeta . • • • • • . • . 105

Geu. Montezumia Sauss. • • • • • • 110

Division Antezumia. Head flattened before. Abromen pediculate. (Appearance nearly like some Pachymenes) • • • • • • • • . 113

Division Metazumia • • • • • • . 114

Division Montezumia (propr. dict.) • . . 117

1. Abdomen pediculate . . . . . . 117

2. First segment of the abdomen subsessile . . 118

A. Thorax moderately lengthened, first abdominal segment funnel-shaped, convex, divided by a feeble groove. Vertex somewhat swollen . 118

a. Wings transparent or ferruginous . . . 113

b. Wings obscure, smoky, fuscous or black . . 119

* Body more or less ferruginous . . . 119

* Body quite black. . . . . . 124

B. Head strongly dilated on the vertex behind the eyes. Thorax much lengthened. First segment of the abdomen depressed or flattened above and divided by a very distinct groove . . 127

Division Parazumia • • • • • • . 127

Division Pseudozumia . . . . . . . . 127

Gen. Monobia Sauss. • • • • • • • . 129

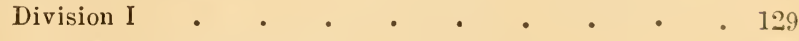

A. Metathorax bispinose . • . . • 129

B. Metathorax rounded, unarmed . . . . 132

Division II • • • • • • c . . 132

A. Abdomen conical; the first segment wide and truncate. Hinder portion of the netathorax bordered by trenchant ridges and armed on each side with a dentiform angle . . . . . .

B. Abdomen ovalo-conical; the first segment more rounded, less truncate, less sessile. Metathorax romuled: its concarity not bordered above by trenchant ridges . . . . . . . 134 
a. On each side of metatloorax a dentiform angle . 134

b. Metathorax without distinet spiniform angles . 137

C. Abdomen slightly fusiform, enlarging as far as the extremity of the $2 \mathrm{t}$ segment; the 1 st segment a little funnel-shaped, diviled by a feeble longitudinal groove. Thorax lengtleued . . . 137

Gen. Nortonia Sauss. . . . . . . . . 139

Gen. Rlynchium Latr. . . . . . . . . 142

Gen. Odynerus Latr. . . . . . . . . 143

Definition of the subgenera . . . . . 149

Subgenus Symmorphus Wesm. . . . . . . . . 151

a. Segunents 1-4 of the abdomen bordered with yellow 152

b. Segments $1,3,4$ of the abiomen bordered with yellow 153

c. Segments 1, 2 only, of the abdomen bordered with yellow . . . . . . . . . 155

Subgenus Ancistrocerus Wesm. • . . . . . 157

Division Ancistrocerus (properly speaking) • • • 157

Table to assist in the determination of the species of Ancistrocerus . . . . . . 158

I. Metathorax haring its concavity angulate, bordered all around by trenchant ridges . . 159

A. Form lengthened, slender . . . . 160

B. Form still lengthened, but less slender . • 163

C. Body more gathered, normal, but the thorax still sensibly longer than wide . . . 167

a. Netathorax destitute of strong spines . 167

b. Metathorax having two strong spines . . 173

D. Form very stubbed. Thorax cubical, nearly as long as wide. . . . . . 170

II. The concavity of the metathorax forms no distinct lateral angles • • . . . . 177

A. Posterior face of metathorax remaining margined, but without distinct angles. Body slender, elongate . • • • • 177

a. Post-scutel strongly truncate . . . 177

b. Post-scutel not truncate, angulate posteriorly 179

B. Metathorax not distinctly marginate. Body not slender, of normal form . • . 180

a. Abdomen nearly conical. The border of the $2 \mathrm{~d}$ segment not reflexed. Body velutinous

b. Abdomen more oralo-conical; the border of $2 \mathrm{~d}$ segment rugose or rellexed. 
c. Abrlomen not as sessile; its first segrnent distinctly narrower than the second, which is in the shape of a hawk's bell, with a reflexed margin. Metathorax not excavater in the form of a wide cavity, but of a wide channel

Division Stenancistrocerus . . . . . . 189

Table to assist in the determination of the species of Division Stenancistrocerus

1. Form lengthened. Metathorax prolonged norizontally behind the post-scutel, then truncate vertically, etc.

2. Form very slender. Metathorax not so distinctly produced behind the post-scutel; its concavity large, etc. . . . . . .

A. First segment of the abdomen rather funnelshaped or bell-shaped, truncate anteriorly .

B. First segment of the abdomen in form of a prolonged bell, rather squarely-rounded, about as wide as the second segment, not contracted before . . . . . . 198

a. First segment sharply truncate anteriorly . 198

b. First abdominal segment more rounded anteriorly, rather like a square bell . .

3. Form slender, but the abdomen sometimes slender, sometimes ovoid, especially among the $\delta$. The first segment cupuliform, narrower than the $2 \mathrm{l}$, having the suture indistinct, often presenting a transverse fluting bordered by two traces of sutures. Concavity of the metathorax generally small, its borders indistinct . . . . .

a. Suture of the first abdominal seguent rather strong; excaration of the metathorax somewhat distinctly margined . . . .

b. Suture of the first abduminal segment not so strong. Excavation of metathorax haviug its edges rounded, without precise limits . 20?

Division Hypancistrocerus . . . . . . 210

Division Ancistroceroides . • . . . . 211

Subgenus Odynerus Latr. (sensu strictiore) . . . 212

Division Hypolyuerus . . . . . . . 213

Table to assist in distinguishing the species of the loivision Ilypodyuerus . . . . . $216^{\circ}$ 
I. First segment of the abdomen bell-shaped, pyriform, uniformly a little comb-shaped. Appearance of Montezumia

II. First segmeut of the abdomen offering an anterior and a superiur face separated by a sort of transverse ridge or swelling (the true Hypodynerus) . . . . . .

A. Form lengthened; first abdominal segment small, nodiform or pedunculiform, very much narrower than the $2 d$; its anterior face in a lengthened triangle . . • .

B. Form shorter, wider; first segment wide on its posterior border; its anterior face in the form of an equilateral triangle and a little pedicellate; its superior face large . .

a. Wings rufous along the anterior band .

b. Wings fuscous, with violet iridescence -

C. Form very wide, short and depressed, first segment very wide; its anterior face sessile, in the form of a wide triangle; its superior face very short, 3-4 times as wide as long

D. Form also quite chubby, but not so much depressed; metathorax rounded, flat or convex behind, smooth, without marginal edges; first segment of the abdomen very short; its superior face transverse-linear. (Appearance of a Vespa.) . . . . . .

Division Pachodynerus . . • • • .

Table to assist in distinguishing the species of the

Division Pachodynerus . . . . .

1st Section.-Thorax cubical (at least among the males) or square, lengthened. Abdomen conical ; the first segment very large, as wide as the second . . . . . .

A. All the segments except the first bordered with yellow . . . . . .

a. Metathorax forming a lateral angle on each side. . . . . .

b. Metathorax rounded, not forming on each side a dentiform angle $\cdot$. $\cdot$.

B. All the abdominal segments margined with yellow or rufous . . . . . . 237

a. Superior edges of metathorax not sharp - 237

b. Superior edges of metathorax sharp . . 238 
C. Only the first two abdominal segments margined with yellow. (The $3 d$ and 4 th sometimes indistinctly marginate.) . . . .

$2 d$ section.-Form more lengthened; thorax lengthened square or retracted behind. Abdomen less conic, more cylindrical or depressed.

a. All the segments of the abdomen, except the first, bordered with yellow . . . 244

b. Abdomen varied with black and rufous . 245

Division Odynerus • • • • • • • • 247

Table to assist in distinguishing the Division Odynerus and Stenodynerus, with regard to Pachodynerus.

Table to assist the determination of the species of Divi-

sion Odynerus . . . . . . .

Section I.-Post-scutel sharply truncate; its transverse edge often creuulate. Abdomen conical or ovate-conical; the second segment not strangulated at base; the first segment including it very naturally . . .

1. Posterior plate of metathorax angulate, forming on each side a lateral dentiform angle.

A. Concavity of the metathorax polygonal, margined with straight or arcuate ridges, which form at their meeting a sharp angle. The superior lateral edges superiorly terminating in a tooth or eminence, separated from the post-scutel by a deep fissure, or by a notch . . . .

a. Ridges of the metathorax very salient; its posterior face excavated . . .

* Posterior margin of $2 \mathrm{~d}$ and $3 \mathrm{~d}$ abdominal segmelits reflexed . . . .

** Posterior margin of $2 d$ and $3 d$ abdominal segments not reflexed, but impressed and rough . . . . .

b. The hinder face of metathorax more flattened; its superior edges not so salient

* The superior ridges forming two elevated spines behind the post-scutel .

** The superior edges of metathorax rery slight, only forming behind the postscutel two very small teeth . . 20 
B. Metathorax as in Section A, but the superior edges of its hinder plate not so much elevated, no longer forming, in the females, distinct teeth behind the postscutel, etc.

a. Hetathorax excavated; edges straight

b. Metathorax more flattened; the superior edges roughened, not acute . . .

C. Hinder plate of metathorax no longer margined superiorly by sharp edges; lateral angles still existing . . . . .

2. Posterior plate of metathorax orbicular or more or less ronnded, not forming on each side a distinct dentiform angle.

A. Posterior plate of metathorax still margined with sharp edges, salient in its superior part, and forming on each side at the summit a tooth or elevation, separated from the post-scutel by a fissure (sometimes very small). . . . .

a. The concarity deep, excavated, with salient ridges. Abdomen conical; its base sharply truncate . . . . .

b. Posterior plate of metathorax less excavated; its marginal edges but slightly salient, although still sharp. Abdomen orate-conical, slightly attenuated at base

B. Posterior plate of metathorax no longer margined with sharp ridges, and not forming post-scutellar teeth

a. Posterior plate of metathorax much excavated, margined with salient, blunt, and rough edges

b. Posterior plate of metathoras more flattened; its margins rounded and punctured • • • • • .

Section II.-Body yet stubbed, not slender, nor cylindrical. Abdomen not conical, but still sessile; the 1st segment smaller than the $2 \mathrm{~d}$, as strongly or more strongly punctured than the $2 d$; the $2 d$ constricted at base to fit into the first and more or less deformed; having its margin very strongly canaliculate and reflexed, and more or less swelled before tlie channel 
A. Metathorax not narrowed below, much excavated, with very slıarp edges; post-scutel bituberculate; abdomen quite deformed.

B. Metathorax triangular, narrowed posteriorly, not so much excavated, with sharp superior ridges. Post-scutel not crested. Second abdominal segment channelled and reflexed, scarcely swollen . • . • . 299

Division Stenodynerus . . . . . . . 301

Table to assist in the determination of the Stenodyneri 304

I. Metathorax having its posterior plate superiorly terminated by two erect teeth, or by au erect crest • • . . . . . .

A. Metathorax not prolonged beyond the postscutel, but truncate at its apex, posteriorly excavated, angulate on each side; the superior edges of the posterior plate terminating in two erect spines, which are separated from the post-scntel by deep fissures . . .

B. Metathorax truncate, excavated; superiorly margined by an arcuate ridge, rather crenulate, separated on each side from post-scutel by a fissure

C. Form not very slender. Netathorax produced horizontally beyond the post-scutel; then vertically truncate; the post-scutel quite enveloped by it posteriorly, not reaching up to the edge of the posterior face of metathorax; the posterior face of metathorax superiorly terminating in an erect crest, parted by a fissure. Vertex in $q$ having two pilose tubercles . • • • • • .

II. Metathorax not forming erect spines or crests behind the post-scutel. Its superior face not produced behind the post-scutel. This last not posteriorly truncate, but angular. Costscutel generally yellow, scutel usually black

1. Body slender, cyliudrical. Concavity of the metathorax wide, sometimes rather distirctly limited. First ablominal segment bell-shaped, ratlier elongate, widely rounder anteriorly, sessile or subsessile. Thorax rather elongate, vaulted, subcylindrieal . 
A. Netathorax slightly prolonged under the postscutel beyond it, being truncate before; its concavity margined with sharp edges, nearly angulate on each side

Abulomen slender, cylindrical; first segment as wide as the second. Body relrety

B. Metathorax scarcely, or not distinctly produced under the post-scutel, beyond it . Abdomen elongate, cylindrical, with ihe 1st segment as wide as the $2 \mathrm{~d}$, elongate; or oroid-elongate with the 1st segment a little narrower, rounded . . .

* The 1st and $2 d$ abdominal segments each adorned with two yellow spots, or fascir beside their marginal fascia.

** Only the second abdominal segment adorned with two yellow spots which are often wanting, principally in the males

*** No free yellor spots on the first tro abdominal segments . . .

2. Form less cylindrical, not much elongated, the thorax often short, and wide anteriorly, contracted posteriorly. Netathorax more convex, rounded; its fossette generally sinall, but always distinct. Abdomen ovoid or irregular, the first segment narrower than the second, not truncate anteriolly, nut as sessile; second segment more swelled than in the preceding, short and convex, contracted at base to fit into the first

A. Form rather stouter, abdomen rather wide in the middle, but yet attenuated before. The fossette of the posterior face of metathorax rounded, almays distinct . .

a. Thorax but slightly adorned with yellow; (sometimes quite black, with a yellow spot under the ring); post-scutel quite black or adorned with two yellow dots.

3. Anterior margin of prothorax adorned with yellor, but not the posterior margin; the yellor fascia of en bilohed or interrupted. Fossette of metathorax large, rather triancular. ncenpying nearly the whole width of the metathorax . 
* Sometimes there are two little free spots on the $2 d$ abdominal segments . . 334

** No lateral yellow spot on the abdomen. 3:3á

c. Posterior margin of prothorax, and often also the anterior margin bordered with yellow. (Insects often velvety.) .

d. Prothorax qnite yellow above. Scutel and post-scutel yellow.

3. Body elongate, slender ; the abdomen especially, very slender. Metathorax convex, having no longer a distinct excavation, but sooner parted by a large groove, which separates its two cheeks. Abdomen slender, spindleshaped; the first segment elongate, funnelshaped, sometimes subpedunculate . .

III. Metathorax not produced superiorly beyond the post-scutel, convex; its hinder face parted by a deep gronve. Post-scutel truncatehaving a sharp edge . . . . . 352

A. Metathorax quite unarmed superiorly . . 352

B. Metathorax armed superiorly with two tubercles, sometimes very small . . . 355

Subgenus Epiponus • • • • • • • . 360

Division Antepiponus . . . . . . . 361

Division Epiponus . . . . . . . . 363

Appendix to the genus ()dynerus . . . . . . . 30't

Gen. Leptochilus Sutss. . . . . . . . . $366^{\circ}$

Gen. Pterochilus Klug. . . . . . . . . 368

Gen. Ctenochilus Sauss. . . . . . . . 372

Gen. Alastor Lepel. St. Farg. . . . . . . . . . 373

Gen. Smithia Sruss. . . . . . . 375

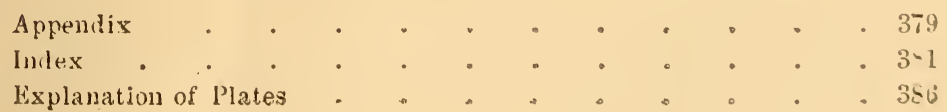





\section{VESPID㐫}

\section{OF \\ A M E R I C A.}

\section{FAMILY VESPID无.}

Characters. - Wings folded longitudinally when at rest. Prothorax extended backward as far as the origin of the wings.

Mouth. Mandibles variable. Lip quadrifid or quadrilobed, sometimes only bifid; labial palpi not having more than four articles; maxillary not more than six articles.

Aniennæ elbowed, forming either a lengthened or a subfiliform club, composed of twelve articles in the females, and thirteen in the males.

Eyes ernarginate (except Paragia).

Abdomen sessile (without apparent petiole) or pedicellate, composed of seven segments in the males and of six in the females, and armed with a retractile sting.

Legs slender, without hairs.

Wings always presenting. two recurrent nervures and three or four cubital cells. Both sexes are always winged.

The Vespidx are easily recognized by their folded wings (when at rest). It is true, this character is not always very distinct, especially among the Masarinx and Raphiglossinx, but in this case one identifies them with ecrtainty: 1st, by their elbowed antennæ; 2d, by their prothorax, which, instead of forming a knobbed or transverse collar, offers a distinct upper surface, prolonged on each side as far as the wing seales; ${ }^{1} \mathrm{bd}$, also by their

1 As among the Pompilice and Pepsider, from which they are distinguished aspecially by their elbowed antemne, prolonged into chubs, by their folded wings, eto. 
general appearance, which is much more easily detected than described.

The habits of the Vespidx are quite different; some being social, some solitary, liṿing by rapine, and some parasitic.

These three moral tendencies correspond to the special forms which characterize the groups, into which we have separated the following subfamilies:-

I. Masarixe, or Parasitic Wasps. - Wings having an indistinct duplication. Antennæ sometimes enlarged into a club, their last articles often soldered together. Prothorax generally convex before. Scutel superposed upon postscutel. Claws of tarsi generally unidentate; posterior and inter. mediate tibiæ terminated by two articulate spines. Lip quadrifid or bifid.

Wings having but three cubital cells. Eyes slightly emarginate.

II. Eumexise or OnYNerise, ${ }^{1}$ or Solitary Wasps.-Wings having a more distinct duplication, al ways offering four cubital cells. Antennæ subfiliform, with the articles distinct. Lip lengthened, quadrifid. Claws of the tarsi unidentate.

III. Vespine, or Social Wasps.-Haring the same characters as the Enmeninæ, but the claws of the tarsi not toothed; the wings always having a very distinct duplication; the lip short, quadrilobed.

The Masarine can easily be distinguished by the inner neura. tion of their wings, etc. ; but the solitary and social wasps present so few distinctive general characters, that they are always puzzling. It will hardly be deemed superfluous to gire hare a table of empirical characters which may assist in distinguishing them in every case.

I In my "Etudes sur la Famille des Vespides" I have given to this tribe the name of Eumeniens (Eumenine), after the oldest genus of the tribe. But as the genus Odynerus is inuch more important, and as the trilie Vespince is named after a sessile genus, I have thought best to adopt in preference that of Odyneriens (Odynerina) for the sake of confurmity in the names of both tribes. 


\begin{tabular}{l} 
Soli'ary Wasps. (Odynerinx.) \\
\hline Mandibles often long and sharp, or \\
having latcral teeth. Labial palpi \\
with three or four articles. Maxil- \\
lary palpi with three, four, five or \\
six articles. \\
Eyes always extending to the base \\
of the mandibles. \\
Thorax always wide and truncate \\
before. \\
The second abdominal segment al- \\
ways the largest, widening like a \\
bell, and like a socket to those \\
following. \\
Clypeus variable, emarginate, biden- \\
tate, truncate or rounded on its \\
inferior border; never terminated \\
by a tooth. \\
Second cubital cell always narrowed \\
toward the radial. \\
The second recurrent nervure some- \\
tines received by the third cubital \\
cell.
\end{tabular}
$\frac{\text { Social Wasps. (Vespiax.) }}{\text { Mandibles al ways short and obliquely }}$ truncate, with the teeth rather ter- minul. Labial palpi always with four articles. Maxillary palpi with five or six articles.
Sometimes an open space between the base of the inandibles and the eyes. Thorax solnetimes strongly contract- ed bef re.
The second segment sometimes fun- nel-shicped. The third segment in that case the largest and a sort of socket for those following.
Clypeus often cordiform, terminated by an angle or sort of tooth or by a rounded lobe.

Second cubital cell sometimes square.

The second cubital cell always re. ceiving the two recurrent nerv ures.

\section{TRIbe MASARIN Æ.}

\section{(Parasitic Wasps.)}

Among these insects one notices in the antennæ a tendency to consolidation of the articles and to a rurlimentary condition of the maxillary palpi, as in general among parasitic insects. The abdominal segments among some species are constricted at the base so that one cannot receive another within it.

The wings often fold with difficulty; they offer but three cubital ceils, and the two recurrent nerrures always terminate upon tho second.

The lip is at times quadrifid, and sometimes bifid. When bifid it is also extensile by virtue of a peculiar mechanism.'

We know as yet but two representative general of this tribe in America-one of which forms a genns limited to this continent.

1 See: Saussure, Etudes sur la Famille des Vespides, IlI, 23, etc. ; aul Aunales des suiences Naturelles, 1557 , VII. 


\section{Gen. 'TRIMEIRIA Sauss.'}

Antennæ clubbed, lengthened; the last articles very indistinct. Lip not extensile, tongue shaped, bifid. Labial palpi composed of three articles; maxillary apparently of none. Mandibles tolerably sharp. Abdominal segments constricted at their base ; not retractile.

\section{T. americana SAUSS.}

Erinnys americana Sauss. Am. Soc. Ent. Fr. 3d ser. I, Bull. xx, 1853.Trimeria americana Sauss. Vespides, III, 1854, 81, Pl. iv, fig. 2 ,.

Hab. Brazil.

\section{Gen. MASAIRIS FAB.}

Antennæ of $\delta$ long, of $q$ short, composed of twelre articles, of which the five last are soldered into a single bare mass (leaving but eight articles apparent). Articles 4-7 long in the males, short in the females, and incompletely soldered; the terminal mass (8th article) forming an oval club in the male, variable among the females. Lip extensile; the tongue bifid, inclosed in a contractile sheath, in the form of a lamina, placed edgewise: labial palpi short. ${ }^{2}$ Jaws short; maxillary palpi rudimentary. Mandible's short, arcuate, bidentate. Clypeus notched like the arc of a circle. Metathorax flattened behind (bispinose). Abdomen flattened beneath, the segments contracted at the base, the third and following not retractile into the second; the abdomen equally wide and rounded at tip in the $q$; lengthened in the $\delta$, attenuated toward the end, bifid at the anus, and segments 2-3 armed beneath with a salient process.

1 I at first named this genus Erinnys in commemoration of a discussion upon the antenna of Musaris which for a long time occupied the Fntomological Society of France (see loc. cit.); but finding this name already employed, I changed it to Trimerin, which seems scarcely better, as there are already two genera Trimera. Nevertheless I think it better to retain the new name, since it is not identical with the last.

2 See for the composition of the lip, Sauss. Vespides, III, 23, and Annales des Sciences Naturelles, 1857, VII. 
This remarkable genus counts as yct but five representatives, of which two are African, the others were recently discovered in North America.

The American Masaris differs from the $\Lambda$ frican by having the labial palpi much longer. The 1 st joint long; the $2 \mathrm{~d}$ very short, about one-third or one-fourth the length of the first; the $3 d$ arcuated, a little shorter than the first, and ciliated at tip. The 4th is quite rudimental, soldered to the inner face of the extremity of the third. The tongue is quite extensile as in the $A$ frican type. The maxillary palpi are also quite rudimental, only apparent as a little tubercle. The American Masaris are also distinguished from the African by the antennæ of the $\$$ which are more globularly clubbed, nearly as in Celonites. The males which I can only judge by the figure given, have also the terminal part more globular or at least less elongated than in MI. vespiformis.

1. Antennæ of $q$ clubbed, having 5 soldered terminal articles, slightly dilated, not forming a distinct knob; the first article very long. Labial palpi very short

M. vespiformis LATR. (North $\Lambda$ frica.)

2. Antennæ of $q$ terminated by a knob, as well as those of $\delta$; the five last articles forming an oval dilated mass. Labial palpi moderate.

1. M. vespoides Cress. - Nigra, flavo variegata, abdominis segmentis late flavo-fasciatis; fasciis $2-5$ utrinque nigro-maculatis; $6 \circ$ segmento fiavo-bimaculato; alis flavescentibus; scutello planato metanoto bispinoso; antennis $\delta$ elongatis, articulo primo brevi, globoso, ultimis $s$ in clavam ovalem glntinatis; $q$ brevibus, primo articulo tertio breriore, 30 elongato, 40, 50 mediocribus, ultimis 5 in clavam subglobosam glutinatis; abdomine $\delta$ apice fisso, segmentis $2-3$ subtus processibus 2 instructis.

Masaris vespoides Cresson, Proc. Ent. Soc. Philad. II, 1563, 69, Pl. is ; III, 673 .

$\delta$. Total length, 9 lines; expanse of wings, $15 \frac{1}{2}$ lines.

q. Total lengtl, 8 lines; expanse of wings, $1+$ lines.

Male.-Clypeus subquadrate, decply emarginate, with the angles rounded; mandibles somewhat obtuse, with two indentations near the apex. Antemna a little longer than the head and 
thorax; 1st joint short and thick, 3 d to 6 th about equal, somewhat flat; 7 th shorter, the 5 apical joints soldered into a broad oval knob, slightly concave beneath; the sutures somewhat distinct beneath. Metathorax forming on each side a somewhat flattened square angle, armed with an acute spine. Anterior femora rather curved and tibiæ dilated; posterior tibiæ armed with two spurs, one of which is elongate and deeply bifid. Tarsal claws simple. Abdomen elongate, convex above, gradually narrowed posteriorly ; apical segment subquadrate, deeply emarginate at the apex, with two longitudinal carinæ, each bearing a small obtuse tubercle on the posterior third of the segment; $2 \mathrm{~d}$ and $3 d$ segments beneath with a bifid projection at their base; that of the $3 d$ rery prominent and arined posteriorly with an acute spine.

Body black; clypeus, apex of the labrum, middle of the mandibles, a transverse dilated line between the antennæ and the inner and outer orbit of the eyes above the antennæ, yellow; antennæ above, with the base of the first and second joints black; the apex of 1 st, inner side of $2 \mathrm{~d}$, and the 4 following joints, yellow; the apical joints yellowish, varied with fuscous, blackish beneath. Anterior margin of prothorax, a spot beneath the wings, wing scales and a spot above, apex of scutellum and angles of metathorax yellow. Legs yellow, at base black. Each segment of the abdomen above with a submarginal yellow indented band; apical segment with a quadrilobed yellow spot. Wings stained with yellowish, nervures honey yellow about the base, fuscous toward the apex.

Female.-Form shorter. Clypeus widely and deeply emarginate, very coarsely punctured, roughly folded and reticulate at the top. Labrum carinated, elongated and rounded at tip. Forehead carinated transversely between the antenna. Head and thorax densely, metathorax finely punctured; scutellum polished. Mesothorax carinated. The thorax depressed; the angles of metathorax flattened and depressed, terminating in an acute spine. Abdomen finely punctured; the segments very little constricted at base. First joint of the anterior tarsi ratiner dilated.

Black, with fulrous pubescence. Antennæ fulvous; the 1st and $2 \mathrm{~d}$ joints blackish, the 1st yellow at tip; the club obscure on the upper side, blackish at tip. Palpi, the middle of mandi- 
bles, borders of labrum at base, a transverse line at top of clypeus and orbits of the eyes behind and over the emargination, yellow. Anterior border of prothorax and sometimes also the posterior edge, tegulæ, a spot under the wings and the angles of the metathorax, yellow. All the abdominal segments bordered by a wide yellow band, the first beneath interrupted;" the three following more or less emarginate in the middle, and with a black transverse spot on each side. Anal segment with two yellow maculæ. Feet yellow; black at base. Wings a little grayish, with basal and costal veins ferruginous. Radial cell having its greater width in the middle of its length; $2 d$ recurrent vein inserted after the middle of the border of the $2 d$ cubital cell.

The yellow ornaments of $\delta$ vary much in form and extent; still more in $q$, the bands being of very different width, emargination, spots, etc. The bands are sometimes emarginated in midcile, and even interrupted on each side by the emargination. Sometimes the fascia at head and thorax are divided into several dots.

Var. a. Sides of clypeus and labrum not margined with yellow; no spot on the mandibles; a yellow spot at top of clypeus.

b. No yellow spot beneath the wings, no spots on mesothorax.

c. Metathorax with posterior angles slightly produced and tipped with yellow.

This insect differs from $M$. marginalis by its very rough clypeus, by the carina of the forehead, its depressed thorax, by the spines of metathorax, etc.

It has much resemblance to $M$. vespiformis; but the knob of the antennæ of the $\delta$ is shorter; the projections of the $2 \mathrm{~d}$ and 3 d ventral segments are also differently constructed, that on the 2d segment of the American species being less developed and bifid, while that of the $3 d$ segment is strongly developed, bifid, and bearing an acute spine behind. The antenna of the $q$ are very different; the 1 st joint being shorter than in M. vesprformis, and the apex more swollen, as in Celoniles. The color and distribution of the markings of $q$ is also rery different. M. reypiformis $q$ having its ormaments rufous and much more developed. Nevertheless the two species are so closely allied, that it is impossible to separate them generically.

Inhabils Rocky Mountains, P'ike's Pcak. (Coll. Ent. Soc. Phila.) 
This fine insect was discorered by W. J. Howard, and described by L. 'T. Cresson. Numerous individuals were taken by Ridings in Colorado Territory on a plaut allied to Lobelia.

2. M. zonalis CRess.-Nigra, fusco-hirta; antemnarum articulis 4, 5 brevibus; clypeo areuatim emarginato; thorace parum depresso; seutello carinato; metanoto utriuque canthum compressum longe spi- uosum effïciente; corpore valde sulfureo-variegato; abdomine fasciis coupletis 5; ano bimaculato; alis subferrugineis. $\$$.

M. zonalis Cressox, Proc. Ent. Soc. Philad. III, 1864, 674, 2. ㅇ. $\hat{\delta}$. ․ Total length 15 mill.; wing $8-9 \mathrm{~mm}$.

\$. Clypens notched in arc of circle, conrex, finely punctured. Lahrum triangular, rounded at tip, pubescent, with fulvous hairs. The whole insect rery finely sculptured. Thorax but little depressed. Metathorax flattened behind, but not depressed ; the angles compressed into strong carinæ, armed on each side with a long spine, as in $M$. vespoides.

Black, with brown hairs. Antennæ fulrous; scape black, with a yellow spot; 2 d joint black; $3 d$ rellow; those following very short; the club blackish above. Mandibles, a spot in the forehead, the whole orbits, the hind margin of prothorax, and (partly or completely) the fore margin, a spot under the wing, tegulæ, post tegulæ, margin of scutellum and the angles of metathorax, sulphur-yellow. A complete and regular submarginal fascia on all the segments of the abdomen; beneath, only lines of maculæ; 6th segment abore, with two rellow spots. Feet black at base, rellow from the knees to the end. Wings as in the preceding, with ferruginous reins; radial cell rather brown; 1st recurrent vein inserted nearly at the inner angle; the $2 \mathrm{~d}$ about in the middle of the 2 d cubital cell.

Var. A rellow spot on the clypeus; 2 spots on the forehead; antennæ more black; a rellowish tip on the coxæ. Fasciæ of the abdomen a little emarginated; the band of the 6 th complete.

$\delta$. A larger subquadrate spot beneath the insertion of the antennæ, and the clypeus and labrum pale rellowish-white. Clypeus shaped like that of $\boldsymbol{M}$. vespoides $\hat{\delta}$, but more flattened and less deeply emarginate at tip; antennæ rather longer than head and thorax, proportioned as in Vespoides $\hat{\delta}$, except that the club is not at all flattened beneath; the joints pale yellowish- 
white above or rather exteriorly, the two basal joints more or less black above at base, the fourth, fifth, and sixth joints at tip beneath, and the whole of the remaining joints beneath, pale fulvous; the club above at tip, more or less black; the five articulations of the club are closely soldered together, the sutures indistinct. Wings as in M. vespoides $\delta$. Legs shaped as in Vespoides $\delta$, except that the anterior tarsi are scarcely ciliated, and the basal joint of the posterior tarsi is scarcely as long as the four remaining joints together, shaped like that of Vespoides $\delta$; shining black; all the segments except the terminal one, with a continuous pale lemon-yellow band; those on the fire basal segments more or less emarginate on each side anteriorly; the band on the sixth segment generally entire; apical segment black, polished, deeply bifid or forked at tip when viewed from above; when viewed in profile the tip is rather broad and obtusely emarginate, the lower process being the shortest and stoutest; when viewed endwise the tip has a subtriangular shape, concave, more or less lemon-yellow, with the lower process rather deeply emarginate; venter flattened, shining black, most of the segments with a lateral yellowish spot; the second segment with a more or less developed fold anteriorly, obtusely emarginate on the middle; on the disk of the third segment a large, robust, welldeveloped process, obtuse at tip, but with a short, stout, subacute spine posteriorly, similar to that of Vespoides $\delta$, but less developed. Length 5 lines; expanse of wings 9 lines.

This species is nearly the miniature of Vespoides, but is nevertheless a very true species.

The male differs from that of $M$. vespoides in sereral points of structure, viz., the club of the antemm is rounded and not flattened beneath, the basal joint of the posterior tarsi is scarcely as long, while in Vespoides $\delta$ it is almost twice as long as the remaining joints; the apical segment of the abdomen differs much from Vespoides $\delta$, in having no carinse on the disk, and in the tip being much more deeply bifid, both above and bencath, and the projection on the third rentral segment more robust, and not compressed or emarginate at tip as in Vespoides $\delta$.

In the $q$ the thorax is less depressed, but a little more than in marginalis. The yellow ormanents are more abundant; the abdominal fascia entire. The scutellum is carinated, while it is 
not in Vespoides; the fore part of the mesothorax is also carinated, but the hind part is depressed, while in Tespoides it is rather elerated. The 4 th and 5 th joints of the antennæ are quite short, while in Vespoides the 4 th is longer than broad.

Hab. Rocky Mountains, Colorado Territory.

$\mathrm{Mr}$. Ridings discovered this species in August on a plant most likely to be of the genus Phacelia.

3. M. marginalis Cress.-Nigra, tenuissime punctulata; thorace quadrato, haud depresso, angulis metanoti compressis, haud spinosis; macula frontis, marginibus pronoti, tegularum abdominisque segmentorum 1-5 margine luteo; tibiis et tarsis luteis. $q$.

1. marginalis Cresson, Proc. Ent. Soc. Philad. III, 1864, 677, $q$.

․ The whole insect, including the head and clypeus rery finely punctured, coriaceous. Thorax quadrate, a little longer than wide, not depressed as in M. vespoides, very finely punctured, a little rougher along the anterior margin of mesothorax. Clypeus convex, not carinated, not so much emarginate as in Vespoides. Labrum triangular, with the tip truncate and rounded; its margin and pubescence fuscous. The angles of metathorax not depressed, but compressed, not spined. Pubescence black (or grayish, when not fresh). Palpi, tip of mandibles, a line along the orbits behind and on the upper part of the sinus in front, a transverse line or 2 spots at the insertion of the antennæ, luteus. Antennæ fulvous ; the 1st joint and upper part of the club, blackish; the other joint rather obscure on the upper side. Border of anterior and posterior edge of prothorax (more or less), and outer half of tegulæ, whitish. Abdominal segments 1-5 adorned above with a narrow whitish band, not quite marginal, sometimes interrupted; at least the first. Tibiæ luteus, tarsi fulvous. Wings lyyaline, with ferruginous reins; radial cell pear-shaped, narrowly produced at its inner extremity; both recurrent reins inserted before the middle of the 2 d cubital cell.

Var. The bands of head and thorax replaced by mere dots; clypeus with a white line; a macula on the pleura beneath the wing; anal segment with 2 white dots; the 3 d segment beneath with a row of white dots.

Differs from MI. vespoides by the finer punctuation, not rough clypeus, not carinated labrum, by its forehead without carina, etc.

Hab. Rocky Mountains, Colorado Territory. 
This insect, like the preceding, was discovered by Mr. Ridings. I have a specimen of each of the three species here described through Mr. Edw. Norton

\section{'TRIBE ODYNERINA.'}

\section{- (Solitary Wasps.)}

Nails of the tarsi uniclentate. Clypeus never terminated by a tooth; mandibles long, prolonged in the form of a sharp beak, or truncate, trenchant or dentate; lip lengthened, often very long, always quadrifid, its lateral lobes forming long prongs separated even to its base and articulate.

In general, each of the four divisions of the tongue has at its extremity an opaque horny point; but in some cases these points disappear, and the lobes become very long, linear and plumose (Synagris).

Antennæ scarcely clubbed, lengthened, simple in the $q$; terminated in the $\delta$ by a hook, or twisted spirally at the extremity, or simple. Eyes strongly emarginate; thorax always wide before; metathorax not prolonged.

The abdomen is quite variable, but the second segment is always the largest; those following are retractile, and can easily be foreed back into the second.

The solitary wasps have not the nabit of living in society, and it is this characteristic which establishes the principal difference between the Odynerina and Tespina; for those distinctions which are drawn from their organization are not of much consequence, and can be reduced to the difference of claws, which in the solitary wasps are armed with one tooth, and are simple among the social. The solitary wasps have, in fact, more carnivorous instiucts. Although nourishing themselves by sucking flowers, they attack very many larva, spiders or other animals, to provide food for their offspring. Their larve are earnivorous, although the per-

1 See on page 2 and 3 the table to aid in distinguishing the Odlynerince and Vespince. 
fect insects sustain themselres by sucking regetation. The Odynerine establisll their nests in holes in walls, in the hollow interior of the stems of certain plants, or in habitations which they construct in the open air, of clay or of some regetable and gummy substances. The eggs deposited in these nests are abundantly provided with larra or insects stupefied and reduced to a state of liring mummies by the effect of the poison of the mother. These animals so inclosed are incapable of defending themselres, but retain sufficient life to prerent decomposition, and serre for the support of the larve of the wasps. The nests, after haring been provisioned, are carefully closed by the mother with clay, with just sufficient corering that the young insect can pierce it to escape when it has undergone its last transformation.

Certain species of Odynerinæ (Zethus) appear to manifest a tendency toward social habits; they form small agglomerations of nests which resemble a little the irregular nests of humble bees (Bombus), but grouped ret more confusedly. But there always prerails this difference between the cells formed by the social and those made by the solitary Hymenoptera that the first have a cylindrical inner space, while the second are rather extended masses which are not in regular juxtaposition, so that they seem more like splieres and ellipsoids joined together, than cells constructed side by side on a general plan. In other words, the solitary species never seek to form a comb, although they sometimes form agglomerations of cells. The most part of them do not construct these rough cells one upon another, but disperse them into different positions.

\section{THE ANOIMALIPENNES.}

The first recurrent nervure receired by the second cubital cell; the second recurrent nerrure receired by the third cubital cell.

I. Lip extremely lengthened, bent back under the sternum; mandibles truncated obliquely, having terminal teeth.

Genera: Raphiglossa Sacxd.-Sienoglossa Sauss.

Not known to be represented in America.

II. Lip shorter; Mandibles moderately long, sharp. 


\section{Gen. GA EELA SPIN}

Mandibles forming a beak by their union; labial palpi composed of four articles; maxillary, of six. First segment of the abdomen eontracted in the form of a knob or an inflated disk.

\section{Gayella eumenoides SpIN.}

Gayella eumenoides Sprox. Gay's Fauna Chilena (Hist. fisica de Chile), Zool. VI, 1851, 333, 1, pl. ii, fig. 2.-Sauss. Vespides, I, 1852, 6, pl. viii, fig. 4.

Hab. Chili.

\section{THE NORIIALIPENNES.}

The two recurrent nervures received by the second cubital cell.

\section{Legion I. The Zethites.}

Mandibles short, obliquely truncated at the extrenity, with teeth placed on the oblique border of the truncation, and so rather terminal than lateral (vide Saussure, Vespides, I, pl. ii, 1c, 3c; pl. iii, 1c, 3c) ; forming by their union an obtuse beak.

\section{Gen. ZETIIUS FABR.}

Mandibles short, obliquely truncated, and in general armed with teeth placed on the oblique terminal border. Lip and jaws lengthened; labial palpi composed of 3-4 not feathery articles; the maxillary, of 6 .

Head large, expanded, in general wider than the thorax, discoidal or wider than long, swelled behind the eyes and emarginate like an arc of a circle on its posterior face. Antenne inserted in the middle of its height. Clypeus rounded or in a large square, in general wider than long.

Thorax slightly contracted before, sharply truncated on its anterior extremity, so that there is a space in the form of a circle between the head and anterior border of the prothorax; this last generally flanged, carrying a crest in form of a sharp plate or edge. 
Abdomen pediculate; the first segment in the form of a petiole, linear at its base, next inflated, and finally more or less contracted at its extremity, which renders the inflation globular or elliptical. The second segment, in form of a rounded bell, is often pediculate.

Sexual differences. - The males have the clypeus transrerse, quadrate, broad. Their antennæ are terminated either by a hook, or by a spiral. ${ }^{1}$ The females have the antennæ simple and the clypeus discoidal, often convex or lozenge-shaped, transverse.

Insects $A$ merican.

This genus is easily recognized by its peculiar face, its transverse clypeus, large head, and the singular form of its abdomen. ${ }^{2}$

Among the Zethus the mandibles are quite short, overlapping beneath the clypeus; their triturating edge is terminal, not lateral as among the Eumeninæ.

The size of the head is such that the eyes do not entirely cover the cheeks. The metathorax has such variable forms that it recalls what one sees in the Odynerus; one can always here distinguish two lateral ridges, which cxtend from the base of the wing to the insertion of the petiole, as in certain Odynerus (Hoplopus or Epipone).

The petiole is quite variable. Its expansion produces a form sometimes globular, sometimes more lengthened. The 2 d abdominal segment, whether subsessile or long pediculate, has the form of a bell or compressed oval. It is dilated suddenly (globularly), or gradually (like a pear). Its posterior border always presents two distinct foliations, the inferior projecting remarkably. This

1 It is not possible to establish a definite limit between these two forms: for often, with the hook, there also commences a spiral. When the spiral is rery distinct, the $13 \mathrm{th}$ article, in place of terminating in a point as when it forms a hook, is lengthened, curved and obtuse. (See Saussure, Vespides I, pl. ii, fig. $3, d_{\text {.) }}$

2 The Zethus were mostly confounded with the Eumenes up to the time when I remited the species in one genus, of which the buccate characters and the general form are too distinct to admit of any confusion. But I conld not entirely separate from the genus Eumenes, some species which I had not seen, and of which, even as wasps, the descriptions were incomplete (E. rufinoda LEP.; E. substricta HaLD., etc.). 
form of the two first segments recalls specially that of Icaria (Social Wasps).

In general with Zethus, above all among the small species, the head and thorax are cribrose with coarse punctures. 'These sometimes extend upon the petiole, but commonly the metathorax is less punctured and the abdomen very smooth.

Most of these insects are colored black and yellow; but the yellow markings are often wanting, and the variations are very numerous. ${ }^{1}$

The genus Zethus is particularly interesting in view of its zoological affinities. In fact, here the head becomes large and excavated posteriorly, as in the Vespinæ; the mandibles are short as among them; and one remarks a certain relationship in the appearance or some resemblances which seem to establish an affinity with the Social Wasps $;^{2}$ while in the construction of the parts of the thorax, one recognizes some traces of the forms of the Odynerinæ sessiliventres.

Zethus seems also to establish a lien between the Odynerinæ and the Social Wasps by their habits; for the Zethus, although certainly solitary insects, construct nests composed of irregular cells, few in number but agglomerated, which is probably a preliminary step in the series toward the construction of numerous serried and regular cells. (See Zethus Romandinus.)

Even with all the gradations of form which we observe in passing from one to another in this genus, we do not think that one can divide the Zethus into more genera. Even the Asiatic type Calligaster seems so intimately attached to Zelhus that we can scarcely keep it separated now that more numerous Asiatic species are known.

In conchision, the genus Zelhus is a very numerous American group, peculiarly abnudant in the intertropical parts of this continent. In the United States it is represented by but one known species; while in Mexico we find a very great number, which seem to be but an indication of a very much greater number which must exist in the other parts of tropical $A$ meriea.

1 From my ignorance of this fact, I regret having published in my Monographie des Grepes Solitaires, descriptions of a certain number of species of Zethus, the distinctions of which are founded especially on the distribution of eolors.

2 See below, the division Zethus. 
This circumstance promises to render the study of the species exclusively difficult.

\section{Division ZETHUS' (sensu strictiore). \\ (SAuss. Vespides I, 9, III, 115.)}

Second abdominal segment subsessile; expansion of the petiole globular, lengthened. Thorax moderately lengthened. Metathorax convex, presenting two rounded convexities, separated by a groore. Antennæ of the males terminated by a spiral. The 6th abdominal segment bearing underneath two lamellar appendages (copulative?). Species large, having a feeble sculpture, but not polished and with a dull metallic color.

It is impossible not to be struck with the resemblance of these insects to the Synoeca. The same form of head, indented behind, the same dull metallic color, great size, pediculate abdomen, mandibles almost the same form, etc.

The representatices of these two genera inhabit also the same countries of America. There is, in their color and appearance, one of those analogies which we sometimes find impressed upon insects of the same regions of our globe, ${ }^{2}$ and this seems especially one of those openings that modern zoology should carefully mark as suitable to cast some light on the relatiouship of species.

\section{Z. coruleopennis ${ }^{3} F_{A B R}$.}

Vespa corule pennis FABR. Ent. syst. Suppl. 263, 1798.

Zethus coeruleopennis Fabr. S. P. 282, 1.-Latr. Gen. IV, 137; Encycl. pl. 393, fig. 12, 13.-SAdss. Vespides, I, 9, 1 : Revue Zool. X, 1858, 64.

Zethus brasiliensis Sadss. Vespides I, 10, 2, $\uparrow$; III, 115, $\widehat{\delta}$ (prob. variety of this species).

Zethus magnus Sadss. Vespides I, 11, 4, pl. viii, fig. 5, $\hat{\delta}$.

Abdominis petiolo globoso-clavato, sulco tenuissime partito.

Hab. South America, Cayenne, Para, Brazil, Quito.

1 I have separated from this division a certain number of small species, which have rery much the same form of abdomen, but which, by their clypeus and the angular form of the metathorax, find a more natural place in the division Zethusculus.

2 The Vespides of Chili present a yet more striking example of this. See below Hypodynerus.

3 The Vespa surinama Lixw. (Gmel. V, 2759, 23), is either this species or a Synoeca. 
2. $\mathbf{Z}$. recurvirostris $D_{E}$ GEeR.

Vespa mexicana Linv. 12, Edit. 953, 6.-OLiv. Encycl. Meth. Ins. VI, 673. Vespa recurvirostris De Geen. Mém. 111, 579, pl. 29, fig. 4, 1773.

Vespa cyanipennis F'ABR. lint. syst. II, 277, 86, 1793; Polistes cyanipennis, S. P. $275,30$.

Zethus cyanipennis Latr. Genera, IV, 138.-ERicus. Faun, et Flor. Brit. Guiana, III, 590.-Sauss. Vespides, I, 12, 6; III, 116; Revue Zool. 'X, 1858, 63.

Eumenes cyanipennis Latr. Hist. Crast. et Ins. XII, 345.

Zethus lugubris Perty, Delect. An. Artic. 144, pl. 27, fig. 4, 1830.-SAdss. Vespides, I, 11, 5 ; Revue Zool. X, 1858, 63. rufo.

Clypeo $q$ lato, satis rotundato, truncato; petiolo ovato-clavato, nigro vel

Hab. Brazil. Does not seem to imhabit Mexico.

\section{3. $Z$. chalybeus Sauss.}

Zethus chalybæus Sauss. Vespides, I, 10, 3; Revue Zool. X, 1858, 63.

Clypeo $q$ transverso, rhomboidali, utrinque acute angulato, apice truncato, bidentato.

Hab. Brazil.

\section{2 . carbonarius Sмiтн.}

Zethus carbonarius Sмiтн, Cat. Brit. Mus. Vespid. 10, 5.

Hab. Brazil, River Amazon.

Division HEROS.

(SAuss. Vespides, III, 115.)

Clypeus Inzenge-shaped, transverse, forming on each side a sharp lateral angle; abdomen depressed, its second segment subsessile, cularging gradually. Head swollen at vertex, and convex. Ocelli arranged upon a very oblique, almost rertical plane.

\section{Z. gigas Spir.}

Zethus gigas Sprnoua, Ann. Soc. Ent. Fr. X, 1841, 129, 80.-Sidss. Vespides, I, I2, 7; Ів. III, 115.

Calligaster heros Sauss.' Vespides, I, 23, I, \&, pl. ix, fig. 6, 1852.

1 This name was given by De Haan; but it is a collective name, and after having eited Haan, for satisfaction, in the deseription of the species, we here suppress the name; considering that we do not recognize the onllective name, as we have said elsewhere, and do not wish, by setting wil example, to preserve it. 
Hab. South America. Cayenne.

This type has very much the form of Zethusculus, on the part of its clypeus, and yet this form of clypeus appears in $Z$. spinipes.

Division ZETHUSCULUŚ Sadso.

(Sauss. Vespides, I, 15; III, 118.)

Second abdominal segment subsessile, or briefly pediculate (the pedicle having at most a quarter the length of the segment). Petiole lengthened, its inflation variable.

Species small, ornamented with black and yellow.

The insects of this group often have the clypeus armed with two little separated teeth; this part is in general moderately rounded, but is at times lozenge-shaped, as in the division Heros, with the lateral angles sharp ( $Z$. spinipes); the head and thorax are cribrose with great punctures, often rugose-the vertex offering frequently a corrugation which includes the antennæ. The thurax is generally short, and at times strongly angulate; the metathorax in particular is sometimes convex as with the true Zethus, and at times becomes angulate. The lateral ridges are very distinct and the flanks beneath are smooth, compared with the rest of the thorax. The posterior face of the metathorax is convex, having two convexities or moderately flattened elerations, always relvety, less punctured than the rest of the thorax, and in general corered with striæ or wrinkles, silky upon the dividing groove. Sometimes the posterior face of the metathorax is concare and offers under the post-scutel a little excavation, which recalls what one sees among certain Odynerinæ. 'One often perceires, also, two longitudinal carinæ which start from the angles of the post-scutel. ${ }^{1}$ When these carinæ become enlarged, they produce ridges which border the cavity ( $Z$. miniatus).

The petiole is quite variable; sometimes the knob is elliptical and depressed, but more often the swelling is moderately cylindrical; at first somewhat large, it then diminishes in size gradually to the extremity. In fine, it inclines to the campanular form, whether lengthened pyriform, or clubbed and calling to mind the Eumenes or eren tubular; but the other characters always suffice

1 When I say: metathorax bicarinate, it is meant that the carinæ exist on the posterior face of the metathorax; for as the lateral edges or ridges are found on all the species, I do not mention them in the descriptions. 
to enable one to distinguish these exceptional species from the Eumenes (viz. : the clypeus transverse and not longitudinal, the mandibles truncate and not tapering, the head emarginate behind). The petiole is, in general, less strongly punctured than the thorax, more strongly than the abdomen.

Among the species of this division the antennæ of the males are terminated, sometimes by a rolled-up spiral, sometimes by a hook. 'They form, in this way, two parallel series, based upon this character; in each one of them one sees the second abdominal segment at one time subsessile and at another becoming more and more pediculate. These two series continue in the Didymogastra. The two forms of antennæ combine with all the degrees of pro. longation of the abdomen, thus showing that the character drawn from the manner of termination of the antennæ is not of any generic value.

As the most of the insects of this genus are not well described in my "Etudes sur la Famille des Vespides" I will here give a diagnosis of the species of Meridional America which I have before my eyes :-

\section{A. Antennæ of the males terminated by a rolling-up spiral.}

a. Petiole presenting a nodulous or ovoid expansion.

6. $Z_{\text {. }}$ arietis $\mathrm{F}_{\mathrm{ABR}}$ - - Niger, capite et thorace valde cribratis. Clypeus cribratus, integer, apice subtruncatus. Pronotum vix carinato-marginatum; metanotum minus rugosum, sericeum, in medio excavatum. striatum. Petioli tumor haud nodosus, elongatus ut in $Z$. Westroodi, at angustior, nitidus, tenuiter punctatus; abdominis $2 \mathrm{~m}$ segmentum paulum (sed distincte) petiolatum, elongatum, ovato-dilatatum. (now globoso-dilatatum ut in Z. spinipede, Westwoodi, ete.). Petiolus et pedes rufi ; alæ infuscatæ cyaneæ; $\delta$ anteunis subtus apicem versus fulvis. Longit 0.017 .

Vespa arietis FABR. Ent. Syst. II, 1793, 282.-OLIv. Encyel. Meth. Ins. II, 676.

Polistes arietis Fank. Syst. Piez. 280, 50.

Zethus arietis SAdss. Vespides, I, 14, 11; Revue Zool. X, 1S5S, 64.

Hab. Brazil.

\section{\%. "T. rufinodus LATR.}

Eumenes rufinoda Latu. Genera, IV, 1809, 137, pl. xir, fig. 5. Sarss. Vespides, I, 42, 19.

Zethus rufinodus Savss. Vespides, III, 118, 4, pl. ri, fig. 3, q. 
Nay be a variety of the preceding.

Hab. Antilles.

8. Z. piriformis SpIs. - $q$. Ater, nitidus, punctatus, sed nihilominus politus; clypeo et fronte planatis; illo apice subemarginato, margine punctato, de reliquo lævi, substriato; pronoto valde cristato-marginato, sed haud bidentato, postscutello et metanoto relutinis, argenteo-sericeis, hoc parum striato, supra utrinque lævi; petiolo ovato-intiato, nitido, punctulato, margine Havo-limbato; secundi segmenti wargine subjacente producto; reliquis valde punctatis; antemnis subtns apicem versus ferruginescentibus; alis hyalinis, costa anguste nigra; celiula $2^{\text {a }}$ cubitali trigonali. Longit 0.017.-Varat secundo segmento flavo-limbato.

Zethus piriformis Spin. Ann. Soc. Ent. Fr. I, 1S41, 135.--Satss. Vespides, I, 15,12 .

Zethus binodis Sacss. (per errorem) Vespides, I, pl. viii, fig. 8.

Hab. Cayenne.

This species is remarkable for its body appearing smooth, although punctured, having the punctures apparently effaced. I cannot say with certainty if this is really the species described by Spinola. The $2 d$ segment of the abdomen is swelled suddenly, and globular, a character which distinguishes this Zethus from $Z$. fraternus.

9. Z. fraternus SACss.-Niger, punctatus; punctis 2 frontalibus flavis. Pronotum paulum cristato-marginatum. Scutellum convexum, sulco partitum. Mletanotum minus punctatum, sericeum, clunibus 2 couvexis, sulco profundo sejunctis et utrinque carina verticali spatium striatum marginante instruetis (uon sunt illæ carinæ laterales metanoti, sed faciei posticæ). Petiolus ovatus, sat brevis, punctatus, margine flavo; abdominis secundum segmentum distincte petiolatum, ovato-dilatatum. Alæ infuscatæ, costa nigra, apice et postice parum obscuræ.

$\hat{\delta}$. Clypeus in dimidia parte inferiore flavus margine infero recto, dentibus 2 distantibus nigris; antemnæ subtus, apicem versus flaræ. Longit 0.016.

Zethus fraternus SAuss. Vespides, I, 16, 14, 1852; Revue Zool. X, 1858, . 163.

Hab. Brazil (lower provinces). Typus in museo Saussuriano.

The swelling of the petiole is a little flattened, and wider than in Z. piriformis: the second segment is more briefly pediculate, more gradually swelled and less globular. The body is more strongly punctured. 
110. W. WestWoddi SAuss.-Niger, capite et thorace grosse foraminatocribratis, metanoto argenteo-sericeo; abdomine valde aureo-sericeo; petioli ampliatione ovata, elongata, haud clavata; secundo segrrento petiolato; pronoti margine, macula subalari, scutellis, et abd. segmentorum 1-2 margine, flavis; alis infuscatis; f clypeo integro utrinque margine flavo; $\delta$ clypeo flavo, antemis subtus et cochlea fulvis.

Zethus Westwoodi SAuss. Vespides, I, 1852, 16, 15; III, pl. vi, fig. 2, ᄋ. Total length, $18 \mathrm{~min}$. ; wing, $13 \mathrm{~mm}$.

․ Clypeus polygonal, entire, covered with coarse punctures; its inferior border a little truneated and rétroussé. Head and thorax covered with coarse cribriform punctures; on the forehead a feeble transverse depression, and above the insertion of each of the antenuæ a vertical medial depression extending to the clypeus. Prothorax angulate; its anterior border edged by a crest in form of a vertical lamina. Post-scutel unarmed. Metathorax rounded, smooth, hairy, with little or no punctuation, and covered with a silky down, in color strongly silvery or a little golden; its excavation has its upper edges moderately distinct; the lateral edges of the metathorax prominent. Petiole smooth, shiniug, golden, like the abdomen: the linear part almost naked, the expansion much lengthened, oval, occupying most of its length, a little swelled above. The remainder of the abdomen shining, distinctly golden, garnished with a silky pile, having cupreus reflections. Second segment ovate-globular, pediculate, the pedicle oceupying a fifth of the length of the segment; the part swelled (or the bell), wider than long, but less wide than the length of segment; the second leaf of its border very prominent.

Insect black; on each side of the clypens an oval spot, two dots above the insertion of the antemn, margin of the prothorax, a spot under the wing and scutels, yellow or orange. A border of this color oceupies the margin of the two first segments; that of the first extending along the sides of the petiole (these markings are liable to be wanting, particularly on the head and the prothorax). The remainder of the abdomen and the second margin of the second segment, ferruginous. Antemme and legs black. Wings smoky, the anterior borders brown with a riolet reflection. Wing seales yellow or brown.

The $\delta$ as large as $q$; clypeus yellow, slightly bidentate (a third hareily pereeptible tooth between the two laterals). Flagellum of the antenna yellow beneath, cspecially undel the 
terminal bend, which is sometimes entirely tawny. The yellow or tawny border of the prothorax is interrupted by some black points in both sexes.

Var. Size small, 13 mill. Prothorax black.

Ress. a. diff-Approaching to $Z$ aztecus, but rery distinct by the pedicle of the second segment being sensibly longer; by the petiole, of which the inflation is more lengthened, which does not form any prominence ahore and which is not strongly punctured.

$H a b$. The hot regions of the gulf side of Mexico. Tampico.

$N$. B.-The type from which I first described this species, l. l., has the "etiquette" Peñon de los Baños, a locality of the valley of Mexico (cold region). This should be an error of the "etiquette," for I have myself taken this species in the region approaching the hotter zone of Mexico.

11. Z. Iurine SAuss.-Gracilis, niger, nitidns ; capite et thorace tenniter punctatis (punctis quasi obliteratis); hoc nitido, metanoto brevi, albidosericeo, planato. Petiolus ovatus, valde dilatatus et maxime depressus, nitidus, vix punctatus; secundum abdom. segmentum basi petiolatum, dein globoso-dilatatum, ut petiolus nitidissimum; segmenta reliqua punctata. Pronoti margo, macula subalaris et tegularum limbus posticus, puncta 2 in scutello, maculæ 2 rotundatæ in metanoti parte imma, flava; abd. segmentorum limbus tenuissime albidus vel flavus. Alæ infuscatæ. Longit, $0.015 \mathrm{~mm}$.

$\hat{\delta}$. Clypeus flavus, sericeus, superne niger, et margine tenuissime nigro, subbidentato; antennæ subtus apicem versus fulvæ.

. Clypeus integer subtruncatus, uiger, sublævis.

Zethus Jurinei Sauss. Vespides, I, 1852, 15, 13; III, 118; Revue Zool. X, 1858,162 .

Hab. Antilles? South America. Caracas. (Typus in museo Genevensi et Saussuriano.)

12. Z. nigricornis n. sp.-Nigerrimus, nitidus, punctnlatus; metathorace et abdomine cinereo-sericeis; abdominis petioli margine et linea submarginali angusta $2^{\mathrm{i}}$ segmenti, sulfureis; alis infumatis, costa uigra; O antemnis et clypeo planato nigris, $\delta$ clypeo albido, margine tenuiter nigro; antennarum flagello subtus albido-annulato; tibiis intermediis linea albidaornatis.

오. Total length 15 mill.; wing $10 \mathrm{~mm}$.

The same form and sculpture as $Z$. aztecus. Jet black, immaculate, having only the yellow border of the petiole and a very 


Eumenes coloradensis Cless. "q. Black; rather densely chthed witt a

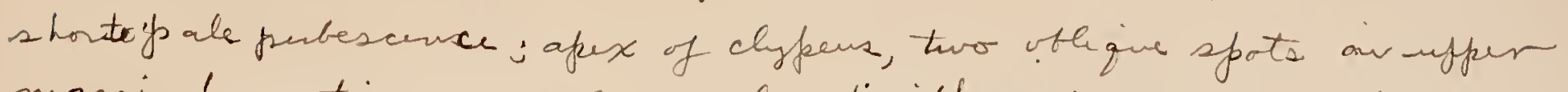
margin (somatims nearly confluentivith aficul spett), clavate afort tetiveen the anternocie, dut fehind summit of each eye, seafe teneath, anterion margin of forothorax, dofbeneath winge, dot ow each sicle of sentellum, pootoratettur, a wind sfut on each side of notatherex at tase, afex of fomora, anterior pair teneath, ale the tibian, dot on each scide of first segment of abdomen abovesits nosureand wary ofucial margin, a tronsverse, rathe oflizue mark of variable size

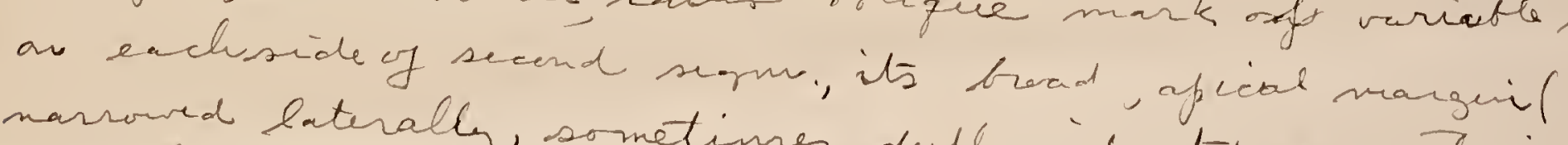
narroved baterally, sometimes defly indented on artesion middle, sometines entiv, inclosing a black dott, afical segm. smargin igrmaining sequ. above and beneath (more or hes indented latinally above.), and a lange quadrate mark on ofax of securd ventral segnent lemow-yellvw; vings suthy aline

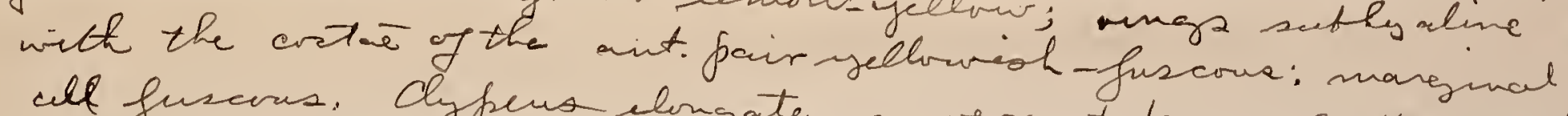
all fuscars. dypens elongate, conver at lase, flatterned at apex, which is deffly emarginate, the surface shining, with

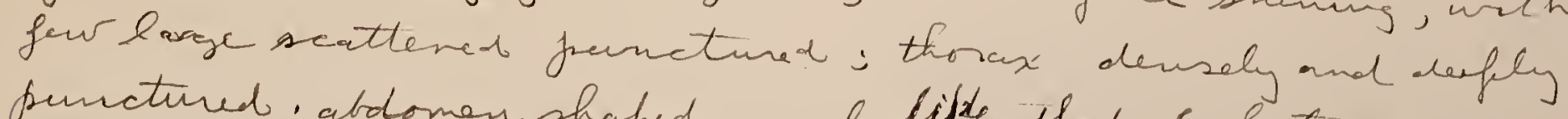
punctured; abdomen shaped nunch lite that of fioterna demaly frunctured, elothel w. adense yellowish, ourcions pile, very conspicurus in centain liglts: lateral turerch en fsist segnest distinet. Lengeh $5 \frac{1}{2}$ himes

"I of aries corsideratly in markings; clyfous atively

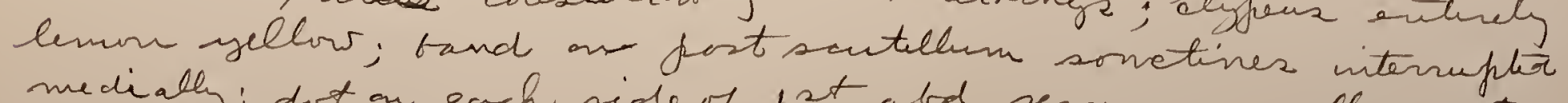
medially; dot an sach side of 1 st abd. se gur. geverally wanting. lateral mank on seand segm. varies consiclerably both is lengith

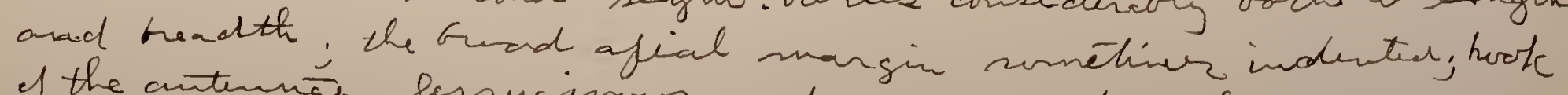

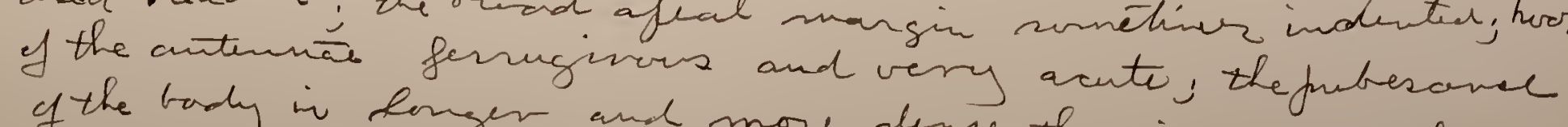
of the bady in houger and move dense them in $q$, and the "sols frible an abdomen more conspicuous. Fingth 5-6 line 50 q seciners; Glonde; Dr. H.C. Yarrow. This is allied to verticalis Say itut in less roterst and mone densely pubeacene; I clyfens narwers, with afux morep deffly encuginat!! 

fine submarginal sulphur-yellow line on the $2 d$ segment. The antenus quite black.

$\hat{\jmath}$. Clypeus flaltened, only delicately punctate-strigate, a little trilobed in the middle of its inferior margin; metathorax not so much hollowed posteriorly; a little strigate on sides; the exeavation not margined at top; the lateral carinæ very sharp and prolonged nearly down to the end, not obsolete beyond the angle; the lateral faces polished. The swelling of the petiole not so oval, but more attenuated posteriorly; the second segment more pediculate, so that it might be almost classed in the Division Didymogasira.

The body is not clothed with golden silky hair, but only with a little grayish pubeseence on the metathorax and abdomen; the face or clypeus not silvery as in $Z$. aztecus.

$\widehat{\delta}$. Antennæ black; all the joints of the flagellum annulated beneath at their base with pale-yellow ; the first joint having its macula near the end; the scape black. Clypeus broad, quadrangular, transverse, whitish-yellow, not silvery; its inferior edge black, widely emarginate, with 2 distant teeth. The intermediate tibiæ ornamented before with a white line, running over the first joint of the tarsi.

Hab. Mexico, the eastern Cordillera. Orizaba (Mr. Sumichrast).

This species has the appearance of $Z$. Jurinei, because of its oval petiole being posteriorly attenuated; and its black shining color, but it is smaller; its petiole is not impunctate, polished, etc.

\section{b. Swelling of the petiole cylindrical. \\ * Metathorax not excavated.}

13. Z. HIeydeni n. sp.-Niger, punctatus, tomento aureo ubique restitus; pronoto cristato-marginato, sed angulis haud spinosis; petioli tumore cylindrico, subdepresso; corpore maxime flavo-variegato; abdominis segmentis omnibus tenuiter flaro-limbatis; pedibus flaris, femoribus nigro-variis; alis pellueidis, venis ferrugineis.

$\delta$. Mandibulis et elypeo flavis; hoe in medio margine producto-truncato; antennis fulvis sub seapo fascia flava, apice cochleatis.

Total length, $16 \mathrm{~mm}$; wing, $11 \mathrm{~mm}$.

q. Insect slender. Head wider than high, densely cribrose. Thorax densely eribrose; prothorax strongly flanged, but the 
angles not spiny; post-scutel feebly bilobate; metathorax convex, slightly divided by a simple furrow, strongly wrinkled-its lateral edges sharply carinate. Petiole of moderate length, its enlargement not being oval but in form of a tube slightly flattened, a little compressed behind, punctured; the remainder of the abdomen pear-shaped, the $2 d$ segment bell-shaped, a little pediculate, slightly funnel-shaped, offering a second distinct border, not turned up at edge.

The whole insect of a shining black, everywhere garnished with a pile of tawny hair; a transverse spot on the forehead, sinus of the eyes, a spot behind each eye, a large border on the prothorax, a spot under the wing, wing scales, two spots on the scutellum, a band on the post-scutel, and two large spots on the posterior face of the metathorax, vellow. Segments of the abdomen all narrowly bordered with yellow; legs yellow, thighs varied with black. Mings transparent, nervures ferruginous.

$\widehat{\delta}$. Clypeus yellow, conrex, terminated by a truncate projection; mandibles yellow; antennæ entirely orange or ferruginous, only a little dull above; the scape marked with a yellow line; the 3 last articles forming a rolled spiral.

Ress. a. diff.-This species is distinguished by the color of its antennæ, and especially by the form of its petiole. This form resembles a little that of $Z$. miniatus, but that has the angles of the prothorax dentiform and the petiole more cylindric and coarsely cribrose.

The $Z$. Heydeni is much less coarsely cribrose than the $Z$. Aztecus, Westwoodi, or chrysopterus, which it slightly resembles ; and the exceptional form of the clypeus, $\delta$, also distinguishes it clearly : for with these species the clypeus is large, quadrate, the same as with the $Z$. Jurinei, which is less punctured and has the wings obscure. The enlargement of the petiole is also very much more globular than among all these species.

Finally, this Zethus might be confounded with some one of those species described by Smith, and which we cite at the end of the genus; but the author haring omitted to indicate dirisions into which these species enter, or the characters which permit one to classify them with precision, it is not possible to recognize them with certainty. The $Z$. curinatus presents much the same appearance, but it is very much smaller.

Hab. Brazil. (Museum of Senkenberg.) 
This charming insect was communicated to me by Mr. de Heyden.

* Metathorax excavated; the excavatim margined with slarp carince.

$\dagger$ Thorax short, quadrate or rounded.

14. Z. OH foveolato-punctato; metanoto valde excavato, acutissime carinato; petioli tumore cylindrico, rugosissimo, carinato; mandibulis, clypeo, punctis 2 frontalibus, 2 scutelli et 2 post-scutelli, margineque segmen. torum $1^{\mathrm{i}}, 2^{\mathrm{i}}$, flavis ; pronoto rufo-maculato; femoribus posticis subdeformibus.

Total length, $11 \mathrm{mill}$; wing, $8 \mathrm{~mm}$.

․ Smaller than most of the preceding. Head moderate, covered with scattered moderate punctures. Mandibles widened to beyond the middle; the cutting border oblique, having an acute point, a rounded tooth, and an obtuse lobe. No transrerse carina above the antennæ. The vertex having a little arcuate depression behind the ocelli. Thorax short; prothorax attenuated anteriorly; its anterior border crested, the crest forming on each side a little acute but not marginal angle, the anterior margin being much narrower than the rest of the thorax; the lateral parts of pronotum not margined. Scutel rather salient; postscutel destitute of tubercles, quite truncate, having a posterior face, punctate along its superior arcuated margin. Metathorax quite angular in shape, as in some Odynerus; its whole posterior face occupied by a large and deep sericeous excaration margined by very sharp and prominent carinæ, starting from the angles of the post-scutel; the top of the carinx separated from the postscutel by a fissure; the inferior extremity of the posterior carinæ meeting the lateral sharp carine, and forming with them a sharp angle; the upper side of metathorax divided into two triangles included between the carinæ. The thorax covered with very large but not deep pnnctures; still larger on the metanotum, where they are nearly little grooves. Petiole having its swelling cylindlical, extremely coarsely punctured, the punctures rery large and confluent; the middle somewhat carinated by the rough seulpture, the extremity a little contracted and with a large groove; on each side in the middle an obsolete sort of a tooth; the anterior extremity of the swelling truncate, polished. Second segment. subsessile, convex beneath at base, but not tubereulous; temuously 
punctured, but not more on its margin than elsewhere; the third segment densely punctate; the following impunctured; the first margin of the $2 d$ a little arcuate and depressed in the middle; the second lamellar margin of $2 \mathrm{~d}$ and $3 \mathrm{~d}$ segment growing a little wider on the sides; that of the $3 d$ rather transversely cut out in the middle third. Posterior tibiæ arcuated, a little deformed.

Black, with a very dull silky reflection, rather fulvous. Mouth, mandibles, and clypeus, yellow, a little orange, or reddish at top of clypeus. Scape and the end of flagellum beneath, yellowish or tawny. Two spots over the antennæ, two lines on the vertex starting from the eyes, and two lines behind the eyes, not marginal, tawny. Both margins of prothorax and two spots on the lateral margins of scutellum, yeliowish-tawny; two spots on the edges of post-scutel, the margin of petiole and a narrow yellow submarginal line on the second segment, yellow; anterior feet more or less ferruginous or yellow-tawny beneath. Trings subhyaline; veins brown; $2 d$ cubital cell lengthened at base (on the side looking to the base of the wing).

ๆ. Clypeus rounded, densely and strongly punctured; a little velutinous; its inferior margin arcuate, not truncate nor emarginate; its summit a little carinate. The head beneath and around the mouth, post-sternum and anterior coxæ, sulphur-yellow.

$\hat{\delta}$. Clypeus a little wider, having the same shape and color as in the $q$. The oblique cutting borcler of mandibles with but 2 little notches. Antennæ tawny beneath; the last two joints obtuse, forming nearly a hook. Anterior tibiæ, tarsi, and thighs beneath ferruginous; intermediate tibiæ beneath and 1 st, $2 d$, and $3 d$ joints of the tarsi beneath yellow; the $3 d$ segment slightly margined with yellow.

Var. Prothorax black, with its angles and two marks, tawny.

Hab. Mexico. The Oriental Cordillera. Orizaba (Mr. Sumichrast).

Ress. a. diff.-This is a rery distinct species in the remarkable form of its metathorax and the rugosities of its petiole; quite different from all other Mexican Zethus, except from clypeatus. It differs by its more excavated metathorax, the excavation being polished and more carinated, and by its prothorax, more rounded anteriorly, not square shaped nor crested on the sides; by its rougher petiole, carinated in the middle, etc. It has such an extraordinary resemblance to $Z$. miniatus that it might be 
considered a Mexican variety of this; but it has the mandibles a little less indented, the petiole a little thicker and shorter; the lamella of $3 d$ segment less cut out; and a less high coloration.

It approaches in the same way toward $Z$. lobulatus.

It differs from $Z$. toltecusby its short thorax, the carinx of metathorax which converge on each side to a sharp angle, ctc.

Its appearance is that of a true Zethus.

Hab. Mexico. The Oriental Cordillera, Orizaba (Mr. Sumichrast).

15. Z. mimiatus ${ }^{1}$ Satss. - Parvulus, niger, caput et thorax mediocriter profunde punctata ; pronotum cristato-marginatum, angulis spiniformibus; mesonoti discus sulcis 2 profundis brevibus e scutello emergentibus notatus; post-scutellum angulatum, margine postico subconcavo, et in lateribus cristulis 2 (ut dentibus e scutelli angulis emissis) instructum; metanotum ferrugineum maxime excavatum, utrinque crista verticali e post-scutelli angulis emissa instructum; petiolus cylindricus rugosissime cribratus; secundo segnento globoso-dilatato, subsessile. Caput fulvo sericeum, aurantiacum, fronte nigro; mandibulis et antennis aurantiacis; pronotum, maculæ subalares et scutellares, aurantiaca; abd. segmenta tenuissime flavo-limbata; alæ secnudum costam infuscatæ; pedes antici et intermedii aurantii. Longit, $0.011 \mathrm{~mm}$.

Clypens $q$ discoidalis, $\hat{\delta}$ subtruncatus; in utroque sexu aurantiacus. Antemnæ $\hat{\delta}$ apice vix cochleatæ.

Zethus miniatus Sauss. Revue Zool. X, 1858, 64.

Hab. Para. ('Typus in museo Saussuriano.)

\section{Z. Iobullatus SaUss.}

Zethus lobulatus Sauss. Vespides, III, 116, 2, pl. vi, fig. 4, ९, 1854.

Hab. Brazil. Amazon.

† Thorax elongate, attenuated anteriorly, elliptical.

1\%. Z. Toltecus n. sp.-Niger, cinereo-sericeus, punctulatus; thorace elongato, depresso, antice attenuato; metanoto crassissime foreolatopunctato, 4-carinato, foveolâ quadratì inter carinas instructo; petiolo cylindrico, rugosissimo; 20 segmento subtus basi tubereulato; elype transverso, rotundato ; antemis subtus, mandibulis, capite subtus, linea

1 Perhaps a variety of the following, with the second cubital cell less retracted. In this the exeavation of the border of tho second segment was probably due to an aceident of nature. 
post-oculari, punctis 2 pronoti et scutelli, margine abdominis segmentorum 10,20 , coxis peribusque anticis, flavis. $q$.

Total leugth, $12 \mathrm{~mm}$.; wing, $\delta \frac{1}{2} \mathrm{~mm}$.

Head moderate, moderately punctured; the trenchant margin of mandibles very obsoletely lobed. 'Thorax elongate and depressed, polished, covered with delicate punctures, having a tendency to striæ, but the pleuræ covered with stronger scattered punctures, much attenuated anteriorly and posteriorly; its anterior margin short, margined; the disk of the mesothorax flattened, with tivo sulcose places at base; scutellum flattened, not divided by a sulcose basin, post-scutellum very small; metathorax elongate, oblique, triangular, very coarsely punctured (or rather reticulaterugose); its lateral carinæ very sharp, the sides under the carinæ polished, but a little reticulated near the carinæ, posterior face having two strong carinæ, starting from the angles of the postscutel, the extremities of which do not meet the lateral carina; the space between the middle carinæ forming a square excavation, rather widened posteriorly, polisher, furnished with gray sericeous hair, as also the terminal acute angles of metathorax, behind the end of the middle carinæ.

Petiole (as in Olmecus) cylindrical, truncate and polished in front, extremely coarsely punctured, very rugose, a little carinated at base, the extremity marked with a semicircular groore, and also constricted on each side. Second segment of abdomen rather elongate, a little depressed, with quite delicate oblique punctures; the punctures beneath stronger, on the base swelled tuberculously; the first margin above slightly angular in the middle, the subjacent lamina very salient on the sides but very little in the middle; margin of the $3 \mathrm{~d}$ segment arcuate, the lamellar edge strongly and broadly cut out in the middle.

Black, furnished with silvery hairs (except on the head, where they are yellowish;; a line of them behind the eyes (but not marginal) and a line or the scape, yellow; the flagellum of $q$ beneath yellowish-ferruginous; two dots on the prothorax, two on the scutel, margin of petiole and a filiform line on the upper margin of the $2 \mathrm{~d}$ segment, yellow ; prosternum, anterior coxæ, and legs, yellow; intermediate knees and tibiæ annulated with yellowishbrowu. Wings washed with brownish, with a golden reflection.

․ Clypeus in a rounded lozenge-shape, truncate at the top and 
extremity, but without angles, delicately punctured-strigate. Clypeus, mandibles, and the under part of the head, yellow.

Ress. a. diff.-This species has just the same form of head and clypeus and just the same system of coloration as Z. olmecus; the petiole is also the same, but the thorax, lengthened, flattened, very delicately punctured, the metathorax less excavated, with not so salient carinæ, make it easy to distinguish. The middle earinæ of metathorax stop before reaching the lateral carinæ. The appearance of the insect is quite different, and it looks more like a Discolius (D. zonalis) than like a Zethus; and this appearance, due to the elongate thorax, distinguishes it also from $Z$. miniatus and lobulatus.

Hab. Mexico. Oriental Cordillera (Mr. Sumichrast).

B. Antennæ of the males terminated by a hook.

a. Species having the appearance of the true Zethus. Mlead wider than high; thorax short, not being one and a half times longer th'n wide; dilatution of the petiole elliptical or cylindrical, a little contracted behind; the second segment of the abdomen in form of a globular bell.

18. Z. Spinipes SAY.-Medius, niger, nitidus, densissime et grosse eribrato-punctatus; punctis 2 frontalibus flavis; clypeo lato, $q$ nigro, subbidentato, rugose cribrato; $\hat{\delta}$ punctato, albido, surpra nigro; antemnis $q$ atris, $\delta$ linea in scapo albido; abdominis secundo segmento minus conspicne punctato, subpedunculato; petiolo inflato, campanulato, grosse punctato, apice $\mathbb{1 f a v o - m a r g i n a t o . - V a r i a t} q \hat{\delta}$ pronoto, lateribus, scutellis, albido variegatis et abdominis secundo segmento margine albido.

Zethus spinipes SAY, Bost. Jouru. I, 1837, 387, ᄋ.-SAUss. Vespides, III, $122,10$.

Eumenes substricta II ald.! Proc. Acad. Phila. II, 18 44 , 54.—SAuss. Vespides, III, 152, 42.

Zethus variegatns' Sauss. Vespides, I, 13, 9, ९, 1852; Revue Zool. X, 185s, 66.

Eumenes pensyl ranica Hatd. Proc. Acad. Phila. 1853, 365, $\delta$.

Zethns bicolor Sauss. Vespides, I, 17, 16, $\delta$.

q. Insect of medium size; ocelli disposed in a wide triangle. Clypens having the form of a transverse lozenge, twiee as wide as long; having the lateral extremities very sharp, and its ante-

I'The collection, with bad locality marks, of M. do Rominl, has iend we into very many errors. 
rior border armed with two little distant teeth. Head extremely dilated at the vertex, strongly excavated behind, wider than the thorax. Thorax very short, not being one and a half times longer than wide. Prothorax slightly retracted before, its anterior margin bordered by a sharp projection, which forms on each side an indistinct angle. Mesothorax carrying on its posterior part four longitudinal furrows, and upon its anterior part one middle groove. Scutellum divided by a sinus. Metathorax offering a feeble concavity, wrinkled and striate. Petiole moderately short, its expansion globular, having almost the same form as in the $Z$. coruleipennis, but less contracted behind and truncate; the second segment globular-ovate, bat depressed.

Insect black, polished and shining. The metathorax garnished with a grayish pile. Clypeus, head, thorax, and petiole densely cribrose with great punctures: this last carrying near its terminal border a large sunken place. Abdomen sown with finer punctures, sometimes very fine. There is often a slight depression toward the middle of the border of the second segment. A frontal dot at the insertion of each of the antennæ, the border of the prothorax or only two spots upon the shoulders, often a spot below the wing, a band or two spots upon the scutellum and the anterior border of the post-scutel, and also two spots at bottom of the metathorax, of a pale yellow. Margin of the petiole, and a narrow border along the margin of the second segment, of the same color. Feet black. Wings brown, with riolet reflections.

$\hat{\delta}$. Smaller. Clypeus wide, moderately rounded, not having a lozenge shape, its inferior border straight, hardly bituberculate. This part either wholly or only in its inferior moiety, whitish. The scape of the antenna before, is ornamented with a whitish mark; the terminal hook black; on the face is often a little yellow dot at the side of the insertion of each of the antennæ. The third abdominal segment is often adorned with a whitish border. This is the E. substricta Hald. The female presents the same variations.

Var. a. Scutels, prothorax, and two great spots on the metathorax yellow ( $Z$. variegatus, bicolor).

$b$. Often the scutels have hardly any spots, and the second segment is scarcely edged with pale yellow ( $Z$. substrictus). Markings sometimes ferruginous.

c. Certain specimens are entirely black, with a little yellow 
about the end of the petiole. These are the $Z$. spinipes Say ( $q$ ), and the Eumenes pensylvanica Hald. ( $\$$ ).

d. Quite black; the clypeus margined with yellow $(\delta)$ (Missouri ; Edw. Norton).

The punctures vary quite notably among this species. The head and the thorax are very coarsely cribrose; with the $q$, the clypeus is strongly rugose; the vertex often becomes shining from use. Among the 9 , the clypeus is less strongly cribrose. The second segment is sometimes hardly at all, sometimes quite strongly punctured. A specimen from Florida has the swelling of the petiole very coarsely cribrose.

Ress. a. diff.-Easily recognizable by its size, which is superior to that of all the following species, and by its violet wings.

Hab. United States. Conn., Pa., Ill., Tenn., Ind., Fla. (14 $q$, $6 \varsigma)$.

Nota.-As I have already said (loc. cit.), the description given by Say is very defective, and calls for an interpretation. When this author says: "Peduncle rather slender," it is without comparison with the other species, the most of which he did not know. The "piceous dentate band of the margin of the peduncle" is but the subjacent double margins, which do not make it dentate except in the color. The "posterior margin abruptly and smoothly impressed of the $2 d$ segment," alludes to the subjacent lamina on the border of the segment which are salient in almost all the insects of this genus, and which appear like a more distinct border than the veritable margin of the segment, which has the yellow band. By "tibiæ spinous behind;" the author means without doubt the posterior extremity (which offers a rery short border) armed with stylets common to all the Vespides. (From this the name spinipes.) Finally, the author says that the second segment "has a distinet neck at base," which signifies a very short neck, for if it had been long, the word distinct was out of place. This species is not then a Didymogastra, but really a true Zethus (or Zethusculus), which makes us think, that it really is, without any doubt, the present species

1.D. Z. Spinosus SAuss. (Fig. 2, 2a.)-Parvulus, niger; capite, thorace et petiolo grosse percribratis; elypeo integro, $q$ nigro-sericeo, 5 flavo; fronte cariua transversa et linea flava; pronoti margine cristatissimo postscutelloque spinoso fascia flava; petiolo cylindrico, rugoso, 
flavo-marginato; seginentis tenuiter flavo-limbatis; secundo sericeo, nitido, punctato; alis sublyyalinis.

Zethus spinosus Sauss. Revue Zool. IX, 1857, 270.

Total length, $13 \mathrm{~mm}$.; wing, $9 \mathrm{~mm}$.

?. Small, excessirely rugose. Head large, dilated and convex, densely cribrose with great pits; face carrying a transverse ridge, which covers the insertion of the antennæ. Clypeus almost transverse, convex, punctured, but much less rugose than the head; corered with a pile of dull gray silky hair; its inferior border entire; the middle of this border a little arched. Thorax all cribrose with large sunken pits resembling a sieve. Its anterior border carrying a transverse rim in the form of a quite prominent lamina, which prolongs itself a little at the sides, descending along the margin of the prothorax. Post-scutel armed in the middle with a spiniform sharp and raised tooth, or rather, with a spine. The concavity on the posterior truncated face of the metathorax is divided by a furrow. The metathorax is rery angulate; its lateral ridges very sharp; its posterior concavity very distinct, striate, bordered by two parallel longitudinal ridges, beyond which the metathorax is again quite rugose. Petiole as rugose as the thorax; its base alone smooth; its expansion lengthened, cylindrical, but little contracted behind, and cribrose with rery large confluent punctures. Second segment globular-ovate, a little pediculate, its pedicle hardly equalling a sixth the length of the segment. This segment is polished, shining and sericeous, although punctured, and appearing as wide as long when examined from above.

Insect black, with a transverse line on the face, a little dot behind each eye, margin of prothorax, post-scutel, two pyriform lines on the metathorax and a line on the border of segments 1 , 2 , 3, yellow. Sometimes also all the segments are bordered by a yellow or ferruginous band, and the last segments now and then ferruginons. Legs black; tarsi and tibire garnished with silky ferruginous hair; anterior knees spotted with yellow; intermediate tibir with a yellow line; the femora with a spot at end. Wing scales black, terminated behind by a yellow point by the side of which is a little yellow process. Wings sub-smoky, with brown nerrures; the $2 \mathrm{~d}$ cubital cell triangular, quite contracted anteriorly. 
$\delta$. Clypeus transverse quadrate, either wholly pale-yellow, or only its lower part; inferior margin entire and arcuate; the last two articles of the antennæ tawny beneath.

Var. a. T'wo yellow spots on the scutellum.

$b$. The yellow niark of the fruntal ridge and that on the postscutel, interrupted; the face presenting but two yellow points. 'The border of the prothorax is sometimes sprinkled with black dots.

c. The yellow markings hardly visible. Prothorax black. Legs black; wings a little smoky, with some ferruginous tints and the nervures brown.

d. The spine of post scutel yellow or black.

$e$. In small specimens, principally $\delta$, the spine is obliterated, or replaced by a little longitudinal carina.

$f$. The peduncle of the $2 d$ segment rather longer; the spine of post-scutel obliterate.

g. The extreme edge of the clypeus $\delta$ black, or partly black, which causes very fallacious appearances.

Ress. a. diff.-This species is very distinct, by its ridges, prominences, and rugosities, hy the very large punctures of its petiole, and especially by the long spine of its post-scutel.

Hab. The gulf side of Mexico, in the warm parts. Tamaulipas, Huasteca, ete. Very common in Tampico. I have taken a score of specimens in view of the town of P'ueblo-Tiejo, against posts exposed to the sun. Tarious specimens also from Orizaba.

Fig. 2. The insect seen in profile, enlarged. 2, b. Its natural size. Fig. $2, a$. The abdomen more enlarged.

20. Z. imitator n. sp.-Niger, crasse, dense punctatus: metannto minns crasse punctato; petiolo ovato-cylindrico, crassissime cribrato ; punctis 2 clypei; 2 frontis, pronoti margine, macula subalari, tegularum limbo, scutelli fascia intermpta, post-scntelli fascia, maculis 2 motanoti, abdominis segmentorum 10-30 limbo anguste, tibiisque intermediis basi extus, flavis. $q$.

Total length, $12 \frac{1}{2} \mathrm{~mm}$. ; wing, $9 \mathrm{~mm}$.

9. Form and sempture about the same as in spinosus. Head small. Clypens much rougher, very coarsely and confluently punetured, not broad, but rounded, more prolonged and truncate. A carina between the antenne, prolonged on the elypeus. 'The rest of the punctuations about the same, very rough. Prothorax 
a little more elongate; its angles very prominent; the postscutellum quite destitute of a spine. Metathorax triangular, not carinated and not so rough. Petiole a little less cylindrical, a little more swollen, coarsely cribrate; the beginning of the swelling punctate like the rest, not polished (as if smelted) as in spinosus; 21 segment less globular, more pyriform, only punctate along its margin.

The ormaments more numerous than in spinosus, haring a spot on each side of the clypeus, two on the face, the scape beneath, the border of prothorax, a macula under the wing, edges of the tegulie, an interrupted fascia on the scutel and on the post-scutel, two maculæ on the metathorax, margin of petiole and a submarginal line on the edge of the $2 \mathrm{~d}$ and $3 \mathrm{~d}$ segments, yellow. The rest of the abdomen brownish; an abbreviated yellow fascia on the intermediate tibiæ. Wings hyaline, a little brownish along the anterior margin; the 2 d cubital cell not anteriorly contracted, liaring a distinct radial border.

Ress. a. diff.-This species slightly rescmbles IIontezumæ but is very distinct by the rest of its coloration, by its swollen, not depressed, and more coarsely cribrose petiole; and by the second, more globular, less elongate segment of the abdomen.

It differs from aztecus and Westuoodi by its more sessile 2d segment, its more coarsely cribrose and more cylindrical petiole, its maculated metathorax, without excaration, only parted by a sulcosity; smaller head, rough clypeus, etc.

It is nerertheless an embarrassing species, intermediate between spinosus and Montezumæ.

Hab. Mexico; the Oriental Cordillera (Mr. Sumichrast).

21. 2. CIYpearis n. sp.-Niger, crassissime dense cribrato-punctatus; pronoto acute angulato; metanoto 4-carinato, post-scutelli angulis dentiformibus; petiolo orato tumilo; punctis 2 frontalibus, pronoti margine, punctis 2 scutelli et 2 post-scutelli margineque petioli, flovis; margine $2^{i}$ et $3^{i i}$ segmenti siuuato, linea præmarginali flava; alis fumosis. $\hat{b}$.

Total length, $13 \mathrm{~mm}$. ; wing, $9 \mathrm{~mm}$.

Form and puncetures as in $Z$ spinosus. The hearl rery little wider than the thorax; the thorax short, crested in front, rery square anteriorly; its angles sharp, a sort of erest bordering the sides of pronotum up to the wing-scale. Scutel rather salient; 
post-scutel truncate, somewhat emarginate; its angles secn from before, elevated as two triangular tecth. Head and thorax quite densely cribrose with very coarse confluent punctures; the scutel divided by a flat line. Metathorax coarsely but not so decply cribrose, short; its lateral edges very sharp; the posterior face having two strong vertical carinx, starting from the angles of the post-scutel, but not going down to the extremity; the channel between them punctate; the sides of thorax as cribrose as the clorsum, those of the metathorax not quite so rough. P'etiole quite coarsely cribrose, rather biclentate, with the anterior side polished, impunctate (as if smelted) as in aztecus, but the swelling not cylindrical (as in aztecus) but oval, thick, and truncate as in olomitus. The $2 \mathrm{~d}$ segment subsessile (its form being a half splere), and punctured; its second lamellar edge wide, getting wide: on the sides. The first border of the $3 d$ segment advanced in the midlle; the $2 d$ lamellar border sinuate, advanced in the middle, and emarginate on each side; getting wider outside of the emargination. 'The other segments very delicately punctate.

Black; the pilosity brown; that of the abdomen long and fulvous on the 2 l and $3 d$ segment. A line on the anterior margin of the mandibles, two spots over the antennæ, anterior border of prothorax; two dots on the angles of scutel, two on the postscutel, posterior border of petiole, and submarginal border of $2 \mathrm{~d}$ and 3 d segments, yellow. The posterior margin of prothorax and the margin of the tegulæ, brown; the second border of $2 d$ and 3 d segment piceous. Knees and tarsi brownish; a yellow macula at end of the 1st femora; a yellow line on the 1st and 2d tibie outside; this sometimes tawny. Wings clouded with brown, with yellowish reflection.

$\delta$. Clypens rather rounded, black, very coarsely eribrose, its inferior margin with three indentations in the midlle, two little carine terminating in the extemal teeth; its surface rery conrex, having a rery prominent transverse swelling, somewhat like a very ohtuse carina; a yellow triangle with the angle turned downards extends from that swelling to the emel, and terminates in the midelle indentation of the inferior malrain. Antemm: rither thickened, terminated by a short biarticulate ferruginons obtuse hook

Re'ss. a. diff.-This repy remarkable speeces comes quite near to $Z$. spinesus, from which it differ's by its bidentate, not spined 
post-scutel and by its square, angled, not contracted prothorax; by its metathorax and petiole, etc. The very coarse punctation and very particular details of form of all the parts of the body distinguish this species from all the other Mexican Zethus, except from Olmecus with which it musi be compared.

Hab. Mexico. The Oriental Cordillera, Orizaba.

22. Z. Aztecus Sacss. (Fig. 1, 1a.)-Niger, rugose punctatus; pronoto antice valde cristato; fronte transversim in lineam elevato, flavobipunctato; petiolo ovato-inflato, crasse punctato; secundo secmento subpetiolato, fulvo-sericen; pronoti margine, macula subalari, scutelli maculis 2, post-scutelli fascia abdominisque segmentorum 1-3 limbo, flavis; alis subhyalinis.

Zethus aztccus Sauss. Revue Zool. IX, 1857, 270.

Total leugth, $15 \mathrm{~mm}$; wing, $10 \mathrm{~mm}$.

․ Head, thorax and petiole cribrose with coarse crowded punctures, but less rough than with $Z$. cristatus and $Z$. spinosus. Clypeus polished, cribrose with more distant oblique punctures, and hardly notched on its inferior border; the emargination divided by a little middle tooth; a little wayy transrerse carina on the vertex, forming a sort of extension upon the insertion of the antennæ. Clypeus and orbicles rather silvery. Prothorax bordered by a vertical lamina in form of a crest, but which does not prolong itself upon the sides. Metathorax furrowed, with the concavity bordered abore and furnished with a pile of gray hairs, haring a slight tawny reflection. Post-scutel unarmed. Swelling of the petiole neither cylindrical nor globular, but oval, and, as seen in profile, dilated above. Second segment ovate-globular, not enlarging itself as suddenly as in the $Z$. cristatus; but it has no more length of pedicle, and the same silky, golden reflection.

Insect black; two dots on the forehead, border of prothorax, a spot unler the wing, two on the scutel, the post-scutel, and the border of segments 1, 2, 3 orange-yellow. Wing-scales often touched with yellow. These color's offer the same variation as in the specics cited; the crest of the vertex being often adorned with a yellow line, while the nuetathorax has no spots of this color. ${ }^{1}$

1 At least in my specimens. It will not do, however, to accept this as a constant character. 
Feet black ; tarsi rather ferruginous. Wings transparent, clouded, yellowish-brown, with the nervures brown-their reflection golden-gray.

$\delta$. Anterior border of the clypeus notehed as in the female; the angles of the indenture in the form of teeth, the middle tooth smaller than the lateral. All the clypeus covered with a silvery down; its lower moiety of a yellow color, as well as a line upon the scape of the antennæ. Mandibles yellow in front, the end of the antennæ black, the hook clongate, edged, and sharp; the terminal joints sometimes a little rolled up.

Ress. a. diff.-It is a little smaller than $Z$. Westwoodi, and is distinguished from it by its more swelled and more coarsely punctured petiole, by its more indented, more strongly punctured clypeus, etc. It has the form of $Z$. spinosus, but it has no postscutellar spine, etc.; and althougl rather coarsely punctured, that is really less so than this species.

Mab. Mexico, on the gulf side. Tampico.

Fig. 1. The nale enlarged. Fig. 1, $a$. The head of the male seen from before.

Observation.-The figure 1 is not entirely satisfactory: the heal not snfficiently thick, and the second abdominal segment with the pedic!e a little too long.

23. Z. Otomitus n. sp.-Niger, dense punctatus; capite et thorace cinereo-, abdomine fulvo-hirto; antennis nigris, seapo linea flava: punctis 2 frontalibus, pronoti margine, fascia post-scutelli, abdominisqne segmentorum 1-3 linea marginali, flavis; petiolo orato-tnmido nitido, punctato, apice truncato, superne impressione transversali; genibus et tarsis fuscescentibus; alis fusco-aureo nebulosis. $-\delta$ clypeo trapezino, fascia submarginali flava.

Total length, $14 \mathrm{~mm}$; wing, $10 \mathrm{~mm}$.

o. Quite the same form and punctuation as Z. aztecus. But the clypens not square, more triangular, wide inferiorly, narrowed at the summit, or rather in the form of a half circle, a little convex, densely punctured; the inferior margin wide and transverse; witl a wide transverse emargination and two little treth. A pale yellow band oceupies the inferior part, but the extreme marein is black. The flagellum of the antenne quite black; only the look is sometimes brown beneath. The lateral carine of the metathorax a little more pronouneed the petiole not so coarsely punctate, a little wider behind, more truncite, somewhat as in 
spinipes; the 2d segment without any impression before its border; scutel black; no macula under the wing. 'The intermediate femora have no yellow fascie. The wings are washed with brown, with a golden reflection; the 2 d cubital cell generally triangular; its radial side wanting or quite short.

Clypeus and head gray-silky; abdomen golden-silky as in Z. aztecus.

Hab. Mexico; the Oriental Cordillera. Orizaba. (6 $6 \hat{\delta}$ sent by Mr. Sumichrast.)

It is not without hesitation that I separate this species from $Z$. aztecus; but the clypeus is decidedly of a different form, and the coloration is quite the same in my six specinens, seeming to indicate a decided species. The end of the antemne is quite black as in Aztecus.

21. Z • chrysopterus Sauss.--Niger, ferrugineo-hirtus, staturæ Z. Westwoodi; eapite latiore quan longiore, dense-punctato. Thorax valde punctatus, reticulato-rugosus; pronoti margine cristato, angulis prominentibus; scutello sulco partito; metanoto lævi, hirsuto, postice foveola distincta, carinis longitudinalibus 2 marginata instructo. Petiolus ovato-cylindricus. inflatus, parte lineari basali lrerissima; secundum segmentuin globoso-dilatatum, vis pedunculatum, fulvo-velutinum. Puncta 2 frontis et pronoti angulorum abdominisque segmentorum limbus anguste flava; tarsi ferruginei; alæ subferrugineæ, tegulis pieeis vel flavo-marginatis. Longit. 0.017 .

$\widehat{\delta}$. Clypen punctato, dimidio iuferiore aurantiaco, margine tenuiter nigro, bidentato.

Zethus chrysopterus Sadss. Vespides, I, 13, 8, pl. viii, fig. 7, §, 1§52; Rerue Zool. X, 1858, 66.

Hab. Probably from South America. (Typus in auctoris museo.)

\section{Z. ferrugineus Sarss.}

Zethus ferrugineus Sauss. Vespides, I, 14, 10, 1552.

Hab. South America. Para.

26. Z. cinerescens Sarss. + -Niger, cineren-sericens; clypeo plano, punctato-striato, bidentato; eapite dense punctato; thorace cribrato, striato-rugoso, antice cristato, angulato; post-scutello truncato; metanoto postice producto, rugoso, lateraliter cristato-carinato; in medio foreclato sed haud bicarinato; petiolo hreri, globoso-clavato, haud cribrato; abdom. secundo seguento subsessili, sed piriforme-dilatato (haud globoso), sericer.-Puncta 2 frontis, pronoti margo, post-scutellum 
et petioli limbus frequenter flava; tarsi fusei ; ala infuscatæ, secundum eostam nigræ, tegulis ferrugineo-marginatis. Longitudo, 0.015.

Zethus cinerascens Sauss. Vespides, III, 117, 3, 1554.

Hab. Brazil. (2 9 in museo auctoris; typus in nuseo Taurinense.)

Z. fraterno affinis, at differt pronoto cristato et angulato, thorace rugose, petiolo minus punctato et globosiore.

The male is not known; some doubt still exists about the place this species must occupy.

\section{2\%. Z. big}

Zethus biglumis Sprioma, Ann. Soc. Ent. Fr. צ, 1841, 135, 83.-Sadss. Vespides, I, 19, 20.

Hab. Cayenue.

25. $Z$. discolioides SAUss. - Niger, capite et thorace valde cribrato-punctatis, punctis confluentibus rugosis; clypeo rugoso, cribrato, subbidentato; pronoto cristato-marginato, biangulato; scutello sulco partito ; metanoto supra foveola striata instructo, cujus margines laterales fere carini formes sunt; abdominis primo =egnento brevi, ovatocampanulato, inflato, truncato, valde punctato ; secundo segmento piriformi, sericeo.-Tegulæ ferrugineæ; frons et post-scutelluu tiavo-bipunctata; petiolus flavo limbatus; pedes fuscescentes; alæ paulum infuscatæ, aureo-nitentes. \&.-Longit. 0.013.

Zetlus discalioides Sarss. Vespides, I, 17, 17, 1852.

IIab. South America. Para.

Species moderately stout_viewing its short form and strongly inflated petiole-and resembling to some extent $Z$. cinerascens, though its 2 d abdominal segment is less pyriform and the clypeus more strongly punctured and not distinctly striate.

This species, in riew of its petiole, campinulate and truncate rather than contracted behind, might alnost be placed in section 3. (This form shows itself also among the $Z$. sprinipe's.)

B. Species which have more the appearance of Eumenes or Discrlins. Head less inflated, less hollowed ont at the occiput; thorare of moderute lengih; peliole more as in the Eumenes if Dicision a.

1 Last line of this page (of Vespides), instead of Zethus, read Discalius. 
29. Z. Montezuma Sauss. (Fig. 3, 3a.)-Parvulus, rugosus, niger et pilosus; abdomine ovato ut in genere Eumene; petiolo elongato perrugoso; reliq̧ua parte abdominis piriformi, depressa; pronosi, postscutelli et abdominis seginentorum 1, 2, margine, flavo vel ferrugineo; scapo, macula subilari et scutelli, margineque clypei, flavis.

Zothus Montezuma Sauss. Revue Zool, IX, 1857, 270.

Z. Guatemolzin Sauss. ibid. (var. $९$ ).

९. Total length, $13 \mathrm{~mm}$; ; wing, $10 \mathrm{~mm}$.

$\hat{o}$. Total leugth, $10 \mathrm{~mm}$.; wing, $8 \mathrm{~mm}$.

q. Insect small, slender'; head but little inflated. Ocelli in a regular or even lengthened triangle. All the head rugose, cribrose with coarse punctures; clypeus entire, also cribrose, convex and rugose. Thorax lengthened, one and a half times longer than wide, cribrose with large punctures, rugose; on the disk of the mesothorax two arcuate grooves leave the scutellum, and extend to the anterior suture. Angles of the prothorax spinose; its margin relatively little prominent. Metathorax attenuated, conrex, rugose, but with a lateral, very distinct truncation. Petiole quite lengthened, its anterior third, at least, linear ; the remainder enlarged, pyriform, much lengthened and truncate, rugose, cribrose with very large punctures (larger than those of the thorax); its enlargement but little raised, hardly contracted behind, its marginal depressions forming a transverse groove. The remainder of the abdomen depressed, regularly pyriform, lengthened as in the Eumenes, at the base sub-pediculate, gradually swelling; the second segment shining, polished, silky-gray, delicately punctured, more coarsely along its border.

Insect black, very hairy, even its abdomen being covered with a pile of erect hair in fresh specimens; hair of the head and thorax obscure; that of the metathorax and of the abdomen gray. Inferior and lateral border of the clypeus often ferruginous; a line under the scape of the antennæ, two dots at their insertion, 1нargin of the prothorax, a point under each wing, two at the scutellum, two on post-scutel, and the border of the first two abdominal segments yellow or ferruginous. These markings are variable, the scutellum being often black and the post-scutel yellow; or the markings are entirely wanting. Wing-seales brown or ferruginous. Wings hyaline, nervures brown, and often a brown cloud in the radial cell.

$\delta$. Smaller. Clypeus transrerse, black, covered with silkr. 
gray hair ; its inferior margin carrying in the middle a rery small notch, above which is a little yellow. Antemne a little tawny at the extremity, terminated by a hook and by a slight rolling up. Metathorax spotted with yellow; anterior border of prothorax often black.

Var. a. Clypeus and scutel black; no spot under the wing.

b. At botton of metathorax two yellow spots.

c. A yellow line in front of the mandibles.

Ress. a. diff.-'This species is recognizable by the particular form of its abdomen. The lengthened petiole, longitudinally linear, becomes suddenly campanular; the second segment gradually swelled, so that the abdomen is pyriform rather than globularovate. The lengthening of the thorax and the head a little enlarged, recall the forms of the Eumenes. ${ }^{1}$ The metathorax, also, presents no concavity; the position of the furrow is, however, indicated, and it is rugose and striate, but is convex in place of being excavated.

This insect appears to be allied to $Z$. discolioides.

Hab. The temperate regions of Mexico. I have taken it in the valleys of Cordova, of Orizaba, and of Mextitlan (four females, five males).

I possess one specimen, a $q$, as small as the $\hat{\delta}$, and which is a little more strongly punctured, which has the petiole shorter in the linear part, and is sensibly more coarsely punctured in its enlarged part. The scutellum and post-scutel each have two yellow spots. Length, 0.010 ; wings, 0.008 .

Is this a variety of $Z$. Montezuma, or a species? I hare taken it on the banks of the Rio Panuco, in the Huasteca.

Fig. 3. Zethus Montezuma, $q$, enlarged. Fig. 3, a. The head $q$ seen from before.

30. Th. parvulus Sauss.- $q$. Parvulus, gracilis, niger; clypeo convexo, apice truncato, late subemarginato; pronoto cristato-marginato, utrinque angulato; post-scntello carina arenata antrorsum convexa instructo, metanoto anguloso, supra carinulis 2 simutis e post-sentelli angulis emergescentibus et postice convergescentibus, instructo; petiolo gracili, in medio campanulato, punctato; secundo segmento panlmm in. fundibuliformi.-Caput et thorax dense punctata, argenteo-sericea; am, tennarmm articulis 1-3 sultus, genibns, tibiis et tarsis, furrugineis ; 
petioli margo flavo-notatus; alæ secundum venas infuscatæ. Longit, 0.011 .

Zethus parrulus Sauss. Vespides, III, 119, 5, pl. ii, fig. 1, $\uparrow, 11154$.

Hab. Brazil. Sunth of the Provinee of Goyaz. (Collected by the savant botanist Auguste de St. Hilaire.)

This species approaches to the form of $Z$. IIontezuma; but it is much less coarsely punctured, smaller, and rery clearly recognizable by the areuate ridge of the post-scutel, which in comtinuation of the carinæe of the metathorax, forms a promiuent horseshoe.

r. Petiole quite linear, filiform, depressed, very much elongate, as in Eumenes of Dirision $\zeta$. The appearance of a Calligaster.

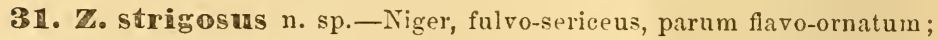
pro- et mesonoto valde oblique strigatis: metanoto rugoso ; petiolo lineari; 20 segmento basi breviter pedunculato; pedibus nigris, liavescentipilosis; alis subhyalinis.

?. Total length, $14 \mathrm{~mm}$.; wing, $11 \mathrm{~mm}$.

$\delta$. Total length, $12 \mathrm{~mm}$; wing, $8 \frac{1}{2} \mathrm{~mm}$.

. Slender. Head strigate-punctured. Prothorax sharply margined, angular on each side, but not spined, obliquely strigose. The whole disk of mesothorax strongly obliquely strigose and wrinkled; the striæ converging against the middle carina. Scutellum shining punctate, a little sulcate in middle, as the postscutellum. Metathorax rugose, velutinous, wrinkled on each side, at base parted by a channel; the lateral cantlii carinated on the sides. Petiole very long and slender, not globulously swollen, but quite linear (as in Eumenes of Division Zeta) flattened, shining, and parted by an impressed line, punctate on the sides. Collar of the $2 \mathrm{~d}$ segment distinct; the hinder margin of this segment very slightly reflexed.

Black, furnished with a yellowish-silky, or rather golden pubescence; the metathorax and pleura with cinereous pubescence. $A$ line on the base of the inner margin of mandible, a line on the scape, tiwo dots on the front, a very narrow line on both margius of prothorax, the post-tegulæ, angles of post-scutellum, and two

1 The male of this species is not known. It is possible that it should be placed in section $d$. 
fascix on metathorax yellow. Scales margined with hrown; a narow yellow submarginal line bordering all the segments of the abdomen; the 6th segment yellow. Feet black, knees a little fulvous; tibiæ furnished with silky-golden hairs. Intermediate tibise with a yellow line. Wings subhyaline, with lorown veins. On each side of the clypeus is a very dull, obsolete, yellow macula.

. Clypeus rounded, a little truncate at tip, punctured, rugose, black.

§. Clypens broad-quadrate, strongly punctured, slightly truncate in the middle of its inferior margin, with two hardly sensible edges; black; the lateral yellow spots often distiuct. Antennæ rather thick; the whole terminal hook and the last three joints of the flagellum beneath, yellowish.

Var. 5.-a. Clypeus yellow, with the top part and extreme margin black; sometimes also with two black dots on the yellow.

b. Clypeus more or less margined with yellow.

Var. $\delta$. . - a. 'The spots of the forehead wanting.

$b$. The posterior margin of the prothorax not margined with yellow.

c. 'The anterior margin having only the angles yellow, or also a little line in the middle.

d. Prothorax black.

Hab. 'The Gulf side of Mexico. Orizaba. (Sumichrast.)

This species, although very variable in its coloring, is rery distinct by its filiform pedicule and by the strong strigie of its dorsum. It lias the facies of an Elimus.

\section{Species which I do not know, and of which the antennæ $\delta$, have not been described.'}

32. Z. albopictus Sutu.- - . Niger, sat teuniter punctatus : cinereo sericeus; antemis subtus apice ferruginescentibus; vlypeo utringlus flavo-notato; pronoti margine, macola subalari, pumetis 2 in tegnlis, scntelli margine intermpto, punctis 2 post-scutelli tibisqutu extus, albidis; abd. segmentorm 1-3 limbo et lineola (utrinque?) in hasi secumdi, albidis; alis pellucidis, secumdum eostam fuscis. Lomgit, $4_{4}^{3}$ lim.

I As the form of the alidnmen has not been deseribed, I presmeme that it offers nothing remarkable, and that in consequence all these species pertain to the division Zethusculus. 
Zethus albopictus Sмrтн, Cat. Brit. Mus. Vespidæ, 1857, 15, 32.

Hab. St. Domingo.

33. Z. gracilis Surtr.-Niger, capite et thorace grosse punctatis; fronte sulco transverso inter antentas et carina rerticali ad medium clypenm producta instructo; metanoto in lateribus striato; petiolo sparse punctato; abdouine sericeo; punctis 2 froutalibus abilominisque segmentorum limbo auguste, flavis. $\delta$ antenuarum scapo antice flavo. Longit, $4 \frac{1}{2}$ lin.-Afinis videtur, $Z$. IFontezumce.

Zethus gracilis Smrn, Cat. Brit. Mns. Vespidæ, 1S57, 17, 43.

Hab. Mexico.

Small species, of the size of $Z$. MIontezumæ.

31. Z. Iavinodus Sniтn.- + . Niger, capite grosse, vertice sparse, punctato; clypeo rugose striato, apice subemarginato; thorace polito, punctis distantibus aliqnot; pronoti margine acute marginato, acute angulato; mesonoto antice carina abbreviata, et sulcis 2 e scutelli angulis emergentibus ad pronotum ductis; metanoto relutino, biconvexo. Thorax maculis 2 in pronoti angulis, macula-subalari, postscutellique fascia interrupta, flavis; abdomine polito; alis fusco-cyaneis. Longit, 9 lin.

Zethus lavinodus Smitн, Cat. Brit. Mus. Vespidæ, 1857, 17, 44.

Hab. Mexico.

By the fuscous wings this species comes near to $Z$. spinipes, but is separated from it by its distinctly polished mesothorax, and by its remarkably large size.

35. Z. pallidus Sмiтн, Cat. Brit. Mus. Vespidæ, 1857, 11, 10.

Hab. Brazil. (Num Zethusculus?)

36. Z. Sculpturalis Smit, ibid. $11,11, \delta$.

Hab. Brazil.

3\%. Z. dubius Sмrth, ibid. 13, 19, ㅇ $\delta$. Hab. Brazil.

35. Z. carinatus Surtu, ibid. $13,20, \widehat{\delta}$

Hab. Brazil. 


\section{Division DIDYMOgastra Perty.}

(Sauss. Vespides, I, 18; III, 120.)

Second segment of the abdomen lengthened pediculate; its pedicular part forming at least a fourth of the length of the segment. The other characters as in Zethusculus.

These insects have very slender forms on account of the extraordinary length of their abdomen, by the double articulation of which, they enjoy the singular faculty of folding the abdonen bencath the thorax, and of placing the terminal pear against the face of the head.

The Didymogastra inhabit the hot regions of America.

One cannot establish any line of demarcation between the Zethusculus and the Didymogastra; these last form the continuation of the same genera and only represent the more lengthened morlification of the type. The two series, based on the form of the antennæ of the males, continue themselves in the Didymogastra. So this division is wholly empirical, and should not be preserved except to facilitate the determination of species.

\section{A. Antennx of the males terminated by a rolled spiral.}

39. Z. Poeyi Sauss. (Fig. 4, 4a.)--Niger, rugose punctatus, metanoto vix striato, velutino; petiolo polito, tenuiter punctato, gibboso ; secundo abd. segmento lrvi, nitido, pedunculo mediocriter elongato ; mandibulis, frontis fascia, orbitis bis intermptis, pronoto antice, maculis 2 subalaribus, tegulis, scutello et post-scutello antice, maculis 2 metanoti, petioli apice pedibusque, anrantiacis; his rufo vel uigro variis; abdomine nltra petiolum rufo; alis flavescentibus, apice grisescentibus.

$\widehat{\delta}$. Fronte carinato; clypeo aurantiaco, emarginato, bidentato; manoibulis flavis; antenuarum articulis 1-2 rufis, fascia 1lava; flagello subtus flaroannulato, apice cochleato, flavo.

Zethus Poeyi Sauss. Revne et Mag. de Zool. 1857, 270.

Total length, $14 \mathrm{~mm}$.; wing, $10 \mathrm{~mm}$.

Head and thorax quite densely cribrose (molerate and a little irregular often, in form of an oblique prick of pin). Ocelli prominent, arranged in a rather large triangle. Tertex $\delta$ forming a ridge in form of a $\mathrm{T}$, of which the rertical limb tonches the clypens. The posterior part of the vertex a little more elerated than the ocelli. 'Thorax contracted before, its margin little 
salient. Scutellum punctured with coarse points, anr?. dirided by a groove. Metathorax punctured on each side of its summit, neither punctured nor striate on its posterior face, but relvety. Enlargement of the petiole conrex; its swelling, seen in prolile, is more salient near its base, and is depressed and contracted behind; on its extremity is an excavation. This enlargement, seemingly smooth and polished, is quite finely punctured. Second segment very shining and polished, its pedicle equalling a third of its length and widening posteriorly; the globular bell, as long as wide, enlarging gradualiy. Seen in profile, it is much more swelled above than beneath.

Insect black, with orange markings, which are in general arranged as follows: sinus of the eyes, the t:ansrerse bar of the frontal $\mathrm{T}$, a point on the summit of each eye and the orbit behind the eyes; the prothorax, wholly or in part, a spot under the wing, wing-scale, the anterior portion of the scutellum and of the post-scutel, two spots on the metathorax and the extremity of the petiole, orange. These markings are more or less dereloped; they may be more extended, or in part wanting. 'The remainder of the abdomen is of a beautiful red or ferruginous, with the base of the pedicle black. Scape of the antennæ ferruginous. Feet yellow, raried with ferruginous. Wings ferruginous, with the end lightly gray, carrying a little reflection of riolet.

․ Clypeus rounded, black, with two oblique yellow bands at the superior margin; $2 d$ joint of the antennæ ferruginous; a whole band of yellow under the wing; the margin of the $2 \mathrm{~d}$ abd. segment narrowly rellow.

$\delta$. End of the antennæ rolled spirally. Clypeus orange, finely punctured; its inferior border armed with two separated teeth, with an areuate border between them, in the middle of which is a little salient tooth, often hardly risible. The first two and the last two articles of the antenma orange; the flagellum annulate with this color beneath; the terminal spiral orange; the last article obscure.

Irar. The specimens of other localities possess, without doubt, more of black on the abdomen and antennie.

Ress. a. diff.-Whis Didymogastra is easily distingnished from $Z$. Chicoterca!l, by the ruguse aspect of its hearl and thorax, by its much less striate metathorax, by its petiole more swelled 
above, distinctly punctured; by its second segment wit? it.s less extended pedicle, and by the yellow markings of all the body.

It differs from $\%$. Malzicatzin, in its smaller size, in its much more lengthened thorax, having a mesothoracic disk longer than wide; in its metathorax, devoid of middle carina and of smooth spaces at the superior angles; in its scutellum, simple, depressed, angular (not emarginate) posteriorly; in its less cnlarged and more punctured petiole, and in its. head smaller, without swelling of the vertex.

The $\delta$ differs in its clypeus, quadrate, large, convex and notcher as in the Z. Poeyi, not flattened and advanced in the mic!lle as with the Matzicatzin; by the antennæ terminating in a spiral, by the ocelli placed upon a scarcely oblique plane, etc.

Hab. The island of Cuba. This beautiful insect was given me by Prof. F. Poey.

Observation.-In the figure, the thorax is too large and the form of the abdomen is not perfectly natural.

40. Z. Romandimus SAuss.-Niger, cinereo-sericeus, capite lato, dense punctato; thorace grosse cribrato, antice cristato-marginato; scutello convexo, sulco, bipartito; metanoto convexo, haud foveolato, velutino, tenuiter punctato, supra utrinque spati, nitiso læri; petiolo derse punctato, nitido, postice paulun attenuato, flavo-marginato; secundo segmento sat breviter pedunculato tanguam in Didymogastru, piriforniter dilatato, marginem versus tenuiter punctato, tenuisime flavo seu ferrugineo-limbato; reliquis punctatis, piceo-limbatis; tegulis ferrugineo marginatis, pedibus, fuscescentibus; tibiis intermediis llavovariis; alis diaphanis, subfuscescentibus.

. Clypeo trausversim quadrato, flavo, tenuiter bidentato; antennis subtus apicem versus flavo-anmulatis et apice cochlea fulva.

Longitudo, $14 \mathrm{~mm}$.; ala, $10 \mathrm{~mm}$.

Zethus Romandinus Sauss. Vespides I, 20, 22, pl. ix, fig. 1, \&, 1\&52. Revue de Zool. X, 1S5S, 164.

Hab. Cayeme. ('Typus in auctoris musieo.)

'This Zethus constructs with woody fibres and gummy materials several rounded eclls, with thick walls towald the bottom and irregularly muited, recalling a little those of Bumbus (sec salls: Tespides, I, pl. ix, fig. 1, c). The instincts of these inserets appente to progress toward the habits of the social II aspls. 
11. Z. anrulentus Sacss.

Zethus aurulens Sauss. Vespides, III, 121, S, pl. vi, fig. 5, $~ 1854$.

Hab. Brazil.

42. Z. Matzicatzin SAUSs.-Niger; capite discoidali, lato, facie cribrata, vertice supra inflato, minus cribrato; ocellis in declivitate frontis sitis; thorace grosse cribrato, postscutello truncato, postice exciso, carinato; metanoto sulco conspicuo, at foreola nulla; infra ralde striato, supra lævi, in medio bicarinato; petiolo polito inpunctato, valde inflato, apice puncto maximo impresso; secundo segnento longe pedunculato, medio margine impresso, cum reliquis rufo; tertio punctato, in medio producto; punctis frontalibus et post-ocularibus 2, pronoti margine, macula subalari et maculis 2 scutelli, limboque segmentorum 1,2 , flavis; tibiis rufis; alis fusco-flavescentibus.

$\widehat{\delta}$. Scutello plano, tenuiter punctato, infra macula lævi et margine in merlio subproducto; antennarum scapo subtus flavo.

Zethus Matzicatzin Sacss. Revue et Mag. de Zool. 1\&57, 271.

Total length, $18 \mathrm{~mm}$.; wing, $11 \mathrm{~mm}$.

Mandibles obliquely truncate, trenchant, without teeth, but with a single lobe. Head very large, much wider than thorax; face flattened; ocelli arranged in a broad triangle and placed, not on the summit, but on the slope of the vertex. Tertex strongly enlarged transversely behind the ocelli, but swelled upward. Face-offering between the antennæ two little rertical carinæ. Thorax very short, quadrate, depressed; the margin of the prothorax little prominent. Disk of the mesothorax wider than long; its anterior curve describing a semicircle, not an ellipse as in all the preceding species. Scutellum divided by a channel. Post-scutel truncate, angulate; its posterior border offering a concarity and carrying an arcuated ridge interrupted in the middle (which especially distinguishes it from the preceding species, which has the post-scutel whole rounded above). Metathorax very angulate, having four sharp ridges, so to speak: 1st, the two ordinary lateral ones, which here form two sharp crests; $2 \mathrm{~d}$, two other very short ones, which start from the angles of the post-scutel; the middle divided by a strong channel, but, properly speaking, without any concavity. The summit of the metathorax, especially the space situated on each side between the two ridges, is smooth, shining, not punctured (or rery finely striated), the remainder wrinkled. The flanks under the lateral ridges smooth 
and shining. Petiole quite lengthened-pediculate; its elliptical enlargement is globularly swelled above, as high as wide (sub)compressed), having on its posterior extremity above, a large excavation, and on each side a large transverse groove, which compresses the end of the petiole, but without coalescing with the middle groove. Second segment lengthened-pediculate, almost as in the $Z$. Chicotencats; its globular part very flat beneath, and much swelled above from its base; its first posterior border a little sinuous, preceded in the middle by a vague depression-its second border not being at all reflected. Margin of the third segment formed in the same way, but the first border more sinuous. Head coarsely punctured; the face cribrose, but the vertical inflation very much less. Thorax cribrose with sunken points, except the metathorax. Petiole and abdomen smooth and shining, while the last is very fincly punctured. The third segment punctured.

Insect black, garnished with a gray or slightly golden pile; two spots on the face, one behind each eye; margin of the prothorax, a point under the wing, two spots on the scutellum, and the borders of the 1 st and $2 d$ segments, yellow. The abdomen, except the petiole, of a brown purple or ferruginous. Feet black, raried with ferruginous. Wings washed with brown-yellowish, nervures brown; wing scales bordered with brown or yellow.

$\widehat{\delta}$. Clypeus very flat, punctured; its inferior margin advanced in the middle, entire; a smooth lozenge or triangle in the middle of its inferior extremity; this piece is black, covered with gray hair-its lozenge-shaped part smooth, often yellow. Antenni black, with front of the scape yellow and terminated by a little ferruginous hook.

Ress. a. diff.-See the affinities of $Z$. Chicotencatl and Poeyi.

The $Z$. niger offer's also two metathoracic carine starting from the angles of the post-scutel; 'but in this species the post-scutel is not cremulated, and there is between these carine a concare pit, while here the two moieties of the metathorax remain convex and are separated by a deep furrow. The thorax and the head are also smaller, ete.

Hab. 'The gulf side of Mexico. 'Tampico. I have taken but one specimen $(\delta)$.

By the very remarkable form of its clypeus and its mandibles, 
this species deserres to be noted as fit to serve as the type of one section of this genus.

\section{B. Antennæ of $\delta$ terminated by a hook.}

43. Z. Hillarianus Sarss. - Gracilis, niger; capite dense punctato, supra et pone oculos tumefacto; thorace minus dense punctato; pronoto valde cristato-marginato, sed angulis hand acutis ; mesonoti disco carinis 2 lævibus trajecto; post-scutello medio subdentatı; metanoto velutino, rugoso, striato, in medio canaliculato; abdominis petioli tumefactione ovata, sat gloloso-inflata punctulata; secrindo segmento globoso, sericeo, basi sat longe petiolato (petiolus tertiau partem longitudinis efficiens); segmentis reliquis punctatis. Corpus omnino velutinum, argenteo-sericeum; puncta frontalia 2, maculæ 2 post-oculares, antennarum articuli 1-3 et apex, thorax, petioli latera et pedes, rufa; petioli apex et lineola utrinque in secundi segmenti petiolo, flava; segmentorum limbus tenuiter piceus vel rufus. Alæ infuscatæ, costa nigra. Longit, $0.016 \mathrm{~mm}$.

․ Clypeo convexo, punctato, apice late subexciso, tridentulato; maculis 2 lateralibus rufis.

$\hat{\delta}$. Clypeo truncato, rufo vel flavescente macula media et basi nigris, vel nigro margine infero rufo et laterali flavo; antennis apice ultimo minuto rufo.

Var. Color variabilis, plus minusve rufescens vel nigrescens; disco mesonoti obscuro vel nigro, carinis rufis; etc.

Zetlus Hilarianus Sauss. Vespides, III, 120, 7, pl. vi, fig. 6, q, 1854.

Taries in having the margin of pronotum and the post-scutel yellow, and in the distribution of colors, the reddish and black passing one to the other; but, nevertheless, a distinct species by its mesothoracical carinæ.

Hab. Brazil. Middle of the province of Goyaz. (The type is in the Paris museum.)-Venezuela, Caracas.

\section{4. $\mathrm{z}$. geniculatus SpIN.}

Didymogastra geniculata SpIx. Mem. Acad. Turin, XIII, 1853, 80, 60. Zethus geniculatus SAuss. Vespides, I, 22; III, 120, 6.

Netanoto postice bicarinato; colore affinis $Z$. nigro.

Hab. Brazil. Para. (Typus in mus. Taurinense.)

45. Z. dicomboda Spr.,-Niger, gracilis, dense punctatus, cinereosericeus; pronoto antice cristato-marginato, angulato; mesonoti disco bicarinato; metanoto conrexo, velutino, haud rugoso, in medio striato. 
Abdomen gracile, petiolo elongato, parum inflato, punctato, apice puncto impresso nullo; secundo segmento sat longe pedunculato, ovato-dilatato, depresiso et tenuiter punctato.-Puncta 2 frontis, pronoti et tegularum nargo, post-scutelluin, fasciæ 2 nietanoti et abd. segmentorum 1-2 margo, nec non fascia utrinque petioli secundi segmenti (vel petioli apicis) albida; femora intermedia subtus albido varia; alæ hyalinæ, venis ferrugineis, apice griseo-nebulosæ. Longit, 0.015 mm.

q. Clypeo nigro, rugoso, truncato, sub-bidentato (vel sub-tridentato).

$\delta$. Clypeo albido, supra nigro, margine infero bidentato, tenuissime nigro limbato; antennis nigris, uncinatis.

Epipona dicomborla Sprivola! Gay's Historia fisica de Chile (Fauna Chilena), VI, $1851,250$.

Zethus discombuda Sauss. Vespides, I, 21, 25.

Hab. Chili. (Typi in museo Parisiense et in auctoris servantur.)

\section{Species of which the section remains undetermined.}

46. Z. Clicotencat SArss. (Fig. 5, 5a.)-Niger, politus, fulvo hirtus, clypeo convexo, capite dense punctulato, thorace lævigato, in medio disco nitidn, impunctato; pronoto antice et pone angulos in lateribus cristato-marginato; metanoto haud excavato, ubique ragose striato, petiolo parum inflato, impunctato, nitidissimo, secundo seguento longe pedunculato, sericeo, secundum marginem punctato, margine subjacente reflexo; antennis subtus flavis; punctis 2 frontalibus, maculis 2 metanoti, et abdom. segmentorum limbo (aliquaudoque pronoti), tibiisque supra, flavis; alis ferruginescentibus. $\quad$.

Zethus Chicotencatl Sauss. Revue et Mag. de Zool. 1557, 271.

Total length, $17 \mathrm{~mm}$. ; wing, $12 \mathrm{~mm}$.

q. Mandibles strongly tridentate. Clypeus rounded, rery convex, but fincly punctured, truncate or sub-bilobed on its inferior border, in the middle of which is a smooth space. Head densely punctured, but not rugose. Ocelli salient, placed in a regular triangle on the vertex, the head a little contracted behind. Thorax shining and polished, not being punctured abore the middle; margin of prothorax forming a salient lamina; this margin reflexes mon its angles and prolongs itself behind, alone the lateral border of the prothorax orer a moiety of the distance from the wing seale. Mesothorax punetured alomg the sentellum. without groore on its hinder part, but carrying a donhle longrtudinal groove on its anterior moiety; sentellum eonrex and shining, feebly punetured. Mctathorix a little fattened belind, 
having a very small gruove, strongly striated transversely or rather channelled in all its superior and posterior surfuce (situated above the lateral ridges). Some strix, but less distinct, also cover entirely the lateral faces of the metathorax, beneath the angles. Enlargement of the petiole in an oval form, much lengthened, depressed, without any globular swelling above; its linear portion short, equal to a third the length of the petiole, smooth, shining, without punctures. The posterior depression not having an excavated point, but a transverse shining channel. Second segment much lengthened, pediculate; its pedicle forming almost the moiety of the length of the segment, which offers a zone of fine punctures along its posterior border; the second lamina of this margin a little reflected. 'ihe whole insect is covered with a tawny pile almost woolly on the thorax, gray on the metathorax, a little golden on the abdomen, but the body is polished and shining, especially the petiole, which does not show any punctures.

Color black; antennæ ferruginous beneath, obscure above. Two dots on the face, two spots on the metathorax and often the post-scutel and the margin of the prothorax, yellow or tawny. Petiole having a yellow interrupted border; the abdominal segments wholly or in part margined with a very narrow yellow line. Feet black. Tibiæ yellow before. Wings transparent, washed with yellowish-gray.

Ress. a. diff.-This species appears to me rery near to $Z$. tubulifer. It may even be identical; which I dare not say positirely, not having the type of this last before my eyes, and being without a sufficient description.

It is vely recognizable by its back as well as its petiole, being without punctures and shining. The $Z$. Chicotencall is not difficult to distinguish from the $Z$. Matzicatzin, by its metathorax, rugose even to the summit and without middle carinæ, by its postscutel, which is not notched behind, by its much less enlarged petiole, by the border of its second segment, which is punctured, and by the second lamina of its border, which is turned up ; perhaps also by its thorax, which is not cribrose, and by the ocelli, which occupy the summit of the vertex.

Hab. The gulf shore of Mexico. I have taken it at Tampico. (The $Z$. tubulifer comes from Orizaba in the Cordilleras.) 
Observation.- In the figure the petiole is not quite surdenly enough enlarged, and the profile of the pedicle of the second seginent is a little too short, as also in the linear part of the petiole.

4\%. Z. tubunifer Sauss. Vespides, I, 18, 19, ๆ.-Niger: clypen rotundato ; antennaruin scapo subtus ferrugineo-notato ; pronoto angulato; punctis 2 frontalibus, pronoti margine, tegulis partim, maculis 2 scutelli, fascia interrupta post-scutelli, maculis 2 metanoti, margine lineolaque laterali utrinque petioli apicis, segnentorum margine punctisque coxarum, flavis; pedibus flavo-variis; alis fumosis. Longit, $0.017-18$.

\section{Hab. Mexico. Oriental Cordillera.}

48. Z. Zendalus n. sp.-Niger, punctulatus, capite et thorace griseo-sericante; metanoto tenuissime strigato; pronoti fascia, macula subalari, maculis 2 scutelli, 2 metanoti, petioli apicis lineolis 2 lateralibus, et lineolis 2 lateralibus $2^{\mathrm{i}}$ segmenti basis, citrinis; segmentis reliquis late rufo-marginatis; ano rufo. $q$

\section{‥ Total length, $14 \mathrm{~mm}$; wing, 10-11 $\mathrm{mm}$.}

Head and thorax densely and delicately punctured. A little compressed brilliant point between the antennæ. Prothorax margined, but not angulated. Metathorax velutinous, very delicately strigate, divided by a channel. Petiole ovate, narrow, very delicately punctured like the abdomen, destitute of an impression at the end. Peduncle of the $2 d$ segment rather long.

Black, with grayish hair; the margin of prothorax, a spot under the wing, two on the scutel, two elongate maculae on the metathorax, and a sinuous lateral line on each sile of the extremity of the petiole, a line on each side of the peduncle of the $2 \mathrm{~d}$ segment, and two dots at its base, lemon-yellow; a broad fascia on the margin of segments 2d-5th, and the 6th segment, orangeyellow or rufous. The apex of the petiole has no yellow margin and no groove, but the base of the peduncle of the seeond segments has two yellow dots, which can be easily taken by error for a yellow marking of the apex of the petiole. Feet black. Wings smoky with a golden reflection, the nerves black.

9. Clypeus rounded, densely punctate, black like the antennie and mandibles.

Riess. a. diff.-Distinet from Matzieatzin by its moderate head, absence of impression at the end of petiole, and absence of 
carinæ on the middle part of the metathorax. Differs from Chicotencall by its prothorax not crested on the sides, its petiole narrower, ete. It comes very near to liomandinus, but the thorax is shorter anteriorly, more narrowed posteriorly; the petiole narrower, less inflated, etc.

Hab. Mexico. The Oriental Cordillera (Mr. Sumichrast).

49. Z. Miscogaster SAoss.- $q$. Minutus, niger, dense punctatus, cinereo hirtus; clypeo integro, rugoso, piloso; fronte inter antenuas transversin carinato; ocellis in summo fronte sitis. Thorax antice cristatus, carinatus, humeris haud spinosis; postscutello et metanoto laud rugosis, velutinis, hoc tenuiter striato, nec carinato, nec distincte foveolato, sed sulco profundo diviso. Abdomen politum, sericeum; petiolo elongato, parum inflato, supra parum gibboso; secundo segmento longe pedunculato, ovato-dilalato subdepresso. Caput immaculatum; pronoti margo, macula subalaris, maculæ seutelli et 2 metanoti, lineola utrinque, petioli apex, limbus secundi segmenti, lineolaque utrinque in basi pedunculi, flava. Alæ subpellucidæ, venis fuscis.-Longit. (1.015.

$Z$. discombodie similis at minor, et pronoto haud auguloso differt. A $Z$. Romandino differt staturâ graciliore, petiolo minus punctato et minus tumefacto.

Zethus miscogaster SAdss. Vespides, I, 18, 18, $q, 1852$.

Zethus microguster (per errorem) SAdss. Revue Zool. X, 185S, 163.

Hab. South America. (Typus in auctoris museo.)

50. $\mathbb{Z}$. binodis $\mathrm{F}_{A B R}$ - Tracilis, niger, dense punctatus. Caput latum, dense cribratum; clypeo rugose cribrato, integro. Thorax cribratus, cristato-marginatus, clypeo convexo, nitido, cribrato; postscutello hand cribrato, postice truncato, sed cantho acuto nullo; metanoto in medio foreolato, carinis prominentilus duabus e postscutelli angulis emergentibus; spatio extra carinam sito utrinque valde striato-plicato; usque ad canthum lateralem acutum. Abdominis petiolo polito, teluaiter punctato, sat ovato-tumefacto, apice utrinque flavo-notato; secundo segmento globoso, longe pedunculato, ubique tenuiter punctato, sericeo setoso, in medio margine impresso; tertio, in medio margine paulum producto: 20 et 30 tenuissime fiaro-marginatis; reliquis piceis vel ferrugineis. Tibiæ 1, 2, ferrugineæ. Alæ subhyalinæ. Longit, 0.017.

Vespr binodis Fabr. Ent. Syst. Suppl. 1798, 264.-CoqubB. Illust. Icon. Ins. pl. $x v$, fig. 2.

Eumenes binodis Feabr. S. P. 287.

Lethus linodis Sauss. Vespides, I, 20, 23.1

1 Typus in museo Parisiensi. 
Zethus niger SAuss.' Vespides, I, 1852, 21, 24, pl. viii, fig. 9.2

A Z. Romandino differt metanoto carinato, foveolato et plicato; petiolo globosiore et minns valde punctato; secundo abd. segmento giobosiore, magis pedunculato, et punctatiore; segnentis 3-5 minus punctatis; tertii margine in medio producto.

Hab. Cayenne.

\section{R. didymogaster SPIN.}

Zethus didymogaster Spin. Ann. Soc. Ent. Fr., 1841, X, 133, ㅇ․

Hab. Cayenne.

This species differs from $Z$. binodis in its very wide clypeus, having a straight border, armed with two distant teeth. (Has not the author taken a male for a female? Only the males have the elypeus twice as wide as long.)

\section{W. fuschis Perty.}

Didymogastra fusca Perty, Delect. Anim. Artic. 145, pl. XXVIII, fig. 5, ㅇ, 1830 .

Zethus fuscus SAuss. Vespides, I, 19, 21 ; III, 120.

Hab. Brazil. Amazon.

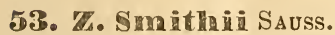

Zethus Smilhii Sauss. Vespiàes, III, 122, 9, $q$.

Metanoto striato; alis fusco-cyaneis.

Hab. South $\Lambda$ merica.

\section{SPECIES WHICII I DO NOT KNOW.}

The following species of the genus Zethus, all from Brazil, have been deseribed by Fred. Smith in the Catalogue of the Vespidie of the British museum, page 11-18.

7. pallidus-sculpturalis-dubius.

Z. carinatus-albopichus-gracilis-lavinodus.

1 Typus in auctoris museo.

2 Hrata. Fig. 8, pl. viii, Vespides, I, does not represent this species, but $Z$. piriformis. 
Gen. LAIBUS SAUSS.

Labus Sauss. Reise d. Oesterr. Fregat. Novara. Hym., p. 3.

Mandibles short, obliquely truncate, with 3-4 terminal teeth. Maxillæ elongate; their palpi elongate, 6-jointed. Labium elongate, quadrifid, its palpi 4-jointed. Head rounded, swelled at the occiput; clypeus rounded or truncate.

Thorax elongate; its anterior angles sharp.

Abdomen very slender; its petiole elongate, linear. Wings somewhat as in Eumenes and Zethus.

As the forms of the insects of this type are hecoming various, one could well think that the genus Labus might be fused into G. Elimus, which only differs from this by another form of thorax and petiole. Such differences occur under the species of the genus Zethus.

A. Petiole filiform at base, a little widened posteriorly; its extremity margined by a transierse rounded cordon preceded by a transverse channel (as in Eumenes of Division Omicron). Second segment sessile, elongate. Metathorax, attenuated. Head inflated. Second cubital cell much prolonged at the basilar extremity; the second recurrent vein inserted after the middle of its posterior border. (Asiatic type.) L. Spiniger Sauss., L. Humbertianus Sauss.

B. Petiole linear, slender, prismatic; $2 d$ segment subpediculate. Thorax elungate; metathorax short; prothorax crested anteriorly. Second cubital cell equally dilated at both extremities; second recurrent vein inserted in the middle of its posterior border. (American type.) ${ }^{\mathrm{l}}$

1 The genus Elimus would make a third type:-

C. Petiole linear, rather thick (very elongate, somewhat pyriform), bidentate; its extremity marked with an impressed point; head moderate; thorax oval, not acute angled anteriorly; metathorax rounded; the $2 \mathrm{~d}$ segment elongate, rather attenuate posteriorly; $2 \mathrm{~d}$ cubital cell in a regular truncate triangle; second recurrent nerve inserted in the middle, or a little before the middle, of its posterior border. 
1. L. Sicheliamus n. sp. (Fig. 20, 14a.)-Niger, gracilis, thorace elongatiusculo, antice cristato-marginato, superne crassiuscule punctato; petiolo lineari-prismatico; 20 segmento basi subpedunculato; capitis maculis, pronoti margine antico, maculis 2 scutelli et 2 metanoti abdominisque segmentorum marginibus, flavis.

Total length, $11 \mathrm{~mm}$.; wing, $8 \mathrm{~mm}$.

9. Antennæ rather clubbed. Head quite orbicular, rather swelled and rounded at the occiput, densely punctured; a little carina between the antennæ. Mandibles short truncate, armed with three terminal teeth, tricarinate at end. Clypeus ovate, as wide as long, a little truncate at tip, covered with coarse punctures, substrigate. Ocelli disposed in an equilateral triangle. Thorax a little depressed, flattened above, rather ovate (that is, elongate), rounded posteriorly, a little contracted anteriorly, truncate and margined with a crest; the angles of prothorax salient. The thorax above strongly punctured, not so strongly on the sides; the metathorax a little shagreened; the lateral faces of this not punctured. Metathorax having its posterior face vertical, somewhat truncate, triangular, but quite arcuate at the summit, and margined by a little arcuate ridge, rough and obsolete; the hind face parted by a depression and a little strigate in the groove. Disk of mesothorax elongate, having two arcuate furrows. Petiole elongate, quite linear; only its base filiform; the rest depressed and compressed, making it prismatic, with a dorsal, two lateral faces and an inferior face; the faces having scattered punctures; the superior one not parted by a furrow, but with a round impression before the border; the inferior one carinated; the lateral faces having the margin a little salient becanse of their compression; the compression being more sensible behind the middle of petiole, so that the anterior part of the swelled portion is a little wider than tre rest and a little ovate. The rest of the abdomen nearly impunctate; the second segment globular, but its base a little funmel-shaped and articulate by a very short neck as in the Zethusculus. Anterior tibia very short.

Black, with short gray pile. Antemna a little ferruginous at the extremity beneath; a spot in the middle of the mandibles, a line on the scape, a spot on each side of clypeus, two dots over the insertion of the antenne, and one in the sinus of cach eye, 
yellow. The anterior margin of prothorax, two marginal spots on each wing scale, post-tegulie, two spots on post-scutel, two longitudinal fascie on the metathorax, the end of petiole and the margin of the abdominal segment, yellow; the lamellar margin of these also yellow or ferruginous, as well as the margin of the anus. A spot at the end of the femora and a line on the tibire of the first two pair, yellow. Wings subhyaline with brown reins; the 2 d cubital cell subtriangular; its radial tip very little truncate; the second recurrent nerve inserted in the middle of the posterior margin.

Liess. a. diff.-This remarkable type has a certain resemblance to the Eumenes of Dirision Zeta, because of its elongate linear flattened petiole; but this is not so much flattened, nor parted by a furrow, but prismatic, and the head with its short mandibles is quite that of a Zethus.

It has a very near relationship to the Asiatic Labus but differs essentially by its prismatic petiole, a form which I hare not yet met with in the WVasp.

Hab. Chili. (This insect was given to me by the celebrated oculist and remarkable entomologist, Dr. Sichel, to whom it is dedicated.)

\section{Gen, Discoenies latr.}

Lip moderate. Labial palpi composed of four articles. Maxillary palpi composed of six articles. ILandibles short, obliquely truncate. Head often enlarged and a little emarginate behind. Thorax leugthened, often angulate before. Abdomen pediculate; the first segment transformed into a campanular or linear petiole.

This genus differs from Zethus by its labial palpi composed of four articles, and from Eumenes by the mandibles which are not prolonged in the form of a beak.

This genus connects itself to Zethus by its mandibles, and to Eumenes and to Odynerus by its complete palpi; the forms of its representatires are also intermediate, in some degree, to Zethus and to Eumenes, and somewhat to Nortonia and Zethus by the subpediculate abdomen. The form of the thorax, often bordered and angulated hefore, especially assimilates it to that which one sees in the Zethus. 
1. ID. merota Corts.

Discolius merula Curtis, Trans. Linn. Soc. XVII, 325, 1831.-SAdss. Vespiltes III, 124.

Epipona chilensis Sprs., Gay's IIist. fisica de chile, Zool. VI, 248, 1851.

Discorlius chilensis Sauss. Vespides, I, 25, 1, 1852.

Discolius Spinolw, ${ }^{1}$ Sauss. Vespides, I, 25, 2, 1852 , III, 124.

Hab. Chili.

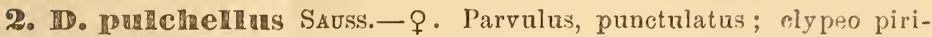
formi ; apice truncato; pronoto antice biangulato, metanoto rotum lato ; petiolo brevissimo, campanulato grosse punctato; apice puncto inpresso ; abdominis secundo segmento nitido, supra inflato.-Insectum nigrum, - mandibulis puncto basali, clypei apice macula nigra, fascia frontali, puncto post-scutellari, scapi fascia antica, flavis; antennarun fligello subtus ferrugineo; pronoto antice, tegulis, scutellis et metanoto, 1lavis, (sed puncto in tegnlis et matanoti sulco nigris ;) abdominis segmentorum $1^{\mathrm{i}} 2^{\mathrm{i}}$ linbo et secundi maculis 2 lateralibus, flavis; pedibns flavis. fusco-variis; alis hyalinis, stigmate et areola radiali fuscis, costa fuscescente.

$\widehat{~}$. Mandibulis et clypeo flavis; hoc apice subbidentato, antennarum uncino minuto ferrugineo.

Discolius pulchellus Sauss. Vespides, III, 127, 15.

Hab. Mexico; Jamaica.

\section{Legion II. The Odynerites.}

Mandibles more or less lengthened, terminating in a point, forming generally by their union a long sharp beak, or when crossed, an X. Their teeth placed on their inmer border (Vide Saussure, Vespides, I, p. 27, 11).

\section{Gen. EUMENES FABR。}

Organs buccate, very long. Tongue long, a little plumose. Galeas (or appendices) of the jaw very long. Palpi lengthened; labial composed of four articles; the maxillary of six. Mandibles very long, sharp pointed, having a triturating lateral border and forming by their mion a lengthened beak. (In cxecptions the mandibles are sometimes shorter.) 
Head much compressed trausversely, that is, wide, but not thick, nor enlarged; the eyes very convex and entirely corering the cheeks. Clypeus always longel than wide, with a variable termination (bidentate, indented, truncate, or rounded).

Thorax variable, globular, or long quadrate, rarely compressed, but always without spiniform angles.

Abdomen lengthened pediculate. The first segment forming a linear or subcampanulate petiole, about as long as the thorax; the remainder of the abdomen pyriform.

This genus is very abundant in species, and is found over all the surface of our globe. It is broken up into peculiar types, of which one (Division Alpha) is represented everywhere, and the others solely on one part of our planet. These types are connected by natural transitions which embarrass one in assigning them very fixed limits.

The Eumenes are well represented on the new continent. Of six divisions' into which I have divided the genus, four are found on the Western Continent, but the divisions Pachymenes, Omicron, and Zeta, are only represented in the tropical parts of America. The insects, peculiar to the Dirision Omicron, iuhabit all the equinoctial parts of the continent; and those which belong in the Division Alpha, extend themselves over the two American continents within their most extended limits.

Division PACHYMENES.

(SAuss. Vespides I, 73, III, 153.)

Abdomen much depressed, never compressed, petiole widened or campanular, parted by a groove; its hinder margin having usually a transverse groove; clypeus generally bidentate; body smooth, silky, and chatoyant or velvety; wings large. (A merican type.)

These insects have the appearance of Polybia, as the Montezumia have that of Synœca. It is especially by this appearance that one recognizes them and the semblance holds good in the depressed form of the petiole and in the pyriform abdomen as well as the silky appearance of the body.

1 I do not count the Division Pureumenes, which is worthy to form a genus (Etudes sur la Famille des Vespides, III, 133). 
A mong certain species, the thorax becomes narrow, lengthened, eompressed, and the metathorax is sometimes lengthened, so that the resemblance to the Polybia increases. Although the Pachymenes present a series of forms corresponding to those which one sees among the P'olybia; yet one can easily distinguish them from these social inseets by their truneate or bidentate clypeus, which is not angularly terminated by a sort of tooth. ${ }^{1}$

This group is not as yet well studied; most. of its species, which appear to be rather numerous, are only known by rare speeimens seattered about in eollections which have much similarity among themselves, all having a silky body and colurs pale or variable, so that one ean easily eonfound them.

Unfortunately it is impossible for me here to establish good differential charaeters between these inscets, from only knowing some of them by unique speeimens and not having under my eyes the types of all speeies heretofore described.

I established the genus Pachymenes in the monography of solitary wasps to receive those Eumenes of whieh the clypeus is bidentate, the abdomen depressed, and of which the smooth and satin-like body reealls the appearance of Polybia. But I have now renouneed this section, so diffieult to define, although including insects of a very peculiar appearanee; for sinee that time I have found many Ameriean Eumenes having the elypeus bidentate at the end, while ecrtain Pachymenes have a bidentate petiole, whieh destroys one of the differences on which the genus Paehymenes was founded. I liave, therefore, undertaken to reduce the consideration of this generie group to that of a simple division of genera, and this division itself goes over into the division Omicron so that it is impossible to fix a refined limit between them. (Ex. E. Santa-Anna goes over to division Omicron and is quite elose to E. laxvis.)

1. Form rather lengthened; thorax longer than wide; abdomen hardly depressed, the 2 d segment not campanular.

A. P'etiole campanular, enlarged above beyond the middle,

1 In my Monographie des Guepes Solitaires, I have confomded certain species of Polybia described by Fabricius with the Pachymenes. See Vespides, III, p. 153. (() n the line before the last of that page, for chrysothora.x, read pallipes.) 
humped, the boss divided by a groove ; its extremity bordered by a salient band.

a. Therax rather compressed, lengthened.

1. E. sericeus Sacss.-Gracilis, fusco-niger; thorace compresso; pedibus, petiolo et thorace supra ferrugineo-fulvis; hoc valde fulvovelutino; alis subhyalinis, costa fusca. $q$.

Pachymenes sericea Sacss. Vespides, I, 74, 1 (Sṛn. excl.); pl. xii, fig. 5 ; III, 153 .

Total length, 19 mill.; wing, 15 mill.

P. Slender; thorax compressed, rather narrow anteriorly. Head black; clypeus bicarinate at the extremity, bidentate or notched; the inner orbits and a line behind the eyes rather yellowish. Antennæ at tip a little ferruginous beneath. Thorax blackish, but haring its upper parts ferruginous or ornamented with yellowish, and all covered, as well as the sides, with relrety fulrous hair, rather woolly, which makes it quite fulrous. Petiole slender, ferruginous velrety; its base brown, its extremity a little obscure with a more yellowish border; the rest of the abdomen of a brown-oliraceous color. Feet ferruginous, more or less brownish or yellowish.

Ress. a. diff.-Tery much resembles auratus, from which it differs principally by its quite woolly, relrety hairy thorax and by its less biclentate clypeus.

Hab. Brazil. Bahia. (Paris museum.)

2. E. auratus n. sp.-Fulvo-olivaceus; capite fusco; clypeo bicentato, apice testaceo-marginato; thorace aureo-sericeo, compresso, metanoto valde angusto, sed pronoto antice haud coarctato, petiolo campanulato, gibboso, sulco subpartito, apice puncto impresso, basi nigro; mandibulis, orbitis, prunoti marginibus, mesonoti et metanoti fasciis 2 , scutellis, tegulis et macula subalari, frequenter testaceis; alis paulum ferrugineis. $q$.

Total length, 17 mill.; wing, 13 mill.

․ Insect slender, of an olive-brown, rather relutinous. Head blackish, with the orbits somewhat bordered with testaceous; clypeus flattened, a little bicarinate, toward the end strongly bidentate; its teeth spiniform, separated by a triangular notch; its extremity and its inferior border yellow-testaceous, as well as the mandibles. Antennæ ferruginous beneath, especially toward 
the end. Thorax convex, strongly compressed, strongly contracted toward metathorax, but not on the prothorax, which is squarely truncate. All the corselet covered with a silky goldenyellow pile; the posterior border of the prothorax and its anterior margin about the angles, two bands on the mesothorax, two on the metathorax, scutels, wing scales, and a spot under the wing testaceous. Abdomen olive-brown, silky, having an olivaceous reflection; petiole campanulate in the middle; its dilated part carrying a boss terminated by a groove, its border limited by a rim or rounded band. Its linear part black at the base and a little testaceons, second segment oval, lengthened, depressed. Legs varied with testaceous; wings transparent, ferruginous, with the extremity griseous.

Ress. a. diff.-This species resembles the $E$. olvivareus in the form of its head and of its abdomen, but its thorax is more compressed, more narrow and lengthened in proportion; the metathorax is much compressed and is not bicarinate.

It may be that this is a variety of the E. sericeus of which the woolly hair of the thorax has been rubbed off?

Hab. Brazil. Bahia.

3. E. cllirysothorax Sauss.

Pachymenes chrysothorax Sauss. Vespides, III, 153, 43.

Hab. Brazil. (Typus in museo Parisiensi.)

This species, of which I cannot again examine the type, is most likely a var. of E. sericeus. It is proper to notice that the forms should be those of $E$. pallipes.

\section{b. Thorax not compressed, moderately wide.}

4. E. pallipes Sadss.-Fusco-oliraceus; capite nigro ; antennis apice subtus ferrugineis; clypeo bicarinato, apice bispinoso, testaceo; orlitis partim, mesonoti fasciis 2 , scutellis, metanoto superne pleurisque, tha rotestaceis ; pedibus ferrugincis; alis ferrugineis, apice fusco-nebulosis; petiolo sat dilatato, superne tumido, ante marginem canaliculatu. $q$. Longit. $17 \mathrm{~mm}$.

Pachymenes pallipes Sauss. Vespides, I, 75, 3 (Syn. exel.); III, 153.

This species is not so slender as the preceding; the petiole is wider. The insect is probably sericeous when living.

Tar, Prothorax bordered with testaceous

The colors are certainly very rariable.

Hab. Sonth America. (Paris muscum.) 
5. E. Oliraceus n. sp.-Olivaceo-fuscus, clypeo ralde bidentato, apice flaro-testaceo; thorace aureo-sericeo, antice quadrato, metanoto superne bicarinato; petiolo tumido sulco partito; antennis subtus, tegulis et tarsis, ferrugineis; orbitarum maculis fascia interupta post-scutelli tibiisque extus testaceis; alis diaphanis, ferrugineis. $q$.

Total length, 20 mill.; wing, 15 mill.

Brown-chocolate or olive. Head and antennæ blackish. Head and thorax very delicately punctured, sericeous; prothorax broad and square; metathorax narrower, short, having in its superior part two carinæ which start nearly from the angles of the postscutel. The whole thorax with a golden reflection, velutinous principally on the metathorax. Petiole pyriform-campanular, swelled above, parted by a delicate groove, bordered by a cordon preceded by a transverse groore. The rest of the abdomen depressed-pear-shaped; the 2d segment rather elongate.

Antennæ ferruginous beneath, principally at the extremity; wing scales and tarsi ferruginous. Mandibles, a line behind each eye, and often the inner orbits testaceous. Tibiæ, knees, and coxæ varied with pale yellow; an interrupted line of this color margining the post-scutel. Borders of prothorax often ferruginous owith golden reflections. Wings transparent, ferruginous.

․ Clypeus oral, black, scarcely punctate, ending with two carinæ in two long teeth, separated by a triangular notch; its extremity and inferior margins yellow-testaceous.

Ress. a. diff.-This species much resembles E. obscurus and ater, but differs by its metathoracic carinæ. It differs from $E$. brunneus by its scrolled, swelled, and bordered petiole.

Hab. Surinam. This species has been communicated to me by Capt. Ton Heyden from the Senkenberg Mnseum at Frankfurt (Germany).

6. E. Obscurus Sirth,-Validus, niger, sericeus; clypeo apice bidentato; mandibulis, flagello, pedibus anticis subtus, pronoti margiue postico tegulisque, ferrugineis; alis hyalino-ferrugineis. $q$.

Pachymenes olscura Sмiтв, Cat. Brit. Mus. Vespid., 34, 7 (1857).

Total length, 22 mill.; wing, $18 \mathrm{~mm}$.

9. Black. Clypeus pyriform, having a triangular notch at its extremity, and bidentate; often two little carinæ terminating in the apical teeth. Mandibles long, slender, a little arcuated at 
tip. Thorax rather square shaped anteriorly, not margined. Petiole campanulate, rather short; its dilatation broad, swollen superiorly; the longitudinal channel quite obsolete, only distinct on the anterior part of the dilatation. The rest of the abdomen depressed.

The whole body very smooth; head and thorax very fincly punctured, covered with a fine fulvous silky pubescence. Mandibles, flagellum of the antennæ, fore legs beneath, posterior margin of the prothorax and wing scales, ferruginous; the borders of the abdominal segments often brownish or ferruginous. Wrings transparent-ferruginous with brown nervures; their apical part griseous.

Var. a. Legs, knees, etc., rather ferruginous.

b. Abdomen quite black.

c. A little ferruginous spot under the wing; two dots on base of antennæ.

d. An interrupted ferruginous line on the post-scutel and two obsolete lines on the mesothorax.

e. Metathorax and scutels marked with ferruginous (obscura Smith).

$f$. The general color brownish.

g. The emargination of the clypeus more or less pronounced; the clypeus not bidentate, only a little emarginate at tip.

h. A yellow mark on each side of the clypeus.

Ress. a. diff.-This species much resembles $E$. ater, but the thorax seems to be shorter and thicker. It differs from Aztecus by its shorter petiole, of which the dilation is more triangular, less elongate, and by its clypeus destitute of spines. Compare L. ater.

IIab. The temperate parts of Mexico. Orizaba. 6 .

\%. E. ater SAuss.-Niger, obscure-sericans ; clypeo bidentato, sulfurenmarginato; orlitis partim, post-scutelli fascia interupta et petioli nargine, sulfureis vel ferrugineis. -5 tibiis flavo-rariis.

Pachymenes atra Sauss. Vespides, I, 75, 2; III, 153.

Total length, 20 mill.; wing, 15 mill.

Form nearly as in Fobscurus; clypeus bidentate in the same way; the same punctuation, but a little smaller in size. The metathorax clothed with gray pile. The petiole not quite so 
much dilated posteriorly, having on its hinder part a very obsolete wide chamnel. The thorax shorter, more convex; the anterior margin a little bordered.

Black, with a fine sericeous reflection; flagellum of the antennæ beneath, principally at tip, ferruginous; an interrupted line on the post-scutel and on the hind margin of the petiole, yellow. The end of the femora and the tibiæ a little tinged with ycllow. Wings ferruginous.

․ The emargination and the lateral borders of the clypeus, a line along the orbits inside and at top outside, sulphur-yellow; mandibles in part and the tarsi, ferruginous.

Var. The mesopleuræ marked with ferruginous; the end of the clypeus not yellow. Margin of segments brownish.

$\widehat{\delta}$. Antennæ terminated by a little brown hook. The rellow ornaments of clypeus more extended. Mandibles black; tibiæ with a yellow band.

Var. No yellow border at the petiole.

Ress. a. diff.-This species differs from Olivaceus by its metathorax, which is not carinated.

Hab. Brazil. Rio Janeiro. 2 , 2

B. Petiole pyriform, depressed, less inflated above, not divided by a groove.

S. E. Santa-Anna. (Fig. 6,6a.)-Niger, politus, vel punctulatus, argenteo-sericeus; clypeo bidentato; metanoto brevi, convexo, abdomine depresso ; puncto frontali, pronoti margine postico, et antice fascia interrupta, scutelli margine, post-scutello, maculis subalaribus, et segmentorum abdominis 1, 2 limbo tibiarumque fascia, luteis; alis fuscorenosis. - Valde variabilis species.

Eumenes Santa-Anna SAuss. Revue. et Mag. de Zoolog., IX, 1857, 272.

Total length, 16 mill.; wing, $11 \mathrm{~mm}$.

Of medium size. Body polished, nearly impunctate. Ocelli arranged on an arcuate line. Clypeus bidentate; its teeth spiniform. Thorax wide and quadrate before; very slightly hordered anteriorly; its angles a little rounder. Metathorax short, conrex, as among the true Eumenes, polished and punctate. Abdomen much depressed. Petiole nearly of the length of the thorax, campanulate, smooth, and shining, its posterior moiety very wide and strongly depressed, its posterior border thickened 
in a marginal cordon, which is preceded hy a transverse groove; the convexity not divided by a longitudinal furrow. Sccond segment short above, nearly wider than long; its posterior border not turned up. The metathorax has its lateral faces plane and oblicquely cut.

Insect black, little or not at all punctured, but smooth, shining, and garnished with a silky pile of gray hair, which gives it a satin-like or silvery appearance. A line on the scape, a little dot on the face, a line behind each eye, posterior border of prothorax along the curve of mesothorax, an interrupted border on the anterior margin of prothorax, two spots under the wings and a point on each side of the sunmit of the metathorax, anterior border of the scutellum, post-seutel, and border of segments 1, 2, of a sulphur-whitish color, generally a lateral yellow spot smelted with the border of the petiole. Antennæ black, ferruginous beneath. Legs black, the tibiæ marked with a yellow line. Wings transparent, with the nervures, the costa, and the radial cell brown. Wing seales red or brown; their appendicular scale yellow at the extremity.

․ Clypeus margined with yellow on each side.

Var. Clypeus black; the scape only tawny beneath.

$\delta$. Hook of the antemm long and ferruginous. Clypeus black, argenteous.

Var. a. No spots on the metathorax. The spots of the thorax more or less eomplete. This part of the body often passing into brown. The flagellum ferruginous beneath.

Hab. The gulf side of Mexieo. Tampieo. Orizaba, Cordova. 5 \&, 1 ๙ .

2. 'Thorax short, globular. Petiole somewhat funnel-shaped, much lengthened; 2 ll sugment almost the shape of a globular bell. Body velvety, bristling with hair.

\section{E. ventricosus Sauss.}

Pachymenes ventricosa Sauss. Vespides, I, 77,5, pl. xii, fig. 7 .

Var. a. Second abdominal segment not margined with yellow. b. Wings rery dark with brown reflections.

Hab. Sonth Americal. Sante Fid de Rogutar (not Carolina, as a false "etiquette" made in print). Venczuch. 
Division OMICRON.

(Sadss. Vespides, I, 71 ; III, 133, 148.)

Body sericeus. Clypeus $q$ bidentate, often bicarinate. Thorax very short, cubical before, globular behind. Petiole very elongate - pear-shaped, not campanulate in the middle, swollen into a polished boss at the extremity ; its margin borciered by a polished cordon, preceded by a transverse channel or constriction, but without impressed point at the extremity; the marginal cordon forming a simple yellow (or black) line, without indentations as in Division a. The rest of the abdomen more or less depressed, nerer compressed, often polished. Second abd. segment having its colored border followed hy a second lamellar margin; second cubital cell short. Antennæ of males with a very small terminal hook, or eren quite destitute of hook, as in the females.

Ornaments. - The colored border of the posterior margin of prothorax more pronounced than the anterior one; fascix generally not wide. The petiole often ferruginous in the middle and on the sides, its hind margin with a yellow band, and often also ormamented on each side by an oblique yellow line fused with the yellow border.

This section only contains species of small size. The head and the thorax are very large compared with the abdomen; they are sometimes cribrose with great punctures and covered with a silvery pile, in place of being hairy, sub-woolly as most species of the Division Alpha. The clypeus is more or less bidentate, never distinctly truncate, and the ocelli have a tendency to arrangement in a straight or arcuate transverse line. The emargination of the eyes is situated very low, almost in the middle of their height, and these organs entirely cover the sides of the head, which is short. The antenuæ are inserted very low, sometimes below the middle of the head.

The thorax is drawn together so as to become at times wider than long. In front it holds in effect to the cube, being squarely cut; behind it is rounded, tending rather to the globular form. The part situated before the scutellum is always sensibly wider than long, and the prothorax is not in the least attenuated; on the contrary, it is angulate, squarely cut, and forms the wider part of the thorax. The sculels are quite driven back upon the slope of the metathorax, which is completely drawn together, liaving its 
inferior part almost retracted before; its posterior face is convex, not at all or hardly divided hy a chamnel into two ridges: its lateral faces are oblique, and form at their meeting with the hinder part two trenchant vertical edges. Behind the wing scale there is a little process The petiole, at first slender, expands at the extremity more like a small funnel than in a pyriform shape.

The clypeus of the males is generally not colored yellow as in the division Alplua, but resembles that of the female.

The most perfect type of this little group is the E. globicollis Spin.

'The characters which call for enumeration are on each side more and more effaced among the species which by their form approach to the type of Division Pachymenes and of the Division Alpha. (For example the E. callimorpha holds almost middle ground between the Division Omieron and Alpha; E. Sumichrasti has a sort of impression at the end of petiole, as in Division Alpha; E. infernalis has the second segment swelled, subeompressed, etc.)

One must not be too particular about the indefinable limits of the divisions.

A. Thorax quile short, cubic-globular, larger than the pear of the abdomen; the $2 d$ segment of this wider than long (as in genus Tatua), wide-globular.

10. E. globicollis SPIx. $q$-Niger, cano-sericeus, dense-cribratopunctatus; eapite latiore quam longiore; elypeo pentagonali. levi, punctulato, apice snbfis:o; thorace globo:o, prenelatiore quam longiore, superne valde convexo, antice truncato, vix perspicue marginato; petiolo antice lineari, postice trigonali parum marginato; 20 abd. segmento depresso, truncato, conn sequentilus ralde cano-illudente: antemnic subtus, macula frontali, promoti marginibus, scutellis pedibusque. petiolo subtus, nec nou abd. sergmentormm margine, plus minus obs:ure fusco-fernginescentibus; orbitis postice, post-tegulis, marginegue petioli, flavis; alis bavi frecescentibus. Iong. 9 mill.

Vuriat. fere ommino niger, vol 20 abd. segmento flaro-limbato.

Zethus globicolis, Spixous AmI. Soe. Fut. Fr., 1841, X, 150, pl. xiii, fig. (i. Eumenes globicollis sauss. Et. Vespilles, III, 151, 40, pl. riii, tig. b, bin.

Mab. Brazil. Para. (Typus in museo Spinole (mus. Taurinense) et in anctoris museo.) 
11. E. regulus Sauss. (Fig. $7,7 a, 7 b$. )-Minutus, niger, subsericeus; thorace minore, sparse cribrato-puuctato; abdomine polito; clypeo subemarginato; antennis subtus et pronoti margine antico, ferrugineis; puncto froutali, margine postico pronoti, post-scutelli et abdominis segmentorum 1-2, fiavis; alis infuscatis, stigmate opaco; tegulis ferrugineo-marginatis.

Eumenes regulus Sauss. Rev. et Mag. de Zool., IX, 1857, 272.

Total length, $7 \frac{1}{2}$ mill.; wing, 6 mill.

․ Tery small. Head densely punctured. Ocelli placed in a line rery little bent, not forming a triangle. Clypeus delicately punctured, convex, having its extremity pointed, hardly notehed and bidentate. Thorax strongly cubical, offering all the characters of the division, cribrose with large deep scattered punctures; angles of the prothorax a little raised. Metathorax flattened convex, only divided by a line, cribrose like the rest of thorax. Petiole as long as the thorax, polished, not cribrose, linear as far as the middle, then enlarged triangularly, bossed, swelled above at the extremity and finally bordered with a salient yellow cordon, which is preceded by a transverse channel; the pyriform part of the abdomen rery small. Second segment globularly bellshaped, depressed, wider than long, flattened beneath, conrex above, polished, offering a satin-gray reflection; its hinder border rather concave, cut out.

Insect black, clothed with a silvery pile: mandibles, the scape and extremity of the antennæ beneath and a point between their insertion, ferruginous; posterior border of the orbits and a point in their sinus, yellow or ferruginous; anterior border of the prothorax ferruginous; the posterior one margined with a yellow band, which makes an angle with a ferruginous or yellow fascia placed on the sides before the wing scale. Anterior margin of scutel, post-scutel, and a line on each side on the edge of the metathorax, or only a spot on each side on its summit, yellow; wing scale ferruginous or bordered with brown, the post-tegular process yellow. Often there is on the thorax something of brown. Petiole often having its middle and a line on each side ferruginous; its hinder margin adorned with a pellow border, fused with a yellow spot on each side of its extremity. The second segment margined with rellow. The other segments black, or bordered by a yellow or testaceous submarginal slightly sinuous band. Feet 
black, varied with ferruginous; tarsi and tibiæ 1st, 2d, brown or ferruginous. Wings transparent, smoky; brown along the anterior margin; the brown extending as far as the end of the radial cell. Stigma very large, black, often opaque, surrounded by a trausparent zone. First discoidal cell almost rectangular; third cubital wider than long; the second small.

ऽ. 'Thirteenth article of the antennæ very variable, sometimes rudimentary, not forming a hook, but only a little tubercle, sometimes forming a very small black hook; sometimes more elougate, ferruginous. Sometimes the antennæ are simple, as in the females. Clypeus as in the $q$, hardly emarginate, shining, black; its inferior extremity only presenting two small approaching projections, or a little parted by a channel; black, as in the $q$, or with two yellow dots near the summit.

Var. a. Markings of the thorax often ferruginous and the little process situated behind the wing scale, not yellow; the yellow fasciæ of the last segments of the abdomen dull, sometimes ferruginous.

b. Head entirely black. Scutel scarcely marked with yellow.

$c$. The scape of the antennæ ferruginous, obscure above.

d. Wing scale ferruginous.

e. Petiole quite black.

$f$. The yellow ornaments changing into ferruginous.

g. Metathorax quite black.

h. No yellow fascia before the tegula on the sides.

Common varieties.-A. The $2 \mathrm{~d}$ segment a little shorter; its margin a little more concave. Hinder margin of prothorax honey-yellow or fulvous; scutel and post-scutel dull rufous, mesopleura dull rufous. $(10 \uparrow, 2\}$.)

Var. Scutel rufous, post-scutel yellow. I cannot consider this as a different species.

B. Prothorax quite black, with the hinder margin yellow; sentel black; post-tegula and post-scutel.yellow; two yellow dots on top of metathorax, or two lines on its angles.

Ress. a. diff.-Differs from the L. mieroscopricus (its near neighbor) by the arrangement of the ocelli, which do not form a triangle, but only an areuate line.

It is distinguished from ky. Mexicanus by its small size; by its yet shorter thorax, more analogons to that of the E. globicollis: by its abdomen, longer and smaller in proportion; by its clypens 
not distinctly bidentate at the end; by the opaque stigma of the wing; and by the much coarser puncture of the thorax. It differs from $E$. aviculus by its smaller thorax, polished, impunctate abdomen; from thoracicus by its smaller, regularly conrex thorax; from Totonacus by its grayish-silky body, its pale yellow ornaments, its narrow abdominal bands, and its wings in which the $2 \mathrm{~d}$ recurrent nerve is not interstitial, but falls into the $2 \mathrm{~d}$ cubital cell. This Eumenes much resembles Polybia occidentalis, parcula, etc., but differs by its clypeus not angular and by the punctures of the body.

Hab. The hot and temperate regions of Mexico. Tampico, Cordova, Orizaba. (I have taken several specimens, $q \delta$, at Tampico and at Cordova, 44 $\$ 27 \mathrm{\delta}$.)

Fig. 7 represents the male enlarged; the petiole is a little too short, and its pyrifom part too large. In the fig. Ta, the clypeus is not sufficiently prolongerl at the extremity, and too truncate. In the fig. $7 b$, the abdomen is too large.

12. E. Totomacus n. sp.-Minutus, niger, nitidissimus; thorace punctato, petiolo elongato, lineari, apice trigonaliter dilatato; pronoti margine postico, post-scutello, metanoti strigis 2 , aldominis segmentorum $1^{i}, 2^{\mathrm{i}}$ margine sat late, læte flavis, petiolo medio ferrugineo; alis iufumatis, $2^{a}$ vena recurrente interstitiali.

q. Total length, 8 mill.; wing, $6 \frac{1}{2}$ mill.

$\delta$. Total leugth, 7 mill.; wing, $5 \frac{1}{2}$ mill.

Q. Quite similar to E. regulus; only differing by the following: Body more brilliant black, less grayish-silky. Clypeus shining, delicately punctured, and its extremity parted by a groore, subbidentate. Head finely punctured. Scutel convex, parted by a strong groove. Metathorax parted by a groove up to the top as in Regulus, or still more strongly; more polished, punctures more scattered. Petiole a little longer; all of the abdomen very much polished.

Black: A spot at base and extremity of the scape, and the extremity of antennæ beneath, tawny; a spot in the sinus of the eye and one behind the summit, yellow or tawny; posterior margin of prothorax, post-tegulæ, post-scutel, and angles of metathorax, bright yellow; the middle of the petiole ferruginous; its margin rellow; on each side a transverse line fused with the yellow border; the second segment with a rather broad yellow 
fascia; those following with a piceous border. Tiliæ and tarsi more or less ferruginous. Wings cloucly, the $2 d$ recurrent nerve quite interstitial, or even falling a little into the third cubital cell.

o. Hook of the antennæ very small.

Var. $a$. Metathorax without yellow fasciæ.

b. $\Lambda$ spot under the wing and the anterior border of prothorax in part, yellow or tawny.

Ress. a. diff.- This species is an example of the difficulty of the study of these numerous little Mexican species, which is not possible but with numerous specimens. It quite resembles $E$. regulus, but the body is very much polished (like glass), very black, not grayish, and the more elongate filiform part of the petiole gives it a peculiar appearance; the yellow ornaments also are bright yellow, not citron; the yellow fascia of the 2 d segment is wider, and nearly double; the tip of petiole lıas a fascia; lastly the character of the wing is a very sure gaide in distinguishing this species.

Hab. Mexico. Baños. $3 q, 1 \delta$.

13. E. aviculus n. sp.-Parvulus, thorace ralido, globoso, convexo, dense cribrato-punctato; abdomine punctato; petiolo postice trigonali obscure rufo-variegato, scutellis et pedibus partim rufis; alis nebulosis; variat scutello nigro, post-scutello flavo.

q. Total length, $8-9$ mill.; wing, 6.3 mill.

$\delta$. Total length, 7.5 mill.; wing, 5 mill.

P. Form much the same as in E. regulus. But the thorax much larger, cubic; the petiole wider, more triangular posteriorly, and more inflated. Head a little more strongly punctured, thorax more densely, quite densely cribrose; the petiole and abdomen are also densely punctured, but not so coarsely as the thorax. Clypeus a little wider, cribrose, its apex also subbidentate, or divided by a little groove. I)isk of mesothorax more wide than long, parterl anteriorly by a little sulcosity; scutels quite oblique, forming altogether with the metathorax the convex hind face of the thorax. Second segment depressed.

Black, very slightly sericoous. Tips of mandibles, antemue bencath, a fromtal spot, a line behind the eyes, borders of prothorix, mesoplenre, tegula, scutcls, sicles of metathorax and of the abdomen, berder's of all the segments, tibix, and tarsi, dull- 
rufous. Tings cloudy, iridescent; nerres and stigma blackish; 2d cubital cell as in E. regulus, as long as wide; its radial wargin broad

Var. a. Mandibles more ferruginous. Antennæ dull ferruginous with an obscure line on the scape, and blackish on the flagellum.

b. Head black without ferruginous spots.

c. Prothorax ferruginous.

d. Pust-scutel and tegulie blackish.

e. Prothorax black, only the posterior border ferruginous.

$f$. Angles of post-scutel, post-tegulæ, and border of petiole yellow.

§. Smaller. Clypeus grayisl-silky. Antennæ with a little ferruginous hook. 'The frontal spot, scape beneath, margin of petiole yellow.

Var. Prothorax black; its hinder margin yellow; post-scutel yellow; margin of the abdominal segments yellowish.

Common variety._Generally of small size. Body quite black; scape and apex of the autennæ beneath ferruginous. Posterior border of prothorax, post-scutel, border of abdominal segment, 1st, 2d, yellow; of the others dull-yellowish. Tegulæ fuscous; feet partly ferruginous. Petiole not so much dilated posteriorly, more pyriform than triangular. ( $5 \uparrow, 2 \delta$. Cordora.)

Ress. a. diff.-A very distinct species by its large conrex thorax and strongly punctured abdomen. The head and thorax are much as in Thoracicus, but the dorsum of the thorax is regularly conrex, not deformed. In the little rarieties, the thorax gets smaller, and the petiole narrower than in Regulus, but the punctured abdomen always enables one to distinguish the species.

Hab. Mexico; the Oriental Cordillera; Orizaba, Cordoba, Moyoapam. (12 $\uparrow, 6 \hat{\jmath})$

14. E. thoracicus n. sp.-Parrulus, niger fulvo-relutinus: thorace sat valido, glohoso, superne deformi, wesonoti disco sublicarinato, utrinque foveolato et subgibberoso, sparse cribrato-punctato; abdomine impunctato, petiolo postice piriformi; corpore obscure rufo-variegato; scutellis rufis; petiolo flaro-limbato: alis nebulosis.

q. Tntal length, $10 \mathrm{mill}$; wing, $8 \mathrm{~mm}$.

ऊ. Total length, 9 mill.; wing, $7 \mathrm{~mm}$.

. Head and thorax as in E. aviculus. Clypeus punctured, but not bicarinate, and parted by a groore at tip; liaring tlie tip 
flat, a little truncate, or sub-emarginate. The head a little more unequal; the grooves of the antennx stronger, ete. The thorax not quite so large nor so cubic anteriorly; the diak of the niesothorax somewhat gibbous, having two longitudinal caringe in the middle and on each side before a sort of sinking or exeavation, behind which is an eminence next to the wing seale; two suleosities continue the excavation up to the scutel; the scutellum oblique, parted by a groove; the metathorax still more divided by a groove. 'The thorax covered with strong, rather seattered punctures; on the metathorax not so strong. $\Lambda$ bdomen polished, not punctured, or only indistinctly; petiole more elongate, not so broad, behind more pyriform-truncate than triangular, not much inflated.

Black, with a fulvo-sericeus pile. End of mandibles, antennæ beneath, a frontal spot, a line behind the eyes, and a spot in their emargination, dull ferruginous. Both borders of prothorax, tegulæ, post-tegulæ, scutels, and sides of the abdomen, obscure ferruginous; border of petiole with a yellow margin; the other segments with an obscure ferruginous marginal band; that of the third and following segments twice notched. Feet ferruginous, black at base. Wings clondy, nerves blackisb.

$\delta . \Lambda$ little smaller, but quite identical with the female. The clypeus night be a little more bidentate; the hook of antenne small, blackish.

Var. a. Antennæ, prothorax, and mesopleuræ nore or less ferrnginous.

$b$. The disk of mesothorax not bicarinate.

Ress. a. diff.-This species is very much like E. aviculus, having nearly the same coloration, but differs principally by its not strongly punctate abdomen, and narrower, longer petiole. It is easy to distinguish from all neighboring species by its deformed mesothorax; in other things quite close to E. reguhus.

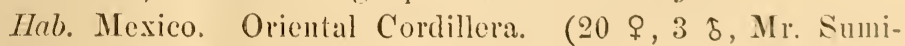
christ.)

B. Thorar a little Ionger than wide. The ad segment of abdomen sometimes rather elongate.

15. N. Mexicanus. (Fir. S, Sa.) - Sat miuntus, niger, dense punctatns; seutello erassius cribrato; elypeo plano, nitilo, apice hispinoso; utringue antenuis subtus et pronoti margine antico, ferrugineis, puncto 
frontali, pronoti margine postico et abl. segmentorum 1;, 2 limbo, flavis; pedibus obscure ferrugineis, basi nigris; alis sub.ufuscatis.

Eumenes 1Hexicanus Sacss. Rer. Zool., 1557, VI, 272.

‥ Total length, 11 mill.; wing, $8 \mathrm{~mm}$.

$\delta$. Total leugth, 10 mill.; wing, $7 \mathrm{~mm}$.

Not so small as the preceding; head wide, densely punctured. Clypeus pyriform, flattened, terminated by two sharp, spiniform teeth ; a fruntal carina between the antennæ continued liy a delicate sulcosity up to the middle ocellus. Thorax cubical before, rounded behind, nearly as wide as long; densely punctured throughout; its anterior margin a little turned up.

The punctures a little finer on the metathorax, those of scutellum coarse and more distant or scattered. Disk of mesothorax parted by a delicate sulcosity. Abdomen shining and polished; petiole punctured but shining, at first linear and then truncate, pear-shaped, bossed, somewhat bidentate, rimmed at the extremity ; the rim preceded by a strong constriction; the prriform part of the abdomen shining and satin like; rery finely punctured; the second segment a little contracted behind, slightly depressed; that is, wider than ligh, somewhat wider than long; truncated a little from above downward and from before backward; that is, the inferior face is a little longer than the superior; the posterior border slightly sinuous in the middle; the subjacent lamina not sinuous.

Body black, clothed with a silvery-fnlrous pile Mandibles ferruginous at the extremity and sometimes tinged with that color at base. A jellow or ferruginous spot between the antenuæ; these last black abore, ferruginous beneath; often the scape is chestnut-bay beneath and at base. Pusterior border of the prothorax marked with a narrow yellow line; the anterior and lateral horders rufous. Scutellum often bordered with yellow or tawny anteriorly, or with two yellow marks; post-scutel yellow, with the anterior border black; petiole a little ferruginous on the sides and on its narrow part; the two first segments of the abdomen bordered by a yellow cordon; the lamellar border of the second and the margins of the following testaceus-rufous. Feet sombre forruginous; black at the base. Wings smoky. Wing scales furruginous, marked with a yellow dot on their posterior margin.

ᄋ. Clypeus black, with a yellow macula on each side near the 
top, or bordered with yellow on its lateral margins, or entirely b) lack.

§. Clypeus yellow, covered with a silvery pile; the flagellum of the antennx more ferruginous at base, black in its second part, with a moderate ferruginous hook. 'Thorax a little more elongate.

Var. Clypeus bordered all round with black.

Var. In both sexes, the teeth of the clypeus are more or less spiniform, sometimes the noteh between them is filled by a little arcuater border, which makes the teeth short and not spiniform. I'he diiated part of the petiole is more or less wide; more or less bidentate, or not bidentate; the frontal and mesothoracic sulcosity not distinct.

a. Clypeus and head entirely black. Anterior border of the prothorax and scutellum black. Petiole without ferruginous.

b. Clypeus margined on both sides with yellow.

c. Mesothorax with two rufous lines; scutels bordered with yellow.

d. The metathorax and mesopleuræ passing to ferruginous.

e. The end of petiole mixed with brown,or with two transverse lines, smelted with the yellow border.

$f$. Abdomen passing to brown.

g. The yellow marking of the thorax more or less wanting; no spot on the wing scale.

Ress. a. diff.-This species is very near to the E. callimorphus Sauss, but is distinguished from it by certain characters diffeult to describe. 'The elypeus is flatter; its teeth are a little shorter' the ocelli are placed upon a less areuate line, and the vertex has two transverse grooves between the summit of the eyes and the external ocelli. The thorax is more coarsely and less densely punctured and above all wider and larger in proportion; its angles are a little upturned at the shoulders. The petiole is shorter; its dilatation is more funnel sliaped, less prriform. 'The second segment seen from above is a little more sinuous, which renders the lamellar edge more salient. The abilomen is more distinctly punctured. The eoloration, funally, is strongly analogous. Distinct from E. regulus and totonacus by its langere size, and its flattened, bidentate clypens, ete. Diflers from $l$. olmecus by its smaller size, punctate, not velutinous thorax, more 
inflated petiole, shorter 2 d segment, with rather sinuated margin, etc. See also the E. Nortoniana and Cressoniana.

IIab. The Gulf side of Mexico. (I have taken some specimens of it at Tampico.) The Oriental Cordillera, Banio (Mr. Sumichrast). 9 ㅇ, 5 ऊ.

Wrta.-Mr. Sumichrast attributes to this insect a most interesting nest. It is formed of a mass of cellules or liabitations composed of a black bark which seems to be agglutinated by some gummy material. These habitations are more or less cylindrical and gummed one against another. But although they form a double row, they are not always parallel like the cells of social wasps, but a little oblique the one upon the other, which renders their arrangement quite irregular. This nest is fixed upon a little branch of the oak. It greatly resembles in its system that of Zethus Romandinus, which I have cited as apropos of this species. But its surface, instead of being fibrous, is liere cellulousrugiose; one remarks here some little rounded or polygonal cells, the borders of which form a sort of reticulation, which is, howerer, but a simple sculpture; the fossettes are too small to be compared to basal sockets, and have absolutely nothing in common with the outlines of cells which one often finds on the border's of wasps' nests. I should not be surprised if this nest should be rather that of a Zethus than of the $E$. mexicanus, and that it should prove to be an error in the "etiquette" mark.

16. E. Sumichrasti n. sp.-Crassiusculus, nigh; clypeo bidentato ; thorace quarrato, tenuissime ruguloso; abromine nitido, petiolo sparse punctato, campanulato, inerassato-marginato; a picesulco diviso ; frontis macula, margine postico pronoti, abdominis segmentorum $1^{i}, 2^{i}$ limbo, post-scutelloque, flavis. $\nmid$.

Total length, 11 mill.; wing, $\$ .3$ mill.

P. Quite closely related to E. Mexicanus. A little larger. Clypeus bidentate, not so much flattened. Thorax a little longer, not so distinctly punctured but quite delisately shagreened all over. The petiole more campanulate, wirler, truncate; much swelled, also bordered by a salient cordon, but parted by a groove with a shallow impression before the borler; 2 d segment rather clongate, the lamellar edge very narrow, hardly distinct, although the first elge is not thick.

Black, with grayish-silky reflection; ahdomen silky-shining, 
very delicately punctured; the petiole distinetly punctured. Mandibles in part, antennæ beneath, tegulæ, knees and tibiæ partly rufo-fuscous; a dot between the antennæ, a line behind the eyes, hind border of prothorax, post-scutel and horder of segment 1st, $2 d$, yellow; the rest of the abdomen, even the lamellar edge of 2d segment, quite black. Wings eloudy.

Ress. a. diff - Resembles very much E. Santa-Anna and lrvis, in the form of its petiole, but this is parted by a groore at the end, and the therax is shagreened; the petiole is also shorter.

Hab. Mexico; the Oriental Cordillera. Orizalua (Mr. Sumichrast).

1\%. E. Brasilanus n. sp.-Niger; clypeo nigro, apice bidentato; thoraee punctato, quadıato, pronoti inargine postico ferrugineo vel flavo, tegularun margine ferrugineo; abdominis segmentorum margine 1-5 flavo limbato; mandibulis, tibiis et tarsis antice ferrugineis, reliquis ferruginescentibus; alis subinfuscatis. $q$.

\section{Q. Total length, $10 \frac{1}{2} \mathrm{~mm}$; wing, $8 \frac{1}{2} \mathrm{~mm}$.}

ว. This insect is exactly like the $E$. mexicanus, and only differs from it in certain character's.

The clypeus is less flattened, and is not shining but dull; there is hardly any frontal carina. The punctuation of the body is apparently the same or a little more dense. The scutellum is a little less strongly cribrose. The antennæ are scarcely ferruginous beneath. The clypeus and the scutels are entirely black; the segments 3-5 have their borders delicately oruamented with yellow above and beneatl.

This species may be but a variety of the E. mexicanus. In both species the 2 d cubital cellule of the wing is quite large, trapeziform, with straight borders; the radial border is large.

Hab. Brazil. ('The author's collection.)

18. E. Lavis Mnr.-Niger, cinereo-sericeus, læris, fere impunctatus; clypeo acute bidentato; thorace antice quadrato; abdomine depresso; petiolo depresso-gibboso; mandibulis et antennis subtus, ferrugineis; linea scapi antemuarum, lineola pronoti marginis postici et temuissima marginis antioi, faseia scutelli, lineis 2 metanoti et margine petioli, flavis; abdominis segmentis rufo marginatis, fascia promargiuai tlara; tibiis thavo-variis; alis fuscescentilus. $q$.

Viriat. abd. segm, margine $30-50$ ferrugineo.

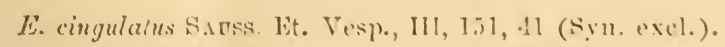

'otal length, 12 mu.; wing, !) nแm. 
This species has not been sufficiently well described.

. Clypeus flattened, polished; its apex cariuated into two very acute tecth, separated by a shallow notch. Thorax globular, polished, square anteriorly, with its angles insensibly raised. Metathorax very delicately punctured, parted by a channel. Abdomen polished, much depressed; the second half of the petiole rather wide, although swelled above; the hind margin of the second segment straight; not sinuous.

Insect black, with an argenteous reflection. Antennæ slender, ferruginous below at the apex; frequently a yellow line on the scape. A spot on the forehead and in the sinus of the eyes, yellow. A narrow interrupted line on the anterior border of the prothorax, a line on the posterior margin, a spot before the wing, two dots on the anterior angles of the scutellum, a band on the post-scutellum, and two lines on the metathorax, yellow; the margin of the first two abdominal segments also bordered with a yellow line; that of the petiole smelted with two lateral spots; the lamellar borders of segments $2 d$ and following, rufo-testaccous; this color preceded by a fine yellow line. Coxæ and tibiæ ormamented with yellow. Wings cloudy, with golden reflection.

Ress. a. diff.-This species approaches very much to $E$. callimorpha, but its abdomen is much depressed; the petiole not so long, more dilated; the clypens less notched. The thorax, although more polished, has just the same form. In its appearance this Eumenes quite resembles E. mexicanus, but it is larger, the clypeus is more ovoid, not so pyriform; the borly is not punctured, and the thorax is a little longer than wide. In its depressed abdomen and its impunctured body, it quite resembles E. Santa-Anna, but it is more slender, less depressed; the thorax has another appearance, etc. Serertheless, it annoys me much to separate $E$. lavis from $E$. Sanla-Anna, but the first seems to be a smaller Brazilian representative of the last.

IIab. Brazil; Para. (The type in the collection of Spinola, Turin mus., and in the author's collection.)

Observalion. - The Fabrician synonym is very doubtful; I first adopted it according to the collection of Spinola, but the description giren by Fabr. does not fit our insect, which, as we thiuk, must be cousidered a different one. 
19. E. Novara Sadss.-Gracilis, niger, flavn et barlio tenuiter variegatus; antennis sultus ferrugineis; clypeo birlentato; ablomine depresso, segmentis anguste flavo-limbatis; petiolo elongato, piriformi.

E. Novarce Sauss. Reise d. Oesterr. Fregat. Novara, Zool., II, Hymen.6, 1 , fig. 3 .

Total length, $14 \mathrm{~mm}$; wing, $10 \frac{1}{2} \mathrm{~mm}$.

9. Black, sericcous. Thorax short, globular, very convex. Petiole elongate, not campanular, bordered by a cordon. Body very delicately punctate, the metathorax a little more strongly, argenteo-sericeous. The extremity of the mandibles, teeth of the clypeus, antennæ beneath, a spot on the forehead, fulro-ferruginous; base of mandibles, lateral border of clypeus, a dot in the sinus of the eye, and a line behind their summit, yellow; a line on the hind margin of prothorax and a line on each angle and border of tegulæ, ferruginous; two spots on the angles of scutel, a line on post-scutel, a dot and a line on the sides of thorax, and a little line on the margins of the segments of abdomen, yellow. Feet black with the coxæ maculate with yellow; knees and tibiæ outside yellow. Wings liyaline, with black nerves and the anterior margin narrowly brown.

Var. All the ornaments more or less yellow or ferruginous.

Ress. a. diff.-This species has a depressed form; it resembles E. Santa-Anna, although it is not so much depressed, and more slender. It comes very close to $E$. lxevis, but with a shorter thorax. Not having the type, I dare not give a more approximate composition. It is a little larger than $E$. olmecus, and a little smaller than E. Santa-Anna.

Hab. Brazil, Rio Janeiro. (Museum of Tienua.)

20. E. minutus FABR.-E. regulo paulo major, niger, punctatus, aureo-sericeus; clypeo convexiusculo, punctulato; antemnis subtus ferrugineo-variis ; pronoti margine postico, post-scutello abdominisque segmentormm limbo, flavis; pedibus nigris, tibiis et tarsis obscure ferrugineis; alis subinfuscatis. $q$.

q Eumenes minuta FaBr. Syst. Piez., 291, 23 (1Sn 4 ).

'lotal length, $9 \mathrm{~mm}$. ; wing, $7 \mathrm{~mm}$.

F. A species extremely near to E. mexicanus. Size a little smaller; body a little more slender; elypens slightly convex, punctured and oroid, subemarginate at tip (not strongly biden- 
tate); no frontal carina. 'Thorax smaller, a little shorter; the angles of the prothorax not upturned; the petiole more slender; the second abdominal segment a little shorter and with a less sinuous border. The scutel having about the same punctuations as the rest of the thorax.

Insect black, clothed with a golden pile; antennæ slightly varied with ferruginous bencath; a yellow line behind the summit of the eyes; posterior margin of the prothorax and post-scutel marked with a honey-yellow cordon; anterior border of the prothorax on each side a little tawny; a fceble dot under the wing and the post-tegulæ yellow, as well as a narrow border on all the segments of the abdomen. (The second lamina of the border of the second segment, also yellow.) Wing scale black, bordered with brown. Feet black, tibiæ outside and tarsi ferruginous. Wings slightly smoky, stigma opaque.

Ress. a. diff.-It is larger than $E$. regulus, the thorax not covered with strong punctures but finely and densely punctured; the end of petiole not so much canaliculate before the margin. It comes quite near $E$. totonacus, but is a little larger, the thorax more densely punctured; the scutel not gibbous and not parted.

Hab. Brazil.

\section{E. cingulatus FABR.}

Eumenes cingulata FABr. S. P., 287, 13 (1804).-SAUss. Vespides, III, $151,41$.

Hab. Cayenne. (Typus Saussurii in mus. Spinolæ, Taurinensi.)

\section{E. parvulus Sauss.}

Eumenes parvulus SAdss. Vespides, III, 149, 37, pl. viii, fig. 5, 5a (1854).

Hab. Brazil. (Typus in museo Parisiensi.)

\section{E. pusillus Sadss.}

Eumenes pusillus Sadss. Vespides, III, 149, 38 (1854).

Hab. Brazil. (Typus in museo Parisiensi.)

24. E. microscopicus Súss.

Eumenes microscopica Sadss. Vespides, I, 72, 62 (1852).

Hab. Brazil. (Typus in musen Parisiensi.) 
These species are imperfectly known; I do not possess them in my collection, and it may be possible that our E. minutus proves to be one of them.

C. Thorax not so wide; longer than broad; not larger, or even smaller than the pear of the abdomen. (Form very much as in Division Alpha.)

25. E. callimorphus Sauss.-Niger, lævis, gracilis; clypeo valde bidentato; thorace tenuiter dense punctato, mesonoto haud sulcato; abdomine gracili, petiolo subelongato, angusto; antennarum articulis 1-4 plus minusveferrugineis; corpore ut in $E$. Mexicano tlavo-ornato, petiolo utrinque linea fiava.

Total length, $14 \mathrm{~mm}$.; wing, $9 \mathrm{~mm}$.

E. cullimorplia Sauss. Et. Vesp., I, 71, 61, pl. xiii, fig. 4; ibid. III, 148. ? E. campanulata FABr. S. P., 291, 22, :

Clypeus terminated by two spiniform teeth. A more or less distinct frontal carina. . Thorax quadrate before, delicately punctured; its angles slightly reflexed. Petiole elongate; its pearshaped part slender, truncate, bordered, and channelled as in the other species. The abdomen depressed.

Black, covered with a very short silvery pile; the abdomen quite polished; the pile making it appear tenously strigate. Antennre beneath, a part of the mandibles, and teeth of clypeus, ferruginous. A spot on the forehead, one in the sinus of each cye, a line behird the eyes, yellow tawny; both borders of prothorax, (the anterior one interrupted), a spot under the wing, posttegulx, anterior border of scutels; posterior border of the abdominal segments, a line all along the sides of the petiole and an oblique spot smelted on each side with its border, yellow or rather ferruginous. The extreme margin of the segments 2-5, brown. Knees, tibiæ, and tarsi most ferruginous. Wings smoky.

9. Clypeus black, with two jellow spots near the top; its tecth spiniform, carinated.

ऽ. Clypeus yellow, argenteous; its teeth not so sharp, not carinated.

Var. The colors are more or less dereloped, as in other species. The legs more or less ferruginous, at times entirely red; the petiole beneath and on the sides is of the same color; no yellow line upon the scutellum. The clypeus is more or less strongly 
bidentate, the teeth are at times long, sharp, separated by an angular notch; often less long and separated by a shallow notch like the arc of a circle; a little carina often parts the anterior margin of the scutel. Wings with some violet reflections.

Ress. a. diff.-This is larger and more slender than all the preceding, butsmaller than $E$. olmecus. It makes the transition to the Division Alpha. It has the same coloration as most of the species of the same division, except that it possesses all along each side of the petiole a yellow line. The petiole and the pear of the abdomen are also more elongate, the $2 d$ segment longer than wide.

Hab. Brazil. $2 \uparrow, 1 \delta$ from Bahia. $2 \uparrow$ (coll. Spinola), from Rio Janeiro.

The description which Fabricius has given of his E. campanulala does not mention the two lateral yellow lines of the petiole, nor the spots of the clypeus, nor does it accord well in the antennæ with the $E$. callimorpha, for which reason we do not dare to assert positirely that this is the $E$. campanulata of Fabr.

There are probably more than one species rery closely allied to this which might be easily confounded with it; $f$. $i$, the following description which $\mathrm{I}$ find in my notes seems to indicate a different species with sulcate mesonotum.

26. E. incertus. $-E$. callimorpho simillimus, at clypeo minus bidentato, mesonoti disco 2-vel 4-sulcato; corpore nigro; antennis subtus et tibiis extus, ferrugineis ; pronoti marginibus, petioli lineis literalibus 2 et margine, segmentorumque $2 \circ-40$ linea præmarginali tenuissima, sulfureis. $\$$.

9. Figure, size, and form the same as that of E. callimorpha, but differs in the clypeus, shining, offering also two carinæ, but less strongly bidentate; its latero-inferior borders sinuate. Thorax a little more distinctly punctured; the disk of the mesothorax offers four longitudinal furrows.

Insect black, shining, with silvery reflections. Antennæ ferruginous beneath; a fine line bordering the two margins of the prothorax, ferruginous or yellowish. The bordering of the petiole, a little mark on each side of the middle of it, and a spot above toward its base, sulphur-yellow, as well as a fine submarginal line upon segments $2-t$, both above and beneath; the extreme border of these last, black. Tibiæ 1st, $2 \mathrm{~d}$, ferruginous before; wings a little smoky. 
Hab. Para. (Collect. of Spinola. Collected by Mr. Ghiliani.) May be a variety of the E. callimorpha?

2\%. L. miles n. sp.-Niger, punctulatus, cinereo-sericans; mandibulis pedibusque partim rufis; clypeo apice bispinoso, utrinque fascia aurantia ; corpore valde aurantio-variegato; alis nigrescentibus. $q$.

Length of the wing, $10 \mathrm{~mm}$.

9. Size of E. pomiformis, smaller than fraternus.

Black, grayish-silky, shining, delicately punctured. Ilead rather broader than long. Mandibles very long, arcuated at tip, reddish, with a yellow spot at base. Clypeus flattened, ending in two sharp spines, in which fall two short carinæ. The borders of clypeus yellow; antennæ blackish; fulvous beneath up to the 4th joint. $\Lambda$ spot on the forchead, one in the emargination of each eye, a line behind the eye, a fascia on the fore and on the hind margin of prothorax, a spot under the wing, the anterior margin of scutel and post-scutel, and two fascix on the metathorax, orange yellow. Margin of the wing scales, knees, tibiæ, and tarsi, ferruginous; the latter rather obscure above. Wings smoky, rather blackish on the costal margin, with violet reflections; $2 d$ cubital cell broad at its hinder margin, narrow at its radial side. (Abdomen ..... ?).

Hab. Guiana, Surinam. (Hamburg museum.)

By the form of its clypeus and its silky-pubescence this species fits in this Division, but the inneuration of the wing assimilates it more to Division $\alpha$.

2S. E. Olmecus n. sp.-Niger, punctulatus; clypeo apice bispinoso; thorace superne convexo, metathorace angustiore in clunis 2 per sulcum profundun diviso; petiolo elongato-piriformi, apice truncato, marginato; antemis subtus pedibusque partim, obscure-ferrugineis ; capitis maculis, pronoti limbo postico et utrinque antico, abdominis segmentorum margine subtus obscure-ferrugineis vel flavescentibus; post-scutelli linea, margineque segmentorum $1 \mathfrak{i}, 2 \mathfrak{i}$, 1lavis ; alis costa nigra. $q$.

Total length, $14 \mathrm{~mm}$. ; wing, $10 \mathrm{~mm}$.

9. Antenna slender. Clypeus bidentate at tip; the librum large, truncate; ocelli disposed in an areuate line. Thorax quadrate anteriorly, short, convex, delicately punctate and velutinous; behind the angles of the prothorix an obsolete depression. Metathorax compressed, angulated; parted by a decp groove; 
its lateral ridges sharp. Petiole as in Iturbicle, clongate-pyriform, truncate, convex, not parted by a channel; the hind margin bordered, the border preceded by a transverse channel. The rest of the abdomen depressed.

Black, with a fulvous or purple-silky reflection. The extremity of the labrum, the lateral borders of clypeus, a spot between the antennæ, a dot in the emargination of the eyes, the antennæ beneath, the end of mandibles, and a line behind the top of the eyes, tawny. The hinder margin of prothorax, an interrupted line on the anterior margin, or only on its angles, a line over the middle coxx, tawny; wing scale brown or ferruginous; two dots on the anterior angles of scutel, a line on the post-scutel, and the margin of segment 1st, 2d, yellow; the lamellar margin of $2 \mathrm{~d}$ segment and of those following, brownish. Beneath, the margin of the segments fulvous. Feet ferruginous and blackish. Wings hyaline, smoky, with iridescent reflection; the anterior margin blackish.

Var. The spots on the head and hinder margin of prothorax, yellow; two yellow dots on the clypeus; scape of antenmæ almost wholly ferruginous.

Ress. a. diff.-This species is quite intermediate between the Divisions Pachymenes, Alpha, and Omicron; or between $E$. Santa-Anna, Iturbide, and callimorphus. The clypeus is bidentate and the abdomen elongate depressed as in the Pachymenes; but the thorax is not depressed, but on the contrary convex, not polished as in $E$. Santa-Anna, but densely punctured, and the petiole not so widened, not campanulate but gradually widened.

It differs from $E$. Iturbide by its depressed, not globular or subcompressed $2 \mathrm{~d}$ abdominal segment; its flattened clypeus with spiniform (not lamellar) teeth; its compressed triangular metathorax; its petiole without impressed point at tip, but with a transverse submarginal channel. From E. callimorphus and the other species of Division Omicron by its large size; its more depressed and elongate abdomen; its compressed, prominent metathorax parted by a deep groove, and by its general resemblance to Division Alpha.

Hab. Mexico. The Oriental Cordillera. I caught 3 in the neighborhood of Cordova.

29. E. infernalis n. sp.-Gracilis, niger rufo-ornatus; clypeo bidentato; thorace dense foraminato-punctato; abdomine polito, segmentis 
$1, \circ 2 \circ$ flavo-limbatis; 20 superne gibbo crasse cribrato-punctato instructo. $\&$.

Total length, $12 \mathrm{~mm}$; wing, $8 \mathrm{~mm}$.

Q. Form alnost like that of E. callimorphus. Head dotted with punctures. Ocelli in a slightly arcuate line. Clypeus quite flat, pyriform, notched and terminated by two sharp lamellate teeth. Thorax very convex, especially behind; the wings inserted behind the middle; all the surface densely cribrose with pit-like punctures, more strong than those of the head; these punctures become more strong upon the scutellum and very dense on the metathorax. Abdomen smooth, shining, without punctures. Petiole quite long and slender; almost filiform in its first moiety, then swelled pyriform, truncate, convex, shining; the posterior border preceded by a transverse groove. The $2 d$ segment before the middle of its dorsal face strongly elevated in form of a boss, slightly compressed and cribrose with punctures; a sort of shining canal passes around behind this gibbosity. The other segments shining, black. Mandibles and antennæ ferruginous; these last, obscure above, with the scape a little yellowish before. The two lateral borders of the clypeus as far as the end of the teeth yellow, as well as a little spot on the front and the posterior border of the prothorax. Wing scales reddish or brown. Segments of the abdomen all ornamented with a yellow border. Petiole offering on its middle two little yellow or reddish marks; its posterior border yellow or reddish, at least in the middle; its lower side more or less reddish. Legs reddish; coxie black; femora brown; the two anterior spotted with yellow toward the end. Wings slightly washed with brown-ferruginous, having brown nervures.

Var. a. 'The thorax more or less varied with ferruginons.

b. Posterior border of prothorax, ferruginous; the borders of segments 3-5, ferruginous or brown.

c. The anterior border of prothorax, a spot under the wing. two spots or a band on the seutellum, two spots on the metathorax, ferruginous or yellowish; legs brownish or ferruginous in part.

Ress. a. diff.-This species has the thorax a little more lengthened anteriorly, and the head and thorax much more strongly punctured than the E. callimorphus. It is very distinc: 
in the strongly cribrose boss of the second abdominal segment. It differs from $E$. mexicanus in its much larger size, in its less strongly cribrose, less globular metathorax. In fact, the form, swelled and cribrose above, of the $2 \mathrm{~d}$ abdominal segment, distinguishes the L. infernalis from all others of the Division Omicron. This character is a transition to the Dirision Alpha, which constitutes an exception in the Division Omicron.

Hab. Brazil. Para. (Cull. Spinola.) Guiana. (Mus. of Hamburg.)

\section{Division BETA.}

Mandibles rather hooked at end, or truncate. IIead in form of a transverse oval, not rounded-triangular; the ejes very large in their inferior part. Thorax not larger than the pear of the abdomen, globular or cubic. Petiole elongate, filiform, cylindrical, only very little dilated at the end in a funnel shape, ${ }^{1}$ its posterior border marked with an impressed point. The 2 d segment not depressed, not compressed.

These insects slightly resemble in form the Pareumenes; but they are much more slender. The thorax has quite another shape, not being widened and depressed, but cubic, more as in Division Omicron, although smaller. The abdomen also is not depressed, but the petiole quite recalls the form it has in Pareumenes, although much more slender.

The mandibles are rather hooked, strongly dentate as in Pachymenes, but by exception short and blunt ( $q$ ) more as in Zethus.

This Division is intermediate between the Pareumenes and the Eumenes of Division Omicron.

a. Mandibles short, pointed in the males, blunt, rounded at tip, with separated small teeth in the females.

30. E. Nortonianus n. sp.-Niger, dense crassiusenle punctatus; oculis infere valde inflatis; mandibulis brevibus, $q$ apice rotundatis; clypeo pentagonali, bidentulo; carina frontali nulla; petiolo elongato, filiformi, apice tenuiter, eylindrico-infundibuliformi, puncto apicali impresso; abdomine dense punctato; puncto frontali, marginibus pro-

1 Not campanulate, more pear-sliaped as in Division Alpha or Omicron, but filiform, widened at end somewhat like a clarionet. Seen from above, the sides of the petiole are not arcuate-convex but rather arcuato-concave. 
noti et post-scutelli, rufis; pedibus et antennis partim ferrugineis; abdominis segmentorum $1^{\mathrm{i}}, 2^{\mathrm{i}}$ margine flavo; alis fumosis.

q. Total length, $11 \mathrm{~mm}$.; wing, $8 \mathrm{~mm}$.

$\hat{\delta}$. Total length, $10 \mathrm{~mm}$; wing, $7.5 \mathrm{~mm}$.

Very similar to E. mexicanus in its appearance, but a very different type. Itead transverse-oval; eyes very much inflated.

Head more strongly punctured over the antennæ; no frontal vertical carina, but the space between the antennæ flat. Thorax small, more densely and coarsely shagreened; roughish; the metathorax as coarsely shagrecned as the mesothorax. Postscutel with a little arcuate crest on its anterior margin.

Petiole elongate, as long as head and thorax, arcuate, more filiform and cylindrical; not at all campanulate or pear-shaped, but only a little funnel-shaped in the last third ${ }^{1}$ (the lateral margins forming not a somewhat convex line but a somewhat concave one). Its extremity not rimmed nor canaliculate transversely, but having a marginal impression above only, which forces backward the middle of the border. The $2 \mathrm{~d}$ segment not depressed nor compressed. Petiole and second segment densely and rather coarsely punctured; the following polished.

Black, grayish-silky; antennæ beneath, margin of the tegulæ, and fect partly, dull-ferruginous; a spot in the sinus of the eyes, a frontal spot, both margins of prothorax, a little line under the wing, post-tegulæ, two spots on scutel and post-scutel, dull ferruginous; the margin of segments 1 st, $2 \mathrm{~d}$ of the abdomen, yellow. Petiole beneath and above in the middle, brown-ferruginous. The lamellar margin of the second segment, piceous; the margin of the following, testaccous or yellowish. Feet ferruginous, brown against the base. Wings subhyaline or smoky; nerres brown.

. Clypeus black, rather pentagonal, not elongate, delicately punctured; its inferior border areuate, scarcely bidentate; the teeth small, not distant, or formed by two little parallel marginal carinæ; its superior margins brownish. Mandibles short, rather dilated at the extremity, rounded (or the outer margin areuate, the imner one obliquely truncate), with small teeth. When resting, they retract themselves behind the border of the elypeus, crossing their teeth one into the other.

o. Clypens black, argenteous, with a rufous or yellow line on

1 Somowhat like a straight trumpet or a clarionet. 
each side; hook of the antenuæ ferruginous. Mandibles short, but triangular, acute, with four little teeth.

Ress. a. diff.-This insect, although haring quite the general appearance of an Eumenes, approaches Iniscelius in the form of its mandibles, short and widened towards the tip in the female. But it is rery easy to confound it with $E$. mexicanus and callimorpha. It differs by its rather convex clypeus, not so bidentate, by the absence of frontal carina, by its head transrerse-oral, not oral-triangular, because of the great enlargement of the under part of the eres, which is wider transrersely than longitudinally, and $b y$ its shagreened abdomen. The exceptional form of the inandibles, truncate and rounded at the end, with the external side very arcuate, as also the particular form of petiole, will distinguish this species from all its neighbors.

This is quite an exceptional trpe, remarkable by the unequal form of mandibles in both sexes.

Hab. Mexico. The Oriental Cordillera. Cordora. 2 \%, 1 .

b. Iandibles more elongate, not truncate, rather hoolied at tip, with strong teeth on the interior margin.

31. E. Cressonianus n. sp. - Niger, cinereo-hirtus, ralde punctatus; clypei marginibus lateralibus, puncto frontali et orbitarum sinus, marginibus pronoti, lineaque præ tegulis, post-scutello, margineque petioli et $2^{\mathrm{i}}$ segmenti, flaris; petiolo medio flarescente, puncto apicali impresso, haud in marginem producto; segmentis $20-50$ fusco-marginatis. $\subsetneq$.

Total length, $11 \mathrm{~mm}$; wing, $\delta$ mm.

9. Quite the same form as in Nortonianus, but the mandibles elongate, not truncate, arcuate at tip; the internal border armed with four strong lobular teeth; the clypeus emarginate in a little arc of a circle. The thorax not so rugose; not roughly shagreened, but more polished and cribrose with coarse punctures; the metathorax not so coarsely punctured; the post-scutel without any crest. The extremity of the petiole a little margined; its impressed point not intrenching upon the margin. The second segment a little depressed, a little more strongly and less densely punctured.

Black, with the same ornaments as in Nortonianus, but of rellow color ; the antennæ beneath and tip of mandibles ferruginous. Feet ferruginous, blackish at base; the tibiæ rellow outside. Tings smoky. The scutel not spotted. 
Ress. a. diff.-Differs from Mexicanus and all the species of Division Omicron by the form of its petiole.

Hab. Mexico; the Oriental part. Cordova.

32. E. simulans n. sp.-Niger, sulfureo multipictus, histrionicus; thorace crasse cribrato-punctato, mesonoto fasciis 2 llavis; abdomine punctato, petiolo lineari, apice tenuiter infundibuliformi; secundo segmento faciis 2 transversis flavis. 9 .

. Total length, $11 \mathrm{~mm}$.; wing, $9 \mathrm{~mm}$.

․ Head transverse-elliptic, very punctate. Mandibles elongate, rather hooked at the tip, and armed with three strong lateral teeth. Clypeus polygonal, a little longer than broad, a little emarginate and bidentate at tip. Eyes very large inferiorly, their sinus deep, rather triangular. Thorax small, globular, metathorax quite rounded. Petiole moderately long; its second part funnel-shaped, with an impressed point at end. The petiole and $2 d$ segment of abdomen punctate; this is neither depressed nor compressed.

Black, with yellow hair. The head beneath, clypeus, mandibles, the orbits all round, their sinus, a transverse line on the vertex, sulphur-yellow. Antennæ orange-ferruginous, olsscure above; the scape yellow. Thorax beneath and on the flanks, both margins of prothorax, two lines on mesothorax, tegulæ, scutel partly, post-scutel, and metathorax more or less, yellow; this with a sort of black $\mathrm{T}$. The middle of the petiole, posterior margin, and sides, yellow; 2 d segment with two yellow fascia; the first placed on the middle of the segment, the second being submarginal; both fused together on the sides; the other segments with sinuous yellow margins; anus and abdomen beneath quite yellow; the lamellar margin of $2 \mathrm{~d}$ segment, brown. Feet yellow; the femora brown above. Wings hyaline, washed with amber, a little gray at the extremity.

Var. 'The black and yellow color's are more or less extended. Pleura and metathorax only maculate with yellow.

Ress. a. diff.-A quite distinct species. By its forms only it resembles E. Nortonianus and Cressonianus. The petiole is a little more widened behind, and the body much more coarsely punctured. It might be compared with E. Smithii, americanus, ete. which have also two fasciac on the $2 d$ segment, but the petiole in these is pyriform and the second segment compressed, ete. 
Hab. Mexico. Oriental Cordillera. Moyoapam.

This is a sort of mimic species. It bear's the coloration and rather the form of some Polybia, f. i., P. fasciata Lep. We know a Cerceris of the same country ${ }^{1}$ which shows the same peculiarity. Entomologists ought to study whether these insects of mimic resemblance do not have some relationship in their habits.

\section{Division ALPHA (Eumenes proprie dieti).}

(Sacss. Vespides, I, 2S; III, 128, 137.)

Mandibles long, dentate. Clypeus pyriform, notched or truncated at the extremity. Antennæ generally inserted above the middle of the head. Ocelli arranged in a broad triangle. Thorax generally longer than wide; squarely truncated before, but without salient angles; metathorax conrex, but not prolonged, rounded and having two distinct conrexities separated by a channel. Petiole of the length of the thorax, linear at its base; about the middle rather suddenly swelled into the form of a club or of a truncate pear, or campanulate; feebly bidentate (or bituberculate) in the middle, generally bordered by a salient cordon; the swelling generally parted by a groore, and having an impressed point before the margin. Pyriform part of the abdomen globular or compressed, or at least not much depressed. Antennæ of the males terminated by a hook.

The body of these insects is in general densely punctured and covered with thick sub-woolly hair, and the clypeus of the males is usually jellow, clothed with a silvery pile, while among the females it is only marked with yellow. But these characters suffer certain exceptions among the American species.

As it was said, there is no regular limit between this group and the Division Omicron, but if we compare the extreme forms of both, as for instance $E$. globicollis or aviculus with $E$. globulosus, there will be an easy distinction of both types, which exists no longer if we compare all the species. In general terms we can say that here the thorax is often more lengthened; the metathorax more parted; the petiole more campanulate; the extremity of this

1 Cerceris simulans Sacss. Reise d. Oesterr. Fregatte Novara. Hymenopt., p. 81, No. 1, fig. 53. In this, even the forms of Cerceris are so modified as to approximate to those of Pulybia, the abdomen becoming elongate-petiolate. 
is sometimes not margined, sometimes margined hy a little cordon; this is not preceded by a regular channel as in Division Omicron, but rather by three impressions, which makes the salient margin appear somewhat bidentate before; the impression of the middle is always the most distinct.

A. Large species, with black wings. The pear of the abdomen rather depressed; that is, not compressed.

a. Bodly smooth, shining, not punctured. (Thorax elongate, petiole strongly campanular; its swelled part convex, not parted by a groove, its margin preceded by a channel as in Division Omicron.

33. E. Aztecus Sauss.-Validus, ater, nitidus, haud punctatus; pronoti margine postico medio, post-scutello, petioli margine, et abd. secundi seginentf limbi fascia interrupta, pallide ochraceis; antennis et tarsis anticis subtus ferrugineis; alis nigro-cœruleis. + .

Total length, $22 \mathrm{~mm}$; wing, $17 \mathrm{~mm}$.

Eumenes Aztecus Sauss. Revue et Mag. de Zool., IX, 1857, 272.

․ Large, black, smooth, and polished, without punctures: the body throughout smooth, shining, and satin-like, nearly glabrous, with neither punctures nor distinct striæ, even on the metathorax or the petiole. Clypeus bidentate at the extremity, smooth and polished like the remainder of the body. Its emargination angular. Thorax long; disk of mesothorax lengthened. Pyriform part of petiole wide, strongly campanulate; little swelled, convex above; its posterior border formed by a salient cordon preceded by a channel. Second abdominal segment depressed; but the end of the abdomen a little compressed (without this last character this insect would have the appearance of a Pachymenes).

Antennæ long and slender, black, ferruginous beneath. Feet black; tibix and anterior tarsi with golden hairs, appearing yellow. A little areuate line in the middle of the posterior border of the prothorax, two dots on the scutellum, post-scutel, and a narrow edging on the margin of petiole, pale tawny; second segment generally marked with a pale-tawny submarginal border, narrow and widely interrupted in the middle. Wings black, raried with rery deep-violet reflections.

Var. Only the post-sentel and the petiole marked with pale tawny. 
Ress. a. diff.-This handsome species has no similarity to any but the E. favicornis, and to the E. Wagneriana, from which it is easily distinguished by its notched clypeus and its body with. out sculpture.

Hab. The gulf side of Mexico. Tampico.

Observation.-One can discover with a strong magnifier, a fine sculpture on the thorax and elsewhere; the scutellum in particular is very finely punctured, but we only speak here of characters easy to discover and relative to those of other species.

b. Body punctured. Petiole elongate; its dilatation flattened-elongate, parted by a groove, not sensibly margined. (Passage to the Division Zeta.)

34. E. Alavicornis SAuss.-Valiđus, earbonarius, E. Wagneriano simillimus, at clypeo truncato, haud bicarinato; antennis, clypeo, orbitis, macula frontali mandibulisque apice, aurantiis; antennis $\delta$ apice haud uncinatis, sulco minuto subtus notatis. Long. $25 \mathrm{~mm}$.

E. favicornis Sadss. Et. Vespid., III, 141, 27 ; pl. vii, fig. 4, 仿 (Syn. excl.).

Hab. Venezuela. (Museum auctoris.)

35. E. Wagnerianus n. sp.-Niger, sericeus; thorace dense punctato, petiolo depresso, sulco partito; clypeo $q$ valde bicarinato, apice subexciso; alis nigro-violaceis.

Total length, 23-24 mm. ; wing, $21 \mathrm{~mm}$.

q. Large, black, shining; head and thorax finely punctured. The whole body clothed with a fine grayish pile. Clypeus rather rugose, punctured and striate, lengthened and widely truncate at its inferior border and slightly notched, its anglés rounded, receiving two strong parallel distant carinæ which cross the clypeus for about two-thirds of its length. Prothorax slightly retracted, rimmed; its angles a little salient. Abdomen depressed, smooth, and silky, with silvery reflections; enlargement of petiole flattened, wide, and lengthened, divided by an impressed line. The whole body of a deep black. Wings of a deep brown, with violet reflections.

Ress. a. diff.-This species rery much resembles-

1st. The $E$. aztecus, from which it is distinguished by its distinctly punctured thorax, by its much longer clypeus, rugose, more flattened, not bidentate; by the enlargement of the petiole, 
more lengthened, not bossed and divided by a strong groove; by its angulate prothora $x_{r}$ etc.

2d. The E. flavicornis, of which it has the form and the punctuation.

3d. The E. niger Brulle, from which it differs by its emarginate clypeus, in the $\$$; by the more lengthened, less dilated enlargement of the petiole, etc.

Hab. The Isthmus of Panama. (My collection.) This beautiful insect was sent me by the celebrated traveller, Maurice Wagner, of Munich.

The flattened and sulcated petiole of the E. Wagnerianus and flavicornis forms an exception to the species of the Division Alpha, and approximates it somewhat to the Division Zeta, although the petiole is too wide to allow it to be classed with that Division.

B. Smaller species, with the abdomen more globular or compressed. The border of the petiole a little margined; the margin preceded by an impression. (Regular type of Division Alpha.)

a. Wings smoky, with violet iridescence.

\section{E. Ghilianii SPIN.}

Eumenes Ghilianii Sproca Hymen., rec., par Ghiliani, No. 61 (Mẻm. Acad. de Turin, 1846).-SAuss. Vespides, III, 140, 26.

Hab. Brazil. Para. (Mus. Spinolæ, Taurinense.)

3\%. E. fraternus SAr.-Niger, dense punctatus, cinereo-hirtus; abdomine nitido; lineola verticali inter antennas, clypeo summo, pronoti margine, post-scutello, metanoti summi maculis 2 , abdominieque segmentorum 1, 2 vel 1-3, margine, secundo maculis 2 lateralibus, sulfureis; $\delta$ clypeo toto luteo; segmentis abdominalibus $1-4$ flaro-lim. batis; metanoto impunctato.

․ Total length, $17 \mathrm{~mm}$.; wing, $12 \mathrm{~mm}$.

$\delta$. Total length, $13 \mathrm{~mm}$.; wing, $9 \mathrm{~mm}$.

Eumenes fraterna SAY, Long's Sec. Exped., II, 344 (Append., Ti), 1, $\delta$ (1825).-SAY's Eutomol. (Le Conte), I, 23:, 2.-Sarss. Vespides, I, 40, 17, $q\}$.

E. fervens Sadss. Vespides, I, 40, 15, $९\}$ (1552).

E. macrops SAuss. ibid. I, 41, 18, $\delta$ (var. ? 1852).

L. minuta Sauss. ibid. I, 39, 14, $\delta$ (Syn. exclus.). 
. Clypeus conrex, punctured, the tip flattened, notched, and bidentate; the teeth lamellar. Head short, not dilated behind the eyes, cribrose with punctures, as also the thoras, which is large, short, globular; the metathorax convex and more densely punctured; the scutels conrex, much inclined, continuing the conrex surface of the metathorax. Petiole at first linear, then prriform, lengthened, and truncate, corered with punctures, insensibly bidentate in the middle and bordered posteriorly by a hardly salient cordon, before which are three depressions, of which the middle one often forms a large hollow. Second segment compressed, flat beneath, very convex above, corered with punctures, but ret smooth and shining; toward the middle of the posterior border of the second segment they are so gathered together as to form a depression (which, howerer, is often wanting); its posterior border with double leares; the upper leaf thick, a little sinuous, slightly concare in the middle; the second border not being bent upward. All the body corered with a short, gray pile, not chatorant.

Insect of a shining black; two obliqne spots at the summit of the clrpeus, the carina between the antennæ and two dots behind the eyes, border of the prothorax, post-scutel, often a spot under the wing, often two spots at the summit of the metathorax and at times two dots on the middle of the same, two rariable dots on the sides of the second segment and along the margin of the same a scalloped horder, sulphur yellow; legs black, tibiæ raried with yellow; wings brownish with riolet reflections. Wing scales b]ack, bordered with brown or spots of yellow or red. $\delta$ clypeus bidentate, entirely yellow or with a black dot, corered with a silrery pile; scape of the antennæ marked with a yellow line and the hook of the same ferruginons.

Tar. $\{\delta$. The second abdominal segment more or less compressed, the third and fourth segments often wholly or in part bordered with yellow. Wing scales shining, often black, or marked with a yellow dot. A yellow dot under the wing. The yellow dot behind the eye often wanting.

This is a rery distinct species from its large size, its strong puncturing in the form of pin holes, from its slender form and its violet wings: from its shining black color, generally but little changed by the rery short hair of the insect. 
I possess some specimens, especially males, which, without exactly resembling the others, do not yet seem suffieiently different to constitute another species :-

1st. Petiole shorter and wider, with a longitudinal indistinct groove; second segment short, and all the segments bordered with whitish; wing scales ferruginous; the thorax quite villose. Size smaller. (Towa.)

2d. Wing scales black or marked with a yellow dot; wing entirely bluish, as if steeped in pale ink, with some violent reflections, without any reddish or brownish tint; seen by their transparcnce, they have this same gray-violet color, while in the type they appear brown. Hooks of the antennæ blackish; the second segment seen in profile less dilated above, smoother, and less punctured. Size s.maller. (New York.)

Hab. The eastern part of the United States. Very common..

This insect extends from New Orleans to Canada. I have more than forty specimens, which I have collected in Louisiana, in South Carolina, in New York, or which have been sent me from Tennessee, Wisconsin, Pennsylvania (Haldeman), Illinois (B. F. Walsh), Connecticut (E. Norton).

The species is very distinct in its appearance. Though presenting a great similarity in form and coloration to the small European Eumenes (E. coarctatus), it can easily be distinguished from it by the much greater size, by the black, shining, not pilose body, on which the markings are little extended, and the color straw-yellow or whitish; by its black scutellum, with the post-scutel always yellow and often presenting two dots at the summit of the metathorax; by its smoky or violet wings ; finally by its body, strongly cribrose, even on the abdomen.

'These characters, as well as the but little rariable markings of this insect, form a peculiar appearance which enables one to recognize it at first sight. It is a species really special to America, and which camnot well be taken for a variety of $E$. coarctatus Lin. Although the males, of which the size is often less and among which the eharacters of the species are generally less well developed, resemble closely those of the Li. coarctatus, one can, nevertheless, distinguish them by these character's and the much stronger punctures of the abdomen.

This Eumenes has habits analogous to those of the Eumenes of Europe. It constructs with argillaceous earth a nest which. 
resembles a sphere terminated by a little bell-mouthed neck, which it obliterates after filling. One often finds these nests in the country, joined to the upper surface of leares, or stuck to little branches, or fastened against a wall. 'i he insect places its eggs in it with a provision of caterpillars which can serre for the nourishment of the young larræ According to Say (Long's Sec. Exp., II, 346), it chooses the larræ of nocturnal lepidoptera, lut the Eumenes are not particular in their choice. Harris also saw the same species collect larræ (canker worms). ${ }^{1}$ The larva occupies about a month in its derelopment, and the perfect insect makes its exit by piercing the walls of the cradle which is then no more to it than a prison.

b. Wings transparent or yellowish. (Body generally clothed with short woolly pile.)

* Seconil abdominal segment vithout lateral yellow spots.

33. E. ferrugineus Cress.- $\hat{\delta}$. Pallide ferrugineus; orbitis, clypeo, margine antico pronoti, maculis 2 mesonoti, scutello, post-scutello, macula subalari, maculis 2 metanoti, pedibus partim, abdominis segmentorum 1,2 margine apicali, obscure flarescentibus; antennis mediis nigrescentibus; alis pallide hyalino-flaridis; clypeo bidentato, $\delta$ argenteo. Long. $4 \frac{1}{2}$ lin.

E. ferruginea Chess. Proc. Ent. Soc., Phila., 1865, 158. $\nmid$.

Hab. Cuba.

39. E. Iturbide Sacss.-Eum. pomiformis statura, niger, dense punctatus, fulvo-hirsutus; secundo abd. segmento supra maxime gibboso. margine canaliculato; pronoto lato, subdepresso; antennis omvino nigris; clypeo bidentato, $\hat{f} q$ nigro, cum macula in summo flarą; macula frontali, pronoti et abd. segnentorum margine, post-scutello et macula subalari, sulfureis; tegulis, tibiis et tarsis, ferrugineis; alis suthyalinis.

Eumenes Iturbide Sadss. Revue et Mag. de Zool., IX, 1857, 271.

Total length, $13 \mathrm{~mm}$; wing, $9 \frac{1}{2} \mathrm{~mm}$.

P. Clypeus deeply notched, rery convex on its upper part; the teeth of the emargination long and triangular, slender and lamel-

1 I have seen one of this species with the green larra of a Dinrnal leridopter. Mr. Walsh writes that he has found its uests stored with green larvæ.

E. N. 
late. Thorax wide, a little depressed, that is, less high than wide; cribrose with thick punctures. P'etiole pyriform, a little less strongly punctured than the thorax, bordered by a salient rim before which is a hollow space. Second segment covered with quite fine and dense punctures; flattened beneath, very conrex, and nuch dilated above, into a prominent boss of an almost tubercular form; behind this boss is a species of transverse channel which forms a submarginal depression; finally the border is sensibly turned up in the middle.

Insect black, very pilose, bristling with tawny or fulvous hair, which is short and chatoyant on the abdomen. Antennæ entirely black; a spot on the middle of the summit of clypeus, a point on the face and two behind the eyes, one under the wings, postscutel and border of all the segments, yellow; the border of the last a little scalloped. The prothorax is also ornamented with a narrow margin, twice interrupted or with three transverse spots, yellow. Wing scales red: Legs black, tibiæ and tarsi forruginous. Wings transparent, sullied with brownish-ferruginous, or yellow often passing into ferruginous. The spots of the hear and of the thorax are often wanting wholly or in part; the middle only. of the prothorax bordered with yellow.

$\hat{\delta}$. Hook of the antennæ ferruginous. The remainder exactly as with the female, but the clypeus covered with a silvery pile among fresh specimens and marked at the summit with a large yellow spot.

Ress. $a$. diff.-This species is very well characterized by the singular deformity of the second abdominal segment, which has no yellow lateral spots; by its red wing scales and by its very velvety appearance (even the scape of the antenne is quite bristling with hair in fresh specimens), by its black elypeus, spotted with yellow in both sexes, which is diflerent in most other speeies (among which the elypeus of the male only is yellow). Compare Li. olmecus.

Hab. 'The temperate regions of Mexico. I have taken it in the Michoacan and in the deep baranea of Meztitlan. One specimen, + , having the clypeus entirely black, was taken in Mechoacan, near 'Tuxpan. (Temperate region.)

Observation.-One peenliarity is worthy of remark in this species, that, contrary to the habitual rule, the male is stoutcr than the female. 
40. E. consobrinus Sadss. - Niger, fulvo hirsutus, valde punctatus; thorace depresso; abd. 20 seguento supra compresso et inflato, margine medio transversim impresso; tegulis, tiliis et taris rufis; pronoti fasciola et punctis 2 humeralibus, post-scutello et alid. segmentorum margine sulfureis.

$\hat{\delta}$. Clypeo bidentato, in summo flaro-maculato.

E. consobrianus Sauss. Et. Vesp., III, 140, 25.1 $\delta$.

Total length, $11 \mathrm{~mm}$; wing, $9 \mathrm{~mm}$.

$\widehat{\delta}$. Clypeus punctured, relutinous, lengthened, triangular, separated by a triangular incision. Thorax a little depressed, more wide than high, but short, almost square, distinctly punctured throughout, the metathorax very densely so. Petiole punctured, pear-shaped, lengthened, and truncate, not campanulate, offering at the extremity, before the border, a sunken place; 2d segment flattened beneath, but compressed abore, forming a salient boss, and presenting in the middle before its border a transrerse depression, so that the border is a little elevated in the middle; this segment, above, very densely punctured, but less strongly than the thorax. A testaceous lamina extending beyond the border of all the segments.

Insect black, all the body clothed with a long yellow pile. Wing scales, hook of the antennæ $\delta$, tibiæ, and tarsi red; an oval spot on the summit of clypeus $\delta$, a point on the front, two little dots behind the summit of the eyes, two dots on the angles of the prothorax, a little line in the middle of its posterior border, post-scutel and a regular and narrow border on the segments 1-5 of the abdomen, sulphur-yellow. Tibiæ often brownish at the end. Wings subsmoky.

Hab. Brazil. (Collection of Sen. the Marquis Spinola, at Turin.)

This species, which is of the smallest size, approaches very much to the $E$. compressus Sauss.

\section{E. Uruguyensis Sadss.}

Eumenes Uruguyensis Sauss. Vespides, III, 139, 24, pl. vii, fig. 6, 1854.

Hab. Uruguay. Monte-Video. (Typus in mus. Parisiensi.)

1 L. c. 3me ligne de la description, au lieu de: base, lisez basse. I'si t. Gme ligne de la description, au lieu de: bout, lisez haut. 
12. E. Placidus Smin.-Niger, antennis, pronoto, metanoto utrinque, petiolo partim pedibusque, rufis; antennis superne partim nigris; pronoti margine postico abdominisque seginentoruın $1^{\mathrm{i}}, 2^{\mathrm{i}}$ limbo, $3^{\mathrm{i}-5^{\mathrm{i}} \text { fascia }}$ abbreviata, liavis. (E. Uruguyensi affinis species.) Longit. $4 \frac{3}{4}$ lin.

Eumenes plucidus Sмiтu Trans. Ent. Soc., London, 3d series, I, p. 37, (1862).

\section{Ilab. Panama.}

** Second abdominal segment with a yellow spot on each side (sometimes wanting in v' riety).

43. E. globulosus Sauss.-Niger, dense punctatus, sul,ferrugineohirtus; abdomine nitido, fulvo-subsericeo; petiolo breviore; clypeo summo, lineola inter antemnas, punctulo pone oculos, pronoti margine, macula subalari, scutelli maculis 2 , post-scutello, maculis 2 in surnmo metanoto, abd. segmentorum marginibus, secundique maculis obliquis 2 lateralibus, flavis: tibiis et tarsis ferrugineis, seu flavis; alis sublyalinis; tegulis flavis puncto rufo. $\$$.

Eumenes globulosus Sauss. Vespides, III, 139, 23, ․ (1854.)

Total length, $15 \mathrm{~mm}$; wing, $10 \mathrm{~mm}$.

9. This species differs from E. fraternus: By the clypeus being less bidentate, much less notched; by its smaller size, and a little shorter petiole; also in the part of the same enlarged and so much divided by an obsolete channel; by its finer punctures, especially on the abdomen; by its more ferruginous pile, which is longer and gives the insect a sub-woolly appearance. Also by a more complete marking; the clypeus often presenting two yellow spots, the wing scale bordered with yellow and having a red dot in the middle; and the abdomen shining upon the quite wide borders of segments $2-5$; that of the $2 \mathrm{~d}$ being scalloped and its lateral spots often lengthened; finally by the transparent wings, slightly washed with ferruginous along the side. It is fitting to add that the yellow border of the prothorax, in place of being enlarged at its two extremities as in the E. fraternus, is narrow and is at times bi-interrupted.

Var. a. Clypeus black, or with two yellow marks at the summit; no subalary spot.

b. The yellow band of the post-scutel interrupted. Sentel black.

c. Clypeus yellow, bordered with black below and marked with a black trident.

d. I'rothorax black, or only with a little yellow in the midille. 
Tar. (probable). Posterior margin of the prothorax also bordered with yellow?

I have nerer seen the males.

Fess. a. diff.-This species recalls the European E. pomifor. mis much more than the $E$. fraternu, by its smaller size, l,y the body being a little relvety, and by its transparent wings, also by its petiole being shorter and more enlarged than in the $E$. firaternus, and at times also divided by a groore. Olie might $a=\mathrm{k}$ whether $E$. globulosus may not be a type derived from the European E. pomiformis, which may hare transmigrated to America.

It differs from the $E$. americanus by haring different markings and by its black antennæ; from E. Iturbide by its abdomen, which has not the rimmed border on the second segment, and by its differently marked clypeus, for it has all the superior part, especially laterally, marked with rellow, while in the $E$. Iturlide, the yellow upper spot is in the middle, not marginal; the clypeus is also more shining, less strongly punctured, etc.

$H a b$. The interior of the Cnited States. Illinois, Wisconsin,

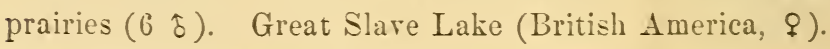

44. E. auropilosa Surtr.-Niger, aureo-pilosus; thorace crasse punctato; clypeo sulmarginato; antennis subtus ferrugineis: puncto frontali et oculari, macula utrincue et limbo postico prounti, macula subalari. post-tegulis, linea scutelli et post-scutello maculisque 2 metanoti, flavis; petioli margine et puncto utrinque apicali, segmentorum reliquorum margine, fasciaque laterali utrinque $2 i$ segmenti cum margiue conjuncta, flavis; pedibus rufis basi nigris; alis subhyalinis. $\hat{\delta}-$ Longit. 4 lin.

E. auropilosa Sмrтн Cat. Brit. Mus. Tesp., 30, 71.

Hab. Brazil. (Tilla Nora.)

** Second abdominal segment hating on ench side a yellore fascia, or a con pl te transverse yelluro land on it.s vilille.

45. E. Cubensis Cress.-Fuscus. fulro, metanoto cano, pilosus; clypon emarginato; corpore ralde punctato; orbitis, clypeo, macula fiontali, margine antico pronoti, macula subalari, maculis 2 mescnoti, tegulis partim scutelli margine antico, post-seutello, metanoto partim, tibiis et tarsis, abdominis petioli apice, fasciisqne -2 secundi segmenti, flavis; antelnis ferrugineis, basi flarescentibus, apice nigrescentibus; alis fusco-hyalinis, apice fuliginosis. + . - Long. 7 lin.

E. Culensis Cressox, Proc. Ent. Soc. of Pliila., IV, 1\$65, 157.

Hab. Cuba. Seems to approach rers near to $E$. Smithii. 
16. E. Americanus Sauss.-Niger, dense punctatus, ferrugineohirtus; petiolo gracili; antennis ferrugineis, apice nigris; pronoto, tegulis, scutelli margine, metanoti et petioli lateribus, ferrugineis ; postscutello, abdominis segmentorum marginibus, secundi fascia utrinque laterali et pedibus, rufis vel aurantiacis ; alis subferrugineis.

E. Americanus Sauss. Vespides, I, 39, 13 (1852).

Total length, $13 \mathrm{~mm}$. ; wing, $9 \mathrm{~mm}$.

Form of $E$. fraternus, but smaller and a little more slender. All the body feebly shagreened or rather cribrose; the thorax with confluent punctures; not very rough. Clypeus bidentate, yellow, covered with a silvery pile, in both sexes. Thorax short, quadrate. Petiole lengtliened, slender, gradually enlarging, insensibly bidentate in the middle, eribrose with slightly separated punctures, and bordered at its posterior extremity with a salient cordon, parted by a middle groove. Second segment compressed, flattened beneath, very eonvex above, densely punctured, and carrying toward the middle of its posterior margin a transierse depression.

Insect black, covered with an abundant ferruginous pile; the black passing much into ferruginons; mandibles ferruginous, black at base; a spot between the antennæ, margin of the notch of the eyes and a line behind them, yellow; the prothorax, wing scale, sides of metathorax, and a spot under the wing, the postscutel, the anterior border of the scutellum and the sides of the petiole ferruginous or rufous. The second segment ferruginousbrown. The two borders of the prothorax and that of the petiole, in general marked with a yellow edging; post-seutel, a wide border on all the segments of the abdomen, and often two spots on the petiole, orange; the border of the seeond segment very wide in the middle (not emarginate) being narrower at the sides and often confounding itself with two yellow oblique spots or lines, which occupy the sides of the segment. The abdomen ferruginous beneath; legs ferruginous, with the tibia and the tarsi yellow and the thighs abore sometimes blackish. Intenna ferruginous, black above on the six last articles. The seape yellow beneath. Wings transparent, with ferruginons nervures, at the end grayish.

9 . Clypens marked with an orange spot at base and in the middle; its teeth acute.

§. Clypens narrower, sulphur-yollow; hook of the antenna ferruginous. 
Var. The whole insect covered with fulrous woolly pubescence. Thorax and petiole rufous; second abd. segment fulvous with a transverse black band produced to the base, separating on each side a yellow macula. Wings obscure, with rufous costa.

Ress. a. diff.-This species sometimes offers a resemblance to the E. globulosus Sauss, which also has the markings yellow rather than whitish and which is corered with ferrugino's hair; but it differs essentially from it in its compressed abdomen, in its petiole, narrow, elongate-pyriform, not campanulate in the middle; in its antennæ ferruginous at the base, etc. It is quite approximate to $E$. Smithii, but smaller; the petiole more slender; the metathorax more triangular; the punctuation of the body not so strong.

$H a b$. The hot regions of Mexico. I have taken it in the ralley of Mextitlan between Mexico and Tampico.

4\%. E. Smithii Sacss.-Ferrugineus, corpore crasse et densissime punctato, etiam in abd. secundo-segmento; antennis ferrugineis; vertice, mesonoti disco et petioli basi, nigris; postscutello, pronoto et abd. segmentorum 1 i, $2^{\mathrm{i}}$, limbo flavis; secundo segmento fusco, fascia transversa rufa vel aurantiaca.

$\hat{\delta}$. Clypeo argenteo.

Var. Niger, rufo et flavo varius.

Eumenes Smithii Sauss. Vespides, I, 43, 21 ; pl. x, fig. 1 (1852).

Total length, $18 \mathrm{~mm}$. ; wing, $11 \mathrm{~mm}$.

9. Of moderate size. In size and in form, resembling $E$. fraternus. Prothorax slightly retracted before; petiole a little longer than in the species cited. Abdomen compressed. The whole insect densely cribrose with strong punctures; the second segment of the abdomen a little less coarsely so, but yet strongly cribrose. All the body clothed with a grarish pile. Clypeus black, satin-like, notched. Head black; mandibles and antennæ ferruginous; these last obscure abore; margin of the eyes and a spot on the front often ferruginous. Thorax red, with the sutures black; the mesothorax at times black with two red stripes and something of black on the flanks and in the furrow of the metathorax. Border of the prothorax, of the wing scale, and the post-scutel often yellow; abdomen black, segments 1, 2 bordered with a yellow cordon; the second marked with a red transrerse band; the other segments red, shaded with black at their base. 
Feet red or varied with yellow. Wings washed with ferruginousbrown, with golden reflections; the radial cellulse a little brownish.

$\widehat{\jmath}$. Clypeus lengthened, bidentate, red or yellow, with a silvery pile; fore part of scape of antennæ yellow.

Var. 'The ground color is often red throughout, and the only black is on the vertex, the disk of mesothorax in part, and the base of petiole. The second segment then has an orange band mingling on its margin with the red or the brown which borders it. It is probable that the highly-colored specimens have the scutellum, the prothorax, and wing scales yellow.

Ress. a. diff.-This species is easily recognized by its colors, especially by the transverse band of the second abdominal segment and also by its strong puncturing. It has the abdomen very densely punctured and this character would be sufficient to show its difference from $E$. fraternus, if its markings did not already suffice to distinguish it. Ito is also very similar to $E$. americanus. Compare this species.

Hab. The Southern United States. Florida. (I possess two males.)

c. Species of uncertain origin.

\section{E. compressus S̀auss.}

Eumenes compressa Sauss. Vespides, III, 142, 28; pl. viii, fig. 5, $5 a$ (1854).

This species has the form of $E$. fraternus, but the petiole is a little longer, and the $2 \mathrm{~d}$ segment of the abdomen has no yellow spots.

Its origin is not known.-A merica??. (Mus. of Paris.)

It would fit next to $E$. Iturtide, in the section $\mathrm{B}$, a, the wings being rather cloudy iridescent.

\section{Division ZETA.}

(Sadss. Vespides I, 67; III, 132, 146.)

Petiole very long, linear at its base, there depressed and widened in form of a ribbon; generally divided upon its dorsal face by a longitudinal groove. The remainder of the abdomen pyriform, compressed at the end; the second segment subpediculate; its base in some degree a short continnation of the petiole.

In this group the mandibles are very long, having indistinct teeth; the head is flattened before; the thorax has a relvety surface. It is wide before and its anterior angles are rery distinct. The abdomen is quite lengthened. 
This dirision is more distinct than the preceding, lut, never. theless it joins itself to Division Alpha by the E. Wagnerianus and flavicornis.

49. E. abdominalis Dnckr. - Validus, gracilis ; corpore relutino; clrpeo apice parum emarginato, dentibus rotundatis; petiolo deplanato, sulco partito; alis ferrugineis; antennis ferrugineis, apice supra nigris. (Colorum distributio maxime rariat in hoc insecto, a enpere omnino ferrugineo, al nigro- et flaro-rariegatum; varietas maxime abhorrens videtur esse thorace nigro, pronoto et scutellis flavis. Sæpius petiolus viger permauet, margine flaro, et abdowine ferrugineo.) $q \delta$.

Total length, 21 mm.; wing, $17 \mathrm{~mm}$.

Sphex abdominalis Drers, Illust. of Ins. I, tab. 45. fig. 2 (1770).

Tespu atieruata OdIv. Eucyc. Meth. VI, $67 \pm$ (1791).-Fabr. Eut. Syst. II, 282.

Sphex extensa Christ, Hymen. ibid, Xxxil, fig. 7.

Polistes attenualus FABR. S. P. 279 (1\&04).

Eumenes abdominalis SAcss. Vespides, I, 7()$, 5 £$, et in La Sagra, Hist. de Cuba Ins. $768 .-$ Cressos, Hymen. of Cuba, Proc. Eut. Soc. Philad. IV, $1 \& 65,15 \%$.

Eumenes colona Sacss. Vespides, I, 70, 59 (1\$52), et in La Sagra, Hist. de Cuba Ins. $768, \mathrm{pl} .19$, fig. 1.

Eumenes versicolor Sacss. ibid. I, 71, 60.

Eumenes ornatus Sarss. Vespides, III, 147,35 , pl. viii, fig. 3 (1854), et in La Sagra Hist. de Cuba Ins. 768.

Eumenes picta Surth, Catal. Brit. Mus. Vespidæ, 32, 79 (1557).

$\delta$. Large. Mandibles forming a long beak by their union, presenting two lines of punctures. Clypeus a little emarginate at its extremity; the notch placed between two rounded projections. Ilead and thorax punctured, relvety. The angles of prothorax a little salient. Petiole arcuate, shining; of the length of the thorax; dirided by a groore. The remainder of the abdomen prriform, almost fusiform, subrelrety, or eren silkr. The body clothed with a gray pile.

Antennæ ferruginous, with the extremity of the scape of $\delta$ ornamented with a rellow line. Mandibles ferraginons. Wings transparent, of a yellow ferruginous along the side. Nothing is more variable than the distribution of the colors on the remainder of the body.

One can arrange the following principal rarieties:-

a. Color in the main black; a frontal spot, border of the orbits, an interrupted transrerse line before the ocelli and clypeus, rellow; this last marked with a black spot at its summit. Prothorax, a 
spot, below the wing, scutellum, and post-scutel, extremity of the petiole, a large sealloped border on the second segment and the following segments, yellow. Legs yellow, with the thighs in part black. (E. ornalus Sauss.)

Hab. Isle of St. Thomas.

b. 'Two yellow spots on metathorax. The border of second segment so wide that no black remains but a tricuspid basilar spot. Sometimes there are two yellow smooth spots on the second segment. 'T'wo yellow spots appear on the disk of mesothorax. The elypeus and legs are without black, but often present some ferruginous color. (L. versicolor.)

Hab. Jamaica. Venezuela.

c. The pyriform part of abdomen ferrnginous, with its seg'ments more or less distinctly bordered with yellow. (E. abdominalis.)

Hab. Jamaica. Cuba.

There is often a yellow line on the scape of the antennæ and the yellow original markings reappear on the ferruginous color of the thorax. (E. picta.)

Hab. Saint Domingo.

d. 'Thorax almost entirely yellow, presenting only a black spot on the extremity of the disk of the mesothorax, a band before the scutellum, and an oblique one on the flanks. Abdomen ferruginous; the petiole blark, bordered with yellow or orange, with the base black and the border yellow. (E. colona.)

Hab. Hayti. Jamaica.

$e$. The whole insect ferruginous, a little varied with yellow on the head and thorax, not offering more of black than the thoracic sutures, and a frontal and vertical line.

Hab. Cuba.

Its form also varies. Specimens which I have taken at St. Thomas are stout; they have the petiole wide; those which I have captured in Jamaica are slender and lithe; their petiole is remarkably narrower.

In conclusion; these variations are not only dependent upon the localities, but probably, also, on the seasons and diverse fortuitous circumstances.

\section{L. caunaluculatus Our.}

Vespa canalienlata Ot.1v. Encye. Meth. VI, 672 (1791).

Vespa diadema Fabs. Fint. S. Suppl. 263 (1798); S. P. 285 (Eumenes).

Eumenes camahculatu Sauss. Vespide. I, 68, 56; pl. xi, tig. 5.-1) bitiers Mem. Ins. 1I1, 579, Tab. 29, fig. 3. 
Tar. a. Tholly ferruginous, with the wings obscure.

b. Abdomen black, with the end ferruginous; petiole ferruginous, with a black margin.

Hab. South America.

51. E. Orbignyi Sacss.

Eumenes Orbignyi Sacss. Etudes sur la Fam. Tespides, I, 69, 57 (1852).

Hab. Boliria. Probably a rariety of the preceding.

52. E. Chalicodoma n. sp.-Niger; capite et thorace ferrugineis, fronte et mesonoto vigris; tuberculis 2 obsoletis ferrugineis in fronte; clypeo lato, emarginato; abdomine fere impunctato; petiolo mediocri, læri, rix sulcato, apice puncto impresso et margine flaro; alis infuscatis. $q$.

Total length, 15-20 mm.; wing, 12-16 mm.

․ Head orbicular, longer than wide. Clypeus large, widely but not deeply emarginate at its inferior border and a little bicarinate; the carinæ distant. Between the antennæ an elongate tubercle parted br a sulcosity, and orer this, next to the top of the eres, two frontal rounded tubercles; rertex arcuate. Thorax elongate, compressed, anteriorly margined by a feeble crest. Scutel conrex, parted by a groore; metathorax parted by a channel, nearly to the top. Head and thorax delicately punctate. Disk of mesothorax with two or four sulcosities at base. Petiole moderate, polished, impunctate, as long as the thorax, a little gibbous in the middle; its sulcosity rers obsolete; the end without elerated margin, but with an impressed point. The rest of the abdomen elongate, pear-shaped, not compressed, nearly impunctate, except along the edge of the margins; the second edge obsoletely separated from the first.

Head ferruginous; the forebead black, with its three tubercles ferruginous; antennæ ferruginous; the flagellum black abore. Thorax ferruginous, beneath and in the groores of the sides, black; disk of mesothorax black. Abdomen black; the petiole margined with yellow. Feet ferruginous, raried with fuscous. Wings washed with brown; the costa more obscure.

Pess. a. diff.-Nearly of the same coloration as $E$. canaliculatus, but smaller; the head less broad, not so triangular, distinct by its two frontal feeble tubercles; the thoras much narrower, more margined anteriorls, more canaliculate posteriorly; the 
scutel not flat nor entire; the petiole shorter, not so distinctly sulcate. - Very distinct from filiformis by the same characters and by its nearly impunctate abdomen.

Hab. Brazil. Pernambuco. 'This insect was bred in a nest of Chalicodoma; if as a parasite I could not ascertain.

53. W. filliforma is SAuss.-Niger, antennis subtus et abd. apice, ferruginejs; clypeo elongato, flavo-marginato, apice obtuse emarginato, et flavo-bimaculato; thorace brevi, dense punctato, postscutello et metanoto crassius punctatis, petiolo valde elongato, punctato, tenuiter sulcato, pone medium subcoarctato; secundo abd. segmento punctatissimo, rugoso, margine subreflexo; margine postico pronoti, petioli et secundi segmenti, flavis ; alis infuscatis, apice subhyalinis. $\{$.

E. jiliformis Sauss. Lt. Vesp. III, 146, 34, ㅇ.

Total length, $17 \mathrm{~mm}$; wing, $13 \mathrm{~mm}$.

Antennæ long and slender. Thorax shorter than that of $E$. canaliculalus, almost globular, squarely cut before, densely punctured; the post-scutellum and the metathorax cribrose with punctures, stronger and less serrate, while in the species cited the thorax is everywhere velvety and finely punctured. The petiole is a little longer than the thorax, very narrow, a little enlarged from before backivard, arcuate, flattened, irregularly punctured. Its groove but slightly distinct. The second segment compressed, very densely shagreened, appearing rugose above; the punctures much more dense, but not as large as on the metathorax; the first posterior border of this segment slightly turned up and preceded by a transverse depression in the middle; the 2 d border nairow, profoundly sunken.

Var. The ornaments of the thorax and of the abdomen are generally of a sombre ferrnginous rather than yellow, indistinct; the border of the 2d abdominal segment is sometimes yellow, sometimes ferruginons.

Black, fulvo-velutinous; flagellnm of the antenne beneath, edge of wing seales, knees, and margin of the abdominal segments ferrnginous; posterior margin of prothorax and an intermpted faseia at the extremity of the petiole, yellow. Wings washed with brown in the basilar half, sublyaline at the extremity.

9. Clypens black, smooth, lengthened, narrow abore; its greatest width is in its lower third, earring two little bosses in the middle (of its height), the terminal border notehed at a rery 
obtuse angle, anc. forming two slightly diverging salient or obtuse angles.

'Two spots at the extremity of clypeus, the lateral margins, and the froutal carina, yellow.

Ress. a. diff.-A very distinct species from all the others of this Dirision by its very punctate compressed abdomen, and by the much impressed edge of the $2 d$ segment, which renders the first edge very sharp. The other species have this edge flat, so that the first edge is hardly distinguishable.

Hab. Brazil. (Author's collections and Spinola's at Turin.)

\section{Gen. MONTEZCMA SAOSS.}

Mandibles rery long, terminating in a point, channelled, and forming by their union a long beak. Lip and jaw very long; labial palpi presenting but three articles and often terminated by long hairs. ${ }^{1}$ Naxillary palpi composed of five articles.

Head normal; generally dilated behind the eyes, and a little concare behind; between the antennæ is a little carina which reaches the clypeus. Clypeus $q$ longer than wide, pyriform (that is, rounded at the summit, diminishing downward); emarginate and bidentate; $\delta$ polygonal, generally as wide as long, and terminated by a nearly straight border placed between two distant side teeth.

Thurax generally lengthened, convex (at times wile) hardly retracted before; prothorax rery sharply truncate; metathorax rounded, offering two conrex faces, separated by a channel or by a carity, which are not bordered by sharp, but rounded, efiaced edges.

Abdomen generally fusiform; the first segment enlarges

1 Although the 3 d article has a parabolic form, one sees rery distinetly that it is the 4 th which is wanting, for the 3 d preserves at its extremity the long stiff hairs which arm the 3 d among the types mhich have the labial palpi composed of four articles (Nortonia). Furthermore, one often discovers that the extremity of the 3 article is formed by a rudiment of the 4th article soldered upon it. This disposition becomes more distinct among the Munolia. 
graduals, is funnel like, pedieulate or sessile, at times campanulate, but when the pedicle exists it only occupies the anteriol part of the segment and does not compose the entire segment; it carries above, near the extremity, a longitudinal groove or a rounded excaration.

Most of these insects have an appearance very easy to grasp, thanks to their fusiform abdomen of which the first segment is funnel-shaped. Their principal distinctions are found in this form of the abdomen, combined with the length of the mandibles and the reduced number of the articles of the palpi. The mandibles are long and form a beak as with the Eumenes, although less sharp; in the females these organs have four teeth or lobules; in the males the inner edge is more entire or with three notches. 'The clypeus, in general more long than wide in the females, recalls the Eumenes also, but its narrow extremity has a triangular notch, separating two triangular teeth; in the males it offers the polygonal form, a quite different type, which by the separation of its terninal teeth has a sort of analogy to the Zelhus. The head and body are almost equally and always strongly punctured; the abdomen is also wholly punctured, lout less strougly. All the body moreover is covered with a relrety pile which often conceals the sculpture. The anterior border of the prothorax is subconcave, but the angles, although at times distinct, are never spinose as with certain Zethus.

The form of the abdomen recalls, in the normal types, the torm of Polistes; it is also fusiform, the 1st segment being fumel shaped, much narrower than the second; but the first seguent being larger, and always convex (not completely funnel shapel) suffices always to distinguish this genus, even though the bead, with its long mandibles and clypeus, should be wanting. Also the strong puncturing of the thorax and the always sloort, chubby and wide metathorax assist in marking its differences.

The genus Montezumia also includes sereral types and numerous forms which are slight marks of distinction.

'The first segment of the abdomen is often narrow, eampanulate and strongly bossed, in such case presenting the form which appears in certain Odynerus, having the pedienlate abdomen; or, even the thorax becomes wide and flattened; the metathorax 
carinate, and hence we have established separate divisions to receive these types.

Let us add that these insects have wholly the appearance of the Nortonia, and that one cannot distinguish them but by the dissection of the mouth. If then we separate these two genera, it is that they seem to us to form a deviation from the genus Odynerus in two different ways; the Nortonia conducting to the Eumenes, and the Montezumia forming rather a detached ramification which seems more to direct toward the Polistes or Zethus.

In fine the Montezumia have nearly the same buccate organization as the Monobia, and are distinguished from these insects by their slender forms; by their abdomen pediculate or fusiform, not distinctly sessile; and by the form of the metathorax, which is convex, divided by a groove, but not excavated as with the Odynerus, or which always at least offers two salient enlargements rather than a posterior excarated surface. ${ }^{1}$

The genus Montezumia is almost exclusively American, but it does not extend into the cold latitudes of this continent. It appears only in Mexico, and extends southward as far as the borders of Patagonia. It has not yet been met with in the United States. It also appears to be limited to the eastern face of the Andes, at least it has not jet been found upon the western side of A America.

The habits of these insects remain to this day entirely unknown, although the structure of their mouth does not leare any doubt that they lead a solitary life. Now, however, we may throw some light upon this question, thanks to the kinduess of Mr. G. Claraz, who has been willing to send us the nests of Montezumia ferruginea described below.

These structures very much resemble the nests of Pelopœus. They are of agglutinated masses of earth, in which one finds the cells disposed in a parallel order, in which the insect imprisons

1 It is true that certain Montezumia having the pediculate abdomen offer a sort of concarity of this kind on the metathorax (M. Lepriurii, Iuastecr) but the types with the non-pediculate abdomen, which alone could be confounded with the Monolia, have always the metathorax convex, clubbed, and unarmed. Constantly here, as elsewhere, one finds transitory types, but we liare allowed that the genus Monobia is not entirely decharacterized in the genus Montezumia (see the Monobia egregia and especially the Monobia rariabilis). 
its prey with the egros which she has deposited in it. Each one of these lunus contains abont ten of the cells. Unfortunately we could not discover what composes the prey of the insect which constructs these, the little cells being found occupied by the nymphes already quite prepared to hatch or even by insects already hatched.

This observation becomes exceedingly interesting by revealing among the solitary wasps a different mode of nidification which is allied to that which one knows among other genera and which recalls the architecture of the Syhegides. So we know that the Eumenes establish for their offspring separate and distinct cells likewise formed of earth; the Zethus build their nests composed of aggregated cellules, established commonly in regetable matters and fixed upon little branches of trees. The Odynerus nidify in holes in walls, in the stems of plants, etc. The Montezumia, finally, construct their houses of many roons, a little like those of Zethus, but very much more massively built of earth and stuck against walls or rocks as are those of the Sphegides and some of the mason bees.

\section{Division ANTEZUMIA.}

Head flattened before (Eumenoide). Abdomen pediculate; the petiole composed of the first segment, of which the first moiety (or the base only) is linear; the second moiety being campanular, not receiving the $2 \mathrm{~d}$ segment. (A ppearance nearly like some Pachymenes).

a. Hlead very flat; clypeus entire; abdomen but little pediculate.

\section{M. Chalybea Sauss.}

Montezumia chalybea Sauss. Vespides, III, 161, 49; pl. ix, fig. 2, ९.

Hab. Brazil.

b. Ilead less flat; clypens trunca:e or notched; abdomen morc lengthened pediculate.

2. M. petiolata Sauss.

Montezmia petiolata Sauss. Vespides, III, 161, 50; $\mu 1$. ix, figy. 1, ?.

Hab. Brazil. 
c. Head less flat; clypeus truncate or notched; petiole rather flattened triangular.

3. M. brunea Sacss.-Velutinu-sericea, punctata; clypeo punctato, margine apicali late truncato, biangulato; thorace valde velutino, haud compresso; metanoto brevi, striato, aureo-sericeo; 10 abd. segmeuto petiolari, companulato, apice sulco partito: capite et antennis nigris; his subtus ferrugineis; thorace et petiolo rufis; pronoti margine postico. tegulis, postscutelli maculis 2 petiolique linea marginali, flarescentibus ; pronoto, thorace subtus et petiolo ante marginem frequenter fuscis; abdomine fusco-olivaceo; pedibus rufis; alis infumatis, costa fusca.

Variat. Secundo segmento ferrugineo-limbato.

$\delta$. C'speo lato, sericeo.

Pachymenes brunnea Sacss. Vesp. I, 76, 4 ; pl. xii, fig. 6 (1852).

Total length, $16 \mathrm{~mm}$; wing, $12 \mathrm{~mm}$.

This species has rather the appearance of an Eumenes, because of its narrow lst abdominal segment, campanulate as in Pachymenes, but quite flattened, and not bordered at end.

The clypeus $\delta$ is polygonal, as wide as long, broadly truncate; its inferior margin having a tooth on each side; it is black, silky, with the inferior part yellow.

The body is velutinous; the thorax very much so, rufo-ferruginous with golden reflections; anteriorly blackish; the petiole, broadly club-shaped, parted by a groore, is ferruginous, with the extremity blackish, and the hind margin finely bordered with yellow. The rest of the abdomen brown-olive, with golden reflections. The feet of the color of the thorax.

Ress. a. diff.-It has much the livery of $\boldsymbol{M}$. infernalis, but is rery different by the petiolar form of the 1st segment of the abdomen, and by its shorter thorax.

Hab. Cayenne. Tenezuela.

Observation.-L. c. I have mentioned that the 2 d cubital cell of the wing is triangular in $q$, but this seems to be a mere accident; it is not so in $\delta$.

\section{Dirision METAZUMIA.}

Head more or less dilated; metathorax conrex at summit, a little prolonged and presenting a distinct fossette, but unarmed. Abdomen prriform, but the first segment retracted, subpediculate at the base, then suddenly campanulate; dilated nodulously 
above by the meeting of the anterior and superior faces of the segment. The second segment widening toward its base in an ovoid form.

The insects of this division have somewhat the appearance of Discolius, on account of the form of their abdomen, but the labial palpi are distinctly composed of three articles only and the maxillary of five.

1. M. Huasteca SAuss. (Fig. $9 \hat{\jmath}, 9 a$ $९$.)-Nigra, nitida, dense punctata ; pronoto cristato-marginato; metanoto et abdom. 10 segmento grosse cribratis; mesonoto et abdom. 20 segmento tenuiter punctatis ; clypeo longiore quam latiore, bidentato striato-punctato; metanoto rotundato, in medio excavato, foveola striata, haud acute marginata instructo; abd. primo segmento angusto, campanulato, supra nodoso inflato; scutelli et postscutelli fascia interrupta, abdominisque segmenti $1^{i}-2^{i}$ (quandoque $3^{i}$ ) margine, fulvis; alis hyalinis costa nigra; antennaruın flagello subtus ferrugineo.

$\delta$. Clypeo flavo, antennis uncinatis.

Montezumia liuasteca Sauss. Rev. et Mag. de Zool. 1857, 271.

Total length, $16 \mathrm{~mm}$.; wing, $13 \mathrm{~mm}$.

Appearance of a Discolius; clypeus more long than wide, bidentate; the teeth distant, separated by a straight or concave margin; ocelli large, approaching; a deep groove on the rertex. Prothorax strongly rimmed, angulate; scutels flattened, divided by a feeble line, separated by a strong sulcus. Metathorax forming two convex cheeks behind the post-scutel, but its posterior face occupied by an almost round fossette, regularly excavated, shining and striate, slightly punctured, garnished with a gray pile, but without decided border or limiting marks. Lateral ridges effaced. First segment laving its anterior fourth pediculate in form and the remainder campanulate, quadrate, nodulously swelled above; (seen in profile this segment has the appearance of carrying a great tubercle, which results from the mecting of the superior with the anterior face at a right angle): this segment less than half the width of the second and offering above a depressed point; second segment rounded, depressed, flat beneath, convex above, enlarging gradually. Head, thorax, and petiole densely punctured; the prominences of the metathorax and the first abdominal segment cribrose with large punctures; the mesothorax not strongly punctured; the head punctured, 
even striate before; the second and the following abdominal segments densely and finely punctured.

Insect of a shining black; antennæ black, the flagellum ferrugrinous beneath, both scutels ormanented with a band or with two ubscure yellow points. The two, often the three, first segments of the abdomen, equally bordered with a submarginal edgir:g of the same color; that of the first segment continuing itself upon the sides. Legs black. Wings transparent, with the antcrior edge blackish.

9. Clypeus black or more or less tawny or yelluw.

Var. End of the abdomen slightly ferruginous; often two tawny dots at the summit of the pro- and of the metathorax.

$\checkmark$. Clypeus yellow, a little margined with black, strongly bidentate; the teeth sharp, separated by a notcli on the are of a circle. Hook of the antennæe pointed, black or ferruginous. No groove on the vertex.

Ress. a. diff.-This species has some resemblance to the $\boldsymbol{M}$. sepulchralis Sauss. Its form is quite like that of $M$. Leprieuri; one might be inclined to take it for a black variety of this species, but the disk of the mesothorax is less strongly and the metathorax less densely punctured in Huasteca than in Leprieuri.

$H a b$. The Gulf side of Mexico. I caught sereral $q \delta$ near Tampico; some others have been taken near Orizaba.

In this species the third joint of the labial palpi is almost as long as the second and the form distinctly parabolic-pointerl; this article is very abruptly terminated and lias no appendix. The maxillary palpi have their first article dilated; the two following slender and long, the others smaller and smaller.

5. M. Leprieurii SplN.-Nigra; capite, thorace abrominisque primo segmento, valde cribratis; abdomine de reliquo tenuiter punctato; clypeo elongato, bidentato, scutellis, metanoto, abdominis primi segmenti limbo, aurantiacis; alis subinfuscatis, costa nigra.

$\delta$. Clypen, anrantio; supra et lateraliter nigro-marginato; pronoti margine postico et inacula in basi mesonoti disci, aurantiis.

Variat autenuis subtus ferrugineis; secundo ablominis segmento, farolimbato; reliquis margine picer). Longit, 0.015 .

Odynerus Leprieurii Sprivola, Ann. Soc. Ent. Fr. X (1841), 127, 78. Montezumia pelagica Sauss. Vespides, I, 93, 11, pl. xii, fig. 10, $\$$ (1852). Montezumia Leprieurii Sauss. Vespides, III, 160.

Hab. Brazil. Cayenne. 
Observation.-The specimen described by Spinola has the wings facied, ferruginous.

\section{Division MONTEZUUIA (propr. dict.).}

IIead dilated. Ciypeus truncate or bidentate. Metathorax offering two convex cheeks, unarmed, separated by a furrow. $\Lambda$ bdomen fusiform; the first segment funnel-shaped, but enlarged above, capable of retracting more or less of the following one.

In this division the forms are rounder; the first segment is less enlarged above, it does not present a superior and anterior face; it becomes more funnel-shaped and wider, which gires to these insects the appearance of Polistes with which they have often been confounded.

1. Abdomen pediculate. The first moiety of the first segment lineal.

Division ALPHA.

(Sauss. Vespides, I, 88; III, 160.)

6. M. coerullea SAuss..+- Valida, nigro-rœrulea; abdomine cœruleo clypeo piriformi, punctato, apice suberarginato, subbidentato; capite et thorace densissime granulato-punctatis, fulvo-lirtis; metanoti sulco striato; pronoto angulato, cristato-marginato; abdomine fusiformi ; tenuiter dense-punctato, primo segmento basi petiolato, in prino dimidio lineari, dein infundibuliformi, in medio subbidentato, supra sulco profundo punctiformi canaliculato; pedibus ferruginen-sericeis; antennis subtus ferrugineis; alis nigro-cyaneis. Longit, 0.023 .

Variat. clypei margine, tarsorum articulo ultimo, seutelli fascia, rufis. $\widehat{\delta}$. Clypeo truncato; antemnis ferrugineis uncinatis.

Montezumia corulea Sauss. Vespides, I, 90, 5 ; pl. xii, fig. 8, $f$ (1£52); III, 160.

M. rubritarsis Sauss. ibid. I, 90, 4.

11. rufipes Sauss. ilid. I, 89, 3; pl. xr, fig. 1, ९ (1852); III, 160.

Odynerus azurescens Sprox, Mém. Acad. Turin, xiii, 1853, 82, 62, 5 .

Ilab. Brazil. I’ara. Rio Janeiro. Guyana. Cayenne.

\%. M. azameipenais SAoss.-M. caruler simillima, at abdomine nigro; primo seguento suleo parmu profumdo et utringue linea angulata flava instructo; alis nigro-ceruleis.

$\delta$. Clypeo rubro, truncito, subbidentato, antemnis uncinctis. 
Variat ore, tarsis apice, scutellorum fasciis, rnfis.

Montesumia azureipennis Sadss. Vespides, I, 89, 2 (1852); III, 160.

Montezumia rufidentata Sadss. Vespides, I, \&8, 1 (1852).

This insect is most likely a mere variety of $M$. cerulea.

Hab. Brazil. Mexico.

In this section one might nearly place also $M$. Ghitianii, and $M$. azteca. (See below, No. 16 and 18.)

2. First segment of the abdomen subsessile.

Division BETA.

(Sarss. Vespides, I, 90; III, 162.)

A. Thorax moderately lengthened, first abdoniinal segment funnel-shaped, convex, divided by a feeble groove, vertex somewhat swollen.

a. Wings transparent or ferruginous.

8. M. migriceps Spr.-Niger; abdominis 10 segmento infundibuliformi, brevissime petiolato, latitudine $\frac{3}{4}$ secundi ; mandibulis ferrugineis ; thorace et pedibus rufis; illo paulo nigro-rario; post-scutello flavobinotato; abdominis primo segmento basi rufo, anguste flaro-limbato; alis hyalinis, venis testaceis.

$\delta$. Clypeo polygonale, albido, margine antico truncato, integrro; antennis apice uncino obtuso testaceo instructis. . Long. 5-6 lin.

Eumenes? nigriceps Spixola, Ins. rec. a Cayenne par Leprieur, Ann. Ent.

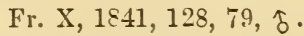

Muntezumia nigriceps Sauss. Vespides, III, 162, 51.

Hab. Cayenne.

9. M. infundibuliform is FABR.-Gracilis, clypeo piriformi, trnncato, punctato-striato ; corpore punctato ; pronoto marginato, angulato; mesonoto nitido, sparse punctato; metanoto dense punctato, velutino, hirto, in medio tantum canaliculato; capite, thorace et pedibus nigris, tomento aureo rariore sericeis; abdomine ferrugineo, vel badio : primo segmento infundibuliformi, fasciis 2 nigris et utrinque dente laterali instructo; segmentis $3-5$ punctatis; tarsis apice rnfis; mandibulis ferrugineo-variis; antennis subtus obscure ferrugineis; alis hyalinis, renis nigris.

Var. Segmentis $1^{\circ}, 2^{\circ}$ limbo flavescente; tarsis et tibiis fuscescentibus. Longit, $18 \mathrm{~mm}$. 
\$. Clypeo apice truncato vel subemarginato, infere ferrugineo vel albido marginato.

$\widehat{\delta}$. Clypeo truncato, frequenter albido-marginato.

Eunienes infundibuliformis FABr. Syst. Piez, 288, 14 (1804).

Montezumia dimidiata Sauss. Vespides, I, 91, 13 (1852); (Syn. Olivieri exclus), ibid. III, 160.

Hab. Brazil. (Author's collection.)

This species has a remarkable resemblance to Polybia because of its hyaline wings. It must not be confounded with Polybia dimidiata Ol., or Polistes bicolor Sss.

10. Pr. Cortesiana SAuss.-Carbonaria, velutina, nigro-fulvo hirta, purpureo-sericea; clypeo punctato, apice truncato, subexciso; capite densissime punctato; pronoto, post-scutello et metanoto densissime grosse punctatis; mesonoti disco et scutello sparse, abdomine tenuiter, punctatis; pronoto angulato, cristato-marginato ; abdominis primo segmento elongato-campanulari, supra sulco foreolato; tarsis anticis apice, clypei marginibus lateralibus et mandibularum margine interno, rufis; antennis ferrugineis, basi nigris ; alis pallide flavo-gliseis, venis anticis fusco-ferrugineis. $\subsetneq$. Longit, $0.020 \mathrm{~m}$.

Montezumia Cortesia Sauss. Vespides, I, 92, 10, $q$; pl. xv, fig. 2, $q$ (1852).

Hab. Mexico. (Typus in auctoris museo.)

1. NI. Sepuldaralis SAuss. $\delta$--Præcedentis statura et facie, illi simillima; clypeo et mandibulis nigris, vel clypeo utrinque puncto rufo; primo segmento obscure ferrugineo-limbato; alis ferrugineis. (Anne præcedentis varietas?.)

Montezumia sepulchralis Sadss. Vespides, III, 163, 54 (1854).

Montezumia mortuorum Sauss. Vespides, III, 164, 55 (1854).

IIab. South America.

\section{M. amallis SAUss.}

Montezunia analis Savss. Vespides, III, 1033, 53.

Hab. South America.

b. Wings obscure, smoky, fuscous or black.

* Body more or less ferruginous.

13. M. Spinola Savss._Sat gracilis, omnino relutina; eapite et thorace dense punctatis; metathorace crassissime rugato, late plane foreolato; sentellis convexis, sulco longitudinali divisis; antennis, 
capite, mesonoto, abdominis segmentis 20-70, nigris; pedibu; promoto, scutellis tegulis et pleuris, metaunto et abdominis 10 segrnento, rufis, aureo-velutinis; frequenter pronoti margine postico, tegulis partim, metanoti maculis 2 et canthis, primique segmeuti margine, flaris; alis fusco-riolascentibus, costa nigra, apice pallidiore.

ઈ. Clypeo punctulato po?ygonali, fere latiore quam longiore, late exciso; macula genarum flara; antennarum uncino et scapo subtus, ferrugineis.

Turiut. a. Clypeo flavo-maculato.

l. Abdomine omnino nigrescente, apice fere ferrugineo.

c. Mesonoti disco ferrugineo-bilineato; 10 abd. segmento fasiia flava iuterrupta.

Montezumia Spinolce Sacss. Et. Vesp. I, 93, 12; pl. xii, fig. 9, $q$ var. $(1852)$.

Odynerus infernalis SPIxola, Mém. Acad. Turin, XIII, 1\{53, 81, 61, $\delta$. Muntezumia infernalis Sarss. Et. Vespides, III, 162, 52.

Total length, 16-18 $\mathrm{mm}$; wing, 11-15 $\mathrm{mm}$.

Strongly and densely punctured. Front a. little channelled transversely above the antennæ, vertex a little swelled behind in a transserse pad. Prothorax angulate, truncate before, following a slightly concare trenchant line. Clypeus and post-scutel dirided by a groore. Metathorax short, vertically wide, rugose, punctured and relrety; its concarity almost in the form of an angle, plane, a little bordered at summit. First abdominal segment campanular subsessile, finely punctured, with a groove above toward the extremity. The $2 d$ segment notably more enlarged, with scarce punctures clothed with a relrety pile, as if striolate. The other segments densely and finely punctured.

Black; labrum very lung, ferruginous; a little yellow line bordering the eyes beluw and another upon the scape of the antenuæ, $\checkmark$. Thorax of a relvety ferruginous; disk of the mesothorax black; prothorax and flanks brownish, with the borders of the first and some spots on the second reddish; wing scales spotted with yellow; post-scutel adorned with a yellow line; metathorax having some silky golden-yellow reflections and two yellow spots upon the summit. First segment red, with a yellow border. Legs ferruginous, with golden reflections. Wings of a black riolaceous, with the extremity more pale. (Surinam.)

The color of the thorax raries rery much, from ferruginous to obscure brownish. The border of prothorax and the sides of the f'toras under the wing, ormamented with yellow. 
$\hat{\delta}$. Clypeus rather convex at the top, flattened belor, terminated by two distant teeth, separated liy a straiglit border; its color obscure like that of the head, or having in its inferior part a yellow mark or triangle.

Var. a Clypeus and antennæ entirely black, without yellow.

b. 'Thorax entirely ferruginous except the disk of the mesonotum, which is blackish.

c. 'The first segment of abdomen blackish (Spinolæe, Sss.).

d. The first segment ferruginous, margined with yellowish; the yellow fascia preceded by a fuscous stain.

Ress. a. diff.-I have joined $I I$ infernalis to Spinolæe, for it is very likely to be the same species. These velvety, partly ferruginous insects are so variable that only the examination of numerous specimens can settle the entomologist as to the value of the species. Compare this species with $M$. Ghilianii, Mexicana, and ferruginea.

Hab. Brazil, Para; Surinam. (Type of Spinola in Turin museum; the author's type in his own collection.)

Observation.-The name $M$. infernalis was given by my excellent friend Marquis Max. Spinola before I gave the specics the name of Spinolx, but the manuscript of Spinola having taken a long time to print, the name Spinola was published first, so that I was obliged to preserve it.

14. M. Ghilianii n. sp.-Velutina, nigrescens vel fusca; metanoto, scutellis, pedibus et abdominis primo segmento, rufis; hoc flavo-margiwato; thorace lato; abdominis primo segmento depresso, sulpetiolato.

Total length, $18 \mathrm{~mm}$.; wing, $15 \mathrm{~mm}$.

Size and livery as in $I I$. Spinole, but the thorax much wider, dilated, and the prothorax not quite so angular. The sentel and post-seutel not parted by a longitudinal groove, but rather by a sort of indication of a carina. The metathorax shorter than in the said species, less chubby, more angular. The first abdominal segment a little more petiolate; its dilatation shorter, depressed, not so convex, bell-shaped.

Body quite relrety, covered with golden hair. Ifead lilack: antenne fermginons beneath. Thorix black; hind mareins of prothorax bordered by a rufons line; tegule, sentels, metathorax, legs, and varions spots under the wings rufo-fermginous. Abdo- 
men l)lackish; the first segment rufous, margined with rellow and blackish before the yellow band. Wings brownish, dark along the custa.

$\delta$. Clrpeus black, terminated br tro distant teeth as in the other species.

Rezs. a. ditf.-This certainly rery rariable species is quite similar to M. Spinolæ in its size and lirery, but the thorax is not so slender, the head is more inflated, the 1 st segment more flattened. It has nearly the facies of a Pachymenes because of the exceptionally depressed form of this segment, which forms nearly a campanular petiole.

Hab. Brazil.

I have described the specimen in the Turin museum; it is also a species of the rich collection of Spinola.

15. M. Mexicana Sarss. (Fig. 11.)-Obscure ferruginea; alis dilute fuscis; capite et thorace ralde punetatis; clypeo bidentato; pronoto laud angulato scutellis sulco partitis: post-scutello carinato-crenulato, flaro; metanoto rugoso, per sulcum rel foreolam hand margiratam diriso; abdomine sericeo; primo segmeuto infundibuliformi, apicem rersns linea impressa notato; alis infuscatis, cranescentibus. $q$. Tariat. Omnino ferruginea, alis fuscescentibus.

Muritezumia Mexicana SAcss. Tespides, I, 94, 14 (1§52).

Total length, $20 \mathrm{~mm}$; $\pi i n g, 15 \mathrm{~mm}$.

†. Insect slender. Head and thorax densels cribrose, shagreened, rugose. Clrpeus prriform, conres, strongly punctured, terminated by two little subcontiguous teeth. Between the antennæ is a little carina in form of a T. Thorax lengthened; prothorax slightly retracted anteriorly, rers finely rimmed, not angulate. Scutellum and post-scutel dirided br a longitudinal groore; the post-scutel separated from the scutellum br a deep furrow and forming a ridge, transverse, crenulate, dirided br the medial groore. Metathorax offering two conrex cheeks much more rugose than the remainder of the thorax, dirided by a striate fossette, which has no distinct margin; the lateral ridges effaced he the rugosities. Abdomen smooth, shining, sericeous, or relrety; the first segment at the base subsessile, then funnel-shaped, conrex, haring a lengthened depression abore; the second segment moderately larger than the first, its border a little upturned. The abdomen finel? punctured beneath its relrets pile. 
Insect ferruginous. The thorax often varied with black in the sutures and upon the mesothorax. Antennx ferruginous, with the flagellum blackish above, beyond the third article; post-scutel orange; (probably often also the wing scale, the posterior border of the prothorax and that of the first two abdominal segments sometimes of the same color; the yellow border of the first segment, when it exists, is often interrupted.) Legs ferruginous; wings brown, slightly darkened, with violet and golden reflections.

Var. The thorax is sometimes less lengthened than in the type.

Ress. a. diff.-I think this species nearly related to $M I$. ferruginea Sauss., which does not appear to have violet wings. It is near to Mexicana, but the abdomen of this last is a little pediculate and the head more swollen. It is also closely related to M. Spinolæe, but it differs from it by its thorax without angles, with little margin, by its metathorax slightly attenuate, less truncate vertically, less excavated, more rounded, less quadrate. It is very similar also to $M I$. infernalis Sp., with which I cannot compare it, the sexes not being the same in the two types; the metathorax is more rugose in Mexicana $q$, and not so excavated. It resembles also the Nortonia tolteca, but is perfectly distinct from it by its lengthened thorax, as high as wide and not depressed and widened; by its violet wings, by its strongly divided scutels, by its crenulate post-scutel, etc.

Hab. The gulf side of Mexico. I have found a female near Tampico.

16. M. ferruginea SAUSs.-Gracillima, ferruginea dense punctata, subvelutina; capite pone oculos producto; paulo altiore quam latiore; thorace valde elongato, compresso, angusto, metanoto postice producto, sulco profundo diviso; abdomine gracili; primo segmento elongato, depresso; sulco valde impresso partito; antemnarum flagello superne vel omnino nigro; clypeo et capite flavis, vertice ferrugineo-notato; abdominis segmentorun marginibus lituris subinterruptis fla ris ornatis; alis infuscatis purpureo-nitentibus, costa, præcipue in apice, ferruginea. Longit, $19 \mathrm{~mm}$.

․ Clypeo piriformi, apice bispinoso; mandibulis crenulatis.

Variat. Omnino ferruginea, seu pedibus flavo-variis, vel thoracis suturis nigris.

Montezumia ferruginea Sauss. Vespides, I, 91, 7 (1852).

IIab. South America. Uruguay. La Plata. Patagonia 1 \&. (G. Clariz.) 
This is a distinct species, remarkable by its slender body. Its nidification has been indicated before in the description of the genus.

\section{** Body quise llack.}

1\%. M. Morosa Sadss.-Nigro-cinerea; capite et thorace dense punctatis; pronuto tenuiter marginato; scutelli parte postica et post-scutello sulco partitis; metanoto haud attenuato, valde excavato, argenteo hirto, utrinque convexo, rugato; aldomine dense punctulato, cinereo sericaute; pedilus anticis partim, wandibulis, clypeo antennarumque scapo subtus obscure ferrugineis ; alis fusco-violaceis custa obscuriore. Long., $1 \mathrm{~s}-22 \mathrm{~mm}$.

\$. Clypeo late pirifumi, apice dentulis 2 invicem propinquis iustructo.

$\hat{\delta}$. Clypeo breviore, longitudine latitudini subæuali, late emarginato dentibus 2 invicem distantibus instructo; antennarum uncino rufo.

Montezumia morosa Sadss. Vespides, I, 90, 6 (1852).

This species is characterized by its black body, with gray-silky changes, but without violet-green reflections. The wings are more or less obscure, with more or less of riolet changes. The metathorax is rather broad, not attenuated; the prothorax not much angulated. The abdomen is subsessile, the first segment bell-shaped with a little groove on its superior side.

A male specimen from Mexico, which I cannot separate from this species, has the thorax a little larger than the specimens from South America.

The inner edge of the mandibles of the male is not lobed nor indented, but only a little unequal.

Hab. The eastern part of South America. Brazil. Guyana. Mexico. (I caught a male on the castern coast of the guif, near San-Andrès-Tuxtla.)

15. M. Marthae n. sp.-Nigra; post-scutello, metathorace abdominisque 10 segmento basi sulfureis; alis fusco-violascentibus. $\$$.

Total length, $17 \mathrm{~mm}$; wing, $15 \mathrm{~mm}$.

9. Head and thorax much as in M. morosa. Clypeus corered with longitudinal punctures; its inferior end formed by two little teeth separated by a straight border. IIead and thorax very densely shagreened; metathorax short, much rounded. Abdomen very fincly punctured, not so regularly fusiform as in morosa; the first segment somewhat narrower compared with the sceond 
one, but having the same form as in morosa and marked with a subapical sulcosity.

Insect black, furnished with a short grayish pubescence. Postseutel, metathorax, and first abdominal segment sulphur-yellow; the latter margined with a black band. Tarsi furnished with a golden-silky pile having a brownish reflection; tibial spines rufous. Wings dark fuscous with dark violet irldeseence; the apex paler.

Hab. Santa-Martha. Antilles.

\section{M. Elatemsis.}

Moulczumia platinia Sauss. Vesp., I, 92, $9 ; \mathrm{pl} . \mathrm{xv}$, fig. 3, $q$.

\section{Hab. La Plata.}

20. DI. anceps SAuss.-II. morose affinis, at corpore panlo magis tenuiter punctato ; clypeo longiore, minus rugoso, apice truncato, biangulato; thorace paulo breviore; pronoto angulato; mesonoto breviore, metanoto minus obliquo; alis apice et postice pellucidis, basi et in costa nigris. 9 .

Vuriat. Primo segmento utrinque lineola submarginali fulva.

$$
\text { Total length, } 15 \mathrm{~mm} \text {; wing, } 12 \mathrm{~mm} \text {. }
$$

Montezumia ancops Sauss. Vespides, I, 92, 8 (1:52).

Much rescmbles $M$. morosa, but in this the clypeus is in form of a short and wide pear and terminates in a point, parted by a little notch; in $I I$. anceps it is more lengthened, truncate, and bicarinate, the carinx forming a tooth on each side of the little inferior border. The wings are hyaline with the costa up to the stigma dark-brown, this color very soon becoming faint; the second cubital cell is also less contracted in $M$. anceps, which is also a smaller species.

HIab. South America. Rio Janeiro.

21. MI. Azteca n. sp. (Fig. 10,10a.)-Viridi-cœrulea, cinereo-sericea; capite et thorace valde punctatis; abdomine punctulato, nigro; alis fusco-violaceis.

§. Clypeo infere fulro-binotato, margine truncato subbidentato; antennarum articulo ultimo deplanato, ferrugineo.

Total length, $20 \mathrm{~mm}$. ; wing, $14 \mathrm{~mm}$.

$\delta$. Ifead short, the width of thorax. Thorax long, neither retracted before nor behiud. Irothorax sharply truncate, rimmed, 
with the angles rather sharp. Metathorax quite rounded, offering two large dilated cheeks, strongly separated by a wide channel; the lateral ridges effaced, rounded. Abdomen having the same form as in $I I$. cœrulea, funnel-shaped, but its petiole much shorter, forming hardly the third or the fourth of the first segment; this retracts the second as in the Polistes, and carries a distinct groove above; the second segment having its borler insensibly subreflexed. Head and thorax very densely and coarsely punctured throughout, of an elegaut bluish-green violet, having metallic reflections and garnished with a whitish pile, especially distinct on the metathorax. Abdomen shining, black, with some iridescent reflections; densely punctured, but with a silky pile, of gray hairs. Legs black; the anterior tarsi at times ferruginous. Wings brownish, with violet reflections; the anterior edge darker.

今. Clypeus polygonal, widely truncated, covered with a silrery pile, offering toward the bottom two little arcuate carinæ, which end at the two distant teeth, limiting each side of the anterior margin. The color of clypeus is bluish, like that of the head, but it is marked on its anterior border with a double, pale, orange spot; the margin delicately black. Antenuæ black, rolled spirally at the extremity, with the last article flattened, obtuse, and ferruginous. Mandibles almost without teeth, offering only some feeble notches.

Ress. a. diff.-This species approaches the II. morosa, although it is easily distinguished from it by the blue, not black, color of the thorax and the head, its punctures are larger, not so dense; the metathorax is more channelled and not so excavated; the scutellum more flattened and parted in its length by a delicate groore. The first abdominal segment is less dilated above; its base is linear, pediculate for the length of a half line or less, while with the $\boldsymbol{M}$. morosa this segment is more sessile.

One might confound it also with $M$. corulescens, of which it has much the appearance, except that its petiole is much shorter.

$H a b$. The gulf side of Mexico. I have taken.but one specimen near Tampico.

Observation.-This species is quite intermediate between Sect. 1 st and Sect. 2 d, its abdomen being rather pediculate. 
B. Head strongly dilated on the vertex behind the eyes, having (so lo speak) an anomalous form. Thorax much lengthened: abdomen often large. The first segment depressed or flaitened above and divided by a very distinct groove.

22. M. IBrasiliensis Sauss. $\delta$ - - Præcedentium staturæ vel paulo major; occipite maxime producto, thorace eodemmodo elongato, sed antice magis rotundato et metanoto paulo latiore, truncatiore, foveolato; abdomine latiore, segmentis, 10,20 , depressis; primo lato, sulco profundo diviso. Insecti color omnino castaneus; metanoto, lateribus et antennarum flagello, nigris. Alis fusco-cyaneis, stigmate ferrugineo. Longit, $19 \mathrm{~mm}$.

Variat: Pedibus flavo-variis; abdominis primo segmento flavo-marginato; corpore plus minusve ferrugineo.

$\hat{\delta}$. Antennis apice uncino parvulo fulvo instructis; clypeo ferrugineo apice emarginato, valde bidentato.

Montezumia Brasiliensis Sauss. Vespides, III, 164, 56 (1854).

Mab. Brazil. Province of the mines. (Typus in museo Parisiensi.)

\section{M. macrocephala SAuss.}

Montezumia macrocephala Sauss. Vespides, III, 165,157; pl. iv, fig. 3 , $\delta$ (1854).

Abdomine maxime dilatato.

In this species the male has the abdomen squat or flattened, strongly dilated and depressed; its first segment is parted by a strong groove, sometimes continued on the 2 d segment. In the female the abdomen is not so flattened down but is slender and of the normal form. The clypeus $q$ is terminated by two small, rather distant teeth.

Var. Often the clypeus , the face, tarsi, and margins of the ahdominal segments become yellowish. On the contrary, the whole insect often becomes uniformly ferruginous.

Hab. Brazil. (The type in the Paris museum.)

Division PARAZUMIA.

(Sauss. Vespides, III, 166.)

Head much dilated behind the eyes; thorax wide and stronerly depressed; metathorax prolonged behiud obliquely; its lateral

2 Eirrala.-10th line of the deseription, instead of "dessous des antennes," read: "dessus des antenncs." 
ridges very sharp. Abdomen sessile, depressed; the first segment wide, sessile, funnel-shaped.

21. M. carinulata SpIx.-Niger, mandibulis, tarsis et abdomine ferrugineis; corpore polito, fulro-sericeo; capite nigro, veruice impressione post-oculari notato; clypeo biangulato, angulis rufis et utrinque supra angulos dentulo instructo; thorace depresso, latiore quam ahdomen, superne convexo, polito; scutello post-scutelloque deplanatis, hoc postice angulato, haud truncato, per metanotum iuvolutum; metathorace superne convexn, ntrinque cantho laterali acuto, in medio incisura Hongato-quadrata strigataque exarato; ejus marginibus acutis, tenuiter flaris; abdomine gracili, primo segmento elongato-piriformi, superne carinula longitudinali partito; alis hyalinis, succineo-subinquinatis, venis fuscis. $q$.

Odynerus carinulatus Sprxola! Acad. de Turin, XIII, 1853, 83, 63. Montezumia carinulata Sauss. Vespides, III, 166, 58, $q$ (nec $\hat{\delta}$ ).

Total length, $16 \mathrm{~mm}$; wing, $14 \mathrm{~mm}$.

In this species the clypeus is terminated by a little margin, truncate, with the angles rather salient, but there is somewhat higher, a sort of depression imitating a fase truncature, forming also on each side a little tooth-like eminence. The thorax is wide, depressed, rery large if compared to the slender abdomen. Its upper surface forms a sort of flattened rault, without gibbosities; the scutel and post-scutel are flattened, making the continuation of this rault with the upper face of metathorax, which is not to be distinguished from the posterior face. The latter is canaliculate with a sort of square notch, bordered with sharp ridges.

The body is not relrety, but much polished, although garnished with fulvous hair. ('iype of Spinolæ.)

Hab. Brazil. Para. (Typus iu museo Spinolæ, Taurinis.)

\section{Dirision PSEUDOZUMIA.}

Body depresserl. Thorax wide; lateral ridges of metathorax distinct. First segment of abdomen in the form of a lenglhened triangle, flattened and longitudinally striate.

Insects Asiatic.

M. indica Sauss. Vespides, III, 167; pl. ix, fig. 4.-India. 


\section{Gen. IMONOMRA'SA}

Lip moderate. Labial palpi composed of three or four articles, the fourth rudimentary and soldered when it exists. Maxillary palpi composed of five articles.

Mandibles lengtheried, channelled, lobulate toward the end on the inner border and terminating in a point as in the Odynerus.

Melathorax excavated. Abdomen sessile, conical or ovoid, not fusiform.

The Monobia are Odynerina among which the number of articles of the palpi is diminished and which for this reason approach the Montezumia and Synagris. Their bodies offer different forms, peculiarly varied like the Odynerina, such as: metathorax rounded, or marginate or bidentate, the abdomen more or less conic or even rather ovoid, etc.

The buccal organization of the Mlonobia is evidently the same as with the Montezumia; lowever, the labial palpi are more variable, and one sees in these organs the rudiments of the 4 th article nore clearly developed.

The Monobia differ from the Montezumia by their wide and excavated metathorax and by their abdomen, conical or at least sessile and not pediculate nor fusiform. Tet here also one meets intermediate types which form the transition from one genus to the other'; (see the Monubia egregia and variabilis.)

Nevertheless the greater number of species hare wholly the forms of the Odynerus and cannot be distinguished from this genus but by the dissection of the mouth.

\section{Division I.'}

Labial palpi composed of three article, the $3 d$ elongate.

\section{A. Metathorax bispinose.}

1. M. Caldifornica Sauss.-Gracilis, ferruginea, sparse punctata; metanoto foveolato, utrinque spinoso; antemis superne ultril medium nigrescentibus; macula frontali flava; rertice nigro, fascia arcuata et

1 Perhaps this division should not be separated from the secomb, but not having the insects before my eyes, it is impossible for me to decide. 
orbitis ferrugineis; mesonoti disco nigro, signaturis 2 rufis; abdominis segmentis basi nigris; pronoti et abdominis segmentorum 1-2 margine, tegulis, scutellis, tibiis et tarsis, flavis; alis fumosis.

Montezumia Californica Sauss. Revue de Zool., xv, 1863.

- Total length, $18 \mathrm{~mm}$; wing, $13 \mathrm{~mm}$.

\$. The slender and lengthened form of Montezumia, but the abdomen more truncate at its base. Head rather small. Thorax very little retracted before or behind; metathorax squarely cut, scarcely prolonged behind the post-scutel; its posterior face truncate, excarated in almost all its width, occupied by a vertical furrow, smooth and shining, slightly striate from the middle downward; armed on each side with a strong spiniform tooth; the inferior borders of the concarity quite trenchant, but the superior, situated above the spines, completely rouncled and effaced. Scutellum and post-scutel separated by a deep groove and divided by a longitudinal groore; the post-scutel rather carinated. Head and thorax smooth, corered with finely punctured spots, the metathorax more strongly punctured. Abdumen lengthened, but subsessile; the first segment wide, roundedtruncate at its base, but still less wide than the $2 \mathrm{~d}$, which is longer than wide. All the segments having their posterior border divided by a little longitudinal groove.

Insect of a bay-ferruginous, with satin-like, slightly glaucous reflections. Clypeus ( $\delta$ ) convex, polygonal, a little notched in the arc of a circle and armed with two angular teeth. Front and vertex black, but a spot above the insertion of the antennæ yellow. A space behind the eyes and the complete border of the orbits orange-ferruginous; the two lines which border the summit of the eyes unite on the posterior part of the vertex, forming a horseshoe. Mouth and antennæ ferruginous; these last a little obscure above in their second moiety and nearly to the end. Thorax varied with black beneath and along its sutural lines; disk of the mesothorax black, with a double ferruginous spot; a little black at the bottom of the concarity of the metathorax and at the base of the abdominal segments. Wing scales, post-scutel, and margin of the first two abdominal segments, yellow; the border of the second a little festooned and narrow in the middle; the border of prothorax and of the other segments also a little yellow. Legs ferruginous, with the tibiæ and tarsi yellowish. Wings smoky, with slight vioiet reflections. 
This doubtless varies much. Its yellow markings are probably often more developed and the body partly encroached upon by black.

Ress. a. diff.-This species is remarkable from its slender form and its metathorax puffed or chubby at the summit. By this character it establishes itself in the genus Monobia and marks the transition from the Montezumia.

In its colors it recalls certain Odyneri of the old world ( $O$. multicolor and allies), and also certain Odyneri of its own country, such as the O. annulatus, pratensis, and in fine some Mexican species, such as the 0 . Iturbide. But it differs from all-1st, by its abdomen lengthened, not conical; $2 d$, by its metathorax which is chubby at its summit on each side of the post-scutel, because that is a little prolonged behind; $3 \mathrm{~d}$, by its labial palpi distinctly composed of only three articles and the maxillary clearly of five.

It differs from the $M$. egregia by its metathorax, chubby at the summit and truncate, not in a line with the post-scutel, but more behind; having a smaller concavity and of another form, more inclosed, and of which the spiniform angles are placed above the middle.

It approaches more to the $M$. variabilis in its form, but is more slender, and the body is not strongly cribrose nor velvety, as with this species, but smooth, satin-like, with glaucous reflections.

Hab. Lower California. Taken at Cape St. Lucas by T. Xantus.

Observation. - With this species the buccal organs are but little lengthened; the tongue, the galea, and the maxillary palpi are quite short; the labial palpi are slender, the articles long.

\section{M. cyanipenn is Goer.}

Odynerus cyanipennis Guer. Voy. de la Coquille, Ins., 264; pl. ix, fig. 5, $\hat{\delta}(1530)$.

Monobia cyanipennis Sauss. Vespides, I, 96, 2.

Hab. Chili. ('Typus in mus. Dom. Guerin Ménerille.) 
B. Metathorax noc bispınose.

a. Metuthorax with rough angles.

3. N. Silvatica SAuss.-Nigra, punctata; clypeo apice truncato: metathoracis canthis rugosis haud acutis; abdomine sessili, hasi trun. cato, primo segmento secundo æquilato, secundi margine subcanaliculato et valde punctato; mandibulis, macula, frontali et post-oculari, clypeo, antennis basi, pronoto, tegulis maculisque 2 scutelli, ferrugineis; abd. 10 segmento repande flavo-limbato; pedibus flavis, basi nigris; alis fusco-violascentibus. $q$.

Tarial. Corpore plus minusve flavo-variegato.

Monobia sylvatica Sauss. Vespides I, 95, 1; pl. x7, fig. 7, ㅇ.

Hab. Brazil. (Typus in mus. Parisiense.)

This insect closely resembles Rhynchium (Odynerus) dorsale, but it is somewhat smaller. The species seems to be distinct from this, and I made some confusion with it in my Vespides III, p. 168.-Compare Odyn. dorsalis, page 260, Obs.

b. Metallorax rounded, unarmed.

4. M. ancmala Sauss.

Monobia anomala Sauss. Vespides, I, 96, 3 ; pl. xv, fig. 4 (1852).

Hab. Brazil. (Typus in mus. Dom. Guérin Méneville.)

\section{Division II.}

Labial palpi composed of three articles; the $3 \mathrm{~d}$ carrying at its extremity a 4 th rudimentary article, soldered to the 3 d, difficult to distinguish, embodied with it, and armed with stiff hairs like the extremity of the $3 \mathrm{~d}$.

A. Abdomen conical; the first segment wide and truncate. Hinder portion of the metathorax bordered by trenchant ridges and armed on each side with a dentiform angle.

This type establishes the transition to Odynerus from the subgenus Odynerus, properly called, to Rhynchium, by its quadrate thorax and its conical abdomen.

5. N. quadridens Lisw. - Valida, nigra, capite et thorace valde punctatis; clypeo piriformi, apice $\delta$ bidentato, $q$ biangulato; abdomine conico; pronoti maculis 2 , post-scutello et abd. primo segmento supra, albidis; $\delta$ 'minor, clypeo albido. 
Vespa 4-dens Liss. Syst. Nat. II, 95, 15 (1767).-А мб: Acar. VI, 413.Mulider, Ed. Lin. II, 881, 15.-(ihrist Hymen., 234.-Illiger, Comp. Ins. rarior., 30, 92 .

Vespa uncinata FABr. Syst. Ent., 367, 22 (177!5).-Syst. Piez., 259, 31.1 Oliv. Encycl., VI, 685.

Vespa cinctu-nigra Deg eER. Mem. Ins. III, 583, 8; tab. xxix, fig. 12.

Odynerus uncinutus LEP. St. Farg. IIym., II, 619, ?.

Odynerus quadridens SAY, Bost. Journ., I, 386, 3; Ed. Le Conte, II, 766, 3. Monolia quadridens Sauss. Vespides, I, 97, 4; III, 168.

Monobia uncinata Sauss. Ibid. I; pl. xvi, fig. 1 (bad figure).

Total length, $20 \mathrm{~mm}$.; wing, $17 \mathrm{~mm}$.

Large. Head densely punctured, often presenting on the vertex a little depression. Thorax densely punctured; prothorax with a slencler margin; mesothorax offering above the scutellum two distinct grooves; scutellum fecbly convex, but little divided, post-scutel subdivided, not crenulate; metathorax slightly retracted, offering on its posterior face a subconcave furrow, very finely striate, distinetly margined (at least at bottom) and armed on each side with a spine. (The upper ridges are often a little effacer by the punctures.) Abdomen smooth, ovalo-conical, covered with fine scattered punetures; the first segment perfectly sessile, truncated before, punetured on its anterior face, as wicle as the $2 d$ and divided by a groove on its upper face; the $2 d$ quite strongly punctured witl separated points, more and more dense towarl the posterior border.

Insect black, shining; two great spots on the prothorax, the post-scutel and the first segment of the abdomen above, whitish. Wings of a black violet.

․ Clypeus black, pyriform, punctured, terminated by two dentiform, diverging, carinated angles.

$\hat{\delta}$. Clypeus whitish, margined with black, terminated by two separated teetlı, divided by a wide slightly concave border. Antenna terminated by a hook.

1 The description of Jinnens is incomplete, that of Fabricins touchert with error, and the name has two typographical faults in the syst. liez. Yet there can be no doubt regaribing the species. Linne has countert as teeth the two angles at lontom of metuthorax which receive the articulation of the abdomen. Fabricins does not notice the metathoracic teoth, donbtless beranse the abdomen, raised and pressed against it, concealerd them from his sight. 
Tar. Scutel and metathorax with two whitish spots.

Ress. a. diff.-The Monobia 4-dens is very difficuit to distinguish from the Odynerus bidens; however, one can always recognize it-1st, by its clypens armed with two teeth $\delta$, with two salient angles $\$$; $2 \mathrm{~d}$, by its abdomen, punctured more strongly and throughout, especially on the anterior face of the first segment and upon the second which does not offer an arcuate band of strong punctures along its border; $3 \mathrm{~d}$, by its maxillary palpi which have but five articles and the labial having the 4 th article rudimentary and soldered upon the third. Compare also Odynerus quadrisectus.

Hab. The United States. A species common in all the eastern part of the country.

I possess a great number of specimens taken in all the Eastern States, in New England (Norton), in Illinois (Walch, Kennicott), in Tennessee (Freudenreich-Falconnet, Fuchs), in South Carolina, Louisiana (author), Florida (Norton).

B. Abdomen ovalo-conical; the first segment more rounded, less truncate, less sessile. Metathorax rounded; its concavity not bordered above by trenchant ridges.

a. On each side of metathorax a dentiform angle.

6. M. angulosa Sauss. - Valida, nigra, punctata; clypeo $\nmid$ piriformi, punctato, infere striato, subbicarinato, apice biangulato, $\delta$ apice truncato ; metanoto velutino, bidentato, excavatione punctata instructo, nullomodo acute marginata; abdomine ovato-conico, sericeo, metanoti angulis utrinque fascia laterali aurantiaca; genibus, tibiis et tarsis præcipue anticis, testaceo-variis; alis fusco-cyaneis.

$\hat{\delta}$. Antennis subtus ferrugineis, scapi fascia flava; tarsis subtus sulfureis.

Monobia angulosa Sadss. Vespides, I, 98, 6; pl. $\times \mathrm{v}$, fig. 5 (1S52); III, 169.

Total length, $23 \mathrm{~mm}$; wing, $18 \mathrm{~mm}$.

Large. Clypeus strongly punctured, almost in striæ; pyriform, at the extremity truncate, almost biangulate. Between the antennæ is a kind of tubercle, grooved above. Metathorax forming on each side a compressed tooth; the concavity a little striate and punctured, but the superior edges effaced; roughly punctured. Head and thorax densely punctured; the metathorax rery rugose abore. Abdomen conical as among the true Rhynchium, shining, punctures scattered; the border of the $2 d$ segment and the following on the contrary very densely punctured, dull. 
Body black with gray-silky reflections. Two spots on metathorax prolonged as lines on the inferior ridges, pale orange-yellow, or yellow. Wings black, with violaceous reflections. (Mexico.)

Var. a. Tarsi and anterior tibiæ rather ferruginous. The first abdominal segment adorned on each side with a yellowish margin. (Brazil.)

b. Mandibles and extremity of clypeus brown ferruginous.

c. Metathorax black; only its inferior ridges yellow. (Surinam.)

d. The metathoracic cavity more or less punctured.

$\delta$. Smaller. Clypeus black, punctured, rather short; its inferior border broadly truncate, or a little concave with its angles rather projecting. Antennæ slender, armed with a terminal hook; beneath ferruginous; the scape with a yellow line. Often a yellow spot between the antennæ. Anterior margin of prothorax rather concave. The angles of the metathorax blunt. Wing scales brownish. Tarsi sulphur-yellow, with a brown line on their superior face. (Brazil.)

Ress. a. diff.-This is sufficiently distinguished from M. biangulata by its more rugose clypeus and the punctuation of its abdomen, for in this the border of segments $2 d$ and $3 d$ is shining, testaceous; and the segments $3 d-5$ th are not more punctate than the 1 st and $2 \mathrm{~d}$.

Hab. Mexico (Orizaba) and South America.

\%. M. biangulata n. sp. (Fig. $12,12 a$.) -Valida, nigra, punctata; $M$. angulose affinissima; metanoto valde excavato, foveola nitida tenuiter punctata instructo et utrinque angulato; macula frontali et subalari, puncto post-oculari, maculis 2 metanoti fasciaque interrupta in pronoto et abdominis segmentorum margine 1,2 , fulvis ; alis fusco-cyaneis.

Total length, $19 \mathrm{~mm}$.; wing, $16 \mathrm{~mm}$.

9. Large. Head and thorax cribrose with punctures; metathorax velvety, offering a circular concavity, deep, smooth, and fincly punctured, but which is not hordered at the summit cxecpt by some depressed ridges; on each side a sharp dentiform angle is placed without the concarity. Abdomen smooth, seriecous, oralo-conical; the first segment a little narrower than the second, rounded ; the of and sd segments both offering along their borter a line which forms a separation like a seeond hordere.

Insect black, clothed with a fine gray pile. Seape of the antemae more or less ferruginons bencath. A spot on the face, 
a point behind the summit of each eye, two spots or an incomplete border on prothorax, a spot under the wing and two on metathorax, pale yellow; first abdominal segment oruamented with a border of the same color, interrupted in the middle and extending along the sides; the $2 \mathrm{~d}$ and $3 \mathrm{~d}$ having their border brownish, the 2d beyond being ornamented with a pale yellow border, interrupted and submarginal. Coxæ $2 d$ and $3 d$ spotted with yellow; anterior tibice and tarsi raried with ferruginous; the hair of the legs a little golden. Wings brown, with violet reflections.

Ress. a. diff.-This Monobia differs from M. angulosa by its clypeus, which presents a flat surface, bordered by two litile arcuate, convergent ridges, which end in meeting the two dentiform terminal angles of the clypeus, which approach nearer than with the $I I$. angulosa, where the ridges are straight; $2 \mathrm{~d}$, by the deeper concarity of the metathorax; $3 \mathrm{~d}$, by the structure of the border of segments 2, 3, of which one sees no trace in the II. angulosa.

Hab. The torrid parts of Mexico.

8. M. nigripenuis n. sp.-Valida, nigra, valde cribrata; clspeo 9 apice bidentato, fulvo-marginato; metanoto rugoso, bidentato, foveola punctata, sed haud acute marginata instructo, alis nigris.

Total length, $20 \mathrm{~mm}$. ; wing, $15 \mathrm{~mm}$.

\$. Large. Appearance of a Rhynchium. Clypeus pyriform, convex, cribrose with coarse pits, terminated by two dentiform angles. Head and thorax densely and coarsely cribrose; back convex; anterior margin of prothorax crested; post-scutel punctured abore; its posterior face coinciding with the truncation of the metathorax. This last rugose; its concarity distinct, punctured, but not inclosed; its upper edges effaced by the rugosities; on each side is a spiniform tooth. Abdomen conical, very densely punctured, relrety; the first segment nearly as wide as the second, anteriorly truncate, but not presenting any distinct edge; the $2 \mathrm{~d}$ moderately long; those following not being more strongly punctured.

Insect entirely black, relrety; its hairs black; the feet only a little grayish; a spot on upper part of mandibles and a line along the latero-inferior horders of clypens, tawny. Wings black, their terminal border only, a little whitish.

Ress. a. diff.-This insect much resembles the Monobia api. 
calipennis and is distinguished from it by the two spines of the metathorax, by the post-scutel without any crest, by its wings of which the extremity has but very little white, ete.

Hab. The hot regions of Mexico. I have taken a specimen near Tampico.

๖. Metathorax without distinct spiniform angles.

9. M. apicalipenn is SAuss.-Nigra, eapite et thorace densissime punctatis; abdomine ovato, velutino, tenuiter punctato, segmentorum margine paulo distinctius et densius punctato; capite satis minuto; clypeo truncato, subbidentato; thorace antice paulo coarctato, biangulato; post-scutello paulum transversirn cristato, postice truncato; metanoto lævi, truncato, lato, rugoso, in medio foveola lævi instructo, sed ubique rotundato, canthis nullis, et nullomodo bidentato; clypeo, mandibulis, spatio post-oculari, antennarum scapo subtus, tibiis anticis antice, tarsis anticis apice ungnibusque, rufis; alis nigris, apice albidis. ․ Longit, $16 \mathrm{~mm}$.

Monolia apicalipennis SaJss. Vespid., I, 98, 5 ; pl. xv, fig. 6 (III, 168, var.?)

IIab. South America. (Typus in actoris musco.)

This species differs from the $M$. nigripennis, by its strongly angulate prothorax and by its rounded metathorax.

(I found in Mexico one of the Apidre which could rery easily be confounded with this Monobia.)

C. Abdomen slightly fusiform, enlarging as far as the extremity of the $2 d$ segment; the 1 st segment a little funnel-shaped, divided by a feeble longitudinal groove. Thorax lengthened.

These insects have the appearance of Mlontezumia and one would readily confound that with those of this geuns, were it not for the rudiment of the 4 th article of the labial palpi. They form the transition from Montezumia, and one can almost class these with that genus from the formation of their body; however, the structure of their palpi, their sessile abdomen having the first segment in form of a bell rather than funnel-shaped and above all their metathorax excavated and bidentate, assigus them their place among the Nonobia.

10. M. Variabillis n. sp.-Ferruginea, dense punctata ; (lypeo sublidentato; metanoto ferrnginoso, foreolì striatâ et utrinque dente instructo: abdomine basi angustiore, segmento primo flaro-limbato; atpite et mesonoto nigro-variis; alis obseuris, violascentibus.

Total length, $18 \mathrm{~mm}$, wing, $15 \mathrm{~mm}$. 
․ Forms of a Montezumia. Clypeus pyriform, strongly punctured, bicarinate laterally, terminated by two angles or teetb. Head and thorax rery densely punctured; vertex offering a depression on its hinder part. Thorax rather elongate, slightly relvety; metathorax extending a little beyond the scutellum, rery coarsely and densely punctured above, wrinkled, relrety; its concavity striate, limited by edges, not very apparent, because of the convex form of the two superior cheeks of the metathorax; and offering. on each side a dentiform angle. Abdomen silky, almost relvety, punctured; its width augmenting as far as the extremity of the $2 d$ segment; first segment narrower than the second, slightly funnel-shaped, and divided above by a groore; margin of the $2 \mathrm{~d}$ a little borciered and densely punctured, as also those following.

Insect ferruginous. Antennæ black above in their second moiety; face varied with black; forehead and vertex black, with a ferruginous arc. Thorax varied with black beneath; mesothothorax raried with black above on a red ground (or black varied with ferruginous); abdomen fulvo-relutinous, silky; base of $2 \mathrm{~d}$ segment obscure; border of the 1st jellow. Wings brown, with golden and violet reflections.

Ress. a. diff.-This species much resembles the MI. egregia, but the 1st segment of the abdomen is longer and the metathoracic concavity is smaller and less flattened. The metathorax is more conrex at summit and the thorax is more punctured. The colors ar'e, without doubt, variable. It has much the same form as $M$. californica, but the body is much more punctured; the abdomen densely so.

Hab. Mexico. Oriental part. I caught a $q$ in the valley of Cordova.

11. M. egregia Sadss.-Staturæ Mr. variabilis et illi conformis ; dense punctata; metanoto supra minus convexo, foveola latiore, valde striata, utrinque dente armata; abdominis primo segmento breviore, antice truncato; capite, thorace et abd. primo segmento, nigris; segmentis reliquis rufis; clypeo, mandibulis, antennis, orbitis et in vertice fascia arcuata, provoto, scutellis, tegulis, lineolis 2 mesonoti, macula subalari, lineolis 2 in metanoti canthis, tibiis, tarsis abdominisque segmentorum limbo, aurantiacis; alis ferrugineis. $q$.

Variat. Pronoto flavo-marginato.

Monnbia egregia Sauss. Vespides, III, 168, 60; pl. iv, fig. 5, $\subsetneq$ (1854). Hab. The Antilles? 


\section{Gen. NORTONIA (Mmi).}

Mandibles lengthened, dentate or lobate.

Lip and jaws lengthened; labial palpi composed of four articles; the first three armed with long hairs; maxillary palpi composed of six articles.

Clypeus pyriform, truncate or emarginate.

Abdomen having its first segment retracted, funnel-shaped or subcampanulate, subbidentate in the middle.

Metathorax short, convex, its groove shallow, flattened behind, its lateral edges distinct.

The remainder as in the Mrontezumia.

This type establishes the transition of Odynerus to Eumenes.

The organs of the mouth are almost the same as in Eumenes and Odynerus, but the body has the form to which it inclines in Montezumia, the first segment being funnel-shaped, not sessile, as in Odynerus, but not contracted into a petiole as in Eumenes.

\section{N. intermedia SAuss.}

Odynerus intermedius Sauss. Vespides, I, 155, 39 ; pl. xvii, fig. I, III, 224 (1852).

Hab. Southern Europe.

2. N. sy mumorpha SAuss.-Nigra, nitida, dense punctata; clypeo o subemarginato, $\delta$ integro flavo; antennis subtus ferrugineis, scapo $\delta$ fascia flava;'mesonoto bisuleato, metanoto medio foveolato, pronoto

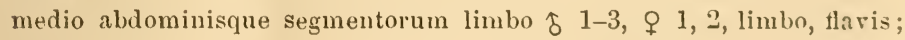
segmentis 2, 3 margine subreflexo; tibiis et tarsis flaris; alis fuscoviolaceis.

Odynerus symmorphus Sauss. Vespides, III, 246, 119 (1S54).

Total length, $17 \mathrm{~mm}$.; wing, $14 \mathrm{~mm}$.

․ Clypens black; oval, convex, punctured; its inferior boveler chamolled, terminated by a slender and shining, subemarginate, subbilobate lamina; between the antemne a little transverse tuberele or carina. On the vertex is a transrerse depression. Thorax moderate, ovate. Head and thorax punetured and elothed with a ferruginous pile; mesothorax marked on the posterior part of its disk with two or four longitudinal groores; 
metathorax small, very strongly and densely punctured, offering in the middle a little excavation, distinctly striate. Abdomen smooth, shining; the first segment funnel-shaped, subcampanulate, subpediculate, bidentate, strongly punctured and divided above by a distinct groore; border of the second and following segments densely punctured; the margin of the second and third slightly upturned.

Insect black, shining. Antennæ ferruginous beneath. Wing scales ferruginous, at times marked witl yellow. A point behind each eye, a mark on middle of prothorax and border of segments 1, 2, yellow; the border of the first enlarged in the middle; border of third segment piceous; tibiæ and tarsi yellow. Wings of a transparent brown, with beautiful violet reflections.

$\delta$. Clypeus wide, truncate, yellow. A mark on the front and a line on the scape of antennæ, yellow; their hook ferruginous; the third abdominal segment often bordered with yellow.

Var. No spot on the front, nor yellow border on the second abdominal segment (Florida).

Hab. The eastern United States, Florida, New York, Connecticut ( 3 \&, 3 $\delta$, E. Norton).

3. N.Tolteca n. sp. (Fig. 13, 13a.)-Ferruginea, fulro-hirsuta, sparse punctato-cribrata; clypeo bidentato; thorace $q$ dilatato, latissimo, maximo, depresso; $\hat{\delta}$ normali; abdomine velutino, punctato, primo segmento infundibuliformi, supra linea impressa partito; secundo duplo latiore, margine reflexo; antennis ultra $4^{\mathrm{m}}$ articulum supra nigris; alis ferrugineis, frequenter cyanescentibus.

Variat. Vertice, mesonoto, thorace subtus, abd. segmentis basi, nigris; segmentis flavo-limbatis; corpore flavo maculato.

§. Minor; clypeo polygonali, flavo; antennarum uncino ferrugineo.

․ Total length, $22 \mathrm{~mm}$.; wing, $17 \mathrm{~mm}$.

个. Total length, $18 \mathrm{~min}$.; wing, $13 \mathrm{~mm}$.

. Insect very stout, wide and depressed. Labial palpi composed of four articles; the fourth quite small; the maxillary, of six articles, the $2 \mathrm{~d}$ and $3 \mathrm{~d}$ long and slender; the last three small. Clypeus pyriform, wide, punctured, offering two little obtuse mammillæ; its inferior margin thinned, armed with two little separated lamellate teeth. Between the antennæ is a transverse carina, almost forming a little tubercle. Thorax strongly depressed, rery wide, much wider than high, wider than the abdomen. Scutellum and post-scutel flat and depressed; metathorax 
rounded; its cheeks, not dilated, separated by a cavity without distinct margin; on each side of metathorax, the lateral edge is quite distinct. Head narrower than thorax. Abromen strongly retracted at the base of the second segment; the first subpediculate at the base, and suddenly enlarged, parted by a feebly excavated line near its border; second segment and often the third. having their border feebly upturned. Head and thorax shining, wholly cribrose and throughout bristling with a thick tomentose, orange, or ferruginous pile. 'The punctures are a little separated and the metathorax hardly rugose, but shining and punctured, like the rest of the thorax. Abdomen velvety, satin-like.

Insect ferruginous; some varying black colors in the sutures of the thorax and on the vertex. Antennæ black above, beyond the fourth article. Mesothorax often black with two ferruginous lines, either arcuate or terminating with a hook. Base of the abdominal segments often blackish and their border often yellow. Legs ferruginous with the tarsi yellowish. Wings ferruginous, washed with gray, with their terminal border margined with brown, and brilliant with beautiful golden reflections. Wings ferruginous or grayish, with purple reflections.

ऽ. Smaller; offering nothing very striking in form, the thorax not being inordinately wide as in the $\$$; puncturation a little stronger. Face offering a little vertical carina, which extends to a little frontal tubercle on the clypeus; metathorax more rugose, garnished with a pile of gray hair; borly a little less liirsute, thorax shorter; abdomen more slender; the first segment more lengthened, almost pyriform; more strongly punctured.

Clypeus yellow, polygonal; its inferior border with two little separated teeth. Hook of the antemne ferruginous; orbits often bordered with yellow, scape of the antenne often yellow beneath. Face, vertex, mesothorax, and middle of metathorax often black; border of the second and third segments strongly upturned; all the abdominal segments bordered with yellow. W'ings subhyaline or amber colored or smoky, with violet reflections.

Var. \& $\delta .-a$. The thorax molerneath black; abclomen either ferruginous or having the segments bordered with yellow.

b. Black; mandibles, lip, a spot beneath the antemne, and a line bohind the eye, yellow; prothorax ferruginous, with a yellow mark in the middle; two dets on the scutel and post-sentel yellow; metathorax ferruginous on both side, with its inferior edges 
yellow; border of segments 1-3 yellow, the following ferruginous; the sides of the second segment chestnut-brown or ferruginous. (Cordova.) The colors are very variable.

c. (Highly-colored livery.) Forehead and vertex black, with a sellow spot between the antennæ. Thorax blackish or black, with the prothorax, two lines on the mesothorax, two spots or a band on the scutel, and the sides of metathorax, rufous; postscutel yellow. The first abdominal segment blackish, with two rufous spots, or a band, and the hind margin yellow; the rest of the abdomen brown-rufous, with yellow margins. Feet black at base. Tings smoky, of a blackish-yellow with a golden reflection. - $\delta$. Clypeus yellow, with a rufous shading.

Ress. a. diff.-The females are remarkable for the flatness of the scutels and of metathorax; for the separated punctures and the body hirsute with tawny hair almost as among the hairy insects. As regards color this exactly resembles the Odynerus tuberculiceps, and approaches rery much the Montezumia Brasiliensis and macrocephala in form and in the ferruginous color.

$\mathrm{Hab}$. The hot and the temperate regions of Mexico. I hare taken diverse specimens of this interesting insect in the ralley of Meztitlan (eastern Cordillera), at Morelia, and at Pazcuaro (Michoacan).

\section{Gen. RHYMCHICM Latr.}

Rygchium Spixola, Latr., Sat, Lep., St. Faeg.

Rhynchium S.toss.

This genus is so unnatural, that if one did not feel the necessity of separating as many species as possible from the large genus Odynerus, I should have abandoned it.

Indeed the Rhynchium only differ from the Odynerus by their large size, in the conical form of the abdomen, and in the lengthening of the maxillary palpi, of which the second and third joints are long and slender, while the last three taken together are not longer than the third. But this latter character seems to accord rather with the large size of the insect than with its peculiar form Several Odyneri have a tendency to this, as for instance the O. luctuosus, which, however, differs in having the first segment shrunken and the abdomen not conic. Te cannot say, therefore, where the genus is to be limited.

As to the conic form of the abdomen, it is met with in a great 
number of species of true Odynerus, of which, however, the palpular articulations diminish quite regularly in size from the first to the fifth (O. truncatus, O. nasidens, etc.), so that this formation is not sufficient to characterize the genus.

The true Rhynchium belong especially to Africa. I know in America but one species which can figure in this group; it is the Rh. dorsale Fab., but even this species has not entirely the same palpi with the Rhynchium, for the last three articles are too large and the third is relatively too short. The Odynerus luctuosus might from its palpi figure as well in the genus Phynchium, as the Rh. dorsale.

Beside this, if the smallness of the last three and the lengthening of the second and third palpular joint should separate generically the insect so distinguished, it would be necessary to form quite a corresponding genus of the great African and Asiatic Eumenes (vide Saussure Vespidæ, I; pl. iv, fig. 2, b), and separate generically, $f . i$., the $E$. conicus from the $E$. coangustatus, which would be an impossibility. I see, therefore, no need of adopting the genus Rhynchium in the description of the American fauna, the utility of doing which appears the less as it would only free the genus Odynerus from one species. I have conse= quently left this species in the latter genus. ${ }^{1}$

1. Rh. dorsale FABR.-(Vide Odynerus dorsalis, p. 257).

\section{Gen. ODYNERE LATr.}

Abdomen sessile or subsessile. Labial palpi 4-articulate. Maxillary palpi 6-articulate. Mandibles elongate, as in Eu. menes, more or less toothed. The second cubital cell not petiolate.

This genus may be distinguished by its elongated mandibles and sessile abdomen. In numerous species, howerer, the abdomen is subpedunculate, that is, the first segment is rather funnel-shaped,

I In my Studies on the Families of the Fespide I also described as an American Rhynchium the Rh. limbatum, p. 117, 27; pl. xr, fig. 10 (not 9). But this type, now in my possession, in consequence of the acquisition of the collection of the late M. de Romand, appears to me incontestably Asiatic. Like many others in this collection, it bore a wrong label. 
but never as much petiolated as in Eumenes, the base only of the first segment being slender, if at all, while its extremity always enrelops the base of the $2 \mathrm{~d}$ segment. The form of the different parts of the body is quite variable. The thorax is short or elongate, angulate or rounded, the abdomen may be thick or slender, quite conical and sessile or sessile and not conical, but ovate and cylindrical; it becomes also subpetiolate, the first segment being more cup-shaped or campanulate. The abdomen is also often attenuated anteriorly and posteriorly, which makes it spindleshaped, etc. Several of these forms make transitions to other genera. In Odynerus, as in all the genera with more or less sessile abdomen, the styliform appeudages at the eud of the posterior tibix are not as much developed as in the petiolate genera. The exterior spine of the hinder femora is always small. The Odynerus are distinguished: from Alastor by their wings, which have the $2 d$ cubital cell not petiolate upon the radial cell; from Pterochilus by their labial palpi, comparatively small and not pectinate or feathery; from MIontezumia by a different facies and by the composition of their palpi; from Nonobia only by the formation of the palpi.

It is to Nortonia that these insects hare the most similarity. They differ by their less petiolate abdomen (really not petiolate) and by the emarginate or variable metathorax, which in Nortonia remains as in Eumenes, convex and stubbed.

Nerertheless it would be difficult to set a distinct limit between Odynerus and the most closely allied genera. = Ex.:-

Transitions to Alastor.-In most species of Odynerus the $2 \mathrm{~d}$ cubital cell has a little radial edge which makes it very distinct from Alastor, but in some intermediate types the 2d cubital cell becomes quite triangular, only touching the radial cell with its anterior angles. This is really quite a transition to Alastor, but we keep the intermediate types in the genus Odynerus, reserving for the genus Alastor only the species in which the $2 \mathrm{~d}$ cubital cell is distinctly petiolate upon the radial cell.

Transitions to Pterochilus.-In the subgenus Epipona, the thorax becomes short and rounded, the abdomen oval and depressed. The whole insect assumes quite the appearance of a Pterochilus and can only be distinguished by its normal labial palpi.

Transitions to Monobia.-As said above, the two genera can 
only be distinguished by the composition of the palpi, which are not 4-and 6-jointed in Monobia, as in Odynerus.

Transitions to Montezumia. $-\Lambda$ few Odyneri take the appearance of Montezumia, the first abdominal segment becoming quite funnel-shaped (O. tapiensis, etc.). In this case they can only be distinguished by the examination of the palpi. Lut in general the facies is very different in Odynerus.

Transitions to Nortonia. $-\Lambda$ number of Odynerus have the abdomen subpetiolate, the first abdominal segment becoming elongate. This is especially the case in the species of the subgenus Odynerus, Division Hypodynerus. 'These form a regular transition to Nortonia, and are only distinguished by their appearance and more angulate metatborax; the first segment has also a more triangular, depressed, and gibbous form, not being funnel-shaped in the same way. In Nortonia it is properly funnel-shaped. In Hypodynerus a sort of petiole only is formed by the anterior face of the first abdominal segment. Nortonia is quite intermediate between Odynerus and Eumenes, while IIypodynerus quite connects itself with Odynerus. by decided transitions, and has the thorax very different from Eumenes. Indeed in Nortonia the petiole cannot be doubted when the abdonen is elevated; while in Hypodynerus, when the abdomen is raised, the anterior face of the first segment is applied against the metathorax and fits against it, and one can only see the upper face of the segment, which is quite transverse and which causes the abdomen to appear quite sessile.

Though it is not possible to define a trenchant limit between Nortonia and Odynerus, yet as the most changeable types are not American, it would be superfluous to insist upon this point.

Geographical distribution.-The genus Odynerus is much the greatest among the Vespidæ, and, in a philosophical point of ricw, one might take it for the stem of the family.

Judging by the numerous species which have been fond in the countries already explored; by the number known in North America and in Europe; by the numerous species which have resulted from my researches in Mexico (althongh I could only give to it very little time), and by what other travellers have brought from various parts of the work, it is beyond donbt that there exist more than a thousand species of Odyncrus, and 
perhaps nearly double this number, for there is no region of the globe which does not offer an abundance of these insects.

Therefore the prospect of the future leads us to sce riches which by their very abundance will bring the entomologist to desperation in keeping the genus Odynerus out of a general chaos.

Among the so various forms of this group,.some are claracteristic of general zoological groups, which form natural suludivisions of the genus. These forms present themselres on sereral continents and are not peculiar to all the species of one continent. Other forms are, on the contrary, so to speak, mere geographical impressions, which belong to particular regions of the glube, which stamp their character upon all the species of those localitics, through all the genera, but are not to be found in other countries.

Examples of modification in the first way.-(General zoological modification, special to one or several genera, but not peculiar to one country.)

a. The modification of the first segment of the abdomen, taking a transverse suture (subgenus Anristrocerus and Symmorphus) is to be found on the whole globe. It forms quite a zoological group, repeated in Odynerus and in Alastor.

$b$. The modification of the antennæ of the males simple, not taking a terminal hook. This is to be found amid the Odyneri with a sutural first segment, in Symmorphus. The Symmorphus are spread over the northern hemisphere, mixed up with Odyneri having hooked antennæ.

c. This same character of the $\hat{\delta}$ antennæ destitute of a hook appears also in the true Odyneri, where it forms the dirision Pachodynerus, but in those insects it is already a more geographical character, for the Pachodynerus is a special American type spread over the new continent, and is particularly abundant in the central parts. But, though quite American, it is not exclusively a geographical group, for in America it is mixed with Odyneri of other gromps.

This same character also presents itself and much in the same way in the genus Eumenes where it forms the Division Omicron, resuming the species with simple $\delta$ antennæ and has just the same geograplical type as Pachodynerus, being only American, but also mingled in America with the hooked Eumenes. This 
character is a regular zoological one, for it advances together with a thick and short thorax in looth genera.

Examples of the second modification.-(Local geographical modification, not peculiar to one or several geuera, but quite special to one country.)

a. $\Lambda$ s a very striking example in this way, one could not choose better than in the group of Chilian Vespidx. This forms quite a remarkable collection of species, all having the same very striking appearance. Indeed, all the Chilian Vespidx, to what. ever genus they belong, have the same peculiar livery; black, with long black hair and whitish ornaments; with rufous or black feet, rufous wings olscure at the apex. This livery (with its varieties) is so striking, that one may at the first look distinguish a Chilian species, and this facies is to be found in all the genera, Odynerus, Gayella, Ctenochilus, Alastor, etc. The forms of the body, although quite variable, are also very characteristic in their appearance. In the Chilian true Odynerus they even become so very peculiar that we have been forced to make for them the Division Hypodynerus. Nevertheless this is not properly a zoological group, as it is again found in all the genera, but is evidently ouly a stamp of the country which every species of any genus seems to receive when it has the citizenship of that country.

b. The species which popnlate the continuation of the same region in the north, that is, the occidental side of the Andes of Ecuador and New Granada, hare also a peculiar facies, still similar to that of Chili, but more approximate to the common type of Odynerus. They are still hirsute with loug black pile, black-velutinous, but the ornanents are golden-yellow; the wings are no longer ferruginous. The same character is also apparent in other genera (f. i. Pachymenes rentricosa).

c. In the Antilles the Odyneri are more marked, and have common forms. They take a rich livery, with numerous orangeyellow bands and spots. The same modifieation may be noticel in all the other generia of Vespidie in this region, even in the social wasps.

d. In the Mexican region there are to be found types, with dull rufous colors and with the margin of the ad abdominal segment chamnelled and reflexed; the stenodymerus berome quite abundant, with a velutinous body ( $O$. hustecus, olomitus, ene), 
or very elongate, naked, with white ornaments (totonacus, chi. chimecus, etc.). But numerous species hare also the normal forms.

e. In the United States, oriental side, the Odyneri and all the Vespida take the same characters as in Europe, as to forms and coloration; except that the wings are more olscure.

$f$. In the prairies of the southwest, the colors grow pale; the black passes into ferruginous.

g. On the occidental coast the rellow ornaments become bright sulphur-rellow and extend orer a great part of the body.

These considerations of the geography of the species, and conrersely on the modifications which follow their distribution, have been too much neglected up to this day. They have a high importance in the study of the origin of species, and they require the attention of entomologists, who alone can fix them, for only those who hare much to do with numerous insects can make the frequent and minute obserrations which enable one to generalize rules of ans ralue. And if entomology does not do its share in helping to elucidate the questions of natural philosophr, it will be a mere amusement of amateurs and will fall to the lowest rank of the science.

Classification.-Notwithstanding the rastness of the genus Odrnerus and the rarious furms which it offers, one cannot well arrange its species according to Sections, which are easy to discorer. This results, first from the multiplicity of the transitions which almost insensibly ally each form with sereral others, and often conduct from one form to another in rarious wars; it results also from the multitude of details of form which make their appearance in the same series, creating a great perplexitr in subordinating the characters to a srstem. Far from being able to establish large dirisions, to be subdirided according to a regular succession, one gets lost in numberless details and exceptions which quite disorganize the subdirisions, so that it can only be defined by loose indications in which the reader becomes lost. This I must say for excuse, if I hare not giren better characteristics.

The evil would be perfectly irremediable in a general system of the Odrneri, in which the complication would become quite a sort of chaos, as each continent possesses its series of special forms, with numerous ramifications, beside the general sepries 
common to most parts of the globe. The evil is much less if the fauna of one continent only is considered.

The only groups which can be well defined are the four subgenera which Wesmael has indicated and which we have adopted in our Etudes sur la Famille des Vespides. ${ }^{1}$ These subgenera we are obliged to subdivide again to justify the arrangement of the species, but it is prudent to say that these subdivisions are very artificial, and that one must not trust too much to the definitions of them, because of the difficulty of involving in them all the exceptional forms, as well as of giving a true description of the details of the forms.

\section{Definition of the subgenera.}

A. First abdominal segment parted by a transverse suture.

a. First abdominal segment rather fumnel-shaped, parted by a deep longitudinal groove; antennæ of the males simple, that is, without a terminal liook. Symmorplus.

b. First abdominal segment truncate at base, not parted by a deep longitudinal groove; antennx of the males terminated by a hook.

Ancistrocerus.

B. First abdominal segment with no transverse suture.

c. Thorax more or less square anteriorly; abdomen conical, oval-couical or spindle-shaped.

Odynerus.

d. Thorax more globular or oval, rounded posteriorly, not very square anteriorly. Abdomen oval, subsessile, more or less depressed, having the same form as in Pterochilus (sublenticular).

Epiponus.

The last two sections rather overlap each other; those preced. ing are more defined and easier to distinguish. All of the four subgenera are represented in North America. The 4 th is the only one which has not yet been discovered in South America. Although these groups are not sharply delined, their respective representatives can be easily distinguished by the eye, if one is thoroughly familiar with their facies. The only rery cmbarrassing types are those which unite Odynerus with Epiponus,but they are not $\Lambda$ merican.

\section{Determination of the species.}

We must here say, that, the most important specific characters of the Odyneri being in the metatholax, the inseets must be prepared with the abdomen bent dowmard, so as to leare the hinder

Comp. this work, rol. I, p. 118-121. 
face of metathorax quite free, and with the wings remored sidewise. If not prepared in this way, it is impossible to determine them with certainty. Before all things, one must thoroughly acquaint himself with the characters of the metathorax, which I will briefly repeat for this purpose. ${ }^{1}$

In the most cliaracteristic type, the metathorax is truncate, together with the post-scutel; its hinder face is excavated, and the excaration or hinder plate is angulate, forming on each side a lateral dentiform angle. ${ }^{2}$ The concavity is also margined with sharp ridges. - The ridges running from the lateral angles up to the angles of the post-scutel are the superior edges; the ridges running from the lateral angles down to the articulation of the abdomen, are the inferior edges. - Beside these, there is a third sort of edge placed on the lateral faces of metathorax, rumning from the lateral angles to the base of the posterior wing; these are the lateral edges. There should be no confusion between the superior ridges, which, seen from behind, may also be taken for lateral vidges. The superior edges are often rather elerated, and at their superior extremities are separated from the postscutel by a little fissure or by a notch. These characters become more and more effaced in the series of species until the metathorax becomes quite conrex, rounded, destitute of ridges, except on the lateral edges, which nearly always continue, more or less. The superior ridges become less salient, no longer making a sort of tooth behind the post-scutel; they then become blunted ( $O$. dorsalis); or quite effaced (O. sulfureus, pratensis); finally, also, the lateral angles disappear. In another series the margins of the hinder plate of mesothorax are quite arcuated, and there are no lateral angles, although the margins are rery sharp (O. Megrra, turpis, etc.); but, nerertheless, the same names can be applied for the superior and inferior part of the marginal ridges. These circular margins also become more and more blunted (O. molestus), until the metathorax becomes quite conrex, rounded, as in the preceding case (O. leucomelas). In some cases the lateral ridges are continued with the inferior ridges, the superior ones being effaced, etc. (Numerous Stenodyneri.)

1 I hare noticed this in my Etudes sur la Famille des Vespides, rol. III, p. 184 ; pl. xii, fig. $1,2,3$.

2 Compare Odyn. Itidalgi, Boscii, dorsalis, nasidens, Cubensis, capra, etc. 
In conclusion, I must add, that in most cases it is impossible to determine a species in this large genus with certainty, if it is not represented by more or less numerous specimens, because the

forms of the mesothorax are more or less variable in the same species. One must also make the determination upon females, the males being less distinctly characterized. 'They must be separated by the eye to their respective females.

\section{Subgenus SYMMORPHUS' WESM.}

Body lengthened. Abdomen subsessile, the first segment funnelshaped, carrying a strong, transverse suture, and divided on its superior face by a deep, longitudinal groove. Antennæx thick; those of the males simple, with no terminal hook.

The insects which enter into this group inhabit Europe and America. They all present quite a similarity in form, which is the reason of their name. Their body is more or less slenter; the clypeus is rounded, a little hollowed; the thorax is lengthened, smooth, but traversed in all its length by two arcuate grooves; the post-scutel, the metathorax, and often the first segment of the abdomen are rugose; this last, while it is funnel-shaped, is also truncated anteriorly before the suture and is, in consequence, less petiolate than in the Nortonia. One notices among these insects a particular marking; the $3 d$ abdominal segment often loses its bordering, while the 4 th preserves it, and among the females the clypeus, while it does not become wholly black, takes at the summit a ycllow medial spot and not two lateral spots as mostly in Ancistrocerus.

The insects of this group are very easily distinguished by their first abdominal segment provided with a sulure and divided by a longitudinal groove. They share this character with the Nortonia only-the short thorax, the rounded metathorax, the more pediculate abdomen, and the absence of the suture of the first segment of which, suffice for a distinction.

In my Etudes sur la Famille des Vespides (T. III, p. ISti), I hare substituted the name of Protodynerus for that of Symmorphus, under the belief that the name Symmorpha had been employed during thes same year. But as the two terms are not absolutely identical, it serems best to me to preserve the so-well-chosen name which Mr. Wesmat proposes. 
One funds in America and in Europe some corresponding species, so to speak, which reproduce in each country the same forms and the same distribution of colors.

\section{a. Segments 1-4 of the abdomen bordered with yellow.}

1. S. Walshianus n. sp.-Niger, punctatus, gracilis, postscutello et metanoto rugosis; mesonoto sparse, scutello crassius, abdominis primo segmento grosse, punctatis; puncto frontali et post-oculari, maculis 2 pronoti, 2 scutelli et utrinque 1 suhalari, tegnlis abdominisque segmentorum 1-4 limbo, flaris; tiliis et tarsis flavis; alis fusco-nebulosis.

. Macula in summo clypeo flava.

Total length, $12 \mathrm{~mm}$; wing, $10 \mathrm{~mm}$.

9 . Of a larger size than the O. Philadelphix, but of a similar form. Clypeus bidentate, punctured, and rugose toward the base. Thorax less lengthened than in the species cited above. Prothorax finely rimmed but not bidentate. Head and thorax quite densely punctured; the punctures effaced on the summit of the mesothorax, which bears only some scarce punctures and which is traversed by two groores in its whole length. Clypeus cribrose with points which are coarser, but separated and few, indistinctly divided by a groove. Post-scutel and metathorax very rugose; the first presents, on its anterior border, a feeble, rugose, divided projection, which does not extend as far as the angles. I'late of the metathorax strongly rimmed but not bidentate. Abdomen shining. The first segment coarsely cribrose abore with large punctures and divided by a groore; its suture very strong; the first moiety of the $2 \mathrm{~d}$ segment, its extremity, the $3 \mathrm{~d}$, and the $4 \mathrm{th}$, punctured.

Insect black, clothed with a short grayish pile. A spot on the summit of the clypeus, a mark between the antennæ, a little point behind the summit of the eyes, an interrupted line on the scape of the antennæ, two spots on the prothorax, one beneath the wing, two on the scutellum, and the border of the segments 1-4 yellow; the bordering of the first two a little festooned, especially that of the first, which is a little enlarged in the middle. Wing scale yellow, with a testaceous point. Legs black; knees, tibiæ, and tarsi yellow; the last article of the tarsi brownish. Wings smoky, with light violet and golden reflections.

The markings are of a golden yellow.

今. Unknown. 
Ress. a. diff.-This species differs from the O. Philadelplize in its greater size, its more complete marking, the 31 segment of the abdomen being bordered with yellow; in its yellow wing scales, tibir, and tarsi, in its thorax, less lengthened, and not bidentate upon its anterior angles; in a slightly different puncturation.

One could say that the $O$. Walshianus is the $\Lambda$ merican representative of the $O$. gracilis Wesm., an entircly corresponiding species of Europe, although smaller, and more ornamented with yellow, having a more slender thorax and a bidentate prothorax.

The $\mathrm{O}$. Walshianus is quite intermediate between the $O$. crassicornis and the $O$. gracilis, both in the forms and size, but its yellow markings are less extended, as may be observed in general of the American species.

It differs from the O. pumilus in its greater size, in its less slender form, in its prothorax which is not bidentate, in its first abdominal segment which has the superior face twice as wide as long, etc.

Hab. The United States. Illinois.

I possess but one female, sent by Mr. Benj. D. Walsb, to whom I dedicate the species.

\section{b. Segments 1, 3, 4 of the abdomen bordered with yellow.}

2. S. FPhiladelphiae SAuss.-Niger, punctatus, gracilior, post-scutello et metanoto rugosis; abdominis primo segmento valde punctato; religuis nitidis; puncto frontali et post-oculari, maculis 2 pronoti, macula subalari, maculis 2 sentelli et abdominis segmentorum $1^{i}, 2^{i}, 4^{i}$ limbo, tharis ; tegulis nigris; tiliis flavo-variis.

․ Clypeo nigro frequenter macula flava; $\hat{\delta}$. Clypeo flavo, mandibulis, linea in scapo antennarum, et $5^{i}$ segmenti limbo, flavis.

Odyn. Philadelphice SAuss. Revue Zool., IX, 1857, 272.

Total length, $11 \mathrm{~mm}$; ; wing, $8.5 \mathrm{~mm}$.

9. In form rery slender and lengthened. Clypens romated, convex, punctate, hollowed, and distinctly bidentate. 'Thorax m": h lengthened; prothorax rimmed, its angles a little salient: mesothorax trarersed in its whole length hy two stroug groores: its anterior part punctured, like the prothorax; the remainder of the disk smootli, funely punctured; sentellum smooth, divided by a large groore; post-seutel and metathorax rery ruguse; the 
first forming a little rugose crest; the trench of this last bordered with treuchant and rugose ridges. Abdomen very slender; the first segment lengthened, funnel-shaped; its upper face as long as wide, rather coarsely i)unctured, divided by an maistinct groove; the suture strong, areuate. The other segments smooth.

Insect black. A spot at the summit of clypeus, another between the antenuæ, a dot behind each eye, two spots on the prothorax, one below the wing, two on the scutellum, and the border of serments 1, 2, 4, yellow. Tarsi ferruginous beneath; tibiæ marked with yellow at the summit; the anterior pair yellow. Wings transparent, a little washed with brown. Wing scales black.

Var. a. Spot on the clypeus very small.

b. Clypeus wholly black.

. A little smaller. Clypeus, rounded and bidentate, pale vellow; mandibles yellow before, bordered with black; a yellow line on the scape of the antennæ; extremity of the flagellum a little ferruginous beneath. The yellow dots of the head and thorax small; that under the wing sometimes wanting. A yellow border upon the 5th segment. Tihiæ yellow; tarsi yellow, gray at the extremity. Groove of the first segment deeper.

Ress. a. diff.-This species greatly resembles the $O$. sinuatus Fabr., although its markings are less rich. But its first abdomiminal segunent is much less coarsely punctured and the diriding groore much less pronounced. It differs from the O. pumilus in its much greater size, in its first segment being less rugose, and in its different ol'namentation.

Hab. North America. Pennsylrania. New Tork. Canada. Prairies. Fort Tejon. California. $6 \uparrow, 1 \delta$.

3. S. allonnarginatus SAcss.-Niger, punctatus; metanoto rugoso; abdominis primo segmento grosse punctato, sutura elevata; puncto inter antennas et frequenter altero in summo clypeo, maculis 2 pronoti, 2 scutelli, puncto subalari abdominisque segmentorm 1-4 marginibus, albidis; tiliis albido-variis; tarsis subtus ferrugineis. Alis hyalinis. Lomenit, 9 mum.

Vuriat. Abdominis tertio segmento haud marginato.

Odynerus allomarginatus Sauss. Et. Vespides, III, 1854, 195, 90, $q$.

Mab. America borealis, Indson`s Bay. (Typus in Mas. Londinensi.) Connecticut. (Ed. Norton.) 
c. Segments 1, 2 only, of the abdomen borlered with yellow.

4. S. debillis $n$. $s p$.-Niger, punctatus, maxime elongatus, gracillimus; postscutello et metanoto rugosis; hoc maxime pone post-scutellum producto; abdominis primo segmento elongato, grosse punctato, sulco valde diviso; puncto frontali et post-oculari, punctis 2 scutelli, macula subalari sulfureis; abdominis segmentorum $1^{\mathrm{i}}, 2^{\mathrm{i}}$ fascia marginali sulfurea, secunda interrupta; tibiis basi sulfureis; alis hyalinis, tegulis fusco-nigris. $q$.

Total length, $8.5 \mathrm{~mm}$; wing, $7 \mathrm{~mm}$.

․ Small and extremely slender. Form much lengthened. Head large, higher than wide; antennæ inserted notably below the middle of its height. Clypeus widely and not deeply hollowed, subbidentate, a little rugose toward the bottom. Ilead fimely punctured. Thorax very long; prothorax punctured, finely rimmed, forming on each side a very small tooth. Mesothorax and ofypeus little punctured; this last divided by a very large groove. Post-scutel and metathorax very rugose; the first flattened obliquely, bordered before; the second strongly prolonged behind; its concavity oblique, strongly hemmed, especially toward the top a little striate.

Abdomen very long and slender. The first segment of a lengthened funnel-shape, longer than wide, its suture very strong, a little angulate in the middle; its surface very coarsely punctured and divided by a wide and strong groove. The remainder smooth. Insect of a shining black; a spot between the antennre, a dot behind each eye, two spots on the prothorax, one bencath the wing, two dots on the scutellum and the marginal belt of the first segment of the abdomen, sulphur-yellow; the 2 d segment ornamented with a yellow border (sometimes interrupted), which is almost wanting bencath. Legs black. Tibia and anterior tarsi and the superior moiety of the tibia of the other pairs, rel-. low; tarsi ferruginous. Wings transparent, a little brown on the side about the stigma. Wing seales brown or black.

Var. On the 4 th segment a trace of a border and at times a dot at the summit of the clypeus, yellow.

o. Unknown.

Ress. a. diff.-This little species differs essentially from the O. Philadelphia in its more slender form, in the head being higher than wide, in its much prolonged metathorax, in its more rugense first segment, its very much more decided suture, and in the yel- 
low livery of its abdomen. It closely recalls the $O$. bifasciatus Fabr, although its head is narrower and its clypeus more enarginate. It also elosely approaches the O. debilitatus Sauss., which has nearly the same form of head, but which is less slender and has the thorax especially, much more strongly spinose.

Hab. United States. Connecticut. Wisconsin. Illinois.

I owe this interesting species to the kindness of Mr. Edward Norton and Mr. B. D. Walsh.

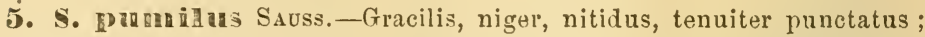
pronoto biangulato; post-scutello et metanoto ruyosis; illo postice excavato, antice paulum altiore et utrinque in lateribus carinula longitudinali marginats; hoe profunde exeavato, foveola elevato-marrinata instructo ; mesonoto valde sulcato; scutello sulco valde partito; abdominis primo segmento elongato, sutura valde prominula instructo, superne rugosissime punctato et sulco obsoleto diviso; seginentis reliquis nitidissimis; puncto frontali et prst-nculari, maculis 2 pronoti, 2 scutelli, puncto subalari, limboque segmentorum abdominis omnium, flavis; (segmentorum 3-5 fascia undulata submarginali); pedibus nigris, tibils tarsisque flavis; alis hyalinis, venis ferrugineis. $\delta$. Clypeo rotnudato, bidentato; mandibulis et scapo antice fascia flava. Longit, $9 \mathrm{~mm}$.

Odgn. pumilus Sauss. Vespides, III, 1854, 197, 93.

Hab. Peru. (The author's collection.)

6. S. cristaturs Sauss. - Sat parvus, niger, O. murario formis similis; metanoto rugoso; abdominis primo segmento sat grosie punctato, sutura elevata, secundo latiore, basi punctato; puncto frontali, maculis 2 pronoti, fascia interrupta scutelli, macula subalari, fiavis vel rufis; abdominis segmentis $1,2,4$ sulfureo limbatis; tibiis tarsisque ferrugineovariis; alis hyalinis, venis fuscis, radio ferrugineo. ㅇ. Long. $9 \mathrm{~mm}$.

Odynerus cristatus Sacss. Vespides, III, 196, 92, $q$.

Hab. North America.

This species appears to me to be very nearly, if not wholly identical with 0 . Philadelphiæ.

\%. S. Camadensis SAUss.-Parvulus, niger, gracilis, rugosus; puncto froutali, maculis 2 pronoti, 2 scutelli, macula subalari, abdominisque limbo segmentorum 1 i, $2^{\mathrm{i}}, 4 \mathrm{i}$, flavis; tegulis fuscis; capite inflato, antennis infere insertis; abdominis secundo segmento angusto, vix latiore quam primum; alis hyalinis, apice fuscescentibus. $q$. Longit, $8 \mathrm{~mm}$.

Odynerus canadensis Sauss. Vespides, III, 196, 91, $q$.

Hab. Canada. 
This species, like the preceding, has not been described with sufficient precision to be recognized with certainty, until the number of species has been auginented. It appears to be very near to the O. debilis in the form of its head and abdomen.

\section{Subgenus ANCISTROCERUS Wesr.}

The first abdominal segment divided by a transverse suture; its superior face (situated behind the suture) not divided by a deep groove. Antennx of the males terminated by a hook.

This subgenus includes insects of variable forms, in which, although they are very hard to define, we can distinguish four principal types. These are mere divisions of the subgenus.

A. The second cubilal cell of the wing haring a distinct radial side.

a. Form rather depressed, more chubby; the upper face of the 1st abdoninal segment transverse.

Ancistrocerus. ${ }^{1}$

$b$. Form rather cylindrical, more slender.

* The hinder face of the metathorax more or less excavated; the border of the excavation rough or rounded. Slenancistrocerus.

* The hinder face of the metathorax having a deep round cavity, surrounded by a very sharp circular ridge. Hypancistrocerus.

B. The second cubital cell of the wing triangular, quite contracterl on ils radial side, but not petiolate.

Ancistroceroides.

Division ANCISTROCERUS (properly speaking).

SAussure Et. Vespides, I, Section 1, a, p. $135 ;$, b. p. 139.-III, Section 1, p. 216.

Abdomen quite depressed, sessile; its first segment truncate anteriorly so as to show two faces, one anterior and one superior; its two faces distinctly separated by the suture; the superior one forming a wide square or a transwerse band. This segment short and wide. Thorax flattened above; disk of the mesonotum offering at its base two longitudinal grooves.

'The inseets of this series have their form rather depressed than cylindrical. They are generally rather wide, but are sometimes slender; the thorax is somewhat cubical, although generally

1 The division Ancistrocerus is also to be distinguished by the fact, that the yellow margin of the first segment is a band, either regular, or willened on the sides, while in the others it is generally either regular or narrowed on the sides. 
lengthened and rather flattened above. The clypeus is pyriform among the females, but is usually wide or wider than long; its extremity terminates in a little border, channelled by a small trench which often makes it appear bidentate; among the males it is polygonal and bidentate. The disk of the mesothorax offers two or four grooves on its hinder part. Above all the metathorax is very characteristic. It is a little oblique. Its posterior plate always presents an excaration, which is dirided by a rertical carina. The post-scutellum is truncate, at times subcrenulate, but its trench never coincides with that of the metathoracic fossette. The abdomen, always depressed and sessile, has an ovalo-conic, nerer flatly conic form. It is at times relrety, never coarsely punctured, except perhaps on borders of the segments. The first segment is wide, cut squarely and shortly abore.

In fine, eren when the form is much lengthened (O.tigris), the general appearance is preserved, the body being rather flattened than cylindrical. In this group the males are quite rariable. Among certain species they nearly assume the size of the females. Among others they are rery much smaller and rary endlessly in form, so that one can scarcely refer them to their females, but by a series of groupings.

Table to assist in the determination of the species of AxCISTRnCERes (principally based upon the females).

1. Wings fusco-violaceous.

2. Margin of secoud segment smooth; post-scutel black.

2, 2. Margin of second segment rough; post-scutel yellow.

$$
\text { 11. Spinola. }
$$

1, 1. Wings sublyaline or smoky.

24. unifasciatus.

2. Margin of the second segment reflexed
-3. Color rufous, vertex tuberculate.
26. tuberculiceps.

3,3 . Color black, argenteous.

29. Aristu.

2, 2. Margin of the second segment not reflexed.

3. Abdomen and antennæ mostly yellow.

27. Sutterianus.

3,3. Ahdomen and antemm mostly black.

4. Netathorax with two long spines; angle of prothnrax dentate. 19. Cluruzianus.

4, 4. Metathorax with short spines or not dentate.

5. Thorax black, body velvety.

6. The first abd. segment not margined with yellow.

23. Parredesi. 
6,6. The first abd. segment margined with yellow.

7. 'Two yellow fascix on the abdomen. 28. pilusus.

7, 7. Five yellow fasciæ on the abdomen. 18. Sylveiru.

5, 5. Thorax black, with yellow or luteous ornaments; body sericeous or shining, not velvety.

6. Abdomen. with 2 yellow or luteous fascix.

7. Body very coarsely punctate, posterior margin of prothorax luteons.

21. conspicuns.

7, 7. Body not very coarsely punctate; anterior margin of prothorax yellow.

8. Post-scutel black.

8, 8. Post-scutel yellow.

9. ambiguus.

22. cingulatus.

6,6 . Abdomen with 3 yellow fasciæ.

7. Post-scutel black. 16: Santa-Annce.

7, 7. Post-scutel yellow. 25. cumpestris. p.183

$6,6,6$. Abrlomen with 4 or 5 vellow fasciæ.

7. Thorax eubic, short.

8. Two yellow spots on the second segment.

8,8 . No yellow spots on the second segment.

20. birenimaculatus.

20., birenimaculatus.

17. \{ Bustamenti.

7, 7. Thorax more elongate.

8. Metathorax with sharply defined border.

9. Post-scutel black.

10. Ornaments yellow

10, 10. Ornaments white.

10. \{ capra.

14. $\{$ adiubatus.

12. albophaleratus.

9, 9. Post-scutel more or less yellow

10. Body normal.

11. Color gray, sericeous.

11, 11. Color black, shining.

18. Sylveirce.

15. I fustidiosusculus.

13. $\{$ Cutslillensis.

10,10. Body slender, elongate. 8 . tigris.

8, 8. Metathorax rounded behind. 25. campestris. 1013

I. Metathorax having its concavity angulate, bordered all around by trenchant edges (Sect. I, a, Sauss. Fespides, I, 135).

\section{(Group of O. parictum Liss.)}

A mong these insects the metathoracie carity has a polygonal form, determined by its angulate edges. The medial carina divides the fossette into two equal parts, which eam be compared in form to two coupled pentagons. Their angles often make on each side a sort of tooth (which is rariable among individuals of 
the same species, as it happens to be more or less dereloped); and at the summit two other teeth separated at the post-scutel by a sort of groore or wille fissure 'The concarity is in general punctured, but is often striate in the middle or toward the base.

The Anistrocerus of this dirision are rery common, both in Europe and North America; one can eren find corresponding types among the species analogous to the two countries. However, I have never met the same identical species upon the two continents.

Here, as in other solitary wasps, the American species are generally less ornamented with yellow than the European; the bands are narrower and the wings have a much greater tendency to pass into brown-riolet. In short, the American types have a more sober appearance.

\section{A. Form lengthened, slender.}

S. A. tigris SACss.-Sat minutus; niger, puuctatus, gracillimus; metanoti foveola subrugosa, acute marginata, utrinque in dentens excurrente, marginibus rectis ; puncto in basi mandibularum, $q$ maculis 4 in clypeo, puncto frontali et post-oculari, linea in scapo, fascia bilobata pronoti, macula subalari, 2 scutelli, post-scutello et abdominis segmentorum marginibus anguste, tibiis tarsisque, flavis; antennis subtus ferrugineis; alis hyaliuis, apice fusco nebulosis.

? Odyn. decdaleus Harris Cat., 1833, p. 589, undescribed.

Odyn. tigris Satss. Revue Zuol., IX, 1857, 273.

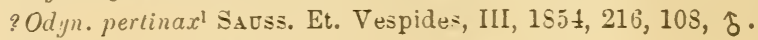

Odyn. cervus Sadss. Rev. Zool., X, 1859, 165.

\section{q. Total length, $11 \mathrm{~mm}$; wing, $8 \mathrm{~mm}$.}

$\hat{\delta}$. Total length, 8 min.; wing, 6 mm.

․ Small. Form rery slender, much lengthened, but depressed, not cylindrical. Clypeus pyriform; coarsely punctured, terminated by a little border, hardly concare, but appearing at times as if bidentate, because of a black and shining depression. Thorax much lengthened, prothorax scarcely retracted before, edge delicately upturned; its angles not spinoșe. Anterior portion of mesothorax often presenting a little smooth line and the posterior part two grooves. Scutel flat Postscutel arcuate on its posterior border. Metathorax having its hinder plate clearly marked, its surface dall subrugose, formed of two plane inclosures of a pentagonal shape, rery angulate,

I Small male, not easy to determiue. 
borlered hy very sharp and trenchant ridges, not arcuate, bit straight and forming on each side an acute spiniform angle. The latero-superior borders of the plate are straight, salient, terninated above by an elevation which is separated from the post-scutel by a kind of notch or feeble fissure. Upon the sides of the metathorax, the ridge is prolonged by a wide and indistinct furrow (in other words, the latero-superior faees of the metathorax are feebly and widely channelled along the edge which borders the posterior side); the superior medial ridges which form the re-entering angle are less strougly pronounced. Abdomen depressed. Head and thorax densely cribrose. Superior face of the metathorax very rugose.

Insect black. $\Lambda$ spot at the base of the mandibles, another upon the front, a point behind the eyes, the anterior borcter of the prothorax, a spot below the wings, the posterior border of the post-scutel and two spots on the posterior border of the scutellum, yellow. Clypeus either with four yellow spots, or yellow with a black square, or bordered with yellow. Antennæ black, forruginous beneath, with a yellow line upon the scape. Segments of the abdomen all ornamented with a regular yellow border; the borders of $3 \mathrm{~d}$ and 4 th often very narrow and the 5 th wanting. Feet blaek, tibiæ and tarsi yellow, these last often orange. Wings transparent, washed with brown-violet toward the end; wing seales yellow, with a brown dot.

$\hat{\delta}$. Smaller, having the form equally slender, although the thorax may be shorter. Coloration the same, but in general the border of the seutellum presents but two yellow dots, while the post-seutel is blaek, or also marked with two yellow points. Head large; eyes mueh swollen; clypeus lengthened, pentagonal, terminated by two teeth, entirely yellow, as well as the mandibles. Angles of the prothorax dentiform. Legs entirely yellow, the femora at times marked with black abore; eoxw spotted with yellow. Antenne very large and rary thick, orange bencatl, terminated by a ferruginous look, or they are wholly ferruginous upon the last two articles.

Observation.-There exist some quite singular differenees in the form of the males. In general, the thorix is less length. ened than in the ?. The teeth and metathoracie ridges are also subject to vary within certain limits, being often blunted. When the last segments of the abdomen are retracted, the insect 
loses its slender appearance. The first segment of the abdomen is often quite strongly punctured and even sometimes divided by a groove. We possess many males of very small size (lengt! 6-7 mm.) and quite slender, taken by Elward Norton in the environs of New York and in Massachusetts, which offer very slender yellow markings, and in which the metathoracic ridges are quite blunted. One, howerer, recognizes them by their enlarged antennæ, yellow beneath at the extremity. With this species the borlering of the prothorax is narrow, a little bilobed, terminating in a point on each side. Sometimes the metathorax is but little angulate, while the superior ridges are also more arcuate.

Ress. a. diff.-This species is recognized by its form, very slender and elongate, but yet different from that of $O$. fulvipes, in that the thorax is flattened above and the abdomen beneath, as with the $O$. capra and its congeners, not cylindrical as with the 0 . fulvipes and its neighbors. In its livery it resembles the O. campestris, but is distinguished from it by its very much more slender form, by the very sharp ridges bordering the metathorax, by the first segment having the border not enlarged upon the sides, etc. The very small males could be easily confounded with those of the 0 . Philadelphir, but can be easily distinguished from them by the wide and short form of the superior face of the first segment and by the absence of its great longitudinal groore.

Hab. The United States. Canada. (Lake Superior.) Connecticut. New York. Pennsylvania. Illinois. Louisiana. The Prairies. (Fort Tejon.) (14 \$, $10 \delta$.

9. A. ambiguus SpIN.-Niger, punetatus; metanoto rugoso, excavato, acute marginato, utrinque angulato ; antennis subtus rufis ; pronoti margine antico, macula subalari, et scutelli, abdominis segmentorum $1^{i}, 2^{i}$ margine postico, luteis; secundo subtus basi tuberculato; alis rufescentibus, apice griseis, tegulis flavo-marginatis; $\delta$ clypeo flavo, tibiis et tarsis rufis; scutello et pleuris nonnunquam immaculatis.

Odyn. ambiguus Spıx., Gay's Hist. fis. de Chile, Zool., VI, 264, 9 (1851) ९.-Sauss. Vespides, I, 14n, 23, $q$.

Odyn. Bustillosi Sauss., Gay's, Chili, ibid. 567, 10, $ో$-Sacss. Vespides, I, 141, 25, 今; III, 205.

९. Total length, $9.5 \mathrm{~mm}$; wing, $6.5 \mathrm{~mm}$.

$\delta$. Total length, $7 \mathrm{~mm}$; wing, $5.5 \mathrm{~mm}$. 
Small, black; head and thorax densely punctate. Hearl rounded; the antennx inserted a little lower than the middle of face. Clypeus rounded, convex, slightly bidentate at the apex; angles of prothorax sharp. Post-seutel transverse, a little elevated, rounded and rough. Metathorax roughened above; its posterior face excavated, with sharp edges, and bidentate on each side; the lateral tooth or angle placed rather lower than the midale of the metathorax; the excavation smooth. Abdomen very little punctured; the first segment anteriorly truncate and smooth; the suture angulate; the upper face with shallow punctures and parted by a slight groove; second segment slightly constricted at base, tuberculate at base beneath.

Antennæ ferruginows beneath. A little dot behind the eye, anterior edge of prothorax, a spot below the wing, the posterior margin of scutel, and of the first two abdominal segments, sulphur-yellow or whitish. Wings subhyaline; the costal part and base washed with ferruginous.

․ Clypeus more triangular, strongly cribrose, black. Wing scale yellow, with a brown spot. Feet black; tarsi and anterior tibiæ rather ferruginous beneath.

Var. Clypeus with an interrupted yellow band and two yellow spots or with yellow spots only.

¿. Clypeus yellow, tenuously margined with black. Inok of the antennæ very small. Knees, tibix, and tarsi ferruginous. Spot under the wing small. Wing scales black, margined with yellow. The yellow fasciæ of scutel narrow or interrupted.

Var. No spot under the wing; scutel entirely black, mandibles passing into a pale color.

Ress. a. diff.-The male rather differs from the female, so that I first thought them to be different species; however I have no doubt as to their identity, having been able to compare $s q, 9 \delta$.

Hab. Chili. In the woods.

\section{B. Form still lengthened, but less slender.}

10. A. capra SAdss.-Validus, gracilis, niger, punctatus; antennis V'estm everias m

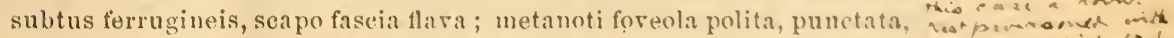

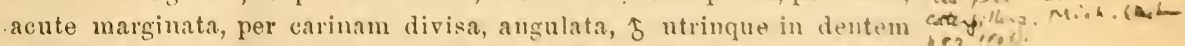
lateralem excurrente; clypei maculis 2 rol 4 , puncto frontali et post- 
oculari, macula subalari, punctis 2 scutelli, pronoti margine et abdominis vittis 4 vel 5 , 施 6 , tiliisque sullureis.

९. Total length, $17 \mathrm{~mm}$; wing, $13 \mathrm{~mm}$.

今. Total length, 14 mm. ; wing, 10 mщ.

Odynerus capra Sauss. Rev. Zool., IX, 1857, 273.

Form quite slender as with the $O$. unifasciatus, but of larger size. Head and thorax cribrose with moderately dense punctures. Clypeus widely pyriform, conrex, punctured, terminated by a border almost straight, but impressed and smooth in the middle, so that it even appears a little bidentate. Head and thorax densely punctured. Tertex offering at times a double impression toward the middle of the posterior border. Thorax lengthened; angles of the prothorax feebly indicated; metathorax having two or four longitudinal crooves. Post-scutel large, a little truncate, but without any sharp ridge, slightly bossed, and cribrose with punctures as far as the trench; metathorax rugose; its posterior part wide, shining, punctured, and bordered all around by a salient cordon which forms at the summit two distinct angles and upon each side an angle, at times subdentiform; this plate beyond divided by a medial carina into two pentagons. Abdomen a little depressed, finely punctured, more distinctly upon the 1st segment and on the border of those following, but the borders not channelled nor upturned; the first segment distinctly truncate, its suture very salient; its superior face trapezoidal, as with the 0 . unifasciatus, but wider and shorter.

Insect black, clothed with a grayish or ferruginous pile. A spot at the base of the mandibles, two arcuate spots on the summit of the clypeus, a dot on the front, and another behind each eye; two triangular spots forming a bilobate border on the prothorax terminating in a dot upon each side; a spot beneath the wing and two upon the scutellum, yellow. Antennæ black, with the flagellum beneath ferruginous or yellow, and carrying a yellow line upon the scape before. Wing scale spotted with black, with brown and with yellow. Abdomen shining; its segments 1-4 or 1-5 regularly bordered with yellow. Feet black; tibix yellow, at least above; tarsi brown or ferruginous. Wings transparent, feebly washed with brown along the nervures and in the radial. 
Var. Two yellow spots at the base of the clypeus. Clypeus ycllow with a black dot in the middle.

5. Clypeus strongly bidentate, polygonal, and with the labrum and the mandibles before, yellow. Hook of the antennx very small, black. Border of the concavity of the metathrax much more salient; its superior angles elevated into two pyramids separated from the post-scutellum by two fissures. Lateral angles of the metathorax prolonged in the form of a spine-like tooth. Segments 5 and 6 adorned with a narrow yellow edging; knees, tibia, and tarsi yellow.

Var. $\delta$. No yellow spots beneath the wing nor on the scutellum (Illinois, Wisconsiu).

Observation. - The markings upon this species are of a sulphuryellow. The first two segments of the abdomen have a regular border; that of the first is at times a little enlarged in the middle. The bordering of the segments $3-5$ is but a narrow edging.

This Odynerus is literally the American representative of the O. antilope of Europe. It has the same form, the same sculpture, the same design, and cannot be distinguished but by the less developed yellow ornaments and by a little larger size.

Ress. a. diff.-This species is especially characterized by the form of the metathorax, the plate of which is shining as with the O. antilope, and has the inferior borders more salient. It is distinguished also by its great size, by its form, lengthened but not narrow, by the regularity of its abdominal bands, and by its livery of yellow ormaments, but little developed and constant. It differs from the $O$. unifasciatus by its large size, by its 21 abdominal segments having the border not upturmed, by its numerous yellow bands.

Hab. North America, the eastern portion, where it is rery common. I possess 20 of the $q$ and $t \delta$, which have been taken in Canada, Lake Superior ( $\Lambda$ gassiz), Commecticut (Norton), Penusylvania (Rathron), Tennessee (Fuchs), Illinois (Walsh), Missouri, Louisana (Norton).

18. A. Egpinare SAoss.-Validus, niger, nitidus, punctatus, statura et formis O. capra simillimus, at metanoti diseo $q$ magis acute marginato supra angulosiore; elypeo, seutello et thoracis lateribus immaculatis ; 
abdomine tantum fasciis 2 llaris; prima latissima, nigro emarginata, secuuda angusta; alis fusco-violaceis. $\subsetneq$.

Odyncrus Spinolce Sacss. Vespides, III, 216, 107 (1851).

Total length, $16 \mathrm{~mm}$; ring, $12 \mathrm{~mm}$.

․ Large, clypeus widely prriform, coarsely cribrose, termi. nated by a little, almost straight, and appearing bituberculate, border. Ocelli large and approaching; upon the rertex a little woolly space. Thorax lengthened. Prothorax neither angulate nor rimmed, having the shoulders only lightly defined. Disk of the mesothorax wide, bearing four longitudinal groores and a fifth quite feebly marked which occupies the middle of its anterior part. Pust-scutel short and truncate, cribrose, and rugose, almost forming a ridge. Concarity of the metathorax surrounded by a salient and trenchant border, forming on each side a sharp spiniform angle and on the summit two ret more distinct angles, separated from the post-scutellum by a groore; the posterior plate dirided into two pentagons by a medial carina. Suture of the first abdominal segment rery decided; border of the second segment smooth, haring no larger punctures than upon the remainder of it; those of the following segments strongly punctured. Head and thorax shining, cribrose, with separated punctures, metathorax rugose.

Insect of a shining black, clothed with a gras ferruginous pile; a spot at the base of the mandibles, one betreen the antennæ, a dot behind each ese, and two triangular spots on the prothorax, yellow. Antennæ black, ferruginous, or yellow beneath, their scape marked with a yellow line. First abdominal segment entirely yellow abore, behind the suture, with a black depression of rariable form in the middle; second segment ornamented abore by a narrow rellow border, at times badly limited, slightly mingled with the black, a little interrupted or passing into brown. Feet black; tibix and tarsi yellow. Wings of a transparent brown; with dark violet reflections; wing scales brown or black, with a sellow dot. The ornaments are of a lirely sellow.

Ress. a. diff.-This species is easily recognized by its large size, its violet wings, the wide border of its first segment, and that of the second segment at times retracted in the middle and its black clypeus. It is easily distinguished from the 0 . unifasciatus by its rery angulate netathorax and by the border of the second segment, which is not rugose. 
It has exactly the size and form of the O. capra, but is distinguished from it by its inetathoracic plate having sharper angles, by its more truncate post-scutel, and by its second abdominal segment being less punctured along the border; perhaps also by its violet wings and the absence of spots beneath the wings and on the scutellum, and by the absence of yellow bands upon the $3 \mathrm{~d}$ and 4 th segments. It is distinct from the $O$. unifasciatus by the border of the $2 \mathrm{~d}$ segment, which is neither channelled nor rugose.

Hab. The United States. Connecticut. Pennsylvauia. Indiana. Illinois. Tennessec. (6 f.)

C. Body more gathered (not so elongate), normal, but the thorax is still sensibly longer than wide.

c. Metathorax destitute of strong spines.

12. A. abopraleratus Sauss.-Medius, niger, punctatus; puncto frontali et post-oculari, pronoti et abd. segmentorum margine, maculis 2 scutelli, 1 subalari, tegulisque, niveis; $\$$ clypeo albido-bimaculato, et antennarum scapo subtus testaceo; $\delta$ mandibulis, clypeo bispinoso lineaque scapi et pedibus albidis; pronoto et metanoto bidentato.

Odynerus albophaleratus Sauss. Vespides, III, 217, 109.

․ Total length, $13 \mathrm{~mm}$; w wing, $10 \mathrm{~mm}$.

$\delta$. Total length, $10 \mathrm{~mm}$.; wing, $8 \mathrm{~mm}$.

․ Size moderate. Head and thorax denscly punctured. Clypeus widely pyriform, punctured, terminated by a little straight or subemarginate border. Thorax mediocre; prothorax moderately wide; its angles distinct; mesothorax marked with fonr grooves at its base, with two across the whole; metatlorax rugose; its posterior plate finely shagreened; bordered by a cordon which marks ont the usual pentagon, which is but little angulate, without lateral teeth. Abdomen oralo-conit; the first segment wide and druncate with a very distinct suture; the whole abdomen quite finely punctured; the 1st segment most strongly.

Insect black. $\Lambda$ spot upon the frout, another behind each eye: a slender border on the prothorax, two dots on the sentellum, and a regular border on every segment of the abdomen, whitish. Antenua black; the seape testaceous beneath. Lergs black, the tibia white abore; tarsi slightly ferruginous. Wings transpa- 
rent, with the radius and the stigma brown, except a little washing of brown ferruginous about the nerrures.

$\hat{\delta}$. Clypeus lengthened, bidentate; the teeth permitting between them a narrow emargination. Mandibles, labrum, clypeus, and a line on the scape of the antenux, white. Extremity of the antemn beneath and the hook, ferruginous. Angles of the metathorax dentiform; marginal ridges of the metathoracic plate rery trenchant, forming on each side a spiniform tooth; scutellum parted by a groove; post-scutel rugose, offering on the summit of its posterior trench a sort of interrupted rugose ridge. Kuees, tibiæ, tarsi, and often the femora, whitish.

Tar. Scutellum bordered with whitish.

Ress. a. diff.-This species is rery well characterized by its white ornaments, and it has the appearance of the European species of the subgenus Epipona. One might easily err in ranging it with this group in spite of the anteriorly truncated abdomen. The clypeus ( $\delta$ ) in particular is cut exactly as with these insects. See the affinities of the O. Catskilli.

Hab. North America. I took this Odynerus in abundance in the environs of New York in the month of April, but I met none except the males. I finally receired 12 from Connecticut, Illinois, and Pennsylrania.

Observation.- Te possess one individual 9 , having the form sensibly more stubbed, which has the clypens white, with a black spot and the scutellum almost entirely white; the borders of the segments quite wide. (Illinois.) Is it a simple rariety?

13. A. Catskinensis SAtss.-Niger, punctatus, crassus; 0. albophalerato statura et 0 . campestri picturâ similis; corpore flavo-picto; metanoti foreola acute marginata, frequenter utrinque macula flava; scutellorum limbo interrupto, flaro; antennarnm scapo fiavo-lineato.

Orlynerus Catskilli Sarss. Vespiđes, I, 136.

Oilyn. Catskillensis Sauss. Et. Vespid., III, 204.

․ Total length, $11.5 \mathrm{~mm}$.; wing, $9.5 \mathrm{~mm}$.

. Total length, $9.5 \mathrm{~min}$.; wing, $8 \mathrm{~mm}$.

\footnotetext{
1 The fig. 8, pl. xri, which is named as representing this species in the work cited, does not represent it at all. It is a lapsus to be regretter?, without considering that the figure is rery bad. One should not take it into account at all.
} 
P. Form stout. The size and shape of the O. albopthaleralus, but the thorax is shorter. Clypeus wide, quite triangular, truncated at the extremity or appearing lightly bidentate, strongly punctured. Body densely punctured and clothed with a gray pilc. Concavity of the metathorax dull, finely wrinkled, strongly bordered; its marginal ridges areuate and quite strongly salient at the summit, where they alnost form two little tecth separated from the post-scutel by a fissure; on each side there is formed another dentiform angle, at times not very decided. Abdomen short; the first segment short; almost as wide as the $2 \mathrm{~d}$.

Insect black, much resembling in coloration the $O$. campestris. Antennæ ferruginous beneath, with a yellow line upon the scape. A dot upon the mandibles, four spots upon the clypeus, one on the front, one behind each eye, a narrow border on the prothorax, a spot beneath the wing, an interrupted bordering on the scutel, and two areuate spots upon the lateral ridges of the metathorax, yellow. All the segments of the abdomen adorned with a narrow, regular border; knees, tibiæ, and tarsi yellow; these last often ferruginous. Wings transparent, washed with brown in the radial and along the nervures. Wing scales yellow, touched with brown.

Var. a. Clypeus yellow, with a black spot.

$b$. Only four ycllow borders upon the abdomen.

c. Spots of the metathorax very small, occupying the base of the ridges.

d. No spots on the metathorax.

. A little.smaller, stubbed. Mandibles, labrum, and clrpeus yellow; this last wide, rounded, and bidentate. Hook of the antennæ ferruginous, as well as the extremity of the flagellum beneath. Border of the 1st abdominal segment often blended upon the sides with a yellow dot; femora yellow; feet almost entirely yellow. Two yellow dots on the sides of the 2 d segment.

Var. a. No separate yellow dots upon the $2 \mathrm{~d}$ segment.

b. Scutels black.

Ress. a. diff- This species can be recognized br the short first abdominal segment, as wide as the 21, and by the two yellow spots on the metathorax. But this last character being subject to be wanting, it is not advisable to give it too much importance. One can distinguish this Odynerus from the $O$. eama by its very much smaller size and by its stubbed form: from the $U$. spronolie 
by its smaller size, its less angulate metathoracic plate, by the narrow border of the first segment, by the transparent wings and quite different livery: from the $O$. albophaleratus by its yellow ornaments; its shorter thorax, a little less strongly panctured, its abdomen having more punctures, its antennæ more colored, and the size a little larger: from the $O$. unifasciatus and campestris by its metathoracic plate bordered throughout by sharp ridges and by the border of the $2 \mathrm{~d}$ segment which is not rugose. But above all it might be confounded with the 0 . birenimaculatus. It is distinguished from it by the less rich livery, by the regular border of the first segment, by the very much less gross form, by the much smaller size, etc. Compare these two species carefully.

Hab. The United States. New York. Connecticut. Illinois. (10 ㅇ, 5 $\delta$.

Observation. - This species is the Amcrican representative of the $O$. renimacula and it appears to me to differ from this species only by the rather less defined angles of the prothorax and by the metathoracic plate, which is not striate.

I possess a very small individual, ㅇ (long. $8 \mathrm{~mm}$.), which perhaps indicates the existence of another allied species. The thorax is a little more lengthened, the first segment of the abdomen is divided by a feeble groove, the clypeus offers but two yellow dots toward the base, and the metathoracic ridges are marked by two little yellow lines. (Connecticut, Mr. Edw. Norton.)

I possess also many more little males which I cannot but ascribe to this species and which, in fact, do not present any difference from the males of the normal size, but in being much smaller, and that some of the punctures of the first segment of the abdomen are a little stronger. Length, $8.5 \mathrm{~mm}$; wing, 7 .

These specimens hare no separate spots on the $2 d$ abdominal segment. The 1st segment carrics a regular border, not enlarged upon the sides. The scuteilum offers two yellow spots; the postscutel is in general black, at times bipunctate.

I do not doubt but that these little males really belong to this species, just as one often meets variations among the insects of this group. These males greatly resemble those of the O.tigris, but they are howerer larger, and above all, wider and more stubbed in form. Connecticut. New York. Illinois. 


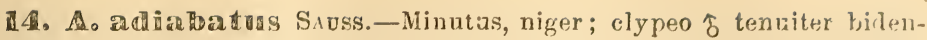
tato; metanoto bispinoso, superne rugoso, haud acuto; abdomise gracili ; primo segmento elongato; alypeo, mandibulis, scapo antice, puncts frontali et post-oculari, pronoti linea antica, tegulis, puncto subalari abdominisque segmentorum marginibus anguste, flavis. Pedibus flavis, femoribus nigris; alis subhyalinis. $\hat{\delta}$.-Long. $8 \mathrm{~mm}$.

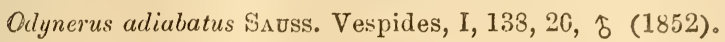

Hab. North America. Carolina. (Type in the Paris Museum.)

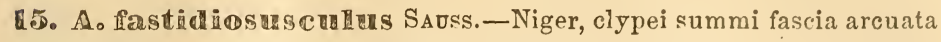
utrinque, macula frontali et post-oculari, scapo subtus, pronoti margine, tegulis, fascia interrupta scutelli, fascia post-scutelli, macnla subalari abdominisque fasciis 4 , flavis ; fascia primi segmenti utrinque dilatata; pedibus basi nigris; alis subhyalinis. Long. $10 \mathrm{~mm}$. $q$.

Odyncrus fastidiosusculus SAuss. Et. Vespid., I, 137, 19,

\section{Hab. Brazil. (Type in Paris Museum.)}

16. A. Samta-Ama SAuss.-Niger, densissime punctulatus, clypeo grosse cribrato; pronoto subangulato; metanoti foveola acutissine marginata, bidentata; abdomine subvelutino, ovato; puncto froutali et post-oculari, litura angusta pronoti abdominisque vittis 3 , flavis; alis ferrugineis; - + clypeo atro flavo bipunctato, antennis atris, macula subalari et 2 scutelli, llavis; - $\delta$ clypeo, subbidentato, flavo, seapo flavo lineato.

Odynerus Santa-Anna Sauss. Revue et Magas. de Zool., IX, 1857, 273.

Total length, $10 \mathrm{~mm}$; wing, $11 \mathrm{~mm}$.

․ Clypeus pyriform, truncate, or fecbly subbidentate, rery coarsely punctured. Prothorax not retracted before; its angles aistinct. Mesothorax with a little smooth carina before; its grooves moderately pronounced. Post-scutel truncate, offering a feeble ridge at the summit of its posterior face; this ridge interrupted and fincly crenulate. Plate of the metathorax triangulate, very clearly bordered all around by very trenchant straight ridges, which inclose the two pentagons in a rery distinet manner. 'The lateral angles cientiform; the superior' ones acute. Abdomen punctured, orate; the first segment narrower than the $2 d$, punctured, having a rely strong snture. Border of the al and the following segments densely punetured, but neither rugose nor channelled. 'That of the first oflering a vunctured line. 
Head and thorax finely and very densely shagreened; abdomen punctured, a little velvety.

Insect black, corered with gray hair. Two lateral spots on the summit of the clypeus; another between the antenna, a dot behind each eye, a narrow border on the prothorax, a spot bencath each wing, two on the posterior border of the scutellum, two dots on the wing seales, and the border of segments, 1, 2, 3 of the abdomen, sulphur-yellow; there is often a yellow dot at the base of the scape of the antennæ and upon the anterior tibiæ. 'The yellow bands of the abdomen are regular; the first often slightly enlarged at the two extremities, the two others at times retracted in the middle, and complete beneath. Wings transparent, washed with brown ferruginous. Wing scales black, spotted with yellow.

Var. Clypeus and antennæ black.

$\hat{\jmath}$. Size same as the female. Clypcus yellow, armed with two short teeth separated by a semicircular emargination; its inferior margin finely bordered with black; mandibles and labrum black. Scape of the antennæ in general marked with a yellow line; hook black. Wing scales, scutellum, and the flanks, in general, black, without yellow spots; the fourth segment carrying a narrow ycllow band interrupted above. Tibiæ yellow beforc. Post-scutel divided by a little medial groove. The superior angles of the metathoracic plate pronounced.

Ress. a. diff.-This species is peculiar in its wholly black antennæ and in a very marked tendency to lose its yellow ornaments. Its thorax is short and little arched. Its abdomen has a velvety appearance. It has the form of the $O$. Catskillensis, but the first abdominal segment and the thorax are a little less wide; its size is a little greater. The $\delta$ has the clypens sensibly less bidentate than the North American species of this gromp. It is closely allied to the 0 . Bustamente. (Sce the description of this species.)

$H a b$. The hot and temperate regions of Mexico. Cordova. Jalapa, the Michoacan.

1\%. A. Bustamenti Sadss.-O. Santa-Annce simillimus, niger; clypeo integro maculis 4 flavis; thorace latiore, pronoto latissimo, tenuiter flavo marginato, metanoto angustiore, canthis inferis flavo-ornatis; macula subalari et scutelli fascia interrupta, flavis; abdomine velutino, basi lato, segmentis 1-5 fiavo-marginatis; tegulis flaro-bipunctatis. $q$.

Odynerus Bustamente Sadss. Revue et Mag. de Zool., IX, 1857, 273, $q$.

Total length, $11 \mathrm{~mm}$; wing, $9 \mathrm{~mm}$. 
9. A species elosely allied to the O. Santa-Annx, having exactly the same appearance and the same sculpture; the abcomeu being also of a deep velvety black.

Clypeus wider than long, its anterior border truncate, straiglit, or a little concave, not bidentate. Thorax very short, sensibly wider than with the species eited; the prothorax less angulate, but very wide, the disk of the mesothorax wider than long; its grooves indistinct; metathorax a little retracted, so that the thorax increases in width from behind forward. The posterior plate of the metathorax a little striate, wider and less strongly bordered. The yellow ornaments more abundant than in the preceding species; clypeus earrying four yellow spots, or yellow with the scutellum black on the summit; scape of the antennæ adorned with a yellow line; border of the prothorax very narrow. 'Thorax with a spot beneath the wing, an interrupted band on the scutellum, and with two spots upon the inferior edges of the metathorax. Segments of the abdomen all regularly bordered with sulphuryellow; the last ones very narrowly; the first ones very short, as wide as the second. Feet black, tarsi and tibiæ ferruginous. The remainder as with the $O$. Sanla-Annæe.

Var. Two yellow dots on the scutellum.

ऽ. Unknown.

This species very much resembles the 0 . Catskilli, but differs from it by the very punctate border of the abdominal segments, the first segment being also wider and shorter.

$H a b$. The cold regions of Mexico. I have taken this Odynerus upon the Coffre de Perote.

\section{A. Sy liveira Sauss.}

Odynerus Sylveirce Sauss. Et. Vespides, III, 217, 110; pl. $\mathbf{x}$, fig. 8, $q$ (1854).

Hab. Brazil. Sylveird. (Type in the Paris Muscum.)

\section{b. Metathorax having two strong spines.}

19. A. Cla mazianum SAuss.-Niger, sericeus; capite rufo vel obseuro: capite et thorace superne rugose punetatis ; pronoti angulis emarginatis, lobatis; post-scutello valde cristato, emarginato; metathorace postice excavato, canthis peracutis marginato, utringue spina et infere dente armato; antemis nigris; pronoti margine postico, nacula subalari, 
tegulis, fascia scutelli et post-scutel'i, metanoti angulis adominisque segmentorum 1-3 margine, pallide flavis; alis antice fusco-marginatis. $\hat{\delta}$. Clypeo bideutato luteo.

Anc. Clarazianus SAcss. Rev. de Zool., 1S70, 55, 3, $ᄋ \uparrow$.

q. 'Jotal length, $12 \mathrm{~mm}$; ; wing, $10 \mathrm{~mm}$.

ई. Total length, $10 \mathrm{~mm}$.; wing, $8 \mathrm{~mm}$.

․ Body stubbed. Head rather large, the vertex transrerse, not convex; ocelli set in depressions. Thorax slightly convex; prothorax having each of its angles extended into a lamellar rounded process, which is separated from the anterior margin by a wide notch. Disk of mesothorax parted by a longitudinal groore, and posteriorly bicarinate; the carinæ sinuous, terminating at the angles of the scutel. Scutel parted by a groove and separated from the mesothorax and post-scutel by deep furrows. Post-scutel truncate, elevated into a high crest, rather concare behind; the crest broadly emarginate, forming two nearly triangular lamellar teeth. Metathorax much excavated, margined with very sharp edges; the lateral angles produced iuto strong spines, the upper arcuated edges rery salient, rather crested; the inferior edges forming on their lower part, each a triangular tooth. Head and thorax above coarsely and roughly punctate; thorax on the sides and behind finely punctate and covered with silky, silvery pile. Abdomen short, finely punctured, silky, with gray-golden reflections, the first segment nearly as wide as the second, short, its suture transverse, very distinct.

Black. Antennæ black, the 1 st and $2 d$ joints rufous beneath ; head and mandibles rufous or orange-red, about the antennæ and a little on the vertex black. Anterior margin of the prothorax very delicately rufous; posterior margin of prothorax, a spot beneath the wing, a band on the scutel and one on the hinder part of post-scutel, the angles of metathorax, and the inferior edges, pale yellow; the crest of post-scutel also jellow, finely margined with black on its hinder face. Tegulæ rufous, margined with pale yellow; the process next to them yellow. The first three abdominal segments adorned with a regular yellow margin; the first narrow, fusing on each side into a little lateral spot; the second widest, the third narrowest. Feet brown or passing into ferruginous; tibiæ, the 1 st and $2 d$ anteriorly, and the extremity of $2 \mathrm{~d}$ femora, marked with yellow. Wings hyaline; anterior margin and radial cell brown. 
Var. The head more or less obscure, passing into black or quite brick-red.

. Clypeus pyriform, coarsely punctate, terminating with two small brown approximating teeth.

$\hat{\delta}$. Head blackish or black; orbits rufous; inner margin of the eyes, a frontal spot, and a line on the mandibles, pale yellow; the scape at times with a yellow line; clypeus polygonal, strongly bidentate, pale yellow. Anterior femora and tibiæ yellowish before (Bahia Blanca).

The male is described from a southern specimen, which may be the reason of its black head. Specimens from Buenos $A$ yres may have the head red like the females?

Ress. a. diff.-This is a quite distinct species in the form of the thorax. It has also a different appearance from all other Ancistrocerus.

Hab. The Argentine Republic, 5 ㅇ, 4 $\delta$. Buenos Ayres (Meyer Dürr), 1 \&, $3 \hat{\delta}$. Bahia Blanca (G. Claraz).

D. Form very stubbed. Thorax cubical, nearly as long as wide.

20. A. Direminaculatus SAuss.-Crassus et brevis; tenuiter punctatus; clypeo flavo, $q$ truncato, $\delta$ bidentato; thorace brevi, quadrato; metanoti foveola acutissime marginata, utrinque et superne angulos dentiformes efficiente; macula frontali et post-oculari, fascia in scapo antennarum, pronoti limbo late, tegulis, scutello, post-scutello macula subalari et utrinque metathoracis pedibusque, flavis; ablomine lato, conico, segmentorum margine punctato, late flavo-limbato, secundo sæpius utrinque macula flava; primi fascia utringue antrorsum dilatata.

Odynerus birenimaculatus SAuss. Vespides, I, 135, 16, q, var.

Total length, $14 \mathrm{~mm}$. ; wing, $11 \mathrm{~mm}$.

q. Large and very stubbed. Form very short and rery wide. Clypeus wider than long, trmeate, finely punctured. Thorax stout, very wide, cubical, a little longer than wide. Prothorax not angular; mesothorax marked posteriorly with two profound grooves. I'ost-scutel short, truncite, having a sort of ridere, blunted in the middle. Metathorax very wide; its posterion plate wide, quite flat, fincly shagreened, rery angulate. and bordered all around by some very trenchant ridges, which form on each side a spiniform angle and on the summit two sharp teeth. Head and thorax very densely and fincly punctured. 
Abdomen wide and conical; the first segment short, as wide as the 2d, elerated at the suture; its superior surface often longitudinally striate along the suture; the border of the segment distinetly punctured; that of the 2 d insensibly reflexed.

Insect black, strongly mingled with yellow. Mandibles brown at the extremity. Clypeus yellow, at times adorned with a little brown dot. Antennæ black, with the scape yellow before and the flagellum ferruginous beneath at its base. A spot on the front, one behind each eye, a wide border on the prothorax, a spot below the wing, wing scale, scutel, post-scutel, two arcuate spots occupying the angles of the metathorax, and a wide border on every segment of the aljdomen, yellow; these borders regular; that of the 1st segment joined to two oblique lateral spots; the $2 \mathrm{~d}$ ornamented on each side by an oblique spot, sometimes separated, sometimes confounded with the border. Anus yellow. Feet yellow, thighs obscure at their base; coxæ spotted with yellow. Wings transparent, a little smoky along the side and toward the end, with a light violet reflection.

Var. a. Scutellum having but one yellow interrupted band.

$b$. No yellow lateral spots on the $2 \mathrm{~d}$ segment.

c. The borrler of the $2 d$ segment festooned in consequence of the fusion with the lateral spots.

d. The yellow ornaments passing into orange.

$\delta$. Same size as the $q$. Extremity of the antennæ and their hook ferruginous; clypeus bidentate. Mandibles yellow. Scutellum divided by a groove. Yellow ornaments narrower, often interrupted on the scutel; lateral spots of the first two segments small. Anus only spotted with yellow. (The border of the first segments in general regular, only confounded on each side with a yellow dot.)

Var. Size small, length $11 \mathrm{~mm}$.; wing $8 \mathrm{~mm}$.

Ress. a. diff.- This beautiful species is very distinct in its very stubbed form, in its size, in its cubical and finely punctured thorax, not cribrose with holes, in the exceptional width of its yellow markings. It can, however, be confounded with the Odynerus Catskillensis, from which it may be distinguished by the yellow clypeus of the female, by the much richer ornamentation, by the notably more stubbed form, and by the two oblique yellow spots of the first segment which ningle themselves with the border; by the elevated and truncate post-scutel and by its superior size. 
The O. birenimaculatus differs from the O. Spinolæx by its very much more densely punctured and not smooth body, by its transparent wings, by the margin of the $2 \mathrm{~d}$ segment which is densely punctured, by the first segment which is wider, by its stubbed form, etc.; from the $O$. campestris and unifasciatus by the very much more densely and less coarsely punctured thorax, by the form. of the metathorax, by the less coarsely punctured margin of the $2 d$ segment, etc.

Finally, the $O$. birenimaculatus offers a great resemblance also to the $O$. renimacula of Europe, although its form is very much more stubbed than that of this last species.

Hab. New England. New York. 24, 3 $\delta$.

\section{The concavity of the metathorax forms no distinct lateral angles.}

Here the posterior plate is often rugose. It is at times still bordered at the summit by some ridges or one double arch; sometimes it is not limited, especially not on the sides, where it is effaced and lost in the sides of the metathorax. The concarity is often formed by the meeting of two convex facettes.

A. Posterior face of metathorax remaining margined, but without distinct angles. Body slender, elongate.

a. Post-scutel strongly truncate.

21. A. conspicuus Sadss.-Gracilis, niger, ubique punctatus; capite et thorace crassissime et rngose punctatis; prothorace antice cristato, angulato, post-scutello valde truncato, facie postica polita ; metathorace utrinque haud angulato, foveola lævi, tenuiter marginata, abdomine dense punctato; primo segmento minuto, acute suturato; antennarum scapo subtus, puncto frontali et subalari, pronoti abdominisque segmentorum 1, 2 limbo postico, fascia interrupta scutelli, fascia post-scutelli, lineaque femorum intermediorum, luteis. $\subsetneq$.

Ancistrocerus conspicuus SAuss. Rev. et Mag de Zool., IX, 1857, 247.

Total length, $9.5 \mathrm{~mm}$; wing, $7 \mathrm{~mm}$.

․ As slender as a Stenancistrocerus. Ifead and thorax rery roughly punctured. Clypeus very coarsely punctured, finely bicarinate at tip and minutely bidentate. Head margined posteriorly. Vertex having a tuberele garnished with an erect brush of hair. Thorax searcely contracted posteriorly, very square 
anteriorly; the prothorax with a crested margin, its angles dentiform, acute. Post-scutel very short, strongly truncate; its posterior face flat, polished; its superior face rough, transverse; its posterior ridge very finely crenulate, the middle with a very small compressed tubercle. Metathorax coarsely cribrose, silkygrayish, its linder face widely excavated, as polished as the posterior face of post-scutel, somewhat punctate, finely margined; the margins forming behind the post-scutel two quite small erect teeth (not easy to distinguish); no distinct lateral angles. Abdomen slender, slightly depressed; the first segment small, shortly and quite sharply truncate anteriorly; the suture elevated; its superior face short, rather strongly punctured; $2 d$ segment not quite so strongly punctured, its hinder margin with a line of punctures, the following segments densely punctured.

Black; grayish-silky. Mandibles partly fulvous; antennæ ferruginous beneath, scape yellow beneath. Two dots on the summit of clypeus, a frontal spot, and post-ocular line, pale yellow. Hinder margin of prothorax with a narrow luteous band; its angles, appendix of wing scale, a spot under the wing, an interrupted fascia on scutel, a transverse line on the hincler face of post-scutel, and two large maculæ on the hind face of metathorax, pale yellow. The first two abdominal segments narrowly margined with luteous. Intermediate femora with a luteous line. Anterior tibiæ and tarsi brown or ferruginolis. Wings hyaline, smoky, nerves and anterior margin of the apex fuscous; the $2 d$ recurrent nerve falling nearly upon the $2 \mathrm{~d}$ transverse cubital vein.

Var. Anterior margin of prothorax also margined with luteous.

Ress. a. diff.-This is quite a distinct species and a peculiar type, making a sort of transition to Stenodynerus by its slender form, and its punctate abdomen, having the 1st segment more punctured than the second. The form of the scutel, post-scutel, and metathorax is quite unusual, and the very coarsely punctured thorax makes it at once distinguishable.

Its livery much resembles that of the A. Fariasi, but it differs from this in all its form and its punctures; in the first segment being very short and truncate, its superior face quite transverse; the scutel trincate, not triangular; the punctures of thorax and head being much coarser, etc. It has also a resemblance to $O$. (Stenodynerus) totonacus. 
Hab. The temperate parts of Mexico. I caught a $f$ near Cordova.

\section{b. Post-scutel not truncate, angulate posteriorly.}

This type has the post-scutel formed much as in Stenancistrocerus, but the form of the abdomen remains as in the division Ancistrocerus, and the appearance remains also as in this group, so that we have to leave it in the division Ancistrocerus, prop. dict.

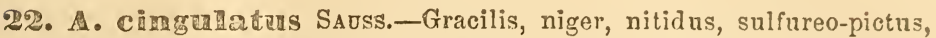
pronoti angulis in processus 2 productis, antemnis subtus et basi flavis; abdominis segmentis 1, 2 late flavo-marginatis; primo antice truncato, suturâ prominula, fascia flava utrinque aucta marginato.- $q \hat{\delta}$. Clgpeo truncato, flavo.

Odynerus cingulatus Cresson, Hymen. of Cuba, Ent. Proc., Phila., II, 1865,162 , ‥

今. Total length, $9 \mathrm{~mm}$.; wing, $7.5 \mathrm{~mm}$.

․ Total length, $12 \mathrm{~mm}$; wing, 9 mm.

Rather small. Form slender, elongate. Head and thorax punctured. Angles of prothorax strongly produced into blunt processes. Seutel and post-seutel flattened, the former parted by a deep groove. Metathorax rounded, rather roughly punctate; its concavity strigose; bordered by a rather distinct salient line, but its angles obsolete and destitute of teeth. Abdomen delicately punctured, most distinctly on the first segment and the border of the others; 2 d segment somewhat swelled above; the first segment narrower than the second; its suture elevated.

Shining black. Antennæ black, with their first two joints and the under side yellow. A triangle on the forehead, a line behind the eye, a broad fascia on the edge of prothorax, a spot under the wing, the scutel, and post-scutel, yellow. The first two abdominal segments with a broad yellow margin; the fascia of the first widened on each side. Feet yellow; coxie and hinder femora except at tip, black, intermediate coxi yellow anteriorly. Wings elouded, principally at the end; the anterior margin as far as the stigma ferruginous.

$q \delta$. Clypens polygonal, longer than wide, rollow; its inferior border narrowly truneate, tenuously maregined with black. Mandibles dentate; ferrugiuous, or yellowish, black at base and tip. 
Hab. Cuba. Sent to me by Dr. Gundlach.

This species is very distinct, but by its appearance might be confounded with $O$. Hacanensis, which has quite a differently formed abdomen, having the angles acute, but not so much produced, and the clypeus notched.

- Its slender form makes it resemble O. tigris, although it is very different in the produced angles of prothorax and rounded metathorax.

B. Metathorax not distinctly marginate. Body not slender, of normal form.

a. Abdomen nearly conical. The border of the $2 d$ segment not reflexed. . Body velutinous.

23. A. Parredesi Sarss.-Niger, velutino-hirsutus, argenteo-sericeus; antennis subtus ferrugineis; puncto frontali, pronoti medio et tegulis in margine, ferrugineis; abdominis segmentis 2-5 flavo-marginatis; secundo in margine valde punctato; alis ferrugineis, apice griseo-nebulosis.- $\$$. Clypeo infere ferrugineo-maculato.

Odynerus Parredes Sauss. Rev. et Mag. de Zool., IX, 1857, 273.

Total length, $13 \mathrm{~mm}$; wing, $10.5 \mathrm{~mm}$.

Appearance of the $\mathrm{O}$. nasidens. Clypeus convex, quite finely punctured; its inferior border truncate, short, and bordered with a salient rim. Prothorax angulate: its angles almost dentiform. Metathorax having its posterior plate punctate and striate, bordered by slightly salient ridges; its superior ridges arcuate in the form of the end of an arch, not forming any superior angle, and on each side only a blunt, indistinct angle. Post-scutel blunted, punctate. Abdomen conical; the first segment wide, anteriorly truncate; its suture distinct.

Insect black, finely punctured, rather more strongly on the metathorax; all the body covered with a thick velvety pile, silvery and a little golden; the abdomen shining relutinous, with silky and golden reflections, the $2 d$ segment quite strongly punctured along its border, but not channelled. The antennæ ferruginous beneath, as also a spot toward the base of the clypeus. A dot between the antennæ, a line in the middle of the prothorax, and the border of the wing scale fawn-colored or ferruginous. Segments of the abdomen, all except the first, adorned with a 
regular yellow border. Legs black, varied often with ferruginous. Wings ferruginous with the end gray.

Var. The yellow passing into ferruginous and the ferruginous into yellow.

Ress. a. diff.-This speeies wonderfully resembles those which form the group of the $O$. nasidens, but it is sufficiently distinct from it in the presence of the suture of the first segment of the abdomen. It is also more slender.

Hab. The temperate climes of Mexico. Valley of the Mextillan. 4 ㅇ.

\section{b. Abdomen more ovalo-conical; the border of the $2 d$ segment rugose or reflexed.}

(Section I, b, Saussure Vespides, I, 139.)

Group of the Odynerus unifasciatus.

2.1. A. un ifasciatus SAdss.-Gracilis, niger, cribri instar punctatus; abdominis secundi segmenti margine canaliculato, subreflexo, perrugoso ; antennis subtus ferrugineis; puncto frontali et post-oculari, macula biloba pronoti, post-scutello et abdominis primi segmenti unargine, flavis. - . Clypeo flavo-bipunctato.- $-\hat{\delta}$. Clypeo, mandibulis et abd. secundi segmenti, limbo, flavis.

Variat. $\$$ secundo $\hat{\delta}$ tertio et quarto abd. segmento flavo-limbato.

Odynerus uncinatus ${ }^{1}$ SAY, Boston Journ., I, 1837, 286, 4. SAY's Entom. (Le CoNTE), II, 766, 4.

Odynerus unifasciatus Sauss. Vespides, I, 138, 21; III, 205.

९. Total length, 14-15 mm. ; wing, $11 \mathrm{~mm}$.

\}. Total length, $11 \mathrm{~mm}$. ; wing, 8 .

q. Form slender. Head and thorax cribrose with great separated punctures. Clypeus convex, strongly punctured, widely pyriform, terminated by two very small, near together and diverging teeth. Head strongly and densely punctured. Thorax quite lengthened, a little retracted posteriorly, ererywhere strongly cribrose with foraminiform punctures. Prothorax fincly bordered, without angles. Mesothorax presenting two groores on its hinder part. Metathorax very rugose abore, retieulately shagreened, corrugated; its concavity quite flat, indistinctly striate and punctate, without spines on the sides, superiorly bordered by an

1 It is eridently not the O. unifasciatus which Fubricius described under the name of Vespa uncinata, which is rather the Monolia 4 -dens, because ho says that all its markings are snowy-white, a dhat the sizo is that of the respa maculata. 
arcuate trenchant ridge. A bdomen slender; first segment a little narrower than the $2 \mathrm{~d}$, distinctly truncate anteriorly, subperliculate at the base, with the anterior face smooth; the superior face slightly widened behind, bounded before by a stroug sutural ridge, rery distinct. The abdomen very fincly punctured, but the $3 d$ and following segments rather strongly so, and especially the border of the $2 \mathrm{~d}$ segment offering a wide zone, very strongly cribrose, vigose, subchannelled, with subturined up border. Near the margin of the 1st segment one sees also a line of punctures.

Insect black, clothed with gray-ferruginous hair. Two lateral dots on the clypeus, one behind each eje, a mark on the front, yellow or ferruginous; a bilobate spot in the middle of the prothorax and post-scutel, wholly or partly jellow. Wing scales brown. Abdomen wholly black; only the first segment adorned with a rellow border, suddenly widened on the sides (or joined with two lateral spots). Tibix and tarsi ferruginous or yellow ; antennæe ferruginous beneath, black above, with the scape at times wholly ferruginous at the base. Mings of a transparent brown, with riolet reflections, particularly obscure along the nervures.

Var. A spot beneath the wings and a border on the $2 d$ abdominal segment, yellow.

§. Smaller. Antennæ rery large, terminated by a little hook; clypeus sellow, with a triangular notch; labrum and mandibles before, rellow; post-scutel yellow, or only bipunctate with yellow; the 2d abdominal segment a little compressed at the base, bordered with yellow; its margin a little sinuate, concare arcuate in the middle abore, more or less retroussé, compressed; the $3 \mathrm{~d}$ and 4 th segments often adorned with a fine yellow edging. The border of the 1st segment often presents a little of red; sometimes a little widened on the sides. With this species the ornaments are yellow-golden or sub-orange.

Var. a. A yellow dot under the wing. Border of the prothorax entire, bilobate.

b. $\delta$. Post-scutel black. On the abdomen only tro narrow borders. (Illinois.)

c. $\delta$. Head and thorax entirely black; mandib.es margined with yellow; 1st abd. segment narrowly, 2d rery narrowly bordered with rellow. (Florida.)

Ress. a. diff.-This Odynerus is quite easy to recognize by the very rugose and channelled border of the $2 d$ segment; by the 
unique bordering of the first segment, although certain females possess a second band like the males; by its olscure faco; by its slender form, by its abdomen which is not briefly sessile, and the thickness of the border of the first segment of the abdomen, which causes the $2 \mathrm{~d}$ segment to appear so subcompressed at its base. See the O. campestris, to which it is closely allied.

Hab. The United States. Connecticut. Illinois. Iowa. Prairies (Rio Pecos). Tenuessec. North Carolina. 10 \% $12 \delta$.

Observation.-Among the dried specimens one generally finds the abdomen extremely swelled, as if the segments had been violently distended. This peculiarity belongs especially to this species and gives it an unusual appearance.

25. A. campestrûs SAuss.-Niger, grosse punctatus; metanoti foveola haud acute marginta, inermi, striata et grosse punctata; abdominis segmentorum $2^{i}-5^{i}$ nargine rugose punctato; antennis subtus fulvis, scapo flavo-lineato; clypeo $\$$ favo, macula atra, $\widehat{\jmath}$ emarginato, flavo; puncto frontali et post-oculari, pronoti et abd. segmentorum $1^{i}-3^{\text {ii }}$ limbo (prini utrinque aucto), post-scutello, maculis 2 scutelli maculaque subalari, tibiis et tarsis, flavis; alis fusco-nebulosis.

Odynerus campestris SAuss. Vespiảes, I, 137, 18; III, 204, 战

‥ Total length, $13 \mathrm{~mm}$.; wing, $11 \mathrm{~mm}$.

9. Head and thorax cribrose with great pits, quite visible to the naked eye. Clypeus pyriform, as wide as long, cribrose with great punctures; its anterior border small, bordered, subconcave, upon the vertex often a little fossette. Prothorax unarmed, finely bordered. Mesothorax marked with two grooves; scutel flat; post-scutel short, sloping. Metathorax rounded, rugose; its concavity pronounced, but not limited; divided by a rertical carina which bifureates at the summit to form two ares which indistinctly border the cavity at the summit; the middle and the bottom of the concavity wrinkled; the summit coarsely punctured. Abdomen ovalo-conic, punctured; the first segment large, almost as wide as the $2 d$; borders of the segments $2-5$ presenting a wide coarsely punctured zone, rugose, bnt not turned up; the border of $2 \mathrm{~d}$ segment sinuous, forming a concare are.

Insect black, clothed with a grayish pile. Antemne ferruginous beneath. Clypens yellow, with a triangular black spot. A line on the scape of the antenna, a spot on the front, one behind each eye, border of the prothorax, a spot bencath the wing, wing seales, two dots on the seutel, post-sentel, and a 
border upon segments $2-5$ of the abdomen, knees, tibir, and tarsi yellow; the first segment of the abdomen having its border widened upon the sides, or rather, confounded with two lateral spots; border of the $3 \mathrm{~d}$ much narrowed. Wings transparent, but washed with brown-violet especially along the borders.

Var. Clypeus black with four yellow spots, segments 4 and 5 of the abdomen with no yellow border.

$\hat{\delta}$. Clypeus emarginate, yellow; mandibles yellow.

I possess a male very closely allied to $A$. unifasciatus $\delta$, having also the margins of the $2 d$ and $3 d$ segments sinuous and coarsely punctured. But it differs from this species in the smaller hook of the antennæ, in the metathorax, wholly rugose; eren on its concavity, which is less defined and not striate; in the first abdominal segment, which is parted by a quite strong longitudinal groove, and in the $2 d$ segment more compressed at its base. It has the same markings, unless the prothorax has a little less of yellow in the middle. As this $\delta$ has the metathorax rounded and the wings slightly washed with brown, it seems that it cannot but belong to the 0 . campestris, unless it represents a species which may have escaped us.

It differs sometimes from the $O$. campestris in its scutellum deprived of spots and in the groore of the first segment which approaches to it, as well as the smallness of the antemnary hook of the Symmorphus.

Ress. a. diff.-This species has the appearance of the $O$. parietum. It can be confounded not only with the Ancistrocerus of this group, but with different Odyneri, properly speaking.

It differs from the $O$. unifasciatus in its more stubbed form, its less violet wings, the less upturned border of the $2 \mathrm{~d}$ abdominal segment, and in its livery, more rich in rellow (spot beneath the wing, spots on the scutellum, etc.); from the 0 . capra in its metathoracic excaration without border, in its smaller size, its more obscure wings, and the strong rugosities of the border of the $2 d$ and $3 d$ segment, etc.; from the $O$. Spinolæ, in the same characters, except that the wings of this last species are darker.

Hab. The United States. Pennsylvania. Illinois. Carolina. Connecticut ( 7 \%).

26. A. tuberculiceps SAdss.-Niger, grosse punctatus, piloso-velutinus; mandibulis, clypeo, oculorum marginibus, pedibus, pronoto, tegulis, scutellis, maculis subalaribus et metanoti, rufis; antennis rufis, superne apicem versus nigris; abdomine rufo, segmentis flavo margi- 
natis, 10 et 20 basi nigrescentibus ; secundi margine perrugoso, maxirue canaliculato, et reflexo; alis ferrugineis apice inquinatis.- $-\hat{\delta}$. Clypeo flavo, bidentato; vertice tuberculo nitido instructo.

Odynerus tuberculocephalus ${ }^{1}$ SAuss. Vespides, I, 139, 22 ; pl. xvi, fig. 9, $10 a$.

Odynerus tuberculiceps, Ibid. III, 205.

$$
\begin{aligned}
& \text { ․ Total length, } 13 \mathrm{~mm} \text {; w wing, } 11 \mathrm{~mm} \text {. } \\
& \hat{\delta} \text {. Total length, } 9 \mathrm{~mm} \text {; ; wing, } 8 \mathrm{~mm} \text {. }
\end{aligned}
$$

Clypeus pyriform, strongly punctured, truncate, and subbidentate at the extremity. Head strongly and densely punctured. Behind the ocelli is a little, indistinct tubercle, shaped like a 4 th ocellus. Anterior ocellus very large. Thorax cribrose with large distinct points. Angles of the prothorax a little prolonged, subdentiform; scutellum divided by a groove. Concavity of the metathorax appearing punctured or rugosely striate, according to the way in which it is seen, with the borders perfectly rounded; there is only a little border at the summit in a feeble arch. Abdomen punctured; the 1 st segment narrower than the $2 \mathrm{~d}$, bordered by a slightly salient cordon; the $2 d$ having its margin very strongly annulate, very strongly upturued, and very rugose, a little sinuate in the middle.

Insect clothed with long gray or ferruginous hair, abdomen velvety. Head and thorax black. Mandibles, clypeus, a dot upon the front, border of the eyes, interrupted at the summit, prothorax, scutel, wing scales, two spots beneath the wings and two others on the metathorax, of a ferruginous red. Mesothorax with two red lines. Abdomen ferruginous, with the base of the second segment and the anterior face of the first, blackish. Posterior border of all the segments margined with yellow, but this color often passing into ferruginous on the last segments. Legs ferruginous; femora black or spotted with ferruginous. Antenux red, with the second moicty black above. Wings washed with ferruginous, with the end brownish.

$\delta$. Notably smaller. Clypeus bidentate, notehed, yellom, as well as the mandibles and a line on the scape of the antenna: the flagellum with more of black; hook very small, forruginous. Tubercle on the vertex very much larger than that of the fomale, distinct and shining. Concarity of the metathorax pmetured, with little or no superior border. Abdomen a little more com- 
pressed at the base of the second segment, the middle of segments 1 st, 2 d generally black, the red less dereloped. Legs often varied with yellow.

Var. The middle of the prothorax a little yellow. The black encroaching upon the red. The scutels often black, bordered with ired; the metathorax also often wholly black; the sculpture of this last appears also to rary somewhat; at times the red is more dereloped. Metathorax red; flanks varied with red.

Ress. a. diff.-Tarious Odynerus, properly speaking, are often identical in color with this. Such are the O. Morelize and Guerreri, but they may be sufficiently distinguished from it by the absence of the tubercle on the rertex and of the suture upon the 1st segment.

The O. tuberculiceps hardly differs from the O. Sutterianus, but by a less brilliant lirery and by its prothorax slightly retracted and angles less salient.

$H a b$. The temperate regions and the plateau of Mexico. I have found this Oilynerus common in the most rarious localities. In the eastern Cordillera ; in the ralleys of Orizaba and of Jalapa, of Urero; in the Sierra Madre; in the ralley of Mextillan; in Huasteca on the Pacific slope, and in the prorince of Mechoacan, about Morelia, Tuxpan, Zinapecuaro, Patzcuaro, and finally on the plateau in the valley of Mexico. $16 \%, 18 \mathrm{~s}$.

2\%. A. Sutteriauus n. sp.-Niger, O. tuberculicipiti simillimns; vertice tuberculato, pronoto valde biangulato; abdominis spcundi segmenti margine canaliculato, rugoso, reflexn; antenuis aurantiis, apice supra nigris; ore, clypen, fascia post-oculari, frontis macula et lineolis 4, pronoto antice; tegulis, macula subalari, post-scutello, maculis 2 scutelli, tibiis tarsisque, sulfureis ; abdomine sulfureo, segmentis 10,20 , basi nigris; alis ferrugineis, apice griseis.

Total length, $12 \mathrm{~mm}$; wing, $10 \mathrm{~mm}$.

9. Form and punctures exactly like those of the 0 . tuberculiceps; clypeus prriform, finely bidentate. The same tubercle on the rertex, appearing like a fourth ocellus, but the prothorax not retracted before, more square: the angles alone rery salient, direrging and prolonged, perhaps bluntly terminated, not forming a sharp spine; the abdomen a little more slender; the margin of the $2 \mathrm{~d}$ segment a little less strongly upturned; the border of 
the first segment preceded by a little stronger zone of punctures and its suture a little more salient. Horder of sergnents 2-4 sinuate in the middle.

Insect black, elothed with yellowish hair. Mandibles and clypeus yellow; this last very finely bordered with black and often offering on the summit a vertical black line. $\Lambda$ line behind the eyes, a spot on the front, and a little vertical line on their inner border beneath the ocular sinus; these are black. $\Lambda$ nterior border of the prothorax widely yellow; the yellow often encroaching upon the surface and extending along its linder borders. Tegulæ, a spot beneath the wing, Cost-scutel, two spots on the scutel, yellow. Abdomen wholly yehow; the ariterior face of the first segment black, as well as in rlepression at the base of the second and often a widened mark behind, on the first. Legs yellow, coxx and femora black. Anteunx orange; the scape before yellow and the last third black, or obscure above. Wing ferruginous, with the end gray. The markings are of a sulphur-yellow.

Var. Scape of the antennæ yellow with a black line abore.

§. Smaller. Clypeus yellow, bidentate. Antennæ large, terminated by a small look. Angles of prothorax very satient; border of $2 d$ segment very rugose, more strongly reflexed; 1 st and $2 d$ segment with a great black square notch (variable), the following segments black, bordered with yellow. Anus black.

Ress. a. diff.-This Odynerus may be almost considered as a California variety of the $O$. tuberculiceps, in which the red markings have passed into yellow, all becoming reduced; the metathorax being black, etc. This insect presents, like the $O$. sulfureus and like the Californian Polistes, a striking example of the local influence of California which tends to give to insects a uniform sulphur-yellow color by the angmentation in extent of the yellow ormaments and the reduction of the deeper color.

Hab. California. I owe twenty individuals to the kinduess of Mr. Sutter and of Mr. Berton.

28. A. Dillosus Sauss-Niger, longe nigropilosus, hirsutus: prounto angulato, metanoto utringue tenuissime hidentato; prini abilominis segmenti sutnra in facie antiea sita ; $2^{i}$ segmenti margine ralide punetato; puncto frontali, prouoti margine, fascia interrupta in seutello et in post- 
scutello, tegulis, abdominisque segmentorum $1^{\mathrm{i}}, 2^{\mathrm{i}}$ margine, allidis; alis vix infumatis.- $\delta$. Clypeo albido truncato.

Ollynerus pilosus Sauss. Et. Vespides, III, 218, 111 (1S54).

Hab. Peru. (Type in the museum of Paris.)

c. Abclomen not as sessile; its first segment narrowed, distinctly narrower than the second, which is in the shape of a hawk's bell, with a reflexed margin. Metulhorax not excavated in the form of a wide cavity, but of a wide channel.

29. A. Arista SAUSS.-Medius, niger, argenteo-sericeus; puncto frontali et post-oculari flavo; thorace punctato; pronoto valde biangulato, in medio flavo-notato; metanoto convexo, in medio canaliculato-diviso; abdomine haud sessili, primo segmento late infundibuliformi sutura angulata, secundo ventricoso, margine maxime canaliculato, rugoso et reflexo; segmentis omnibus flavo-marginatis; alis ferrugineis.- $\hat{\delta}$. Clypeo flavo, bidentato; antennis subtus ferrugineis, scapo flaro-fasciato.

Odynerus Aristce Sauss. Revue Zool., IX, 1857, 274.

$\hat{\jmath}$. Total length, $12 \mathrm{~mm}$; wing, $10 \mathrm{~mm}$.

Size moderate. Form wide, stubbed. Prothorax armed on each side with a strong tooth, its anterior border wide and turned up. Post-scutel blunt. Metathorax forming two convexities, swelled, separated by a profound striate furrow, which is divided by a rertical carina; the convexities bordered exteriorly by the lateral edge of the metathorax which is prolonged as far as its inferior extremity. Abdomen quite misshaped; the first segment widely bell-shaped, the suture very distinct, not being straight, but forming in the middle an angle directed backward; its superior face short and wide, the posterior border formed by a cordon, along which is a line of punctures. Second segment widened and a little retracted posteriorly in the form of a hawk's bell; its posterior border very strongly canaliculate, very strongly upturned, undulating in the middle. Head densely, thorax more strongly but less densely punctured. First segment of the abdomen slightly punctured near its border; the second segment very much so toward its hinder part, and cribrose with rugose punctures in its strong flutings; the following segments having the borders punctured, especially in the middle.

Insect black; all its body covered with a beantiful silvery velvet pile, above all on the abdomen which has beautiful reflec- 
tions. A spot on the front, one behind the eye, a little line in the middle of the prothorax, yellow. 'Tegula black, bordered with brown. All the segments of the abdomen regularly margined with yellow; the first carrying but one narrow yellow band; the second widely bordered. Legs black, knees, tibixe, and tarsi varied with ferruginous. Wings washed with yellowish, with the end grayish.

$\widehat{\delta}$. Clypeus yellow, wider than long, notched in a half circle and strongly bidentate; its teeth quite removed. Labrum and mandibles yellow. Antennæ black, terminated by a little book, ferruginous beneath, with a yellow line on the scape.

Ress. a. diff.-A species very distinct by its form, by the angular suture of the first segment and by the very deep flutings of the second; by its slightly sessile abdomen and its watery reflections. By its velvety reflections, this species recalls the $O$. Parredesi, but its forms are entirely different.

Hab. The temperate regions of Mexico. I took two males about Yautepec in the south of the province of Mexico.

\section{Division STENANCISTROCERUS.}

Sadssure Vespides, I, Sect. 1, c, p. 140 ; III, Sec. 2, p. 129.

Form lengthened; body slender and cylindrical, rather than depressed. Prothorax little retracted or none, angulate; abdomen cylindrical or campanulate, often little sessile. First segment bell-shaped, rounded before, or cupuliform, or in the form of a truncate or subpediculate bell; 'often lengthened, its two faces frequently not being distinctly separated, but passing from one to the other convexly; the suture variable, often irregular, either a little salient or followed by a transverse fluting, often placed on the anterior face. The whole insect strongly punctured; the abdomen in most cases coarsely punctured.

The insects of this division are remarkable by their elongation, and by their cylindrical or compressed form. The clypeus is generally narrower than in the Ancistroceress, properly speaking. The thorax is arched above, cribrose with great punctures, and the grooves of the mesothorax, in gemerial, wholly wanting. The tegule are large and closely fitted, contaning the arch of the back, and behind these one secs an apophyse or 
appendix, and on each side of the scutel is a distinct depression. While in the true Ancistrocerus the post-scutel is nearly always truncate posteriorly, having a posterior face (with rare exceptions), ${ }^{1}$ in Stenodynerus it is not truncate but angulate posteriorly ; the metathorax being produced a little beyond the post-scutel and not so sharply truncate posteriorly, fiom which circumstance the posterior angle of the post-scutel is not cut off. The posterior plate of the metathorax nerer offers a basin regularly bordcred as in the true Ancistrocerus, and with spiniform angles. The abdomen is in general strongly punctured; ${ }^{2}$ the first segment being also as much or more strongly punctured than those following. This segment is sometimes conrex, rounded, at times divided into two distinct faces by the suture as with the true Odrnerus; but the superior face is often narrow and lengthened, not short and wide as in the true Ancistrocerus.

The suture is often placed at once on the declirity of the anterior face of the first segment. It is subject to become indistinct, so that one dues not know whether to consider it as a suture or a simple line of rugosities. Among certain species one perceires a double rugose line and between the two lines a sort of fluting, so that the segment appears to have two sutural lines.

The Stenancistrocerus hare an appearance, which, when it is known, permits one to distinguish them quite easily from the true Ancistrocerus, the form being wider and more flattened. But they resemble in so striking a manner certain Stenodynerus, that one can confound them with these last, and there are rery many species of each group with forms so correspondent, that without the presence or the absence of the suture at the base of the abdomen, one would confound them specifically. (See the Odynerus of the Dirision Stenodynerus.)

In fine, I will indicate as an enipirical guide, what may serve to distinguish the Ancistrocerus, properly called, from the Stenancistrocerus; in the first the band on the 1st abdominal segment is in general either regular or widened on the sides, while in the second it is either regular or retracted on the sides.

1 Ancistrocerus cinqulalus Cress.

2 The species of South America, particularly those of Chili, often have the abdowen feebly punctured. 
Table to assist in the determinution of the species of Division STENANCISTROCELUS. ${ }^{1}$

1. Wings fuscous.

2. Body black, ornaments luteous or yellow.

3. No separate spots on the second segment.

3, 3. Two separate spots on the second segment.

2, 2. Body black and rufous.

30. $\{$ Aztecus.

31. quadriseclus.

39. dejectus.

36. histrio.

1, 1. Wings smoky or subhyaline.

2. The first abrominal segment rufous.

36. listrio. p 199

2.2.\%. Insect black and yellow (the fascir sometimes rufous).

4. Second abdoninal segment with a yellow spot on each side.

5. Segments 1st and 2d only, margiued with yellow.

6. Scutel yellow; first abdominal segment without separate yellow spots, narrow.

33. obliquus.

6, 6. Scutel black; segments 1 and 2 with yellow spots, about equally wide.

38. $\{$ scecularis.p. 202

39. dejectus.

5, 5. More than two segments margined with yellow.

Segments 1, 2,4, margined with yellow. 42. occidentalis.

Segments 1, 2, 5, margined with yellow. 39. dejectus.

Segments 1-5 margined with yellow. 43. Paraensis.

4,4. Second abdominal segment without yellow spots.

5. First abdominal segment with a lateral spot on fascia anteriorly.

37. $\{$ fulipes.

40. $\{$ Bravo.

5,5. First abdominal segment without lateral separate spot.

6. Only the first two abdominal segments margined with yellow or luteous.

7. Anterior margin only of prothorax adorned with yellow.

Species of South Ameriea.

34. incommodus.

Species of Mexico.

40. Bravo.

Species of Chili.

\{ ambiguus.?

35. $\{$ scabriusculus.

7, 7. Posterior margin of prothorax adorned with yellow.

32. Furiasi.

6, 6. More than two yellow fascix.

7. Anterior margin of prothorax yellow. 41. Gruzmani.

7, 7. Posterior margin of prothorax yellow, or prothorax quite black.

44. Sumichrasi.

I Compare also the tables of Division Ancistroccrus, prop. dict. (page 158), and of Division Stenodynerus.

2 Vide supra, Division Ancistrocerus, prop. dict. p. 159, 9, et 10:2, 9. 
1. Form lengthened. Metathorax prolonged horizonlally behind the post-scutel, then truncate vertically; offering above, in the rear of the post-scutel, a sort of carity limited posteriorly by a vertical plate divided by a fissure. First abdominal segment entirely sessile, wide, distinctly truncate anteriorly, so as to form a sharp transierse ridge, its suture indistinct, especially in the middle. Tertex of the females offering tuo little mammx. filled with hair. Iales nearly as large as the females. ${ }^{1}$

(Group of the 0 . quadrisectus.)

(Satss. Tespides, I, p. 145. Sect. 21.-Division Pseudodynerus.

Ibid. III, 220.)

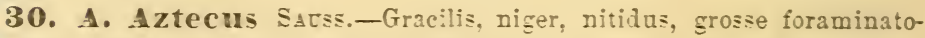
punctatus; rertice arcubus duobus penicillatis instructo; metanoto pone post-scutellum producto, postice foreolato, superne cristnlam per fissuram divisam ferente; abdomine dense punctato; antennis subtus ferrugineis, scapo flaro-lineato; mandibulis, tibiis anticis, puncto frontali: clrpeo $q$ lineolis 4,5 omnino. pronoti et abd. sesmentorum 1, 2 margine, post-scutello, macula subalari, metanoti punctis 6 , et primi segmenti puncto utrinque, luteis; alis infuscatis riolaceis.

Odynerus Aztecus $S_{\text {arss. }}$ Rerue de Zool., 1\$57, 275.

Total length, $15 \mathrm{~mm}$; wing, $15 \mathrm{~mm}$.

․ A species closel r allied to the 0.4 -sectus, haring the same form, bnt smaller. Clypeus prriform, rery coarsely punctured, with a depressed point, and carring toward the apex a rertical groore. Head and thoras polished, cribrose with great holes. On the rertex, behind the ocelli, one sees two tubercles of brown hair: or a double bush of hair surrounding a smooth space. Anterior border of the prothorax slightly concare; its angles sharp. Metathorax not retracted behind; its superior face cribrose with strong punctures like the remainder of the thorax. Its concarity smooth, excarated, finel p punctured, with blunted horders, except at its superior extremits, where it is terminated br a little rertical plate. Abdomen quite slender: its first seg-

1 In the third rolume of my Etudes sur la Fam. de Fespides, p. 220. I hare placed in this Dirision the O. luctuosuc, but it roult be better placed in the Suhgenus Odrnerus. (See below the corresponding Section formed. by this species ) 
ment cribrose with punctures of a little less size than those of the thorax, its suture distinct; near to its border, a badly marked depression. The remainder of the abdomen less strongly and densely punctured; the punctures throwing forth some short, gray hairs.

Insect black. Antennæ ferruginous above. Mandibles before, borders of the summit of the clypeus, two little lines toward its base, a dot on the forehead, scape of the antennæ before, border of the prothorax, a large spot beneath the wing, a dot on the wing scale and its posterior appendix and post-scutel, of a pale yellow. One sees in addition, six yellow spots on the metathorax, two at the sides of the post-scutel, two on the angles of its posterior plate, and two lines at the top of its concavity. Segments 1,2 , ornamented with a border of the same color, narrow, submarginal, and at times interrupted on the $2 \mathrm{~d}$ segment; the first adorned in addition with two lateral dots which at times join themselves to the border. Legs black, tarsi brownish, anterior tibiæ yellow before. Wings of a transparent brown with beautiful violet reflections.

§. Clypeus bidentate, yellow, with a very fine black edging all around it. Vertex with no hairy tubercles. A pale yellow spot on the front. Hook of the antennæ brownish.

Var. The yellow markings more or less extended; the bordering of the prothorax interrupted, and the concavity of the metathorax bordered with whitisl.

Hab. The coast of Mexico. I caught $q \delta$ near Tampico.

31. A. quadrisectus SAY.-Validus, gracilis, grosse foraminatopunctatus; clypeo apice truncato; corpore albido-variegato; maculis 2 magnis promoti, macula subalari, post-scutello, maculis 2 magnis metanoti, abdominisque segmentorum, $]^{\mathrm{i}}, 2^{\mathrm{i}}$ limbo, albidis; primo superne albido, macula nigra; alis nigro-violaceis.

Odynerus quadrisectus SAY, Bost. Journ. I, 1837, 355, 1.-SAUSS. Et. Vespides, III, 206.1_SAY's Entom. (LE Contr), II, 765, 1.

Odynerus Bellone Lerei St. Farg. Hymen. II, 660, 40 (1S 41 ). - SAUss. Et. Vespid., I, 146, 32, pl. xvi, fig. 10, ․

Total length, $20 \mathrm{~mm}$.; wing, $16 \mathrm{~mm}$.

1 The variety fig. 1 . c. pl: ix, fig. 9, $q$, is quite a different species. Comp. Monobia maxillaris. 
q. Of a shining black, closely allied to the form of the $O$ Aztecus, but larger, and with the whitish markings more developed. Upon the rertex two tubercles of brown hair. Body equally cribrose with great punctures, but the metathorax insensibly retracted behind; and its rertical plate a little more elevated. The second segment a little more swelled above, so as to imitate a sort of indistinct tubercle. Mandibles often spotted with yellow at their base. Clypens black, ornamented toward the top with two lateral yellow lines, its inferior extremity truncate and cut out into a furrow rather than a groove. A line on the scape of the antennæ, a spot on the forehead, two great triangular spots on the prothorax, a spot beneath the wing, two dots on the wing scales, post-scutel, two great slashed spots on the metathorax and the border of the first two segments of the abdomen, whitish. The first segment yellow above, with a triangular black spot or having at least two lateral spots reunited with the bordering. Wings brown with riolet reflections.

s. Clypeus of the same form with that of the female, offering at the summit a white are and below two white lengthened spots (or almost entirely white); this color terminates toward the bottom in four teeth and often presents in the middle a black dot. Hook of the antennæ ferruginous. No little hairy mammæ on the rertex.

Var. a. Two yellow spots on the scutellum.

b. Post-scutel black. Two yellow spots on the prothorax and two on the metathorax; only two yellow spots on the border of the second segment of the abdomen (Sauss. Tespides, III, pl. ix, fig. 9). This last variety may be noted as like that of St. Marte in Columbia, in South America. It may very well be a distinct species from the 0.4 -sectus.

$H a b$. The United States, especially at the South. I possess specimens taken in Louisiana, Florida, Carolina, Tennessec, Pennsylvania.

Ress. a. diff.-This species differs from the O. Aztecus, by the entire border of the clypeus, by its black antennæ and feet, by its greater size, and by its always more extended ornaments. These are in general whitish, at times of a pale golden. It bears a great resemblance at times to the $O$. luctuosus. 
2. Form very slender. Melathorax not so distinctly produced behind the post-scutel; its concavily large, limits rather well defined. First abdominal segment elongate, bell-shaped, having a distinct suture.

(Group of 0 . histrio.)

A. First segment of the abdomen rather funnel-shaped or bellshaped, truncate anteriorly.

32. A. Friasi Sauss.-Sat minutus, gracilis, foraminato-punctatus ; pronoto bidentato, inetatioracis foveola grosse punctata, angulata; abdominis primo segmento infundibuliformi, basi truncato, secundo angustiore; antennis et tarsis subtus ferrngineis; pronoti marginibus tenuissime albido-limbatis, post-scutelli limbo antico, nacula subalari, lineolis 2 in metanoti canthis abdominisque vittis 2, albidis.- $\delta$. Clypeo albido, elongato, bidentato.

Odynerus Farias Suuss. Rev. de Zool., 1857, IX, 274.

$$
\text { 오. Total length, } 11 \mathrm{~mm} \text {.; wing, } 8 \mathrm{~mm} \text {. }
$$

․ Slender, lengthened. Head densely cribrose with great punctures. Clypeus bearing some great shallow punctures, strongly bicarinate toward the bottom. In impressed point on the vertex. Thorax smooth, cribrose, with holes slightly separated; metathorax rugose above. Prothorax scarcely retracted before; its anterior border concave; its angles spiniform. Metathorax retracted and slightly prolonged behind the postscutel, then truncate; its posterior plate forming rather a truncation than a concavity; this plate a little triangular; widened at the summit, retracted below, its form sharply defined, although with little or no border; having its latero-inferior borders armed with a trenchant edge directed backward, and which terminates inferiorly in two strong teeth between which fits the base of the abdomen; the contour of the cavity angulate, forming on each side a sharp angle, but which is not detached in the form of a tooth; the smmmit of the plate cribrose with great punctures, but the lower portion is excavated into a striate furrow, punctured, and divided by a vertical earina. The whole plate defined in a manner comparable to a donble pentagon, eharacteristic of the Ancistrocertas, properly called (comp. p. 157, ex. (). capra), but here the pentagon is lengthened, higher than wide. Abdomen lengthened, the first segment prolonged, bell-shaped, 
but truncate before, narrower than the $2 \mathrm{~d}$ segment; its superior face lengthened trapezoidal, offering at times a trace of a longitudinal groore; the suture distinct, placed on the anterior fourth of the segment, but clearly separating the anterior and superior faces. Second segment prolonged, slightly retracted at its base; its surface cribrose with great, slightly separated, punctures, more crowded toward the posterior extremity; the following segments finely punctured. Border of the 2 d segment not channelled.

Insect black, with some gray reflections. Antenure ferruginous beneath. A dot on the front, an edging ornamenting the anterior and the posterior border of the prothorax, a line on each side on the ridges of the metathorax, the anterior border of the post-scutel and a spot beneath the wing, whitish, or pale-fawn color. Posterior border of abdominal segments 1 and 2 ornamented by a whitish cordon; that of the $2 \mathrm{~d}$ segment rery slender. Knees and tarsi slightly ferruginous. Tings hyaline or washed with brown. Tegulæ bordered with ferruginous; their appendix very wide, squamiform, Jellow.

Var. Two spots or yellow lines on the summit of the clypens.

$\hat{\delta}$. Abdomen more rugose, also more of venter; the $2 \mathrm{~d}$ segment more swelled, and more compressed at its base; no little excaration on the vertex. Clypeus prolonged, terminated by two blunt teeth, whitish; the carina of the front, the scape beneath, and a line bordering the orbit as far as the bottom of the sinus, whitish. Antennæ fawn-colored beneath, with the last articles black; the hook black, lengthened and arcuate.

Ress. a. diff.-This species is rery remarkable in the structure of its metathorax. It approaches in its form to Symmorphus, the first segment being narrower than the second and campanulate, and the metathorax being truncate as in the Symmorphus; but it belongs distinctly to the subgenus Ancistrocerus, as is evident from the absence of the distinct diriding groore of the first abdominal segment, the erlindrical form of the thorax, the prothorax not retracted, the kind of punctures, the pyriform clypeus, and the presence of a large hook on the antennæ of the male; the mesothorax offers no more longitudinal groores; the post-scutel is not rugose, nor the $2 d$ segment smooth as with the Symmorphus. It has quite the form of the 0 . incommodus, but 
is distinct from it in not having the border of the $2 d$ segnent at all turned up.

Hab. The Mexican coast. Tampico and the barrancis of the Cordillera. 15 \%, 12 .

33. A. obliquus Cress.-Niger, nitidus, sulfureo-multipictus ; antennis basi flavis; pronoti angulis in dentem productis ; netanoto postice planato; abdominis segmentis 1020 late fiavo-marginatis; 20 basi flavo. himaculato; 10 valde punctato, valde angustiore quam secundum; sutura distincta; alis rugulosis, costa et stigmate ferruginescentibus; macula radiali fusca.

Odynerus obliquus Cress. Philad. Ent. Proc., IV, 1865, 163.

Total length, $8.5 \mathrm{~mm}$; wing, $6.5 \mathrm{~mm}$.

$\hat{\delta}$. Small, punctate, very shining. Head circular. Thorax rather attenuated behind; prothorax square, polished; its angles rather dentiform; scutels flattened, polished; metathorax polished, but slightly punctatc, flattened behind, destitute of lateral angles, with the lateral carinse not very sharp. Abdomen slender; the first segment small, half as wide as the second, rather elongatcbell-shaped, punctate like the thorax; bearing an obsolete depression; its suture very distinct. Second segment ovate, as long as wide, with effaced or delicate punctures, subtuberculate above.

Black. Antennæ fulrous beneath; the first two joints yellow, mandibles ycllow; the forchead between the antenna, sinus of the eye, and a broad margin behind them, sulphur-yellow; a broad anterior margin on the prothorax; the large tegule, a large spot beneath the wing, scutel, post-scutel, angles of metathorax, a broad marginal fascia on the border of the first two abdominal segments, and a spot on each side at the base of the secoud segment, sulphur-yellow. Feet yellow; coxæ black, the 1st and 2d pair yellow anteriorly; posterior coxie and femora black. Wings subhyaline, cloudy, principally at the extremity, with a dark cloud in the radial cell; the anterior costa and the stigma rather ferruginous; sometimes the wing is ferruginous with its apex smoky.

9. Clypeus pyriform, punctate, bidentate, yellow, with its apex black.- $\delta$. Clypeus yellow, rounded-pentagonal, teminated by two little triangular teeth, scparated by a triangular noteh. The yellow margin of the second segment is wide and resular ; that of the first not so wide and rather narrowed on the sides. 
Ress. a. diff.-In its size and colors, this has rather the appearance of $O$. cingulatus, but is rery distinct from it in its more slender body; its metathorax, without bordered cavity ; its narrow first abdominal segment, with the yellow margin narrowed, not widened at the sides, and in the two yellow spots of the $2 \mathrm{~d}$ segment. These spots and the partly ferruginonsly tinged wings distinguish it from all the other Stenancistrocerus.

Hab. Cuba (Dr. Gundlach).

\section{A. incommodus Sauss.}

Odynerus incommodus Sauss. Vespides, I, 143, 29, $ో, 1852$.

O. tolteco affinis species at diversa.

Hab. America meridionalis. Columbia (Typus in mus. Parisiensi).

B. First segment of the abdomen in form of a prolonged bell, rather squarely-rounded, about as wide as the second segment, not contracted before.

a. Fïst segment sharply truncate anteriorly.

35. A. scabriuscuinus Spix.-Parvulus, niger, gracillimus, elongatus, cylindricus, valde punctatus; clypeo $\$$ convexo, punctato, apice truncato ; thorace elongato, antice lato, bidentato; postice angustiore; ubique grosse punctato; metanoti rugosi foveola punctata marginibus rugosis, superne canthis prominulis acutis marginata; his a post-scutello per fissuram sejunctis; abdomine gracillimo, cylindrico; primo segmento basi distincte truncato, supra grosse punctato; secundo elongato, dense punctato; haud latiore quam primum, margine hand rugoso; antennis subtus ferrugineis; puncto frontali et oculari, pronoti marginis antici fascia sinuata, macula subalari, tegulis, post-scutello, abdominisque segmentorum $1^{i}$, $2^{\mathrm{i}}$ limbo albidis; tibiis extus albidis. Alis hyalinis. Longit. $7.5 \mathrm{~mm}$.

$\widehat{\delta}$. Clypeo emarginato, albido; fascia in scapo et orbitarum margine interno, albidis.

Odynerus scabriusculus Spivola, in Gay's Hist. fisica de Chile. Zool., VI,

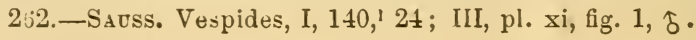

Hab. Chili.

This Odynerus is remarkable by its very slender form and by its first abdominal segment being sharply truncate, in such a

1 Page 141, in place of : ferrugineux, read fortement ponctue. 
manner that there exists one anterior and one superior face, distinctly separated by a trenchant ridge which bears the indistinct suture. This segment is not campanulate, but almost as wide before as on its posterior border. ${ }^{1}$ The $2 \mathrm{~d}$ segment is hardly wider than the first.

b. First abdominal segment more rounded anteriorly, rather like a square bell. (Melathorax slightly prolonged behind the post-scutel; then truncate; its concavity rounded. Body rugose.)

36. Anistrio LeP.-Gracillimus, rugosissime punctatus; metanoto rngosissimo profunde foveolato, foveolæ canthis valde prominentibus et acutis; niger, antennis, macula frontali et oculari, pronoto antice, tegulis, macula subalari, post-scutello, metanoto utrinque, abdominis primo segmento pedibusque rufis; alis eyanescentibus.

Variat. Post-scutello et abdominis segmentorum $1^{\mathrm{i}}$, vel $1^{\mathrm{i}}, 2^{\mathrm{i}}$ margine, amantiacis.

Odynerus histrio LEP. St. Farg. Hyménopt. II, 638, $23^{2}$ (1841).-SAUsS. Vespides, I, 208, 112; III, 242.

?Odynerus ammonia Sauss. Vespides, I, 144, 30 (1852).

Total length, $11 \mathrm{~mm}$; wing, $9 \mathrm{~mm}$.

ㅇ. Form very slender and lengthened. Clypeus pyriform, rugose, terminated by a little biangulate border, appearing bidentate, because of a terminal fossette. Head densely and strongly punctate; thorax coarsely cribrose, with very large depressed points; the punctures a little separated; prothorax slightly retracted before, subangulate; metathorax retracted, rounded, but its hinder plate very strongly excavated, offering a fossette, punctured, rugose, bordered all around by very salient and trenchant ridges, of which the summit is notched and sometimes separated from the post-scutel by two grooves. First abdominal segment lengthened, a little narrower than the 2d; its superior face very rugose, as strongly cribrose as the thorax, but more densely; covered like the metathorax with enormous reticulate rugosities, and offering a vague depression on its anterior part; its irregular snture, placed but a little on the anterior face and often followed by a fluting. Second segment prolonged and slender, strongly punctured; its border very coarsely punctured.

1 In the fig. eited, this sogment is badly represented; it has not this roumded form.

2 Page 639, in place of 3 lines, read 5 lines. 
Insect black. Mandibles, summit of the clypeus, the first two or three articles of the antennæ, a spot on the forehead, the inner border of the orbits, or a spot in their sinus, a spot behind the summit of the ere; two spots on the prothorax, tegula, a spot under the wings, post-scutel, angles of the metathorax, first segment of the abdomen, and feet, red; bordering of the first two segments of the abdomen, rellow. Wings brownish, with riolet reflections.

Tar. a. Clypeus wholly red.

b. Second segment entirely black; ouly presenting an interrupted border.

c. The ridges which border the fossette of the metathorax blunt, interrupted on the summit. The suture of the first segment effaced by the punctures. Punctures notably less coarse. (In general, some small females with the 2d segment bordered with yellow.) Wings only smoky toward the end.

o. Sculpture rers coarse. Clypeus punctate, shortly bidentate, pale rellow or orange. Scape of the antenuæ often adorned with an orange line; the flagellum like that of the female, or wholly black, or ferruginous beneath in its first moiety; hook black. Size as with the female.

Tar. A. Post-scutel rellow. The oruaments of the head and those of the anterior part of the corselet, orange or yellow. Their size rariable.

$B$. Metathorax entirely red.

$C$. No pellow band on the first segment; its base black.

D. The prothorax almost entirely red.

$E$. Second segment adorned with two yellow dots. (The $O$. ammonia.)

Pess. a. diff.-This species is distinct by the coarseness of the punctures, by the strength of the ridges of the metathorax, and by the red ormaments of the body.

Hab. The Southern Cnited States. Carolina. Florida, etc. 5 \&, $4 \delta$ (E. Norton).

Observation. - We hare not before our eres a specimen which corresponds to our description of the O. ammonia Sauss., in which the $2 \mathrm{~d}$ abdominal segment is ornamented with two yellow spots and the suture of the first rery indistinct or wanting. Te think, howerer, that this Odrnerus is but a rariety of the $O$. histrio. 
3\%. A. fuvipes SAuss.-Niger, elongatus, cylindricus, crassissime punctatus, flavo vel rufo multipictus, frequenter $q$ macula mesonoti Slava; abdominis segmentis valde punctatis 10,20 , limbo flavo; primo insuper utrinque fascia flava, et sutura elevata distincta; secundi margine paulum canaliculato, paulum reflexo.

Odynerus flavipes Sauss. Vespides I, 142, 27 (Syn. excl.); pl. xvi, fig. 3 , १, 1852 ; III, 205.

Odynerus fulvipes Sauss. Vespides, III, 205 (1854).

Total length, $12 \mathrm{~mm}$.; wing, $9 \mathrm{~mm}$.

․ Form very slender, lengthened, cylindrical. Clypeus pyriform, slightly truncate at the extremity, very coarsely cribrose, especially toward the bottom. Head coarsely punctured. Thorax quite cylindrical, arched, very coarsely cribrose. Prothorax finely rimmed; its angles a little dentiform, directed forward. Metathorax slightly prolonged behind the post-scutel; its hinder plate strongly concave in all its width, strongly punctured; its borders a little trenchant or blunted by the very large reticulate holes which occupy the superior face of the metathorax, forming sometimes at the summit two ridges separated from the postscutel by a fissure. Abdomen cylindrical, the first segment bellshaped, lengthened, as wide as the second; its suture distinct, but placed upon the declivity of the anterior face, and often followed by a groove; $2 d$ segment cylindrical, not swelled, nor wider than the 1st. The first two segments strongly punctured throughout the length of their posterior border, the border of the $2 d$ lightly reflexed. The $2 d$ segment offers some very large sparse points beneath. The $3 d$ segment is cribrose with immense depressions, especially in the middle.

Insect black; a spot on the mandibles, an are on the summit of the clypeus, a line on the scape of the antenna, a spot on the forehead, one in the sinus of the eyes, one behind each eye, an interrupted border on the prothorax, a spot under the wing, another at the base of the disk of the mesothorax before the scutel, post-scutel, angles of the metathorax, regular border on the 1st and 2 d segments of the abdomen, and two oblique lines on the sides of the first, orange. Tegula red, spotted with yellow; their appendix yellow. Iegs black, knees, tibie, and tarsi orange. Wings tramsparent, smoky, a little violet toward the end.

Tar: a. No yellow spot before the seutel.

b. Clypeus, metathorax, and femora black. 
c. The markings pale yellow; no spot before the scutellum.

d. Some indiriduals from Florida have all their markings orange or blood red. The wings are a little more smoky. These specimens are also more strongly cribrose, more rugose; the first moiety of the antennæ is reddish with a black line on the scape. One sees on the first segment a transverse fluting which passes along the suture, especially distinct upon the sides, at times effaced in the middle. As one finds all the transitions of our type in these indiriduals, I have concluded that it is but a simple variety, formed by a more perfect derelopment of individuals under the infuence of the heat of the climate of the southern districts. These individuals hare no mesothoracic spot before the scutellum.

$\hat{\jmath}$. Almost as large as the female. Clypeus prolonged, polygonal, bidentate, yellow or whiísh; its teeth slightly variable, at times black; inner border of the orbits yellow; spots of the metathorax small or wanting. Second segment of the abdomen a little wider.

Ress. a. diff.-This species is difficult to distinguish from the O. sxcularis and the O. pedestris. (See the description of these species.) In other things it closely approaches the $O$. vagus, $O$. conformis, which have almost the same marking, but do not offer any suture on the 1st abdominal segment; a little less similar also to the $O$. collega and Xantianus, which have, however, the $2 d$ segment more swelled and which finally offer no suture on the first abdominal segment.

One often sees the suture in this rariety become feeble, seeming then to form a transition to the 0 . vagus; nevertheless, the metathorax is always more rugose than in this species, and the punctures of its thorax are stronger also.

Hab. The Southern United States, Louisiana, Florida, Tennessec, Illinois. 5, $6 \hat{\delta}$.

33. A. sacularis Sadss.-Niger, elongatus, gracilis, cylindricus, grosse punctatus; flaro-multipictus; O. fulvipedi simillimus, sed metanoto rotundatiore, abdominis primo segmento grossius punctato, supra valde punctato, antice lævi, sutura rix perspicua; seymentis 1-4 flarolimbatis, primo insuper fascia interrupta flava et secundo macula utrinque flava.

Odynerus sæcularis SAc'ss. Et. Vesp., I, 142, 26. 
Form, sculpture, livery, almost identical with that of the 0 . fulvipes. The size may be a little less. In fact it cannot lue distinguished from this species but by the following characters.

Prothorax not having its angles dentiform. Concavity of the metathorax having its borders perhaps a little more coarsely punctured, more rounded. First ahdominal segment more strongly cribrose; its punctures as strong as those of the thorax. The suture feeble, but yet distinct. (The anterior face of the segment is smooth and the superior face is very coarsely cribrose with little or no channel along the suture.)

The livery differs by the yellow being a little more extended on the head, a wider yellow arc on the clypeus, and the yellow of the scape much extended at the base. Segments 3-4 also are bordered with yellow and the $2 \mathrm{~d}$ segment ornamented on each side near its base with a yellow spot; the two oblique spots of the first segment forming an interrupted band.

Var. Mesothorax above with or without yellow spot.

$\delta$. The metathorax is notably more rounded than with the $O$. fulvipes, and does not form two lateral angles. Clypeus, mandibles, inner bordering of the orbits, and the legs, yellow, as well as the femora. The remaining livery as with the female; the 1st segment ornamented with an interrupted band, and the 2 d with two lateral spots, yellow. No yellow spots on the disk of mesotliorax.

In spite of these differences the $O$. sxcularis may be but a var. of the $O$ fulvipes.

Ress. a. diff. - Naturally, this species has a rery great resemblance also to the $O$. conformis and vagus, but is distinguished above all by its first abdominal segment, of which the great punctures are suddenly arrested on meeting the anterior face of the segment so as to define the suture. It differs from the (). anormis by its more cylindrical abdomen, more strongly pune. tured, with the 1st segment more lengthened, adorned with two oblique bands and not with two yellow dots. Compare also the O. dejectus.

Hab. 'The Southern United States. $\& \delta$ from 'Tennessec.

Observation. - The O. fulvipes, sacularis, ragus, conformis are types which appear almost to pass from one to the oflee and of which it is diflicult to trace the precise limits. One should take notice of the first two for the rariations of the same species 
in which the suture tends to disappear or has itself well developed. See also the $A$. collega and Xantianus.

39. A. dejectus Cressox.-Niger, clypeo valde emarginato, superne flavo; capitis maculis, anteunarum scapo, pronoti margine antico, macula mesonoti et subalari, tegulis, post-scutello, metanoti canthis, abdoninis segmentorum $1^{\mathrm{i}}, 2^{\mathrm{i}}, 5^{\mathrm{i}}$, margine tibiisque, flavidis; primo abdominis segmento valde punctato, utrinque fascia obliqua flavida; zo utrinque macula flava; alis fusco-hyalinis. $q$.

Odynerus dejectus Cressox, Philad. Ent. Proceed. IV, 1865, 164, $q$.

Total length, 4.5 lin.

‥ Opaque black, deeply and closely punctured; a line behind the eyes near their summit, the sinus in front, a spot between the insertion of the antenuæ, and the basal half of the clypeus, deeply and squarely emarginate before, obscure jellowish; antennæ black, the basal joint, except the apical half above, yellow. Thorax; the anterior margin of the prothorax slightly interrupted on the disk, a small quadrate spot on the disk of the mesothorax posteriorly, tegulæ, a minute spot on each side just behind the tegulæ, a round spot on each side of the pleura, the post-scutellum, and an elongate mark on each side of the metathorax, yellowish. Legs black; tips of the four anterior femora, their tibiæ, and the posterior tibiæ, except tips, yellowish. Abdomen robust, not much contracted at base; basal segment roughly punctured, with a faint transverse suture at base, its apical margin bordered in the middle, continued along the lateral margin, and then produced to within about one-fourth the width of the segment, jellowish; second segment large, convex, shining, finely punctured, more strongly at the tip; the apical margin above and beneath, and a rounded spot on each side near the base, as well as the apical margin of the fifth segment, not quite reaching the sides, yellow. Legs black, tips of the four anterior femora, their tibiæ, and the posterior tibiæ, except their tips, yellowish. Wings fusco-hyaline, darker along the costa, darkest in the radial cell.

Ress. a. diff.-Closely allied to A. bacuensis, but it is distinguished by its more robust form, the spot on the disk of the mesothorax, the absence of bands on the fourth and sixth segments of the abdomen, its black scutel, etc.

It is still more closely allied to $A$. sæcularis, if not the same. Hab. Cuba. 
40. 1. ravo SAuss. - O. fulvipedi affinissimus, punctatissimús, niger, fulvo-pictus; abdominis segmentis 10,20 margine grosse punctato, fulvo; primo frequenter flavo-bipunctato, sutura distincta. $\$$.

Odynerus Bravo Sauss. Rev. de Zool., IX, 1857, 274.

Total length, $10 \mathrm{~mm}$; wing, $8.5 \mathrm{~mm}$.

q. The slender and lengthened form of $O$. fulvipes; size and puncturing the same. Clypeus pyriform, rugose, joined to the forehead by a vertical carina; its inferior extremity subemarginate. Angles of the prothorax acute. Concavity of the metathorax rugose, coarsely punctured; its border quite trenchant. Abdomen quite cylindrical; its first segment very great, as wide as the second; its sutmre distinct, at times elevated and followed by a groove. All the body cribrose with deep punctures forming regular pits; abdomen almost as strongly punctured as the thorax; the border of the first two segments insensibly depressed and more strongly punctured, but neither channelled nor reflexed. The following segments finely punctured.

The insect black. Nandibles brown; antennæ ferruginous beneath with scape below yellowish. A dot on the forehead, one in the sinus of each cyc, and another behind each cye, often a spot or an arc at the top of clypeus, the anterior border of the prothorax, a spot under the wing, the post-scutel, and the lateral edges of the metathorax, whitish (or changing into tawny). Segments 1, 2 of the abdomen adorned with a regular whitish border; first segment in addition on each side with a little oblique line, or a spot, of the same color; one sees also a spot on the mesothorax, before the scutellum Legs black; tibix and tarsi ferruginous. Wings transparent, washed with brown, above all in the radial and along the side. 'Tegula large, ferruginous or pale, as well as the apophyses placed behind them.

Var. Mesothorax, metathorax, and first segment without spots. Ress. a. diff.-This species is very near to the 0 . fulvipes. But this is a little smaller in size; and the thorax appears to me a little more densely punctured. The markings are also less abundant. However, one might consider it as a Mexiean rariety of the same species, a little smallex, as in general the Odynerus are smaller within the tropies, than in the north.

Hab. The coast of Mexico. I took $2 q$ at Pueblo-Vicjo near Tampieo; 2 o taken near Cordura (Sumichrast). 
3. Form slender, but the abdomen sometimes slender, sometimes ovoid, especially among the $\delta$. The first segment cupuliform, narrower than the 2d, having the suture indistinct, often presenting a transverse fluting bordered by two traces of sutures. ${ }^{1}$ Concavity of the metathorax generally small, its borders indistinct.

(Group of the 0 . occidentalis.)

The insects of this category offer at times two sutural lines on the first segment of the abdomen (the second usually interrupted) so that one feels the need of classing them in my Division Subancistrocerus (Tespides, III, 206; I, 126). But as all their affinities tend toward the group of the $O$. fulvipes, I think best to leave them in the same division. The sutures become wholly double in certain species or indistinct, so that one does not know whether or not to take them for simple rugosities and class the insects which carry them in the subgenus Odynerus (Division Stenodynerus).

a. Suture of the $f$ 'st abdominal segment rather strong; excavation of the metathorax somewhat distinctly margined.

41. A. Guzmani Sauss.-Parvulus, niger, dense cribratus; pronoto bidentato; metanoto perrngoso, foveola orbiculari punctata, snbmarginata instructo; abdomine valde punctato; primo segmento bisuturato; secundi margine maxime cribrato, subeanaliculato; prothoracis segmentorumque $1^{i}, 2^{i}$ limbo, post-scutello, puncto frontali et frequenter subalari, flavis; pedib.: fulvo-variis; tegulis maximis, flavo-marginatis.

Odynerus Guzmani Sauss. Rev. de Zool., IX, 1857, 275, $ో$.

Total length, $7 \mathrm{~mm}$; wing, $6 \mathrm{~mm}$.

§. Small. Prothorax wide; its anterior border concave, turned up, forming on each side a little tooth directed obliquely forward. Head and thorax before coarsely cribrose throughout. Scutel divided by a groove. Metathorax feebly prolonged behind the post-scutel, then vertically truncate, extremely rugose; its middle occupied by a circular concavity, shining and cribrose with punctures; a little rimmed, especially at the summit. First

1 Sometimes the two sutures are feeble and difficult to distingnish. It is necessary in that case to turn the insect into the proper light to perceive them. 
abdoininal segment cupuliform, notably less wide than the $2 d$, coarsely punctured and rugose; offering two irregular sutural lines, between which is a fluting or transverse furrow, apparently interrupted in the middle. Border of this segment thick. Second segment ovoid, swelled, but longer than wide, strongly punctured above, especially toward the border, which is a little retracted and channelled.

Insect black, clothed with a short grayish pile; a spot on the front, anterior border of the prothorax, post-scutel, a little dot under the wing, and a regular border on the first two segments, tawny-yellow: Tegulæ ferruginous, bordered with yellow, or yellow with a red dot. Legs black, tarsi and tibiæ varied with ferruginous or yellow. Wings sub-transparent, radius and radial cellule brown.

$\hat{\delta}$. Clypeus yellow, punctured, terminated by a split beak (or by two little separated teeth); bordered with black laterally. Antennæ black, with a yellow line on the scape.

Ress. a. diff.-This little Odynerus is easily recognized by its first abdominal segment fortified with two sutural lines. These sutures are but little salient and the second above all (posterior) can be known by the border of the fluting, rather than by a suture. Nevertheless I think the insect well characterized by the configuration of this segment.

$H a b$. The temperate parts of Mexico. Mextitlan.

I dedicate this pretty species to Don Jose Mariano Guznan, the Mexican naturalist whose amiable hospitality permitted me to explore the beautiful valley of Mextitlan.

42. A. occidentalis Sauss.-Parvulus, niger, punctatissimua, metanoti rugosi foveola rotundata, superne vix marginata; abdominis valde punctati secundi segmenti margine paulum canaliculato grosse punctato; puncto froutali et post-oculari, pronoti margine interrupto, macula subalari, tegulis, post-scutello, abdominisque limbo segmentorum supra 1 , $2,4,5,6$ et subtus 2,3 , flavis.- $\delta$. Clypeo bidentato, autennarum scapo antice, litura oculorum et pedibus, flavis.

Odynerus occidentalis Sauss. Rev. de Zool., IX, 1857, 274.

Total length, $6.5 \mathrm{~mm}$; wing, $5 \mathrm{~mm}$.

Size very small. Ifead circular. Ocelli large, aranged in a regular triangle. Antenne inserted below the middle of the head Thorax wide before; its angles quite sharp, ent at a right angle. Scutel parted by an indistinct longitudinal groove. Coneavity 
of the metathorax regular, in the form of a concave, punctured scullcap; its borders wholly rounded and punctured, without any spiniform angle; the superior part slightly bordered by an arcade. The latero-superior parts of the metathorax quite swelled and prolonging themselres a little behind the postscutellum. Abdomen wholly oral. First segment small, regularly cupuliform; the suture feeble, placed (about) on the anterior third of the segment; behind the suture an insensible fluting can be distinguished. Margin of the segment thick, followed by a little compression at the base of the second. Thorax deusely cribrose with great points. Metathorax very rugose. Abdomen strongly punctured; the second segment carrying along its border a zone of great punctures and rather narrowly channelled.

Insect black. A spot on the front, another behind eacls eye, the interrupted border of the prothorax, a spot under the wing, post-scutel, tegulæ, their apophyse annexed, and a spot on the mesothorax before the scutel, yellow. Segments 1, 2, 4, 5, 6, of the abdomen bordered with yellow abore; the third being only beneath, the second equally bordered beneath; this last carrying in addition on each side a yellow spot near its base; segments 4-7 brown beneath, without bordering. The borders regular. Legs yellow, black at the base. Wings a little smoky, having a great brown stigma.

$\widehat{\delta}$. Clypeus yellow, higher than wide, strongly punctured, polygonal, terminated by two long separating teeth. Mandibles, a long spot between the antennæ, the inner border of the orbits as far as the bottom of the sinus of the eyes, yellow; antennæ large and long, black, with the scape before rellow, the hook black; the haunches before, yellow. Extremity of the abdomen brown, a little ferruginous beneath.

Var. Tegulæ red. No spot on the disk of the mesothorax.

Ress. a. diff.-This little species is remarkable in the singular distribution of the borderings of the abdomen.

Hab. Western Mexico. Sonora, Michoacan (3 $\delta$ ).

13. A. Paraensis Sauss.

O. Paraensis Sauss. Vespides, III, 207, 95 (1851). ${ }^{1}$

Hab. Para (typus in Mus. Parisiensi).

1 In the description, p. 203 , line 5 th, instead of: huitieme cubitale, read: troisieme cubitale. 
b. Sulure of the first aldominal segment not so strong. Excavation of metrthorax having its edges rounded, without precise limits.

44. A. Sumnichrasti Sauss. + .-Gracilis, niger, grosse foraminato-cribratus; at metanoto parum punctato, huud rugoso, foveola parvula rotundata, haud marginata, post-scutellum attingente, instructo; abdomine valde punctato; primo segmento utrinque ad suturam parum perspicuam subcanaliculato; antennarum scapo subtus et pedibus partim, ferrugineis ; puncto mandibularum, frontis, summi clypei et post-oculari, fulvis ; post-scutelli fascia flava; abdominis segmentis omnibus late flavomarginatis. $q$.

Odynerus Sumichrasti Sadss. Rev. de Zool., IX, 1857, 275.

Total length, $9 \mathrm{~mm}$. ; wing, $7 \mathrm{~mm}$.

9. A species very near to the O. huastecus. Clypeus a little wider than long, bearing toward the bottom two salient carinæ which appear like two teeth, between which is a little slightly arcuate border. Thorax lengthened. Angles of prothorax distinct. Metathorax offering very trenchant lateral ridges; its concavity small, rounded, punctate, and striate, without defined borders, but extending as far as the post-scutel. Head and thorax very densely, strongly, and regularly punctured; the metathorax being notably less strongly so; the same offering a smooth space on each side of the post-scutel. Abdomen quite lengthened, the first segment cupuliform, almost bell-shaped, quite large, although smaller than the $2 \mathrm{~d}$, nearly as grossly punctured as the thorax, but smooth at its base, and offering an irregular, hardly sensible suture (especially visible when one regards the insect from before), which is not formed by a crest, but which is rather the result of the coarseness of the sculpture. Behind this suture the segment is creased on each side by a groove which makes a portion of the sculpture and of which the posterior bordel figures as a second interrupted suture. Second segment a little swelled above at its base, strongly punctured, above all toward its posterior border, which is not channelled but bordered by a light cordon. The following segments more finely punctured.

Insect black, covered with a gray pile, especially on the metathorax; a spot at the top of the mandibles, a dot at the summit of elypeus, another on the front, another in the sinns of each eye, and one behind the eyes, ferruginous; these dots often wanting 
or very small. Scape of the antenuæ beneath, tawny. Anterior border of the post-scutel, yellow; the rest of the thorax black, except a yellow dot on the appendix of the wing scale, and a rudiment of an edging on each side before the wing scale along the posterior border of the prothorax. All the segments of the abdomen widely and regularly bordered with yellow-golden; the first bordering more narrow, feebly notched in the middle. Legs black, tibiæ and tarsi varied with ferruginous. Wings transparent.

Var. The posterior border of the prothorax edged with yellow.

Ress. a. diff.-A species very distinct by its metathorax, smooth or at least more smooth than the rest of the thorax. Tery near to the little species of the group of $O$. huastecus; particularly above all by its thorax to the $O$. Peyroti, from which it hardly differs but by its narrower thorax and by the feeble suture of the first segment. It differs from the O. Fariasi, by its first abdo. minal segment cup-shaped, not truncate-funnel-shaped, and deprived of the crest-shaped suture; by its metathorax less rugose than the rest of the corselet, by its less slender form, etc. These last characters distinguish it also from the $A$. occidentalis, Guzmani, and the O. fulvipes, which have a more pronounced suture.

$H a b$. The temperate lands of Mexico. One female from the hot regions of the province of Mexico, near Cuautla (Morelos) taken by my friend Mr. Sumichrast.

\section{Division HYPANCISTROCERUS.}

(Hypancistrocerus Sauss. Et. Vesp., III, 222.)

Head swelled. Antennæ inserted low upon the face. Superior face of metathorax produced horizontally a little beyond the post-scutel, then vertically truncate, the posterior face having a deep orbicular cavity, with very sharp margins. Suture of first segment very salient.

This type presents the extreme form of the elongate and cylindrical Ancistrocerus. It forms a group corresponding to Hypalastoroides, by its slender body and the peculiar shape of its metathorax. 
45. A. advena Sauss.-Gracilis, cylindricus, punctatus, niger, thorace antice lato, angulato, postice attenuato; metatlorace panlum ultra postscutellum prorlucto, truncato, foveola superne semicirculariter acute marginata, margine utrinque infere angulato; 10 segmento angustiore quain $2 \mathrm{um}$, antice truncato; 20 superne basi coarctato, subtuberculato; antennis fulvis, flagello superne nigro ; capitis maculis, pronoti margine antico et postico, macula subalari et præscutellari, tegulis partim, metanoti abdominisque segmentorum marginibus anguste, flavis ; primi segmenti fascia utrinque lateraliter continuata; pedibus flavis, uigrovariis; alis infumatis. + . Longit. $9 \mathrm{~mm}$.

Odynerus advena Sadss. Et. Vesp. III, 222, 117; pl. xi, fig. 3, 4, ㅇ.

Hab.-Brasilia (Typus in Mus. Londinensi).

\section{Division ANCISTROCEROIDES.}

(Ancistroceroides Sauss. Et. Vesp. III, 221; I, 146, III Divis.)

Second cubital cell of the anterior'wing subpedunculate. (Metathorax excavated, armed on each side with a spine.) .

46. A. alastoroides SAuss.-Gracilis, niger; capite et thorace punctatis; clypeo $\delta$ bidentato; pronoto antice lato, quadratim secto, postscutello bituberculato; metathorace valde excavato, acute marginato, utrinque spinoso; abdomine sericante, in basi $2^{i}$ segmenti constricto; 10 segmento superne sulco partito; clypeo, puncto mandibularum, puncto frontali et post-oculari, orbitis internis, linea scapi, pronoti margine postico, macula subalari, linea utrinque metanoti infere et fascia scutelli, flavis; antennis subtus et tegulis fuscis; abdominis segmentis 10-30 flavo-limbatis; pedibus fuscis, flavo-lineatis; alis iniufumatis. $\delta$ Longit. $10 \mathrm{~mm}$.

Odynerus alastoroides SAuss. Et. Vesp. I, 147, 33, $\delta$.

Hab. Montevideo.

This species might almost be placed in the genus Alastor (subgenus Alastoroides), where it would form a section, characterized by the 2 d cell of the wing being subpedunculate only, and by the presence of spines on the metathorax. 
Subgenus ODYNERUS' LATR. (sensu strictiore).

Leionotus Sadss. Et. Vesp. I, 151.-O.lynerus propr. dict. Sadss. ibid. III, 223.

First segment of the abdomen without any transverse suture. Antennæ of males terminated by a hook, or simple (or a little iurled at the extremity, only in Hypodyncius). Mandibles of the males simple.

This subgenus contains insects of the most varied forms; types stubbed or elongate, with the abdomen sessile and conical or subpetiolate with the first segment funnel-shaped.

The species with a quite sessile abdomen have been detached into the genus Rhynchium, and that with the most petiolate abdomen into the genus Nortonia.

The limits between this subgenus and the subgenus Epipona are not clearly defined. In subgenus Odymerus the abdomen is conical, orate-conical or subpetiolate, spindle-shaped. In subgenus Epipona it is depressed oval, lenticular as in Pterochilus. In Odynerus the thorax is more square, its anterior margin being straight or concare, its angles often sharp, and the metathorax is generally excavated in the middle. In Epipona, the thorax is short, orate; its anterior margin rather convex; the metathorax convex and rounded.

The two groups can be easily distinguished by the appearance, but not readily by the description alone. We separate the subgenus Odynerus into four divisions for the better: arrangement of the species. Unfortunately the transitions from one form to another are so gradual, that it seems impossible to define them clearly enough. But this is the greatest difficulty in all the divisions of the genus Odynerus.

These four divisions are as follows:-

1. Hrpodynerus. - Body depressed or stubbed. Thorax not angulate before. Abdomen rather petiolate or sessile, depressed; the first segment either quite funnel-shaped as in Montezumia or peculiarly cut, so that its triangular anterior face fits against the metathorax and its superior face is transverse, very short, parted by a groove; the separating ridge rounded or swelled like a transverse pad. Post-scutel not distinctly truncate.

1 Consult. at the end of the genus, the list of the species incertce sedis and of the species dubio. 
Body hirsute with a long pile. Antenns of inales terminated by a long hook or spirally curled at the extremity.

These are insects of Chili or the occidental side of the South American Andes, adorned with sulphur-white and often with rufous bands, having the wings obscure or ferruginous with the extremity obscure.

2. Paciodynerus.-Body stubbed. Thorax quadrate. Aldo- p.228 men quite sessile, very conical, truncate at base. Post-scutel truncate. Antennæ simple in the males, not terminated by a hook.

3. Odynerus. - Form about the same as in Pachodynerus; abdomen sometimes more orate-conical, the first segment being a little contracted. Post-scutel generally truncate. Antennæ of the males terminated by a hook.

4. Stenodynerus.-Form slender. Abdomen cylindrical, slender, subsessile; or spindle-shaped, attenuate at base, the first $p .301$ segment small, cup-shaped or funnel-shaped, not rery sessile. Post-scutel entire or truncate. Antennæ of the males terminated by a hook.

The separation of these Divisions being difficult, they will be defined more fully hereafter.

\section{Division HYPODYNERUS.}

(SA שss. Vespides, III, 225 ; ibid. I (2d division), p. 160.)

Forms of insects depressed, velvety, bristling with long hair. Thorax little or not at all angulate. Abdomen pedicellate or sessile, with the 2 d segment wide, depressed; the first variable but almost always formed according to the same system. offering a triangular anterior face which fits itself against the metathorax and a superior face, rery short, divided by a groove; the meeting of these two faces forming a boss or a transwerse saddle-back. Sometimes, however, the first segment is simply depressed bell-shaped. The abdomen is not conic, but oval, depressed.

These insects which lepresent the fama of Odynerus of certain regions of South I meriea, offer an appearance very easy to defime. in view of the rariety of their forms.

Above all, one can distinguish them by their relrety or long 
black hair with which they are bristling, and by their exceptional livery. They have the wing for the most part strongly reddened, with the end of a brown-viclet or entirely brownish; the feet red or black, often also the antennæ, tegulæ and the clypeus $\$$, red; sometimes even the prothorax. Almost all carry some yellowwhite markings, and have two bands of the same color on the abdomen. Among these insects the posterior face of the metathorax is neither more smooth nor more rugose than the rest of the thorax; it offers the same appearance, which is quite exceptional among the Odynerus.

Tery many of these Odynerus have at the base of the $2 d$ segment beneath, a fold, which seen in profile, appears like a tubercle, some specimens presenting even an acute tubercle. The clypeus of the females is pyriform, truncate, or subemarginate at the end, black or red. That of the males is narrow, lengthened, bidentate, and of a pale yellow color.

The form also is generally rery characteristic. The posterior face of the metathorax is not shaped like that of a true Odynerus, but in a sort of pentagon, growing larger from its inferior extremity as far as the middle, where are the lateral angles, then fincly retracted as far as the post-scutel, forming with it some latero-superior ridges which converge from below upward (the post-scutel forming the 5 th side of the pentagon); here the posterior face of the metathorax is generally triangular; it widens as far as the summit and the marginal ridges, at which place they are distinct, straight, and oblique, converging toward the bottom. There remains then only the latero-inferior ridges of the metathorax. (O. humeralis.)

This conformation of the metathorax involres an analogous configuration in the 1st abdominal segment, for this is always such, that it in a manner conforms itself to the metathorax so that it places, or exactly fits its anterior face against the posterior face of the inctathorax (and this results from the fact that the two pieces are applied against each other during the period of the metamorphosis so that they are in reality moulded against each other).

The first abdominal segment has also its anterior. face triangular, and the depressed form of the abdomen causes the superior border of the triangle to be but a little arcuate.

As the metathorax is quite vertically truncate, the first segment 
applies itself exactly against it, and it results that the superior face of this segment meets the anterior face almost at a right angle. 'This face is very short, sometimes four' or five times wider than long (sometimes, however, it has but little width):

'This structure is always the same, theoretically speaking, but it becomes less and less marked in the extreme types. So, when the first segment is petiolate and narrow, it only fits itself against the middle of the metathorax which offers then a sort of furrow to reccive it, while the lateral borders of the metathorax, remaining disengaged, become rounded (O. arcuatus, tuberculatus). When the form becomes very club-shaped and the abdomen sessile, the first segment is wide, triangular, sessile (O. Antucensis, villosus), and fits itself exactly upon the whole width of the metathorax; then this is flattened or exeavated in its whole width, and its lateral borders become quite trenchant. Finally, when the first segment becomes rounded and sessile and when it no longer fits itself as strongly against the metathorax, the borders of the metathorax become blunted and rounded ( $O$. vespiformis) and one sees it produce a form quite similar to that of the Vespa.

It is easy to understand from what precedes, that the abdomen will have two forms according to the way in which one regards it. $^{2}$ If it is fitted against the abdomen it will appear sessile, for one sees only its very short superior face; if it is open it will appear more or less pediculate, for, the anterior face being triangular, it forms, when it is let down, a sort of petiole having a bell-shaped form, which would not happen if the anterior face was more or less circular.

One sees then that the petiole is only the result of a deceitful appearance of the abdomen placed in an abnormal position, ${ }^{2}$ very different in this from that which the Eumenes offers, where the petiole exists separately and camnot be disguised by any position of the abdomen whaterer. It proceeds from this fact that the lengthened types of the Division Hypodynerus belong truly to Odynerus, and not to Eumenes, as Spinola decided, nor to Sortonia, as one might be tempted to judge at first sight.

The Hypodymerus offers all degrees of prolongation of body

1 Take, for example, the O. labintus or the O. humeralis as average types.

2 The normal position of the abdomen is when it is applied against the metathorax. 
from the more slender types which form a passage from Nortonia up to the more blunted species which seem to form a transition from Vespa (O. vespiformis).

These singular Odyneri form the fauna of Chili and of the western face of the $A$ ndes. They continue, however, to orerleap the chain of the Andes, to show themselves in the Argentine Republic, for the $O$. albocinctus is proved to inhabit that country on the western slope of South America.

Some analogous types extend upon the side of the Equator and of New Grenada, and appear to pause toward the direcion of Venezuela. But yet these offer some altered characters, the markings become golden-yellow (O. Romandinus), and the forms are generally more like those of the Division Odynerus.

If the Hypodynerus form the forndation of the fauna of the Odyneri of the southern coast of the Pacific, they are not, however, the unique type of that region. One finds there, also, the Ancistrocerus (O. scabriusculus, ambiguus, etc.) and the true Odynerus (O.Gayi, O. Peruensis, etc.). But as we have indicated above, the characters of the livery which are so marked among the Hypodynerus, reproduce themselves more or less among all the solitary wasps of Chili, ${ }^{1}$ although they do not continue among the hymenoptera of other families which inhabit the same countries.

In the arrangement of species, I have here followed the series created by the modification of forms, commencing with the more lengthened, and finishing with the more blunted.

I give the complete diagnosis of the species which I possess, but I must limit myself to some short diagnostic phrases for those which $I$ have not before my eyes.

Table to assist in distinguishing the species of the Division Hypodynenos.

1. Wings fuscous with violet or cloudy reflections.

2. Body and antennæ quite black; 1st abd. segment funnel-shaped.

47. Tupiensis

2, 2. Body ormamented with luteous bands; abdomen sessile.
3. Antennæ and feet rufous.
59. villosus.

3, 3. Antennæ black, the scape rufous; feet rufous, obscure, passing into black.

60. obscuripennis.

1, 1. Wings ferruginous, with the extremity fusco-violaceus.

2. Prothorax rufous.

3. Antennæ rufous, with the extremity black.

1 Compare the former page 13 , gayella; 50 No. $45 ; 162$ No. 9 , etc. 
1. First abdominal segment tuberculate before its groove.

51. tuberculatus.

4, 4. First abdominal segment not tuberculate.

3, 3. Antennæ entirely rufous.

56. humeralis.

63. ruficollis.

2, 2. Prothorax black or bordered with Juteous.

3. Antennæ black on the superior face.

4. Their first joint rufous.

57. Tarabucensis.

4, 4. The whole antennæ black above.

5. The $2 d$ abd. segment tuberculate above. 49. excipiendus.

5, 5. The $2 d$ abd. segment not tuberculate above.

6. Abdomen rather petiolate; hinder margin of prothorax yellow; $2 \mathrm{~d}$ abd. segment not tuberculate beneath.

48. arcuatus.

6,6 . Abdomen more sessile; anterior margin of prothorax yellow ; $2 d$ abd. segment tuberculate beneath.

55. vestitus.

3, 3. Antennæ rufous, or black only at the extremity.

4. Second abdominal segment tuberculate beneath, at its base.

5. Metathorax without sharp edges, not bidentate.

6. Small, post-scutel luteous; clypeus $q$ black.

52. tuberculiventris.

6, 6. Larger, post-scutel black.

7. Two luteous bands on the abdomen.'

8. The hinder margin of the prothorax bordered with luteous; clypeus $q$ black. $\quad 65$. vespiformis.

8, 8. Prothorax not margined posteriorly with luteous.

9. Abdomen rather petiolate, the 1st abd. segment much narrower than the $2 d$; prothorax anteriosly margined with luteous. 54. labiatus.

9,9. Abdomen sessile; the 1st abd. segment sessile, wide; prothorax black. 64. Maypinus.

7, 7. Only one luteous band, placed on the 1st segment; this as wide as the 2d, sessile. 61. Antucensis.

5, 5. Metathorax sharp, biangulate. 62. Chiliotus.

4, 4. Second abdomiual segment without distinct tubercle beneath.
5. Clypeus $\nmid$ rufous.
53. Molinc.

5, 5. Clypeus ㅇ black.

6. Pronotum and segments 1, 2, margined with luteous.

50. subpetiolatus.

6,6 . Only the first segment margined with luteous.

58. albocinctus.

1 Wanting in some varieties. 
Description of the species.

I. First segment of the abdomen bell-shaped, not offering two faces separated by a ridge, but pyriform, uniformly a litlle comb-shaped. Appearance of Montezunia.

These insects can also nearly figure in the genus Nortonia, but the concave form of the metathorax brings it rather nearer to the Odynerus of this Division.

4\%. O. Tapiensis SAUSS.-Omnino niger; capite et thorace punctatis velutinis, nigro-hirsutis; thorace depresso ; metathorace utrinque lateraliter, superne, valde carinato, et in foveola velutino; abdomine nitido depresso, primo segmento infundibuliformi; pedibus rufis, basi nigris; alis nigro-chalybæis. ㅇ?.- $\delta$. Clypeo argentato, bidentato, femoribus intermediis subtus in medio dilatatis, basi excisis.

Odynerus Tapiensis Sadss. Revue de Zool., XXII, 1870, 56, 5 .

Total length, $20 \mathrm{~mm}$; wing, $17 \mathrm{~mm}$.

§. Facies of a MLontezumia. Mandibles slender and styliform. Ocelli large, disposed in a very wide triangle. Thorax wide and strongly depressed. Prothorax widely truncate and a little turned up. Post-scutel not truncate. Metathorax having its lateral ridges very salient and trenchant toward the summit; its posterior face triangular, widening upward; the concarity quite plain, but rugose and relvety; its superior ridges not distinct. Abdomen wide and depressed; the first segment pyriform bell-shaped, depressed, subpediculate at its base and posteriorly divided by a strong groove; the $2 d$ segment depressed, almost discoidal; offering beneath, at its base, an elevated wrinkle.

Insect of a deep black; head and thorax densely punctured and velvety; strongly pilose, woolly and bristling with long black hairs. Abdomen smooth, shining, woolly at its base. Legs ferruginous with the base black. Wings black, with violet or greenish reflections.

§. Clypeus almost as wide as long, polygonal, clothed with silvery hair, arched in its superior moiety; its latero-inferior borders a little concare; its extremity terminated by two spiniform teeth, between which is an arcuate notch. Antennæ strong; the first article short, large, and arcuate; those following, strongly pronounced, the articulations almost nodulose above; the last article forming a large compressed and arcuate hook. Thighs of 
the $2 d$ pair slightly bent in the first third, offering beneath in the middle a dilation, lamellate, oblique, preceded by a wide notch and channelled on its anterior face.

Ress. a. diff.-This little species is very distinct in its numerous characteristics. One cannot confound it with any Iyporlynerus, in view of its uniform black color and its infundibuliform first abdominal segment, which does not offer an anterior and posterior face, separated by a transverse ridge, etc. Its appearance is that of Montezumia and of Nortonia. It is distinct from these genera by the triangular form of the metathorax which recalls the form of the thorax of Hypodynerus. The maxillary palpi are strongly 6-articulate, the 6th article being longer than the 5th; the labial palpi have but three large articles; the 4 th is very small, almost rudimentary, which indicates a passage from MIontezumia and from Mlonobia.

$H a b$. The elevated regions of the Republic of Ecuador. It was taken by Dr. Maurice Wagner on the plateau of Tapia at the foot of Chimborazo. (In collection of the author and collection of the Museum of Munich.)

Observation.-The silvery hair of the clypeus is subject to fall off, especially in the middle of this piece. The clypeus is often, for this reason, only bordered with silver.

II. First segment of the abdomen offering an anterior and a superior face; these two faces separated by a sort of transverse ridge or swelling (the true Hypodynenus).

A. Form much lengthened; first abdominal segment small, narrow, nodiform or pedunculiform, very much narrower than the $2 d$; its anlerior face in a lengthened triangle.-Meta.. thorax with rounded angles; its excavation forming a wide vertical furrow.

48. O. arcuatus Sauss.-Niger, velutinus, nigro-pilosus rel levis, punctulatus; metanoto medio late canaliculato, polito; abiomine depresso ; primo segmento trigonali, petiolato-campanulato, paene duplo angustiore quam secundum, supra transversim tumido, apicis puncto valde impresso; secundo nec supra nee subtus tuberculato; antemis nigris, subtus basi ferrugineis; punctulo frontis luteo; pronoti et abdominis segmentorum 1 i, 2 margine postico, albido; tegulis pedibusque ferrugineis, his basi nigris; alis ferrugineis, apice fusco-cyaneis. -Longit. $15 \mathrm{~mm}$. 
‥ Clypeo subconvexo, nigro, apice recte-bicarinato, submarginato.

$\delta$. Clypeo luteo, argentato, bidentato, lineola post-oculari albida; antennarum uncino et articulo præcedenti, ferrugineis.

Variat. Thoracis et abdominis lituris rudimentariis, incompletis, paene nullis, vel pronoto nigro.

Odynerus arcuatus SAuss. Vespides, I, 160, 45 (1852); III, 326.

This species can be regarded as the Chiliagn type of the genus Nortonia, and places itself in this genus, since all its characters attach it to the Odynerus of this division, but with a particular prolongation of the first abdominal segment.

It is most closely allied to O. vestitus and excipiendus (Comp. these species).

Hab. Chili.

49. O. excipiendus Spry.-Niger, velutinus, O. arcuato simillimus, sed metanoto postice magis punctato; aldominis primo segmento superne minus tumido; secundo segmento medio in tuberculum producto; segmentis 10, 20 luteo-marginatis, vel fere omnino nigris; antennis nigris; pedibus rufis, basi nigris; alis ferrugineis, apice fusco-cyaneis._Longit. $14 \mathrm{~mm}$.

9. Clypeo nigro, planato, apice bidentato et carinulis 2 siuuatis instructo.

5. Clypeo emarginato, luteo, nigro-piloso, utrinque nigro-marginato; antennarum uncino nigro.

Eumenes excipienda Spis. in Gay's Hist. fisic de Chile, Zool. VI, 256, 1 (1851).

Odynerus excipiendus Satss. Vespides, I, 161, 47; III, 227.

Odynerus colucolo Sauss. ibid. I, 161, 46 (1852); III, 227.-Gay's Hist. fis. de Chile, Zool. VI, Suppl. 566, 8 (1852).

In this species, the clypeus $q$ is black, flattened, with two sinuated carinæ, terminating in two apical teeth; the clypeus $\delta$ is luteous, bordered with black on the sides and superiorly; the antenvæ $\delta$ are terminated by a sharp black hook. The thorax is quite black, excepting at times a little yellow line in the middle of the prothorax; the first two segments of the abdomen have often only a rery narrow yellow line, which is sometimes wanting or only indicated by an incomplete line on the margin of the $2 \mathrm{~d}$ segment.

Hab. Chili.

50. O. subpetiolatus SATSs. - O arcuato affinis; formis simillimus, sed minor; abdomine subpetiolato, secundo segmento haud tuberculato; primo segmento postice sublatiore; antennis, tegulis, pedibusque rufis; anteunis apice griseis ; puncto frontali lnteo; pronoti margine antico 
(haud postico) luteo-limbato; abd. segmentis, 10, 20 luteo-marginatis; alis ferruginescentibus, apice infuscatis.-Longit. 13 mu.

१. Clypeo nigro, apice bicarinato, subemarginato.

$\delta$. Clypeo elongato, emarginato, luteo, utrinque nigro-marginato; antennaruin scapo superne nigro vel obscuro uncino winuto, rufo.

Olyn. sulpeliolatus Sauss. Vespides, I, 162, 43 (1852).—III, 227, 와

Odyn. coarctalus Sauss. Gay's Hist. fisica de Chile, Zool. VI, Suppl. p. 565,7 , (1852).1

Hab. Chili.

51. D. tuberculatos SAUSS.-Major quam 0 . arcuatus eique formis affinis, sed thorace latiore; abd. primo segmento paulo latiore, supra postice sulco partito, et ante sulcum in cantho transverso tuberculo parvulo instructo; secundo segmento nec supra nec subtus tuberculato; post-scntello tantum in apice truncato. Niger, rugulatus, velutinus, hirsutus. Antennis ferrugineis, apice nigris ; ore, pronoto, tegulis rufis ; lineola post-oculari, pronoto medio frequenter, post-scutello et abdominis segmentorum $1^{i}, 2^{i}$ margine, luteis ; alis ferrugineis, apice fusco-violascentibus.-Longit. $16 \mathrm{~mm}$.

ㅇ. Clypeo nigro, piriformi, satis planato, bicarinato, apice truncato, vel subemarginato.

$\checkmark$. Clypeo elongato, paulum bidentato, luteo; antennarum uncino apicali nigro; post-scutello nigro.

Odynerus tuberculatus Sauss. Vespides, I, 163, 50 (1852).-Gay's Hist. fis. de Chile, Zool. VI, Suppl. 564, 6, 1S52.-Vespides, III, 228.2

This species differs from $O$. humeralis in its smaller size; its antennæ $\delta$ terminated by a sharp black hook, not by a rufous spiral or a blunt hook. The clypeus is more narrow; in $q$ flattened, bicarinate; in $\delta$ not so sharply bidentate.

IIab. Chili.

52. D. touberculiventris SpIn.-Minutus, O. arcuato form is simillimus; sed pronoto lato, angnlato; post-scutello haud truncato, postice angulato, vel arcuato; abdominis secundo segmento subtus basi tuberculo acuto instructo. Niger, velutinus; antennis, tegulis et perbibus rufis; his basi nigris; macula frontali, punctulo post-oculari margino antico, macula subalari, postscutelli et abd. segmentorum $1^{i}, 2^{i}$, margino postico, luteis. Alis subhyalinis, venis ferruginois, apice griseo. - Longit. $8 \mathrm{~mm}$.

1 This supplement appeared after my book I on Vespides; and hence I preserve the namo silbetiolatus as being the older.

2 In this paragrapl of Vol. III, the aflinitios aro not woll giren. 
‥ Clypeo nigro, apice biangulato.

$\boldsymbol{\delta}$. Clypeo fere pentagonali, luteo, bidentato; antenuarum scapo superne nigro, subtus flavo; flagello apice tlavescente; pedibus flavo-variis.Vuriut. Antemnis supra nigrescentibus.

Eumenes tuberculiventris Spix., Gay's Hist. fisica de Chile, Zool. VI, 267, 2 (1851).

Odynerus tuberculiventris Sauss. Vespides, I, 162, 49; III, 227.

In the male, the femora are black, with rufous knees and with a yellow line; the tibia are yellow on their anterior side.

Ress. a. diff.-Differs from $O$. labiatus, in its luteous postscutel; its black clypeus $q$; its polygonal shaped clypeus $q$, terminating in two small teeth; and its small size.

Comp. also O. Chiliotus.

Hab. Chili.

B. Form shorter, wider; first segment wide on its posterior border; its anterior face in the form of an equilateral triangle and a little pedicellate; its superior face large. Metathorax excavated, offering a trace of a polygonal plate surrounded with ridges.

a. Tings rufous along the anterior margin.

53. O. Molina SAoss.-Niger, hirsutus; antennis, clypeo, mandibulis, tegulis pedibusque, rufis; pronoto medio et fasciis 2 abdominis, luteis; abdominis primo segmento satis elongato, postice sat lato, secundo subtus basi paulum plicato; alis ferrugineis, apice fuscescentibus. $९$ Loing. 14 mm.

Odynerus Molince Sauss. in Gay's Hist. fis. de Chile, Zool. VI, 562, 3, 오 (1852).

Odynerus Molinius Satss. Vespides, III, 251, 126 (1854).

Hab. Chili (Type in the Paris Museum).

54. O. Labiatus Halid.-Sat validus, depressus; postscutello depresso, truncato, metanoto excavato; abdominis primo segmento superne lato, basi parum petiolato, facie antica trigonali, facie supera brevi, lata, sulco profundo partita, antice cantho hebetato, subprominulo marginata ; secundo segmento subtus basi tuberculato. Niger, velutinus, pilis nigris hirsutus; thorace tenuiter punctato, etiam in metanoti excavatione æqualiter rugoso ; mandibulis, antennis, tegulis pedibusque rufis ; pronoti margine antico (noununquam tantum in medio) et abdominis segmentorum $1^{\mathrm{i}}, 2^{\mathrm{i}}$ margine, luteis; alis ferrugineis, apice violascentibus.-Longit. $16 \mathrm{~mm}$.

\$. Clypeo rufo, apice truncato vel subemarginato.

$\delta$. Clypeo elongato, ovato, polygonali, luteo, a pice sat late subemarginato. 
Odynerus labialus Haliday, Traus. Linn. Soc. XVII, 323 (1837). -Sauss. Vespides, III, 228.

Odynerus Lachesis Lep. St. Farg., Iymenopt, II, 667, 44 (1841).-SAUSs. Vespides, I, 164, 51, pl. xvii. fig. 5, क; III, 228.

Odynerus marginicollis Spin. in G'ay's Hist. fisica de Chile, Zool. VI, 256,2 (1851).

Ress. a. diff.-Differs from 0 . humeralis in its coloration; in its narrower form, in its finely punctured thorax, not rugosely shagreened, and in the little ventral tubercle which is not only a wrinkle like that of the $O$. humeralis, but is quite tuberculiform in the middle. In size it is much smaller. Differs from the $O$. tuberculiventris in its triple size; in the clypeus, o rufous, $\delta$ prolonged, narrow (almost an ellipse, lengthened and notched at the end).

Hab. Chili.

55. D. vestitus Sadss.-Niger, nigro-hirtus; metanoto hebetato; abdomine sessili; secundo segmento subtus tuberculato; pronoti margine antico et vittis 2 abdominis, luteis; antenuis nigris; alis subfuscescentibus, costa bási subferruginea. Lougit. $13 \mathrm{~mm}$.

․ Clypeo nigro, biangulato.

$\hat{\delta}$. Clypeo elongato, planato, luteo, apice areuatim emarginato; antennis apice uncino rufo.

Odynerus vestitus SAuss. Vespides, III, 252, 127, q (1854).

Ress. a. diff.-Closely allied to O. arcuatus and excipiendus, but differs clearly in its $2 d$ abdominal segment, tuberculate beneath, and wider and longer than the first. In one specimen the wings are slightly smoky and ferruginous.

Hab. Chili.

56. O. humeralis Halid.-Validus, corpore lato, depresso, velutino, thorace ubique rugose granulato, etiam in metanoti excavatione; primo segmento latiore, basi paulum petiolato ; dehine trigono-infundibuliformiter dilatato, valde punctato ; facie supera lata, sulco profundo partita ; secundo segmento subtus basi transversim plicato-tubereulato.-Corpus nigrum, pilis fulvis vel fuscis longissimis hirsutum; mandibulis partim, pronoto, tegulis pedibusque rufis; abdomine fasciis duabus luteis; antemnis in dimidio basali rufis, in dimidio apicali nigris, tarsis apiee obscuris. Alis fuseo-violaceis, costa et hasi ferrugineis.-Longit. $20 \mathrm{~mm}$. . Clypeo nigro, subconvexo, levi, apice subemarginato.

$\delta$. Clypeo luteo argenteo-piloso, orato, valde bidentato; anbro fusco, 
auteunis apice subcochleatis uncino arcuato, obtuso, ccmpresso, rufo, vel nigro-rario.

Odynerus humeralis Halidar, Trans. Linn. Soc. XVII, 324 (1837).Sacs. Vespides, III, 2208.

Odyn. chilensis Lep. St. Farg. Hyinen. II, 643, 28 (1841).-Sprisola in Gay's Hist. fis. de Chile, Zool. VI, 255, 1.-Sarss. Vespides, I, 166, 54, pl. xrii, fig. 6; III, 22 s.

This large species has some very salient lateral ridges upon the metathorax; the superior ridges of the concavity are saliertly indicated, especially among the males, but the rugosities which corer the metathorax as well as the remainder of the thorax render them obtuse and indistinct. The antennæ $\delta$ terminate in a blunt rufous hook or in a longitudinal spiral; the clppeus $\delta$ is terminated br two rather long spines, and in the male the tarsi are mostly blackish. It is, howerer, closely allied to 0 . tuberculatus. Comp. this species.

Hab. Chili, and the western coast of South America.

5\%. O. Tarabucensis SArss.-Validus; O. humerali similis; niger; pronoti wargine antico et abdominis fasciis duabus, luteis; antennis nigris, scapo rufo; tegulis nigris; mandibulis et pedibus, rufis; alis ferrugineis, apice riolascentibus. $-\uparrow ?$ ?

§. Clypeo luteo, apice dentibus 2 distantibus armato.

Odynerus Tarabucensis Sacss. Vespides, III, 250, 125, $\widehat{\delta}(1 £ 54)$.

Hab. Boliria (I do not possess this species. Trpe in the Mus. of Paris).

\section{b. Tings fuscous, with violet iridescence.}

5S. O. albocinctus PrLs.-Niger, relutinus, nigro-hirsutus. Clypeo piriformi nigro, apice ralde bidentato; antennis, mandibulis et labro, rufis; metathorace rotundato; abdomine pilis nigris longis sparso, tantum primo segmento anguste albido-limbato; secundo seginento subtus haud tuberculato; pedibus rufis, femoribus postice nigris; alis fuscescentibus, riolascentibus præcipue apice; tegulis nigris. + . Long. $20 \mathrm{~nm}$.

Odynerus albocinctus Pols a. Strobed, Atti della Soc. Italiana de Sc. Nat. $\mathrm{XI}, 186 \S, 256$,. .

Hab. The Argentine Republic. Prorince of Mendoza. This is the only species of the trpe Hypodynerus found as ret on the Oriental side of the Andes.

The form not haring been described, I cannot assign to this 
species its place with perfect certainty in the suldivisions of this group.

C. Form very wide, short and depressed, first segment very wide; its anterior face sessile, in the form of a wide triangle; its superior face very short, 3-4 times as wide as long.

a. Wings wholly obscure, violet.

59. D. villosus Sauss. - O. Antucensi staturâ, formis et facie affinis, serl pronoto et capite angustioribus; crassus, ater, velutinus, valde nigro hirsutus; metanoti excavatione polita; abdomine sessili; primo segmento lato, breviter truncato; secundo subtus basi emineute plicato; mandibulis, antennis et pedibus rufis; his basi et fere usque ad genua uigris; tegulis nigris, rufo-maculatis; abdominis vittis 2 luteis angustis ; alis infuscatis, violascentibus.-Longit. $15 \mathrm{~mm}$.

․ Clypeo nigro, lævi, apice punctato, paulum emarginato. - $\delta \ldots$ ?

Oalyn. villosus Sauss. Vespides, I, 165, 53, $q$ (1852).-Gaz's Hist. fisic de Chile Zool. VI, Suppl. 563, 4 (1852).

This may be a variety of 0 . obscuripennis.

Hab. Chili.

60. D. Obscuripena is SpIn.-O. villoso similis, sed major, thorace rugoso, granulato; ater, villosus; antemnis nigris, scapo rufo; pedibus rufis vel nigrescentibus, basi nigris; abdomine fasciis 2 luteis.-Long. $18 \mathrm{~mm}$.

Odyn. obscuripennis Spin. in Gay's Hist. fisic de Chile Zool. VI, 259, 4, ○ (1851).--SAuss. Vespides, I, 165, 52 ; III, 228.

Odyn. Coquimbensis Sauss. in Gay's Hist. fisic de Chile Zool. VI, Suppl. 561,1 (1852).

Hab. Chili (Type in the Paris Museum).

This species not being in my possession, I cannot give a complete diagnosis of it.

b. Wings ferruginous with the apex fusco-violaceus or fuscous, and the anterior margin rufous.

61. O. Antucensis Sadss.-Crassus, velntinus, pilis nigris lougissimis valde hirsutus. Corpns depressum; thorace quadrato, temuiter punctato; post-scntello et metanoto verticaliter truncatis, hujus facie postica trigonali, fere plana, parum late excavata, ut reliquns thorax relntinorugulosa, canthis obtusis marginata. Ahdomine lato, depresso, sessili ; primo segmento antice valde truneato, faciem antioam trigmalem et faciem superan brexissimam ef latissimam praebente: faciernm illarmm concursus canthum transversum efliciens; facio supera sulco partita; 
20 segmento paulo latiore quam primum, subtus basi plicato-tuberculato. Niger; mandibulis, tegulis, pedibus et antennis, rufis; his apice supra griscescentibus; abdominis primo segmento luteo-marginato; alis ferrugineis apice fusco-riolascentibus. - Longit. $15 \mathrm{~mm}$.

․ Clypeo elongato, rufo, apice bicarinato submarginato, utrinque nigrowuarginato. $-\delta$ ?

Odyn. Antuco Sadss. Et. Vespides, I, 167, 55, 9 (1852).-GaY's Hist. fis. de Chile, Zool. VI, Suppl. 562, 2 (1852).

Odyn. Antucensis Sadss. Et. Vespides, III, 228.

Ress. a. diff.-This species is closely allied to villosus, but its body is thicker; the thorax is quadrate and wide anteriorly; the color of the wings and clypeus $q$ is different.

Hab. Chili.

62. 0. Chiliotus Sacss.-Niger, velutinus, nigro-hirtus; O. Antucensi affinis; thorace brevi; metanoto late excavato, canthis marginato, utrinque angulato; abdominis secundo segmento subtus valde tuberculato; segmentis 10, 20 margine luteo; antennis et pedibus rufis; tegulis nigris; alis fusco-violascentibus, costa ferruginea.-Longit. $11 \mathrm{~mm}$.†?.- $\hat{\delta}$. Clypeo elongato, bidentato, luteo.

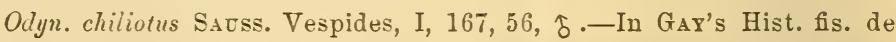
Chile, Zool. VI, Suppl., 566, 9.-Vespides, III, 229.

I do not possess this species, which seems much like $O$. Antucensis. But I cannot think it the male of that, because of its biangulate metathorax. The first abdominal segment seems to have on its anterior face something like a suture, which allies it to the subgenus Ancistrocerus.

Hab. Chili (Paris Museum).

63. O. ruficollis Spix.-Ater, velutinus, nigro-hirsutus, crassus et brevis; abdomine basi valde truncato, lato; metanoto rotundato; abdominis 20 segmento subtus basi plicato-tuberculato; antennis, pronoto, tegulis, pedibusque, ferrugineis; abdomine fasciis 2 luteis; alis ferrugineis, apice fusco-nebulosis.-Longit. $11 \mathrm{~mm}$.

\%. Clypeo biangulato, rufo, nigro-marginato.-\$?

Odyn. ruficollis Spin. 1. 1. VI, 259.- Sauss. Et. Vespid. I, 168, 57, \&.

I do not possess tinis species. By its livery, it would seem a miniature of $O$. humeralis, but the abdomen is more sessile, the clypeus $q$ is rufous; the metathorax is rounded, not sharp, on its margins, etc. The form is more that of $O$. Antucensis.

Hab. Chili (Trpe in the Paris Museum). 
64. O. Maypinus SAuss.-Niger, hirsutus; anteunis, tegulis, pedibusque rufis; abdomine fasciis 2 luteis, primo segmento sessili, lato et brevi; alis ferrugineis, apice violascentibus. - Longit. $13 \mathrm{~mm}$. - $?$ ? $\widehat{\delta}$. Clypeo paulum bidentato, luteo.

Ab Odyn. Antucensi differt, metanoto rotundato, marginibus hebetatis (num ejus masculus?).

Odyn. Maypinus Sadss. Vespides, I, 169, 58, 令 (1852), -In Gay's Hist. fis. de Chile, Zool. VI, Suppl. 564, 5 (1852),-Vespides, III, 229.

\section{Hab. Chili ('Type in the Paris Museum).}

D. Form also quite chubby, but not so much depressed; metathorax rounded, flat or convex behind, smooth, without mar ginal edges; abdomen arched (vespiform); first segment very short; its superior face transverse-linear. (Appearance of a VESPA.)

65. O. vespiform is HALID.-Niger, parum depressus, nitidus, pilis, longissimis nigris hirsutus; capite et thorace nitidis, tenuiter punctatis ; post-seutello breviter truncato; metanoto rotundato, convexo, punctato ; thorace quadrato-globoso; abdomine perfecte sessili (ut in genere Vespa) superne convexo; primo segmento brevissimo, antice excavato, subexciso; secundo subtus basi valde tuberculato; punctulo frontis luteo; antennis pedibus et tegulis rufis; pronoti margine postico et abdominis segmentorum $1^{\mathrm{i}}$, $2^{\mathrm{i}}$ limbo, luteis ; alis ferrugineis apice subinfuscatis.-Longit. $13 \mathrm{~mm}$.

‥ Clypeo nigro, apice rugoso, punctato, bicarinato, truncato ;

§. Clypeo luteo, punctato, bidentato; mandibulis antice fascia flara; antennarum uncino minuto.

Vuriat. Thorace et abdomine fere omnino nigris, fasciis rudimentaris vel nullis.

Odyn. vespiformis HaLID. Trans, Linn. Soc. XVII, 323 (1837).

Odyn. hirsutulus SPIN. in Gay's Hist. fis. de Chile, Zool. VI, 257, 3 (1851). -Sauss. Vespides, I, 212, 118 ; III, 244.

Ress. a. diff.-This species is rendered very distinct by its less depressed formi, and its quite sessile abdomen, which gives it the appearance of a Vespa. The first segment is so short, that the superior face is almost wanting; its anterior face presents as in Vespa a sort of obsolete noteh at its summit, which is an impres sion of the post-scutel. The anterior face has not the triangular form, its superior margin being arenate as in the respa.

Hab. Chili (A eommon species). 


\section{Division PACHODYNERUS.}

Sadss. III , Divis. Sect. Ie, Vespides, I, 169.-Divis. Epsilon, Sect. I, ibid. III, 229, 252 .

Form relatively blunted (stubbed). Antennæ of males simple, not being terminated by a hook. Thorax short, in form of a lang or even cubical square, truncate posteriorly. The postscutellum transiersely truncate, offering for this reason a superior horizontal and transverse face and a posterior vertical face, which makes a division of the posterior concavity of the thorax; these tuo faces being separated by a transverse ridge formed by their meeting. Abdomen always sessile, conical, truncate at its base. (The first abdominal segment less coarsely punctured than the $2 \mathrm{~d}$, more smooth.)

Among the insects of this division the forms are very thickset, short, and stubbed. The clypeus of the females is widened and rounded at the summit, as wide as long, pear-shaped, and truncate at the extremity; the angles of the truncation are often a little salient, dentiform, and sometimes the clypeus appears bidentate by reason of a little fossette which occupies its extremity. Among the males this piece is most often polygonal, truncate, as wide as long.

The thorax is rery cubical, with little or no retraction behind. The metathorax never prolongs itself bejond the post-scutel, but is briefly truncate; its truncation eneroaches strongly upon the post-scutel and gives birth to a smooth plate which occupies most of its width; this plate is polygonal, often armed with two lateral teeth, and bordered by some sharp or blunted ridges, which become especially salient upon the latero-superior borders, where they form on each side a sort of arcade, and are often terminated by a projection, separated from the post-scutellum by a fissure. Among these species having a thorax very square and widened behind, this character is well developed, but the ridges do not bend at the middle to form a re-entering angle under the angle of the post-scutel (as among the Ancistrocerus), but are effaced at the entrance.

The post-scutellum seen abore is almost linear, truncate rertically, and its posterior face makes a dirision of the posterior plate of the thorax; its ridge is sharp and often creulate. The 
abdomen is perfectly sessile, conical; its first segment is wide, often quite as wide as the $2 d$, squarely truncate at its base, which permits the distinction of an anterior and a superior face; the transverse ridge which results from this truncation is sometimes blunted, sometimes sharp. The superior face is always transverse, wider than long. The abdomen is sometimes velvety, sometimes smooth, shining, not rugose, and the first segment is wholly smooth, less punctured than the 2 d.

It is fitting to say that for each one of these characters, there may be met some exception among this and that species.

Of all the Odynerus, the species of this Division have the most cubical thorax and the most conical abdomen. Yet they have almost the same form as a great part of the species of the Division Odynerus which follows, and are only distinguished from them by the antennæ of the males, which are destitute of the terminal hook. Owing to this circumstance the Pachodynerus occupy among the Odyneri a sort of typical position like that of the Eumenes of Division Omicron, these being also distinguished from the other Eumenes by the simple flagellum of the antennæ of the males. The Pachodynerus are also, like the Eumenes of the Division Omicron, peculiar to tropical and temperate America.

The Pachodynerus cannot easily be confounded with the Stenodynerus, because of their thick body and conical, thick abdomen. But, to make certain, one should consult the tables of the species of the Division Odynerus, which are placed before these Divisions.

Table to assist in distinguishing the species of the Division Pacuodynencs.

1. Ornaments of the body all yeilow.

2. Abdominal segments all margined with yellow, except the first.

3. Thorax wholly hlack.

4. Metathorax rounded, destitute of lateral angles.

4, 4. Metathorax forming an angle on each side.

69. argentinus.

5. Thorax elongate, metathorax with four spines; insect black.

s). diabolicus.

5,5. Thorax cubical; metathorax with two angles; insect relvety, grayish.

66. Sirevithorax.

66. breritherax.

3, 3. Thorax with yellow ornaments.

67. nasielens.

68. Isimplicornis. 
2, 2. The first abdominal segment margined with yellow.

3. All the segments margined with yellow

4. Prothorax all yellow.

4, 4. Prothorax margined with yellow.

72. Guadulpensis.

5. The posterior margin of prothorax yellow. 73. $\left\{\begin{array}{c}\text { Guadul } \\ \text { zonatus. }\end{array}\right.$ 76. La Platic.

5,5. Only the anterior margin of prothorax yellow.

6. Thurax wholly or nearly black; abd. much truncate at base.

70. Peruensis.

6, 6. Thorax slightly ormamented with yellow; abdomen more orate.

71. brachygaster.

3, 3. Only the first two segments margined with yellow or luteous.

4. The following segments rufous.

7S. cuberisis.

4, 4. The following segments black.

5. The posterior margin of prothorax, or both margins, yellow.

6. Ornaments whitish. $\quad$ it. $\{$ Gayj.

79. $\{$ californicus.

6, 6. Ornaments yellow.

75. $\{$ pracox.

76. $\{$ La Plate.

5,5. Only the anterior margin of protliorax yellow.

6. Ornaments whitish.

7. Insect short, thorax cubicai. 74. Gayi.

7, 7. Insect more slender, thorax longer than wide.

79. californicus.

6,6. Ornaments yellow, insect not so stout. 77. tibialis.

1, 1. Body more or less adorned with rufous.

2. Prothorax and first abdominal segment, etc., rufous.

\&1. Erinnys.

2, 2. Only the extremity of the abdomen rufous. 78. cubensis.

\section{Description of the species.}

1st. Sectiox.-Thorax cubical (at least among the males) or square, more lengthened. Abdomen conical; the first segment very large, as wide as the second.

In this group one finds the most thick-set forms in the whole tribe of solitary wasps (O. nasidens, $O$. Gayi), the thorax becoming perfectly cubical, as in the Nectarinia, among the social wasps. Howerer, among the most part of the species the forms do not differ essentially from those of the insects of the dirision Odşnerus. 
A. All the segments except the first, bordered with yellow.

These Odynerus have the body silky and adorned with heautiful golden reflections, or they are covered with a velvety satin which often conceals the punctures. They have a close resemblance among themselves, so that, without comparing numerous specimens, one easily confounds all under the same description, taking them for the $O$. nasidens of Latreille. This happened to me at the beginning of my studies. When new specimens arriver, I thought to distinguish niany more species, and I have established differences in the diagnoses which are far from satisfying me. In fine, the increase of my collections has revealed to me such differences of size, of color, and of details of form, that, after having believed for a time that some species were distinguished with clear precision, I have perceived that nothing is more obscure than the limits of these species. A new examination of my very numerous specimens, far from clearing up the chaos, only results in filling me with new doubts; for, contrary to what one usually observes, the species do not appear to class themselves according to their geographical distribution; in lieu of finding one species from Mexico and another from Brazil, I find two species equally diffused in the two divisions of the American continent. In the midst of this confusion I think, however, that I can distinguish the 0 . brevithorax quite clearly, as there is here quite a difference from other species, in the form of the clypeus, etc.

The appearance of these insects recalls very much that of certain other Vespidx which have also their bodies velvety and silky and which inhabit the sane hot regions. Such as ecrtain Ancistrocerus (A. Aristre, Parredesi); certain Nectarinia (N. mellifica), and even certain Chartergus (Ch. chartarius); with which one should be careful not to confound the Odyneri described below.

a. Metathorax forming a lateral angle on cach side.

66. D. Dreviduonax SAuss.-Niger, punctatus, ubique tomento relutino aureo-sericeo indutus; thorace cubico, latitndine longitudini xquali; metanoto in tota latituline excavato; ejus excaratione lari, sęricea, eanthis aentissimis marginata, utrinque in dentem lateralem excurrentibus; abdomine perfecte conico, sericeo; primo segmento bre- 
vissimo; antennarum flagello subtus et scapo apice, ferrugineis ; tegulis testaceo-maculatis; abd. segmentorum 2-5 margine late flavo, et ralde punctato; primo nonnunquam etiam tenuiter flavo-marginato; tibiis antice flavo velfulvo-rariis; alis ferrugineis, apice griseis.-Longit. $10 \mathrm{~mm}$. Vuriat. Metanoti canthis flavis.

१. Clypeo punctato apice, dentibus 2 acutis, inter se distantibus armato; punctis 2 fulvis in dentibus et 2 in augulis superioribus ornato.

$\boldsymbol{\jmath}$. Clypeo in marginibus argentato; apice fere ut in $q$ bidentato, vel emarginato, dentibus 2 trigonalibus terminato; apice lineis 2 , in summo fasci is 2 lateralibus, flavis; labro tlaro; maudibularum margine externo et scapo, linea flava instructis.

Furiat. Clypeo in lateribus flaro-marginato; oculis intus flavo-marginatis, pedibus nigris.

Odynerus brevithorax Sacss. Vespides, I, 172, 621 (1852); III, 231.Rer. Zool. X, 1\&5\&, 166.

The teeth of the clypeus $q$ are spiniform and separated by an arched margin, not angularly notched. The thorax is cubical, not longer than wide; the disk of metathorax is much broader than long, in the form of a half circle; its margins are arcuated anteriorly, not sinuated. The scutel is square, rather elerated, and the post-scutel is situated a little lower, while in auratus, the scutel is more flattened and the post-scutel is on the same plane.

Ress. a. diff.-Compare 0 . nasidens and simplicornis, 0. diabolicus, and also Ancistrocerus Aristæ and Paredesi.-This species, as well as the following, must be carefully distinguished from different species of Neclarinia $;^{2}$ this may easily be done, from their very wide first abdominal segment, not very small and shortly petiolate; from their distinct post-scutel, and the truncate, not angulate, apex of the clrpeus.

Hab. South America. Brazil. Bahia, 2 \&, 3 5.-Tenezuela $q \hat{\delta}$.

6\%. O. nasidens LAtr.-O. brerithoraci simillimus; statura variabili; thorace longiore quam latiore; pronoti margine postico, postscutello, abdominisque segmentornm 2-6 margine ochraceis; alis ferrugineis, apice griseis.

․ Clypeo apice latius bidentato, magis biangulato; dentibus fulvis; interdum superne maculis 2 fulris rel omnino flaris.

1 The figure which bears the same name belongs to the $O$. nasidens.

2 Social $\pi \mathrm{asp}$. 
$\hat{\delta}$. Clypeo polygonali, late truncuto, margine utrinque flavo, vel omnino flavo, macula nigra.

Odyn. nasidens Latrr. Voyage de Humboldt, Zool. II, 112, pl. xl, fig. 1, 2, P.-SAuss. Vespides, I, 171, 61, 1852; III, 230.-Rev. 'Lool. X, 1858, 165, 1.-Packard liep. Peabody Acad. 1869, 5.

Odyn. auralus Sauss. Rev. Zool. X, 1858, 166.

Odyn. brevithorax Sauss. Vespides, I, pl. xvii, fig. 9, ㅇ.!

$$
\begin{aligned}
& \text { ‥ Total length, } 13 \mathrm{~mm} \text {.; wing, } 11 \mathrm{~mm} \text {. } \\
& \delta \text {. Total length, } 10 \mathrm{~mm} \text {. ; wing, } 7.5 \mathrm{~mm} \text {. } \\
& \text { Var. minor. - } q \text {. Total length, } 10 \mathrm{~mm} \text {.; wing, } 7.5 \mathrm{~mm} \text {. } \\
& \hat{\delta} \text {. Total length, } 7 \mathrm{~mm} \text {.; wing, } 6.5 \mathrm{~mm} \text {. }
\end{aligned}
$$

Of variable size, sometimes larger than the O. brevithorax, sometimes of the same size. Head densely punctured. Thorax longer than wide, densely cribrose; post-scutel linear above, finely crenulate, metathorax very squarely truncate; its concavity occupies the whole width, is smooth, silky, and a little striate, bordered above by some arcuate, very trenchant ridges, which abut upon the two extremities of the post-scutel within, but which are not as well separated from it by fissures as the $O$. brevithorax; from each side a dentiform angle turns downward. Abdomen perfectly conical; the first segment very large; quite long, being notably more so than in the O. brevithorax, where it only forms a cup, not a bell.

Insect black, clothed in a beautiful velvet, of silky hair, having golden reflections, which are only distinct among the well-preserved specimens. Mandibles ferruginous at the end, spotted with yellow at the base. Two spots at the extremity of the clypeus and one at the extremity of the scape, post-scutel, ridges of the metathorax, and a regular border upon segments $2-5$ of the abdomen of a yellow-ochre, a little golden; border of these segments strongly punctured; anus bordered with yellow; wing scales marked or bordered with testaceous; knees and end of tarsi a little ferruginous; anterior tibix marked with yellow before. Wings ferruginous with the end gray.

․ Clypeus pyriform, rugose, strigose-punctate, terminated by two diverging or biangulate teeth.

Var. a. Clypeus yellow, or margined witl yellow, or with two yellow spots on the top.

b. A yellow line on the seapo.

1 Only the figure, not the description. 
c. A yellow spot on each side between the eye and the clypeus.

d. I'rothorax slightly bordered with yellow on its anterior angles.

$e$. Prothorax not bordered with yellow, with quite golden reflections.

f. Antennæ quite black. (Bahia.)

g. Tibia with yellow lines or wholly black.

$\widehat{\delta}$. Clypeus polygonal, argenteous, widely margined with jellow on both sides; its anterior margin widely truncate. Antennæ fulvous beneath; the scape with a yellow line; lower part of the eyes bordered with yellow.

Var. Clypeus quite yellow, with a black spot or line in the middle.

Mexican variety. 9.-Mandibles black to the end. Antennæ ferruginous beneath, except at the extremity, and becoming brown ferruginous. Tibiæ all ornamented with yellow. There are often two yellow dots on the front; the teeth of the clypeus only, red.-Mexico.

Small variety. 9.-Of the size of the O. brevithorax, but offering the same characters as the above variety. Borders of the metathorax more rounded.- $-\delta$. Antennæ and legs as in the $f$ variety.-Mexico.

Ress. a. diff.-This species differs from the 0 . brevithorax, in its greater size, in its thorax longer than wide although very square, in its clypeus $q$ less wide, but strongly bidentate, in the disk of the mesothorax a little attenuated before, having the latero-anterior borders a little sinuate. The male differs, by its polygonal clypeus, truncate, not bidentate.

It approaches yet more closely to O. simplicicornis.-Com. pare these species.

Hab. Tropical America. I possess a great number of specimens. 1st. From the hot parts of Mexico (Huasteca, Oriental Cordillera, Michoacan, etc.); 2d. From Colombia and Venezuela; 3d. From Bahia and Brazil. They do not appear to me to differ specifically.

Although the description given by Latreille of his $O$. nasidens does not agree well with our specimens, we do not retain any doubt as to the identity of the species. The description of Latreille is evidently a hybrid description, being partly of a female, partly of a male. When he said that the clypeus was bidentate, 
he had seen the female of it; when he said "bordered with yellow," he had seen the male, which he may have taken for a female, because the antennæ do not possess a hook.

According to Latreille, the prothorax is ornamented with yellow on the anterior border, and it has a yellow dot behind the eyes, but we suppose that he was rather troubled about the golden reflections.

This unfortunate description of Latreille has caused me to lose infinite time in vain researches, without the least result, so that I have finally brought myself to announce the above opinion which I think to be the only correct one.

68. O. sinaplicicorm is SAuss. - O nasidenti simillimus, sed thorace panlo breviore et clypeo in utroque sexu truncato, haud distincte emarginato, $q$ apice flavo-bipunctato, $\delta$ flavo-marginato.

Odynerus simplicicornis SAuss. Vespides, III, 253, $\delta$ (1854); Id. Sagra's Hist. de Cuba, Ins. 771, pl. 19, fig. 5.-Rev. Zool. X, 1858, 166 (faulty),-Cresson, Philad. Ent. Proceed. II, 1865, 165.

․ Total length, $11 \mathrm{~mm}$.; wing, $9 \mathrm{~mm}$.

ऊ. Total length, $8 \mathrm{~mm}$; wing, $7 \mathrm{~mm}$.

․ A little smaller than the large variety of the $O$. nasidens; the same color, the same velvety and silky aspect. Clypens a little striate, less strongly punctured, truncate at the extremity, but biangulate, often a little bidentate. Thorax a little longer than wide; shorter than with the $O$. nasidens, longer than with the 0 . brevithorax; metathorax as with the nasidens, finely striate. Abdomen as with the $O$. nasidens. Antennæ ferruginous beneath in their fipst moiety; a yellow dot on the summit of the mandibles, two at the base of the clypens, and often two more on the front; posterior border of the prothorax, often the anterior also, post-scutel, superior ridges of the metathorax, and border of the segments $2-6$ yellow ; tibire often ormamented with yellow. Wings ferruginous, with the end gray.

$\delta$. Smaller; clypeus polygonal, truncate, offering at the two extremities of its inferior border a marked angle, more decided than in the $O$. auratus $\delta$; its lateral and inferior borders, yollow; a yellow line on the scape and in the sinus of the eyes. Jellow ormaments of the thorax indistinct.

Ress. a. diff.-Diflers from the O. brevithorer by its alypeus, which is not strongly bidentate, and by the yellow oruanents of 
the thorax. One should perhaps consider this species as a rariety of the $O$. nasidens? yet it appear's to us to constitute a local species.

Hab. The isle of Cuba. $6 \uparrow, 3 \delta$.

"The nest of this species is somewhat of an oblate spheroidal shape, constructed of fine earth, of a beautiful fawn-color. It is attached to a slender twig and measures $4 \frac{1}{2}$ by 6 lines; sometimes two nests are attached close together, to the same twig; the vuter surface is uneren, and on the upper side there is a stout peduncle, by which the nest has been attached to another body. The opening made by the imago in its escape is large and always on the side of the nest." (Cresson, 1. c.)

\section{b. Metaihorax rounded, not forming on each side a dentiform angle.}

89. O. Argentinu postice rugoso, rotundato, utrinque angulo nullo; superne utrinque acute-marginato, canthis a post-scutello fissura sejunctis; pronoti abdominisque segmentorum $2^{\mathrm{i}}-5^{\mathrm{i}}$ margine postico flavo-limbato; alis hyalino-ferrugineis, apice grisescentibus; tegulis ferrugineis.- $\delta$. Cly. peo truncato, flavo; puncto frontali ; scapo subtus, tibiis antice, flavis.

Odyn. Argentinus Sauss. Rev. et Mag. de Zool. XXII,1870, 56, 6 .

९. Total length, $11 \mathrm{~mm}$; wing, $9.5 \mathrm{~mm}$.

ऊ. Total length, $10 \mathrm{~mm}$; wing, $8 \mathrm{~mm}$.

†. Head and thorax densely and rugoșely punctured, shagreened; the punctures small. Thorax a little longer than wide. Post-scutel truncate, very short and transverse, crested and a little crenulate. Metathorax posteriorly excarated, rugose, but with arcuate edges, circular, forming no lateral angle whatever; the lateral ridges sharp in their upper half, each terminating in a tooth separated from the post-scutel by a deep fissure. Abdomen of equal width from base up to the end of the second segment, its base truncate and rounded; the whole very finely punctured, with very short hair and with sericeous gray pile; the hinder margin of 2 d segment sometimes slightly depressed or very slightly canaliculated, and a little more strongly punctured than the base.

Insect deep tlack, with very short gray hair. Antennæ black; a line on the hinder margin of prothorax and a regular band on the hinder margin of segments 2-5 yellow; beneath only a mark on each side of the margin of the $2 d$ segment; tegulæ margined with yellow or ferruginous. Anus black. Legs black; articu- 
lations and hooks a little rufous. Wings subhyaline or smoky; the anterior margin rather ferruginous.

Var. a. A little yellow mark on the forehead.

乙. A little yellow line in the middle of the margin of the $1 \mathrm{st}$ seginent.

c. 'The post-scutellar metathoracic eminences indistinct or not developed.

․ Clypeus convex, strigate, bicarinate, terminated by two angles or teeth, sometimes ferruginous.

$\widehat{\delta}$. Clypeus rounded, polygonal, pale yellow, widely truncate, its inferior angles almost toothed. A line on the mandibles and on the scape of the antennæ, a spot between the antennæ, innel orbits, a line on the anterior side of the tibix, pale yello: or ferruginous. Antennæ without a terminal hook.

Var. a. Only the $2 \mathrm{~d}, 3 \mathrm{~d}$, and 4 th abd. segments margined with yellow.

Ress. a. diff.-This insect has the appearance of $O$. diabolicus, but it is a little larger and is easily distinguished frorn it by its metathorax, destitute of lateral angles, but having elevated ridges separated by fissures from the post-scutel. The clypeus $\delta$ is more truncate; its inferior margin being wide.-It differs also from $O$. brachygaster, by its metathorax without angles, and by its deep black, not grayish color-velutinous as in $O$. nasidens and its allies.

Hab. The Argentine Republic. Buenos Ayres. $7 q, 5 \delta$.

B. All the abdominal segments margined with yellow or rufous.

a. Superior edges of metathorax not sharp.

\%0. D. Permensis SAuss. - Niger, cinereo-sericens; thorace autice latiore quam postice; metathorace excavato, strigato, inferis tantum canthis arutis; abdomine conico, basi lato, truncato, 2 i segmenti margine crasse punctato; post-sentelli et metanoti punctis 2 minutis, aludominisque segmentorum limbo late, pallido-flavis; $2^{\mathrm{i}}$ fascia utrinque aucta ; femoribus tibisque obscure rufis; alis subhyalinis, costa subferuginea. Longit, 11-12 $\mathrm{mm}$.

Q. Clypeo rotumdato, emarginato, valde punctato, dentibus 2 distautibus terminato.- $\delta$. Cly peo truncato.

Odyn. Peruensis Sauss. Et. Vespid. III, 253, 1:29, pl. xii, fig. 4 , $q(1554)$.

Mab. Peru. ('Typus in Mus. Parisiensi.) 
b. Superior edges of metathorax sharp.

\%1. O. brachg gaster SAdss.-Niger, valde punctatus, omnino fulvovelutinus; metatlooracis excavatione lata, læẹi, argentes-sericea, utrinque obtusangulata, superne canthis arcuatis acutis marginata; his a postscutello per fissuram utrinque sejunctis ; abdomine ovato, basi truncato ; capite omnino nigro; pronoti maryinibus obsolete, tegulis partim, post scutello, puncto subalari et punctis 2 in angulis scutelli, metathoracis canthis superioribus abdominisque segmentorum $1^{\mathrm{i}-5^{\mathrm{i}}}$ limbo, fulvis; primi fascia angusta, $2^{\mathrm{i}}$ lata ; $2^{\mathrm{i}}$ margine late crasse punctato; pedibus nigris, artibus, tarsis et mandibularum apice obscuro-rufescentibus; tibiis anticis fulvo-variis; alis snbhyalinis, basi et costa subferrugineis apice griseis.- $q$. Clypeo bidentato, dentibus inter se distantibus, rufis. $-\delta$ ?

Odyn. brachygaster Sadss. Et. Vespid. I, 173, 63, pl. xvii, fig. 8 (1S52). -Rev. Zool. V, 1858, 167, 5.

Var.? Margins of the abdominal segments narrow; antennæ ferruginous beneath; wings hyaline, with fuscous reins.

Tery similar to $O$. nasidens; but also very distinct, the abdomen not being as conical and the $2 \mathrm{~d}$ segment more eiongate; the antennæ are also more slender.

Hab. Brazil. (Paris Museum and coll. of author.)

This can be well distinguished from Chartergus chartarius (social wasp) by its truncate or bidentate clypeus (not angulate), its long mandibles, its wider first abdominal segment, etc.

72. O. Guadulpensis Sadss.-Niger, valde punctatus; capite et thorace rugosis, abdominis seginenti $2^{i}$ margine et sequentiluns valde punctatis; linea mandibularum et scapi, macula frontali, pronoto omnino superne, tegulis, macula subalari, maculis 2 scutelli, post-scutello metanoto utrinque, flavis; abłominis segmentis 10, 20 flavo-marginatis, primi fascia utrinque aucta; segmentis $\mathfrak{i}-5$ superne fulvo, subtus flaro, tenuiter limbatis; tibiis et tarsis fiavis; alis flavescentibus apice infumatis. - $q$. Clypeo flavo, nigro-maculato. $-\delta$. Clypeo truncato, polygonali, flavo.

Vuriat. Pronoti angulis posticis nigris.

O. cubensi aflinissimus; ab illo distincte differt: statura panlo minore; mandibulis nigris, flavo-notatis; pronoto frequenter omnino flavn; anteunarum scapo nigro, linea flava ornato; coxis et femoribus nigris; abdominis primo segmento haud acute truncato ${ }^{1}$; segmentis 3-6 nigris tenuiter flavo-marginatis.

Odyn. Guadulpensis Sadss. Et. Vespides, I, 182, 76 (1852).

1 In our $\hat{\delta}$ specimen the first segment offers a sort of sutiure, but this, I think, may be a mere accilent of puncturation. 
Ress. a. diff.-In this species the clypeus $\hat{\delta}$ is hexagonal, as broad as long, truncate, while in $O$. cubensis $\hat{\delta}$ it is longer than broad, bidentate, and its greatest width is situated lower than the middle. The abdomen is not as conical, not sharply truncate at base; the hinder margin of the $2 d$ segment and the following are more roughly punctate, ete.

93. D. zomatus SAdss.-Niger, punctatus; thorace quadrato, paulo longiore quam latiore, metanoto excavato, acute marginato, biangulato; puncto frontali, pronoti margine antico et postico, macula subalari, tegulis, scutelli punctis 2 , post-scutello, metanoti canthis, abdominis segmentoruı margine, tibiisque partim, flavis; alis nebulosis.- $\hat{\delta}$. Clypeo polygonali flavo, argentato; antennis subtus ferrugineis, scapi linea flava.-o?

Odyn. zonatus Sauss. Revue de Zool. XXII, 1870, כ̆7, 8,

Total length, $11 \mathrm{~mm}$; wing, $8 \mathrm{~mm}$.

Head and thorax cribrose. Thorax square, a little longer than wide. Its anterior margin concave, its angles rather produced, but not acute. Post-scutel truncate. Metathorax much excavated; its edges very sharp, forming on each side an angulated tooth. Abdomen conical, truncate anteriorly (but not sharply); the margin of $2 \mathrm{~d}$ segment and those following strongly punctate.

Black, with short fulvous, but not velutinous hair; a spot on the mandibles and a dot between the antennæ, a narrow band on the anterior margin of prothorax, a wider one on the posterior margin, a spot under the wing, wing scales, a spot on each side of the scutel, post-scutel, and the ridges of the metathorax, yellow; all the segments of the abdomen margined with yellow, the fasciæ of the first two segments the widest; that of the first a little wider on the sides. Knees and tibix outside and the first tarsi, yellowish. Wings clondy.

$\widehat{\delta}$. Clypeus polygonal, truncate or submarginate, yellow, silvery; labrum and seape beneatl, yellow; the remainder of anteme ferruginous below; emargination of the eyes argenteons.

Ress. a. diff.-This species comes very near to 0 . mracox Sauss., and may be a local ratriety, with all the segments mingined with yellow, or even a variety of $O$. guadulpensis, yith the ornaments roduced.

Mab. Cayemue. (Author's collection.)

Observation.- The extremity of the antemna being broken off, 
we are not sure that this insect belongs to this group, although the appearance is quite that of $O$. cubensis and neighbors. It might possibly go to the group of the Odyneri with hooked $\delta$ anteunæ?

C. Only the first two abdominal segments margined with yellow. (The $3 d$ and th sometimes indistinctly marginate.)

84. O. Gayi Spin.-Crassus, thorace quadrato, postice late excavato obtusangulato: abdomine brevi, lato, conico, basi truncato, primo segmento secundo æquilato; macula frontali, orbitis internis, scapo subtus, pronoti margine antico, margine postico tenuiter, macula subalari, postscutello, maculis 2 metanoti summi abdominisque segmentorum $1^{i}, 2^{i}$ limbo, albidis; alis subhyalinis antice subferrugineis, apice griseis.

$\delta$. Clypeo subemarginato, luteo. - $q$ ?.

Odyn. Gayi Spinola, in Gay's Hist. fis. de Chile, Zool. VI, 260 (1851).

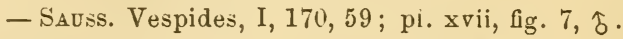

Hab. Chili. (Type in the Paris Museum.)

95. O. praecox SAuss.-Niger, capite et thorace confertim punctatis ; abdomine sericante, conico, basi lato; macula mandibularum, linea frontis verticali, pronoti margine postico, nec non antico tenuiter, macula subalari, punctis 2 in scutelli angulis, post-scutello, maculis 2 metanoti abdominisque segmentorum $1 \mathrm{i}, 2^{\mathrm{i}}$ margine, flavis ; reliquorum margine fusco; tibiis flavo-lineatis ; tarsis fusco-ferrugineis ; alis subliyalinis, costa obscuriore.

. Clypeo apice dentulis duobus rufis. $-\delta$ ?.

Odyn. prcecox Sadss. Et. Vesp. III, 254, 130 ; pl. xi, fig. 9, ㅇ, (1854).

Hab. The southern parts of Brazil and Uruguay. (Paris Museum.)

Observation. - This species may possibly belong to the Division Odynerus with hooked male antennæ? but its peculiarities bring it nearer to the species of Division Pachodynerus.

96. O. La Plata SAuss.-Niger, punctatus; abdomine sericeo, basi truncato; clypeo $\bigcirc$ apice dert'ulis 2 ferrugineis terminato, scapo subtus rufo; pronoti margine postico, signatura subalari, punctis 2 tegularum,

1 The note intercalated in the text of the description of this species referred it to the heading A (Crroup of the O. Megera). One more of the chefs d'œuvre of the printer, who is the cause of all other more grave faults introduced by his negligence into my work on the Vespides. 
flavis; abdominis segmentorum $1^{i}, 2^{i}$ margine flavo, $3^{1}, 4^{i}$ tenuiter flavescente; tibiis $1^{\text {is }}, 2^{\text {is }}$ linea flava; alis ferrugineis macula radiali fusca.

Odyn. La Platce Sauss. Rev. et Mag. de Zool. XXII, 1870, 52, 2 .

․ Total length, $12 \mathrm{~mm}$; wing, $9.5 \mathrm{~mm}$.

․ Form rather slender, very much as in $O$. cubersis and tibialis. Clypeus pyriform, strigate-punctate, terminated by two little ferruginous teeth. Head and thorax densely punctate. Post-scutel truncate, ridged but not crenulate. Metathorax excavated in its whole width, forming on each side an indistinct angle; its superior edges convex, very sharp, their superior extremity hardly separated from the post-scutel by a fissure, not forming salient teeth; the inferior edges straight or a little arched concave. Abdomen polished, silky, the first segment as wide as the $2 d$, almost sharply truncate.

Black; seape ferruginous beneath; a fine line along the posterior edge of prothorax and a very slender one along the anterior margin, on each side, two spots on the tegulæ, a mark under the wing, a line on post-scutel, and the superior edges of metathorax, yellow. Segments 1, 2 of the abdomen narrowly margined with yellow; the extreme margin of the 1st brown; segments $3-5$ narrowly margined with brown or yellowish. Knees and claws ferruginous. Tibiæ 1st and $2 \mathrm{~d}$ anteriorly with an indistinct yellow line. Wings ferruginous along the anterior margin; the radial cell brown.

Ress. a. diff.-This is possibly the same as 0 . præcox, and I should not have distinguished this from it, if in the description of præcox it was not said that the metathorax was rounded, while here the superior edges are very sharp.-It much resembles tibialis, but the livery is rather different and it varies also in its metathorax not sharply bidentate, its abdomen not as conical, its first segment not as sharply truncate, shorter, etc.-From zonatus it differs in its livery and the same changes in the form of the prothorax.

Hab. The Argentine Republic. Buenos Ayres.

\%ซ. O. tibialis Sauss.-Niger, cinereo-hirtus; dense p:nctatus; thorace quadrato, $f$ longiore quam latiore, $\delta$ cubico, depresso; metanoto bidentato, aontissime marginato; abdomine valide conice basi acute truncato et canthum acutum transversum efliciente: segmentorum 2-5 margine punctato. Macula mandibularum, pronoti margine, tegulis, 
macula subalari, post-scutello, metanoti maculis 2 superne abdominisque segmentorum limbo 1,2 flaris; tibiis extus flavis; alis ferrugineis, apice nubecula fusca.-Longit, $11 \mathrm{~mm}$; alæ, $9 \mathrm{~mm}$.

\$. Clypeo piriformi, grosse punctato, apice subbidentato superne flaro.

$\delta$. Clypen ovato, flavo, apice submarginato; antenuarum scapo flavo fasciato; Hagello apice haud uncinato.

Odyn. tibialis Sauss. Et. Vespid. I, 183, 7S (1852), $q$

Ress. a. diff.-This has the form of $O$. cubensis, from which it differs by its black forchead, antennæ, scutel, and feet; by its thorax not so strongly punctured, by the edges of metathorax not so much separated from the post-scutel, and by the clypens $f$ more coarsely punctured and not distinctly bidentate, while the male has the apical margin of the clypeus a little concave, with acute anglês.

Hab. Venezuela. Caraccas + . (Hayti $\delta$.)

Observation. - The 9 comes from the collection of De Romand, whose etiquettes, are not always exact. The male is labelled as caught by me at Hayti. This male is certainly of the same species as the female. The species may come from St. Domingo.

78. O. Cubens is Sadss. -Niger ; capite et thorace dense cribri instar punctatis; pronoto antice subcoarctato; post-scutello truncato, transversim tenuiter carinato; metanoto verticali, excavato, utrinque dente instructo, superne canthis acutissimis marginato, his a post-scutelln fissura sejunctis; abdomine conico; primo segmento antice acute truncato cantlium transversum efficiente; secundi segmenti margine punctato. Mandibulis, macula frontali, antennarum articulis $1^{\circ}, 2^{\circ}$, pro. noti margine autico late, tegulis, macula subalari, scutelli maculis 2 . post-scutello, metanoto summo utrinque, abdominis segmentorum 1-2 margine (primi fascia in lateribus aucta), et pedibus, flavis; abrominis segmentis 4-6 rufis, et frequenter tertio rufo-limbato; alis ferrugineis, apice fusco-nebulosis.-Lougit, $11 \mathrm{~mm}$; alæ, $9.5 \mathrm{~mm}$.

․ Thorace longiore quam latiore; clypeo piriformi, punctato, flavo, macula nigra, apice bidentato dentihus angulatis.

$\widehat{\delta}$. Thorace magis cubico; clypen orato, flaro, lævi, apice truncato, biangulato; oculorum sinu Havo-marginato. Antennis apice simplicibus.

Odyn. cuhensis Sarss. Et. Vespid. I, 181, 75, ${ }^{\prime}$ pl. xviii, fig. 8 (1S52).

Hab. Cuba. (2 $\%, 2$ s.)

1 In this description I have mingled the form of the clypeus $q$ with the description of the $\delta$, doubtless because the simple antennæ of the $\delta$ led me to take a $\delta$ for a $q$. 
79. D. Califormicus Sauss. (PI. 1II. fig. 17, 17 a)-Medius, niger, fulvo-tomentosiss; elypeo of piriformi valde punctato; thorace lrevi, tenuiter punctato; metanoto haud rugoso, biangulato, sed canthis obliteratis, nec acutis, nec rugosis; abdomine conico, segmentis 20 et serqnentibus in margine rugose punctatis; fascia arcuata summi clypei, pronoti et abdominis segmentorum $1^{i}, 2^{i}$ limbo, macula subalari, punctis 2 in tegulis, post-scutello et metanoti canthis, luteis; antennis froute et pedibus immaculatis; alis diaphanis, venis fuscis. $q$.

Odyn. Californicus, Sauss. Rev. et Mag. de Zool. XXII, 1870, 57, 9, q.

Total length, $11 \mathrm{~mm}$.; wing, $9 \mathrm{~mm}$.

9. Size and form of the $O$. foraminalus, clypens pyriform, strongly punctured, terminated by a little border channelled by a fossette and appearing bidentate. Head finely punctured. Thorax not retracted before, its surface smooth, shining, bearing some quite fine, separated punctures (at times effaced, especially in the middle of the mesothorax and of the scutel); post-scutel a little pad-shaped, finely crenulate (or smooth); metathorax not lugose above; its concavity wide, smooth, and shining, finely striate; it occupies the whole width, but its ridges are rounded, or at least blunted, not salient on the summit (although delicately formed), but smooth, not rugose, nor cribrose; on each side an angle, blunt or even rounded, according to individual specimens. Ablomen quite conic; the first segment truncate, but without sharp ridge; the second offering along its border a flat impressed band, carrying a narrow band of very coarse punctures, but the extreme border smooth. The following segments strongly punctured.

Insect black, clothed on the head and thorax with a strong pile of tawny or grayish hair; its hair very abundant on the metathorax. A spot on the mandibles, an areuate band (or two spots) on the summit of the clypeus, a regular border on the prothorax, a spot under the wing, post-sentel, ridges of the metathorax, and a border on the first two segments of the abdomen (the first widened on its sides), of a pale yellow; antennie and legs entirely black; the tarsi ferruginons toward the end only. Wings transparent, a little smoky; nervures brown. Wing seales having two yellow spots; their middle oceupied by a brown spot.

Var. a. 'Two yellow spots on the extremity of the elypens.

b. Inner border of the orbits, a spot on the front, a dot behind each eys, two dots on the angles of the sentel, a spot on the 
knees, whitish; anterior tibiæ ferruginous or whitish; $3 \mathrm{~d}$ and 4 th segments of the abdomen bordered with whitish beneath; 34 finely edged abore with this color.

Ress. a. diff.-This Odynerus resembles the J. Megæra in its whitish oruaments, but it is smaller. Yts smooth thorax, its mesothorax without longitudinal groores, its metathorax, smooth, biangulate and without little teeth behind the post-scutel, its immaculate front, and its transparent wings distinguish it superabuudantly.

The same characters distinguish it from the 0 . foraminatus and the O. leucomelas.

Hab. Lower California. I have receired divers specimens $?$ collected at Cape St. Lucas by Mr. John Xanthus and others from Southern California (Berton).

Observations. - This species has much of the form of the $O$. cubensis, but the male being unknown to me I place it with liesitation in this division. If the male proves to hare antennæ terminated by a hook, the species will fud its place in the Dirision Odynerus, next the O. Alvaradi. With the $O$. Erinnys it is the only Pachodynerus yet known to inhabit the boreal temperate zone.

2D. Section.-Form more lengthened; thorax lengthened square or retracted behind. Abdomen less conic, more cylindrical or depressed.

a. All the segments of the abdomen, except the first, bordered with yellow.

So. O. diabolicus SACss.-Gracilis; capite et thorace dense rugose punctatis; pronoti margine antico concavo, subcristato, angnlis subacutis; post-scutello truncato, transverse cristato-crenulato, metanoto excarato, utrinque bispinoso, marginibus excarationis acutis verticalibus, superne evanescentibus; abdomine subdepresso, antice rotundatotruncato; segmento satis elongato. Omnino niger, abdominis segmentis 2-6 fiaro-ochraceo linbatis; tarsis apice fuscescentibus; alis nebulosis.

9. Clypeo bicarinato, apice bidentato, vel acute biangulato.

$\hat{\jmath}$. Clypeo polygonali, apice truncato, luteo-argentato; labro, antennarum scapo subtus, macula frontali, fascia in sinû oculari, luteis.

९. Total length, $12 \mathrm{~mm}$.; wing, $9.5 \mathrm{~mm}$.

$\delta$. Total length, $11 \mathrm{~mm}$.; $\pi$ ing, $7.5 \mathrm{~mm}$.

Odyn. diabolicus Sacss. Vespides, I, 171, 60 (1852); III, 230.-Rev. et Mag. de Zool. X, 1858, 167, 6 . 
A very distinct species in the form of its metathorax. The Iateral tooth of metathorax is formed principally by the lateral ridge, and placed quite ontside of the margin of the exeavation, which is situated more inside, and rather distant from the tooth. There is, in addition, a very long spine on each side, on the inferior edges near the articulation of the abdomen. It has much the appearance of $O$. argentinus, but the metathorax is without lateral angles.

Hab. South America; Brazil, Venezuela (author's collect.).

\section{b. Abdomen varied with black and rufous.}

81. D. Erimnys LePEL.-Niger, valde punctatus, gracilis; thorace postice attenuaio ; metanoto longe bispinoso, canthis acutissimis marginato; abdomine basi truncato; in marginibus valde punctato; ore, macula frontali et antennaruı articulis 1-5 rufis; pronoto, tegulis, post-scutello, metanoti angulis, abdoininis primo segmento superne et secundi margine pedibusque, rufis; alis infuscatis, costa subferruginea.

○. Clypeo piriformi, crasse punctato, bicarinato, apice biangulato, apice et basi, rufis.

$\hat{\delta}$. Clypeo polygonali, luteo, argenteo-sericeo, subbidentato; anteunis apice haud uncinatis.

Vuriat. Primo et secundo abd. segmentis flavo-marginatis.

Odyn. Erynnis Lep. Str. Fargead, Hymén. II, 645, 30 q (1841).-Sadss. Vespides, I, 178, 70.

Total length, $16 \mathrm{~mm}$; wing, $11 \mathrm{~mm}$.

․ Form slender, moderately lengthened. Head and thorax coarsely cribrose; this last quite lengthened, retracted behind; post-scutel finely crenulate; metathorax having its posterior face a little retracted; strongly excarated, a little oblique, smooth, finely striate; bordered with abrupt very trenchant ridges, which are armed on each side with a long spiniform tooth, prism-shaped, and prolonged obliquely backward; it is placed sufficiently low for the inferior ridges of the metathorax to be almost horizontal; these last offer beyond on each side of the ralves of artieulation with the abdomen, a second distinct spine. The superior ridges are sinuons and terminate under the post-scutel by an are or nearly a right angle; seen in profile their smmmit terminates in ab pyramidal, although but little acute, angle, placed quite behind the post-sentel and separated from it by a triangular noteh. 
Abdomen of little width; finely punctured, the first segment long, almost as wide as the 2 , and boldly truncate on its anterior face; the $2 \mathrm{~d}$ eylindrical; its posterior border and the following segments strongly punctured.

Insect black, clothed with a short grayish pile. Month, extremity and summit of the clypeus, a spot on the front, articles 1-5 of the antennæ, red. Prothorax, wing scales, superior angles of the clypeus and legs, equally red. First abdominal segment above, wholly of a sombre-red; the second bordered with red; the border of $3 \mathrm{~d}$ and often the anus slightly ferruginous. Wings brownish, with violet reflections; the side a little ferruginous.

Var. The 1st segment adorned with an orange border; the border of $2 d$ passing also into orange.

․ Clypeus pyriform, very coarsely cribrose, bicarinate toward the base, prolonged and strongly truncate at the extremity; its little border biangulate but straight.

$\delta$. Clypeus polygonal, a little longer than wide; pale yellow, covered with silvery hair; its anterior border subconcave, subbidentate. Antennæ simple, terminated by a very small sharp nipple. Inner border of the orbits yellow or ferruginous; the frontal spot yellow. Ridges of the metathorax still more trenchant, terminated superiorly by a more acute angle of a pyramidal form.

Var. Clypeus orange.

Ress. a. diff.-This species, although similar in colors with $O$. Boscii and $O$. arvensis, differs essentially from them by its lengthened thorax, strongly retracted behind, by its little metathorax, by its long metathoracic spines, its much more trenchant and elevated ridges, its slender form, its clypeus longer than wide, and the simple antenuæ of the males.

The form of the abdomen slightly recalls that of the 0.4 -sectus; the livery that of $O$. dorsalis, variety.

$H a b$. The Southern United States. Carolina. Florida. $3 q$ 1 f from Florida (E. Norton). 


\section{Division ODYNERUS.}

SAdss., III ${ }^{d}$ divis., Sect. $I^{d}$ (Et. Vesp. I, 177); Divis. Epsilon, Sect. II (ibid. III, 254).

Forms as in Division PACHOdynerus, but often more elongate; the thorax more cubical, always in shape of an elongatesquare, oflen rather narrowed behind. Abdomen conical as in PACHODYNERUs, or ovate-conical, BUT THE FIRST SEGMENT ALWAYS FULLY INCLUDING THE BASE OF THE 2D. (By exception, irregularly contracted at base of the $2 d$ serment, the first seyment being smaller, rather cup-shaped.-O. MoneLII.)Antennæ of the males terminated by a hook.

The Odyneri of this Division have forms quite approximating to those of Division Pachodynerus, forms which have been described above, and they differ from these principally in the antennæ of the males which have the 13 th joint recurved into a little hook:

As these forms are not exactly alike in all, we arrange the species in a series in which we can follow the thorax as it becomes more elongate, and rather contracted behind, with the metathorax becoming more and more rounded, losing its sharp edges, while the abdomen is less conical and more and more ovate-conical.

This Division includes quite varied types, principally characterized by the modifications of the metathorax (which is sharp, spined or rounded, and blunt), and by the form of the abdomen, quite conical or elongate and more ovate. The more elongate species pass into the forms of the Division Stenodynerus. Is these distinctions are difficult to establish, I have prepared a tabular statement of them.

Table to assist in distinguishing the Division ODYneres and Stexodyxerts, with regard to Pachodynerus.

( Post-seutel truncate; abdomen conical.

Post-scutel truneate; abdomen spindle-shaped, the

first segment rather subpetiolate or fumnel-shaped. Stenodyners:

Post-sentel not truncate; oblique, posteriorly angulate, punetate.

$\{$ Thorax cubieal.

Thoras more lengthened.

Stenodynerus.

Puchodignerus.

$\left\{\begin{array}{l}\text { Pachodynerus. } \\ \text { Odyncius. }\end{array}\right.$

Pachodynerus.

Oilynerus.

sienodynerus. 
( Superior face of metathorax produced behind the post-scutel.

Stenodynerus.

Superior face of metathorax not produced behind the post-scutel.

a. Truncate, with the post-scntel.

$\{$ Pachodynerus. Odynerus.

b. Truncate, without the post-scutel, which is not truncate.

Stenodynerus.

( Abdomen elongate, its base widely truncate.

$\{$ O:lynerus.

\{ Stenodynerus.

Abdomen conical.

$\{$ Pachodynerus.

$\{$ Odynerus.

Abdomen spindle-shaped, contracted at base, the first

segment funnel-shaped or cup-shaped.

Stenodynerus.

(First abdominal segment longer or as

long as wide.

Stenodynerus.

First abd. segment having its superior

face wider than long.

$$
\left\{\begin{array}{l}
\text { Pachodynerus. } \\
\text { Odynerus. } \\
\text { Stenodynerus (by exception). }
\end{array}\right.
$$

( First abd. segment more strongly punctured than the second.

Stenodynerus. .

First abd. segment not so strongly punc-

tured as the second, smooth.

First and second segments equally punctured.

$\left\{\begin{array}{l}\text { Stenodynerus. } \\ \text { Odynerus. }\end{array}\right\}$ exceptionally.

The insects of this group hare a marked tendency to become rugose, and the border of the $2 \mathrm{~d}$ abdominal segment is cribrose with strong punctures; in general, at any rate, it offers a zone, rugose and a little impressed or channelled.

But there is a set of species which offers, on the contrary, a smooth, shining body, with a tendency to omit the punctures. This type is represented here by the O. bidens only, but is met again in other genera.

The species presenting a rugose body offer a great similarity to the European species, and this similarity goes so far that one might attempt to indicate with certainty among them the European type from which they seem to be derived. So, for example, the $O$. (Rhynchium) dorsale, derived from the Rhynchium oculatum; the $O$. foraminatus from the $O$. simplex, etc., while those having a smooth body which have been identified, are of a type 
exclusively $\Lambda$ merican. The $O$. bidens in particular, with its great size, its black-violet wings, its white ornaments, forming large spots, its smooth body, is a type of which the form has no similarity either in Europe or elsewhere, while it recalls othel' species peculiar to North America (Monobia uncinata, Ancistrocerus 4-sectus).

The species which form the Division Odynerus occupy in America principally the northern temperate zone. 'They appear to be yet more numerous in North America than in Europe.

\section{Table to assist the determination of the species of Division Odynerus.}

Nota.-Compare O. Crypticus (No. 95), which could not be introduced into this talle, not being sufficiently well known; and at the end of the genus, the list of species incertee sedis.

1. Second abdominal segment having a particular form.

2. Second abdominal segment deformed.

3. Swollen posteriorly, forming two gibbosities, its margin very deeply canaliculate and much reflexed. 110. cluniculus.

3,3 . Without strong gibbosities; the margin only strongly canaliculàte.

111. Morelii.

2, 2. Second abd. segment produced in the middle, forming a sharp angle or tooth.

productus. ${ }^{1}$

1, 1. Second abd. segment not deformed, normal, not swollen.

2. Wings black or fuscous, with violet iridescence.

3 . Oruaments of the body white or luteous.

4. Metathorax black, $2 d$ segment margined with luteous.

101. Megreru.

4, 4. Metathorax maculate with luteous; $2 \alpha$ segment not margined with lutecus.

90. bidens.

3,3 . Ornaments of the body yellow or rufous.

4. Netathorax angulate.

5. First abd. segment sharply truncate at base.

82. Hidalgi, rar.

5, 5. First abd. segment not so sharply truncate, more rounded.

84. f dorsulis.?

$93 .\{$ annectens.

4, 4. Metathorax rounded; insect velutinous. 109. Romandinus.

2, 2. Wings subhyaline or clouded or ferruginous.

3. Body much adorned with rnfous; prothorax often rufous.

4. Metathorax not forming on each side a lateral deniform angle.

1 Compare at the end of Cenus Odynerus, the species incerter sidis.

2 Compare also $O$. Boscii and arensis, sometimes with rather obsure wings. 
5. Insect black and dull rufous, with yellowish ornaments; body relutinous, hairy.

6. Second abi. segment not canaliculate. 10s. Guerreri.

6, 5. Secoud abd. segment haring its unargin strongly canali. culate.

111. Morelii.

5, 5. Insect ftrruginous and black, with bright yellow ormanents; abdomen polished, not relutinus. 94. $\{$ annulutus.

4, 1. Netathorax forming on each side a dentiform angle.

5. Size very large.

6. Wings swoky.

84. dorsalis.

6, 6. Wings feruginous.

5, 5. Size medium or small.

\&5. $\{$ proctus.

86. $\{$ consors.

6. Superior angles of prothoras not prominent.

7. Wings swoky.

99. (apicalis. 94. $\left\{\begin{array}{l}\text { annulatus. } \\ \text { arrensis. }\end{array}\right.$

7, 7. Wings ferruginous.

8. Secoud abł. segment not caualiculate.
9. Size smaller.
98. spectabilis.
9, 9. Size larger.
94. \{ annulatus.
99. Lapiculis.

8,8 . Second segment more or less canaliculate.

9. Post-scutel crenulate; abdomen conical.

89. Iturbidi.

9, 9. Post-scutel not crenulate; abd. not conical.

1]1. Morelii.

6, 6. Superior angles of metathorax prominent, separated from post-scutel by a fissure or a noteh. Size medium.

7. Margins of segments 2d, 3d, reflexed; post-scutel-ellow. - S. All the segments margined with yellow.

8, 8. Segments 1-3 margined with yellow.

s.2. Hidulgi, var.

§.2. Hidulgi, rar.

7, 7 . Margins of segments 2, 3 depressed, but not retlexed; post-scutel black.

83. Boscii.

3, 3. Body hlack, adorned with yellow or luteous.

4. Ornaments luteous.

5. All the abd. segments margined with luteous.

103. leucomelas.

5, 5. Only 2d segment margined with luteous. 101. Megara.

4, 4. Ornaments yellom.

5. Post-scutel black.

6. Segments 1, 2 margined with yellow; wings cloudy, bromish.

83. Boscii.

6,6 . Segments all margined with yellow; wings ferruginons.

5, 5. Post-scutel adorned with yellow.

91. Alvaradi. 
6. Very large species.

6, 6. Species of mediun or small size.

7. Metathorax forwing on each side a lateral angle.

8. Superior angles of metathorax separated from postscutel by a fissure or a notch.

Superior angles produced into erect spines; scutel yellow.

87. scutellaris.

9, 9. Superior angles not spined.

10. Lateral angles acute; margin of $2 d$ segment reflexed; scutel black. 82. Hidalyi.

10, 10. Lateral angles obsolete; margin of $2 \mathrm{~d}$ seginent not reflexed; scutel maculate.

11. Metathorax very sharp; 1st segment broadly margined with yellow. 100. turpis.

11, 11. Metathorax not sharp; 1st segnent not margined in the middle. 88 . Cordocis.

8, 8. Superior angles of metathorax not producer.

9. Scutel yellow or maculate; clypeus $q$ yellow; wings ferruginous.

10. Second segment margined with yellow.

11. Smaller; more slender; scutel yellow.

95. spectabilis.

11, 11. Larger, less slender, scutel maculate.

10, 10. Second segment mostly yellow.

$$
\text { 91. }\{\text { apicalis. }
$$$$
\text { 97. }\{\text { formosus. }
$$

96. sulfureus.

9, 9. Scutel black; clypeus $q$ rufous or black and yellow.

10. Ornaments of the body bright yellow.
11. Wings smoky.
92. arrensis.

11, 11. Wingssmoky-ferrnginous. 94. anmulatus.

10,10. Ornaments dull yellow; wings ferruginous; body rather pubescent. 91. Alvaradi.

7, 7. Posterior face of metathorax more or less orbicular, not forming two lateral angles.

8. Superior edges of metathorax sharp, produced, separated from post-scutel by a distinct fissure or a notel.

9. Segments 1, 2 margined with luteous.

101. Megera.

9,9. Segments 2, 5 margined with yellow or luteous.

10. Second segment without yellow macule.

11. First segment only maculate on the siles.

Ss. Cordorit.

11, 11. First segment margined with yellow.

12. Seutel maculate witl yellow.

13. Wiges of the concarity of metathorax rery sharp.

100 . turpis. 
13, 13. Edges of the concarity of metathorax more blunted. 105. molestus.

12, 12. Scutel black.

13. Fascia of the first abd. segment narrow; ornaments pale. 103. leucomelas.

13, 13. Fascia of the first abd. segment wider: yellow. 102. \{foraminatus. 107. \{favolictus.

10, 10. Second segment with lateral yellow maculæ or fascia. 104. blandus.

8, 8. Superior angles of metathorax not produced behind the post-scutel or scarcely produced.

9. Second segment without lateral yellow spots.

10. Metathorax strongly excavated, rough; all the segments margined with yellow.

105. molestus.

10, 10. Netathorax not strongly excavated, not rough; 2, 3 segments margined with yellow.

109. Romandinus.

9, 9. Second segment with lateral yellow spots or fasciæ. 104. blandus.

Description of the species.

Section I.-Post-scutel sharply truncate; its transverse edge often crenulate. Abdomen conical or ovate-conical; the second segment not strangulated at base; the first segment including it very naturally.

1. Posterior plate of metathorax angulate, forming on each side a lateral dentiform angle. (Thorax square, angulate, posteriorly wide, not contracted. Abdomen very conical.)

A. Concavity of the metathorax polygonal, margined with straight or arcuate ridges, which form at their meeting s sharp angle. The superior lateral edges superiorly terminating in a tooth or eminence, separated from the post-scutel by a deep fissure, or by a notch.

These teeth are more distinct in the males than in the females, sometimes obsolete in the females. ${ }^{1}$ Comp. Sec. B.

a. Ridges of the metathorax very salient; its posterior face excavated.

* Posterior margin of $2 d$ and $3 d$ abdominal segments reflexed.

82. O. Hidalgi SATss. - Niger, crasse cribri instar punctatus; clypeo in utroque sexu truncato; metanoto valde concavo, biangulato, canthis

1 Principally in Orlyn. Boscii and dorsalis. 
maxime acutis marginato; abdomine conico, basi acute truncato; seg-

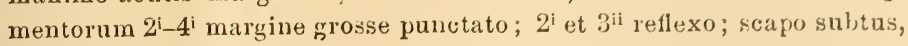
macula frontali, oculari, post-oculari, pronoti nargine anticn, postscutello, tegnlis, macula subalari et utrinque metanoti sumni, aludominis segmentorum 1i-3ii marginibus, flavis; primi fascia utrinque aucta; pedibus et mandibulis ferrugineo- et flavo-variis; alis infuscatis violascentibus. + . Clypeo nigro, flavo-binotato; $\hat{\delta}$ clypeo flavo.

Vuriat signaturis plus minusve fulvis (Am. borealis).

Vurietas Mexicana.-Nigro et rufo-variegatus, vertice nigro; antennarum articulis 10,20 ferrugineis; pronoto, macula subalari, tegulis, scutellis, metanoti lateribus, rufis vil flavo-variis; abdomine rufo; segmentorum limbo flavo-vario; $1^{i}, 2^{i}$ basi nigro-angulato, pedibus rufis.- $-\delta$. Clypeo, capitis signaturis et scapi fascia, flavis; pronoti limbo, scutellis, macula subalari et tibiis aurantiacis.

\section{Total length, 13-14 mm.; wing, 10-11 mm. \\ 今. Total length, $11 \mathrm{~mm}$.; wing, $8 \mathrm{~mm}$.}

Odyn. Hidalgi Sauss. Rev. et Mag. de Zool. IX, 1857, 275 (var).

Appearance of a Rhynchium, but the mouth quite as in Odynerus; the joints of the maxillary palpi becoming regularly shorter from the first to the last.

Clypeus punctured, widely truncate, its inferior part rather flattencd and laterally bicarinate. Thorax in the form of an elongate square, not contracted posteriorly, densely and coarsely punctured. Post-scutel sharply truncate, strongly crenulate. Metathorax very rough on its superior and lateral face; its posterior concavity occupying its whole width, shining, strigose, margined with very sharp edges, which form on each side a very strong dentiform angle, and which terminates superiorly in two eminences separated from the post-scutel by two deep fissures. Abdomen silky, quite conical, not ovate ; its first segment large, as wide as the second, sharply truncate anteriorly; the margin of $2 \mathrm{~d}$ and following segments quite coarsely cribrose; the borler of the $2 \mathrm{~d}$ and $3 \mathrm{~d}$ reflexed but not channelled. Mandibles, a frontal mark, inner orbits, post-ocular fascia, scape of the antenne beneath, anterior margin of prothorax, a spot beneath the wing, tegulx, post-scutel, a mark on each supcrior angle of metathoriax, yellow or rather fulvous; segments 1-3 margined with yelluw, the fascia of the first much widened on the sides or fused with an oblique fascia, often rufous. Legs ferpoginous, hlack at base; tibia with a yellow line, or entirely yellow. Wings infuscated, 
brown with violet iridescence, or fusco-violaceous; the base paler or a little ferruginous.

Var. Prothorax often with some rufous color; the jellow changing to fulvous.

§. A little smaller. Maculæ of metathorax larger; its superior ridges very salient, more arcuate, terminated superiorly by a sharp tooth. Mandibles and clypeus yellow; this last polygonal, wider than long; the angles of its inferior wide margin somewhat toothed, the inferior part not prolonged as in $O$. arvensis.

Mexican variety f.-Insect rufous and black. Head black; mandibles, clypeus, margins of the orbits complete or interrupted at the vertex, a spot on the forehead, and at base of antennæ, rufous; prothorax, tegulæ, a spot beneath them, rufous; scutel rafous, notched, with black at base; their margins all yellow; the margin of the first segment widened on the sides. Anus yellow. Fect rufous, varied with yellow. Wings smoky, mixed with ferruginous (O. Hidalgi Sss., l. c.).

Var. Clypeus, scape of the anteunæ, and forehead, etc., raried with yellow.

. Mandibles, orbits, a triangle on the forehead, a line on the scape of the antennæ, yellow; flagellum often ferruginous beneath; the hook ferruginous. Margin of prothorax, scutel, a spot under the wing, and tibix, often yellow.

Ress. a diff.--This species is peculiar in having its first segment sharply truncate in a right or even more acute angle. It differ's from the 0 . Boscii and arvensis in its reflexed $2 \mathrm{~d}$ and $3 \mathrm{~d}$ abdominal segments, its more sharply truncate 1 st segment; in its more elevated metathoracic post-scutellar eminences, its more truncate clypeus.

The type (northern variety) differs from $O$. Boscii in its yellow post-scutel and black scutel.

The Mexican (Iufous variety) recalls $O$. Guerreri and Iturbidi. It diferers from the first in its form and its not bidentate postscutel; from the second in its metathorax, superiorly very sharp, in the reflexed margin of the $3 d$ segment, the abdomen being sharply truncate at base, not rounded, etc.

Hab. United States. New York. Louisiana (E. Norton).The temperate part of Mexico. I caught $2 \%, 1 \hat{\delta}$, var., in the hot part of the province of Mexico, near Cuautta and Cuernacara. Tamaulipas 1 . 
** Posterior margin of $2 d$ ard $3 d$ abdominul segrnents not reflexed, luut impressed and rough.

83. O. TRoscii Leper.-Medius, rugosus, clypeo late piriformi, dentibus 2 distantibus terminato; $O$. arvensi simillimus at clypeo minus grosse punctato, metanoti canthis superioribus acutissimis, crenatis; niger, rufo et flavo variegatus, sed pronoto sæpius rufo, flavo-marginato, scutello flavo- vel rufo-bimaculato, post-scutello nigro; abdominis segmentis $\{10-20, \delta$ 10-40 flavo-limbatis; primo quandoque ante marginem rufo.

Odyn. Boscii Lepel. St. Farg. Hyménop. II, 637, 22 (1841).-Sadss.

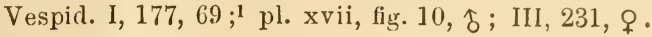

Odyn. castigatus Sauss. Vespid. I, 178, 71 (1852).

Total length, $14 \mathrm{~mm}$.; wing, $11 \mathrm{~mm}$.

․ Size, form, and puncturing of the 0 . arvensis, or a little less coarsely punctured. Clypeus widely pyriform, punctuatestriate, terminated by two little separated teeth. I'ost-scutel strongly crenulate. Metathorax laterally bidentate; its spiniform angles situated a little lower than in the species cited; the posterior plate strongly concave, striate throughout and distinctly bordered with very sharp and trenchant ridges, above all between the spiniform angle and the post-scutel; these ridges a little crenulate and terminating superiorly in a sort of tooth or rather a crenulate angle separated from the post-scutel by a notch; their inner face a little rugose, punctured.

Insect densely and rugosely punctured; the metathorax above very rugose. Abdomen conic; the first segment truncate at base, at a right angle, but the transrerse edge rounded, not sharp. Border of the 2d abrlominal segment depressed, coarsely punctured, but not reflexed; those following strongly punctured. Insect black. Mouth, clypens, spots behind the eyes, red or orange; an arc or two spots at the summit of the clypens, one on the front, and inner border of the orbits, orange; articles 1, 2 of the autenna red or orange, with an obscure line abore. Prothorax red; the anterior border orange; tegule red, spotted with yellow: spot under the wing orange or red; clypens black, with somewhat of red and two yellow spots: fwo orange spots at the summit of the metathorax; segments 1,2 of the abdomen bordered with ycllow; the border of the first widened on the sides; this widen-

I In place of Long. $=0.018$, read: $=0.012$. 
ing varied with red or often almost entirely red. Legs yellow or red, with the base of the thighs obscure. Wings of a brownreddish, slightly darkened, witli some violet reflections (Carolina).

Var. a. Edges of metathorax a little blunted by the rugosities.

乙. Prothorax black, slightly borciered with red and rery slenderly with yellow; ornaments of the head red; borders of the abdomen narrow. Clypeus black, with a yellow band on the summit.

c. Clypeus black, with two yellow spots.

d. Clypeus black, with two red points (New England). The yellow and the red take each other's places and are more or less developed. Base of legs black.

e. Prothorax black, ornamented with yellow, without red.

$f$. The 3 d segment bordered rith yellow.

g. Insect distinctly black and yellow, without red. The ornaments of a sharp yellow. Clypeus black, with a yellow arcuate band on the summit; a jellow line on the scape (New York, Tennessee).

h. Spots on the scutel rery small or none.

$\delta$. Clypeus yellow, but little notched; post-scutel red or yellow; first abdominal segment red, bordered with yellow. Segments 3,4 adorned with a yellow edging.

Ress. a. diff.-This Odynerus differs from the 0 . dorsalis $q$ by its wider clypeus, and by the trenchant and elerated ridges which border the concarity of the metathorax above the spiniform angle, also by its smaller size, etc. From the 0 . arvensis by these same metathoracic ridges, which are more salient and crenulate, which one may perceive especially in profile; by its black post-scutel and its scutel spotted with yellow; by its $3 \mathrm{~d}$ segment, a little less strongly punctured; its final seginents not bordered with yellow. Nerertheless these two species are allied. -From the $O$. Hidalgi by the absence of the reflexed border of segments 2,3 , by the black post-scutel, the 1st segment not so acutely truncate, etc.

$H a b$. The United States, at the South. Florida, 1 \%. South Carolina, 2 \%. Tennessee, 3 \%. New York and Connecticut, 3 ? (E. Norton).

The specimens coming from the South are especially marked with red; those of the north become black and yellow.

Observation.-Lepel de St. Fargeau has described a male, and I unfortunately possess only females. He was evidently mis- 
taken in saying that the post-scutel is slightly crenulate; however, one finds under this description some variations according to specimens.

34. Da dorsalis ${ }^{1}$ FABR.-Validus, niger, valde punctatus; clypeo integro, metanoto postice striato, utrinque dente armato, marginibus rugosis, obliteratis, nullomodo acntis, canthis $q$ nullis, $\delta$ elevatiusculis; ore, clypeo, antennarum articulis $1-3$, maculis post-ocularibus, pronoto, scutello, tegulis, rufis; pronoto medio, post scutello et abdominis primi segmenti margine, flavis; margine secundi t tertii rugosissime punctatis:- $\delta$ antennis basi, maculaque subalari rufa; abdominis segmentorum margine 20,30 flavo, secundo reflexo, subcanaliculato; pedibus flavis, basi nigris; alis fusco-cyaneis.

Variat a fusco et ferrugineo-variegato ad omnino ferrugineum; primo segmento flavo-marginato.

Vespa dorsalis FABR. Syst. Ent. 367, 25 (1775). Ent. Syst. 265, 44.Ouiv, Encycl. Meth. VI, 685, 81.

Polistes dorsalis FABR. Syst. Jiez., 273, 19.

Rhynchium balteatum 'SAY, Bost. Journ. I, 1837, 383, 1.-Say's Entom. LE Conte, II, 764, 1.

Monobia sylvatica Sauss. Et. Vespid. III, $168 .{ }^{2}$

Rhynchium Louisianum Sauss. Et. Vespid. I, 106, 7 ; pl. xiii, fig. $9^{3}$ (1852). Rhynchium dorsale Sauss. Et. Vespid. III, 171.

․ Total length, $17 \mathrm{~mm}$; w wing, $14 \mathrm{~mm}$.

3. Total length, $17 \mathrm{~mm}$; wing, $12 \mathrm{~mm}$.

†. Large. Clypeus wider than long, but pyriform, terminated by a truncation or even a little rounded; its surface covered with quite fine punctures. Mandibles long, hooked; armed in the middle of their inner border with 3 or 4 oblique tecth, but their final portion simply cutting, not dentate. Head and thorax densely cribrose with strong punctures; prothorax retracted before. Scutel briefly truncate, bearing a cremulate crest, interrupted in the middle. Metathorax very coarsely puuctured, very rugose upon its border's; quite variable according to specimens ; its hinder plate quite flattened, striate, forming on each side a dentiform angle (at times blunted); its superior borders sometimes quite trenchant, sometimes effaced, seareely offering tren-

1 Compare Rhynchium dorsale, page 143.

2 Compare page 132, No. 3, most likely a different species.

3 On the inscription upon this plate, in place of: 9 . Rh. limbatum, read: 10. Rh. limbatum; and in place of: 10. Rh, Louisanum, read: 9. Kh. Louisianum. 
chant ridges, but rounded and rugose, rarely elevated so as to be separated from the post-scutel by a fissure, so that the post-scutel appears very salient. The concarity striate, its borders rugose. The superior crest salient or effaced. Abdomen wide, conical ; the first segment truncate, but rounded, without a ridge ; the $2 d$ segment finely punctured, offering along its posterior margin a wide rugose band, a little depressed, garnished with coarse punctures; this band a little widened in the middle, but the little horder (the very edge) smooth; following segments strongly punctured, with the extreme margin smooth.

Black Variety.-Insect black; mouth, clypeus, a spot on the front, inner border of the orbits, a great spot behind each eye, articles $1-3$ of the antennæ, rufous; prothorax, tegulæ, scutel, equally rufous; in the middle of the prothorax a double spot and on the post-scutel a line or two dots, yellow; first abdominal segment ornamented with a yellow border widened on the sides. Legs black, knees, tibiæ, and tarsi, yellow. Wings of a deep brown violet.

Var. a. Scutellum black.

b. Border of $2 d$ and $3 d$ abdominal segments brown.

c. Border of $2 d$ and $3 d$ segments narrowly yellow.

d. Clypeus black, spotted with ferruginous. Scutel black, with two red spots.

$e$. Disk of mesothorax with two hooked rufous maculæ.

$f$. The ferruginous more extended; two ferruginous spots on the mesothorax; scutel and metathorax ferruginous; abdomen ferruginous with the first two segments notched with black at the base and their border yellow (Louisiana) (Polistes dorsalis Fabr. Rh. Louisianum Sauss.).

g. Almost entirely ferruginous, with the border of the first segment yellow. Legs, mandibles, orbits, raried with orange (Illinois).

h. The two metathoracic teeth blunted, not very distinct.

Rufous Variety.-The whole insect rufo-ferruginous; scape beneath, hinder margin of prothorax, tegulæ, a line on the postscutel, border of the 1st segment of the abdomen, yellow; feet mostly yellow, and the flagellum only of the antennæ black.Mexico.

-a. A spot on the vertex, anterior part of mesothorax, base of the first two segments of the abdomen black (Tenuessee). 
-b. All the intermediate degrees between the black and the rufous variety (Illinois, 'Tenuessee).

$\delta$. Metathorax less blunted on the latero-superior borders of the concavity, the superior edges more elevated, forming lines of salient rugosity, and separated from the post-scutel on each side by a fissure; often exhibiting two slightly crenulate salients; the two lateral teeth very sharp. Abdomen more conical.

A little smaller; clypeus as long as wide, yellow. Mandibles, inner borders of orbits, spot on the front, and a line on the scape of the antennæ, in gencral, yellow; hook of the antennæ ferruginous. A red spot under the wing. Borders of abdominal segments 2, 3 adorned with yellow; the $2 d$ reflexed, strongly channelled; rugosities of these two borders excessively strong. Wing not so deeply colored as in female.

Var. a. Angles of metathorax red; a little red bordering the yellow within the black notch of the first segment, especially on the right and the left.

b. 'Two yellow dots on the superior face of the metathorax and two beneath the wings.

c. The whole anterior border of the prothorax red, widely margined with yellow.

d. Wings transparent. Scutellum black.-Illinois (Talsh).

e. Body more and more rufous.

This species scems to become more rufous as it goes southward. It is also rather variable in the strength of the punctures.

Ress. a. diff.-The $O$. dorsalis is remarkable for the inequality of the metathorax in the different sexes, from whence it results that the males are well placed in this section, while the females seem by their effaced ridges to go better into the Divisions B. or C. The species greatly resembles the $O$. Boscii and areensis, but above all it differs from them by its greater size, by its truncate, not bidentate clypeus, and by its more obscure wings. It differs from the $O$. Boscii by the less elevated ridges of the metathorax, and from the arvensis by the mole clevated ridges. The ferruginous individuals resemble the O. Iturbidi. Finally, the species is clearly different by its maxillary palpi, which are those of a Rhynchium. ${ }^{1}$

1 With the O. dorsalis, the maxillary palpi have the 1st article large: the $2 d$ and $3 d$ sleuder and long; the last three quite small. The $3 d$ 
Hab. The United States, especially the South. I possess divers individuals taken in Pennsylvania (Rathron), Illinois (Walsh), Tennessee (Fuchs), Louisiana (Norton), South Carolina (author). I have taken the red rariety in Mexico.

Observation.-I am not entirely certain whether my lionobia silvatica should be fused into this species or whether it is a true Nonobia, the label of it being uncertain and the palpi having been found in an imperfect state. The type I cannot examine again.

55. Droctus Cresson. - Pallide ferrugineus; orbitis, clypeo, margine antico pronoti, scutellis, macula subalari, pedibus partim abdominisque segmentorum $1^{i}, 2^{i}$, marginibus, obscure-flavidis; antennis mediis nigrescentibus; alis pallide flavescentibus. $\$$.

Odyn. Proctus Cressox, Phila. Ent. Proceed. IV, 1865, 159.

Total length, 8.5 lines; expanse of wing, 15 lines.

․ Head dull-ferruginous, dusky abore the insertion of each anteunæ, around the ocelli and on the occiput; inner orbits of the eres, filling up the deep sinus, a small subcordate mark between the antennæ, the clypeus, and most of the mandibles vellowish; clypeus large, closely punctured, flattened on the disk, and slightly and obtusely emarginate at tip; mandibles black at tip; palpi pale ferruginous ; antennæ yellowish-ferruginous, the scape yellowish beneath. Thorax fusco-ferruginous, closely and rather deeply punctured, corered with a rery short, fine, dull yellowish, subsericeus pile; broad anterior margin of the prothorax abore, continued in a narrow line to the tegulæ, and a large spot on each side of the pleura, yellowish; mesothorax fusco-ferruginous, tinged with blackish on the anterior and posterior margins, the disk, with two distant, rery faint, longitudinal, ferruginous lines, confluent behind the middle; scutellum and post-scutellum yellowish, the apical margin of the former blackish, and the yellowish portion divided down the middle by a faint fuscous line; metathorax yellow, the suture between it and the post-scutellum, as well as a large spot on the apical middle, fuscoferruginous; posterior face rather suddenly depressed, with a small tubercle on each side at the angulation; pleura fuscous

article is not longer than the last two taken together, but yet the species may be placed in the genus Rhynchium.-Compare what has been said spropos of the genus Rhynchium, page 142 . 
beneath; tegulx dull yellowish, with a ferruginous stain on the middle. Abdomen obloug ovate, the basal segment dome-shaped, obtusely rounded at base, without transverse suture at carina, distinctly punctured, the remaining segments indistinctly so; apical margins of all the segments above narowly yellowish, almost divided on the disk by a narrow line, those of the second and third segment broader and dilated on the extreme sides, especially on the first segment, where there is a rather largo triangular mark; the bands on the remaining segments more or less emarginate on each side anteriorly; apical segment with a large, broad, angular, dull yellowish mark on the middle; beneath marked as above, except that the apical segment is immaculate, and the second segment is almost entirely yellowish, with three ferruginous spots arranged transversely near the apical margin.

Legs deep yellowish, the femora above and at base beneath pale yellowish and pale ferruginous. Wings deep yellowishhyaline, faintly dusky at tips; nervures honey-yellow.

Var. This species certainly varies much into black, rufous and yellow.

Ress. a. diff.-I do not know this species, and I can only copy the good description of it given by E. 'T. Cresson, so that I can not be perfectly sure it should be placed in this section. It is very distinct by its enormous size, still larger than $O$. dorsalis; being the largest North A merican Odynerus. It is most likely a Rhynchium, as well as $O$. dorsatis. I quite agree with the presumption of Mr. Cresson, that $O$. consors may be its male.

Hab. Cuba.

86. D. comsors Creșon.-Niger; puncto frontali, orlitis, clypeo, pronoto antice, tegulis, macula subalari, scutellis, metathorare partim, pedibus, abdominisque segmentorum limbo, thavidis; abdomine fusco, segmentis 10 et 30 nigrescentibus; alis ferruginescentibus apice griseis.

Odyn. consors Cressox, Phila. Ent. Proceed. IV, 1865, 160.

Total length, 7 lin.; expanse of wing, 11 lin

T. Ifead black, decply and closely punctured; the orbits, filling up the sinus in front, a spot between the antenna, dilated above, clypeus, labrum, and mandibles, exeept tips, rellow (in one specimen more or less ferruginous); antenna neary as long 
as the thorax, terminating in a hook, black, tinged with ferruginous at base and tips, scape yelluwish beneath. 'Thorax dull blackish, densely punctured, slightly pubescent; broad anterior margin of prothorax continued in a narrow line to the tegulæ, sometimes interrupted, a large spot beneath the tegulæ, scutcllum, except its apical margin, and post-scutellum, yellowish, sometimes tinged with ferruginous; pleura slightly sericeous in certain lights, with an oblique dull yellowish stain on each side beneath; metathorax mostly yellowish, the extreme sides spotted or stained with fuscous, the posterior face deeply and broadly excarated, corered with fine transverse striæ, more or less distinct, and with a large blackish mark, covering the disk and spreading out on each side at base; lateral angles prominent and obtuse; tegulæ yellowish, with a ferruginous spot on the middle. Abdomen shaped and marked as in the preceding species, but the general color fuscous, with the third and sometimes the first segments, except their apical margins, blackish, and the spot on the terminal segment abore, scarcely defined.

Legs yellow, the femora tinged with ferruginous above. Wings yellowish-hyaline, more deeply yellowish along the costa; the apex, especially about the marginal celi, dusky; nervures honeyyellow.

Hab. Cuba.

This is most probably the male of 0 . proctus, as E. T. Cresson supposes. But not having the insects before my ejes, I cannot safely decide it, nor make one description answer for both.

\section{b. The hinder face of metathorax more fattened; its superior edges not so salient.}

* The superior ridges forming troo elevatea spines behind the post-scutel.

5\%. O. scutellaris SAuss.-Niger, thorace valde punctato, postice attenuato; post-scutello acute truncato; metanoti facie postica planata, ralde angulata, utriuque dentata, canthis rectis marginata, supra pone post-scutellum bispinosa; abdomine gracili, puuctato; primo segmento basi truncato; segmentis sequentibus margine fortius punctato; macula frontali, post-oculari, pronoti margine, tegulis, macula subalari, scuteili margine, post-scutello, metanoti dentulis, abdominisque segmentorum

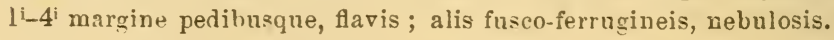

$\delta$. Clypeo ovato-elongato, flavo, apice breviter bidentato.

Ollyn. scutellaris Sauss. Rev. et Mag. de Zool. XXII, 1570, 58, 11, $ో$. Total length, $11 \mathrm{~mm}$. ; wing, $8 \mathrm{~mm}$. 
§. Form quite slender, a little depressed as with the Ancistrocerus tigris. Thorax slightly prolonged, wide before, retracted behind. Post-scutel very freely truncate, offering a very sharp, finely erenulate ridge. Metathorax vertical; its truncation quite flat, wide, occupying all its width, forming a plate of a very angulate shape, as with the Ancistrocerus, notched at the sumnit by the post-scutel (in the form of a double pentagon or a double trapezium); this plate, surrounded by small, straight, little salient ridges, which at their mecting form very sharp angles, forming thus on each side an angle armed with a tooth; their superior angles forming two teeth, wholly spiniform, directed vertically and placed behind the angles of the post-scutel. Abdomen slender; the first segment quite long and as wide as the $2 d$, distinctly truncate at its base and offering on its anterior face a trace of a suture. Head and thorax rugosely, abdomen finely punctured; the border of $2 \mathrm{~d}$ segment more strongly punctured, offering, however, but one depressed band, only becoming thinner as far as the end. Following segment rather strongly punctured.

Insect black, clothed with a tawny or grayish pile; a dot on the front, another behind each eye, anterior border of prothorax, tegulæ, a spot beneath the wing, posterior border of the scutel, post-scutel, and the four little spiniform teeth of the metathorax, orange; segments $1-4$ of the abdomen bordered with orange; bordering of the first wide and notched; that of $2 d$ wide and regular; that of $3 d$ and 4 th narrow, often shortened at the sides. Legs yellow, black at base. Wings washed with ferruginous.

$\hat{\delta}$. Clypens ovoid, notably wider than long, a little notehed and bidentate, yellow. Mandibles spotted with yellow. On each side of the frontal spot a place of golden hair. Antennæ long and thick, black, with a terminal ferruginous hook; scape rery short, yellow beneath. Fifth segment ornamented with a ycllow incomplete border. Legs yellow; thighs varied with brown.

q. Unknown.

Ress. a. diff.-This species described simply from one male, is necessarily incompletely eharacterized, but it is very easy to recognize, from the form of the metathorax, of which the polygonal and flattened plate recalls those of the true Ancistrocerus, but with this difference, that it is still more angular, the laterosuperior ridges not being areuate. Despite the restige of a suture of the lirst segment, this Odynerus ineontestably appertains 
to the true Odynerus, considering the form of the lateral angles of the metathorax and the presence of the post-scutellar teeth. It resembles them more in the strongly punctured border of the $2 d$ and following segments.

This species has the thorax built up upon another system from the $O$. Boscii and its neighbors; it is less excarated; the superior ridges are more convergent and the teeth which terminate them at the summit are spiniform and almost applied to the post-scutel.

Compare with the $O$. spinifer, which presents similar characters (Divis. Stenodynerus).

Hab. California (Berton)

** The superior ed ges of metathorax very slight, on'y forming behind the post-scutel two ver's' small teeth.

88. C. Cordora Sauss.-Niger, sericeus; capite et thorace rugose punctatis; post-scutello crenulato ; metanoto utrinque obtuse subangulato, foveola subplanata, superne acutiuscule marginata; abdomine ovato-conico, segmentorum 2-5 margine crassiuscule punctato; clypeo sunmo, scapo subtus, capitis et pleurarum maculis, pronoti marginibus, tegulis, punctis 2 scutelli; post-scutello, metanoti angulis, abdominis segmentorum 2-5 margine, primi utrinque macula, ano, tibiis tarsisque, flavis; alis subferrugineis apice griseis. $\subsetneq$.

Odyn. Cordorce Sauss. Revue et Mag. de Zool. XXII, 1870, 58 10, $q$.

Total length, $10 \mathrm{mum}$; wing, $8 \mathrm{~mm}$.

f. Head and thorax densely and roughly punctate. Forehead a little sulcate. Prothorax having its anterior margin convex, reflexed, subangulate; post-scutel crenulate. Metathorax very coarsely punctured above, rather flattened behind; its convexity not deep, strigose, not margined, except superiorly, where there exists a little oblique ridge, produced by the rugosities, forming a little tooth behind the post-scutel; this is separated from the post-scutel by a sort of fissure. Lateral angles of metathorax listinct, but blunt. Abdomen orate-conical, truncate at base, smooth and sericeous. Second segment rery finely punctured; its margin and the following segments strongly punctured.

Black; mandibles rufous; scape beneath, froutal, ocular, and post-ocular macula, jellow. Anterior and posterior margins of prothorax, a spot under the wing, tegulæ, two spots or the scutel, post-scutel, and angles of metathorax yellow; segments 2-5 of the abdomen regularly and rather widely margined with yellow; 
the first having on each side a lateral emarginate yellow spost. Anus, knees, tibis, and tarsi, and a spot on the intermerliate coxx, yellow. The yellow ornaments rather orange-yellow. Wings ferruginous at the base, smoky at the extremity.

Var.? 'Tle first abdominal segment narrowly margined.

. Clypeus broad, a little bidentate at tip, strigate punctate, black, with a yellow arc on the summit, and two rufous lines over the teeth.

Ress. a. diff.-Resembles O. nasidens, diabolicus, argentinus, and neighbors, but the abdomen is not so conical, the first segment not so broad, the body not velutinous as in the first, the metathorax not spined as in diabolicus, the thorax not so square, short, and wide as in argentinus, the head concave behind, the prothorax rather convex anteriorly. It has also something of the hook of $O$. La Plat $x$, but the metathorax is not so margined superiorly by arched ridges. In its livery it differ's from all of these. This recalls more $O$. zonatus, which differs from it in the same cbaracters as $O$. La Platx, etc.-Comp. O. formosus.

Hab. Mexico. The Cordillera of Cordova (1 $q$, Sumichrast).

B. Metathorax as in Section A, but the superior edges of its hinder plate not so much elevated, no longer forming, in the females, distinct leeth behind the post-scutel, nor even elevations separated from post-scutel by two fissures. Its edges still rather distinct, linear.

\section{a. Metathorax excavated; edges straight.}

89. O. Lturbidi Sauss. (Fig. 15, 15a.)-Validus, valde punctatus; $=$ crypticus say post-scutello crenulato, metanoto perrugoso, utrinque angulato, marginibus superis ugosis, canthis obliteratis, vix perspicuis; abdominis secundi segmenti margine profunde canaliculato, et valde rugoso. Caput et thorax nigra; ore, clypeo, orbitis partim, macula frontali, antennarum articulis $1-4$, pronoto, macula subalari, scutellis, tegulis, metanoti angulis pedibusque, ferrugineis; abdomine ferrngineo, segmentis ochraceo-marginatis; primo et secundo basi incisurâ nigrà ; alis ferrugineis.

$\widehat{\delta}$. Clypeo polygonali, truncato, integro; frequenter flavo.

Odyn. Iturbidi Sauss. Rev. Zool. IX, 1857, 276, $\Im$.

Total length, $15 \mathrm{~mm}$; wing, $12 \mathrm{~mm}$.

Size and form of O. Boscri. If Iad and thorax cribrose with coarse punctures. Post-scutel strongly crenulate. Metathoras 
very rugose, its posterior face concave and striate; its borders not trenchant but coarsely punctured, rugose, and forming on each side a dentiform angle rather than a tooth; its superior ridges hardly indicated, especially upon the summit, where they describe on each sicle a little arc, but without being at all terminated by a pyramidal point. Abdomen silky; the 1st segment bell-shaped, not being abruptly terminated anteriorly, but rounded, so that its anterior and superior faces are not separated by a ridge. Second segment short, having its border very strongly canaliculate, a little reflexed and very coarsely punctured; the canal rugose, and slightly widened angularly in the middle. Margin of the following segment very coarsely punctured, but not canaliculate.

Head black. Clypeus, mouth, and border of the orbits, ferruginous. Antennæ black, with the first three articles ferruginous. Between their insertion a ferruginous triangle. Thorax black. Prothorax, a spot under the wing, tegulæ, scutelli, angles of metathorax, and legs, ferruginous. Abdomen ferruginous; all the segments bordered with obscure yellow; the 1 st and $2 \mathrm{~d}$ haring a little of black at their base; this color profoundly notched with ferruginous, and forming on the $2 d$ segment a triangle, and on the 1st a lengthened spot in the form of a bottle, or variable. These colors are in fact quite variable; in certain specimens one sees some yellow appear on the clrpeus, on the border of prothorax, on the post-scutel, and on the tibiæ; among other things, the abdominal segments hardly offer a jellow cloud. Wings ferruginous.

$\widehat{\delta}$. Clypeus polygonal, as wide as long, truncate, not bidentate, ferruginous. Hook of the antennæ ferruginous.

?Var. The ferruginous parts of a pale red. Clypeus, mouth, frontal spot, a line on the scape of the antennæ, yellow. Ridges of metathorax a little less effaced; the canal of the border of $2 d$ segment very wide and shallow. (Mesothorax offering two latera rea spots a little before the tegulæ. Articles 2 and 3 of the maxillary palpi slender.) Cordora.

The maxillary palpi of this Odynerus have their last three articles small, but not small enough to cause it to be placed in the genus Rhynchium, to which it bears, in fact, a resemblance. Ress. a, diff.-It is very near to the O. Guerreri and Hidalgi 
Mexican var. (See the description of these species.) In coiors it wholly rescmbles the Ancislrocerus luberculiceps.

It has a greater relation in form to the $O$. arvensis, but it is a little larger, and it difiers from it by the border of the $2 d$ segment, which is not only depressed, but very subcanaliculate; and by the clypeus $\delta$ which is entire, not bidentate, but rather rounded on its anterior border.

Finally, it differ's from the $O$. dorsalis $\hat{\delta}$ by its wings, which are not violet; by the border of the $2 d$ segment, which is not as distinctly reflexed as in the $O$. dorsalis, and by the summit of the metathorax, which does not offer post-scutellar crenulate eminences. The palpi are also a little more slender.

Hab. The hot parts of Mexico. I have taken $4 \delta$ of this species in the valley of Mextitlan, and the var. in Cordova.

90. D. Diders SAuss. (Fig. 14,14a.)-Validus, niger, nitidus; metanoto postice late excavato, acute marginato, bidentato; clypeo $q \hat{\jmath}$ apice truncato, haud bidentato; abdomine conico, sparse punctato, margine segmentorn $2^{\mathrm{i}}-5^{\mathrm{i}}$ densius punctato; pronoti et metanoti maculis 2, post-scutello abdominisque primo segmento superue, albidis; alis fuseo-cyaneis.

$\widehat{~}$. Clypeo albido, puncto mandibularum, scapi et frontis, maculisque 2 transversis in secundi abdominis seguenti basi, albidis; pedibus albidovariis.

Odyn. bidens Sauss. Rev. de Zool. XXII, 1870, 58, 12.

Total length, $20 \mathrm{~mm}$.; wing, $17 \mathrm{~mm}$.

․ A large species. Clypeus covered with scparated points; its extremity abruptly truncate, not bidentate, and without depression. Head large, swelled at the vertex, shining, and covered with separated punctures. 'Thorax loug, square, shining, finely punctured; prothorax hardly reflexed, not angulate, slightly retracted before; mesothorax marked with four groores; post-scntel bent, transverse, joining in the truncation of the metathorax, but not crenulate. Metathorax presenting a great striato concavity, which oecupies the whole width, bounded by rery sharp ridges, which are separated from the post-scutel by a groove, and form on each side a dentiform lateral angle. Ablomen quito conical, the first segment wide, truncate before; the 2 d quite long; its border carrying a wide, not very strong band of punctures: this band not ehammelled, but flat, as if planed; following seg. ments punctured, with a similar band. 
Insect of a shining black, elothed with a fine grayish pile; a spot behind each eye, two great spots on the prothorax, two on the metathorax, post-scutel, and the superior face of the first abdominal segment, of a whitish yellow (the band of the first serrment often notehed with black); wings of a deep riolet-brown.

$\hat{\delta}$. Thorax more strongly cribrose. Clrpeus white, wider than long, polygonal; its inferior border straight truncate, not bidentate, finely bordered with black, a spot on each mandible, a mark on the front, another on the scape of each autenna, a dot under the wing, whitish. Antennæ terminated by a brown hook, a little rolled at the end. Second abdominal segment adorned on each side near its base with a transrerse whitish spot. Haunches, tibiæ, and knees spotted with white. First abdominal segment wholly white abore.

Ress. a. diff.-This Odynerus astonishingly resembles the Monobia quadridens, and it is rare to find two as distinct species which offer so close a likeness. The O. bidens differs from the Monobia quadridens, by its maxillary palpi composed of six articles, ${ }^{1}$ and its labial palpi of four distinct articles; the fourth being articulate; by its clypeus, which is abruptly truncate in both sexes, and neither a little notched nor bidentate, and which is not excarated at the extremity with the female; by the postscutel, more truncate, not bimamnelonate, and by the very distinctly punctured flat band of the $2 \mathrm{~d}$ segment; by the white spots of the metathorax (a character probably of little stability).

The 0 . 4-sectus lias a livery similar to the 0 . bidens, but it possesses neither the metathoracic teeth, nor the sharp lateral ridges.

Hab. The southern United States. 1 from Florida (E. Norton); a $\delta$ from Tennessee (E. Falconet, Freudenreich).

Observation. - As this description is based solely on one indiridual of eacb sex, it may not apply to all specimens brought from localities distant from each other. It is probable that the male does not always offer the rery singular lateral spots of the $2 \mathrm{~d}$ segment.

b. Melathorax more fattened; the superior enges ronghiened, not acute.

91. O. Avaradi Sacss.-Niger, relutinus, confertim punctatus: abdomine conico, aureo-sericeo, marginibus crasse punctatis ; metanoti

1 The maxillary palpi have here the ordinary form which they assume among the Odyneri; the articles 2, 3 are not slender; the 6 th is lengthened. 
marginibns heletatis at supra tenuiter prominulis, a post-scutello per emarginationem sejunctis; capitis maculis, linea in scapo, pronoti nargine postico, post-scutello, tegulis, macula prscalari et puncto utrinque metanoti summi, margineque regulari segmentorum onnium abrominis, fulvo-ochraceis ; tibiis et tarsis ferrugineis; alis ferrugineis; $q$ clypeo late piriformi, nigro vel superne fascia fulva; 合 late truncato, bidentato, fillvo-Havescente.

Olyn. Alvarado Sauss. Rev. de Zool. IX, 1857, 276.

․ Total length, $14 \mathrm{~mm}$.; wing, $11 \mathrm{~mm}$.
. Total length, $11 \mathrm{nmm}$.; wing, $8.5 \mathrm{~mm}$.

Size moderate. Clypeus $q$ wide, terminated by a little truncate or bituberculate point; cribrose with strong punctures. Head anci thorax rugosely punctured. Post-scutel very short, truncate, crenulate. Metathorax very rugose above; the striæ specially distinct in the inferior moiety, the superior moiety being more smooth and punctured; the inferior moiety forming a fossette, separate and slightly margined superiorly. Lateral border of the concavity rounded, not at all trenchant, the latero-superior parts coarsely punctured, rugose; nevertheless one sces on each side a little spiniform angle directed laterally and on the summit a trace of an arcuate ridge, placed a little within, especially among the males; superior angles $\delta$ forming two salients, rugose and plunted, separated from tise post-scutel by a notch. Abdomen conical, like satin, with golden reflections, having the borker of all the segments, save the first, quite strongly punctured; but the punctured band of the seconả quite wide and slightly impressed.

Insect black, clothed with tawny hair. Two spots on the summit of the clypeus, another behind cach eye, a dot on the front, and a line under the scape of the antennæ, tawny. The summit of the clypeus is often entirely of this color, as well as the inner border of the orbits. Posterior margin of the prothorax, wing scales, a dot before the wing, post-scutel, and a dot on ench side, on the summit of the metathorax, ferruginous or tawny. All the segments of the abdomen regularly bordered with yellowtawny; the first more narrowly than the second. Legs black: tibix and tarsi ferruginous. Wing's washed with ferruginous, a little grayish at the end.

§. Clypens as long as wide; its inferior margin widely truneate and armed with two little teeth separated by a wide stright border, in the middle of which is often a third indistinct salient. 
Clypeus, a line on the mandibles, and the line on the scape of the antennæ, of a pale tawny.

Var. No spots on the front nor on the metathorax.

Ress. a. diff.-'This Odynerus is easily recognized by its livery and its velvety aspect.

It differs from the 0 . Guerreri by its conical abdomen and by the superior salients of the metathorax; from the $O$. foraminatus, by its metathoracic concavity, not nearly so well limited, and by the salients of the superior angles, which are not sliarp, but rugose, obtuse, and separated from the post-scutel, not by a little fissure, but by a wide notch. By its livery it recalls the $O$. otomitus, which is near to it, but differs in its conical, sessile abdomen, having the first segment wide and truncate, in its great size, etc.

$H a b$. The hot and temperate parts of Mexico. (I caught $4 \hat{\delta}$, $2 q$ in the valley of Mexlitlan.)

C. Hinder plate of metathorax no longer margined superiorly by sharp edges; the superior edges blunted and effaced by the rugosities of the latero-superior faces, which continue over the edges down on to the posterior face, and lose themselves in its concavity, instead of being separated from the hinder face by the sharp edges. (Lateral angles still existing.)

92. O. arvensis SAuss. (Fig. 16,16a.)-Medius, niger, grosse punctatus; $O$. dorsali simillimus at miuor; ore, macula frontali et postoculari scapoque subtns, rufis vel flavis; pronoti margine, post-scutello, maculis. 2 metanoti abdominisque segmentis $10-30$ vel $10-40$ flavolimbatis, $20-40$ crassissime punctatis ; primi margine utrinque aucto et rufo-vario, pedibus flavis, hasi nigris, alis fumosis.

९. Clypeo valde latiore quam longiore, truncato, grosse punctato, nigro vel rufo; superne fascia flava.

S. Clypeo polygonali paulo latiore quam longiore, flavo, truncato, apice dentulis 2 distantibus instructo.

Odyn. arvensis Sadss. Rev. de Znol. XXI, 1869.

․ Total length, 14, $12 \mathrm{~mm}$.; wing, 11, 5-9 mm.

ऊ. Total length, 12, 5-9 $\mathrm{mm}$. ; wing, $9-7 \mathrm{~mm}$.

9. Form rather near to that of 0 . Boscii, but smaller. The abdomen a little more conical; the $2 \mathrm{~d}$ segment shorter and more coarsely punctured; its inferior border a little lamellate 
and truncate, but often appearing slightly bidentate. 'Thorax widened before, retracted little or none. I'ost-scutel crenulate. Metathorax very coarsely rugose; its concavity striate, but cribrose in its superior moiety from the punctures which continue with those of the superior face; the latero-superior ridges blunted, effaced; on each side a dentiform angle at the meeting of the lateral and inferior ridges. First abdominal segment silky, smooth, truncate, and a little rounded at the base; the $2 d$ short, densely punctured; its posterior border offering a wide depressed zone, widened in the middle, very coarsely cribrose, as well as the following segments; at times a little chamnelled, but the border not turned up.

Insect black. Mouth red, with a yellow spot at the base of the mandibles; supcrior moiety of the clypens yellow or red; inner border of orbits and a spot behind each eye, red or yellow; scape of the antennæ red, with a black line above; a spot on the front, yellow or red. Anterior border of prothorax yellow, often followed with red; tegulæ yellow or red, post-scutel and a spot on each side of metathorax above, vellow; segments $1-4$ of the abdomen regularly bordered with yellow; the first having its border on each side widened or confounded with a spot or oblique band, yellow surrounded with red, which leave above a black trilobed or square notch; often of red on each side or bordered with yellow. Legs yellow, black at the base. Wings smoky or a little reddened with a light violet reflection.

Var. a. Clypeus red, with a yellow band on the summit.

b. No red on 1st abdominal segment.

c. Two yellow or red dots on the scutellum (Tennessee).

d. Prothorax red, bordered with ycllow (Missomi).

The crest of the post-scutel varies; sometimes fincly crenulate and continuous, sometimes dentate and notched in the middle.

$\delta$. A little smaller. Clypeus polygonal, yollow, wider than long, truncate on its anterior border, offering a rery small tooth on each extremity of this border; its apical marein a little prolonged, so that the polygon is not recular, the inferior borders forming thus a larger are than the superior; hook of the antemux black or ferruginous; mandibles and ornaments of the lest pellow or orange; a red dot on the flanks before the trgules; often the posterior border of the prothorax red and a little of red andout the scutels; latero-superior borders of the concavity of the 
metathorax very rugose, coarsely cribrose. Fifth segment often bordered with yellow. With the male especially, the fossette of the metathorax does not reach the lateral borders, but is separated from them on each side by a band hunched and cribrose with great pits; the superior ridges are often quite well defined.

In this species the yellow is clear; often almost orange. The red, the black, and the yellow are susceptible of changing places in the varieties.

Ress. a. diff.-This species greatly recalls the 0 .dorsalis and differs from it by its clypeus $q$ much wider than long and more grossly punctured; by the clypeus $\delta$ wider than long, not prolonged at its anterior extremity, and fincly bidentate; by its smaller size; by its less obscure wings; by its metathorax less widely concare, becoming rounded and convex on the sides of the posterior plate, while, as with the $O$. dorsalis, the concavity occupies the whole width; the $\delta$ differs by the absence of pyramidal post-scutellar eminences formed by the superior termination of the ridges of the metathorax, and which exist in the dorsalis $\hat{\delta}$. It lias greater relationship to the $O$. Boscii and Hidalgi. It differs from this last by its blunted metathoracic borders, without salient ridges; by the border of segments $2 d, 3 d$, which is impressed, rugose, but not turned up; from the first by the scutellum without spots; by the shorter $2 \mathrm{~d}$ segment; the $3 \mathrm{~d}$ and 4 th more coarsely punctured; the 4 th and 5 th without any yellow border.

Hab. The United States, particularly the south. I possess some individuals from Tennessee, some also from Kansas, from Illinois (Kennicott), and from New York (E. Norton), 7 , 10$\}.$

93. O. anmectens Sauss.-Validus, niger, fulvo-pilosus, clypeo piriformi flarc 4 maculato, apice emarginato; orbitis partim, pronoti margine antico, tegulis, punctis 2 scutelli, 2 metanoti, tibiis et tarsis, flavis; abdominis segmentis, 10 superne flavo, nigro-emarginato, $2^{\mathrm{i}}, 3^{\mathrm{i}}$ margine, crassissime punctato, anguste flavo-limbato: alis nigro-riolaceis. $q$.

Odyn. annectens Sauss. Rev. de Zool. XXII, 1870, 59, 14, q.

Total length, $17 \mathrm{~mm}$; wing, $15 \mathrm{~mm}$.

The following description applies to an insect which seems to indicate a species different from $O$. dorsalis, but is certainly very embarrassing by its similarity.

P. Size and form of $O$. dorsalis; the same sculpture, but not quite so rough. Clypeus pyriform, more prolonged than in $O$. 
dorsalis; its apical margin emarginate, concave. Metathorax perhaps a little more depressed, without any superior ridges; it.s lateral angles very pronounced, compressed horizontally. First abdominal segment shorter than in $O$. dorsalis; the second rather velutinous, scarcely punctate, its margin more coarsely punctate (the punctures being rather holes), but not so evidently canaliculate as in $O$. dorsalis.

Insect black, with fulvous, velvety hair. Aper of mandibles and base of scape beneath, ferruginous. A spot on base of the mandibles, an ovate mark on both sides of the clypeus, and two others near the apex, inner orbits of the eyes and a line behind them, two triangular maculæ, forming the anterior border of prothorax, tegulæ except their base, two spots on scutellum and two on mesothorax, yellow; 1st abdominal segment yellow abore with a trilobate black emargination; a narrow border of segments $2 \mathrm{~d}, 3 \mathrm{~d}$ of the same, yellow. Knees, tibiæ, and tarsi, yellow. Wings dark fusco-violaceous. The mandibles and palpi are formed as in $O$. dorsalis.

Hab. United States (Florida, 1 \&, E. Norton).

94. D. annulatous SAY.-O. arvensi affinis, $q$ gracilior, $\delta$ capite majore, valde punctatus, secundo abdominis segmento dense punctato, margine impresso, crasse punctato. Niger vel ferrugineus, mesonoto et abdominis segmentis 3-6 nigris; tegulis, pedibusque rufis; pronoti et abdominis segmentorum margine, post-scutello metanoti marginibus, subfureis; primo abd. segmento utrinque rufo et flavo ornato; alis nebulosis: $-q$. Scapo, clypeo, frontis maculis, rufis.-Vuriat clypei fascia nigra, macula subalari maculisque 2 secundi segmenti, rufis vel flavis.- $\hat{\delta}$. Clypeo polygonali; fronte, scutellis, maeula subalari flaris.

Odyn. annulatus SAx, Long's Sec. Exp. Append. 29 (II, 348).-Say's Ent. (Le Conte), I, 235.-Sauss. Et. Vesp. I, 232.-Cresson, Amer. Iint. Trans. I, 1867, 380, 21.

Rhynchium annulatum SAY, Bost. Journ. I, 1837, 351, 4.-Say's Ent. (LE ConTE), II, 765, 3.-Sadss. Et. Vesp. III, 184.

Odyn. Bairdi Sauss. Revue Zool. X, 1858, $ో$.

९. Total length, $15 \mathrm{~mm}$. ; wing, $12 \mathrm{~mm}$.

$\hat{\delta}$. Total length, $10 \mathrm{~mm}$.; wing, $S \mathrm{~mm}$.

q. Rather slender, densely and coarsely punctate. Clypeus broadly pyriform, strigate punctate, terminating in two approximate little teeth, separated by a small lamellar edge. 'Thorax subelongate. I'ost-seutel truncate, very tenuously crenulate. 
Metathorax vertically truncate; concave, but its margins not ridged, the edges being quite blunted by the dense punctuation. Abdomen subconical, rather slender. The first segment smooth and silky; the second very short, densely punctate everywhere, but its posterior margin having a broad excavated band of very coarse punctures; segments 3-4 very coarsely punctured.

Black; mandibles, clypeus, scape of the antennæ, a frontal mark, and a large spot behind the eyes, rufous. Clypeus often with a transverse black line or with three black spots in a transverse line. Anterior margin of prothorax broadly, the posterior narrowly rufous, or partly sulphur-yellow; tegulæ yellow and rufous, often a yellow spot under the wing; post-scutel yellow ; lateral margins of metathorax rufous or yellow. Abdomen having its first four segments margined with yellow ; this color often preceded by a little of rufous. First segment black in middle; its sides rufous, with a yellow spot fused with the jellow band. Second segment often adorned with two separate rufous spots. Legs ferruginous; coxæ blackish. Wings grayish ferruginous, a little clouded or sometimes even with violet iridescence.

Rufous Variety.-Head rufous, except the vertex. Prothorax and feet rufous. Scutels yellow, or rufous, tinged with yellow; mesothorax black, with a rufous spot; metathorax rufous, marked with yellow. First and second abdominal segments rufous, margined with yellow; the second with two yellow maculæ; $3-5$ segments rufous, margined with yellow; 6th rufous. Wings clouded (Kansas, New Mexico).

Various Varieties. - This is quite a variable species, the three colors interchanging, which gives numerous combinations. The scape is more or less obscure above. The spots on the clypeus, under the wing, on the second segment, are often wanting, etc. The vellow ornaments are of a pale sulphur-yellow.

I consider, as the male of this species, specimens from Texas and Louisiana, which last constitutes a still more rufous variety.

$\delta$. Head large, wider than high, rufous, with black vertex. Clypeus broader than bigh, regularly octagonal; its anterior margin straight, having two insensible, distant teeth at its extremity. Mandibles, clypeus, a triangle on the forehead and sinus of the eyes, a line on the scape, bright yellow; hook of 
the-antennæ and flagellum beneath rather ferruginous; maculx behind the eyes, orange. Thorax shorter, more cubical. Prothorax rufous margined with yellow anteriorly. Post-scutel and angles of metathorax ycllow. First abdominal segment rufous above, surrounded with yellow; the mandible often black. Second segment having its marginal impressed band much impressed and broad; segments 1-5 margined with yellow. Coxæ and fect adorned with yellow (Louisiana).

Texan Variety.-Prothorax, scutels, metathorax, feet, segments 1,2 of the abdomen, rufous. Disk of mesothorax rufous on each side. Border of prothorax, a dot under the wing, two spots on the tegulæ, scutel, post-scutel, edges of segments 1-6, bright yellow; the first segment having on each side a yellow spot smelted with the marginal fascia (Texas).

Mexican.Variety?-_Smaller. Length, $13 \mathrm{~mm}$.; wing, $10.5 \mathrm{~mm}$.

f. Black; mandibles, scape of the antennæ, forchead and the parts behind the eyes, prothorax, a lateral spot, tegulæ, two maculæ on disk of mesothorax, scutel, feet, and coxæ, rufous. Post-scutel yellow: Angles of metathorax rufous and yellow; abdomen rufous; first and second segment with a black portion in the middle and at base; all the segments margined with yellow; the first band fused on each side with a lateral square yellow spot, and the $2 d$ segment having on each side a yellow spot, either frec or confounded with the margin. Anus yellow. Wings washed with fuseous, with a golden, rather violet reflection; the radius ferruginous. The metathorax, although forming two lateral angles, is not toothed; the superior part of its posterior face is not margined on each side by an oblique ridge.

Var. Of course the ferruginous varies into yellow and vice versâ, and the black is more or less developed.

Ress. a. diff.-This species resembles $O$. arvensis, but it is more slender $q$; the male has also a more transverse, very regular polygonal clypeus, while in arvensis it is more prolonged at its extremity; in the female, the elypeus is on the contrary narrower than in arvensis. The post-seutel is not as strongly but quite delicately crenulate. The metathorax is not so sharp, and it has altogether another appearance. It approaches quite closely to pratensis, has the same look, but differs: by its 2d abd. segment not smooth, but densely and strongly punctured throughout; by 
its rather bidentate metathorax; by its clypeus $q$ flattened, not so convex, $\delta$ shorter, not more prolonged below than above.

In the Mexican variety, the form is much as in O. Cordoræ, but it is larger; the clypeus $q$ a little produced at its apical end; head and thorax very coarsely shagreened; the second segment of the abdomen shorter, its margin having its coarsely punctured band inpressed and widened in the middle.-This var. differs from $O$. formosus by its larger size, its clypeus more prolonged at tip, metathorax not bidentate, and darker wings; from $O$. Hidalgi and Iturbidi by its smaller size and metathorax not acutely margined superiorly.

$H a b$. The prairies from Missouri to Texas and New Mexico. Mexican Cordillera (the rariety) 5 \&, $2 \delta$.

95. O. crypticus SAY.-Rufus; abdomine flavo-trifasciato; alis infuscatis.

Odyn. crypticus SAY, West. Quarterly Reporter, II, 1, 1823, 80.—Say's Entom. (Le CoNte), I, 168.

Rhygchium crypticum SaY, Bost. Journ. I, 1837, 384, 3.-Say's Entom. (Le Coste), 765, 3.-Sadss. Et. Vespid. III, 184.

Total length, 5 lines.

Body rufous, much punctured; rertex and origin of the antennæ, black; antennæ dusky at tip; thorax with a black spot before the middle; scutel bilobate, with a longitudinal, deeply impresscd line; metathorax concare; wings dusky, paler at tip; tergum with three yellow bands, the anterior one smallest and subconcealed.

Hab. Arkansas.

This is most likely a pale variety of 0 . annulatus.

96. 0. sulfureus Sarss. (Fig. 18, 18a.)- O Orvensi simillimus, at metanato minus excarato; niger, sulfureo-multipictus; ore, clypeo et facie sulfureis; oculis flavo-, snpra rufo-marginatis; antennis fuscis, scapo rufo; pronoto flavo, angulis posticis rufis ; scutello flaro-bimaculato; post-scutello, tegulis maculis pleurarum et metanoti angulis, sulfureis, abdomiue sulfureo, segmentis 10,20 basi et in medio nigrosignatis; pedibus ferrugineo et sulfureo pictis ; alis ferrugineo-griseis. $q$. Odyn. sulfureus SAUss. Revue de Zool. X, 1858, 170,.

Total length, $12 \mathrm{~mm}$; wing, $9 \mathrm{~mm}$. 
Thorax much shagreened; post-scutel finely crenulate. Mctathorax forming two lateral angles, its excavation only occupying the middle, rounded, strigose; the rest shagreened, strongly punctured, rounded, without sharp edges. Abdomen conical, scarcely contracted at base, truncate anteriorly, but without a sharp ridge, rounded at base. Second segment densely punctured; its margin having a wide impressed band, cribrose with coarse punctures; the following segments similarly crilsrose.

Black: mandibles, elypeus, forehead, and orbits, sulphur-yellow; the upper part of orbits black or brown-rufous; frontal sulci black. Antennæ blackish; the first segment yellowish or rufous obscure above. Pronotum widely marginate with yellow; its posterior angles rufous or black; a spot and various marks under the wing, tegulæ, two spots on the scutel and sides of metathorax, yellow. Abdomen almost wholly sulphur-yellow; the base of first segment black or brown on its anterior face, with a black pyriform notch on the superior face; the $2 d$ having at its base a. black macula, constricted in the middle; the following segments twice notched with black or brown. The coarse punctures of the margins having their groun?-color brown. Anus ferruginous or yellow. Feet yellow and ferruginous. Wings tinged with ferruginous, cloudy at the apex.- + . Clypeus broad, pyriform, wider than long, its apex a little produced, truncate, biangulate.

Var. The black part of the body brown or rufous.

Probable Variety. - The yellow ornaments not so much extended; segments 1, 2 black, with a wide sulphur margin, widened on the sides; the $2 \mathrm{~d}$ with two lateral triangular macula, as in O. blandus.

Ress. a. diff.-It has quite the form of $O$. areensis; the metathorax is a little more flattened, principally on the sides of the excavation, which is a little narrower. It differs from $O$. cingulatus in its livery; these species are much the same in their forms. -It differs from O. pratensis by its biangulate metathorax. In the livery it resembles $O$. blandus, but is very distinct by its not angulate metathorax, its not crenulate post-scutel, its smaller and strongly punctured first abdominal segment, its narrower elypeus and its small size.

Ilab. California ( 9 Berton). 
9\%. O. formosus Sauss.- O. Cordova conformis, at metathorace distincte bidentato; abdowine magis couico; niger, mandibulis, clypeo, scapo, capitis maculis, fulvis; pronoto, tegulis, macula subalari, naculis 2 scutelli, post-scutello, metanoti angulis, abdominis segmentorum marginibus (primi limbo utrinque cam fascia obliqua conjuncta), pedibusque, flavis vel aurantio-variis; alis subferrugineis, apice griseis.

Odyn. formosus SAuss. Rev. de Zool. XXII, 1870, 59, 15, $q$.

Total length, $10 \mathrm{~mm}$.; wing, $8 \mathrm{~mm}$.

9. Size and form nearly as in O. Cordovæx, but the metathorax has its angles on each side produced into a distinct tooth; the cavity not at all limited, not margined superiorly on each side by a little oblique ridge; the abdomen quite conical, the first segment as broad as the second, and more sharply truncate at base; the punctured marginal band of the $2 \mathrm{~d}$ segment decidedly impressed, a little widened in the middle.

Black; mandibles and fect rufous or orange. Clșpeus, frontal, ocular and post-ocular maculæ, yellow or rufous. Antennæ black; scape yellow, a little obscure above. Prothorax, a spot under the wing, tegulr, two spots on the scutel, post-scutel, angles of metathorax, and margin of all the abdominal segments, yellow or rather orange; the fasciæ wide; that of the first seg. ment fusing into two oblique lateral bands, which make nearly an anterior interrupted fascia, sometimes rufous. Anus rufous or yellow. Wings rather ferruginous; the apex clouded.

Var. A.black spot on the posterior angles of prothorax.-A yellow fascia on scutel.

Ress. a. diff.-This does not seem to be a variety of O. Cordovæ. It has the same livery as O. Boscii, turpis, molestus, but a quite differently shaped metathorax; it is also smaller and more slender, nearly one-half smaller tlian the first. It resembles $O$. sulfureus, but its lirery is not so rich nor so pale; the clypeus is not so much produced, the size smaller. It is allied closely also to $O$. annulatus, although smaller and with a metathorax not so much flattened behind. Comp. also O. annulatus (Mexican rariety).

Hab. The temperate parts of Mexico. Oriental Cordillera 4 ․ (Sumichrast).

9S. O. spectabilis SAuss.-Niger, gracilis ; capite, thorace abdomi-

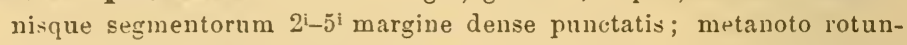
dato, utrinque valde angulato; abdomine subcouico; clypeo, anteunis 
basi, capitis maculis, thoracis margine antico late, macula subalari, tegulis, scutellis, metathorace ntrinque, abdoninis seguentorum mar. ginibus, ano pedibusque, flavo-aurantiis, fascia $1^{i}$ segmenti utrinque aucta $q$.

Odyn. spectabilis SAuss. Revue de Zool. XXII, 1870, 60, 16, $q$.

Total length, $9 \mathrm{~mm}$.; wings, $7 \mathrm{~mm}$.

Slender. Head and thorax rather coarsely and densely shagreened. Thorax square. Post-scutel crenulate, metathorax rather flattened behind, forming on each side a strong, acute angle looking outward, which makes the posterior part of thorax square, the middle of the hinder face a little excavated, rather rugose, but the cavity not margined; the rest quite rugosely punctured, reticulate. Abdomen nearly conical, smooth, silky; the $2 \mathrm{~d}$ segment finely punctured, but its margin and those following strongly punctured.

Black. Antennæ black-ferruginous, with the first three joints ferruginous. Mandibles rufous. Clypeus, a frontal triangle, an ocular and post-ocular large macula, prothorax anteriorly, spot under the wing, tegulæ, scutel, post-scutel, angles of mesothorax and margin of all the abdominal segments, yellow, rather orange; the yellow margin of 1 st segment fused with two large, lateral angular yellow maculæ; anus, feet, even the coxæ, orange-yellow. Wings washed with ferruginous; the radial cell cloudy.

9. Clypeus wide, rather lozenge-shaped, with its apex truncate, biangulate.

Var. The last abdominal segments rufous.

Ress. $a$. diff.-Recalls the O. bacuensis by its appearance, but is very distinct by its broad clypens $f$, its crenulate post-scutel. angulate metathorax, and conical abdomen, ete. From O. cubensis and allies it differs by its more slender form and metathorax without acute superior edges. - From O. formosus, by a larger size and less slender form. If it was not as small again, it would agree perfectly with the description of $O$. apicalis Cress. It may be a small variety of this?

Hab. Cuba (1 \&, I)r. Gundlach).

93. O. apdicalis Cresson.-Niger; elypeo, mandibulis, fascia frontali, antenuis basi, pronoto, tegulis, macula subalari, seutellis, metathorace utrinque; pedibus abdominisque segmentorum 1-3 margine, 1lavis: 
prino segmento superne flavo, disco nigro; segmentis 4-6 rufis; alis fusco-hyalinis.

Odyn. apicalis Cressox, Philad. Ent. Proc. IV, 1865, 161.

․ Total length, 6 lines; expanse of wings, 10 lines.

$\delta$. Total length, 4.5 lines; expause of wings, 7.5 lines.

९. Opaque-black. Head and thorax deeply and closely punctured, the former broader than the thorax, rather short; a broad transverse band on the front, filling up the sinus of the eyes and deeply indicated abore the insertion of each antenna; the broad posterior orbit and the clypeus, yellow, sometimes strongly tinged with ferruginous, sometimes yellowish at the base; clypeus depressed, rhomboidal, the extreme tip truncate. Antennæ black, the two basal joints ferruginous. Thorax: prothorax yellow abore, tipped with dull ferruginous just before the tegulæ; pleura somewhat sericeous, with a large, rounded jellow spot beneath the tegulæ; scutellum with two large, quadrate, yellowish marks, nearly confluent; post-scutellum yellowish; metathorax finely and transversely striated, deeply excavated on the disk, with a large yellowish mark on each side, covering the lateral angles, which are rather prominent and obtuse; tegulæ jellowish, with a ferruginous dot on the midrle. Abdomen ovate, basal segment nearly equal in width to the second; remaining segments gradually tapering to the tip, and more deeply and densely punctured than the basal segments; first segnents rounded at base without suture or carina, the apical margin confluent, with a large angular mark on each lateral margin, yellowish; apical margin of the second and third segments (broader on the second segment), yellow; that on the third somewhat tinged with ferruginous; remaining segments, abore and beneath, dull ferruginous; beneath, the apical margins of the second and third segments are narrowly yellowish, more or less sinuate on cach side anteriorly.

$\delta$. Smaller, the markings of the face tinged with ferruginous; the basal joint of the antennæ yellow within, with a black line abore, the apical joint ferruginous and hooked; the yellow of the prothorax not continued all the way to the tegulæ, being interrupted with black; fourth segment of abdomen black, with the apical margin above and beneath, narrowly yellowish; remaining segments obscure yellowish-ferruginous, more or less dusky at base; beneath, the second segment with a yellow spot 
on each side of the middle. Legs yellowish; the femora except tips beneath, the tibiæ beneath, and most of the tarsi, pale ferruginous. Wings subhyaline, faintly tinged with fuscous; honeyyellow along the costa, with the marginal cell almost entirely fuscous.

Ress. a. diff.-Allied to O. cubensis, by its livery, but the face is much broader, and the basal segment of the abdomen is differently marked, rouuded anteriorly, not truncate, with a sharp edge. It differs also by its hooked antennæ, in the male.

I do not know this Odynerus, which seems most closely allied to O. spectabilis, but much larger. Compare this species.

Hab. Cuba (Mus. of the Am. Ent. Soc., Philadelphia).

2. Posterior plate of metathorax orbicular or more or less rounded, not forming on each side a distinct dentiform angle. ${ }^{1}$ (Thorax rather attenuate posteriorly, abdomen conical or ovate-conical.)

A. Posterior plate of metathorax still margined with a sharp edge, salient in its superior part, and forming on each side of the summit a tooth or elevation, separated from the postscutel by a fissure (sometimes very small).

a. The concavity deep, excavated, with salient ridges. Abdomen conical; its base sharply truncate.

100. O. turpis SAuss. - Niger, thorace crassissime punctato; clypeo lato, piriformi ; metanoto attenuato, extus rugnsissimo, postice in foveolam ovalem valde excavato, lavi, haud biangulato, sed cauthis areuatis acutis narginato, noununquam supra paeno deutem post-sentellarem efficientibus; abd. $2^{\mathrm{i}}$ segmenti margine punctato sed haud impresso; clypeo summo maculis 2 vel fascia, orbitarum marginibus partim, macula frontali, scapo subtus, pronoti et abả. segmentornu $1^{i}-4^{i}$ margine, macula subalari, tegulis, sentelli et metanoti maçulis 2, post-sentello pedibusque, aurantiacis; alis ferrugineo-fusco nebulosis.

Odyn. turpis Sauss. Revue, Zool. XXII, 1870, 60, 17,

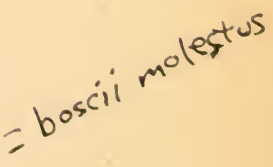

Total length, $13 \mathrm{~mm}$. wing, $11 \mathrm{~mm}$.

1 Sometimes there is still an indication of two augles or eren a small tooth ( $O$. foraminatus, O. leucomelas), in the species in which the posterior plite of metathorax is more or loss angulate. 
․ Insect very coarsely punctured, recalling the $O$. Boscii, but more coarsely cribrose and more retracted on the metatlorax. Clypeus pyriform, wide, punctured, rather wider than long. Post-scutel feebly crenulate. Concavity of the metathorax occupying all its width, rounded, notably wider than high, cxcarated, finely striate and smooth as far as the borders; these are extremely trenchant, but not forming spiniform lateral angles; thes a ridges above all very salient on the summit, where they often terminate in a dentiform or lamellar salient, separated from the post-scutel by a strong notch. The extermal lateral surfaces of the metathorax very rugose. Abdomen conical truncate, at the base haring a sharp ridge; the border of the second and following segments quite strongly punctured; but that of the $2 d$ not sensibly depressed.

Insect black, clothed with tawny hair. Mandibles and at times the end of clypeus, red. Tro spots or an arc at the summit of clypeus, a spot on the front, another behind each eye, and the inner bordering of the orbits, as well as a line on the scape of the antennæ, rellow. Border of the prothorax, a spot under the wing, tegulæ, two spots on the scutel, two others on the summit of the metathorax and post-scutel, yellow; segments 1-4 of the abdomen bordered with the same color; the first border widened on the sides; legs yellow, the base black. Wings transparent, washed with brown-ferruginous. The yellow of the ornaments is almost orange; it often passes, without doubt, into red.

Var. One specimen has its ridges blunted at the beginning or where the lateral angles would be, if they existed, but their summit always forms a trenchant prominence.

. Unknown.

Ress. a. diff.-This species is allied to the O. Boscii, arvensis, Hidalgi, by the distribution of the colors. It has like the $O$. Boscii the scutel spotted with yellow, and like the other species the post-scutel yellow. But it is distinguished clearly from these species: 1st, by its letracted metathorax, not laterally bidentate, in consequence of the rounded posterior plate (not squarely cut), of which, however, the ridges are very sharp and quite arcuate (and not more or less straight or oblique as in the species cited); $2 \mathrm{~d}$, by the border of the $2 \mathrm{~d}$ segment, which, although punctured, is not depressed, and less reflexed. 
From other allied species with similar livery, or adorned with red, it always differs by its very sharp metathoracic ridges. (Sce especially the $O$. molestus: )

The great number of these species all having similar livery renders their distinction very difficult, so that one needs to be familiar with the details of the forms, ahove all with those of the metathorax, which furnish certain very distinctive characters.

Hab. The United States. 2 t taken in Tennessee. Sent by E. Fr. Falconnet.

101. O. Megaera Lepel.-Niger, valde punctatus; metanoti foveola rotundata, striata, utrinque inermi, sed canthis elevatis acutissimis marginata; his supra in dentes 2 excurrentibus, a post-scutello per fissuram sejunctis ; inacula frontali et post-oculari, pronoti et abdominis segmentorum $1^{\mathrm{i}}, 2^{\mathrm{i}}$ margine, primi utrinque aucto, macula subalari et postscutello, luteis; alis fusco-cyaneis. - + . Clypeo piriformi nigro, fascia arcuata, vel maculis 2 luteis.- $\delta$. Clypeo lato, albido, margine truncato, atro; scapo fascia albida.

Odyn. Megara Lepel. St. Farg. Hymen. II, 636, 21 (1841).-Sauss. Et. Vespid. I, 181, 74; pl. xvii, fig. 11, 울 III, 232.

․ Total length, $15 \mathrm{~mm}$.; wing, $12 \mathrm{~mm}$.

$\delta$. Total length, $11 \mathrm{~mm}$; wing, 9 mm.

․ Clypeus pyriform, longer than wide, cribrose with coarse points, terminated by a very small border, at times smooth and lamellate, and appearing a little bidentate. Thorax retracted on the metathorax. Head and thorax densely cribrose. Postscutel truncate, offering a subcrenulate ridge. Metathorax rugose, having its lateral ridges blunted; its posterior plate concave, striate, and a little punctured on its borders; form rounded, but wider than long; bordered with sharp ridges, bnt not forming any lateral spiniform angles.

'These ridges a little crenulate; their summit separated from the post-seutel by a narrow fissure. Abdomen densely punctured, abruptly truncate: at its base a sharp ridge; the border of the 2 d and the following segments very coarsely cribrose, but the border of the $2 d$ withont any depressed zone.

Insect black, clothed with a grayish pile. A spot on the

1 The ornaments are too yellow on this figure in a number of tho copies of this work. 
mandibles, an are or two spots on the summit of the clypeus, a dot on the front and another behind each eye, the border (retracted in the middle) of pronotum, a spot under the wing, post-scutel, often a dot at the wing scale, and the border of the first two segments of the abdomen, of a whitish-yellow; the border of the first segment widened on the sides; often tri-emarginate. Wings of a brown-violet; tarsi brownish.

Var. a. Beneath the scape a ferruginous or whitish line; the 3 abdominal segment adorned with a whitish edging.

b. Clypeus and antennæ wholly black.

c. Tibiæ marked with white on their onter border (Illinois).

§. Smaller. Clypeus polygonal, slightly prolonged at the end and truncate, subbidentate, its color whitish, with the inferior borders black; hook of the antennæ great; on the scape a white line. Metathoracic ridges salient on the summit, terminated Lehind the post-scutel by a more elevated pyramidal tooth.

Var. The ornaments passing into sulphur-yellow.

Ress. a. diff.-This Odynerus is easily recognized by its whitish ornaments. In likeness it resembles:-

1. The O. bidens and the Monobia 4-dens, from which it is distinguished easily by its small size, by the absence of lateral teeth on the metathorax, by the cribrose thorax, and the rugose metathorax, etc.

2. The 0 . 4-sectus, from which it separates itself by its livery and its quite differently formed metathorax.

3. The O. leucomelas, from which it differs by the lirery of its abdomen, by the whitish band of its 1st segment, widened on the sides, by its abdomen truncate, with a sharp ridge at the base; by its metathorax with elevated borders; by its violet wings.

4. The Ancistrocerus albophaleratus; from which it differs by its livery and by the absence of a suture on the first abdominal segment.

In the distribution of colors it approaches the 0 . foraminatus and allies.

Hab. The United States. Carolina, Tennessee, Illinois (Ken. nicott), Florida (Norton), 8 , il $\delta$. 
b. Posterior plate of metathorax less excavated; its marginal edges lut slightly salient, although still sharp. Abdomen ovate-conical, slightly attenuated at base.

102. 0. forrmingat as SAds.-Niger, confertim punctatus; metanoti rugosi foveola rotundata, striata, utrinque inermi, marginibns rotundatis, hand acutis, superne tantum in dentem verticalem excurrentibus, a post-scutello per fissuram sejunctum ; macula frontali et post-oculari, linea in scapo, pronoti et abdominis segmentorum marginibus, tegulis, post-scutello, macula subalari, tibiis tarsisque, sulfureis ; alis diaphanis fuscescentibus. $-q$. Clypeo piriformi, biangulato, nigro, supra fascia arcuata flava.- $-\hat{\delta}$. Clypeo polygonali, vix emarginato, flavo.

․ Total length, $13 \mathrm{~mm}$; ; wing., $11 \mathrm{~mm}$.

$\delta$. Total length, $11 \mathrm{~mm}$.; wing, $10 \mathrm{~mm}$.

Odyn. foraminatus SAdss. Et. Vespid. I, 180, 73, ${ }^{1}$ (1852); III, 232. Odyn. rugosus SAUss. Ibid. I, 179, 72, 令 (1852).

9. Smaller than the O. Megrara. Clypeus pyriform, longer than wide, strongly punctured, terminated by a little straight border, the angles of which are formed like two little tecth. Thorax having almost the same form as in the O. Mlegrera, although a little narrower; the head and the thorax strongly punctured. Post-scutel fincly crenulate. Metathorax rugose; its concavity striate, rounded, being scarccly bordered, but its borders blunted by punctures which are continued with those of the superior face of the metathorax; one sees, howerer, the superior ridges slightly defined on each side; all on the summit forming a little vertical and sharp tooth placed on each side behind the post-scutel and separated from this last by a fissure. Lateral faces of metathorax fincly rugose, becoming coarser toward the postcrior border. Abdomen denscly punctured, not being conical as in the preceding species, but rather oralo-conic, widening slightly as far as the extremity, or as far as the middle of $2 \mathrm{~d}$ segment; the first segment rounded, thongh truncate; a little widened behind. The border of $2 \mathrm{~d}$ and the following segments very coarsely punctured; that of the $2 d$ a little depressed. but not offering a clearly defined impressed zone; the punctures gradually augmenting in size; the following segments cribrose with great pits.

1 Erratum. Line 7 th from the bottom, in place of : Ccusson, reat : postécusson. 
Insect black, clothed with a brownish or grayish pile. $\perp$ spot on the summit of the mandibles, an arcuate band or two spots on the summit of clypeus, a spot on the front, another bchind each eye, a line on the scape of antennæ, a narrow line on the anterior border of prothorax, tegulæ, a spot under the wing, post-seutel, knees, tibiæ, and tarsi, yellow. The first four or five segments of the abdomen regularly bordered with yellow; the border of the first confounded on each side with a spot or an oblique lateral line. Wings transparent, smoky, with some violet reflections; nervures brown. A red or brown dot on the wing scales. (The wings are at times slightly ferruginous.) The last article of the tarsi at times brown.

Var. a. Two yellow dots on the superior faces of metathorax, placed on each side of the post-scutel (Tennessee).

b. Often two yellow dots on the scutel and the lateral spots of the first segment lengthened, oblique (Illinois).

§. Smaller. Clypeus yellow, polygonal, as long as wide, terminated by a slightly concave border, appearing bidentate if looked at beneath. A yellow line on the mandibles. Hook of the antenuæ ferruginous beneath. Last article of tarsi often black. 'The intermediate thighs often varied with yellow.

Var. Frontal and post-ocular spots almost nothing. Borderings of the abdomen very narrow. Wings hyaline. In the two sexes the superior teeth of the metathoracic ridges are often but little developed, indistinct, or eren wanting. One also remarks variations in the punctuation of the border of the concarity of the metathorax. The extremity of the clypeus is often hollowed by a fossette which gires it the appearance of being notched and bidentate.

Ress. a. diff.-This species has the same distribution of colors as the O. Megæra, but its ornaments are of a lively yellow and not whitish. Besides, the abdomen is less conical; the clypens o has its angles more salient and the metathorax is not bounded by distinct and trenchant ridges without. The two superior teeth of the metathorax are as strong as they are well developed. The wings are less obscure.

The 0 . foraminatus somewhat recalls also the Ancistrocerus campestris.

Finally, it resembles in so striking a manner the $O$. trilobus Fabr., that one will be tempted to take it for an American variety 
of this species so common in $\Lambda$ sia and $\Lambda$ frica; but the clypeus is always wider, the abdomen is less coarsely and more densely punctured, the first abdominal segment does not offer the spot trilobate with black peculiar to this species, and the border of the $2 d$ segment is more coarsely cribrose.

Hab. The United States, from Temnessee as far as Canada. Tennessec (E. Fr. Falconnet), Illinois (Walsh. Kennicott), New York (E. Norton), Pennsylvania (Rathron, Haldeman), Connecticut (E. Norton), Wisconsin. 17 \&, 20 .

103. O. Heucomelas SATSS. (Fig. 19, 19a.)-Niger, punctaíus, cinereo-hirtus; thorace postice attenuato; abdomine ovato-conico; metanoti toveola sat planata, striata, utrinque subangulata, marginibus superis tenuiter acutis, rectis, supra in dentem acutum terminatis, a post-scutello per fissuram sejunctum; clypei $q$ maculis 2 vel fascia, puncto frontali et post-oculari, pronoti et abdominis segmentorum limbo anguste, post-scutello, tegulis tibiisque extns, albidis ; alis subhyalinis.- $\hat{\delta}$. Clypeo bidentato, ore, antennarum scapo subtus pedibusque partim, sulfureis.

Odyn. leucomelas Sauss. Et. Vespid. III, 225, 131 (1854).

\section{Q. Total length, $14 \mathrm{~mm}$.; wing, $10 \mathrm{~mm}$. \\ $\delta$. Total length, $9 \mathrm{~mm}$; ; wing, $7.5 \mathrm{~mm}$.}

․ A little larger than the $O$. foraminatus, but the abdomen is a little more ovate-conic, the first segment a little narrower. Clypeus pyriform or rounded, strongly punctured, terminated by a very little biangulate border. The whole insect finely punctured; thorax slightly depressed, widened in the middle, retracted behind; post-scutel finely crenulate. Truncation of metathorax occupying its whole width, but the posterior plate slightly concave, quite flat, in form angulate-rouncled, equally striate throughout, forming on each side a rounded angle, at times slightly salient in the form of a tooth. Latero-superior ridges straight, fine and trenchant, although very little salient, each terminated superiorly by a sharp tooth, directed upward, and separated from the post-scutel by a narrow fissure. Abdomen quite orate, especially among the males; the $2 \mathrm{~d}$ and following segments quite strongly punctured on the border.

Insect black, clothed with a grayish pile. A spot on the

1 In the description of this species, all that which treats of the thoras is omitted. Another of the numberless negligences of tho printer! 
summit of the mandibles, tro on the summit of the clypeus, a dot on the front, another behind each eye, a narrow border on the prothorax, wing scales, a dot under the wing, post-scutel, a quite regular narrow bordering of the segments of the abdomen, and $2 \mathrm{~d}$ and $3 \mathrm{~d}$ tibiæ without, whitish. Tarsi and knees ferruginous. Antennæ wholly black. Wings transparent, or subsmoky; a brown spot on the wing scale.

Tar. a. Clypeus ornamented with a whitish arcuate band on the summit. The bordering of the first segment mingled with a white lateral dot.

b. The last segments without border.

c. No spots under the wing.

$\widehat{\jmath}$. Clypeus bidentate, jellow; labrum, mandibles, the frontal spot, a line on the scape of the antennæ, the hook of antennæ, tibiæ, tarsi, intermediate thighs beneath, and coxæ 2, 3, jellow. No spots under the wing.

Ress. a. diff-This species resembles abore all-1st the $O$. foraminatus, from which it is distinguished by its less concare metathorax, the concavity less rugose, haring the superior ridges straight and pronounced, its antennæ black, its ornaments white, etc.-2d, from the Ancistrocerus albophaleratus, which is almost identical in form and livery, but from which it is clearly distinguished by the absence of the suture on the first abdominal segment, and which has the scutel spotted with whitish, with the post-scutel black.-3d, from the O. Megæra, which has the posterior plate of the metathorax much more concare, and of a rounded not angulate form, the wings black, and only two whitish bands on the abdomen.

Hab. The northern United States. Connecticut (E. Norton), Illinois (Kennicott), $3 q, 1$. ( 1 $q$ from Fort Tejon. Latit. $35^{\circ}$, longit. $119^{\circ}$; altit. 4600 feet.)

Observation.-This species, so very near by the form and livery to the Ancistrocerus albophaleratus, approaches rery much also in the form of the metathorax to the Ancistrocerus group of the species cited. One would say that these tro species issue from the same stock, of which the form of the 1st abdominal segnent is bifurcate, while the livery has continued the same. 


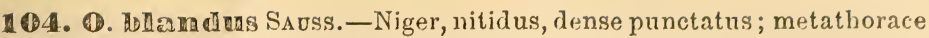
inermi, rotundato; abdomine ovato-conico; antice truncato, sessili; corpore sulfureo-multipicto; abdominis segmentis 1-5) sulfureo-limbatis, 10 et 20 insuper utrinque fascia trigonali sulfurea (vel fascia antica interrupta); pedibus llavis; alis subhyalinis.- $q$. Clypeo et orbitis partim flavis.

Odyn. blandus Sauss. Revue et Mag. de Zool. XXII,1870, 105, 27, 오.

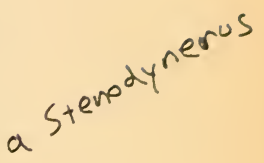

Total length, $9 \mathrm{~mm}$.; wing, $7 \mathrm{~mm}$.

9. Clypeus pyriform, flattened, rather strigose, truncate at tip and rather rounded. Head and thorax densely punctate; postscutel quite shortly truncate, quite linear, transverse, but rounded, not crested; its hinder face rather oblique, punctured; this form being the transition to the Stenodynerus. Metathorax small, short, and rounded, not angulate, shallowly punctured; its excavation strigose, not sharply margined, except superiorly, where it forms a little ridge or tooth behind the post-scutel. Abdomen ovate-conical; the first segment not quite as wide as the second, scarcely truncate anteriorly, but without a sharp ridge, sessile; its superior face slightly depressed, as punctate as the thorax; $2 d$ segment densely punctate, but not quite as strongly, its hinder margin more strongly so, and densely punctured, slightly and widely depressed; the following punctured.

Black, shining; a line on the mandibles, clypeus, inner orbits, frontal spot, a line behind the eyes, the scape bencath, a wide, but interrupted anterior margin of prothorax, a spot under the wing, tegulæ, a dot on mesothorax before the scutel, post-scutel above, and sides of metathorax, sulphur-yellow. All the segments of the abdomen margined with sulphur-yellow. The first, in addition, with two oblique yellow bands or macula, fused with the yellow bordering laterally; the $2 d$ adorned on each side with a large triangular macula, forming a wide interrupted fascia beneath; this segment has similar yellow ornaments. Anus black. Feet yellow; coxa black: the $2 \mathrm{~d}$ and $3 \mathrm{~d}$ pair margined with yelluw and spotted at tip. Wings subhyaline, nerves brown.

Var. . Clypeus with a central black spot.

Ress. $a$. diff.-In its rather stubbed form it recalls the form of $O$. Catskillensis, but its abdomen is still more sessile, more truneate anteriorly, and more square. By its rich livery it recalls O. sulfureus, but is very distinct from it by its non-angulate 
metathorax, more slencler form, etc. This is rather an intermediate type between Division Odynerus and Stenodynerus, by the quite linear form of its post-scutel, not flattened abore and ridged posteriorly; and by its abdomen, although sessile and truncate at base, haring the 1 st segment more punctured than the $2 \mathrm{~d}$ at base.

Hab. California (T. Norton).

B. Posterior plate of metathorax no longer margined with sharp ridges, but having its edges blunted by the rugosities or the punctures (or not rugose); and the summit of the ridges no longer forming post-scutellar teeth, although still separated from the post-scutel by a groove.

a. Posterior plate of metathorax much excavated, margined with salient, blunt, and rough edyes. Abdomen conical, its base sharply truncate.

10.5. O. molest nitido grosse punctato; metanoto perrugoso, liaud bidentato, foveolæ striatæ marginibus prominulis sed perrugosis, laad acutis; abdomine conico, segmentorum 2-5 margine percrasse cribratis; macula frontali et post-oculari, pronoti et abdominis segmentorum $1^{i}-4^{i}$ limbo, macnla subalari, tegulis, scutelli maculis 2 , post-scutello, metanoti sunmi punctis 2 pedibusque, flavis.- $\delta$. Clypeo latiore quam longiore, flavo, valde punctato, antice attenuato, truncato; mandibulis, oculorum margine intus, seapo subtus, flavis. - + ?

Odyn. molestus SAdss. Revue et Mag. de Zool. XXII, 1870, 6̉1, 19, $ో$.

Total length, $11 \mathrm{~mm}$.; wing, $9 \mathrm{~mm}$.

3. Size and appearance of the 0 . arvensis, but the thorax shining and more coarsely cribrose with more separated punctures. I'ost-scutel crenulate. Metathorax but little retracted, rery rugose; its posterior face not bidentate, strongly excavated, the borders sery salient, but not at all trenchant; being on tile contrary blunted, rounded by very coarse punctures. At times the borders are a little channelled becatse of these punctures; their summit is separated from the post-scutel by a fissure, but does not form any salient angles. Abdomen conical, having the same form as the 0 . arvensis; the furst segment truncate, having a sharp angle; the $2 d$ very short, its posterior border impressed and very coarsely cribrose, as are also the following segments. 
Insect black, bristling with grayish hair (among fresh specimens the abdomen is almost velvety). $\Lambda$ spot on the front, another little one belind each eye, anterior border of prothorax, tegulex, a spot beneath the wing, two on the scutcl, post-scutcl, and a spot on each side of this on the summit of metathorax, yellow or a little red. The first two segments of the abdomen bordered with yellow; the border of the first joined on each side with an oblique red or yellow spot; the segments ( $q 3-4$ ), o $3-5$ bordered with a fine ycllow edging. Legs yellow, at the basc black. Wings transparent, a little smoky; nervures brown. Wing scales spotted with red or brown.

$\hat{\delta}$. Clypeus yellow, strongly punctured, wider than long; its inferior extremity slightly prolonged and truncate in middle. Mandibles, scape of antennæ beneath, inner border of orbits, and femora above, yellow. Hook of the antennæ ferruginous.

Ress. a. diff.-This resembles divers species, particularly the 0 . arvensis $\hat{\delta}$, but the clypeus is much more coarsely punctured, wider in proportion, with the extremity narrower and not bidentate. It differs from others: from O. arvensis, Boscii, Hidalgi, and Iturbidi by its metathorax, which is not bidentate and very much more excavated. - It is easily distinguished from the 0 . foraminatus of by the form of its clypeus, by its morc coarsely punctured thorax, by the metathorax surrounded by more salient borders, and very much more rugose, not forming behind the post-scutel the two little separating teeth; by the two yellow spots of the scutel; by its very conical abclomen, truncate at its base, with a sharp ridge. But it offers an appearance wholly similar to the O. turpis; the same size, the same form, the same livery, so far that one would readily take it for the male of that species. Ilowever, it differs from it essentially by the borders of its metathorax, which are blunted, rugose, and not at all trenchant, while in the species of this group the ridges are in general more trenchant at the summit among the males than in the females. Fet the resemblance is such between these two insects that I remain in doubt if they are not the two sexes of the same species, the rather that with the O. turpis ( $q$ ) the rileses are often blunted toward the base.

Ilab. The United States. $2 \delta$ from 'Tennesseo. 
b. Posterior plate of metathorax more flattened; its margins rounded and punctured.

* Abdomen conical, principally among the females.

106. O. pratensis SAdss.-Pallide-ferruginens, citrino multipictus; thorace polito, grosse et sparse punctato; metanoto rotundato, dense punctato, velutino, utrinque inermi, superne canthis nullis, foveola striata minuta orbiculari; abdomine conico, segmentorum $2^{\mathrm{i}}-5^{\mathrm{i}} q$, $2^{\mathrm{i}}-6^{\mathrm{i}}$ o margiue punctis fuscis erassis sparse eribrato; clypeo paulo latiore quam longiore, truncato; antennis basi aurantiis, in dimidio terninali superne nigris vel fuscis; abdominis segmentorum $1^{i}, 2^{i}$ fascia marginali citrina utrinque dilatata.

Odyn. pratensis SAUss. Revue et Mag. de Zool. XXII, 1870, 61, 20, ㅇ․

ᄋ. Total length, $15 \mathrm{~mm}$; wing, $11 \mathrm{~mm}$.

o. Totail length, $12 \mathrm{~mm}$.; wing, $9 \mathrm{~mm}$.

?. Size a little superior to that of the $O$. foraminatus. Punctures of body of little depth, but quite coarse. Scutel smooth, with some coarse, separated, irregular punctures. Post-scutel crenulate. Metathorax rounded, offering a little circular, striate concavity; but its circumference is perfectly rounded, densely punctured, without any spiniform angle, nor any ridge ; not forming behind the post-scutel any kind of tecth, and velvety. Abdomen $q$ very conical, truncate anteriorly, but without sharp ridge. Border of segments $2^{i}-5^{\mathbf{i}}\left(2^{i}-6^{\mathbf{i}}, \hat{\delta}\right)$ cribrose, with very gross impressed points, a little separated, brown in their depth, and forming on the $2 d$ segment an impressed zone.

Insect of a ferruginous orange, garnished with yellow or gray hair; mandibles, clypeus, the whole face, and a little post-ocular space, sulphur-yellow; a brown band on the vertex; antennæ red, clouded with yellow, with their second moiety black abore, and the scape adorned with a yellow line. Middle of the prothorax, a spot under the wing, tegulæ, post-scutel, and sides of metathorax, yellow; scutel orange, varied with yellow; disk of mesothorax red, clouded with brown. All the segments of the abdomen widely bordered with yellow; bordering of 1 st and $2 d$ squarely widened on the sides; anus yellow; femora and tibiæ varied with yellow. Wings transparent, gray at the end, a little ferruginous along the side.

Var. a. Mesothorax obscure, with two ferruginous lines.

b. Yellow bordering of prothorax compiete. 
९. Clypeus yellow, coarsely punctured, a little wider than long, terminated by a little lamellar border; mandibles ycllow or red.

$\delta$. Smaller. Head wide. Clypeus polygonal, more widely truncate. Legs yellow. (Antennæ?.)

Ress. a. diff.-This species varies without doubt infinitely in its colors, passing probably in one place to brown or to black in its decper color, or preserving its yellow ornaments more or less reduced; in another place changing from yellow, by the paling of its deeper color, and the extension of its ornaments, as we have shown above for the $O$. annulatus. It will not do then to seck its distinctive characters elsewhere than in its form.

It is easily confounded with the $O$. annulalus, which has almost the same livery and the male of which also presents a great head. It is distinguished from it by its greater and less dense punctures, the thorax remaining smooth for this reason; by the absence of lateral dentiform angles on the metathorax; by the punctures of borders of segments 2-4, which are greatcr, and separated, and of a brown color; the $\delta$ also by its shorter clypeus, which is not regularly octagonal, the inferior borders not being identical with the superior, the inferior being a little more prolonged.

The $O$. pratensis differs from the $O$. foraminatus by its metathorax, having a smaller concavity, less surrounded by swellings, with more rounded borders, more circumscribed, less extended, as far as the borders of the posterior face; and by the absence of little teeth behind the post-scutel; by a shorter and wider clypeus, etc.

It differs from the $O$. Guerreri by its more conical abdomen, by its less densely cribrose, and not velvety body; etc. Otherwise, its color is of a gay orange-red, "common to insects of the western coast of North America, and not of the brownish-red peculiar to the Mexican insects.

Hal: Lower California and the prairies of New Mexico. ? from Cape St. Lucas (Lower California, G. Xantus); $\delta$ from New Mexico.

** Abdomen more ovate-conical. slightly contracted anteriorly.

10\%. D. Ravopicters Sauss.-O. forminato simillimus, serl metathoracis dentibus superioribus nullis ; clypeo latiore, tlavo, nigro-margi- 
nato, in medio signatura nigra; abdominis secundi segmenti margine crasse punctato sed nec impresso, nec rugoso, $q$.

Odyn. Aavopictus Sauss. Rev. et Mag. de Zool. IX, 1S57, 276.]

Total length, $11 \mathrm{~mm}$; wing, $9.5 \mathrm{~mm}$.

Very similar to $O$. foraminatus; a little smaller, and differing by its clypeus being a little more triangular, and principally by its metathorax, destitute of sharp elges superiorly, not forming behind the post-scutel two teeth separated by a fissure.

9. Rather slender. Clypeus wide, its apex narrowly produced, a little excavated, bidentate. Post-scutel not crenulate. Concarity of metathorax finely striate; its edges roughly punctured, not margined superiorly by any sharp edges. Abdomen a little more contracted anteriorly. The whole body more finely punctured; the margin of the $2 d$ abd. segment strongly punctured, but not rigose; more impressed.

Black, with the same ornaments as 0 . foraminatus; all the abdominal segments margined with yellow; the border of the first segment widened on the sides, with three black notches. Clypeus yellow, with a central black spot, and its apex margined with black. Tings washed with fuscous, with bronze reflections.

Hab. United States. Tennessee.

This may be a variety of $O$. foraminatus, with imperfectly dereloped form.

109. 0. Guerreri SACss.-Obscure rufus et niger, rugose punctatus, fulvo-hirsutus; clypeo truncato; post-scutello $\$$ bigibboso, $\delta$ 2-vel 4-dentato; metathorace ubique obtundato, dense punctato, foreola striata minore, nullomodo acute-marginata canthis nullis; abdomine ovato-conico, marginibus segmentorum $2^{\mathrm{i}}$ et sequentium grosse punctatis; secundi valde impresso; antemnis rufis, apice nigris; capite nigro, orbitis $q$ omnino rufo-marginatis nec noll in vertice sumuo; vertice $q$ fascia rufa transversa ornato; thorace rufo-maculato, pronoto rufo; abdomine rufo; segmentis omnibus flavo-marginatis, 10, 20 basi nigro-variis; alis fusco-nebulosis, costa ferruginea.

Odyn. Guerreri Sacss. Revue et Mag. de Zool. IX, 1£57, 277.

\section{Total length, $12 \mathrm{~mm}$.; wing, $10 \mathrm{~mm}$.}

$\delta$. Total length, $9.5 \mathrm{~mm}$; wing, $8 \mathrm{~mm}$.

q. Insect quite slender, of an obscure red, relrety. Head and thorax densely cribrose; scutel divided by a longituclinal groove; 
crest of post-scutel insensibly bituberculate. Concavity of metathorax quite small, the strix parted in the middle by a cirina; its borders completely rounded and punctured, forming no trace of a salient behind the post-scutel. Abdomen truncate anteriorly; second segment rather wider than long, a little wider than the first; its border offering a wide impressed zone, roughly cribrose with separate punctures, insensibly crenulate. Borders of the other segments very coarsely punctured.

Insect black, velvety, garnislied with an abunclant woolly, tawny pile. Clypeus, mandibles, a spot on the front, and the complete border of the orbits, as well as the vertex, ferruginous; one sces beside on the vertex a transverse band of this color which joirs the summit of the two eyes. Antennæ ferruginous, with their second moiety black. Prothorax, tegulæ, a spot under the wing, scutel and post-scutel, wholly or in part, and angles of metathorax, of an obscurc ferruginous; there is often a ferruginous spot at the base of mesothorax also. Abdomen silky or woolly, ferruginous, with the border of all the segments, yellow; the base of the first two black, which forms variable designs. Legs ferruginous. Wings ferruginous along the side, a little smoky in the rest of their extent, the radial cellule obscure.

Var. a. The little channel of second segment almost null in certain specimens.

b. Metathorax black; scutel black, with two red spots; the black strongly extended on the first two segments of abdomen.

c. The scape blackish above; vertex without red transverse band; legs black and yellow.

d. Clypeus, ornaments of the head, scutel, tegulæ, spots under the wings, passing into yellow.

. Clypeus wide, strongly punctured, its inferior margin truncate, the angles forming two little salients.

$\delta$. Clypeus polygonal, truncation almost straight, yellow. Post-scutel bidentate or 4-dentate, or denticulate; 2d segment very short, concave, its border very rugose, at times a little channelled. Vertex generally black, bordering of orbits incomplete at the summit.

Var. The first segment black, bordered with yellow; the bordering joining with two red lateral spots; the 2 d black, red on the sidles.

Ress. a. diff.-This species has rather nearly the same colora- 
tion as the O. Iturbide and Hidalgi (var. Mex.); but it differs by its smaller size, by its bidentate post-scutel, by its smaller concarity which only occupies the middle. The male grearly resembles the $O$. molestus, but is distinct from it by the metathorax haring its borders more regularly rounded, regularly puuctured, not rugose, not angulate at the summit, nor quite so elevated as to be separated from the post-scutel by a fissure; by the more oval abdomen, by its antennæ, red in their first moiety, etc.

The species closely approaches also to the colors of the $O$. Morelii, and the Ancistrocerus tuberculiceps. (See the description of these species.)

Hab. The temperate parts of Mexico. I took $4 q$ and $9 \delta$ in the beautiful valley of Mextitlan; one $q$ on the confines of Morelia, in Mechoacan; and $2 \&, 3 \delta$ in the hot parts of the province of Mexico (Cuautla).

109. O. Romamdinus SAdss._-Satis gracilis, nigro-relutinus, pilis longis fulvis hirsutus; post-scutello hand acute truncato; metanoto haud angulato; puncto post-oculari, pronoti, tegularum, abdominisque segnentorum 1-3 margine, flavo; post-scutello fascia flava; alis infuscatis, fusco-purpureo nitidis.-Clypeo $q$ nigro; $\delta$ aurantio, basi nigro.

Odyn. Romandinus Sauss, et Vespides, I, 184, 79.

․ Total length, $11 \mathrm{~mm}$; wing, $8.5 \mathrm{~mm}$.

$\hat{j}$. Total length, $9 \mathrm{~mm}$; wing, $8 \mathrm{~mm}$.

Rather slender, very finely punctured and velutinous throughout. Post-scutel depressed, not sharply truncate. Metathorax very slightly excarated, not angulate; the excaration not margined; superiorly, continued without limits from the superior part; the lateral edges continued with the inferior edges. Abdomen orateconical, a little depressed; the first segment not as wide as the second, bluntly truncate anteriorly, and more strongly punctate. Second segment having at base beneath a transverse tubercle.

The whole insect of a deep relret black, and all bristling with long fulvous hair. Antennæ and head black; a little yellow spot behind the eye. Anterior margin of prothorax with a narrow yellow band; margin of wing scales, a fascia on the post-scutel, and the margin of the 1-3 abd. segments narrowly yellow; the $3 \mathrm{~d}$ margin quite narrow. Wings fuscous, with brown and violet iridescence. The ornaments are of a golden sulphur-yellow. 
Var. Post-scutel black, without yellow band.

9. Clypeus pyriform, truncate, bidentate or biangulate at tip, coarsely punctured near the extremity; adorned with two yellow lines at its apex.

$\hat{\delta}$. Ciypeus elongate, a little bidentate at the apex, the inferior part occupied by a large orange macula; its teeth and apical edge black. Hook of the antennæ small, black.

Var. 'The orange macula of the clypeus inuch extended.

Ress. a. diff.- $-\Lambda$ very distinct species, having quite the characters of the Odyneridx of the northern Andes of South America, velutinous, grisly with long black hair. This insect forms somewhat a transition to the Hypodynerus; it lives also quite on the northern limits of the distribution of this group of insects.

Hab. New Granada. Sta Fé de Bogota, 2 \&, 2 $\delta$.

SECTION II.-Body still stubbed, not slender, nor cylindrical. Abdomen not conical, but remaining sessile; the 1st segment smaller than the $2 d$, as strongly or more strongly punctured than the $2 d$; the $2 d$ constricted at base to fit into the first and more or less deformed; having its margin very strongly canaliculate and reflexed, and more or less swelled before the channel.

This group is formed for exceptional types, still belonging to the Division Odynerus by their general aspect, but passing to Stenodynerus by the form of the abdomen, which is no longer conical or ovate-conical, but more narrow anteriorly, and by the scutel, which is not so distinctly truncate, nor ridged on the line of the truncation. The two species which follow are approximate in the form of the abdomen, but very different in that of the clypeus $\delta$.

1. Metathorax not narrowed below, much excavated, with ver!! sharp edges; post-sculel bituberculate; abdomen quite deformed.

110. O. Cluniculus Sauss.-Niger, crassissime cribri instar punctatus; pronoto eristato, post-sentello bimamillari; metathorace valde excavato, snperne acute marginato; 20 segmento postice clunium duarum instar turgente, margine profundissime canaliculato et maxime 
reflexo; macula frontali et subalari, tegulis, macuiis 2 scutelli et 2 metanoti, pronoti abdominisque segmentorum $1^{\mathrm{i}}-4^{\mathrm{i}}$ margine, tibiis et tarsis, pallide-flavis.- $\delta$. Clypeo polygonali flaro; scapo subtus flavo.

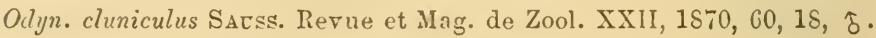

\section{\}. Total length, $9 \mathrm{~mm}$; wing, $7.5 \mathrm{~mm}$.}

Body cribrose, with rery large, deep punctures; head rugose, sharply margined behind. Prothorax anteriorly crested, angulate. Post-scutel bearing a sort of emarginate crest or two bidentate eminences; its hinder face elevated, flattened; metathorax vertically truncate, much excarated, rather polished, very sharply margined saperiorly by two angulate prominent ridges, separated by a sort of channel, being the continuation of the ground of the carity; the superior cheeks rather separated from post-scutel by a sulcosity, and haring a polished space; the inferior part rather angulate inferiorly, but the angles quite rounded; the inferior edges nearly horizontal. "Abdomen quite deformed. First segment short, truncate anteriorly; its transrerse edge blunt, although a little salient because of a depression of the superior face. Second segment slightly orate; quite swelled above into two large, salient, rounded tubercles, separated by a deep excavation, resembling two brushes; the margin forming a rather broad, extremely deep channel, with the posterior edge reflexed into a very much elevated crest, slightly undulating in the middle. Third segment cut a little concarely behind. The first three segments quite as strongly cribrose with enormous punctures as the thorax (also the tubercles of the $2 d$ segment). Those following not as strongly punctured.

Black. A frontal and post-ocular spot, anterior margin of prothorax, a macula under tlie wing, tegulæ, two spots on the scutel, two spots on the metathorax and its blunt angles, and the margins of the first four abd. segments, pale yellow; margins of 1, 2 segments moderate; 3,4 very narrow. Feet black or brown; knees, tibiæ, tarsi, and coxæ 2, 3, pale yellow; tibiæ rather ferruginous. Wings subhyaline, anterior margin narrowly brown.

$\hat{\jmath}$. Clypeus polygonal, as wide as long, coarsely punctured, truncate, pale-jellow, as well as a line on the scape of the antennæ; hook ferruginous.—? ?.

Ress. a. diff. -1 species quite distinct by the unusual form of 
its abdomen, recalling, with exaggeration, the $\Lambda$ frican $O$ ecanaticulalus.

IIab. The temperate part of Mexico. Orizalua ( $1 \hat{\delta}$, Sumichrast).

B. Metathorax triangular, narroned posteriorly, not so much. excavaled, with sharp superior ridges. Post-sculel not crested. Second abdominal segment channelled and reflexed, scarcely swollen.

111. O. Morelini Sauss.-Niger, dense punctulatus, fulvo-tomentosus; pronoto angulato; metathorace haud angulato, foveola postica canthis acutis superne marginata; abdominis primo segmento minore, margine elevato; secundi margine rugoso, valde canaliculato valde reflexo; antennis basi ferrugineis; ore, orbitis et verticis fascia arcuata, pronoto, macula subalari, tegulis, scutelli margine, metanoti canthis, pedibus abdomineque, ferrugineis; segmentorum margine obscure flavo; segmentis 10, 20 basi nigris; alis dilute infuscatis, in costa ferruginea.$\hat{\delta}$. Clypeo rotundato, transverso, flavo; argenteo-tomentoso; vertice tulereulo polito obsoleto instructo. $-\delta$.

Odyn. Morelos Sadss. Rev. et Mag. de Zool. IX, 1857, 276, $\delta$.

Total length, $९, 12 \mathrm{~mm}$. ; wing, $\delta, 10 \mathrm{~mm}$.

5. IIead rather swelled transsersely at the occiput or behind the cyes. Tertex a little hollowed, or with a double, polished low tubercle behind the ocellæ, and between this and the ocellæ, a sort of arcuate depression, often obsolete. Thorax short; prothorax quite squarcly cut, its angles sharp, but not produced. Post-scutel quite shortly truncate; linear, transrerse, insensibly depressed in the middle; but not edged nor erenulate; its hincler face elevated. Netathorax rather narrow; its upper face on each side convex; its hinder face rather triangular, forming each sille almost a blunt lateral angle; the excaration margined superiorly on each side under the post-scutel by a sharp areale or arenated elges, very salient, like a sharp erest, but not erect, forming no teeth whatever behind the post-scutel. $\Lambda$ bdomen constricted at base of the second segment; the first segment rery small, mueh narrower than the second, truneate and rounded at base; its margin a little edged. The second segment rery strongly eanaliculate along its margin; the channel widened in the middle and 
the segment slightly swelled into two little cheeks before the channel; the edge strongly reflexed; the edge of the $3 \mathrm{~d}$ also a little reflexed; the $2 \mathrm{~d}$ beneath as tuberculate at base. The whole insect finely and densely punctured, on the abdomen as well as on the thorax; more coarsely on the margin of $2-4$ segments. The body woolly, furnished with gray-fulrous hair.

Black. Mandibles, the 2-3 first joints of antennæ, a frontal longitudinal line, an clongate large post-ocular spot, not touching the eyes, and an angulate line on the rertex parted by the tubercle, and continuing along the inner orbits of the eyes, ruíous. Prothorax, tegulæ, a spot under the wing, post-scutel, hinder part of scutel, and often the angles of metathorax, rufous. Abdomen rufous; the base of the first two segments black, and the margin of all segments yellowish. The black of the base is often prolonged on the middle of the segment. Feet rufous. Wings smoky, with the anterior edge ferruginous.

$\hat{\jmath}$. Clypeus wider than long, fulvous or yellowish, with argenteous reflections, although haring some black hair; its inferior margin rounded, with a little notch and bidentate in the middle. Hook of the antennæ large, arcuate, black

Tar. a. The head not much rariegated with ferruginous. Orbits and vertex nearly black. A black spot near the edge of the $2 d$ abd. segment.

b. Metathorax black.

Ress. a. diff.-The coloring of this insect is what I should like to call the Mexican livery; this dull ferruginous fulvo-relutinous livery being quite a Mexican type. This coloration is quite that of Ancistrocerus tuberculiceps, and much also that of Odynerus Guerreri. From this it differs, by its abdomen, not conical, the first segment being much narrower than the $2 d$; by the margin of the 1st segment which is hemmed, and that of the second, much more canaliculate; by its post-scutel not sharp nor crenulate, and by its rery large, wide clypeus.

This is quite an exceptional type by the form of its abdomen, post-scutel, and its wide $\delta$ clypeus.

Hab. The temperate parts of Mexico. I caught two males in the fine valley of Mextitlan. 


\section{Division STENODYNERUS.}

(Sauss. Vespides I, Divis. IV, 206.-III, Divis. Epsilon, II Sect., p. 255. Stenodynerus, Melang. Hymenopt. II ${ }^{e}$ fasc., p. 58.)

Body elongale, generally slender; often cylindrical. Abdomen slender and cylindrical, or ovate, not quite sessile, or spindleshaped, subpedunculate. Its first segment variable, having the shape of rather an elongate bell, rounded anteriorly or cup-shaped, subpedunculate, or funnel-shaped, often longer than wide.-Post-sculel generally entire, not truncate, angular posteriorly; but yet sometimes truncate when the abdomen is spindle-shaped and subpedunculate.

This is a type very richly represented in America.

The Odyneri of this division constitute a special type, remarkable by the elongation of their forms, which is among the Odyneri, quite a corresponding similarity between the Stenancistrocerus and the Ancistrocerus.

The parallelism is so complete that one may even designate in both groups some corresponding species of which some are quite approximate, merely differing by the presence or absence of a suture on the 1st abdominal segment, ${ }^{1}$ others very analogous, ${ }^{2}$ although not quite so similar. This very difficult group is not, distinguished by any one special character, but by the combination of several, which are not all general to all the species, each species uniting only a certain portion of them, which partly occur in other Odyneri, but are combined in other ways. This makes the Stenodyneri very difficult to recognize, for one not very familiar with the genus Odynerus.
1 O. conformis.
A. fulvipes.
O. vagus.
$\{$ A. sacularis.

2 a. Abdsmen elongate, cylindrical.
O. Enyo.
A. histrio.
O. totonacus.
A. Mexicanus.

b. Abdomen more ovate, 1 st segment cup-shaped.
O. speciosus.
A. militaris.
O. Peyroti.
A. Sumichrasti.

c. Metathorax produced posteriorly; wings black, ornaments white.
O. luctuosus.
1. quadriscetus, ote. 
The difficulty in distinguishing the Stenodynerus from the Pachodynerus and the true Odynerus obliges us to make a review of the characters which are peculiar to each.

The clypeus is not characteristic in any. Generally pyriform, truncate, and biangulate at tip; in $q$ sometimes rounded; in $\hat{\delta}$ polygonal-truncate and bidentate.

The thorax is cylindrical when the abdomen is elongatecylindrical, vaulted above, anteriorly not contracted, biangulate (O. conformis, toltecus, perennis, etc.). When the abdomen is more orate or spindle-shaped, the thorax is not so elongate, more triangular, contracted behind. It is nearly alwass more or less coarsely punctured, the metathorax being less strongly punctured.

The post-scutel is very peculiar. It has two difierent forms:

1st. Not truncate; that is, angulate behind, not forming a superior transverse punctate face and a posterior vertical polished face, but on the contrary entire; rather horizontal or oblique, falling into the hincler face of metathorax, more elevated anteriorly than posteriorly, as if it had been a little squeezed from behind forwards, so as to accumulate it somewhat along the anterior margin; when crested, the crest is placed on this ele rated part near the anterior margin, and not, as in the Diris. Odynerus, on the posterior elge formed by the truncation. When not truncate, it is punctured on its whole surface.

2d. Truncate posteriorly and crested on the ridge of the truncation, nearly as in Divis. Odynerus. But in this case the truncation is more oblique, as if impressed from behind, and the crest rather pushed forward against the anterior margin. The truncation also is not as straight transversely, but is rather arcuate. In case the scutel is truncate, the Stenodynerus are yet quite distinct from Divis. Odynerus, in having the metatlorax quite convex, not widely excarated, so that the posterior face of the post-scutel does not, as in Otynerus, make a part of the posterior concarity of the metathorax, and besides, the abdomen is cuite slender, spindle-sliaped, the first segment being fumnel-shaped, rather pediculate, not wide and sessile as in the Divis. Odynerus.

The metathorax is quite variable. 1st. Sometimes produced horizontally, further than the post-scutel, including it behind (O. luctuosus), as in some Ancistrocerus (4.4-sectus). 2d. Generally not produced superiorly, but somewhat produced under the 
scutel before it becomes truncate, which is such that the postscutel is not tonched by the truncation; quite rounded, withent lateral angles, with a rounded, fres, not limited fosssette; sometimes produced triangularly, convex, only parted by a longitudinal or sulcate channel. 3d. 'Truncate or biangulate, with a very shar' cavity and lateral angles (O. spinifer), but the post-scutel not truncate. Even when quite rounderl posteriorly, the metathorax does not lose its lateral ridges, which extend from the posterior wing to the articular valves of the abdomen, and which must not be confounded with the superior and inferior edges which constitute the lateral margin of the concavity, when existing.

The abdomen has also various forms: 1st. In the elongatecylindrical type it is clongate and cylindrical, sessile, but the first segment is bell-shaped, elongate, rounded, not or but slightly contracted anteriorly, but not truncate; as long as wide. This form is very different from that of Divis. Odynerus, where the 1st segment is wide, truncate anteriorly, its superior face being always wider than long. 2 d. Elongate, slender, but more depressed; the 1st segment short, truncate, as in Odynerus, but the post-scutel not truncate (O. spinifer). 3d. More ovate, contracted anteriorly, the first segment being small, cup-shaped, rounded, not quite sessile, often subpetiolate; the 2 d segment more swelled. 4th. Elongate spindle-shaped, quite slender, attenuated anteriorly the same as posteriorly; the first segment funnel-shaped, sometimes elongate and subpetiolate.

The abdomen has a tendency to be more produced than in Divis. Odynerus; and the 1st segment is always more coarsely punctured than the $2 \mathrm{~d}$, which is jnst the contrary in Diris. Odynerus. These various forms make quite inscusible transitions from one to another, and their various combinations make it rery dificult to define the subdivisions of the group, so that one mnst. pardon me if I have not succeded in rendering them distinct enongli.

The table of species, based on empirical characters, will perhap:help the reader out of the chaos of the very mmerous species. better than the diagnosis of the subdivisions, and the following table will assist in distinguishing the Stenodynerus from the Divis. Pachodyneins and Odynerus pr. dict. 
A. Upper face of thorax prolonged beyond the post-scutel, involving it behind.

B. Thorax not prolonged superiorly behind the post seutel.

a. Post-scutel entire, angulate behind.

b. Post-scutel truncate posteriorly, having a posterior face.

$\dagger$ First abdominal segment shori, truncate anteriorly, its superior face wider than long.

Odynerus.

†† First abd. segment subpedunculate, funnel-shaped or cup-shaped.

C. Abdomen thick, conical, widest anteriorly.

Stenodynerus.

D. Abdomen not so conical.

Odynerus.

a. First segment truncate anteriorly.

a. Its superior face wider than long.

* Post-scutel truncate; abdomen ovate-conical. Odynerus.

** Post-scutel not truncate; abdomen slender 1st segment nore punctured than the $2 d$.

B. Its superior face about as long as wide.

Stenodynerus.

Stenodynerus.

b. Abdomen slender, cylindrical; first segment bell-shaped, sessile, rounded anteriorly, as long as wide.

c. Abdomen more ovate, first segment smaller, cup-shaped.

d. Abdomen slender, spindle-shaped ; first segment fumnel-sbaped.

Stenodynerus.

E. First abd. segment less punctured than the $2 d$, or equally punctured with it.

Odyncrus.

F. First abd. segment more punctured than the $2 d$ or equally with it.

G. Post-scutel entire, angulate behind.

Stenodynerus.

H. Post-scutel truncate posteriorly.

a. Abdomen sessile, or subsessile, truncate at base. Odynerus.

b. Abdomen subpedunculate, 1st segment funnel-shaped.

Stenodynerus.

It is almost superfluous to say that these distinctions are not mathematical, nature always forming transitions which oblige us to admit a certain latitude in the exceptions and in the meaning of the definitions.

Table to assist in the determination of the Stenodyneri.

1. Wings black, with violet iridescence. 111. luctuosus.

1, 1. Wings cloudy, ferruginous, or subhyaline.

2. A crest or two erect spines behind the post-scutel.

3. Metathorax strongly biangulate, and bidentate superiorly.

112. spinifer.

3, 3. Netathorax superiorly margined with a semicircular ridge. 
2, 2. No erect spines on metathorax, behind the post-scutel.

3. Scutel, metathorax, and first segnent orange, wings ferruginous, with the apex brown.

115. Enyo.

3,3 . Insect black, with yellow or luteous ornarnents.

4. Post-scutel black, truncate or crested; scutel adormed with yellow. Small species very slender.

5. Metathorax unarmed.

6. Quite swall; antewnæ and̉ pleuræ maculate.

149. acolhuus.

6, 6. Larger. Antenuæ and pleuræ $q$ immacnlate.

150. zendalus.

5, 5. Metathorax having superiorly two small tubercles; quite small species.

6. Tubercles large, dentiform; post-scutel truncate, not crested.

154. tepanecus.

6,6. Tubercles small. Post-scutel crested.

7. Tubercles rounded, punctured; post-scutel crested anteriorly.

151. nuhuus.

7, 7. Tubercles sharp, compressed, very small.

8. Post-scutel crested anteriorly. 152. olnecus.

8, 8. Post-scutel crested posteriorly. 153. chichimecus.

4,4. Post-scutel triangular or not distinctly truncate, generally with a yellow fascia.

5. Scutel and post-scutel orange.

5, 5. Scutel always black.

6. Post-scutel crested, yellow.

6, 6. Post-scutel not crested.

142. columbaris.

7. Post-scutel black.

8. Thorax quite black.

9. Only the first segment margined with yellow.

132. Nortonianus, var.

9, 9. Segments 2-5 margined with yellow.

124. Xantianus.

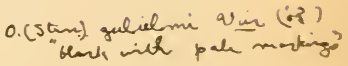

140. similis.

8, 8. Thorax adorned with yellow.

9. Only the first segment margined with yellow.

132. Nortonianus.

9,9. The first two segments adorned with yellow.

10. Second segment with two yellow spots.

132. Nortoniunus.

10, 10. Second segment without yellow spot.

144. coyotus.

7, 7. Post-scutel adorned with yellow; the $2 \mathrm{~d}$ seguent margimed with yellow.

8. Anterior margin of prothorax adorned with yellow, not its posterior margin.

9. Margin of 2 ll sesment very strongly canaliculate and reflexed.

11s. I toltecus.

120. $\{$ T Toas.

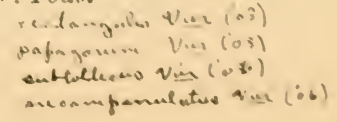


9, 9. Margin of 2 d segment not canaliculate, or only slightly reflexed.

10. Second abdominal segment with two free yellow spots.

11. First segment with two yellow spots.

12. The spots elongate or oblique fasciæ.

13. Smaller, very slender, cylindrical.

117. conformis.

13, 13. Larger, not slender. 116. vagus.

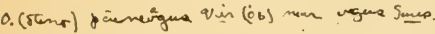

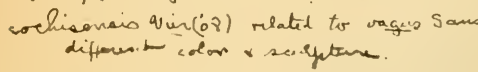

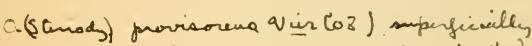
Vike $O(0 d y)$ spectaticiformis $V$ in. $(08)$

$O$ (stenody) yesmus $Q$ ivis (bi) similen to tass but ind ald oy suflexed.

$O$ (Masicupodymars nseg.) maskiofo oum vin (-8) near O(Sting) toltens Git rif.coldenum.

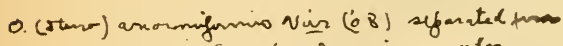
arcormis surs by feringinons alos.

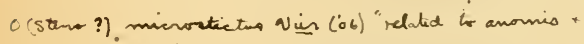

12,12 . The spots rounded, or small, or triangular.

13. Margin of $2 \mathrm{~d}$ segment slightly reflexed.

121. $\{$ collega.

120. $\{$ Toas.

13, 13. Margin of $2 d$ segment punctured, not sensibly reflexed. 119. anormis.

11, 11. First abdominal segment without yellow spots.

12. Post-scutel bipunctate with yellow.

132. Nortonianus.

12, 12. Post-scutel with a yellow band.

13. Margin of $2 \mathrm{~d}$ segment slightly reflexed.

$$
\text { 121. }\left\{\begin{array}{l}
\text { collega. } \\
\text { Tous. }
\end{array}\right.
$$

13, 13. Margin of $2 d$ segment not.reflexed.

14. Ormaments rufous, feet rufous, body velutinous. 126. propinquus.

14,14 . Ornaments yellow or pale; feet black and yellow, or yellow.

15. Small; ornaments luteous.

125. Kennicottianus.

15, 15. Ornaments yellow.

16. Segments 1-4 margined with yellow. Abdomen ovate.

119. $\{$ anormis.

126. $\{$ propinquus, var.

16,16. Segments 1, 2, 4 margined with yellow. Abdomen slender.

17. Body much variegated with orange-yellow; femora yellow.

122. bacuensis.

17,17 . Body passably variegated with sulphur-yellow ; femora black. 123. pedestris.

10, 10. Second abd. segment without free yellow spots.

11. First abd. segment with two yellow spots or fasciæ.

12. With two oblique fasciæ.

116. vagus, var. 
12, 12. Wilh two freespots. 121. collega, var.

13. Fossette of metathorax rather angulate superiorly.

129. T'exeresis.

13, 13. Fossette of metathorax romoded.

121. collega, var.

11,11 . First and second segments without free yellow spots.

12. Only the first two abd. segments margined with yellow or luteous.

13. Tibiæ and tarsi quite yellow or ferruginous.

14. Ratluer large; margin of $2 d$ segment reflexed. 121. collega, var.

14, 14. Sualler, slender ; margin of $2 d$ segment not reflexed.

15. Ornaments wide, deep yellow; $2 d$ segment strongly punctate.

128. perennis.

15, 15. Ornaments uarrow, palesulphur-yellow; $2 d$ segments finely punctate.

145. (Tacubaya, var.

148. Mohicanus.

147. Huro.

136. Callepetlensis.

13, 13. Tibixe and tarsi black, or maculate with yellow or luteuus.

14. Insect not very slender; ornaments yellow; abdomen ovate, margin (f first segment wide, widened on each side; feet black. 135. mystecus.

14, 14. Insect slender.

15. Ormaments pale.

16. Abromen truncate at base; metathorax superiorly margined by an arcuate crest.

13S. Araucanus.

16, 16. Abd. spindle shaped; metathorax not crested superiorly. Yellow margins quite narrow.
144. coyolus, var
146. $\{$ pruinosus.
143. totonucus, lar.

15, 15. Ornaments yellow; first abl. segment rather sessile, square above, rugose. 1:31. figulus.

12, 12. More than two segments margined with yellow.

13. Sogments $1, \ddot{z}, \pm$ margined with yellow. 
14. Dietathorax rough, rather angulate; 5 th segment margined with yellow.

129. Texensis, vur.

14, 14. Metathorax rounded, rather rough; 5 th segwent not wargined.

127. Pennsyleanicus.

13,13 . The third segment margined with yellow.

14. The following segments margined with

$$
\text { yellow. } \quad 147 .\left\{\begin{array}{l}
\text { Huro. } \\
\text { mystecus. }
\end{array}\right.
$$

14, 14. Segments 1-4 margined with yellow.

15. Margin of 2 d seguent rather ietlexed. 121. collega, var.

15, 15. Nargin of $2 \mathrm{~d}$ segment not reflexed.

16. Ouly the seguent $1-4 q, 1-5 . \delta$ margined with yellow.

17. Body elongate; ahdomen cylindrical; metathorax depressed, flattened. 130. fasciculatus.

17, 17. Body not so slender; abdomen more orate, contracted at base; metatliorax short, rounded.

133. Victorice.

16,16. All the segments margined with yellow.

17. Ornaments luteous; anus black. 125. \{ Kennicottiainus. 134. $\{$ Inca.

17, 17. Ornaments yellow.

18. All the margins wide; anus yellow. 137. mayus.

18,18 . The last margins narrow ; anus black. 133. \{ Victorice. 134. Inca.

8, 8. Posterin margin of prothorax adorned with yellow, and often also its anterior margin quite black.

9. A free spot on each side of the 2 d abd. segment.

9, 9. No free spot "n the $2 \mathrm{~d}$ segment. 126. prnpinquus.

10. Qnite slender; only the first two segments margined with pale sulphur-yellow.

11. Feet black; tibiæ of ten maculate with yellow. Small.

143. totonacus.

Very small.

14t. coyotus.

11, 11. Tibiæ and tarsi fulrons. 145. Tacubayce.

10, 10. Not so slender, abd. more ovate; all the segments margined with yellow.

11. Metathorax rugose, reiiculately rugose or punctate. 
12. Body fulvo-velntinous; prothorax and first segment posteriorly well margined with yellow; wings ferruginous on the anterior edge.

139. otomitus.

12, 12. Body argenteo-sericeus ; prothorax and 1st segment very narrowly margined, or quite black; 2 segment widely inargined; wings cloudy. 141. Peyroti.

11, 11. Metathorax punctate, not so rugose; wings smoliy.

138. huastecus.

Description of the species.

I. Metathorax having its posterior plate superiorly terminated by two erect teeth, or by an erect crest.

A. Metathorax not prolonged beyond the post-scutel, but truncate at its apex, posteriorly excavated, angulate on each side; the superior edges of the posterior plate terminating in two erect spines, which are separated from the post-scutel by deep fissures.

This type establishes the passage from the true Odynerus to the Stenodynerus. The metathorax continue to be formed as in the Odynerus propr. dict., angular and sharp, but the post-scutel, instead of being transversely truncate and crested, advances angularly between the spines of metathorax, and is not sensibly truncate. The first abdominal segment is short and truncate anteriorly. The other characters are quite those of Stenodynerus: Head rounded and conrex; body slender, rather cylindrical, the first abdominal segment more punctate than the rest of the abdomen.

112. O. Spinifer Savss.-Gracillimus, elongatus; clypeo piriformi, punctato, apice arcuato-truncato, biangulato. Caput, thorax et abilominis primum segmentum, tenuiter deuse punctata. Thorax confexus, antice haud coarctatus, tenui ter cristato-marginatus; scutellis deplanatis ; post-scutello trigonali, apice hand vel obsolete truncato; metanoto postice obliqne excavato, canthis lateralibus ralde acntis, utrinl̨ue dentem eflicientibus; foveola strigata, rugosa ; canthis inferis acutis, valris articulationis latis; eanthis snperis obsoletis, superne pone port. sentelhm in spinas 2 ereetas elongatas exenryentibus. Abiomen subvelntinum; primo segmento brevi, latitndime fere secumbo xquali, antice rotundato, truncito, snperne frer sulcun pratito: secundo ciongnto: 
segmentis 2-6 tenuissime punctatis. Corpus nigrum; mandibularum apice, tegulis, tibiis tarsisque, ferrugineis; punctis 2 in summo cly peo, puncto frontali, puncto utrinque post-oculari, et altero in oculorum sinu, pronoti linea antica interrupta, macula subalari, puncto utrinque in metanoti dentibus lateralibus abdominisque segmentorum $1^{\mathrm{i}}, 2^{\mathrm{i}}$ fascia angusta, flavis vel luteis. Alis fusco-nebulesis; venis fuscis, tegulis flavo-punctatis ᄋ.-Longit. $10 \mathrm{~mm}$.; alæ, $7.5 \mathrm{~mm}$.

Odyn. spinifer Sauss. Revue et Mag. de Zool. X, 185̆8, 168, $\subsetneq$.

Ress. a. diff.-In this species the distribution of the colors is very characteristic. The scutel and post-scutel continue black, although there is a yellow spot under the wing. The yellow spots are all quite small and the bands quite narrow. These ornaments are whitish on the head and thorax, more yellowish on the abdomen.

This Odynerus resembles 0 . scutellaris by its metathoracic erect spines, but the forms are quite different; the post-scutel is not transsersely truncate; the abdomen is more cylindrical; and it is the 1st segment which is the most strongly punctate, just the contrary of what appears in scutellaris; the head is more rounded, more conrex; the metathorax more excavated, but its concavity is smaller; the livery is quite different.

Hab. Brazil, Para.

B. Metathorax truncate, excarated; superiorly nargined by an arcuate ridge, rather crenulate, separated on each side from post-scutel by a fissure.

113. D. Araucan us SACss. - Párvulus, niger, gracillimus, cribri instar punctatus; pronoto valde angulato; metanoto superue cristulato; linea scapi, puncto frontali et subalari, tegularum marginibus, litura angusta pronoti marginis autici et post-scutelli, nec nou fasciis 2 abdominis, albidis. $q$.

Odyn. Araucunus Sacss. Reise. Oester. Fregatte, Novara. Hymenop. 14, 13, fig. 8 , ․

Total length, $8 \mathrm{~mm}$; wing, $5 \mathrm{~mm}$.

․ Small, slender, cylindrical; head and thorax densely punctate; abdomen rather more finely punctate. Head excavated posteriorly. Prothorax having its angles rery sharp. Meta. thorax almost rertically truncate, rugose on its superior part; its hinder face much excavated; the excavation almost polished, 
nearly forming on each side a sort of angle, acutcly marginate superiorly in an arc of a circle; the margin rough, slightly elevated behind the post-scutel, crenulate, separated from postscutel by a fissure. Abdomen cylindrical; the first segment rather elongate, anteriorly rounded-truncate.

Black, shining; mandibles, apex of the tarsi, and antennæ beneath, ferruginous; a line on the scape beneath, a frontal and post-ocular spot, anterior margin of prothorax, two spots on the margin of the tegulæ, post-tegulæ, one or two spots under the wings, a line on post-scutel, and the margin of the first two abdominal segments, luteous. Feet black. Wings subhyaline, the nerves brown.

Ress. a. diff.-It much resembles Ancistr. sccibriusculus, but is distinct by its abdomen, without suture.

Hab. Chili (Museum of Vienna).

C. Form not very slender. Metathorax produced horizontally beyond the post-sculel; then vertically truncate; the postscutel quile enveloped by it posteriorly, not reaching up to the edge of the posterior face of melathorax; the posterior face of metathorax superiorly terminating in an erect crest, parted by a fissure. Verlex in ? having two pilose tubercles.

This type is in the Stenodynerus, the corresponding representative of the type of $A$. 4-sectus, in the Stenancistrocerus. It has also the metathorax prolonged and the vertex armed with two pilose tubercles. But the abdomen, although polished in the same way, is much contracied at base.

11. O. Inctuosus SAuss.-Validus, ater, rugosus, nigro pilosus ; clypeus piriformis, paulum punctatus, apice paulum emarginatus, bidentatus. Caput et thorax crasse punctata, rugosissime secuudum longitudinem elevato-strigata; vertice cirris 2 pilornm nigrorum instructo, pronoto cristato-marginato, angulato; scutello lari, nitilo, sparse punctato; post-scutello depresso, integro; metathorace rugosissimo, transverse elevato-striato, nec non utrinque subtus arenatostrigato, velutino et longe nigro-vel cinereo-piloso, pone post-scutelluu producto, dein truncato; postice tantum in medio foreolato, grosse strigato; sed in summo, supra foveolam in cristulam producto, transversam crenatam, in medio divisam. Abromen nitidisimum, sparse punctatum; primo segmento hasi truneato valde angustiore quam secundum; secundo supra in tubereulum tumosente.-Linea mandibularum, macula 2 laterales clyperi, linea in antennarum seapo ot macula

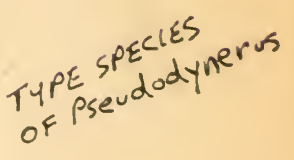


2 magnæ in basi secundi abdominis segmenti, albidæ. Alæ nigroviolaceæ.-Longit. $20 \mathrm{~mm}$; alæ, $17 \mathrm{~mm}$.

Odyn. luctuosus Satss. Et. Vespid. III, 220, 114 (1854).

'This Odynerus has many characters in common with the $O$. 4 -sectus; tubercle of $2 \mathrm{~d}$ segment (here much $\mathrm{m}$ re developerl); form of clypeus, brush of rertex, superior termination of metathorax; but it differs from it by the strong rugosities, by the form of the striæ of the head and thorax, and by its metathorax which offer's no trace of latero-superior ridges, so that the lateral ridges are continued with the inferior ridges, in forming lateral trenchant, but not acute angles.

The first abdominal segment is a little funnel-shaped, truncate. The maxillary palpi have the $2 \mathrm{~d}$ article long and slender, and the last three quite small, although longer taken together than the $3 \mathrm{~d}$.

The two spots of the abdomen might cause this Odynerus to be taken for the $O$. bidens, if its form and punctuation were not wholly different.

Hab. America. Which part, not known.

II. Metathorax not forming erect spines or crests behind the post-scutel. Its superior face not produced behind the postscutel. This last not posteriorly truncate, but angular. Post-scutel generally yellow, scutel usually black.

The great number of species composing this group, and the intimate relations which they bear to each other, make me doubtful of my success in defining them with certainty-The species are all of moderate or small size.

1. Body slender, cylindrical. Concavity of the metathorax, wide, sometimes rather distinctly limited. First abdominal segment bell-shaped, rather elongate, widely rounded anteriorly, sessile or subsessile. Thorax rather elongate, vaulled, subcylindrical.

\section{(Group of O. conformis.)}

This group represents the tiue Stenodynerus with elongate, slender, cylindrical forms Among the Stenancistrocerus this has quite a corresponding facies in the group of $A$. fulvipes, so that one may find it difficult to distinguish some of the corresponding 
species of both series. Thus $O$. varyus seems nearly of a form with A. fulvipes, in which the suture of the first abd. segment should disappear.

\section{A. Metathorax slightly prolonged under the post-scutel beyond it, being truncate before; ${ }^{1}$ its concavity margined wilh sharp edges, nearly angulate on each side. \\ a. Abdomen slender, cylindrical; first segment as wide as the second. Body velvety.}

15. 15. Eny-Gracilis, elongatus et angustus, ommino velutinus; clypeo f piriformi, punctato, apice biangulato; capite et thorace grosse cribratis ; pronoto biangulato ; metanoto granuloso, pone post-scutellun foveolato-truncato; ejus foveola rotundata marginibus arcuatis, hebet atis punctatisque circumdata; canthis inferis utrinque dente duplice instructis ; abdomine valde elongato, angusto ; dense punctato et velutino; primo segmento magno, elongato, basi truncato, supra fere pariter longo quam lato, grosse cribrato et in longitudinem per canaliculum obsoletum partito.-Niger; ore, capite abdominisque segmentis 3-6, obscure ferrngineis; clypeo, thorace et abd. secundo sermento nigris; tegulis, post-scutello, metanoto, abdominis primo segmento et pedibus, aurantiis; antennis aurantiis; basi ferrugineis ; alis flavis, parte apicali nigra. Longit. $12 \mathrm{~mm}$.

\}. Minor; metanoti canthis paulo distinctioribus macula frontali et clypeo, flavis; hoc anguste polygonali, bidentato; antennis uncinatis, aurantiis.

Odyn. Enyo Lep. St. Farg. Hymen. II, 648, 33 (1841).-S.ıess. Et.

Vespid. I, 185, 81.-SAGRA's Hist. de Cuba, Ins. 770.-Cresson,

Philad. Eutom. Proceed. IV, 1865, 165.

Odyn. elegans Gú́r. Icolı. Regu. Anim. Ins. 446, pl. 72, fig. 5 (1842).

Hab. Cuba.

\section{B. Metathorax scarcely, or not distinctly produced under} the post-scutel, beyond it.

a. Abdomen elongate, cylindrical, with the 1 st segment as wide as the 2d, elongate; or ovoid-elongate with the 1 st segment a little narrower, rounded.

* The 1 st and $2 d$ abdominal segments ench adorned with two yelloro spots, or fascic beside their marginal fasciu.

(Olservation.-These spots are often wanting, particularly in 0. coltecus.)

1 This type finds in the Stenancistrocerns its correspending type in Stenanc. histrio. 
Nosts in the ground. 16. O. Vagras SAUss.-Elongatus, gracilis, punctatissimus; flavocutoffikra. Mich. (Peckanp. variegatus; abdominis segmentis 1-2, vel 1-4, flavo-limbatis; primo $99,1965)$. insuper fascia interrupta flava; secundo punctis 2 liberis tiavis, margine subcanaliculato, crassius punctato,

Odyn. vagus SAuss. Revue et Mag. de Zool. IX, 1857, 277, ㅇ.

Total length, 11-12 wm.; wing, $9 \mathrm{~mm}$.

9. The whole insect coarsely punctured. Head wider than high. Clypeus pyriform, subbidentate. Prothorax slightly angulate. Metathorax not very rugose superiorly, presenting on each side of post-scutel a little flat place; its posterior face excavated, but the fossette not margined by ridges; the margins quite rounded and rugose. First abdominal segment rounded anteriorly, cribrose with coarse punctures, which contiuue at some distance on the anterior face; $2 \mathrm{~d}$ segment very little wider than the first, quite cribrose with punctures, not quite so coarse as on the first segment, except on the margin, where they become just as coarse; the margin is also very slightly canaliculate. Beneath, the $2 \mathrm{~d}$ and $3 \mathrm{~d}$ segments are cribrose with large punctures, which are variable or effaced.

Black. Antennæ black, with a yellow line on the scape. An arcuate line on the summit of clypeus, a macula at base of mandibles, a frontal spot, a spot on the sinus of the eyes, and a postocular line, yellow. Two spots on prathorax (or a submarginal interrupted bi-arcuate band), a spot under the wing, tegulæ, and their appendix, a band on the post-scutel, and the edges of metathorax, bright yellow. The $3 d-4$ th abdominal segments narrowly margined with yellow, the $2 d$ more broadly; the 1 st segment adorned in addition with two oblique lateral lines (or an interlupted transverse fascia on its middle, near the base), and the $2 \mathrm{~d}$ with two lateral yellow or rufous spots. The margin of the first wider in the middle, narrower on the side.

Legs black; knees, tibiæ, and tarsi yellow or ferruginous. Wings subhyaline or smoky.

Var. a. Clypeus black, with two yellow dots on its summit and often two at its apex, or yellow, with a black triangle.

b. All the abdominal segments margined with yellow.

c. Only the first two segments margined with yellow.

d. The edge of $2 d$ segment a little reflexed. 
$e$. The yellow maculs of metathorax quite variable, forming two lines or four spots, or only marking the inferior: edges.

$f$. A yellow spot on the mesothorax before the scutel.

g. I'rethorax with a complete yellow margin or with fonr spots.

$h$. 'The spots on the $2 d$ segment very small (or wanting?).

$i$. Ornaments passing into ferruginous.

§. Unknown.

Ress. a. diff.-This species has quite the appearance of Anrisirocerus fulvipes and sæcularis, although withont suture on the lst segment. but these two species must not be taken as accidental varieties of the same. O. vagus has the thorax not so cylindrical, shorter, a little wider anteriorly, and in the middle, varrower behind; the 1st abdominal segment is more rounded, more depressed at base; the $2 d$ segment is also a little wider, which makes the abdomen not so cylindrical; the whole insect is not so coarsely punctured in vagus, especially on the clypeus; and the $2 d$ segment is more finely punctured than the 1st, while in fulvipes and sxcularis, the clypeus and $2 d$ segments are generally as coarsely punctured as the rest, although there exist some differences in the various specimens. It greatly resembles O. oculatus in its livery, but the 1st abdominal segment is larger, with more elongate yellow lines, not spots, etc. - It approximates still more to $O$. conformis (Comp. this species).

Hab. United States, New York (E. Norton), Illinois (B. D. Walsh), Tennessee (E. F. Falconnet).

11\%. (1) Conformis SAdss.-O. vago simillimus, at minor, glacilior, magis cylindricus, crassius punctatus; clypeo $q$ crassissime cribratopunctato, metanoto valde rugoso, primo abdominis segmento basi truncato, in cantho rugoso; 20 segmento crassius punctato, maryine rugosissimo, reflexo; niger, flavo-variegatus; clypeo flavo- 4 -punctato, rel fascia ant lineolis 2 flavis; abdominis segmentis 10,20 solis flavo-marginatis, 10 utrinque insuper fascia obliqua, 20 utrinque macula tlara. $\$$.

Odyn. conformis SAuss. Et. Vespid. III, 219, 112, $q$ var. (1854).

Total length, $10 \mathrm{~mm}$.; wing, $7 \mathrm{~mm}$.

․ $\Lambda$ species quite approximating to $O$. vagus, but smaller, more slender, more elongate, quite cylindrical, and the first abd. segment longer than wille. The punctures coarse; the ornaments nearly the same.-This species still more resembles the $O$. fulvipes; it has much of its elongate-cylindrical form and rugose

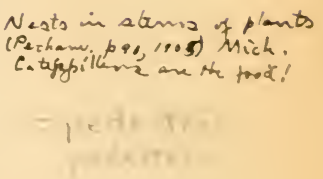


punctures, but the 1st abdominal segment has no suture and is smaller.

Head orbicular or eren higher than wide; the antennæ inserted almost below its middle. Clypeus shining, very coarsely cribrose. Head and thorax coarsely punctate; metathorax a little elongate, very rough; its concarity deep; the upper cheeks more convex and prominent than in vagus; the lateral ridges not so much pronounced. Abdomen elongate and cylindrical, rery coarsely punctured, especially the edge of the $2 d$ seganent, which is rather strongly reflexed; the first segment truncate at base, not so much rounded as in $O$. vagus, forming a transverse rugose edge; the rugosities sometimes resembling a restige of a suture.

The livery is just the same as in $O$. vagus, but tle segments $3-5$ of the abdomen hare no rellow margin; the clypeus generally has two yellow lines near the top and the disk of metathorax a basal yellow spot. In the southern provinces the wings become rather cloudy.

ऽ. Unknown.

Ress. a. diff.-This should be compared with O. pedestris, perennis, Kennicotianus, and anormis.

Hab. The United States, New York (E. Norton), Tennessce (Fuchs).

15. O. Toltecus Sadss. - Niger, gracilis, cylindricus, crasse punctatus, fuivo-pictus; abdominis segmentis 10,20 flaro-limbatis, utrinque flavobipunctatis; secundi margine maxime canaliculato, maxime reflexo.$\delta$ vertice tuberculato.

Odyn. Toltecus Sadss. Revue et Mag. de Zool. IX, 1857, 277.

Total length, $10 \mathrm{~mm}$.; wing, $7 \mathrm{~mm}$.

Form as in 0 . vagus. Body elongate, slender, and cylindrical. Head orbicular. Clypeus finely punctured, pyriform, terminated by a very small edge. Thorax elongate, convex; prothorax slightly angulate; post-scutel slightly carinated transrersely. Metathorax narrow, excavated; the cavity strongly punctured, margined inferiorly by two little converging carinæ; the edges rounded, not sharp superiorly. The upper lateral spine of the articulation elongate; the inferior one triangular on the margin of the articular carity. Head, thorax, and first segment of the abdomen, cribrose with coarse punctures; the following segments 
more fincly punctured. $\Lambda$ bdomen cylindrical, the first segment in for'm of an elongate bell, as wide as the sceond, rounded anteriorly, with a feeble depression above; the second constricter at base; its posterior edge very deeply and suddeuly caraliculate, with its margin very strongly reflexed, like an erect lamella; the very deep channel very coarsely punctured. The other segments finely punctured, not reflexed.

Black. A ferruginous spot at base of the antennæ; a frontal spot, a dot in the sinus of the eyes at a post-ocular spot, a.submarginal fascia on the anterior edge of the prothorax, a spot under the wing, margin of tegulæ, a spot on mesothorax before the scutel, post-scutel, and inferior edges of metathorax, dull -ferruginous or yellowish. The first. two abdominal segments margined with a regular yellow band, and adorned near the base, eacin with two lateral yellow or ferruginous spots; the spots of the first segment a little oblique. Feet black; knees and tarsi beneath ferruginous, or yellowish. Wings subhyaline, nerves fuscous.

Var. a. Prothorax with only two yellow spots; disk of mesothorax not spotted.

$b$. The free spots of the 1 st and $2 d$ segments of the abdomen wanting.

§. Snaller. Vertex having a large double tubercle; this is flattened and polished, parted by a groove. Clypeus polygonal, longer than wide, yellow, terminated by two acute teeth. Scape of antennæ beneath, inner orbits and frontal spot, yellow. Hook of the antennæ black. Mandibles with a yellow line. Sceond abdominal segment slightly swelled; the free spots of the first two segments often wanting in the small specimens, especially those of the $2 \mathrm{~d}$ segment. Tibiæ and tarsi yellowish-ferruginous. Metathorax generally black, except the valves of the articulation.

Var. In small specimens the tubercles of the vertex are (puite obsolete. - The males are sometimes very small. Length, i mm.; wing, $5 \mathrm{~mm}$.

Ress. a. diff.-This species has intermediate forms between $O$. vagus and $O$. conformis ; it is a little more clongate and slender than the first; a little less than the second. It is rery neatly characterized by the strong difference of form of its 2 al abol. senment, the edge of which is extraordinarily deeply and nalrowly canaliculated as in no other species, exeept Ancistrocerus trista ; 
the margin being quite a high crest. In $O$. conformis it is only slightly reflexed and a little canaliculated, but not making a sharp deep channel as in $O$. Bravo. The tubercle of the head of the males is also very characteristic. (Wre notice that such are found in other species with strong canaliculate $2 \mathrm{~d}$ segment as Ancistrocerus tuberculiceps.)

Hab. The temperate Mexico. I caught 13 specimens in the valleys of the Sierra Madre and near Mextitlan.

Nowts in stems ofplouto, Mich. (Pecham p90 1905) Nat higltey packed win calenpithers.
119. (1. amormais SAY.-Niger, valde punctatus, abdominis 20 segmento satis elongato, margine fortius punctato; primo cupuliformi; capitis punctis, pronoti margine antico, tegulis, macula subalari, postscutello, metanoti angulis, abdominis segmentorum limbo, nec non secundi maculis 2, tlavis.- $\hat{\delta}$. Clypeo, maudibulis, antennis subtus, Havis.

Eumenes anormis ${ }^{1}$ SAY, Long's 2d Exped. 1824, Append. 78 (II, 346, 3), $q$ (non $\delta$ ).-Way's Entomol. (Le Covre), I, 234, 3 q (non $\delta$ ).Sauss. Et. Vespid. I, 232 ; III, 340, 225.

Odyn. anormis SAY, Boston Journ. I, 1837, 387, 5.-Say's Entomol. (LE Сомте), II, 767, 5.

Rhynchium anorme Sauss. Et. Vespid. III, 184.

Odyn. oculatus SAY, Boston Journ. I, 1837, 385, $2 \hat{\delta}$.-Say's Entomol. Le Conte), II, 766, 2.-Sauss. Et. Vespid. I, 219, 113, §.-Cresson Amer. Ent. Trans. I, 1867, 387, 23.

Odyn. persecutor SAuss. Et. Vespid. III, 256, 133, pl. xiv, fig. 1, $q^{2}$ (1854).

Total length, $11 \mathrm{~mm}$; wing, $7 \frac{1}{2} \mathrm{~mm}$.

Pronotum wide, its angles sharp; post-scutel not elevated; metathorax having its lateral ridges sharp, but its carity not bordered by sharp edges, nor with well-defined limits. Abdomen ovalo-conical; its first segment cup-shaped, not so wide as the

1 There can be no doubt, whatever, about the identity of this species with 0 . oculatus $q$, it being very well described by Say. He called it anormis, because it has not the form of Eumenes, and he only classed it in this genus because of the similar structure of its mouth, being unaware that these two genera are not to be separately distinguished by the mouth. And further he says (Bost. Journ.), "It is like the Oculatus Say." Besides, he took his female specimen for a male, which made him find some difference from Oculatus, which was described from a male.

2 In some copies the antennæ have been painted all yollow, by mistake. The yellow color is only to be seen beneath when developec under the flagellum. 
$2 \mathrm{~d}$; it is longer than wide. The whole insect strongly punctured; the thorax roughly punctured; the edge of the $2 d$ seginent having a line of strong punctures beneath, as well as on the dorsal side.

Black; a spot on the forehead, inner border of the orbits, a dot behind each eye; an interrupted border on the anterior edge of prothorax, a spot under the wing, post-scutel, tegulæ, and posttegulæ, and the ridges of metathorax, yellow; the tegulæ with a brown spot; all the segments of the abdomen bordered with yellow, the first fascia fused with a lateral spot; the $2 d$ segment adorned on each side with a clear yellow spot; beneath black; feet black at base; knees, tibiæ, and tarsi yellow. Wings hyaline, nerves brown, with a brown cloud in the radial cell.

$\delta$. Clypeus very slightly emarginate, yellow; mandibles and antennæ beneath, yellow. Femora and coxæ anteriorly yellow.

Ress. a. diff.-Very closely allied to $O$. conformis, but not as cylindrical._Compare also the following species.

Hab. North America. Baltimore, Ohio, New York, Connecticut (E. Norton), Illinois (B. D. Walsh), Missouri (Say), New Mexico.

120. D. Toas Cresson.-Niger; elypei summi fascia, punctis capitis, scapi fascia, pronoti maculis 2 , tegulis, macnla subalari, post-scutello, maculis 2 metanoti, abdominis segmentorum limbo, nec non maculis 2 basalibus $2^{\mathrm{i}}$ et maculis 2 confluentibus primi, albidis; secundo segmento margine reflexo; pedibus rufis, genibus flavidis.

Odyn. Toas Cresson, Amer. Ent. Trans. I, 1867, 381, 24.

Total length, 4 lin.

․ Black, densely and deeply punctured; a lunate line at base of clypeus, spot at base of mandibles, another above insertion of antennx, another in the emargination of eyes, and a short line on posterior orbits, pale yellowish-white; clypens with longitudinal punctures, narrowed at tip, which is subemarginate; apical half of mandibles ferruginous; palpi pale; antennæ with the seape whitish on the outside; two transverse spots on prothorax, tegula, except a dusky medial dot, a large spot beneatle and a small spot behind tegula, post-scutelhm, and a transverse mark on each side of metathorax, pale yellowish-white; metathorax rugulose, truncate, and subexcavate behind. Apical marerin of all the abdominal segments, exeept the last, yellowish (that on the hasal segment conflnent, with a listeral subtriangular spot: that on the second sinuous anteriorly), and sub-basal, transverse 
spot on each side of second segment, pale yellowish-white; apical margin of latter segment reflexed; the second segment beneath, with a yellowish apieal margin and the third witl a lateral spot of the same color. Leg's ferruginous; coxæ and part of trochanters, black; tips of femora and base of tibiæ, yellowish. Wrings sublyyaline, dusky along the costa, stigma and costal nerve reddish-brown.

$\hat{\delta}$. Clypeus, upper surface of mandibles, a line between antenux, dilated and sub-bilobed abore, and the anterior orbits, alnost filling up the emargination, but not extending above it, yellowish-white; the clypeus smooth and emarginate at tip; the antennæ black abore, the scape yellowish-white beneath, the flagellum fulvous beneath; the apical joint gradually thickened, the eleventh joint emarginate beneath; the next suddenly smaller, and the apical joint hooked and subacute; the lateral spots on first and second segmeuts of abdomen smaller and more oblique; beneath, the third segment has an entire apical yellowish margin.

Ress. a. diff.-This seems to be very closely allied to 0 . anormis, from which it differs ly its pale, whitish ornaments, and the reflexed margin of $2 d$ segment.

Hab. New Mexico. (Museum of the Am. Ent. Soc. of Philadelphia.)

I do not know this species, and I cannot be perfectly sure of having assigned it the right position.

121. O. collega SACSS - O. anormi affinissimus, at minor; differt insuper metanoti foveola punctata, velutina; marginibus rotundatis; clypeo $\hat{\delta}$ latiore quam longiore, longe bidentato, dentibus spiniformibus, distantibus. Niger; clypeo $(\hat{\delta})$, puncto frontali t post-oculari, orbitis internis, scapo subtus, prouoti fascia minuta submarginali, post-scutello, abdominis segmentorum $1^{i}$, $2^{i}$ margine punctoque minuto ntrinque primi segmenti, flaris vel fulvis; mandibulis, tegulis pedibusque ferrugineis; alis infumatis, violascentiuns, $\hat{\delta}$.

Odyn. collega Sauss. Rev. de Zool. XXII, 1S70,61, 21, $ో$.

Total length, $12 \mathrm{~mm}$; wing, $8.5 \mathrm{~mm}$.

ㅇ.?

$\delta$. Quite approximating to $O$. oculatus. But the size is a little larger; $\hat{\delta}$ as large as 0 . anormis $q$; the punctuation is stronger, as strong or stronger than in anormis $q$, except on the metathorax, which is less rugose, velutinous. The excavation 
of metathorax small, rounded, with edges yuite rounded as in (). propinquus. 'The $2 \mathrm{~d}$ segment is shorter, with its marginal zone more coarsely punctured and the edge more reflexed.

The livery is the same, but the prothorax has a wared submarginal yellow or fulvous fascia; no spot under the wing; tegulse ierruginous. Segments 1-2 margined with yellow; 3 and 4 very obsoletely tipped with fulvous; the first segment adorned with two very small lateral fulvous spots; the $2 d$ without such spots. Feet ferruginous; at base black. Wings smoky, rather iridescent.

Clypeus $(\delta)$ transverse, wider than long, yellow, terminated by two long spines separated by a semicircular notch. Mandibles ferruginous, partly yellow.

Var.? Two small spots on the $2 d$ segment.

Ress. a. diff.-It has the same form of abdomen as in O. Xantianus, from which it differs by its $2 d$ segment, more swelled, bell-shaped, with a little reflexed edge. It is larger than $O$. pedestris, perennis, etc., and is especially distinguished by the form of its clypeus, short and long-spined.

Hab. New England. Connecticut (E. Norton).

Observation. - We are in possession of a $\delta$ specimen nearly identical with the described type, having the first two segments adorned with very small lateral spots (probably liable to be wanting), but the clypeus is triangular, more elongate, terminated by two long spines separated by a narrower deep notch. - Is it another species? (New York).

\footnotetext{
** Only the second abdominal segment adorned $u$ ith two yellow spots which are often wanting, principally in the muies.
}

Observation. - As in the preceding species, the spots of first segment are often wanting, and one nust compare also the species of Section*.

12. O. bacuens is Suuss. (Fig. 28, 28a.)-Niger, crasse-punctatus, flavo-multipictus; metanoto utrinque haud angulato, foveola crasse punctata, superne infra scutellum canthis angulatis acutis terminata; 20 abd. segmento tenuiter punctato : clypeo, antenuis basi, capitis maculis, pronoto antice, tegulis, macula subalari, post-scutell, metanoti lateribus, tegulis, pedibus, abdominis segmentorum $1^{\mathrm{i}}, 2^{\mathrm{i}}, 4^{\mathrm{i}}, 5^{\mathrm{i}}$ margine et ano, flavis; 20 segmento insuper utrinque macula flava; alis subferrugineis apice nebulosis.

Odyn. bacu. Sauss. Et. Vespid. I, 185, 80 (1552).-O. bucuensis Satss. Ibid. III, 232.-C'rksson, Hymen. of Cuba, Proo. Ent. Soc., Philad.: IV, 1865 , 64. 
Slender. Head and thorax coarsely cribrose. Prothorax slightly contracted and angulate. Post-scutel short, having no ridge, but its posterior part receding backward making for it a sort of hinder face. Metathorax a little produced backward beneath the post-scutel and sharply truncate vertically. Its hinder face excavated, coarsely cribrose; the concavity margined superiorly by an angulated edge under the post-scutel; no lateral angles.

First abdominal segment bell-shaped, anteriorly rounded-truncate, quite coarsely punctured, anteriorly roughened, reticulate; second segment very little wider than the first, shallowly and more fincly punctured.

Black. Mandibles rufous. Antennæ orange; the scape yellow anteriorly, extremity of flagellum black. Clypeus, a triangle on the forehead, inner orbits of the eyes, and a macula behind them, yellow.

Antennæ yellow at base (probably black at tip?). Anterior part of metathorax yellow. First segment of the abdomen yellow above, with a tridentate black emargination. Second segment broadly margined with yellow and adorned with two free yellow spots. Segments 4, 5 above with an incomplete yellow fascia. Anus yellow. Feet yellow, or partly ferruginous, coxæ black or spotted with ferruginous. Wings washed with ferruginous; the apex cloudy; the radial cell with a brown cloud.

. Clypeus pyriform, its apex slightly truncate, excarated.

§. Clypeus slightly bidentate, yellow; mandibles yellow.

Ress. a. diff. - This much ornamented species is characterized by the peculiar form of its metathorax; its livery recalls various species of the Antilles: such as 0 . spectabilis, which is distinct by its strongly angulated metathorax; Ancistrocerus Poeyi and obliquus, both distinguished by the abdominal suture; O. cubensis, distinct by its conical abdomen, not slender cylindrical-ovate as in $O$. bacuensis, and by its metathorax truncate on the same plane with the post-scutel, etc.

Hab. Cuba. 1 \& sent to me by Dr. Gundlach.

123. O. pedestris Sadss. (Fig. $22,22 a$.) - O. conformi simillimus, at primo abdominis segmento minore, utrinque immaculato. 
Odyn. fuscipes Sauss. Et. Vespid. I, 143, 28 (1852).

Odyn. pedestris Sauss. Ibid. III, 143, 28, $\widehat{\delta}$ (1854).

Odyn. proximus Sauss. Revue de Zool., IX, 1857, 274.

\section{q. T'otal length, $10 \mathrm{~mm}$.; wing, $8 \mathrm{~mm}$.}

ऊ. Total length, 9 mm.; wing, $7 \mathrm{~mm}$.

9. Form as in O. conformis, or a little less elongate, but rather more Iengthened than in $O$. vagus. Clypeus cribrose with large punctures. Ilead circular, strongly punctured, as is also the thorax; metathorax not so roughly punctured, velutinous; its concavity superiorly margined with rugosities. First abdominal segment strongly punctured, slightly elongate, becoming more rugose anteriorly. Second segment not as strongly punctured, elongate, constricted at base; its margin coarsely punctured, a little canaliculate.

Black, shining; scape bencath, a spot on the mandibles, a frontal dot, two spots or an arcuate line on the summit of the clypeus, a post-ocular spot and a spot in the sinus of the eyes, an interrupted band or two maculæ on the prothorax, a spot under the wing, another before the scutel, post-seutel, and inferior edges of metathorax, yellow. 'Tegulix ferruginous, spotted with yellow. Abdominal segments 1-4 regularly margined with yellow; the 2 d adorned with two separate yellow spots near the base. Knees, tibiæ, and tarsi, yellow.

Var. a. No yellow spots on the disk of mesothorax.

b. Only the segments 1-2 margined with yellow; metathorax immaculate.

c. Segments 3-4 partly margined with yellow.

d. Metathorax more rounded.

$e$. Two very small free spots on the 1 st segment.

§. Clypeus polygonal, a little bidentate, as broad as long, yellow; inner orbits yellow. Hook of antemne black. Disk of mesothorax and metathorax generally quite black. Margin of 2d segment often more reflexed.

Var. 'The tip of clypeus black; spots of the 2 d segment very small.

Ress. $a$. diff.-This may be a mere rariety of O. conformis? The same siye, same punctures, same livery, except the wo oblique yellow lines of the first segment, which are wanting

I This name had been previously employed by Herrich-Schatfer 
Still I find a difference. 1st, in the form of the head, not so circular, a little broader, giving it another appearance; $2 \mathrm{~d}$, in the 1st abd. segment, evidently smaller, not so broad at its base, but a little more funnel-shaped, a little depressed, a little longer, not quite as sessile. 'This becomes very evident when the abdomen is bent downwards. ${ }^{1}$ It is also not quite as wide as the $2 \mathrm{~d}$ segment; this being longer than in conformis and a little constricted at base, to fit into the lst segment.

These characters of the abdomen seem to me to indicate a species different from $O$. conformis, but which can only be distinguished by a very experienced eye.-I can only compare the females, the male of $O$. conformis being unknown to me. Compare $O$. Pennsylvanicus.

Hab. 'The United States. New York, 2, $3 \hat{\delta}$, taken by me. Connecícut, 9 \&, 6 ( (E. Norton).

121. D. Tamthiamus SAdss. $\$ .-N i g e r$, clypeo punctato, thorace lævi, impunctato; metanoto solo rugoso; post-scutello transverse obtuse cristato; metathoracis foveola superne subacute inarginata; abromine punctato; secundi segmenti linea marginali crasse pnnctata; tertio in medio perrugose punctato; reliquis tenuiter punctatis; scapo antice, puncto mandibularnm, frontali, oculari et post-oculari, fasciaqne arcuata in summo clypeo, maculis 2 obliquis pronoti, macula subalari, postscutello, fasciis 2 metanoti, abdominis vittis 2 , maculisque 2 parrulis lateralibus seginentorum $1^{\mathrm{i}}, 2^{\mathrm{i}}$, flavis; pedibus rufis, luteo-maculatis, basi nigris; tegulis rufis, flavo-maculatis.

Odyn. Xantianus Sarss. Revue de Zool. XXII, 1870, 103, 22, ㅇ.

Total length, $11 \mathrm{~mm}$; wing, $7.5 \mathrm{~mm}$.

9. Size, form, livery nearly as in $O$. anormis, but differing from it by the following characters. Clypeus a little more coarsely punctured and more truncate. Thorax smooth, not sensibly punctured, except on the upper face of metathorax. Scutel parted by a groove. Post-scutel elevated into a sort of blunt crest, flattened behind (seen from behind the edge is arcuate or rather trapezoidal, nearly bi-mamillated). Metathorax having its superior face a little prolonged behind the post-scutel, including it on both sides; widely truncate; its hinder face or excava-

1 This position is a quite indispensable condition for the good study of Odynerus, and should be given to all the speciuens. 
tion smooth or a little punctured, superiorly margined by (almost) an elge, making an $\mathrm{NI}$ or $\mathrm{W}$ reversed.

Abdomen laving its first segment nore rounderl, narrower and a little longer; the second short and more strangulated at hase, to fit into the first, its hinder margin with a more simple line of punctures; the $2 d$ segment as coarsely cribrose in the middle as the edge of the $2 d$, but only in the middle.

The arcuate yellow fascia of clypeus wider; the maculæ of prothorax more approximate; tegulæ ferruginous, with two yellow spots; lateral spots of the 1st segment quite small or wanting; knees, tibir, and tarsi ferruginous, spotted with yellow. Segments 3, 4 very narrowly margined, the 5 th black. Wings cloudy.

Ress. a. diff.-This species is easy to distinguish by its not punctured thorax, and elevated post-scutcl.

Hab. Lower California. Cape St. Lucas ('T. Xantus).

125. O. Kennicotianus SAuss.-Niger, nitidus, punctatus, O. Pennsylvanico affinis, at brevior; dense punctatus, metanoto et ahd. primo segmento grosse punctatis; corpore albido-variegato; macula mandi. bularum, clypei, frontis et oculorum, linea in scapo, maculis 2 pronoti, 2 metanoti, 2 subalaribus, post-scutello, tegulis abdominisque segmentorum limbo, secundi puncto utrinque tibiisque, albidis $q$.

Odyn. Kennicotianus Sauss. Rev. de Zool. XXII, 1870, 104, 23.

Total length, $8 \mathrm{~mm}$.; wing, $6 \mathrm{~mm}$.

A species allied to $O$. peclestris. A little smaller; forms the same; the prothorax also fisely angulate, but the thorax shorter; the metathorax a little less retracted and more open, that is, its concavity is a little wider. A bdomen less lengthened, first segment shorter, cupuliform, the 20 as wide as long, a little more densely and finely punctured. The metathorax and the first segment shorter, cribrose with large punctures, almost as in the O. perennis. Seutel divided by a longitudinal groove.

9. Clypeus black. A spot at summit of mandibles, three dors or an areuate line on summit of elypeus, a spot on the front, another in the sinus of the eyes and one behind their summit, a line on the seape of the antemna, two spots on prothorax, one nnder the wing, post-scutel, tegule, and two spots on the summit. of metathorax, whitish; all the segunent of the ablomen mlormed with a white border, wide and regular; the ed ormanented with 
tro dots of this color on its sides. Tibiæ whitish, spotted with black behind. Wings transparent, nervures brown.

Var. No lateral spots on the $2 d$ segment.

Ress. a. diff.-Whis Odynerus differ's from O. pedestris and Pennsylvanicus, by the coarse punctuation of first segment, etc.; from the 0 . perenne, by its thorax, shorter, less strongly punctured than the first segnent, by its less elevated head, its less prolonged form, etc.; from the O. texensis; by its less angulate and less rugose metathorax; by its first segment more coarsely and more equally punctured throughout; by the $2 \mathrm{~d}$ less strongly punctured, especially along its posterior border, etc.-From all by its whitish, not yellow ornaments.

Hab. United States. One $q$ taken in Illinois by Mr. Robert Kennicott.

126. O. propinquens Sauss._Gracilior, ubique dense punctatus, fulvo-velutinus, aurantio vel rufo variegatus; pronoto antice et postice rufo-limbato; macula subalari, tegulis, post-scutello, metanoti cauthis, segmentorum limbo, macula utrinque in secundo segmento pedibusque rufis $q$.

Odyn. propinquus SAuss. Revue de Zoolog. XXII, 1870, 104, 24,

Total length, $11 \mathrm{~mm}$.; wing, $8 \mathrm{~mm}$.

P. Tery similar to O. oculatus. Clypeus not so produced, more truncate, very coarsely punctured, rery obsoletely bicarinate below and biangulate at tip. An impressed point on the vertex. Thorax a little narrower. Carity of the metathorax rounded, smaller, punctured; its margins quite rounded. Abdomen more cylindrical, the $2 d$ segment not much wider than the first, as in $O$. vagus. The whole insect densely and almost equally punctured; the second abdominal segment as strongly punctured as the 1st, and like the thorax, but its hinder margin and the $3 \mathrm{~d}$ more coarsely punctured; the base of the $2 \mathrm{~d}$ above subtuberculate.

Black, grayish-relutinous, with a rather fulrous, hairy clothing; head and metathorax with a grayish reflection. A spot on mandibles, a fascia on the top of the clypers, a frontal spot, a dot on the sinus of the eye, and a post-ocular spot, orange or pale; antenuæ black, joints 1-2 rufous, a little obscure above. Both edges of prothorax, the anterior with a wide bilobed interrupted fascia, the posterior with a narrow line, a spot under the 
wing, post-scutel, ridges of metathorax, tegulæ, the margin of all the abdominal segments, and two free spots on the $2 d$ segment, orange or brick-red; feet ferruginous; coxæ maculate with ferruginous. Wings a little smoky. The rufous margin of the second segment is wide and regular; that of the first fused on each side with a little spot; the fascia of the last segments sometimes pale or yellow.

Ress. a. diff.-This species is noticeable for its velutinous body and rufous ornaments; by its $2 d$ segment as strongly punctured as the 1st, and the thorax, with its margin not channelled, scarcely reflexed at all, which distinguishes it from $O$. collega. It differs from $O$. Xantianus, by its more cylindrical abdomen, its $2 \mathrm{~d}$ segment not short, and post-scutel not elevated.

Hab. Mexico. I caught this species in the "tierras templadas," South of Mexico.

*** No free yellow spots on the first two abdominal segments.

Observation.-Compare also the Sections * and **, for the varieties destitute of spots which the reader may be inclined to confound with the species of this group.-Comp. principally O. collega, O. Kennicottianus, toltecus.

12\%. O. Penmsylvanicus Sauss.-O. pedestri affinissimus, gracillimus ; niger, punctatus ; fascia scapi, pronoti et abdominis segmentorum $1^{\mathrm{i}}, 2^{\mathrm{i}}, 4^{\mathrm{i}}$ margine, post-scutello maculaque subalari, tibiis tarsisque flavis; tegulis rufis.- $q$. Clypeo bidentato flavo.

Odyn. Pennsylvanicus Sauss. Lt. Vespid., III, 257, 134 (1854).

q. Total length, $9 \mathrm{~mm}$; wing, $7 \mathrm{~mm}$.

ऊ. Total length, $8 \mathrm{~mm}$; wing, $6 \mathrm{~mm}$.

Quite approximating to $O$. pedestris. The size a little smaller; but the same form, only more slender. Head orbicular. The punctures about the same, but the clypeus more finely punetured. The concavity of metathorax not margined superiorly by wrinkled rugosities; its summit sooner oceupied by reticulate large punctures. The abdomen very slender, cylindrieal; the 1st segment having the same form as in (). proximus, lather small, elongate, a little depressed, having often merely a restige of a suture. The margin of the ad coarsely punctured, but only marrowly sulcate, or not at all ehaunclled, only slightly depresised.

9. Black. Clypens quite black. A spot on the mandibles, labrum, a line on the seape of the antennar, a spot in the sinus of 
the eye, a post-ocular dot, an interrupted fascia on the prothorax, a spot under the wing, post-scutel and margin of segments 1, 2, 4, tarsi, and tibiæ, yellow. Tegulæ ferruginous; wings subhyaline; nerves brown ferruginous; the radial cell smoky.

§. Antennæ ferruginous beneath; clypeus punctured, polygonal, shortly bidentate, yellow.

Var. $a$. The yellow margin of the 4 th segment incomplete.

b. Segments 5, 6 margined with yellow.

c. The $3 \mathrm{~d}$ obsoletely margined.

d. Only two yellow dots on prothorax.

$e$. Wing scales $\delta$ black.

f. Anterior tibiæ maculate with black.

g. Ornaments $\hat{\delta}$ luteous.

h. Clypeus $\delta$ black on its inferior part. Flagellum of the antennæ $\hat{\delta}$ quite black. (Louisiana.)

Ress. a. diff.-May be a variety of 0 . pedestris?

Hab. United States. New York, Illinois, Wisconsin, Louisiana.

Found mesting in steres of Rubus in Mich. (Perken p59. 1905) Nest of keremis II and cre wasp Clava.

12S. O. perennis SAUss. (Fig. 25.)-Sat minutus, niger, elongatus, gracilis, crassissime punctatus, secundo segmento angusto, elongato ; corpore flavo-variegato; capite paene altiore quam latiore; metanoto et abdominis prino segmento grosse foraminato-punctatis; abdominis segmentis 10, 20 late flavo-marginatis.

Odyn. perennis SAUss. Revue Zool., IX, 1857, p. 277.

Total length, $9 \mathrm{~mm}$.; wings, $7 \mathrm{~mm}$.

Form almost precisely as in $O$. pedestris, but the body more coarsely punctured.

․ Head a little higher than broad, not so densely, but more coarsely punctured. Punctures of clypeus larger. 'Those of thorax very coarse. Those of metathorax and the first abdominal segment still larger, very rough. Those of the top of metathorax somewhat reticular. First abd. segment not quite as wide as the 2 d, rather depressed above. Second segment yet strongly punctured, but much less than the 1st segment; its margin more coarsely, but not so strongly punctured as the 1st segment, not canaliculate; its base rather constricted, making it seem almost tuberculate.

Black. A spot on mandibles, the top of clypeus, scape beneath, a frontal spot, a spot in the sinus of the eyes and a post-ocular dot, a wide marginal band on prothorax and on the 
first two segments of the abdomen, post-scutel, a spot under the wing, knees, tibix, and tarsi, bright yellow (or rather orange). Wings a little smoky; tegula and their apjendix yellow.

Vur. Wing scale rufous. $-\Lambda$ pex of clypeus ferruginous.

$\hat{\delta}$. A little smaller. Head as wide as high. Clypeus polygonal, longer than wide, bidentate, yellow; mandibles almost yellow. Antennæ ferruginous beneatls; hook black. Intermediate coxæ yellow before; posterior coxæ margined with yellow on the inner border.

Ress. a. diff.-Differs from 0 . pedestris by its wide yellow bands and by the absence of free yellow spots on the $2 d$ segments; by its more rugose metathorax and 1st abd. segment.

Compare also O. texensis and Kennicottianus.

Hab. North America. Tennessee $q$, New York $\hat{\delta}$.

129. O. Texensis SAdss.-Sat minutus, gracilis, niger, grosse punctatus; metanoto subangulato, rugosissimo, puncto frontali et oculari, pronoti margine, post-scutello, macula subalari et præscutellari,tegulis, abdominis segmentorum $\mathbf{1}, 2,4,5$ limbo, tibiis tarsisque, flavis ; abdominis primo segmento basin versus rugoso; secundo sat brevi. $\widehat{\delta}$.

Odyn. Texensis Sauss. Rev. de Zool. XXII, 1870, 104, 25, 辂

Total length, $9 \mathrm{~mm}$. ; wing, $6.5 \mathrm{~mm}$.

\}. Quite approximate to O. Pennsylvanicus. Same size, but not quite so slender; the thorax a little shorter, but little attenuated posteriorly, more coarsely punctured. The form almost exactly as in $O$. perennis, but the lateral edges making nearly two blunt angles; the excavation rugose. Abdomen as in perennis, but more densely and not so coarsely punctured; the 2d segment shorter, not so constricted at base; its base flat above, not subtubereulate; its margin coarsely punctured, slightly margined, not canaliculate.

Black. $A$ froutal spot, a spot in the sinus of the eres, a postocular line, a bilobed fascia on the margin of prothorax, tegnlac. a spot under the wing, post-scutel, a spot on the disk of mesithorax, yellow. $\Lambda$ bdominal segments all margined with yellow except the 3d. Knees, tibia, and tarsi yellow. Wings a little smoky.

S. Antenne fuscous beneath; the seape with a yellow line. Clypens yellow; its tecth spiniform; mandibles, inner margin of the orbit, and of the posterior coxe, yellow or lnteons. 
Ress. a. diff.-This species resembles by its livery 0 . Pennsylvanicus, but it differs by its stronger punctures, its thorax and abdomen shorter; the former being more square behind. It is in the nearest relationship with O. perennis. It recalls also Ancistrocerus Sumichrasti.

Hal. 'Texas. $1 \hat{\delta}$.

130. O. fasciculatus SAdss.-Niger, gracilis, cylindricus, ubique dense punctatus ; prothorace biangulato ; metathorace transverse depresso-compresso, superme rugoso ; canthis lateralibus acutis, lamellaribus ; fovela rhomboidali; primo abdominis segmento secundo latitudine æquali; capitis maculis, scapo subtus, pronoti margine antico, tegulis, post-scutelli fascia, metathoracis canthis inferis, abd. segmentorum $10-40$ margine, tibiis, tarsisque, flavis.- $\delta$. Clypeo fascia arcuata et maculis 2 apicis, fiavis.

Odyn. fasciculatus SAuss. Revue de Zoolog. XXII, 1870, 104, 26,.

Total length, $10.5 \mathrm{~mm}$; ; wing, $8 \mathrm{rnm}$.

. Form slender and cylindrical. Head as high as wide; vertex with an angulate groove. 'Thorax elongate, convex, and cylindrical. Prothorax wide, its angles finely dentiform. Metathorax rather compressed transrersely, somewhat lamellate on the sides, oblique and posteriorly produced. Its concavity not vertical, but oblique, wider than long, having somewhat of a lozenge form, scarcely strigose; not margined, limited superiorly by the rugosities of the upper face; its inferior edges compressed, continued with the lateral edges. Abdomen cylindric-depressed, the 1st segment as wide as the second; anteriorly truncaterounded, the $2 d$ elongate. Head, thorax, and abdomen densely punctured; the metathorax more rugose than the rest; the 1st segment a little more strongly punctured than the mesothorax; the $2 d$ segment having its margin widely and very slightly canaliculate, and a little more coarsely punctured than the rest of the segment.

Black. A line on the mandibles and on the scape of the antennæ, a double frontal spot, a dot between the eyes and the antennæ, a post-ocular spot, a double spot occupying the anterior margin of prothorax, a little dot under the wing, tegulæ, a line on post-scutel, and inferior ridges of metathorax, golden-yellow ; abd. segments 1-4 adorned with a vellow marginal band; the first two bands rather wide and regular, but having the anterior side rather lacerated; the $3 \mathrm{l}$ not so wide; the 4 th narrower, 
incomplete. Feet black. Knees, tibiæ, and tarsi yellow. Wings subhyaline, nerves fusco-ferruginous.

9. Clypeus broadly pyriform, black, with a superior fascia or two spots near the apex, yellow; the apex truncate, subdentate.

Var. Clypeus yellow, with a black spot.

Ress. a. diff.-'This species is particulariy distinguished by the furm of its metathorax, which recalls $O$. conformis, the thorax being elongate, convex-cylindric, the prothorax not contracted anteriorly. The abdomen lias the first segment shorter, not as long as wide above, inore as in $O$. conformis. It has some similarity to $O$. perennis, but it is larger; the 1 st segment is as wide as the $2 \mathrm{~d}$, the body not so coarsely punctured, etc.

Hab. Cuba. .

131. D. figulutus Suuss.-Niger, nitidus, gracillimus, pronoto subangulato; abd. 10 segmento antice truneato, supra rugoso; capite, thorace et pedibus, luteo-signatis; pronoti et post-scutelli margine antico liriea lutea; abdominis segenentis $1^{\mathrm{i}}-2^{\mathrm{i}}$ margine luteo; alis liyalinis, in costa subinfuscatis. $q$.

Odyn. figulus Sauss. Et. Vespid., III, 247, 120 (1854). ${ }^{1}$

Total length, $10 \mathrm{~mm}$.; wing, $8 \mathrm{~mm}$.

An insect having a slender, cylindrical, lengthened form.

. The clypeus is rugulose, pyriform, and scems to terminate in two sharp little teeth; but these are only marked out by a fossette on the border. The thorax is wide before, its anterior margin is straight bordered, and the angles are distinct; before these angles the prothorax is slightly retracted. The scutel is notched on each side by a fossette. The metathorax has its lateral ridges horizontal; it forms on each side an angle blunted by the meeting of long inferior ridges; the posterior plate is triangular, ocempied entirely by the concavity, which is bordered on each side by the inferior ridges, while posteriorly they lose themselves in the rugosities of the summit. The abdomen is slender and shining; the first segment is truneated anteriorly, following a ridge quite distinetly; its superior filee is rery coarsely punctured before and behind, always rather less toward

1 It is probably in consequence of a transposition, that this species is found placed 1. e. in the division P'urodynerus 1 am not wholly sure of the place it should ocenpy, not having the type before me. 
the posterior border. 'The border of $2 \mathrm{~d}$ and following segments offers a very much weaker punctuation. Tine liead and thorax are densely, but quite finely punctured. The abdomen does not offer any swelling at the base of $2 \mathrm{~d}$ segment beneath.

Black; a dot on the mandibles, a fiontal and post-ocular dot, scape beneath, anterior margin of prothorax, a spot under the wing; two dots on tegulie, post-scutel, a line on each side of metathorax below, and the margin of segments 1, 2, luteous; libiæ with a yellow line; femora 1,2, spotted with yellow at the apex. Wings dusky, margined with gray.

Hab. Guadaloupe. Collection of the Marquis of Spinola.

2. Form less cylindrical, not much elongated, the thorax more crowded together, often short and wide anteriorly, contracted posteriorly. Metathorax more convex, rounded; its fossette generally small, but always distinct. Abdomen ovoid or irregular, the first segment narrower than the second, having no longer the shape of an elongate-bell, widened anteriorly, which receives the second segment, but is not truncate anteriorly, not having an anterior and a superior face, but the tuo faces lost in a continued curvature; this segment not as sessile; second segment more swelled than in the preceding, short and convex, contracted at base to fit into the first

Insects in general strongly punctured; often relutinous.

(Group of O. Huastecus, otomitus, etc.)

The type of this group is not easily defined, because each species unites only a part of the characters above indicated, the group being composed of an agglomeration of very divergent species Among the Stenancistrocerus this type is reproduced by a $A$. Sumichrasti, Guzmani, etc.

All the species are of small size; they seem to be rery numerous in the southern part of the northern continent.

It becomes more difficult to distinguish the numerous little wasps, because the species are quite approximate to each other, and the character of their punctures and forms varies between certain limits, so that one can only feel sure about them, by 
comparing numerous specimens. It seems nearly impossible to determine single specimens upon simple descriptions.

The details of form and livery upon which I have endeavored to build the subdivisions of the arrangement of the species, are of a very doubtful profit, because of the difficulty of defining them clearly, so that they must not be absolutely relied upon.

A. Form rather stouler, abdomen rather wide in the middle, but yet atlenualed before. The fossette of the posterior face of melathorax rounded, always distinct. (Fossette of metathorax sometimes margined superiorly.)

a. Thorax but slightly adorned with yellow; (sometimes quite black, with a yellow spot under the wing); post-scutel quite black or adorned with two yellow dots. ${ }^{1}$

132. 1. Nortonianus SAdss.-Niger; clypeo antice anguste producto, subbidentato; metanoto rugoso, foveola striata, marginibus punctatis, obtusis; abdomine ovato, primo segmento valde punctato, cupuliformi, basi subtruncato, sessili, secundo magis tenuiter punctato; puncto mandibulari, frontali, post-oculari, lineola in oculorum sinu, macula subalari, punctis 2 post-scutelli et abdominis, segmentorum 1 , $2^{\mathrm{i}}$ margine temuiter, flavis; 20 segmento utrinque flaro-pnnctato et partim llavo-marginato; genibus et tarsis ferrugineis; tibiis anticis flavis. $q$.

Var. $a$. Thorace omnino nigro, macula flava subalari.-b. Secundo abd. seginento haud flavo-marginato.

Odyn. Nortonianus Sauss. Rev. de Zool. XYII, 1£70, 105, 2S, ㅇ.

Total length, $9 \mathrm{~mm}$; wings, $7 \mathrm{~mm}$.

९. Rather small. Clypeus somewhat triangular, rather narrowly produced and subbidentate. Prothorax somewhat angulated. Post-scutel short, forming on its anterior (or superior) part a rounded transverse carina, with a little insensible medial tuberele; its hinder face slightly convex. Metathorax rugose, punctured, quite rounded, its concavity strigose, not marginate. Head and thorax not very coarsely cribrose. Abdomen cylindrieal, oroid; the first segment short, truncate, and rounded anteriorly, as cribrose as the thorax, the 2 d slightly constricted at base, more tinely punctured, beeoming more coarsely punctured on its hinder part.

1 Comp. also A. Peyroti, var. 
Black, shining. A little mark at base of mandibles, and of the scape, a frontal spot, a little line in the sinus of the eyes, a postocular dot, a spot under the wing, and a narrow marginal line on the first abd. segment, yellow; knees and tarsi ferruginous; anterior tibiæ yellow, especially anteriorly. Wings transparent.

Var. a. Black. A spot on the mandibles, scape beneath, frontal and post-ocular spot, a little line in the sinus of the eyes, and one on the summit of the clypeus, yellow; the two spots of prothorax quite narrow; a spot under the wing, only two quite small dots on the post-scutel, a narrow margin on the segments 1,2 of the abdomen, and two free spots on the $2 d$ segment, yellow. Feet black; knees yellow; tarsi ferruginous; anterior and intermediate tibiæ anteriorly yellow.

$b$. The margin of the $2 \mathrm{~d}$ segment with only a small lateral yellow mark.

Ress. a. diff.-This Odynerus is well characterized by its quite exceptional livery, the thorax being quite black, with a yellow spot under the wing. It slightly recalls the description of $O$. Tisiphone, but the post-scutel is not yellow, and the metathorax not ridged on its margin.

Hab. New England, Connecticut. Taken by E. Norton.

b. Anterior margin of prothorax adorned with yellow, but not the posterior margin; the yellow fascia often bilobed or interrupted. Fossette of metathorax large, rather triangular, occupying nearly the whole width of the metathorax.

* Sometimes there are tion little free spots on the $2 d$ abduminal segments. (These rery small spots are very often warting, and do not constitute serious charasters.)

133. O. Victoria SAUss. - Niger, tenuiter dense punctatus; metanoti foveola parum excavata, marginibus inferis subacutis; corpore sericensublanoso; puncto mandibularum, puncto frontali, oculari et postoculari, scapo subtus, pronoti margine antico, macula subalari, postscutello, metanoti canthis, abdominis segmentorum marginibus, tibiis et tarsis, flavis; tegulis rufis.- Variat. puncto mesonoti et puncto utrinque $2^{i}$ segmenti, flavis.

\%. Clypeo crassins strigato-punctato in summo, fascia areuata flava.-

$\widehat{\delta}$. Clypen flavo, hidentato; striga mandibulorum et orbitis internis, Havis; metanoto sæpius immar'ulato.

Odyn. Victoria SAcss. Revue de Zoolng., IX, 1857, 279, $q$.

Total length, $10 \mathrm{~mm}$; wing, $8 \mathrm{~mm}$. 
․ Form and size as in 0 . anormis, clypeus coarsely strigatepunctate. An impressed point behind the ocelli. Thorax shorter. Metathorax rather flattened behind; its concavity not distinctly strigate; the lateral and inferior edges sharp. 'The first segment of abdomen not so sessile, nor so short, more rounded, funnclshaped or cup-shaped; the second constricted at base, to fit into the first. The whole insect finely punctured, more finely and more densely than in $O$. anormis; the $2 d$ and $3 d$ segment more strongly so than the first; the margin of sccond more coarsely cribrose; its edge smooth, very slightly reflexed.

Black, silky, rather woolly. Ornaments of the body yellow, just the same as in 0 . anormis; but the lateral spots of the first two segments are quite small or wanting, and the marginai fascia of prothorax complete. Tegulæ rufous. Wings cloudy, principally in the radial cell.

Var. a. Extremity of clypeus with two yellow marks; 5th abd. segment not margined.

b. Ornaments and feet, except at base, ferruginous.

c. No yellow spots on the $2 d$ segment.

$\hat{\delta}$. Clypeus yellow, bidentate; a line on the mandibles and inner orbits yellow. No spots on the $2 d$ segment.

Var. Metathorax quite black.

Ress. a. diff.-A very difficult species. Most resembles $O$. Mayus; differs from it by its more triangular posterior face of metathorax, somewhat larger size, antennæ not fulvous beneath, etc.-(Nevertheless it may be a variety of $O$. mayus.)

From $O$. anormis it differs by its velutinous body and its less cylindric thorax, wider anteriorly.

Hab. Mexico. I caught 2 in the mountains of Angangueo (Michoacan); $\delta$ q near Cuernavaca; $q$ in the barranca of Mextitlan ; $4 \hat{\delta}, 4 \delta$ from Orizaba (Sumichrast).

$$
\begin{aligned}
& \text { * No lateral yellow spot on the abdomen.1 } \\
& + \text { Excavation of metathorax rather large. }
\end{aligned}
$$

134. (1. Inca Satss.-Parvulus; niger, ubique requaliter punctatus, metathorace rite foveolato, foveola punctata; capitis punctis, pronoti margine antico, macula subalari, tegulis, post-scutello abiominisque

1 Compare also $O$. Tictorice, which is very often destitute of lateral yel. low spots on the 2 d segment of the abdomen. 
segmentorum limbo, pallide-tlaris; perlibus nigris, genibus, tibiis antice tarsisque sulitus luteis.- $\delta$. Clypeo emarginato, Havo; antenuis subtus fulvis; scapi fascia tlava; alis infunatis.

Odyn. Inca Sauss. Rev. de Zool. XXII, 18i0, 105, 29, $\subsetneq \delta$.

Total length, $7 \mathrm{~mm}$; wing, $5.5 \mathrm{~mm}$

?. Small. Thorax convex, narrowed posteriorly, margined and angulate anteriorly. The whole insect densely and about equally punctured, the abdomen as well as the thorax. Vletathorax relutinous, truncate a little behind the post-scutel, having a rather wide carity, which is punctate, rather margined; the lateral ridges salient, forming nearly a blunt angle on each side. First abd. segment small, cup-shaped, slightly depressed above, its punctures not stronger than on the $2 d$; this is constricted at base, subtuberculate at base above, quite cribrose; the punctures a little stronger behind than anteriorly.

Black, grayish-silky. A frontal and post-ocular spot, anterior margin of prothorax, a spot under the wing, tegulæ, a fascia on the post-scutel, and the margin of all the abdominal segments pale-sulphur yellow; the fasciæ of the segments 1-2 the widest. Anus black. Feet black; tibiæ, knees, 1, 2, and tarsi, pale yellow; tibiæ black behind; tarsi obscure above. Wings smoky.

§. Clypeus polygonal-pyriform, notched and bidentate, pale rellow. Mandibles black. A little carina between the antenuæ. Sinus of the eres margined with yellow. Antennæ fulvous beneath; the scape yellow beneath; the hook fulvous.

Ress. a. diff.-This approaches the O. Kennicoltianus, by its form and its pale ornaments, although not as pale; but the scutel is not parted by a groore, the metathorax not so rough; the first segment is smaller, not so coarsely punctured, and the $2 \mathrm{~d}$ is as coarsely cribrose as the first.

Hab. Peru (E. Norton. Taken by H. Edwards).

计 Ercavation of metathorax smaller and rounded.

135. 0. Mystecus SArss.-Niger, flavo-pictus; elypeo, thorace et 10 abd. segmento crasse cribrato-punctatis; secundo segunento polito, sparse et magis tenuiter punctato, margine impresso et crasse punctato; capitis maculis, pronoti maculis 2, post-scutello abdominisque segmentorum $1^{i}-3^{i}$ margine, flavis; primi fascia latiore utrinque aucta, $2^{\text {a }}$ subrepanda, $3^{a}$ tenuissima, $\delta$ incompleta; pedibus nigris artubus subferru- 
gineis; clypeo $\delta$ fiavo, apice nigro, bispinoso ; alis subhyaliuis, tegulis nigris flavo-binaculatis.

Odyn. Myslecus Sauss. Revue de Zool., IX, 1857, 279.

Total length, $8 \mathrm{~mm}$.; wing, $6 \mathrm{~mm}$.

․ Clypeus pyriform, very coarsely punctured, nearly reticulately rugose, prolonged into a sort of beak, subemarginate at tip. Head, thorax, and first abdominal segment densely and strongly punctured. Edge of prothorax finely ruptured, its angles subdentiform. Metathorax vertical, convex, very rugose, rather velutinous; its concavity very small; the rough superior faces prolonging themselves on the posterior side, leaving lut little place for the concavity; the lateral edges sharp and hairy. Abdomen rather short; the first segment rounded, not short, bellshaped, strongly cribrose, rugose at base; $2 d$ segment somewhat in the form of a hawk's bell, rather short, polished, and more finely punctured; its base a little constricted, although the 1st segment is but little narrower than the $2 \mathrm{~d}$; its margin having an impressed zone of coarse punctures; this zone having anteriorly an undulate form; $3 d$ segment densely punctured.

Black, shining, not velutinous like O. Huastecus, Mayus, and other Mexican species, but garnished with a sericeous gray pile, rather argenteous on head and metathorax. Mandibles brown or rufous; there are often two yellow spots on the top of clypeus; a frontal spot, a spot in the sinus of the eyes, and a post-ocular line, yellow. Antennæ black; the scape below yellow. Two spots in the middle of prothorax, touching its posterior enge, a quite small spot under the wing (or none), post-scutel and ridges of metathorax, yellow; tegulæ brown, margined with ferruginous, maculate with yellow; the margin of the first the widest, fused on the side with a lateral spot, making it emarginate on each side; the yellow fascia of the second segment having two wille notehes, or rather undulate, complete beneath; the 3il margin quite narrow. Feet black; knees and tarsi beneath rather ferruginous. Wings subhyaliue, not ferruginous-brown.

$\delta$. Hook of the antenux ferruginous. Clypeus squarely polygonal, longer than wide, produced inforiorly triangularly, and terminated by two separating teeth or spines; its surface quite coarsely punctured, yellow, with its extremity black.

The spots of the head larger, the sinus of the eyes quite yellow. 
The anterior edge of prothorax with a nearly complete submarginal yellow band; no spot under the wing; the yellow band of the $3 \mathrm{~d}$ segment incomplete. The cavity of metathorax larger, more limited superiorly.

Var. $\hat{\delta}$. Clypeus with its lower half black; metathorax black. Ornaments of the head pale.

Var. $\$ \hat{\delta}$. Flagellum slightly ferruginous beneath. Tegulæ blackish; border of $3 d$ segment wanting, or incomplete or complete.

Ress. a. diff.-A small species, rather distinct by the very coarse punctures of the clypeus, the coloration of the male, the colors of abdomen and coarse punctures of the first segment, and its clothing more sericcous than velutinous. The coarse rugosities of metathorax must not cause it to be confused with $O$. otomitus; this is a velutinous insect not as small, with a different livery and more angulate metathorax.

Hab. Mexico. I caught $2 \$, 3 \hat{s}$ near Cuautla, in the hot part of the province of Mexico, and $1 \hat{\delta}$ in the Mechoacan.

136. Catepetrensis Sadss.-Minntus, niger, capite elerato; antennis inferius insertis; metathorace foreolato; mandibulis apice rufis; clypei apice, puncto frontali et post-oculari, maculis 2 pronoti, tegulis, puncto subalari post-scutelloque, flavis; abdomine ralde punctato, segmentis 10, 20 flaro-limbatis; pedibus fulvis, basi nigris. Alis sublhyalinis in costa fusco-ferruginescentibus.-Long. $9 \mathrm{~mm}$.- $q$. Antennis nigris. - $\hat{\delta}$. Clypeo panlum bidentato, flavo; mandibulis antice et scapo subtus flaris; flagello subtus ferrugineo.-Variat. signaturis luteis.

Odyn. Catepetlensis Sauss. Et. Vesp. III, 255, 132.

I did not find this species in Mexico, and hare not seen it again since I described it. The type in Spinola's collection has been destroyed. It seems to approach closely to O. mystecus.

Hab. Mexico.

13\%. O. mayus Sadss.-Niger, cinere-sericeus, flavo-multipictus; pronoto antice, post-scutelli fascia, abdominisque segmentorum marginibus, ochraceo-flavis; tibiis antice flavis; tegulis ferrugineis.- $q$. Clypeo truncato, superne macula fulva.- $\delta$. Clypeo bidentato, vel subbidentato, flavo; antennarum flagello subtus fulvo; pedibus partim flavis.

Odyn. Maya SAuss. Revue de Zool. IX, 1857, 279.

․ Total length, $9 \mathrm{~mm}$.; wing, $6.8 \mathrm{~mm}$.

$\hat{\delta}$. Total length, $8 \mathrm{~mm}$; wing, $6 \mathrm{~mm}$. 
․ Clypeus rather bicarinate, polished, cribrose, truncate at tip. On the vertex a small impression. Prothorax squarely cut, its angles not prominent. Metathorax rounded, punctured a little less than thorax; its cavity small, rounded, punctured. The lateral ridges argenteous. $\Lambda$ bdomen ovate; nearly as strongly punctured as the thorax; the first segment cup-shaped, a little margined; the second rather wide, its margin having a wide zone of more coarse punctures; not channelled, its extreme edge very finely margined; the $3 \mathrm{~d}$ and 4 th rather strongly punc. tured.

Black, silky, with the metathorax argenteous. A spot on mandibles, a transverse spot on the summit of the clypeus, frontal, ocular and post-ocular dot, and scape beneath, ycllow. Anterior margin of prothorax adorned with a moderately wide yellow fascia, sometimes narrowed on the sides, bilobate in the middle. A yellow fascia on post-scutel; wing scales ferruginous, margined with yellow. All the segments of the abdomen regularly margined with yellow (rather ochraceus); the first rather narrowly, the second very widely; anus yellow at the extremity. Feet black; wings subhyaline, nerves subferruginous, the apex somewliat smoky.

Var. Metathorax black, or with two lateral yellow lines.

$\hat{\delta}$. Clypeus pyriform, yellow, terminated by two little triangular tecth (sometimes blunted). A line on the mandibles and a vertical line between the antennæ, yellow. Flagellum of the antennæ fulvous beneath. Yellow margin of prothorax narrow. Metathorax a little more triangular. Second alsd. segment not so widely margined. Knees, tibiæ, and tarsi yellow, obscure on their posterior face.

Var. Wing scales ferruginous.

Var. $q \delta .-a$. Form narrow; anus black; margins of segments $3,5,6$ narrow; anterior margin of prothorax narrow.

b. Metathorax quite black.

c. Margin of the abdomimal segments wide; amms yellow ( $O$ Maya Sauss).

d. A spot under the wing or no spot.

e. The ablomen blacker, with argenteons refection; is yellow ornaments more goldeu.

Ress. a. diff.-It differs from O. mystecus by the livery of its abdomen; by its metathorax, not rougln; by the yellow band of 
1st segment not widened on the sides, but on the contrary narruwed; $2 \mathrm{~d}$ segment without an impressed marginal band; clypeus q not as coarsely punctured and bicarinate; size somewhat larger, ete.

From 0 . Fictoriæ it is distinguished by its shorter form, and metathorax not so triangular, and antenuæ of $\hat{\delta}$ fulvous beneath.

Hab. Mexico. I caught sereral $q \delta$ in the temperate terrace of Cuernavaca, near Yautepec; and in the valley of Mextitlan.

c. Pusterior margin of prothorax, and often also the anterior margin bordered with yellow. (Insects often velvety.)

135. O. Mrastecus Sadss.-Crassiusculus, fulvo-velutinus, densissime punctatús, metanoto argentato, minas distincte punctato quam mesmotan; clypeo apice et superme fulvo-maculato; pronoti margine autico et postico, macula subalari, post-scutelli fascia, metanoti canthis abdominisque sugmentorum limbo, fulvis; $2^{i}$ segmenti margine et tertio grosse punctatis; tibiis antice fulvis; alis subfuscescentibus, tegulis fulvo-narginatis.- $-\delta$. Clypeo orato, flavo-bidentato; secunli abd. segmenti margine paulum reflexo.-Variat. $q$. Clypeo et metathorace nigris.- $-\delta$. Anteunis subtas fulvis.

Odyn. Huastecus Sacss. Revue de Zool., IX, 1857, 278.

Odyn. sobrinus Sauss., Ibid., 278, 战.).

Total length, 11 mm.; wing, $8 \mathrm{~mm}$.

The size of $O$. anormis. A little impression behind the ocelli. Clypeus triangular, pyriform, coarsely punctured, truncate and biangulate at tip. Prothorax upturned, subbiangulate. Head and thorax densely punctured, relutinous; metathorax smoother; its hinder face triangular; having a small concarity, finely strigate and punctured, not margined; superiorly terminated by a double arch, but not ridged. The lateral edges (extending from the hinder wing to the articulation of the abdomen), compressed and sharp, covered with shining silvery hair.

Abdomen ovoid; the first segment rather elongate, cup-shaped or rather shortly convex funnel-shaped; the $2 \mathrm{~d}$ rather in form of a hawh's bell, constricted at base to fit into the first. The whole abdomen silky-relutinous with fulrous reflections, densely but a little less strongly punctured, than the thorax; the second segment not quite as strongly as the first; its margin coarsely punctured, with the edge very little reflexed; the $3 d$ not quite so coarsely, the 4 th finely, the 5 th and 6 th not at all punctured. 
Black, fulvo-velutinous. The extremity of clypeus and a spot at its summit; a frontal and ocular spot, a post-ocular line, a line under the scape, fulvous-yellow ; the auterior and posterior edge of prothorax narrowly bordered with the same color. A spot under the wing, edge of wing-scales, a line on post-scutel, and the edges of metathorax margined with fulvous; segments 1-5 of the abdomen regularly margined with fulvous-yellow; fasciæ of 1st and 21 segments broader; of the others narrow. Feet black; tibix yellow anteriorly; tarsi fuscous. Wings smoky.

Var. a. Last abdominal segments without yellow margin.

$b$. Ornaments of the body more yellow.

c. Clypeus truncate or subbidentate.

$\hat{\delta}$. Of the same size or smaller; not so much of fulvo-relutinous, head argenteous before. Clypeus ovate-polygonal, longer than wide, bidentate, argenteous-ycllow. The hook of antennæ black. Inner orbits fulvous. Metathorax generally quite black. The margin of $2 \mathrm{~d}$ abd. segment more reflexcl, more or less canaliculate; its base above somewhat subtubereulate. Var. No spot under the wing. Var. sobrinus Sss.-Somewhat more slender. The ornaments of the body bright yellow; no spot under the wing. Metathorax quite black. The abdominal segments all well margined with yellow, the fasciæ of medium width. - 9 . Clypeus black or with a yellow spot at its summit; antennæ black, the scape yellow beneath. Knees, tibiæ, and tarsi yellow; tibiæ blackish beneath.- $\delta$. The flagellum of the antennæ orange beneath; knees, tibiæ, and tarsi yellow.

Ress. a. diff.-In livery and size this is just like $O$. ofomitus, hut differs by both margins of prothorax being bordered with yellow and its metathorax not rugose, but only finely punctured. It has, like this species, the anus often margined with yollow and the antenna yellow beneath, but the wings are not ferruginous as in this species.

It resembles O. propinquus, but differs in having the prothorax shorter and the 2d segment too much swelled, with the marerin more reffexed.-Compare also $O$. Peyroti which is a quite allied species, but with black feet and narrow borders of first seguent, and a wide bordering on 2 d serment.

O. Totonams is a much more slender and nakel species.

Hab. The temperate and elevated parts of Mexico. I caught 
a $\tau$ in the ralley of Mexico; and sereral other specimens in the temperate regions of Cueruavaca, of the IIuasteca, and in the valley of Mextitlan.

Observalion.-I have joined 0 . sobrinus with O. Huastecus, because new specimens seem to establish the transition between the two presumed species. Nevertheless, O. solrinus has a somewhat different metathorax. It is extremely difficult to decide upon the species of these small Odyneri, all quite rariable.

139. O. Otomitus Sarss. (Fig.21.)--O. Huasteco similis paulo minor, argenteo-vel fulvo-velutinus; pronoto bidentato; metar. stomaxime ruyoso, valde foveolato; pronoti uargine postico et angnlis, fascia post-scutelli, tegalis, abdominis segmentorum limbo, ochraceis; macala subalari nulla ; metanoto immaculato; tibiis fulvo-maculatis ; alis ferrugineis, apice griseis. - $q$. Clypeo truncato, nigro, in summo marula fulva.S. Clypeo bidentato, albido vel niveo; antennis subtus pallide fulvis. Odyn. otomitus SAUss. Revue de Zool., IX, 1857, 278.

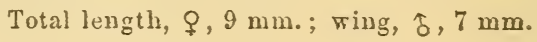

Tery similar to $O$. Huastecus; haring the same appearance, and the same kind of livery; differing principally in the following characters.

․ Size rather smaller. Clypeus less elongate, truncate at tip. The impression of the vertex more distinct. Angles of prothorax quite dentiform. Metathorax truncate; its hinder face occupied by a large and deep concavity, punctured and lugose, but not margined by sharp edges; the upper face of the metathorax and the edges of the excaration extremely rough, occupied by very large punctures, or rather by little reticulate dimples, which occupy the superior margin of the excavation. First abd. segment punctured, much like the head; the second densely punctured, and having on its posterior margin a little stronger zone of punctures, but this margin not canaliculate, nor reflexed; the $3 d$ still rather strongly punctured; those following densely but not strongly punctured. The whole insect rather velutinous, clothed with grarish or fulvous pile. Metathorax argenteous. A spot or a band on the summit of the clypens, a frontal spot, a line on the scape, a rery little spot in the sinus of the eres, and a spot or line behind their summit, dull yellow. Posterior margin of prothorax, its angles, and a line on post-scutel fulrous or dull yellow. Tegulæ ferruginous No spot under the wing nor on the metathorax. 
All the abdominal segments regularly margined with ochreyellow; the anal segment yellow or margined with yellow. The fascis rather wide; the first being the narrowest. Feet black; tibiæ a little spotted with yellow, often yellow anteriorly; tarsi slightly ferruginous. Wings ferruginous with the extremity smoky.

Var. a. The body grayish-velutinous or fulvo-velutinous.

b. Clypeus quite black.

c. Angles of prothorax scarcely dentiform.

d. A little yellow marginal line on both sides of the lower part of the excavation of the metathorax.

e. Anus black.

$\delta$. Clypeus rather pyriform-elongate, bidentate, white or luteous, as also the frontal spot and the inner orbit of the eyes. Antennæ beneath yellow or fulvous; the hook arcuate, black. The 7th abd. segment only, margined with yellow.

Var. a. Clypeus obtusely bidentate.

$b$. Anus not margined with yellow.

An examination of numerous specimens has shown notable differences in the form of metathorax: $1^{\circ}$. Sometimes it is quite widely excavated, the lateral parts forming very salient border's, or it is even rather angulate on each side. The strong rugosities form sometimes a sort of arched edge, margining the fossette superiorly; sometimes they have a tendency to delineate angular ridges margining the cavity, making this bipentagonal as in the true Ancistrocerus (A. capra, etc.).-2 ${ }^{\circ}$. In other specimens the metathorax is not so angulate, nor so excavated; its side margins are not so produced, but it is more rounded; the fossette is smaller and rounded, more closed and confined by the rugosities. This is more frequent in the males.

These various forms greatly embarrassed me until I could compare numerous specimens. It is important to notice that the principal character of this species is thevery rugose senlpture of the metathorax, its form being variable. It is still more rugose and excavated than in $O$. mystecus.

liess. $a$. diff.-A distinct speeies, well characterized by its metathorax, as just indicated; by its bidentate prothoriax, and the abundant yellow margination of the abelomen, and anns, often yellow.

In the malesthe antemar, yellow beneath, recall the O. Huas- 
tecus var., and Peyroti, which have the same livery, but not the rough metathorax, and differ also $\delta$ by the reflexed margin of its $2 \mathrm{~d}$ segment and the first having both the margins of prothorax yellow.

(Compare with 0 . mystecus, which has also a rough metathorax.)

Hab. The hot and temperate parts of Mexico. I caught 5 , $4 \delta$ near Tampico, and in the temperate part of the province of Mexico, near Yautepec. - Numerous specimens were caught by my companion, Mr. Sumichrast, in the Oriental Cordillera, Cordova, Orizaba, etc.

140. O. Similis Sмiтн.-Niger, fulvo-velutinus; puncto frontali et clypei apicis, abdominisque segmentorum $2^{\mathrm{i}}-6^{\mathrm{i}}$ margine, flavis; alis in costa ferrugineis. $९$.

Odyn. similis Sнте, Cat. Brit. Mus. Vespid. 80, 202, $\subsetneq$.

Total length, $4 \frac{1}{2}$ lines.

9. Black, covered with ochraceous pubescence, and having also a clothing of changeable golden pile. Clypeus truncate at the apex; the lateral angles acute, subdentate. A yellow spot between the antennæ and another at the apex of the clypeus. Thorax slightly narrowed anteriorly and posteriorly; the anterior margin of the prothorax not raised or starply truncate. Metathorax rounded at the sides and truncate posteriorly, and slightly concave. Abdomen: first segment much narrower than the second, strongly punctured; its apical border marginate; the apical border of the 2-5 segment with a broad yellow fascia, the apical segment yellow, with a black spot in the middle of its base; the fasciæ of the segments continued beneath. Wings hyaline; the anterior margin of the superior pair yellowish; nervures ferruginous.

Hab. Mexico.

This species by its golden relutinous clothing and ferruginous wings seems to approach very nearly to $O$. otomitus, and mayus, but differs by its quite black antennæ, thorax. first segment, and fect. This should separate it more from $O$. Psyroti var., although differing in sereral characters, this species having more argenteous pile, antennæ not quite black, etc. 
141. O. Peyroti Sadss.-Niger, argenteo-sericens, confertion punctatus; abdomine magis tenuiter punctato; pousoto bidentato, postice tenuiter fulvo limbato; scapi fascia, post-scutelli fascia abdominisque segmentorum 2i-6i marginibus late, ochraceis : primo segmento trigonalicupiliformi, tenuiter fulvo-limbato; pedibus nigris, anticis antice flavis vel fulvis. - $q$. Clypeus superne macula flava, punctis capitis flavis.$\hat{\delta}$. Cly peo bidentato, orbitarum inargine interno, luteis; antennis subtus fulvis.

Odyn. Peyroti Sadss. Revue de Zoologie, IX, 1857, 278.

$$
\text { } \delta \text {. Total length, } 9 \mathrm{~mm} \text {.; wing, } 6.5 \mathrm{~mm} \text {. }
$$

․ Clypeus bicarinate. Thorax short. Angles of prothorax dentiform. Metathorax rounded; its concarity small, rounded, strigate-punctate. Head and thorax densely punctured; the metathorax more velutinous, not so strongly punctate. $\mathrm{Al}$ )domen not sessile; the first segment not truncate anteriorly, but triangularly rounded, cup-shaped, nearly funnel-shaped, about as wide as long. The secoud rather short, its margin more strongiy punctured, the rest more finely punctured than the thorax; the first segment scarcely more strongly punctured than the $2 d$.

Black, grayish-silky, with a strong reflection on head and metathorax. A spot on the superior part of clypeus, a line under the scape, a frontal ocular and post-ocular spot, a very narrow line on the posterior margin of prothorax, and its angles, fulvous; a line on post-scutel, edges of metathorax, the narrow margin of the 1 st abd. segment, and a broad one on the 2 d-6th, ochre-yellow; anus black, or margined with yellow. Feet black, the anterior pair fulvous anteriorly. Wings hyaline, brown at the extremity, slightly ferruginous at base; nerves brown or ferruginous.

Var. a. Both edges of prothorax margined with yellow.

b. A yellow spot under the ving.

c. Anterior edge of prothorax black.

d. Metathorax immaculate.

e. Wings somewhat ferruginous.

$\widehat{~}$. Clypens longer than wide, bidentate, pale-yellow, argenteous. Antenne black, fulvous beneath; the seape and innel orbits with a yellow line. Metathorax quite black. The first segment. smaller, more triangular. The edge of the second segment a little reflexed.

Var. $a$. The first segment senreely margined with fulrous.

$b$. No frontal nor post-ocular spots. 
Ress. a. diff.-This is a very difficult species. The yellow margin of the $2 d$ segment is rather bi-emarginate as in 0 . mystecus. - The body is not fulro-velutinous as in Huastecus and Olomilus, but more black, with silky argenteous reflections; the metathorax is not rough as in Otomitus, nor so widely excarated. -It differs also from Huastecus, by its acute prothoracic angles and smaller size, its deeper and more rounded metathoracic carity, the yellow margins of abdomen, especially the $2 \mathrm{~d}$, wider; the 1st being much narrower, and its feet black. It can be easily distinguished by the wide margin of $2 d$ segment. Sometimes, especially in the males, the head, prothorax, and first segment are almost wholly black.

Hab. Mexico. This was caught in the temperate district of Cuernavaca, south of Mexico, by my companion, H. Peyrot, to whom it is dedicated; $\nmid \delta$ also hare been taken near Orizaba, 4 ㅇ, $2 \delta$ (Sumichrast).

d. Prothorax quite yellow abore. Scutel and post-scutel yellow.

142. O. columbaris SAoss.-Niger; metathoracis foveola submarginata; abdominis $2^{i}$ segmenti margine subreflexo; clypeo $q$ superne, puncto frontali, oculari et post-oculari, flavis; scapo subtus flavo; pronoto, macula subalari, scutello, post-scutello, metathoracis canthis, abdowinis segmentorum limbo, tibiisque antice, flavis; alis subhyalinis, costa subferruginea, apice griseo; tegulis ferrugineis. $\subsetneq$.

Oilyn. columbaris Sadss. Et. Vesp., I, 158, 42 : pl. xrii, fig. 3 (1852).

Hab. South America; Columbia, (type in the Paris Museum.)

3. Body elongate, slender; the abdomen especially, very slender. Metathorax convex, having no longer a distinct excavation, but sooner parted by a large groove, which separates its two cheeks, someuhat as in EunExes. Abdomen slender, spindle-shaped; the first segment elongate, funnel-shaped, sometimes subpedunculate.

\section{(Group of 0. Totonacus.)}

These insects are all small, shining, not velutinous; black, with luteous ornaments. They have quite the same appearance as those of Section III (see below), but the scutel is black, the prothorax has its hinder margin bordered with pale colors, and the post-scutel is not truncate. 
(Among the Stenancistroceri this type is represented by Stenanc. Irariasi.)

143. O. Totomac 㔭 Sauss. (Fig. 23.) - Sat minutus, gracilis, niger, nitidus, cinereo-subsericeus, cribrato-punctatus; metanoto convexo, tenuissime punctulato, foveola vel potius sulco striato diviso, canthis argenteo-pilosis; abdominis primo segrnento convexo-infundibuliforni ; capitis punctis, pronoti margine postico, post-scutello, metanoti fasciis 2 , macula subalari segmentorumque $1^{\mathrm{i}}, 2^{\mathrm{i}}$ margine, sulfureis vel allidis ${ }^{1}$; tibiis antice sulfureo-notatis; tegulis nigris.- $-\hat{\delta}$. Antennis subtus ferrugineis ; cly peo subemarginato, luteo, nigro-marginato.

Odyn. Totonacus Sauss. Revue de Zool., IX, 1857, 278.

Total length, $10 \mathrm{~mm}$; wing, $8 \mathrm{~mm}$.

q. Form slender, elongate, narrow. Head as high as wide; the notch of the eyes opened, triangular; clypeus rather strongly punctate, rather wirlely truncate, biangulate, or having a little concave apical margin. An impressed point on the vertex. Prothorax squarely cut, angulate, slightly bidentate. Head and thorax densely cribrose; the flanks more finely punctate; metathorax narrowed, triangular, slightly biconvex, smooth, rery finely punctured only, not cribrose, like the rest of thorax; its excavation being rather a wide groove than a fossette; delicately strigate-punctate; the lateral ridges very sharp, garnished with whitish hair. Abdomen slender, elongate; first segment convex, triangular, cribrose like the thorax; the second finely punctured, contracted at base or subtuberculate; its margin a little more coarsely punctured than the rest, but without a distinct zone, not canaliculate; the following less and less strongly punctured.

Black, shining, with sparse grayish down. Scape beneath fulvous; a spot on the mandibles, a frontal spot, ocular and postocular spot, pale yellow; posterior margin of prothorax and its angles, a spot under the wing, appendix of tegule, anterior margin of post-scutel, two clongate marks on the inferior extremity of metathorax, and a narrow margin on the 1, 2 abd. segments, pale sulphur-yellow; the yellow fascia of the second generally still narrower than that of the first; both a little prolonged on the lateral angles of the segments. Tegula black or margined with brown. Fect black; tibia anteriorly with a sulphur-yellow line; tarsi slightly brownish, or rather ferruginous. Wings smoky.

1 Vel potius stramineis. 
Var. a. Clypeus with a yellow spot at summit.

b. Head inmaculate.

c. Angles of prothorax black; its posterior margin neariy all black.

d. Metathorax black; only the articular valves yellow.

$e$. The fascia of post-scutel interrupted.

$f$. Segments 3-5 narrowly margined with brown.

g. Tibiæ anteriorly obscure.

$\hat{\delta}$. Not quite as slender; thorax shorter. Second segment more tuberculate at base. Clypeus pyriform, truncate, its apical edge concave, hardly bidentate; its surface white. margined with black. Antennæ orange beneath; the scape lutenus beneath. Mandibles immaculate; head often immaculate; metathorax but little maculate; coxæ 2-3 anteriorly lateous.

Var. a. The femora with a yellow line near the apex.

b. No spot under the wing.

c. Clypeus quite yellow.

d. Segments 3-6 narrowly margined with fulvous (only one specimen).

Var. $\uparrow \hat{\delta}$. Ornaments dull yellow (from alteration?).

Special Variety. - The margin of the second abdominal segment a little depressed or slightly canaliculate, more coarsely punctured, and even a little reflexed in $\delta$. In this variety the yellow margin of the $2 d$ segment is as broad as that of the first. The anterior edge of prothorax is margined with ycllow, and the posterior one incompletely margined. ( $\uparrow \uparrow$, Orizaba.)

Ress, a. diff.-A species distinct by its elongate slender form, its black shining body, cribrose with punctures like fine strings, and smooth metathorax; as also by its scarce ornaments, strawsellow and with only two abdominal fascix, the hinder margin of prothorax being bordered with yellow. It is very similar to O. Tacubayæ, but much larger, and more strongly punctured; the abdomen is not so elongate, the $2 \mathrm{~d}$ segment is scarcely longer than broad, posteriorly truncate, not arcuate, etc.

14. O. coyotus Sadss. (Fig. 26.)-Niger, minutus, abdomine gracili ; corpore subrugose punctato; metanoto tennissime punctato; abdominis segmentis 10,20 valde punctatis : secnndo basi constricto ; scaposubtus, puncto frontali, oculari et post-ocnlari, pronoti margine antico et postico tenuissime, punctis 2 post-scutelli abdominisque segmentorum $1^{i}, 2^{1}$ 
limbo anguste, sulfureis; tibiis antice tarsisque ferrugineis.- $\hat{\delta}$. Clypeo albido, apice subemarginato; antemnis subtus ferrugineis.

Odyn. coyotus Sauss, Kev. de Zool. XXII, 1870, 106, 30, $\mathfrak{\jmath}$.

Total length, 8 mm.; wing, $6 \mathrm{~mm}$.

Form the same as in $O$. totonacus, but the size quite small as in O. Tacubayæ. Head and thorax very densely and rather rugosely punctured, shagreened; post-scutel triangular, but having at its summit a very delicate little arcuate sharp line; looking backward, metathorax not so oblique even as in totonacus, more vertical, not rugose, very finely punctured, convex, with a little fossette on its inferior part; its edges hairy, grayish. The superior articular valves of the apex spiniform. Abdomen slender; the first segment arcuate, funnel-shaped, longer than wide, very slightly petiolate, and with a depression above. Second segment about as wide as long, strongly constricted at base, which makes it subbidentate above and beneath. 'The first two segments alnost equally punctured, as strongly as the thorax, but shining; the following less and less strongly so.

Black. 'The dots on the head nearly imperceptible or wanting; the hinder margin of prothorax and its angles quite finely bordered with pale yellow; only two little yellow dots on the extremities of post-scutel, and the first two segments with a narrow sulphur-yellow margin, which is not continued on the sides of the first segment. Feet black; tibiæ and tarsi somewliat varied with brown or ferruginous. Wings but very little smoky.

$\delta$. Clypeus white, its extremity with an arcuate subemarginate notch. Mandibles witl a white line. Flagellum fulvous beneath.

Ress. a. diff.-This insect has just the same size and appearance as $O$. acolhuus, but yet is very different, having the post-scutel triangular, not flat above, truneate behind, not crenulate. From O. Tacubayæ it differs by its strongly punctured abdomen, and its shorter $2 d$ segment, without an arcuate margin, shorter metathorax, etc.

Hab. Temperate Mexico. I caught two males in the ralley of Mextitlan; one from Orizaba (Sumichrast).

15. O. Tacabay ae Sauss. (Fig. 27.)-Minutus, niger, gracillimus, tenuiter punctatus, metanoto depresso, postice producto; abrominis 13 segmento infundibuliformi: secumito valde elongato, margine prostico arcuato ; scapo subtus, frontis macula, pronoti maginibus, fascia postscutelli et margine abdominis segmentorum 10-20, sulfureis; tibis et 
tarsis ferrugineis. $-\delta$. Clypeo piriformi, nigro et thavo variegato; flagello sulitus fulvo.

Odyn. Tucubayce SAdss. Revue de Zool., 1857, 279, $\lesssim$.

Total length, $8 \mathrm{~mm}$; ; wing, $6 \mathrm{~mm}$.

Quite small. Form quite slender and elongate, particularly the abdomen, which is lunger than head and thorax $(\delta)$, more elongate than in 0 . totonacus. Head and thorax finely cribrose; the former circular. Scutel parted by a groove. Metathorax smooth, quite finely punctured, triangular, obliquely produced posteriorly, convex, rather flattened, parted superiorly by a groove, inferiorly baving a very shallow flattened obsolete fossette; the lateral edges sharp, arcuate, clothed with argenteous pile. The articular ralres of the apex not produced into long spines. Abdomen cylindrical; 1st segment convex-funnelshaped, narrow, longer than wide, as strongly punctured as the thorax; having an obsolete transverse depression before its edge; $2 d$ segment much longer than wide, constricted at base, subtuberculate above at base; its posterior margin arcuale, convex, haring a line of stronger punctures; beneath near the base it has a sort of transverse wrinkle.

Black, shining, grayish-silky. Scape beneath, a spot on the forehead, a post-ocular spot, anterior and posterior edge of prothorax, a line on the post-scutel, and inferior ridges of metathorax sulphur-yellow. Margin of the tegulæ and a tubercle under the wing, ferruginons. Post-tegular appendix black. Articular valves of metathorax yellow. The first two abdominal segments narlowly margined with sulphur-yellow; the sellow margin of the first continued on the sides along the lateral edges of the segments (rather inferiorly); that of the $2 d$ complete bencath. Feet black; tibiæ and tarsi ferruginous. Wings rery slightly smoky.

§. Clypeus prriform, rather bidentate, black, with two lnngitudinal yellow bands, or vellow, with a central irregular black baud, and inferiorly margined with black. Scape of the antennæ fulvous beneath; hook fulvous. Intermediate coxæ spotted with jellow.

Var. Segments 3-6 margined with brown; the $3 \mathrm{~d}$ beneath with a little yellow.

Ress. a. diff.-Resembles $O$. coyotus and totonacus, but not 
as strongly punctured, and very distinct by its metathorax being more flattened and produced posteriorly, and by its long second abd. segment, with an arcuate edge. It is also much smaller than the last.

Hab. I caught only males in the valley of Mexico, near Tacubaya.

146. O. pruimosus Smitr.-Niger, sericeus; capite, thorace et abd. 10 segmento valde punctatis; fascia clypei summi, puncto frontali et post-oculari, pronoti margine antico, macula subalari, tegulis partim, post-scutello, metanoti canthis, abdominisque fasciis 2 , albidis; pedibus 10,20 albido variis; alis subhyalinis. $q$.

Odyn. pruinosus Sмıтн, Cat. Brit. Mus., Vesp., 79, 200, $q$.

Length, 6 lin.

․ Black; in certain lights, covered with fine silvery pile; the metathorax truncate, slightly concave, with a central impressed line, on each side of which it is obliquely striate; a stripe at the base of the clypeus, a minute spot between the antennæ, and another behind the cyes, white; the head, thorax, and base of the abdomen strongly punctured; the anterior margin of the prothorax, a spot beneath the wings, the anterior and posterior margins of the tegulæ, a spot behind them, the post-scutellum and lateral margins of metathorax, a spot on the apex of anterior femora behind, and the anterior and intermediate tibire outside, white; the 1st and $2 d$ segments of the abdomen with white fasciæ on their apical margins; that on the second continued beneath. Wings hyaline, with their margins clouded.

Hab. St. Domingo.

The peculiar forms of this species not being very fully indicated, I cannot be certain of its position. I place it near to O. totonacus, to which it is allied by its livery, which is an indication of the group.

Here probably comes the position of two species of which I have no longer the types under my eyes, and which are not described with sufficient detail.

14\%. O. Wuro Sauss, ${ }^{1}$-Parrulus, elongatus, gracilis, rugosus, niger: clypeo discoïdali, subbidentato; promoto elongato, grosse punctato;

1 Perhaps this might figure better in the subsection of $O$. pennsyleanicus. perennis, etc.? 
abdomine graciii, punctato; antemnis et clypeo onnino atris; puncto frontali, maculis 2 promoti, tegulis partim, post-scutello et abdominis segmentorum $1^{i}, 2^{i}$ margine sat late, tlavis; tertii fascia flava abbreviata; pedibus nigris, tibiis flavis, tarsis fuscis; alis subinfuscatis. ‥-Longit. $9.5 \mathrm{~mm}$.

Olyn. Huro Sacss. Et. Vespid., III, 297, 185, $\nmid$ (1854).

Hab. United States.

14. O. Mohicanus SAcss.-Minutus, gracilis, punctatus, niger; puncto frontali et post-nculari, maculis 2 pronoti, post-scutello abdominisque segmentorum $1^{i}, 2^{i}$ limba, flavis. Tibiis tlavis, tarsis fuscis. Alis hyalinis venis fuscis.-Longit. 8 mun.

ऽ. Clypen discö̈daii, flavo, subemarginato; puncto in labro et fascia in scapo flavis; antemis subtus ferrugineis.

Odyn. Mohicanus SAoss. Et. Vespid., III, 297, 1£5, $\delta$ (1854).

Hab. United States. State of New York.

III. Metathorax not produced superiorly beyond the post-scutel, concex; its hinder face parted by a deep groove. PostSCUTEL TRUXCATE; having a superior transverse face and a posterior vertical or oblique face; the tuo faces separated by a sharp edge.

Form quite elongate, exactly the same as in the last subdivision $(I I, 3),{ }^{1}$ very slender, elongate; the abdomen slender, spindle-shaped; its first segment funnel-shaped. Postscutel always black; scutel often marked with yellow.Insects small, black, shining, with pale ornaments.

These insects hare much the appearance of those of the group of 0 . Totonacus, but the prothorax is marginate anteriorly and the scutel is maculate, not the post-scutel.

\section{A. Metathorax quite unarmed superiorly.}

119. O. Acolhuus Sarss.-Parrulus, gracillimus, elongatus, niger, cribrato-punctatus; pronoto antice cristato-lidentato; post-scutello truncato, elerato-cristato; metanoto tenuiter punctato, inermi, biconvexo, per sulcum partito; abdominis primo segmento infundibuliformi, valde punctato, basi paulum petiolato, utrinque subdentato, su pra tumido, ance marginem transversim subcanaliculato; secundo paulo depresso, basi coarctato; reliquis vix punctatis; pronoto, scutello abdominisque segmentis 10,20 , vel $10,20,40$, flavo-marginatis; macula subalari 
tibiisque basi, flavis.- $\hat{\delta}$. Clypeo flavo-bidentato; antennarum scapo subtus flayo.

Odyn. Acolluus Sauss. Revue de Zool. IX, 1857, 280.

Total length, $7 \mathrm{~mm}$.; wing, $5 \mathrm{~mm}$.

Very small. Head circular or slightly wider than long, rather thick, emarginate behind. Sinus of the eyes not much opened on the inner side 'l'horax wide anteriorly; prothorax having its anterior margin a little concave, crested, its angles spiniform or at least sharply angulate. Scutel flat above, vertically truncate; the truncation making a hinder face, transverse, a little rounded on the lateral angles; the sharp edge separating the superior and posterior face quite crested; the crest erect, transverse, very finely crenulate (sometimes not well developerd). Metathorax rounded-triangular, a little prolonged backward, convex, parted by a groove or a channel. Its apex with produced bifid articulate valves, but not spined. Head and thorax densely punctate, the metathorax more finely punctate than the rest, silky; the lateral ridges garnished with argenteous hair. Abdomen elongate, fusiform (spindle-shaped), subpetiolate; the first segment longer than wide; its base shortly petiolate, the remainder funnel-shaped, swelled above, a little toothed on each side; sometimes transversely channelled before the edge. Second segment not much elongate, bell-shaped, a little depressed. First segment cribrose like the thorax; $2 \mathrm{~d}$ more finely punctured, except on its hinder margir ; $3 d$ and following segments not sensibly punctured.

Black. Head quite black; orbits silvery; a yellow spot at base of the scape. Anterior margin of prothorax, a spot under the wing, posterior margin of scutel, articular valvæ of metathorax, and the margin of the first two abdominal segments, yellow. Tegule ferruginous. Feet black; tibie maculate with yellow at base; their apical spine yellow. Wings smoky, principally on the anterior margin.

Var. a. Segments 3-5 margined with fuscous.

b. Fascia of sentel widle or narrow.

c. Segments 4 , or 4 and 5 incompletely marginate with rellow.

9. Clypeus orate-circular, black, punctate, rather biclentate.

o. Clypeus yellow, nearly heart-shiped, but reversed; the inferior part widest, with a little noteh in the middle, forming 23 
two small triangular teeth; scape of the antennæ beneath with a yellow line.

Ress. a. diff.-A distinct, small species, well characterized by its truncate, crested, black post-scutel, which distinguishes it from O. coyotus, tacubayæ, totonacus, and by its smooth metathorax, which separates it from chichimecus and tepanecus.-Comp. with O. zendalus.

Hab. The temperate parts of Mexico. Several specimens were caught by me in the valley of Mextitlan, others were sent to me from Orizaba by Mr. Sumichrast (5 $\delta, 13 \uparrow)$.

150. 0. Zendalus SAUSS. (Fig. 24, 24x.)-Niger, nitidus; capite et thorace crasse punctatis; abdomine minus crasse et parum profuncle punctato; scutello postice acute truncato, cristato ; primo abdominis segmento trigonali-cupiliformi, superne tumido, præ margine constricto; pronoti margine antico, scutelli fascia, abdominisque segmentorum $1^{\mathrm{i}}, 2^{\mathrm{i}}$ margine, sulfureis. Alis fusco-nebulosis.- $q$. Clypeo rugoso; antennis immaculatis.

Odyn. Zendalus Sauss. Revue de Zool., XXII, 1870, 140, 31.

Total length, $9 \mathrm{~mm}$.; wing, $6.5 \mathrm{~mm}$.

Form and appearance very much as in O. Totonacus. Head and thorax coarsely cribrose. Thorax wide anteriorly, narrowed posteriorly. Prothorax finely crested, angulate. Post-scutel strongly truncate and sharply crested; its superior face very short; the posterior elevated face finely punctured; the crest forming the separation of the two faces finely crenulate, its angles well marked. Metathorax finely punctured, clothed with argenteous pile. Its cavity smooth, rather square. Abdomen spindleshaped; the first segment cup-shaped, subtriangular, swelled above and constricted before its margin. The frst three segments with very shallow punctures, rather large; the following finely punctured.

Black, shining. Head quite black. Anterior margin of prothorax, a fascia on scutel (or two spots), and the margin of the first two abdominal segments, yellow. Tegulæ and feet black; tarsi rather ferruginous. Wings clouded with brown.

․ Clypeus rounded, rough, scarcely emarginate; antennæ quite black

Ress. a. diff.-Quite the appearance of $O$. totonacus, but very distinct from this by its crested and black post-scutel, anterior 
yellow margin of prothorax, and strong punctures. It has much the form of $O$. acolhuus, but differs by its size (twice as large), its stronger punctures, its higher head, its first abd. segment, not petiolate at base, its rather different livery, its immaculate antennæ, flanks and tibia, $q$.

Hab. The temperate part of Mexico. Oriental Cordillera (Sumichrast).

\section{B. Metalhorax armed superiorly with two tubercles, sometimes very small.}

151. 1. Nahums SAuss.-Niger, gracilis, elongatus, crassissime cribri instar punctatus; pronoto bidentato; post-scutello antice transverse cristato, postice cribrato; metathorace producto, rotundato, foveola punctata instructo, superne bituberculato; abdominis 10 segmento subpetiolato, 20 elongato; reliquis tenuissime punctatis; pronoti margine antico, tegularum limbo, fascia scutelli, abdominis segmentorum $1^{i}, 2^{i}$ margine maculaque tibiarum, sultureis. $-q$. Clypeo nigro, rotundato, subbidentato.

Odyn. Nahuus Sauss. Revue de Znolog., XXII, 1870, 140, 32, $q$.

Total length, $8.5 \mathrm{~mm}$.; wing, $5.5 \mathrm{~mm}$.

․ Small. Very slender and elongate, having much the form of 0 . Tacubayæ. Hearl a little higher than wide, not much swollen behind. Thorax elongate; anterior margin of prothorax crested, its angles spiniform. Scutel having on its anterior part a fine transverse crest, finely crenulate; its hinder part behind the crest transverse, cribrose, transversely square, rery obtusely angulate. Metathorax prolonged, rounded, having a distinct concavity, nearly reaching the post-scutel; this cavity cribrose like the rest of metathorax, its margins quite rounded, effaced, but having on the superior part two little rounded tubercles, punctured like the rest. Articular valves of the apex of the metathorax not spiniform, more flattened. Inead and thorax exceedingly coarsely cribrose; the metathorax not as coarsely so, but yet strongly. Abdomen elongate. The first segment cribrose like the thorax, funnel-shaped, a little petiolate; about. as wide as long, convex, and a little constricted before its marein. Second segment cylindrical, much elongated, though not strongly eribrose. The following segments quite finely punctured.

Black, a little silvery sericeous. Head and antemma quite 
black. A narrow margin on the anterior border of prothorax, margin of tegulæ, a transverse band on the middle of scutel, and a narrow line margining the first two abd. segments, sulphuryellow; that of the $2 \mathrm{~d}$ complete beneath. Tibiæ marked with yellow. Wings smoky.

․ Clypeus rounded, very coarsely punctured; its apex with two quite approximate, very small teeth.

Ress. a. diff.-This is an elongate species like O. Tacubayæ, very distinct by its quite coarse punctures, eren on the $2 \mathrm{~d}$ abd. segment; much coarser even than in chichimecus.

It differs: from Tacubayæ by its sharply angulate prothorax, crested scutel, bituberculate metathorax, and wider 1st segment, as also by the margin of $2 d$ segment which is truncate, not arcuate; from $O$. olmecus, by its thorax, not triangular, not so wide anteriorly, not so attenuated posteriorly, its wider cupshaped 1st segment, and by the tubercles of metathorax which are not sharp, but rounded and punctate: from tepanecus by most of the preceding characters. So also from O. chichimecus, except by its 1 st segment which is shaped as in this species; the post-scutel also is not vertically truncate; its edge being an anterior ridge, not a posterior one. This last character distinguishes it also from $O$. acolhuus.

$H a b$. The temperate part of Mexico. Oriental Cordillera (Sumichrast).

152. O. OImecus $S_{A U S S}$-Mlinutus, gracillimus, niger, punctatus; prothorace bidentato; post-scutello medio transiverse cristato; metathorace infere foreolato, superne tenuissime bituberculato, apice bispinoso; abdominis 10 segmento elongato, infundibuliformi; capite omnino nigro, pronoti margine antico, macula subalari, tegulorum limbo, scutelli abdominisque segmentorum $1^{\mathrm{i}}, 2^{\mathrm{i}}$ (vel $1^{\mathrm{i}}, 2^{\mathrm{i}}, 4^{\mathrm{i}}$ ) margine postico, flavis; spinis metathoracis apicis tibiisque extus, flavis.

ઈ. Macula mandibulornm, elypeo, scapo subtus, flavis; flagello subtus fulvo; clypeo latissime truncato.

Odyn. Olmecus Sadss. Rerue de Zool., XXII, 1870, 140, 33, 予

Total length, $7 \mathrm{~mm}$.; wing, $5.7 \mathrm{~mm}$.

Small and slender, elongate. Having much the form of $O$. acolhuus. Head circular, rather swollen and concave behind. Antennæ inserted rather low. Thorax not very elongate, triangular, wide exteriorly, attenuated posteriorly. Prothorax 
sharp, its angles dentiform. Post-scutel truncate, but its posterior face not so vertical, more oblique, its middle occupied by a transverse crenulated crest; the crenulations blunt. Netathorax triangular, prolonged, convex, with lateral sharp edges, clothed with white silvery pile; the middle occupied by a polished punctured cavity, not reaching the top, but continued to the postscutel by a groove. The superior margin of this cavity armed on each side with a very little, compressed, sharp tubercle (or a quite short ridge). The articular valvæ of the apex of the metathorax each bidentate, the superior tooth of which is prolonged into a long spine. Abdomen very elongate. The first segment longer than wide, funnel-shaped; with a sort of transverse depression before its margiu. Second segment a little depressed bellshaped, rather long.

Head, thorax, and 1st segment above, densely cribrose, not quite as strongly as in chichimecus; the metathorax and the $2 d$ segment quite finely punctured, except on the posterior part of the latter.

Black, sericeous. Head quite black. Anterior margin of prothorax, margins of the tegulæ, inferior spines of metathorax, posterior margin of scutel, and of the first two abdominal segments, yellow. Often the 4 th segment also, more or less marginate. The crenulation of post-scutel, and the two little tubercles of the summit of metathorax finely punctate with yellow.

Feet black; knees and tibiæ outside, in their total length $(\delta)$ yellow; tarsi ferruginous beneath. Wings hyaline, smoky along the anterior margin.

$\delta$. Clypeus having a quite exceptional form; square-rounded; as broad as high, or broader; its superior margin rounded; the inferior margin quite widely truncate, subconcave; its angles blunt, but the inferior extremity of the lateral margin rather swelled, somewhat tubercular. A spot on the mandibles, clypeus, a line under the scape, yellow; flagellum fulvous beneatl.

Ress. a. diff.-This differs from $O$. chichimecus, by its larger size, its head as wide as high; its prothorax mucl wider; its metathorax much more elongate and triangular, with a smaller cavity and quite small tubereles; its post-sentel slorter, witl its crest placed near the anterior margin; by its first abd. segment much more elougate, funmel-shaped; by the 2d, quite finely punctured.-From O. tepanecus it is sufliciently distinct by its 
metatlorax, destitute of large tubercles, its crested post-scutel, and not spined clypeus ( $\delta$ ).

From $O$. acolhuus, it differs by its post-scutel not truncate so as to have a vertical posterior face, its crest being more anteriorly placed, not on the posterior ridge; by its metathorax, bituberculate superiorly and bispined at the posterior end. The 1st segment is also more elongate, and the clypeus $\delta$ is not angularbidentate on its inferior margin Comp. also O. nahuus.

From $O$. coyotus and totonacus it differs sufficiently by its crested truncate post-scutel.

$H a b$. The temperate parts of Mexico. One $\delta$ from the valley of Orizaba (Sumichrast).

153. O. Chichimecus Sarss._Minimus, gracillimus, niger, cribri instar punctatus ; prothorace bidentato; post-scutello truncato, cristato; metanoto superwe bituberculato; capite et antennis $q$ omnino nigris; prothoracis margine antico, scutelli et abdominis segmentorum $1^{\mathrm{i}}, 2^{\mathrm{i}}$ margine postico, flaris; tibiis et tegulis flavo-ornatis.

Odyn. chichimecus Sauss. Revue de Zoolog., IX, 1857, 280, $q$.

Total length, $6 \mathrm{~mm}$; wing, $4.5 \mathrm{~mm}$.

․ The smallest species. Head a little higlıer than wide. Anteunæ inserted below its middle. Sinus of the eyes very open. Thorax sleuder, not contracted anteriorly; its anterior margin finely crested; its angles toothed. Post-scutel truncate; its ridge arcuate, crested, but not very strongly. Metathorax convex, prolonged, having a polished shallow cavity, not extended superiorly to the post-scutel; superiorly this cavity is margined on each side by a little compressed sharp tubercle. Extremity of metathorax with two little spines, next to the two teeth which make the articulation. Abdomen elongate; the first segment triangular funnel-shaped, swelled and a little constricted before its margin, which is rather thick. Second segment cylindrical; head, thorax, and first abdominal segment polished and cribrose with strong punctures; metathorax and second segment not quite as strongly cribrose, and with a line of stronger punctures along its margin. Metathorax finely punctured. Segments 3-6 quite finely punctured. Black. Anterior margin of prothorax, posterior margin of scutel, and of the first two abdominal segments of the abdomen, yellow; wing scales marginate with yellow; tibiæ yellow on the superior face, at least at base. Wings subhyaline. 
Var. The yellow band of scutel interrupted.

f. Head and antennse quite black. Clypeus cribrose like the head; having the shape of a square lozenge, its inferior unargin arcuate, imperceptibly bidentate.

Ress. a. diff.-This species has much resemblance to O. Tacubay $x$, because of its elongate $2 d$ abd. segment, but it is quite distinct from it, as also from $O$. coyolus and tolonarus, by it.s truncate, crested post-scutel, and its bidentate metalhorax. This last character only separates $O$. tepanecus, olmecus, and nahuus.

Hab. The temperate parts of Mexico. I caught one $f$ in the valley of Mextitlan.

154. O. tepanecus Sadss. - Parvulus, gracilis, niger, tenuiter punctatus; post-scutello truncato ; metathorace valde bituberculato; abdominis 10 segmento infundibuliformi, subpetiolato; apice puncto impresso notato, capitis punctis, pronoti, scutelli, abdominisque segmentorum $1^{i}$, $2^{\mathrm{i}}$ (vel $1^{\mathrm{i}}, 2^{\mathrm{i}}, 4^{\mathrm{i}}$ ), margine, flavis; tibiis basi flavo-variis.- $\delta$. Clypeo flavo, apice spinis 2 nigris, antennis nigris.

Odyn. Tepanecus SAuss. Revue de Zool., IX, 1857, 280,

९. Total length, $7.5 \mathrm{~mm}$; wing, $5.5 \mathrm{~mm}$.

Very small. General form very much as in $O$. acolhuus, slender. Head circular or a little higher than wide. Autennæ inserted rather low. Notch of the eyes very open. Prothorax not having its angles dentiform. Scutel truncate, transverse, not crested, but having a transverse edge. Metathorax triangular, a little prolonged; its lateral edges arcuate, sharp, hairy; its hinder face parted by a decp channel and armed on each side under the angles of post-scutel with a strong, sharp, dentiform tubercle, looking backward; these tubercles compressed, having a sharp, lateral salient ridge, extending to the angles of post-scutel (very evident, when viewed in profile). A pex of metathorax with two wide articulate, not spined valvæ. Ablomen slender, spindleshaped; first segment small and narrow, subpetiolate, funmelshaped, but swelled above, gibbous, as if truncate anteriorly; an impressed point before its posterior margin. Second scement rather oval, narrowed but not constricted at bise, rather depressed, but not all tuberculate. The whole inseet finely punctured.

Black, sericesus. A frontal, ocular, and post-ocular spot, yellow. Anterior margin of prothorax, posterior marem of scutel, articular valvo of the metathorax, and the first two segr- 
ments of the abdomen, yellow. The 4th segment (often?) with an incomplete yellow band. Wing scale brown, margined with yellow or ferruginous. Feet black; tibiæ at base outside and their apical spines, yellow. Wings smoky._- 9 . Clypeus yellow, widened below, terminated by two very strong, blunt, black epines. Mandibles and antennæ wholly black. A yeilow line between the insertion of the antennæ.

Ress. a. diff.-This small species is quite distinct by its strongly tuberculate metathorax. It could only be confounded with $O$. chichimecus, but it is not so small, nor as slencier; the thorax is not as cylindrical; the body not as strongly punctured; the scutel is not crested; the metathoracic tubercles are much stronger and the direction of the sharp external ridge of these is convergent downward, while in chichimecus the tubercles are on the contrary a sort of superior margin of an indicated cavity of the metathorax.

Compare also 0 . olmecus and nahuus.

$H a b$. The temperate parts of Mexico. I caught only one male in the valley of Mextitlan.

\section{Subgenus EPIPONUS ${ }^{1}$ SнбCK.}

Epipona Shuck.; SAcss.-Oplopus WEsm.; SAuss. Vespid., I, 217.Oplomerus Westwood. - Pterochilus ex. p. Herr.-Scherf.

Abdomen quite ovate, depressed; the first segment cup-shaped, sessile, or subpedunculate at lase, sensibly narrower than the $2 d$, but not constricted at base. Thorax short, rather globular. Metathorax rounded, destitut of angles and of sharp edges, without rugosities. Second recurrent nerve of the anterior wing falling upon the $2 d$ transverso-cubilal nerve or very close to it.-(Appearance of the genus Pterochilus.)

§ $\delta$. Antennæhaving at times the last joint recurved like a hook; these organs being more often elongate, thick, with their last joints compresser, flattened, curled up to a spiral.Clypeus generally wider than long; very strongly bidentate.

This type quite recalls the appearance of Pterochilus and it forms the intermediate step between these insects and the true Odynerus. The characters of the Division Epipona are principally to be found in the males, but the appearance of these insects 
is suffeient to distinguish them; it is even so striking that one would be tempted to raise it to a genus, did there not exist, principally in Europe and in $\Lambda$ frica, a series of intermediate types which allies them by very gradual and natural transitions to the true Odyneri. These transitions are even so complete that one is much perplexed to know how to limit the subgenus Epiponus.' But as the intermediate types are principally inhabitants of the old world, the difficulty with the A merican species is much diminished, although it appears in the case of some Antepiponus.

The Eipiponus seem to be peculiar to the boreal hemisplere and to Africa; the true Epiponus are the northern type, the Antepiponus the southern type, as well in America as in Europe.

\section{Division ANTEPIPONUS.}

(SAuss. Et. Vespid., III, 244.)

Mandibles of the males not nolched, nor armed with a spur. Antennæ of the males either armed with a hook, or curled up into a spiral al the extremity. First abdominal segment cup-shaped, sessile or rather subpedunculate at base. As said above, I at first placed this division in the subgenus ODynerus, but the appearance of its representatives being quite that of the EPIPONus, it will better find its place in this division.

1. Autennæ of the males terminated by a hook. (Sauss. Tesp., I, 213, sect. C.)

No representative yet found in America.

2. Antennæ terminated by a spiral curl. (Sauss. Tesp., I, 216, Sect. $\mathrm{II}^{\mathrm{e}}$.)

This section only differs from the true Emiponus by the mandibles of the males being simple, and the clypeus not so much

I In my Etudes sur la Fam. des Vespides, I have inclnded these transitory species in the division Anteppona (III, 29S), but this division is only an expedient to help in the determination of the species: it is mut a natural division-no more than any section one must form in a eontinuous series, conducting from one form to another ly gradual transitions. (Comp. Et. Vespid., Vol. I, 213, C, and 216 , II.-Ibid., Vol. I11, 2.9s.) 
notched. It quite approaches Pterochilus in its general forms and in the shape of the clypeus. It only differs from these by the labial palpi being small, 4-jointed and not pectinate.

It has the same geographical distribution as the Pterochilus, being the southern type of the genus. In America it has only been found in Mexico as yet; in the old world it is spread over the southern part of Europe and the temperate part of Africa, north and south.

155. E. denticulatus Sadss. (Fig. 30,30 a.)-Validus, niger, fulvohirtus; pronoto, post-scutello, abdominisque segmentis flaro-limbatis; secundo segmento, utrinque macula rufa; antemnarum basi et pedibus badiis. - $\delta$. Clypeo flaro, apice nigro; femoribus intermediis emarginatis ; tibiis posticis dilatatis.

Leptochilus denticulatus Sauss. Rev. de Zool., VII, 1855, 373.1

Total length, $14 \mathrm{~mm}$; wing, $11 \mathrm{~mm}$.

Appearance of a Pterochilus, but the labial palpi small, quadri articulate, not pectinate. Mandibles knife-shaped, with three little notches. Thorax orate, round; first abdominal segment cup-shaped, or widely spoon-shaped, not very sessile; its base subpedunculate. Second segment short. The whole insect densely punctured and hirsute with long fulvous hair.

Black. Anterior margin of prothorax and post-scutel sulphuryellow. Ting scales ferruginous or yellowish. The abdominal segments all adorned with a sulphur-yellow margin, rather wider on the $3 \mathrm{~d}, 4$ th segments than on the $2 \mathrm{~d}$; the margin twice notched with black on the segments $3-6$; the $2 d$ segment adorned besides with two large ferruginous lateral spots. Feet ferruginous or yellowish, black at base. Wings subhyaline, soiled with grayferruginous.

Var. Post-scutel black; tegulæ maculate with rellow.

§. Clypeus wide below; attenuated at its summit; its apex but little prolonged, truncate, biangulate. The surface yellow, clothed with silvery hair, except on its extremity which is black and strongly punctured. Antennæ rery long, black, with the first two joints ferruginous, yellow anteriorly; the last joints quite compressed, anuulate with yellow, principally below. Intermediate femora of rather different form, strongly canaliculate

1 Erratum.-Page 373, line 19th, instead of Tibias, read Facies. 
beneath, and strongly notched beyond the middle, on their anterior face; the notch almost forming three-quarters of a circle; its angles quite sharp, dentiform. I'osterior tibiæ strongly dilated, somewhat as in the Melliferæ, terminated very widely; the inner angle forming almost a process.

Ress. a. diff.-This insect has quite the appearance of Plerochilus aztecus, but it differs by its small and not feathery labial palpi.

Hab. Mexico. I caught but one specimen in the Cordillera of Coscomotepec.

\section{Division EPIPONOS (proprie dicta).}

Mandibles of the males having beyond the middle a large notch, followed by a tooth or spur. Antennx elongate, thick; their extremity curled up into a spiral. Clypeus of wider than long, very strongly bidentate. - The second recurrent nerve of the anterior wing falling upon the $2 d$ transversocubital nerve, or very near it.

The true Epiponusseem to be peculiar to the temperate and northern parts of the southern hemisphere; they are abundant in Europe, rare in America; in the lower latitudes they give place to the Antepiponus, which, with the same appearance, approach more nearly to the true Odynerus.

In regard to the distinction of the species one must notice that, contrary to the usmal case, in this group it is not the female, but the male, which offers the most distinctive character's.

Beside the subgeneric characters, peculiar to the total number of the males, there are others specially belonging to a part of the species; some have the coxæ or intermediate femora indented; others have the clypeus curiously shaped. But the fellales are far from being so well characterized, and the distribution of the colors must be strongly relied upon in distinguishing the species.

156. E. dilectus SAuss. (Fig. 29, 29a.)-Niger, punctatus, fuscohirsutus ; frontis macula, puncto post-oculari, tibiis, tarsis abdominisque segmentorum limbo, sulfureis; ultimis segmentis tantum fasvia abbreviata flava; alis subhyalinis, tegulis fusco et flavo maculatis.- 5 . Clypeo flavo, valde bidentato, ore et antemis subtus tlavis; femoribus intermediis tridentatis.

Odyn. dilectus Sauss. Rerue de Zool., XXII, 1S70, 141, 34, $\delta$.

$\delta$. Total length, 9 mm.; wing, 8 шщ. 
Head very densely punctured; thorax eloseıy shagreened. Post-scutel truncate, having an elevated posterior face; metathorax quite rounded, posteriorly more flattened than excavated, strigose. Abdomen quite ovate, polished; the first segment cupshaped, anteriorly somewhat rounded truncate.

Black; the body all bristling with long fulvous hair, especially on the head and thorax; that of the abdomen shorter and more gray. A frontal transverse mark, a post-ocular spot, and the margin of the middle of prothorax, sulphur-yellow. Wing scales testaceous, black at base. A regular yellow fascia on the segments $1-5$ of the abdomen; the fasciæ $3-5$ abbreviated. Feet black; knees, tibiæ, and tarsi, yellow ( $\delta$ ). Wings subhyaline. The $2 \mathrm{~d}$ recurrent nerve falling nearly into the $3 \mathrm{~d}$ cubital cell.

९. Unknown.

$\delta$. Mandibles yellow, having near the extremity a strong notch, followed by a stout tooth. Labrum yellow. Clypeus wider than long, yellow, terminating in two long teeth, separated by a wide notch in the form of an arch. Anternæ very large, thick, black abore, yellow beneath; the last six joints flattened and rolled up into a spiral, quite black. Intermediate femora strongly bidentate beneath; their first tooth slender and elongate, in form of a broken spine; the intermediate shorter and more widely compressed, the third forming a sort of lamella attenuated up to the extremity of the femur, these tecth separated by wide notches. Intermediate tibiæ apparently notched at base and tumefied from the middle. The 6th segment slightly margined with yellow.

Ress. a. diff.-This is the only American representative known of the subgenus Epiponus. Compared with the European species, it quite resembles 0 . spinipes, except that the $3 d$ tooth of the intermediate femora is not quite so much developed. It might be $O$. spinipes, transmigrated and modified.

\section{APPENDIX TO THE GENUS ODYNERUS.}

1. Species sedis incerlæ.

The following species I cannot introduce in the classification of the genus, their forms not having been sufficiently described. 
1. O. Mufindus Cresson.-Niger, valde punctatus, albido variegatas; metathorace rufo, utrinque dentem efficiente ; abdominis segmentis 1-3 luteo-limbatis; 10, 20 margine reflexo; pedibus rufis; alis nebulosis.

O. rufinodus Ceress. Amer. Ent. Trans., I, 1867, 381, 22, $q$.

Total length, 3.5 lines.

. Black, densely and deeply punctured; head large, face and base of clypeus with glittering pubescence, the latter subconvex; mandibles rufous, black at tips, the inner edge with three obtuse teeth; palpi honey-yellow; antennæ short, clavate, entirely blackish; a transverse line, interrupted medially on prothorax, a round spot on each side of pleura, tegulæ, except a brown medial spot, and two spots on scutellum, white; metathorax rufous, silvery on the sides, deeply excavated posteriorly, the extreme lateral apical angles produced into a subacute spine; wings subhyaline, the costa narrowly fuliginous; legs entirely rufous, the posterior tarsi slightly dusky; abdomen with the apical margins of the first and second segments reflexed and narrowly whitish, as well as that of the third; basal segment campanulate, convex, without any transverse carina and suture at base, rufous; second segment suddenly swollen, convex, its posterior whitish, margin sinuous anteriorly, and continued, narrowly, beneath; fourth and following segments entirely black.

Hab. New Mexico. 1 ㅇ.

This species is most likely very variable in its colors. It may prove to belong to Division Odynerus.

2. O. producturs.-Niger; capite thoraceque flavo-guttatis et valde punctatis; abdomine fasciis duabus flavis oruato.

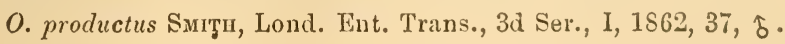

Total length, 3.5 lines.

$\delta$. Black, the head and thorax strongly punctured; the clypeus and a small spot above it, a minute spot in the sinus of the eyes and another behind them, the seape in front and a spot on the mandibles, pale yellow; the flagellum fulvous beneatl. 'The posterior margins of the prothorax, a spot beneath the tubercles, the tegula, post-scutellum, the metathorax behind, and a spot on the anterior and intermediate tibix, yellow; the anterior tibie and tarsi ferruginous; the wings hyaline, with a dark fuseous stain in the marginal cell; a ferruginous spot on the tegule. Abdomen tinely 
punctured, the first and second segments with a broad yellow margin, which is continued beneath; the second segment produced in the middle, forming a sharp angle or tooth; the following segments very narrowly bordered with yellow; the first segment entirely pale beneath.

Hab. Panama

This species is very likely to be classed in Division Stenodynerus.

\section{Species dubia.}

The following species I first thought by its facies to be a North American one, but as it never occurred to me in any American collection, I must deduce from this fact that it did not originate on this continent.

It would find its place in the Division Odynerus.

0. Tisiphone LEP.-Omnino niger, sat gracilis; clypeo vix emarginato, carinato-subdentato; metanoti marginibus superue paulum elevatis, acutis; post-scutello flavo; abdominis primo segmento anguste, secundo tenuissine sulfureo-limbatis; alis nigro-violaceis. ‥-Long. $15 \mathrm{~mm}$.

Odynerus Tisiphone Lep. St. FARG., Hymen. II, 646, 31, 9 (1841).Sauss. Vespides, I, 183, 77.

Hab. .... ? (America?)

Gen. LEPTOCHILUS SaUS.

Leptochilus' Sadss. Etud. Vespid., I, 233, III, 320.

Appearance of genus Odynerus (Stenodynerus), but the abdomen is subpedunculate; its first segment more or less funnelshaped.

Labial palpi very slender. Maxillary palpi slender.

This genus should evidently be united with the genus Odynerus, and will most likely find its place in the Stenodyneri, next to the group of $O$ huastecus. Unfortunately, not possessing the types, I cannot exactly decide how the species should be placed.

The abdomen is constricted between the 1st and $2 d$ segments, more than in the Stenodynerus; nevertheless, this is only a provisional genus which cannot well be preserved. 
1. Maxillary palpi quile slender. Hirst abdominal sergment subpedunculate, much narrower than the second.

1. L. fallax Sauss. - Sat minutus, niger, pronoto antice lato; subangulato, scutello subquadrato; metanoto postice valde excavato, margiuibus rotundatis, rugosis; abdominis primo segmento convexo, infundibuliformi, minus lato quam secundum; hoc basi subconstricto, margine reflexo, valde rugoso ; capite, thorace et abd. 10 segmento $v$ alde punctatis; puncto frontali et post-oculari, sulfureo; antennis subtus et basi, ferrugineis; pronoto, tegulis, macula subalari, post-scutello, pedibus et nomunquam metanoti lateribus, rufis; pronoto insuper antice flavo marginato; abdominis primo segmento rufo, basi uigro, margine flavo; secundo flavo-marginato; basi rufo-bimaculato; 30 et $40(\delta)$ tenuissime flavo-marginatis; alis hyalinis.-Long. $11 \mathrm{~mm}$.

今. Clypeo rotundato, flavo, subbidentulato; scapo antice fascia flava; orbitis intus flavo-marginatis.

Leptuchilus fallax Sauss. Et. Vespid., I, 234, 2, pl. xx, fig. 6, § (1852).

\section{Hab. America?}

Observalion.-Unfortunately, I do not find this species again in the collection of De Romand, in which I described it. As the insects of this collection were very negligently labelled, it may not be an American species?

2. Maxillary palpi moderately slender, the first joint rather swelled. First abd. segment ralher wide posleriorly, although still not funnel-shaped.

2. L. ornatus SAuss.-Niger, valde punctatus; clypeo latiore. quam longiore; post-scutello truncato, cantho acnto instructo; metanoto excavato, marginibus rugosis, rotundatis; abdomine basi subpedunculato; primo segmento valde punctato, margine subreflexo; secunio brevi et latissimo, basi valde coarctata, margine subincrassato; ore et scapo fuscis; clypeo flavo, margine nigro; pronoti margine, tegulis, macula subalari, fasciaque interrupta in scutello, aurantiacis; primo abdominis segmento obscure rufo; segmentis 10-30 tentuiter aurantiomarginatis; pedibus flavis, basi nigris; alis subhyalinis.-Longit. $9 \mathrm{~mm}$. $\delta$. Clypeo et antennarum scapo fere omnino flavis.

Leptochilus ornatus SAUss. Et. Vespid. I, 236, 6, pl. $\mathbf{x x}$, fig. 4, $q$.

Mab. United States. Carolina (Paris Muscum). 


\section{Geu. PTEROCHILUS KLug.}

Pterochilus Klug.; Latr.; Say; Sauss.

Buccal parts elongate.

Labium very much elongate; palpi rery large, thick, and much elongate, composed of three joints, of which the first is swelled at the extremity; the $2 d$ and $3 d$ strongly compressed and bipectinate, with rery long pilosity; the $3 d$ joint very elongate.-M Iaxillary palpi normal, composed of six joints.Mandibles large, elongate, trenchant, in the form of a knife blade; the internal edge trenchant, lobed, or notched; the external edge ciliated with long hair.-Clypeus wide, often lozenge-shaped or trapezoidal, more or less transverse.-Thorax rounded anteriorly and posteriorly, globular or ovate._Abdomen ovate, depressed, the first segment cup-shaped, subsessile.Antennæ of the males terminated by a hook or by a curred spiral.

These insects have much the same appearance as the Epipona, but they are very distinct by the extraordinarily large labial palpi, which are feathery, with very long hair.

The American species belong to the group of Pt. phaleratus and biglumis, characterized by their.indented mandibles and rounded metathorax.

1. Pt. Lewvisii Cressor.-Validus, niger, fulvo-pubescens; clypeo, antennis basi, capitis maculis, pronoti macula subalari, maculis 2 scutelli et 2 metanoti pediburque ferrugineis; tegnlis et post-scutello flavescentibus; abdominis segmentis 10,20 rufis, basi nigris, omnibus flavo-limbatis; alis inquinatis.

Pterochilus Lewisii Cressox, Amer, Entom. Trans., I, 1867, 382, 25, $\subsetneq$.

Total length, 8.5 lin.

9. Robust; head and thorax clothed with a pale fulvous pubescence; abdomen silvery-sericeous in certain lights. Head black, densely punctured; posterior orbits broadly, anterior nithits narrowly, from the emargination down, the clypeus entirely, the mandibles, except the tips and base and lower margin 
beneath, bright ferruginous; elypeus subconvex, sparsely punctured, pubescent, the tip produced and truncate; mandibles large, long, acute at tip, with four obtuse teeth on the inner edge before the tip; the outer surface with two oblique carinse, the lower margin fringed with long yellow hair; maxills blackish, their palpi fulvous, the apical joints fringed with very long liair; antenuæ black, the two basal joints bright ferruginous. Thorax very densely punctured, black, the upper half of prothorax, spot beneath anterior wing, two large, almost confluent spots ou scutellum, and the sides of the metathorax, bright ferruginous; post-scutellum and tegulæ, except a central darker spot, yellowish-ferruginous; metathorax short and very abrupt. Abdomen robust, sessile, very densely punctured; first and second segments dull-ferruginous, with their apical margins bright yellow, and a larger black spot on their basal middle; that on the first segment longitudinal and even, that on the second transverse, angular on the sides and acutely pointed behind; the yellow posterior margin of the second segment is slightly and squarely emarginate on each side anteriorly; remaining segments bright lemon-yellow, the third and fourth more or less black at.base; the two apical segments are tinged with orange and the third to fiftl segments have a transverse orange spot on each side; beneath ferruginous, with a lateral yellow spot at tip, and a large semicircular black mark on the base of the second segment. Leg's ferruginous; coxæ and trochanters black; the four posterior tibiæ and base of tarsi covered with short spines. Wings subhyaline varied with fuliginous; the costa and base stained with yellowish, subviolaceous.

Hab. New Mexico (Museum of the Am. Entom. Society).

2. Pt. Mexicamus Sadss. (Fig. 31, 31a).-Validus, niger, fulvo-hirsutus; ore, clypeo, macula frontali, orbitis partim, antenuis basi, pronoto, lineis 2 mesonoti disci, tegulis, maculis pleurarum, scutellis, metanoto utrinque, pedibusque rufis; abdomine rufo, segmentis flarolimbatis, 10, 20 hasi nigris; alis infuseatis, violascentibus..

Pterochilus mexicamus Sauss. Rev. de Zool. XxII, 1870, 141, 36 .

Total length, $16 \mathrm{~mm}$; wing, $14 \mathrm{~mm}$.

f. Targe. Tabial palpi very large, ciliated with rery long biack hair. Clypens strongly punctured, truncate; its extremity rather exeavated in the middle, with oblique submarginal lateral 
carinæ below, terminating in its angles. Thorax not globular, rather elongate, ovate. Scutel convex, parted by a groove; post-scutel not parted. Metathorax rounded, divided by a channel. Abdomen a little more elongate than in Pt. aztecus, the first segment not so short, subangular posteriorly.

The whole insect densely punctured and clothed with fulvous woolly hair.

Black. Mandibles, clypeus, the first two joints of the antennæ, frontal spot, inner orbits and a large post-ocular band, rufous; the clypeus above and scape beneath, yellow. Prothorax above, two spots or a band on the flanks, tegulæ, two lines on the disk of mesothorax, scutel, post-scutel, and two large maculæ on the metathorax, rufous. Abdomen rufous, with a central band on the 1 st segment, and a triangular part at base of $2 d$ segment, black; all the segments more or less margined with yellow; anus yellow. Feet ferruginous, black at base; coxæ spotted with ferruginous; tibiæ of the two posterior pair corered with small spines. Wings pale fuscous, with violet iridescence.

Var. This species certainly varies greatly in the distribution of its three colors, the black and yellow being more or less extended.

Ress. a. diff.-It differs from $O$. aztecus by its coloration and particularly by its thorax, not globular, but orate, much longer than wide. It is very likely to be a Mexican variety of $P t$. Lewisii Cress. I cannot be sure of this without an examination of the type. It has the wings more violaceous, not ferruginous along the costa; the disk of mesothorax is adorned with two rufous lines and the abdomen may not be as sessile.

Hab. Mexico. One 9 I caught in the valley of Mexico, on the high plateau.

3. Pt. Aztecus Sadss.-Validus, niger, tenuissime punctatus; capite et thorace fulvo-lanosis; abdomine ovato; ore, antennarum basi et pedibus rufis; clypeo flavo, apice grosse punctato, bicarinato, infra medium nigro-bimaculato; puncto post-oculari, maculis 2 pronoti, post-scutello et abdominis segmentorum limbo, flavis; segmentis 10,20 utrinque macula rufa; alis subinfuscatis, costa basi ferruginea; tegulis rufis. $\nmid$. Pterochilus aztecus Sadss. Rev. de Zool. XXII, 1870, 141, 35 ㅇ.

Total length, $16 \mathrm{~mm}$; wing, $12 \mathrm{~mm}$.

१. Mandibles large, armed with three lobiform teeth, beside the apical point; their external sides strongly ciliated with 
$\sigma^{a}$ of Pterochilus 5-fasciatus Say from colo., Cresson, p. 719; 1875, Cresson. 


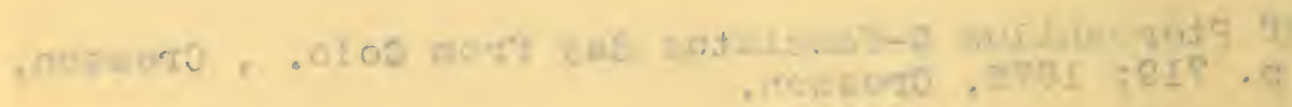


long hair. Labial palpi very large, strongly pectinate with long hair.

Clypeus convex, punctate, truncate and rather bituberculate at tip. The whole body densely punctured and clothed with woolly ferruginous hair. Thorax globular, scutel and post-scutel parted by a groove, anteriorly rather carinated; metathorax quitc rounded, finely strigate in the middle. Abdomen regularly ovate, subsessile; second segment beneath with a transverse carina at base.

Black. Mandibles and the first two joints of the antennæ, ferruginous. Clypeus yellow or ferruginous, with two black marks below, laterally. A post-ocular line, two spots on prothorax and a line on post-scutel, yellow or rufous; tegulæe rufous. Abdominal segments all margined with yellow; the margins twice notched; that of the $2 d$ segment narrower, rather sinuous. The $2 \mathrm{~d}$ segment having on each side also a large lufous separate spot, and the lst segment two similar lateral spots, but placed on the yellow margin. Anus marked with yellow. Feet ferruginous, black at hase. Wings smoky; the anterior margin as far as the stigma, ferruginous.

Var. Post-scutel with an interrupted yellow line, or black.

Ress. a. diff.-This differs from the Ifrican species by its not salient post-scutel, its metathorax not excarated, but snall, rounded, convex, only slightly channelled in the middle; even its lateral ridges quite blunt. It most resembles $P t$ biglumis Sauss., but the clypeus is more conrex and not noteled. It differs from Pt. mexicanus by its globular thorax, nearly as wide as long.

Hab. Mexico. I caught one $q$ near Orizaba.

4. PP. quinque-fasciatus SAY.-Niger, mandibulis emarginatis, clypeo, antennarum seapo, prothorace, tegulis; metanoto utringue peribusque, ferrugineis; macula subalari maculis 2 sentelli, post-scutello et ahdominis fasciis quinque, flavis; segmentis 10,20 utrinque macula ferruginea.

P\%. 5-firciatus S Ax, in Long's lixp. to the sourees of the St. Pet. Tir., II, Supp. $70(18:-4)$._SAcss. Et. Vespicl. I, 2ts, 13; III, 32:3.Say's Entomol. (Le Con're), I, 234.

Rhygchium 5-fusciatum say, Bost. Joum. I, 18:57,385._Sarss. Lit. Vespid., I, 118. - Say's Lintomol. (Le Costr), II, 7ü5, 2.

Total length, 2(1) $11 \mathrm{~m}$. 
"q. Head black, dilated; posterior and anterior orbits, to the emargination of the eyes, ferruginous; hypostoma, scapns of the antennæ, and mandibles, ferruginous; flagellum black-brown; labial palpi testaceous, very long, ciliate with long hair, threejointed, terminate joint much compressed, flat, obtuse at the tip; stethidium black; collar and wing scale ferruginous; scutel with two large yellow spots; metathorax, with a transverse yellow . line, and at the base on each side, a large ferruginous spot; wings a little fuliginous; pleura with a yellow spot beneath the superior wings; feet ferruginous; tergum black, with fire broad, bright yellow, somewhat dentated bands, the posterior one abbreviated; first and second segments each with a large ferruginous spot on each side ; venter black, ferruginous at its base."

$H a b$. Missouri.

I do not know this species. It seems to be very near to $P t$. aztecus, but with a richer coloration.

\section{Gen. CTENOCHILUS' Satss.}

Epipona Spin。-Pterochilus Sadss.-Clenochilus Sadss. Vespid. III, 323.

Labial palpi pectinate as in Pterochilus.

Mandibles rather short, nearly obliquely truncate, strongly indented.-Prothorax angulated.-Abdomen petiolate; the first segment quite contracted in its whole length into a petiole as in Eumenes.

This genus represents the petiolate Pterochilus, and it bears the same relationship to this genus as Eumenes to Odynerus. It presents, however, this difference; the prothorax is angulated and crested, which is not the case in Pterochilus. It has somewhat the facies of Zethus in the form of the petiole, the transverse clypeus, the rather short mandibles (and the labial palpi, probably formed of three joints only, which I cannot verify).

The Ctenochilus occupy an intermediate group between Zethus and Pterochilus.

Ct. pieipalpus Spr.-Gracilis, capite magno, postice excavato; clypeo transverso, apice tridentulato, fimbriato; pronoto cristato-marginato; scutellis prominulis; petiolo lineari, apice globoso-inflato; clypeo

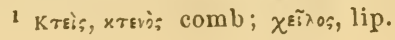


rufo, nigro-marginato et utrinque punctulo albido; antennis rufis, apice nigris ; pronoto, macula subalari, fascia scutelli, post-scutello, punctis 2 in summo metanoto tegulisque, luteis ; petiolo apice, luteo-roarginato; abd. secrmentis 20,30 luteo-limbatis, secundo insuper basi fascia lutea ; pedibus rufis; alis ferrugineis, apice griseis, f.-Longit. $13 \mathrm{~mm}$.

Epipona pilipalpa Spinola, in Gay's Hist. fis. de Chile, Zool., VI, 252 (1851).

Pterochilus pilipalpus Sadss. Et. Vespid. I, 247, 12, pl. xx, fig. 8.

Hab. Chili ( 1 o in the Paris Museur.).

This insect is a native of Chili, and has the same sort of lirery as most of the Hypodynerus, the Gayella and Alaslor from Chili; that is, black, hirsute, with rufous feet and white fasciæ and rather ferruginous wings, fuscous at tip. 'This livery of the Chilian Vespidx is one of the most characteristic to be met with in the geographical distribution of insects.

Gen. ALASTOR Lepel. St. Farg.

Alastor Lep.; SAuss.; Sмith.

The same characters as in Odynerus.-Abdomen sessile.-The second cubital cell of the anterior wing petiolate upon the radial cell.

The Alastors are only, so to speak, but Odyneri, in which the $2 d$ cellule of the wing becomes petiolate. 'This modification can produce itself in every section of the Odyneri; so one finds among the Alastor some types corresponding with the Odynerus, reproducing the same modifications of form.

The genus Alastor in effect offer's, like the genus Odynerus, types of the metathorax angulated or blunted, with ridges trenchant or without salient borders; types with a suture on the first abdominal segment or without suture, and forms the most varied, appear also in the shape of the first segment.

These insects present themselves as if forming a series parallel to the Odyneri, of which the diverse varieties of form secm to be almost born of similar types, taken from the series of Odynerus, types which are changed by the modifieation of the alary venation.

In this genus, as. in all others, one finds transitions to neighboring generia. The second enbital eellule sometimes becones 
very sliglitly pediculate (or even triangular), terminating toward the radial in a point or a subpediculate point, which constitutes an insensible passage to the Odynerus. So the Odynerus Alassoroides might figure indifferently in the one or the other of the two genera.

The Alastor is met with on all the continents, but it is rare or in all cases very much less numerous than the Odynerus. It is in Australia that it attains its maximum development, and in that region of our globe it appears almost to balance the Odynerus by the number of its species. In Europe but one species is known. America furnishes a sinall number of species, but doubtless more will yet be collected. It is probable that the United States possess their Alastor as well as Europe, although it has not yet been met with.

The species of the new continent form a peculiar type with a form lengthened and cylindrical, recalling the Stenodynerus and the Stenancistrocerus, but with the peculiar characteristic of having the metathorax notably prolonged beyond the post-scutel, and then abruptly truncate, and offering a circular concarity, bordered by a ridge, very trenchant and of a circular form.

\section{Subgenus ALASTOROIDES.}

(Sacss. Vespides, III, 327.)

First abdominal segment parted by a transverse suture.

The American species form the

\section{Dirision HYPALASTOROIDES.}

(Sadss. Vespides, III, 328.)

Metathorax superiorly produced behind the post-scutel; then truncate. Its margins sharp.

1. A. Mexicanus Sadss.-Gracilis, niger, crasse punctatns; pronoto lato, biangulato; metanoto ralile rugo:o, pone post-scutellum proilucto, postice valde foreolato; foreolæ marginibus superne semicirculariter arcuatis, acutisimis, denticulatis, marginibus inferis horizontaliter in lamellam hilobatam productis; abdomine hasi acute trumeato; pronoti et abd. segmentornm 1i, $2^{i}$ margine, scritelli margine interrupto, metanoti canthis inferis, fasciaque tibiarum, flaris; alis nebulosis: 
venis nigris. $-\hat{\delta}$. Clypeo grosse cribrato, superne flavo, apice late emarginato.-Vuriat: T'ertio segmento flavo-marginato.

Alastor mexicanus Sauss. Revue de Zoolog., XXII. 1870, 141, 37, ?.

ઈ. Total length, $9 \mathrm{~mm}$.; wing, $7.5 \mathrm{mrm}$. (var. length, $8 \mathrm{~mm}$. ; wing, $6 \mathrm{~mm}$.)

Body slender and cylindrical. Head rather thick. Thorax convex, widest anteriorly, rather attenuated behind. Prothorax having its anterior margin crested; its angles rather spiniform. Scutel and post-scutel quite flattened, not at all salient, continuing the surface of the thorax, which is further continued behind the post-scutel by the metathorax. Head and thorax densely and coarsely cribrose. Metathorax narrower, quite rugosely sculptured, vertically truncate; its hinder face quite excavated, polished and sparsely punctured; its margins quite sharp, forming superiorly a semicircle, not interrupted in the middle, trenchant and acutely denticulate; the denticles forming a sort of erect crest; inferior margins transverse, forming on each side a kind of rounded lamella, having a species of tooth at its base, or bilobed. Abdomen quite sessile, shallowly punctured, the first segment not as wide as the second, short, sparsely truncate anteriorly, its anterior and superior face separated by the suture, which makes a transverse ridge, almost a crest, the second segment having its margin smooth, but this is preceded by a line of strong impressed punctures. The following segments haring their margins smooth also, the base punctured, and the two zones separated by a transverse impressed punctate line.

Black. A dot behind the eye, a narrow line on the anterior margin of prothorax, an interrupted margin on the scutel, inferior edges of metathorax, a narrow marginal fascia on segments 1-2 of the abdomen, yellow. Feet black; tibia with a yellow line. Wings subhyaline, smoky; nerres black; 2d cubital cell much petiolate. Wing scales black.

Var. Smaller. Superior margin of metathorax not denticulate. Third abd. segment marginate with yellow; the the with two lateral yellow bordering marks. Wing scales preceded and followed by a yellow dot.-No yollow dot behind the eye.

§. Clypeus rounded, black, coarsoly punctured, its inferior border widely, but not deeply entarginate. The superiol part yellow. Antema black, the seape with a yellow line; the hook black. 
Hab. The hot parts of Mexico. $3 \delta$. I caught the type in Pueblo Tiejo, near 'Tampico; the variety is from Orizaba.

2. A. Brasiliensis $\mathrm{SAuss}_{\text {- }}$ A. Mexicano affinissimus; at clypeo et thorace inmaculatis; abdominis segmentis $30_{-} 50$ telluissime flavomarginatis, lituris $4^{i}$ et $5^{i}$ interruptis; tarsis ferrugineis.

Alastor Brasiliensis SAdss. Et. Vespid. III, 329, 211, pl. xvi, fig. 1, $\hat{0}$ (1554).

Hab. Brazil.

Subgenus ALASTOR proprie dict.

(Sacss. Vespides, III, 32S.)

First abdominal segment without transverse suture.

The American species form the

Division HYPALASTOR.

(SaUss. Vespid. III, 32S.)

Form slender and cylindrical. Mletathorax superiorly produced behind the post-scutel, then truncale; its margins sharp. (A group quite corresponding to Hypalastoroides.)

3. A. angulicollis Spix.-Niger; pronoti margine antico, macula subalari, tegulis, fascia scutelli, margiue postico abdominis segmentorum $1^{\mathrm{i}}, 2^{\mathrm{i}}$, luteis; autemnis pedibusque ferrugineis, his basi nigris ; alis ferrugineis, apice griseis.-Long. $11 \mathrm{~mm}$.

. Clypeo nigro, antemuarum scapo nigro, flagello superne conspurcato. - $\delta$. Clypeo luteo; scapo rufo superne puncto obscuro.

Odynerus angulicollis Spixou. in Gay's Hist. fis. de Chile, Zool., VI, 261, 7 (1851).

Alastor angulicollis Sadss. Et. Vespid. I, 25\&, 14, pl. $x \leq i$, fig. $7, \widehat{\jmath}$.

Hab. Chili.

4. A.melanosoma SAUss.-Omnino ater, gracilis, cylindricus; clypeo $\uparrow$ grosse punctato, apice late subexciso, subbidentato; capite et thorace grosse punctatis; thorace antice latiore, pronoto biangulato, in margine autico et in lateribus marginato, metanoto valde rugoso, coarctato, valde pone post-scutellum producto; postice valde foreolato ; margine circulari acutissimo superne fisso; margine infero bidentato (seu quadridentato); abdomine antice acute truncato.

Alastor melanosoma Sarss. Et. Vespid. I, 259, 15, pl. xxi, fig. \&, $\subsetneq(1852)$. Total length, $14 \mathrm{~mm}$.; wing, $10 \mathrm{~mm}$. 
Form slender and cylindrical. Forehead rather tumefied, parted by an obsolete groove; between the antennx a vertical carina. Thorax much arched above, anteriorly. Prothorax rather concavely cut anteriorly, its margin hemmed; the liem forming a right angle on each side, aloug the lateral margin; the angles lamellate, inferiorly excavated. Scutel flattened, included behind by the metathorax, which is narrower than the rest of thorax, cylindrical or rather truncate-conical, being slightly narrowed posteriorly, much produced behind the post-scutel and sharply truncate vertically, and parted by a groove superiorly. Its posterior face circular, strongly, spherically excavated, smooth and finely punctured, parted by a fine groove; its superior and lateral margins forming together a sharp edge in the form of a very regular circle, not complete inferiorly and notched superiorly by a fissure; this sharp circular edge slightly reflexed in a sort of crest, but not crenulate; the inferior margins oblique, making by their conjunction with the circular margin on each side a lateral tooth, often notched so as to form a second inferior angle. ${ }^{1}$

Abdomen elongate, cylindrical, quite sessile. First seginent a little narrower than the second, rather elongate, very sharply truncate anteriorly, fitting into the concavity of the metathorax.

Head and thorax coarsely punctured; the metathorax very coarsely; abdomen quite finely and shallowly punctured; the second segment quite obsoletely channelled near its posterior margin, but not rugose.

Quite black; feet rather silky with fulvous reflections. Wings black, violaceous.

․ Clypeus polished, very coarsely cribrose, widely emarginate at the extremity, rather bidentate; the teeth subcarinate.

Ress. a. diff.-Very closely allied to A.singularis.

Hab. Brazil (type in the author's collection).

Observation.-I first characterized this species as having its metathorax quadridentate, but the teeth in the lower part of metathorax are often obsolete, so that it is sometimes only bidentate.

5. A. singularis SAuss. - Niger, eapite et thorace crasse pumctatis; A. melanosome aftinissimus, at clypeo $q$ latiore quam longiore, apice truneato, haud emarginato; metanoti cantho aeuto, orbiculari, intra

1 Notched on one side and not on the other, in one specimen. 
utrinque dente spiniformi armato, supra vix fisso, subdenticulato; abdominis primo seguento tenuissime flavo-marginato; tarsis rufs; alis infuscatis, costa obscuriore.

Alastor singularis Sauss. Vespides, I, 259, 10, $q$ (1852).

Total length, $12 \mathrm{~mm}$; wing, $9 \mathrm{~mm}$.

Closely allied to $A$. melanosoma; having the same form, but yet differing by the following characters:-

Head much swelled behind the eyes. The forehead not so convex, nor parted by a groore; no high carina between the antennæ, but rather an obsolete transverse wrinkle over their base. Metathorax not quite so rough; its circular ridges making nearly three-quarters of a circle; a little crenulate superiorly; its inferior ridges straight, forming, at the meeting of the circular ridge on each side, a distinct spine.

Black; first abdominal segment narrowly margined with yellow or fulrous. Tarsi ferruginous. Wings washed with fuscous; dark along the anterior margin, transparent, smoky posteriorly; the reflection more golden than violet.

Var. Second abdominal segment with a narrow submarginal yellow line, anterior margin of pronotum with a very narrow yellow margin (Rio).

ㅇ. Clypeus rather transverse, nearly lozenge-shaped, more coarsely punctured, its apical margin truncate, not emarginate.

Hab. Brazil (1 $q$ in my collection).

\section{Gen. SMITTHIA SAUSS.}

(Revue Zool. Viī, 1855, 371.)

Abdomen petiolate; the first segment contracted in its whole length into a linear petiole.-Second cubital cell of the wing petiolate. (Forms slender; thorax elongate.)

This genus is formed from the petiolate Alastor. It bears ths same relation to Alastor as Eumenes to Odynerus, as Ctenochilu: to Pterochilus.

The only known species, Sm. natalensis Sauss, is from South A frica. The existence of this type in America has not yet been pointed out. I mention it here only to complete the classifica. tion of the solitary wasps. 


\section{A P P E IDIX.}

\section{SPECIES DUBIA.}

Tue following species I cannot discover, and it is very doubtful if they are solitary wasps.

1. Eumenes atrata FAbr. Syst. Piez., 287, 12.-America meridionalis.

If this species has the same form as E. arcuatus, to which Fabr. alludes, it may be the black variety of this from India, but Fabr. says ; "primo segmento infundibuliformi," which is in entire contradiction with "forte mera varietas" of E. arcuatus. -It may be a Montezumia; M. mortuorum? or some allied species. 'The color of the wings is not given.

2. Eumenes formicaria Fabr. Syst. Piez., 2\&8, 15.-Amer. merid.

This may be a Montezumia or a Polistes.

3. Vespa emarginata Gmed. Ed. Limn., 2759, 26.-Mueluer Ed. Limn. Ins., II, 886, 26.-Clypeus ernarginatus. Abdomen nigrum, petiolo utrinque dente instructo.-America-(Eumenes?).

4. V. cimeraceus Fabr. Syst. Piez, 260, 37.-America (?Alaslor melanosoma??)

5. V. atrata Fabr. Syst. Piez. 260, 36.-Americr insulis (a male), seems allied to Alastor melanosoma, but with hyaline wings.-1/mtezumia?

6. V. bimotata Fabr. Syst. Piez., 266, 71.-America meridionalis.

Has some similarity to Odynerus crypticus Say.

. V. daedala Licntenstein, C. M. П. 203, n. 173-Whibk. Observ. Eutom., 103, 8.-Nigra, odynero parietum panto major; thoracis margine liturisque basi coenntibns flavis; scutello flavo; ablomine ciugulis 5 tlavis; alis albis venis margineque antion fuscis. - Amerioa. 



\section{ALPHABETICAL INDEX.}

abdominalis, 106

Acolhuus, 352

adiabatus, 171

advena, 211

Alastor, 373

ALASTOR, 376

A LASTOROIDES, 374

alastoroides, 211

albocinctus, 224

albomarginatus, 154

albophaleratus, 167

albopictus, 43

Alvaradi, 268

Alvarado, 269

ambiguus, 162

americana, 4

americanus, 103

ammonia, 199

analis, 119

anceps, 124

anceps, 125

ANCISTROCERUs, 157

Ancistroceroides, 211

angulicollis, 376

angulosa, 134

annectens, 272

annulatum, 273

annulatus, 273

anomala, 132

anorme, 318

anornis, 318

Antepiponus, 361

Axtezuma, 113

Antucensis, 225

Antuco, 226

apicalipennis, 137

apicalis, 279

Araucanus, 310

arcuatus, 219

argentinus, 236

arietis, 19

Arista, 188

arvensis, 270

ater, 65 atra, 65

atrata, 379

attenuata, 106

atteruatus, 106

auratus, 62

auratus, 233

auropilosus, 102

auropilosa, 102

aurulens, 48

anrulentus, 48

aviculus, 73

Azteca, 125

Aztec'us, 36, 93, 192, 370

azureipennis, 117

azurescens, 117

bacu, 321

bacuensis, 321

balteatum, 257

Bairdi, 273

Bellone, 193

biangulata, 135

bicolor, 29

bidens, 267

biglumis, 39

birnodis, 54

binodis, 20

binotata, 379

birenimaculatus, 175

blandus, 289

Boscii, 255

brachygaster, 238

Brasilianus, 79

Brasiliensis, 127, 376

Brasiliensis, 16

Bravo, 205

brevithorax, 231

brevithora $x, 233$

brumea, 114

Bustamenti, 172

Bustillosi, 162

errulea, 117

caruleopennis, 16 
Californica, 129

Calitionicus, 243 Culligaster, 17

vallimorpha, 83 campunulula, 83 campestris, 183

Cauadensis, 156 cunuliculuta, 107 eanaliculatus, 107 capra, 163 carbonatius, 17 carinat us, 44 carinulatá, 128 carinulatus, 128 cusligatus, 255

Catepetlensis, 338 Cat.killensis, 168 Catslilli, 168 cervus, 160 chalicodomæ, 108 chalybea, 113 chalybeus, 17

Chicimechus, 358

Clicotencatl, 51 chileusis, 59, 224 Chiliotus, 226 chrysopterus, 38 chrysothorax, 63 cincta-nigra, 133 cinerascens, 38 cineraceus, 379 cingulatu, 82 cingulatus, 82, 179 cingulatus, 79

Clarazianus, 173 cluniculus, 297 clypearis, 34 coarctatus, 221 collega, 320

Colocolo. 220 colona, 106 columbaris, 316 compressa, 105 entipressus, 105 conformis, 315 consobrinus, 100 (nnsors, 261 conspicuus, 177 Corpuimbensis, 225 cor Cortesin, 119

Cortesiana, 119 coyotus, 348

Cressonianus, 90 cristatus, $156^{\circ}$

cryplicum, $276^{\circ}$

(rypticus, 276
Ctenochilus, 372

Cubensis, 10:- 242 eyanipenuis, 17, 131

dædalea, 379 docduleus, 160 debilis, 155 dejectus, 204 denticulatus, 362 diabolicus, 244 diadema, 107 dicombora, 50 didymogaster, 55 DiDYMOG A sTRA, 45 dilectus, 363 dimidiata, 119 discolinides, 39

Discœlius, 58 dorsale, 143 dorsale, 257 dorsalis, 257 dubius, 44

egregia, 138

eleyans, 313

emarginata, 379

Enyn, 313

Epipona, 360, 372

Epiposes, 360, 363

Erinny - $2 \dashv 5$

Eriunys, 4

Eumenes, 59

eumenoiries, 13 exripiend.ı, 220 excipiendus, 220 . exlen:a, 106

fallax, 367

Farias, 195

Fariasi, 195

fascieulatus, 330

fastidiosusculus, 171

ferruginea, 12:

ferruginea, 98

ferrugineus, 38,98

fervens, 95

figulus, 331

tiliformis, 109

flavicornis, 94

Ancipes, 201

flavopictus, 293

foraminatus, 285

formicaria, 379

formosus, $27 \mathrm{~s}$

fraterna, 95

fraterutu=, 20,95

fulvipes, 201 
fusca, 55

fuscipes, 323

fuscus, 55

Gayella, 13

Gayi, 2t()

geniculata, 50

geniculatus, 50

Ghilianii, 95, 121

gigas, 17

globicollis, 69

globulosns, 1u1

gracilis, 44

guadulpensis, 238

Guatemotzin, 40

Guerreri, 294

Guzmani, $206^{\circ}$

Heros, 17

heros, 17

Heydeni, 23

Hidalgi, 252

Hilarianus, 50

hirsutulus, 227

histrio, 199

Hoplomerus, 360

Hoplopus, 360

Huasteca, 115

Huastecus, 340

humeralis, 223

Huro, 351

HYPALASTOR, 376

HyPALASTOROIDES, 374

Hyp A NISTROCERUS, 210

HYPODYNERUS, 212, 213

imitator, 33

Inca, 335

incertus, 84

incommodus, 198

indica, 128

infernalis, 86

infernalis, 120

infundibuliformis, 118

intermedia, 139

intermedius, 139

Iturbide, 98

Iturbidi, 205

Jurinei, 22

Kennicotianus, 325

labiatus, 222

Labus, 56

Laikesis, 22:3

lavinodus, 44

lavis, 79
La Platæ, 240

LEIONOTUS, 212

Leprieurii, 116

Leptochilus, 366

leucomelas, 287

Lewisii, 368

lobulatus, 27

Louisianum, 257

luctuosus, 311

lugubris, 17

macrocephala, 127

macrops, 95

magnus, 16

marginalis, 10

marginicollis, 223

Marthæ, 124

Masaris, 4

MASARIN王, 3

Muya, 338

Maypinus, 227

Mayus, 338

Negæra, 283

melanosoma, 376

merula, 59

Metazumia, 114

Matzicatzin, 48

Mexicana, 122

Mexicanu, 17

Mexicanus, 75, 369, 374

microguster, 54

microscopica 82

microscopicus, 82

miles, 85

miniatus, 17

minuta, 81. 95

minutus, 81

miscogaster, 54

Mohicanus, 352

molestus, 290

Molinæ, 222

Molinius, 222

Monobia, 129

Montezuma, 40

Montezumia, 110

MoN'EZUMA, 117

Morelii, 299

Morelus, 299

morosa, 124

mortuorum, 119

Mystecus, $336^{\circ}$

Naluus, 35.)

masidens, 232

niger, 5i)

niqriceps, $11 \mathrm{~s}$

nigricormis, 22

nigripennis, 136 
Nortonia, 139

Nortonianus, 88,333

Novaræ, 81

obliquus, 197

obscura, 64

obscuripenuis, 225

obscurus, 64

occidentalis, 207

oculutus, 318

ODYNERIN雨, 11

Odynerites, 59

Odynerus, 143

ODYNeRU:, 212, 247

olivaceus, 647

Olwecus, 25, 95,356

Oplomerus, 360

Oplopus, 360

Orbignyi, 108

ornatus, 106

ornatus, 367

Otomitus, 37, 342

Pachodyneros, 213, 228

Pachymexes, 60

pallidus, 44

pallipes, 63

Paraensis, 205

Parazumia, 127

Parredes, $18 \mathrm{r}$

Parredesi, 180

parvulus, 41,82

pedestris, 322

pelagica, 116

Pensyleanica, 29

Penusylvanicus, 327

perennis, 328

persecutor, 318

pertinax, 160

peruensis, 237

petiolata, 113

Peyroti, 345

Philadelphiæ, 153

picta, 106

pilipalpa, 373

pilipalpus, 372

pilosus, 187

piriformis, 20

placidus, 101

Platinia, 125

Poryi, 45

præcox, 240

pratensis, 292

proctus, 260

prodnctus, 365

propiuquus, 326

proximus, 323 pruinosus, 351

P'seudozumia, 128

Pterochilus, 368

Pterochilus, 360, 372

pulchellus, 59

pumilus, $156^{\circ}$

pusillus, 82

quadridens, 132

quadrisectus, 193

quinque-fusciatum, 371

quinque-fasciatus, 371

recurvirostris, 17

regulus, 70

Rhynchium, 142

Rygchium, 142

Romandịnus, 47, 296

rubritarsis, 117

ruficollis, 226

rufidentata, 118

rufinoda, 19

rufinodus, 19,365

rufipes, 117

rugosus, 285

sæcularis, 202

Santa-Anna, 171

Santa-Anna, 66

Santa-Anuæ, 171

scabriusculus, 198

sculpturalis, 44

scutellaris, 262

sepulchralis, 119

sericea, 62

sericeus, 62

Sichelianus, 57

silvatica, 132

similis, 344

simplicicornis, 235

simulans, 91

singularis, 377

Smithia, 378

Smithii, 55, 104

sobrinus, 340

spectabilis, 278

spinifer, 309

spinipes, 29

Spinolæ, 59, 119, 165

spinosus, 31

Stenancistrocerdo, 189

STENodyares, 213,301

strigosus, 42

subpetiolatus, 220

substricta, 29

sulfureus, 276

Sumichrasti, 78, 209 
Sutterianus, 186

sylvatica, 257

Sylveiræ, 173

symmorpha, 139

Symmorphus, 151

symmorplius, 139

Tacubayæ, 349

Tapiensis, 218

Tarabucensis, 224

tepanecus, 359

T'exensis, 329

Thoas, 319

thoracicus, 74

tibialis, 241

tigris, 160

T'isiphone, 366

Toas, 318

Tolteca, 140

'Toltecus, 27, 316

T'otonacus, 72, 347

Trimeria, 4

tuberculatus, 221

tuberculiceps, 184

tuberculiventris, 221

tuberculocephalus, 185

tubulifer, 53

turpis, 281

uncinata, 133

uncinatus, 133, 181 unifasciatus, 181

Uruguyensis, 100

vagus, 314

varialjilis, 137

variegatus, 2!)

ventricos $a, 67$

ventricosus, 67

versicolor, 106

VESPID $\#, 1$

vespiformis, 227

vespoides, 5)

vestitus, 223

Victoria, 334

Victoriæ, 334

villosus, 225

Walshianus, 152

Wagnerianus, 94

Westwoodi, 21

Xantianus, 324

Xantianus, $32 t$

Zendalus. 53, 354

Zethites, 13

Zethus, 13

Zethus, 16

Zethuscolus, 18

zonalis, 8

zonatus, 239 


\section{EXPLANATION OF PLATE I.}

Fig. 1. Zethus (Zethusculus) Aztecus Suuss., $\delta$.

$1 a$. Its head $\delta$ enlarged.

Fig. 2. Zethus (Zethusculus) spinosus Sauss., $\nmid$

$2 a$. Its abdomen enlarged.

Fig. 3. Zethus (Zethusculus) Montezuma Sauss., $q$. $3 a$. Its head $q$ enlarged.

Fig. 4. Zethus (Didymogastra) Poeyi Sauss., $\hat{b}$.

4a. Its head $\delta$ enlarged.

Fig. 5. Zethus (Didymogastra) Chicotencatl Sauss.,.

$5 a$. Its abdomen enlarged, profile.

Fig. 6. Eumenes (Pachymenes) Santa-Anna Sauss., $6 a$. Its head $\$$ enlarged.

Obs. By error this figure is marked $\delta$ on the plate.

Fig. 7. Eumenes regulus Sauss., \&. (Div. O.)

$7 \pi$. Its head $\delta$ enlarged:

7h. The profile enlarged.

Fig. 8. Eumenes Mexicanus Sauss., $q$. (Div. O.)

$8 a$. Its head $q$ enlarged. 


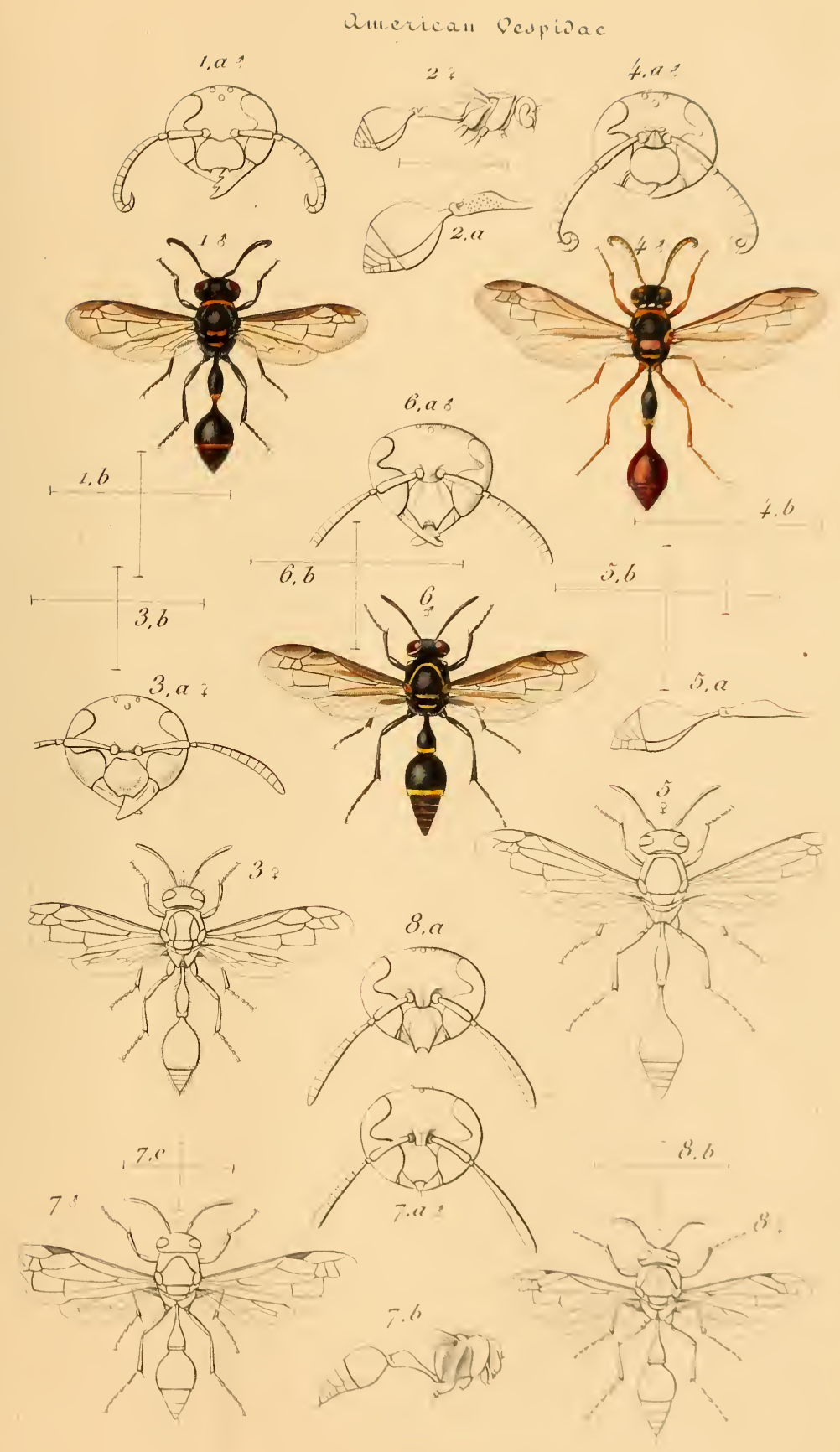

|ग. I 



\section{EXPLANATION OF PLATE II.}

Fig. 9. Montezumia Huasteca Sauss., $\widehat{\delta}$. $9 a$. Its head $q$ enlarged.

Fig. 10. Montezumia zteca Sauss., $\widehat{\delta}$. $10 a$. Its head $\delta$ enlarged.

Fig. 11. Montezumia Mexicana Sauss., \&.

Fig. 12. Monobia biangulata Sauss., $q$.

12a. Its head $q$ enlarged.

Fig. 13. Nortonia Tolteca Sauss., $q$.

13a. Its head $q$ enlarged. 


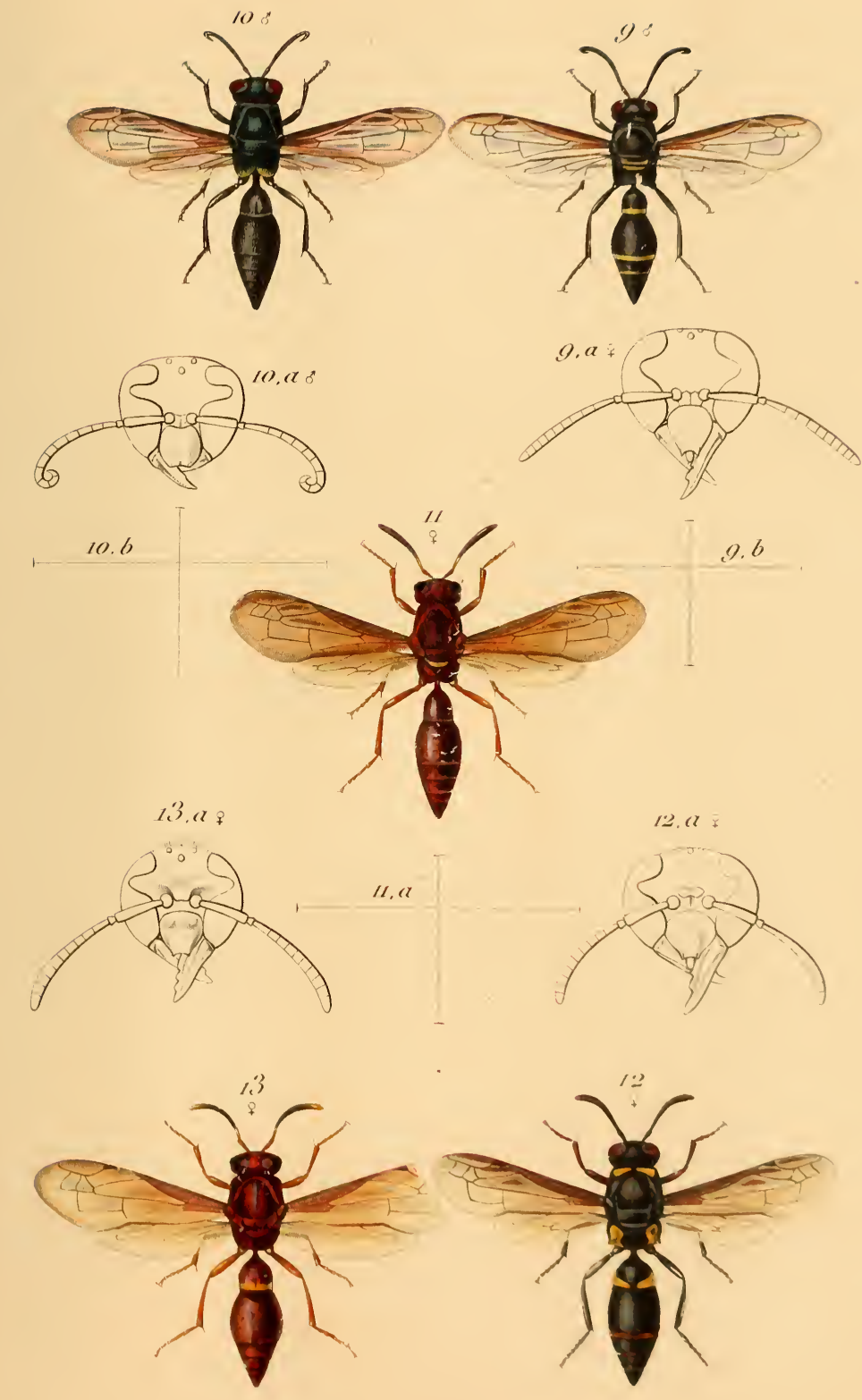

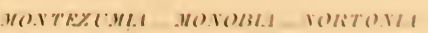

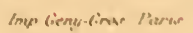




\section{ESPLANATION OF PLATE III.}

Fig. 14. Odwnerus bidens Sauss., $\hat{\delta}$, var.

14a. Its head $\delta$ enlarged.

Fig. 15. Odynerus Iturbidi Sauss., $\hat{\delta}$.

15a. Its head $\delta$ enlarged.

Fig. 10. Odynerus arvenisis Sauss., $q$.

16a. Its clypeus 오 enlarged.

Fig. 17. Odynerus Callifornicus Sauss., $q$.

$17 \alpha$. Its clypeus $q$ enlarged.

Fig. 18. Odynerus sulfureus Sauss., $q$.

18a. Its head $q$ enlarged.

Fig. 19. Odynerus leucomelas Sauss.,

19a. Its head $q$ enlarged. 


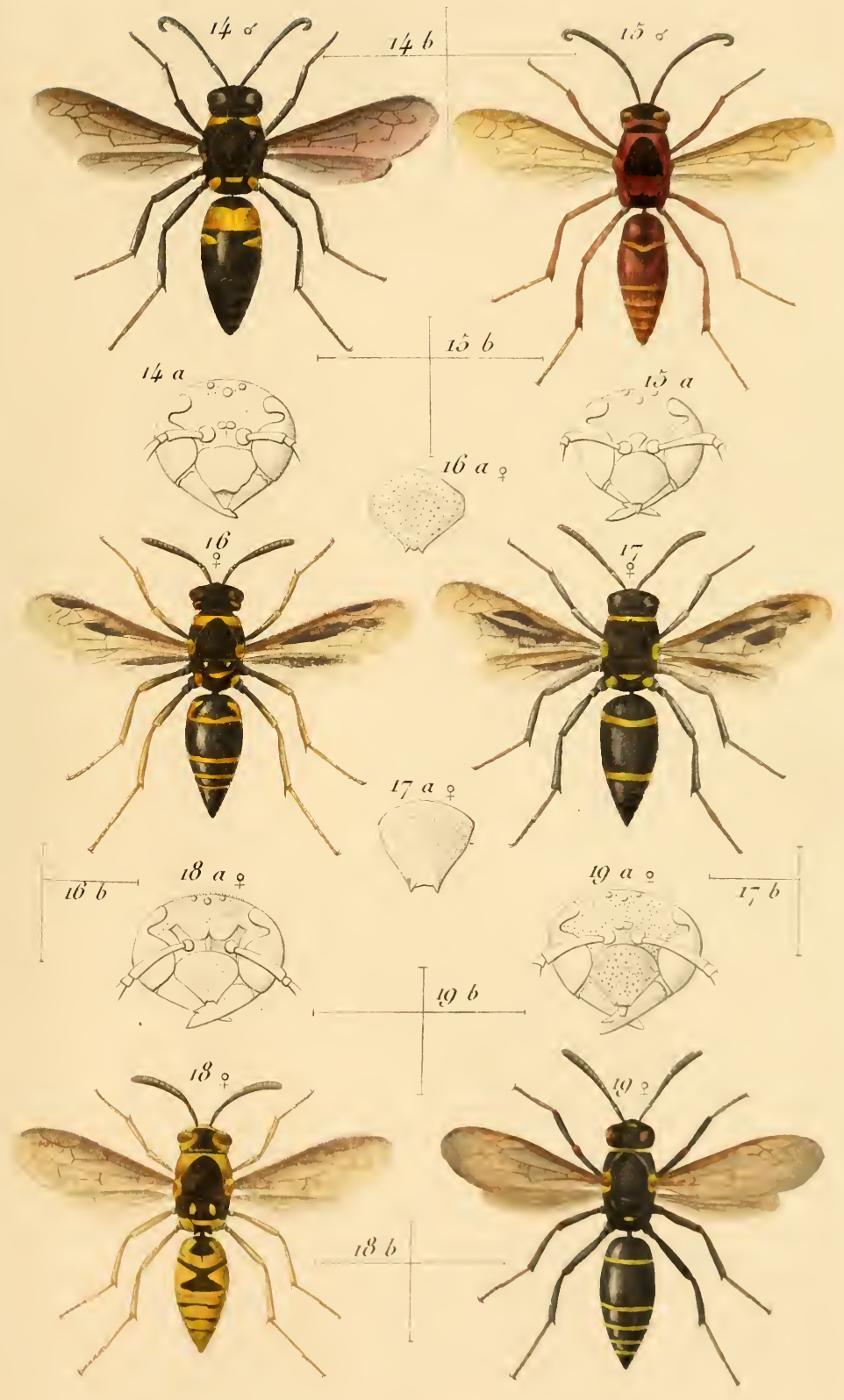

(1)) 16R2 


\section{EXPLANATION OF PLATE IV.}

Fig. 20. Labus Sichelianus Sauss., $q$.

$20 a$. Its head enlarged.

Fig. 21. Odynerus Otomitus Sauss.,

Fig. 22. Odynerus (Stenodynerus) pedestris Sauss., $q$. $22 a$. Its clypeus enlarged.

Fig. 23. Odynerus Totonacus Sauss., $q$.

Fig. 24. Odynerus Zendalus Sauss.,

$24 a$. Its clypeus enlarged.

Fig. 25. Odynerus (Stenodynerus) perennis Sauss., $q$.

Fig. 26. Odynerus coyotus Sauss., $\hat{\delta}$.

Fig. 27. Odyuerus Tacubaya Sauss., $\delta$.

Fig. 28. Odymerus bacuensis Sauss., $\hat{\sigma}$.

$2 S a$. Its head $\delta$ enlarged.

Fig. 29. Odynerus (Epiponus) dilectus Sauss., $ో$.

29a. Its clypeus $\delta$ eularged.

Fig. 3n. Odynerus (Epiponus) denticulatus Sauss., $\widehat{\delta}$

$30 a$. Its clypeus $\widehat{\delta}$ enlarged.

iig. 31. Pterochilus mexicanus Sauss., $q$.

$31 a$. Its clypeus $q$ enlarged. 
Mmericall vespisac

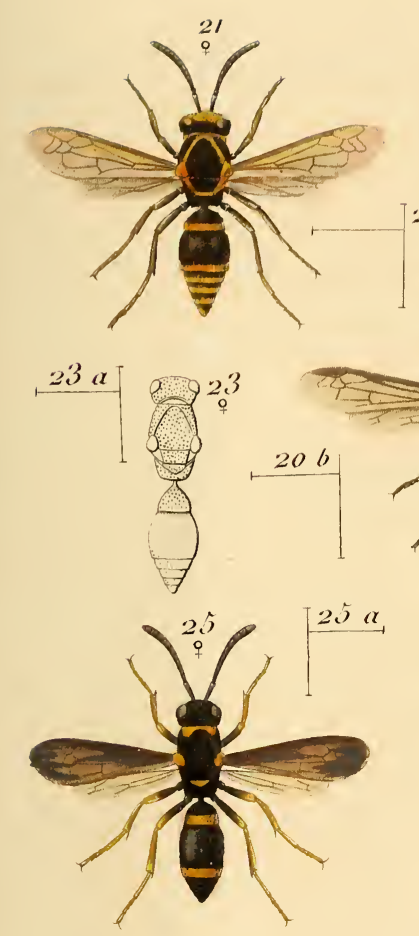

$I^{20 a} 2 b_{20}^{20}$
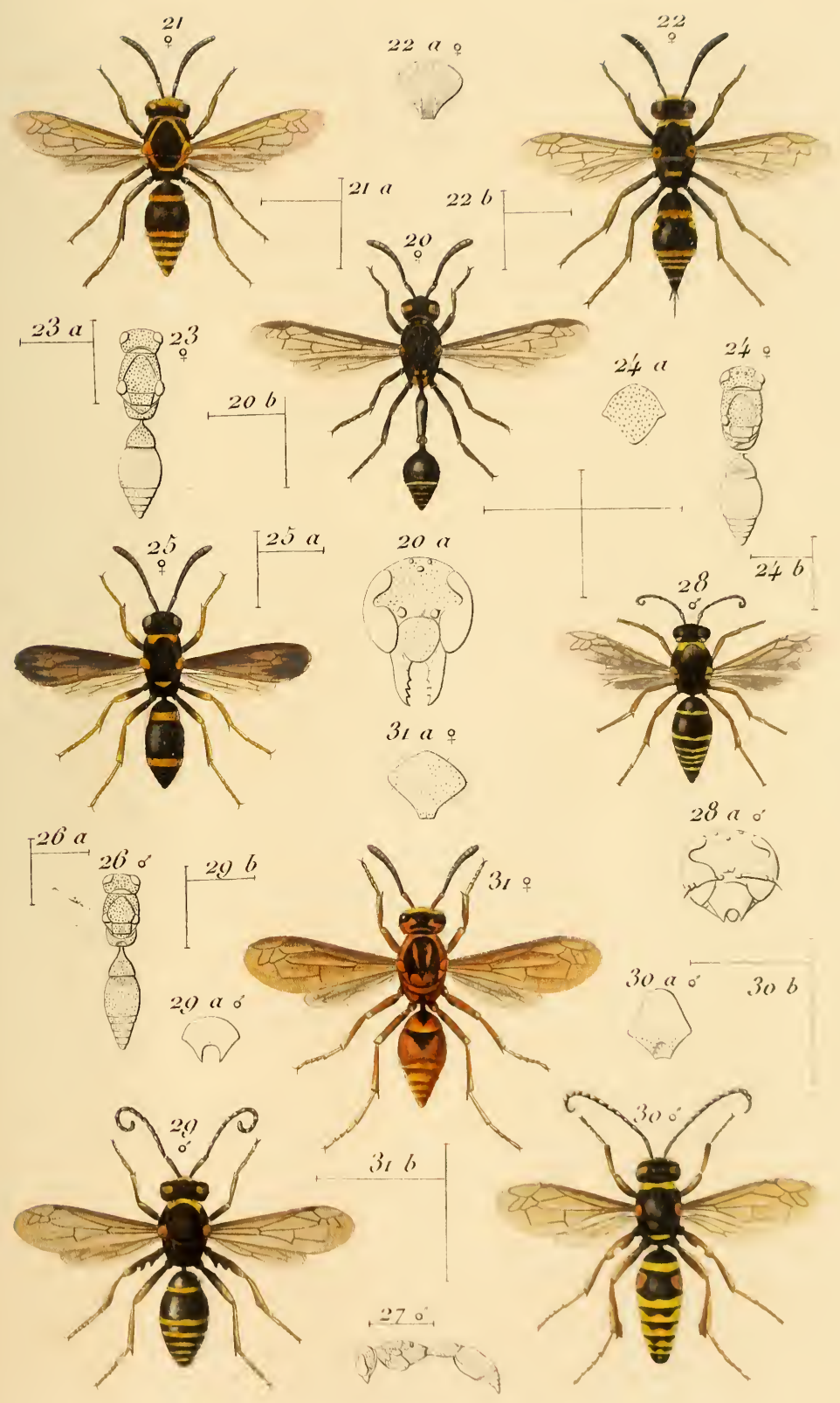

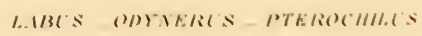

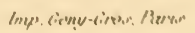








